$\diamond$ 特別講演

非放射性 IN SITU HYBRIDIZATIONによる細胞蛋白合成機棬の検索

長崎大学医学部第三解剖

中根一穗 (PhD)

In situ hybridization 法の最も著名な 利点は免疫組織化学的手法によって存在 が証明された蛋白性抗原がその細胞や組 織で産生されたか否かを証明できる事で ある。更にin situ hybri-dization法は 従来の組織細胞化学的手法では検出不可 能なであるDNAから から蛋白へと翻訳されない場合でも遺伝 子の検出が可能であるので、ウイルスの 潜伏感染等でウイルス核酸は細胞内に存 在するがウイルス遗伝子が発現されてい ない時でもウイルス感染を探知できる利 点がある。今回は方法論、特に免疫組織 化学法とin situ hybridization法の共 通点とその差を主体に講演する。免疫組 織化学とin situ hybridizationは共に 操作過程で組織や細胞の形態を維持する のに固定を必要とする。しかし固定は抗 原基を破壊して抗原一抗体反応を低下さ せるし、標的核酸を蛋白等で被覆してプ ローブとのhybridizationを阻害する。 この基本的矛盾を承知の上で in situ、 hybridization 用の固定条件や被覆蛋白 の除去法を確立する必要がある。我々は DNA 鎖内でチミン同士が隣していると 紫外線により夕゙イマー化され抗原性を得 る性格を活用したチミンダイマー標識 D NAプローベを使用した非放射性 in situ hybridization 法を使用している ので、この非放射性方法による種々の固 定条件下での蛋白の mRNAやウイルスDNA の細胞や組織内分布を検索した結果を闑 㹂する。

\section{$\diamond$ 招請講演}

悪性リンパ怔並びに颣緑疾患の病理

\section{福闹大学医学部第一病理学教室 碀池昌弘 (MD)}

覀性リンパ腫はリンパ球由来の覀性腫综の紷称て あるが 今日非ホジキンリンパ腫とホジキン病に分 けられている。ホジキン病はその䒁胞由来について は問題力解决されていないか組織分類は1966年の

Rye分類によりほ活確立されている。一方、非ホジ キンリンパ腫についてはリンパ球の免妾学的並びに 分子遗伝学的解析力倠み $\mathrm{B} 、 \mathrm{~T}$ 細胞系その他に区 別して考えられるようになり、これに対応した組織 分類力試みられつつある。そこでここでは非ホジキ

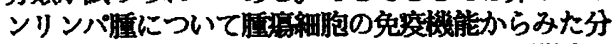
類についてL S G分類を基に説明し、これに関連し た類稀疾患について述べる。

B細胞性リンパ腫はB細胞采分化抗原が見られる 腫富て、従来の分類か良く対応し細胞分化と組織型 との関係は比較的良く理解されている。前赔胞期は Burki tt型と一部のリンパ乐球型、㱆胞期では滤胞 避緑带谓胞に対応するものには中細胞ないし中間細 胞型が 滤胞中心細胞では註胞性リンパ腫の各種の 亜型か含まれる。後涯胞期としては小細胞型並びに 形筫細胞への分化を示すものが含まれる。

T細胞リンパ腫は、分化度からみて前胸腺ないし 胸腺蜔胞期に対応するリンパ事球型と末梢T緗胞に 対応するものとして、それ以外の形热を示すT細胞 性リンパ腫 (小中、大、混合、多形細胞) がある 。成人T細胞性白血病/リンパ腫はここに含まれる 。これらはさらにその機能により多数のhelper/ inducer 型と少数のsuppressor/cytotoxic型に分け られる。さらに特殊な組織像を示すものとして、

Lennertリンパ腫、血管免宍来球性リンパ腫㫌型T リンパ腫、T領域リンパ腫がある。尚、菌状自肉腫 やSezary症候群はT䋚胞性皮沙リンパ腫である。さ らに徉来組織球性として取り扱われていた腫斯の一 群の多くも未分化大細胞型としてT細胞性リンパ腫 に含まれる。

このように多くのリンパ腫はB、あるいはT細胞 性に分けられるかリンパ瘇としての形柋や形贸を持 つか纷類不能の症例もみられる。

㷂性リンパ腫に類緑であるが明らかな単クローン

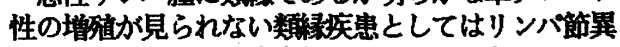
形成をして报われる病变があるのでそれらについて リンパ腫との鑑別点を述べる。 


\section{仓教育講演}

早期肺癌 (扁平上皮癌) の細胞像

ースクリーニングと鑑別診断一

大阪府立成人病センター

O宝来 威 (MD)

早期扁平上皮癌細胞は一般に異型の弱い角化型 の細胞や基底型の細胞が特徴といわれ, また標本 上に出現する癌細胞も数が少なくかつ異型の強い 癌細胞の出現が少ないので, 非癌呼吸器疾患に出 現する扁平上皮系の異型細胞 (化生細胞) と時に は鑑別が困難なととがある。このため肺癌集検で は細胞判定基準 ( A B C 分類), 扁平上皮化生細 胞の判定基準が定められているが，乙の判定基準 は検診結果の指導区分のためのものであり, 化生 細胞の異型の程度の判定が重視されている。

既に報告してきたように早期扁平上皮癌細胞の 診断には, 化生細胞に比べて, 核が大きくN/Cが 増大し, クロマチンの増量と不均等分布が見られ, 核形の不整や細胞質の過染性, 重厚性などの所見 が重要であった。しかし, 早期扁平上皮癌細胞や 化生細胞の判定については未だ各施設, 指導医, スクリーナーの間で統一を見ていない。また両者 の鑑別が必ずしも容易ではない異型細胞にもしば しば遭遇する。従って，スクリーニングにあたっ てはこのような細胞を化生細胞, 癌細胞と分類す るのではなく, 異型扁平上皮細胞と呼び, 癌細胞 の可能性の程度を判断するのが現実的と考える。 大阪地区のスクリーナーは異型扁平上皮細胞どの 程度扁平上皮癌を疑うかによるスクリーニングの ための判定基準を定め, 集検に応用を試みている。

本講演では, 早期扁平上皮澏の細胞像を正しく 認識するためにわれわれの経験した早期扁平上皮 癌の細胞診成績およびその細胞所見と，スクリー ニングのための異型扁平上皮細胞の判定基準につ いて紹介する。

\section{$\diamond$ 会長講演}

\section{婦人科領域における腺㾖の細胞診}

\section{長崎大学医学部産科婦人科学教室}

山辺 徹

婦人科領域における腺癌は女性性器の各部位に みられるが、子宮体部、卵巣および卵管に発生す る癌はほとんどが腺癌であるのに対して、子宮頸 部では扁平上皮㾔が普通で、腺癌は 5〜10\% と されている。また外陰や䐋では腺癌の発生頻度は きわめて低い。このような差は主として各部位に おける組織棈築的な特異性や罢境的因子に基づく あのと思われるが、地理病理学的な相異すみられ る。腺癌の組織型は各臟器によって特徽がみられ るすのの、主としてミューラー管由来の胵上部、 子宮頸部、子宮体部および卵管の腺癌と、胚芽上 皮由来の卵巣癌の間にも発生学的関連性がみられ、 これらの臟器では、同様かきわめて類似の組織型 の腺癌す認められる。しかしながら、同じ腺癌で む、組織発生的な差や部位的・環境的条件の差な ぞから、それぞれ異なった生物学的特性を有する ことが考えられる。

細胞診レベルでは、腺癌細胞は原則として核重 積性の腺集群として出現する。しかも個々の細胞 の所見のみでなく、腺集群にもそれぞれの組織型 に応じて特徽的な配列や細胞相互の結合性が表現 されている。これらの所見の総合によって細胞学 的診断がなされることになる。一般に初期の腺瘦 や高分化の腺癌では細胞結合性が比較的強く、ま とまった細胞集群をつくる傾向がある。また核の 重積性は腺暍細胞の增殖に基づく組織レベルでの 重層化を反映する所見といえる。ただ明細胞腺癌 では、どの藏器の場合む、むしろ腺暍細胸集群は 平面的に配列することが多く、核重積傾向は低い。 これは組織学的にも腺暍細胞が概して単層に配列 することに関連しているすのと思われる。

女性性器にみられる腺癌の各組織型における細 胞診所見の特徽に関して、諸計測値を含めて検討 した成䋶について述べたい。 


\section{$\diamond$ 要望講演〔 I 〕}

細胞診への超微形態学的アプローチ

札幌医科大学産婦人科学講座

橋本正淑

細胞診の判定は主としてパパニコロウ染色によ って光学顕微鏡的に推定あるいは確定されるのが 本来であるが最近は細胞化学的, 免疫細胞化学的方法 により，あるいは電子顕微鏡的手段を加える事によ り更に詳細な情報と知見の拡大が期待されている。 しかし従来の電子顕微鏡的方法は対象組織あるい は細胞群を一塊として資料として観察するのが通 常で, 既にスライドグラス上に載物され, 染色さ れた 1 個ないしは数個の標的細胞そのものを試料 として検索する事は殆んど行なわれていない。我 々は資料を通常のスライドグラスのほかに自家製 のフィルムスライド上に塗沫し, パパニコロ変法 あるいは免疫細胞化学的染色をほどこし鏡検し， 充分観察された標的細胞の位置をスライド裹側に 標識して, その細胞をのせたま〉フィルムスライ ドを切り取り, 白金パラジウムでコートして表面 微細構造を走査電顕にて, 更に必要に応じてこの資 料をフィルムスライドのま〉エポン樹脂に水平に 包埋し同一細胞を超薄切片として透過電顕資料を 作製し, 同一細胞の光顕, 走査電顕, 透過電顕の 連続観察を行ない, 幾多の知見を得る事が出来た。観 察対象は培養細胞の表面構造をはじめとして, 扁平上 皮系細胞に特有な mi croridge 等の表面構造, 細胞間 接合, 細胞内 tonofibril, kera tohyaline顆粒, 頸管 内膜の分泌顆粒, fibrillarbody, 細胞内小器管, 子 宮内膜の成熟期, 閉経期その他ホルモン効果に対応す る種 々相などである。又卵管, 卵巣腫痬における 腫痬細胞の表面構造と超薄切片像との関係, 正常䄉毛, 胞状奇胎と䋐毛性腫瘍における cytotrophoblast と合 胞細胞, 又子宮頸部剥離細胞の koilocytosisとその関 連病変における核周囲の变化や, HPV検出症例におけ る核内のウイルス粒子の集団, 悪性黒色腫における種 々の段階のメラノソーム等々, 従来の光顕所見のみでは到 達し得ない新分野を展開し得る可能性について述べる。 $\diamond$ 要望講演〔II〕

肝癌の細炮診一早期肝癌の診断を目指

してー

\author{
摠協医科大学第一外科 \\ 信田重光(MD)
}

最近特にCT、超音波等の画像診断面の進歩によ り発見されるようになった肝内の小さな病変の診 断に果たす細胞診の役割を論じたい。

教室では肝の小病変に対して超音波誘導下穿刺 細胞診をおこなっている。装置は東芝製のものを 用いて、21-22ゲージの長針と10ccの注射筒を特 殊な吸引装置に装着しておこなう。皮原表面から 壁側腹眹までを局所麻酔する。これまでの所、出 血などの合併症は皆無であった。

最近 5 年間に20例の原発性肝癌及び27例の転移 性肝癌に細胞診をおこなった。原発性肝癌例中18 例より充分な材料が採取されこのうち15例(83.3\%) が細胞診により癌細胞淂性、うち14例(73.3\%)が 原発性肝癌と診断された。また25例の転移性肝癌 中22例(88\%)が細胞診隄性、うち19例(86.4\%)が細 胞所見より転移性肝癌と診断された。

大きさ別では原発性肝癌では径40畐以上の10例 は全例細胞診隄性であるが、40〜30mmのもの2例 中1例、30〜20m清のも4例中3例、20〜10m生 の2例中1例が細胞診陽性で、40m以下のもの計8 例中5例(62.5\%)が陽性であった。一方転移性旰癌 では40m以下のもの7例全例が細炮診陽性であっ たが40m以上のもの18例中15例(83.3\%)が陧性で あった。

これらの成績からみると以下の問題点が考えら れる。

1.腫县径が小さいほど細胞採取は荆しくなり、ま た細胞径が大きくても癌紐泡が採取出来ないこと がある。（細胞採取技術の問題点）2.小病変にお ける高分化型肝細胞淘や肝硬変、旰炎などの良性

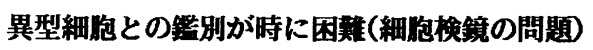
これらの問題点を解決する為の方策などについ ても言及する。 


\section{৩シンポジウム[ I ]}

シ I -1.

喀痰細胞診併用による肺癌検診の

\section{精度管理}

\section{国立道北病院坂井英一（M D )}

昭和 62 年, 第二次老健法により肺癌検診が とりあげられ, 胸部 X線像と喀痰細胞診の二つ の方法で行なわれている。 $\mathrm{X}$ 線像の精度管理も 必要であるが, 今回は対癌協会の成績とくに旭 川センターの細胞診を中心に検討した。

対象 I 群（北海道対癌協会）昭和 51 年よ り 63 年まで 88 , 179 例より肺癌 79 例( I 0 万比 90 ）を発見し，I期例 38 （48\% ), 手術例 $37(46 \%)$ であった。細胞診（ 旭川） 8, 544 件，A $306(3,6 \%)$ で あり, 有効痰 8, 238 中 B 8, 158 (99\%), C $65(0,8 \%)$, D 8 , E 7であった。 対象 II群（北海道肺癌対策協議会）昭和 5 8 年より 62 年の 5 年間, モデル 6 町村で年 2 回法で行ない, 60,883 例より肺癌17例( 1 0 万比2 8) を発見, 工期例 9 , 手術例 7 で あった。細胞診は 7, 445 中 A 344 (4, $6 \%$ ）であり, 有效痰 7, 101 中, B 7, 048 ( $99 \%)$ C $48(0,7 \%), D 3, E 2$ あっっ た。

[考案および結果]

（1）現在，対癌協会（札幌，旭川，釧路）の，検 診の基本項目, 細胞診成績等はコンピューター に入力し, 相互に利用出来るようになりつつあ る。(2) 喀痰容器回収率はIII群で 8, 162 中 $7,445(91 \%)$ 。(3) A (材料不適) は I 群 3, $6 \%$ ，II群 4, $6 \%$ 。(4) C , D，Eについては 再検討し, C は再度喀痰細胞診を, DとEは気 管支フアイバースコープ等の精検をした。

（5）旭川センタ一の指導医 4 名， C T 6 名（全 体で指導医 8，CT20) であり，CTI人あ たりの年間総細胞診数は $8,000-9,000$ 件 であった。
I -2.

乳腺集検における分泌物細胞診の意義

宮城県立成人病センター

武田鉄太郎

宮城県対がん協会では、乳腺集検を開始した昭 和 52 年 5 月当初から、乳頭分泌細胞診を一次ス クリーニングに組み込み、実施してきた。平成元 年9月までの検診総数は $280.02 /$ 件で、その 5 ち34.738件、/ $24 \%$ に乳頭分必を認め、 細胞学的検索を行った。乳腺集検による発見乳癌 は622例で、//5例、18.5\%に乳頭分必が あった。細胞診は陽性29例、疑陽性/O例、陰 性（異常所見あり）３０例、陰性４6例。発見乳 癌中 T is は4 4 例で、29例、6 $1.7 \%$ 亿乳頭 分必を認めた。細胞診は陽性／Ｏ例、疑陽性 3 例、 陰性 ( 異常所見あり) / 4 例、陰性2例。TOは / 2 例で、7例、58.3\% 乳頭分必がみられた。 細胞診は陽性 4 例、矤陽性 / 例、陰性 ( 異常所見 あり）/例、陰性／例。発見乳癌中／７例（ Tis / 2 例、TO 3 例を含む) は他の検查法では異常 を指摘できず、分必物細胞診で拾い上げた。その 細胞診は陽性 / 2 例、疑陽性 2 例、陰性 (異常所 見あり) 3例であった。

癌例の乳頭分泌率が高く、特に Ti s、TO例の 分泌率が約 $60 \%$ ときわて高いのは、癌例特に 早期癌の発見に分必物細胞診が寄与していること を示す間接的データであり、早期癌を主とする /7例の乳癌を分泌物細胞診だけがチェックした といら事実はこれを裏付ける証拠と考えられる。 
シ I -3.

子宮内膜細胞診を用いた子宮体癌 検診の精度管理

北里大学産婦人科

○上坊敏子 (M D )

近年本邦では子宮体癌の頻度が急增しつつあり, 内膜細胞診による体癌検診の精度管理は重要な課 題となっている。我々は, 1987年までの症例の細 胞所見を retrospective に検討することにより, 以下の諸点を明らかにしてきた。1)子宮体癌の診 断法として組織診以上の成績を期待し得る。特に, 分化型の症例, 筋層浸潤の浅い症例でその成績は 良好である。2) 背景, 集塊形成傾向, 集塊の辺縁 の性状, 核の大小不同性, 多形性, クロマチンの 状態，核縁肥厚の有無，核小体の数と大きさ，正 常内膜細胞混在の有無などが判定のポイントであ る。これらの所見により体癌と異型増殖の鑑別, 分化度の判定, 筋層浸潤の有無, 腺腫増殖の診断 が可能である。3)子宮体癌における初回細胞診の false negative率は $16.3 \%$ あっった。特に G 1 症 例, 筋層非浸潤例でその率が高く, 各 $31.4 \%, 33.3$ \%という結果であった。出血性の背景, 多数の正 常内膜細胞の混入などがfalse negativeの原因と なる。4）蠕胞増殖，腺腫増殖，異型増殖における 偽陰性率は各 $81.8 \%, 79.3 \%, 42.9 \%$ と高い結果で あった。我々が経験したfalse negative例, false positive例, class III $a$ 以上と判定し 3 年以上 followした症例，診断の困難であった粘膜内体 癌の細胞所見などを検討することにより, 内膜細 胞診の正診率向上の方向を探る。2)で述べた細胞 診の判定基準を用いて, 1988, 1989 年に内膜細胞 診を施行した症例について内膜組織所見, 不正出 血の状態, 子宮筇腫, 卵巣腫場合併の有無などと 関連させて prospectiveに検討する。そして現在, 陽性, 偽陽性, 陰性と表現されている内膜細胞診 であるが，良性增殖症まで含む内膜病変の細胞病 理学的診断にマッチしたクラス分類の可能性につ いて検討する。
I -4.

東京都に括ける細胞診精度管理の現況 と問題点

佐々木研究所付属杏雲堂病院婦人科

○杉下匡

昭和 57 年に老人保健法が実施されて以来, 都民 のがん検診に対する認識は急速に高まり, 都内の 衛生検查所の数も急増してきた。昭和 57 年に 76 か所であった衛生検查所が昭和 62 年には 91 か所 に增加している。精度管理を成功させるためには, 管理する側の要素と管理される側の要素を考慮す ることが重要である。

東京都の場合は，管理する側の要素として 2 面 性があり，1つは行政的管理指導体制であり,むう 1 つは学術的管理指導体制であろう。行政的管理 指導は東京都衛生局が扰こなっており，ここには 2 つの組織が存在する。

一方は『臨床検查師, 衛生検査師に関する法律 の 20 の 5 規定』に基づいて機能している医務部で あり, 他方は『老人保健法』に基づいて機能して いる公衆衛生部である。前者は衛生検査所に拈け る物的, 人的管理指導を行い, 時には行政処分を 施行することもある。

後者は，その中の成人病管理指導協議会におい て,もっぱらがん検診の精度管理体制を調査する ことにとどまる。

私はこの $2 つ の$ 組織間にある問題点を指摘する。 次に学術的管理指導体制は, 東京都医師会内の 地域医療部に所属する精度管理委員会細胞診部会 が担当して拉り主として子宮がん，肺がん検診の あり方を検討し，その結果を東京都衛生局に具申 する機能を果たしている。

私は，その具申内容についてもくわしく説明す る。最後に，管理される側の要素を考慮するとき， 全く無策に終わっている現況とそこに存在する問 題点についても詳細に述べたいと考えている。 
シ I -5.

頸癌検診の精度管理

佐賀医大産婦人科

○杉森 甫

細胞診に括いて誤診を生ずる原因として、1. 材料採取上の誤り、2. 標本処理上の誤り、3.鏡 検上の誤りの 3 つがあり、とくに 1,3 が重要であ る。頸癌検診は長年にわたり細胞診を一次スクリ ーニングとする方法で行われてきたため、その精 度管理が最も重要であり、検查結果統計によって その精度を推定することもできる。

精度管理は外部管理と内部管理とに分けられ、 外部管理に関しては各都道府県に設置されている 成人病検診管理指導協議会子宮がん部会の重要な 業務の一つに細胞診センターの精度向上維持に関 する監督指導があげられる。

内部管理については各細胞診センターの自主性 によるわけであるが、ここではその幾つかのやり 方と例を示す。その前提として疑陽性、陽性例の 組織診が判明していること、過去の細胞診標本を 保存していること、全受診者の管理を正確にして 逐年追跡ができるようにデータを整理して拈かな いといけない。

1986,87 年度の発見がん患者の受診歴調査から 割り出した佐賀県での集検細胞診の精度は sensitivity $81.2 \sim 92.9 \%$ (上皮内癌の取り扱いで多 少異なる)、specificity $99.63 \%$ と計算された。 また、福岡県対ガン協会の逐年連続受診者の癌発 見率より推定された sensitivityは $83 \%$ であっ た。これらの sensitivityは低いようにみえるか あ知れないが、このようなデータを出せるような 体制にすることがまず重要であることを強調した い。

\section{৩シンポジウム[II \\ シ II -1.}

DNA 多型性解析を用いた䄉毛性疾患 発生病理の検討

大阪大学医学部産科婦人科学教室

○佐治文隆 (MD)、東 千寻 (MD)、

谷澤 修 (MD)

〔目的〕胞状奇胎は受精異常を原因とし、雄核発 生を示す䋐毛性腫瘍である。我々は胞状奇胎とそ の両親について、核内 DNA および核外（ミトュ ンドリア）DNAの多型性を RFLPs（restriction fragment length polymorphisms)を用いて解析 し、胞状奇胎の発生病理を分子レベルで検討する とともに、䄉毛癌との比較を行った。

〔方法】腫瘍組織ならびに患者とその夫の末梢血 から核内 DNA とミトコンドリア DNAを抽出し た。核内 DNA はミニサテライトプローブ 33.15 を用いた Southern blotによりその多型性を解 析した。ミトコンドリア DNA は、2ヶ所の領 域 (15745-686 base number, 3726-5607 base number)に対して polymerase chain reactionを 用いた DNA 増幅を行った後、各種制限酵素 (Hinf I 、Hae II 、Alu I 、Taq I ) による切断 パターンの多型性を解析した。

[結果]正常䋐毛の核内 DNAの多型の DNA 片 は両親のいずれか由来であったのに対し、胞状奇 胎の核内 DNA多型片はすべて父親由来であっ た。一方、核外ミトコンドリア DNAの RFLPs パターンはすべて母親型に一致した。䄉毛癌にお ける核内 DNAの RFLPs では母親型を示すもの と、胞状奇胎同様父親型を示すものの 2 種が認め られた。

〔考察〕胞状奇胎は脱核した異常卵に精子が受精 することにより発生するいわゆる雄核発生である ことが分子レベルで解明された。一方、絨毛癌は 必ずしもすべてが胞状奇胎と同様の雄核発生によ らないことが明らかになった。 
シ II -2.

緁毛癌細胞の Genotype と Phenotype との相関

岩手医科大学医学部産婦人科学教室

$\bigcirc$ 善積昇(MD), 平間隆之(MD), 吉崎陽(MD), 佐藤昌之(MD), 松田壮正(MD), 井筒俊彦(MD), 西谷 嚴(MD)

絨毛癌に抢いて，悪性 trophoblast（以下, Tr. ) より産生される hCGは, Tr.の増殖や, MTXなど による細胞障害効果を monitorする上で臨床上必 須の marker である。しかし, hCGは syncitio-Tr. で産生されるので, Tr. の病勢を示す cyto - Tr.の 増殖と $\mathrm{hCG}$ 産生との関連や，MTX投与中のいわ ゆる細胞効果の機序もいまだ明確さを欠いている。 近年, monoclonal 抗体の開発と Flow cytometry ( FCM )のレーザー分光技術の進歩に伴い, $\mathrm{Tr}$. の核機能と phenotypic markerである hCGとの相 関の詳細な解析が可能となってきた。

そこで, ヒト䋐毛癌培養細胞( ENAMI - 1, BeWo ) を用いて，MTX 効果，DNA 合成および hCG 産生能の相関について, FCM による多角的 な解析に加えて, 免疫細胞化学的検討をあ行った。

MTX 添加時の抗BrdU monoclonal 抗体による DNA 合成細胞の動態の解析から, G 1 - early S 期に部分同調をきたす低濃度 MTX にて, hCG 産 生の著明な增加を認めた。さらに抗 hCG monoclonal 抗体を用いて細胞周期と hCG 産生との相関 を解析したところ, hCG 含有細胞の大半は $\mathrm{G} 1$ 期 に出現した。免疫細胞化学的にも FCM 解析結果 の形態学的裏付けが得られた。したがって, Tr. の hCG 産生は細胞周期の G 1 - early S 期に行わ れることから, hCG は絨毛癌における腫瘍増殖を 予知する marker であるととが確認された。
シ II -3.

\section{䄉毛性疾患でみられる trophoblast subpopul at i on の細胞形態亡生物学的意義について}

水原郷病院産婦人科

○笹川 基 (MD)

香川医科大学母子科学教室

佐々木敏江（M D)，半藤＼cjkstart保（M D)

正常妊娠の䄉毛表面にはcytotrophoblast(CT) と syncy tiot rophoblast(ST)か観察されるが、胎盤着 床部には CT とも ST とも異なる trophoblast が存在 し、intermediate trophoblast(IT)などと呼ばれて いる。ITは母体脱落膜などへと侵入し、侵入先端部 には多核 IT みられる。胞状奇胎や䋐毛癌において あITや多核 IT の観察されることが報告されており、 各 trophoblast subpopulation の持つ生物学的意 義の解明を目的に、子宮摘出された正常初期妊娠 10 例、全胞状奇胎 5 例、妊娠性䋐毛癌 6 例を材料 として形態学的観察を行い、細胞機能を探るため hCGとhPLの局在を酵素抗体法により検討した。

奇胎 trophoblast の細胞形態に関し、CT、STに異 型性はみられなかったが、脱落膜との境界部に細 胞異型のみられるIT、多核 ITの正常妊娠より旺盛 な細胞増殖がみられ、䋐毛癌の発生母細胞を考え る上で興味ある所見と思われた。絨毛癌では、IT 様細胞、多核 IT様細胞の他、ST 様細胞にも著明な 細胞異型が認められた。正常妊娠のIT は、新たな 䋐毛間腔の形成のため母体血管へと侵入してゆく ことが知られているが、䄉毛癌組織において、血 管壁や血管腔に IT様細胞が多数認められた。この ことは、IT様細胞が䋐毛癌の血行性転移に関し重 要な意義を有するととを示唆するあのと思われる。 胞状奇胞に执いて、hCGはSTに、hPLは主として IT と多核 ITにみられ、STに拉りる hPL陽性所見が 減弱している他には正常妊娠との相違点はみられな かった。一方、絨毛癌では、hCGはST様細胞、IT様 細胞、多核 IT様細胞に、hPLは一部のST様細胞に のみ認められ、正常奼娠や胞状奇胎とは細胞機能 をかなり異にするものと思われた。 
シ II -4 .

絨毛癌における癌抑制遺伝子の解析

九大 生医研 生殖生理内分汼部門

$\mathrm{O}$ 岩永知久 $(\mathrm{MD})$ ，佐々木雅弘 $(\mathrm{MD})$, 加藤秀則 (MD)

押村光雄 $(\mathrm{PhD})$, 和氣德夫 $(\mathrm{MD})$

絨毛性疾患は胞状奇胎婏出後の患者管理の進歩 にともない寛解率の向上が顕著である。しかしなお 胞状奇胎患者の $3-5 \%$ は䋐毛癌を発症し, 特に 東洋では若年婦人死亡の大きな原因となっている。

現在, 癌の発生には癌遺伝子の活性化・および 癌抑制遺伝子の欠失あるいは不活化という少なく とも 2 つの現象が必要と考元られ，特に高率な癌 化傾向を示す疾患では癌抑制遺伝子の果たす役割 が大である胞状奇胎は 1 精子受精・雄性発生及び 2 精子受精・雄性発生により生ずるが, いずれの 場合にも対立遺伝子間で多数の木モ接合が形成さ れるため, 体細胞分裂以前に生じた癌抑制遺伝子 変異も木モ接合形をとることになり劣性形質であ っても表現可能となる。てのてとは胞状奇胎の癌 化に癌抑制遺伝子が関与する可能性を示唆する。

われわれはヒト正常線維芽細胞由来の染色体移 入により,ヒト絨毛がん細胞株（CC1）における 腫痬形成の抑制に係わる染色体の同定を試みた。 $\mathrm{pSV} 2$ neoによって標識した 1 番, 2 番, 7 番, 9 番, 11 番染色体を含むマウス A 9 細胞クロ一 ンょり微小核を形成し, C C 1 と微小核融合を行 って，それぞれにつき 2 個から 11 個のG 418 耐性クローンを得た。得られたクローンをヌード マウスに移植し，その造腫痬性を親株（CC1）と 比較検討した。その結果， 7 番染色体を含むA 9 クローンより得られた 4 クローンのG 418 耐性 微小核融合細胞のうち，2 クローンに扔いて造腫 痬性の完全な抑制, あるいは潜伏期の延長が認め られた。他の染色体を移入したクローンについて は, 親株との差を認めなかった。従って 7 番染色 体上に, C C 1 の造腫痬性抑制に係わる遺伝子の 存在が示唆される。
II -5.

\section{非妊娠性䄉毛癌の細胞生物学}

\section{千葉大学医学部産婦人科学教室 \\ O関谷宗英 (MD)}

䋐毛癌は主として娃娠性絨毛癌であるが，稀に 卵巣から非妊娠性䄉毛癌が発生する。卵巣から発 生する䄉毛癌は, 未分化胚細胞腫, 奇形腫などが 混在する混合型が多い。

今回, 原発巣注卵巣の未分化肧細胞腫で, 転移 巣 ( 傍腹部大動脈リンパ節) が䄉毛癌であった非 妊娠性䋐毛癌の 1 症例を呈示し, ヌードマウス移 植腫場組織から樹立された培養細胞株 (IMa)の 特徵を, 組織発生および細胞生物学から検討を加 えた。

症 例

25才，未婚，0 回経妊の患者で, 超音波断層法 で卵巣の充実性腫瘍, 術前血中 LDH 1,470 IU/ml, hCG $360.4 \mathrm{mIU} / \mathrm{ml}$, AFP $330 \mathrm{ng} / \mathrm{ml}$ と高値であ

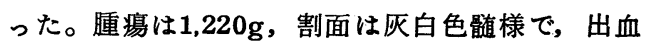
巣, 壊死巣が認められた。タッチおよび腹水のス メアから未分化胚細胞腫が疑われた。病理組織猃 は約100個のブロックすべて単一型未分化狉細胞 腫で, 血中 hCGの再上昇と共飞, 傍腹部大動脈り ンパ節の転移と診断・リンパ節転移巣を切除した。 病理組織診は䄉毛癌を疑わせる所見で, 更に质範 な転移により死亡した。

ヌードマウス異種移植

リンパ節転移巣は BALB/Cヌードマウスに生 着し, 組織診仕䄉毛癌で, cytotrophoblast 主体で,一部に syncytial ce11 が認められた。 培養細胞株 ( IMa )

1）小型多形角細胞が主で, 一部に多核巨細胞 が出現する。2）電顕所見では，N/C 上上 大で, 細胞間結合は発達し. 微䋐毛が存在, 払張した小 胞体が認められた。3）染色体は51〜 59に分布し， 低 3 倍体にモードを認めた。4）hCGおよびサブ ニニットを分泌した。 
৩シンポジウム[III]

シ III-1.

漿膜の特殊な構造とその意義について

東京医科大学病院病理部

海老原 善郎

1)標本作成上の問題が解決された上でも, 体腔液 中にオレンジG好性細胞が稀に出現する. 2)中皮 畽之区別されるべき腹膜原発の腺癌がある. 3)体

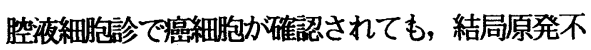
明となる例がある. 4) pmまでの胃癌でも，すでに 腹膜癌症を来していることがある.このような奇 異な現象を説明しうる組織学的裹付けが, 漿膜組 織 主として横隔膜の腹側にあることを述べる. 漿膜表面が扁平上皮に置きかわることはごく稀 で,これまでに, 剖検材料および生検材料の中に 見出された漿膜の扁平上皮巣は数例にすぎない。 横隔膜の保存された剖検例の連続185 例のうち, 18例に腹側の漿膜下に小さな囊胞が見出された。 これらは, 組織学的に 3 型に分類される. 中皮型 (11 例), Walthard(以下, W) 型(3例) および内 肧菒型(4例)である. この他，肝組織も2例に認 められた。このうち, W型のものは子宮付属器の 漿膜下のものと同様のものであるが, 横隔膜のも のは男性例にもある. 䣼素抗体法でW型と内胚葉 型のものはCA-125, CEA に陽性である. これらと 体㓐表面との連続性は証明さていないが，W上皮 巣は中皮との連続性がある. オレンジG好性細胞 が角化を意味すれば, その起源は単一でないかも 知れない.

腹膜湟症はその程度により，a)横隔膜の漿膜下 リンハ槽に癌細胞塞栓として認められるもの，b) 播種像が横隔膜腹側に限局するもの, およびc)定 型的播種像を示すものとに分類される.これは原 発癌の深達度とは関係なく, 腹㓐以外の脿器, 例 えば陰茎癌でも起こる. 問題3)，4）には，腹䐗と の間にstoma をもつリンハ槽の発達した横隔膜腹 側の特別な構造か関係していると考えられる.
シ III-2.

体腔液細胞診におりる抗中皮抗体の 応用一悪性中皮腫と腺癌との鑑別を中心に一

山口県立中央病院病理科 亀井敏昭 (MD)

目的：我々は剖検時に心震中皮を採取し，その 中皮に対するモノクローナル抗体を作製し，中皮 と特異的に反応する抗体を見出し, 報告した。 今回は悪性中皮腫 5 例之臨床的に中皮腫を疑い, 種 々の検索の結果腺癌之診断された 6 例の体腔液 細胞診に扔いて抗中皮抗体(KM 277)の検討を行な うと共に, Keratin, Vimentin, CEA, EMAなど の抗体についても検討し, 両者の鑑別における有 用性を述べる。材料及び方法：悪性中皮腫 5 症例 之上述した腺癌 6 症例の体腔液検体を用い, 抗中 皮抗体を含め, 5 つの抗体により免疫細胞化学的 検索を行った。また，セルブロック標本について あ可能な範囲で検討した。結果：悪性中皮腫では 5 例共に, 腫瘍細胞は抗中皮モノクローナル抗体 に陽性ないし弱陽性を示し，セルブロック標本で あ同様であった。他の抗体は Keratin, Vimentin, EMA は程度の差てそあれ陽性で, CEA は陰性で あった。一方, 中皮腫を疑うあ腺癌と診断された 6 例は抗中皮抗体陰性, EMA 陽性, Vimentin は 2 例を除き陰性であり, CEAは 5 例で陽性であっ た。また, Keratin は陽性, 弱陽性, 陰性など症例 により態度が異なった。考察：体腔液細胞診にお ける腺癌と悪性中皮腫の鑑別は困難な症例が多く， ヒアルロン酸の証明, 電顕的には微絨毛や中間型 フィラメントの発達などの所見, 各種マーカーの 検索, 殊にKeratin, Vimentin の証明が参考に なることが多い。今回の検討では問題となる細胞 の EMA 陽性所見が癌あるいは中皮腫を示唆して おり, その上で, 問題となる細胞の中皮性格を証 明できれば，悪性中皮腫の診断も可能であり，上 に述べたヒアルロン酸の証明, 電顕的特徽に加え, 抗中皮抗体の使用がその一助となるあのと考える。 
密細胞と非密湅胞の鑑別

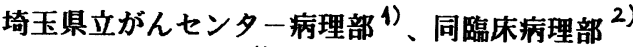
O高山昇二郎 $(M D)^{1)}$ ，松井武寿 $(C T)^{2)}$ 、保泉 恵子(CT $)^{2)}$

体沿液の細胞診にあたっては、大食細胞、中 皮細胞、癌細胞の籃別に苦虑する事がしばしば あり、多くの研究が行われている。我々も非密 細胞、特に中皮細胞と㠅細胞との鑑別について 手掛をさぐってみた。

対象は当センターで体烨液の細胞診を受けた 768例である。検体俚胸水 1149 ，腹水588，心囊 水79, 計1816件である。これらのパパニコロー、 マイ・ギームザ、PAS、アルシアン青染色塗 抹標本について、クラス分類と推定組蟣型を再 検討した。この際、試験切除標本と手術摘除標 本の診断と槳膜侵襲の有無、剖検時の播種の有 無を参考にした。免疫染色の重瘍マーカーには CEA, B F P, SC, C A 19-9, C A-50、 S C C ， S T-439 を用いた。

塗抹標本を再検討した結果、中皮細胞と䄆細 胞を鑑別する際には、次の点に留意するとよい 之思われる。

1. 鑑別が易しい場合はパパニコロー染色で充 分であるが、難しい場合はギームザ染色標 本を詳練に観察する。

2. ギームザ染色標本で中皮細胞を含む異型細 胞を観察した時に、細胞が形態学的に段差 のある 2 群に分けられる時は癌細胞がある とされるが、分けられない時は、多少異型 性の強い細胞があっても、癌細胞はないと 判断する。

3. 既往生検の組織型を念頭におく。

4. 粘液染色の他に、C E Aと S C を畽瘍マカーとする免疫染色が鑑別に役立つ。
胸腹水中に出現する腺癌細胞集塊から の原発巣の推定

藤田学園保健衛生大学医学部病態細胞

○高村幸弘 (MD)

種々の悪性腫瘍患者で眝溜した胸腹水中に癌細 胞集塊が出現することは，良く認められることで あり, 頻度の高いのは腺癌である。我々は, 胸腹 水中に出現する腺癌細胞集塊の形態，性状等によ り原発巣の推定がどの程度可能であるかを明らか にする目的で, 胸腹水の貯溜した癌患者症例にお いて各症例でとに腺癌細胞集塊を各々無作意に50 個づつ以下の点につき検索した。尚比較した症例 は, 肺癌, 乳癌, 胃癌, 胆囊癌, 胆管癌, 膵癌, 大腸癌, 卵单癌である。(1)癌細胞集塊の細胞数及 び集塊の長径，短径，(2)癌細胞集塊の形態，(3)集 塊の重積性，(4) 1 集塊中に打ける核の最大径，最 小径，(5)核小体数及び大きさ，(6)核縁の肥厚，(7) クロマチンパターン，(8)背景の状態，(9)癌の組織 型。以上につき各々原発臓器別にま之め比較検討 した。尚一部の症例に扔いては, 免疫学的検索も 行った。

結果及び考察：(1)集塊の形態; 彗状集塊は種々 の癌に出現するが, 乳癌において特に高率に認め られた。乳頭状集塊は, 肺癌, 卵巣癌では非常に 高率に, 胃癌, 大腸癌, 乳癌, 膵癌であ認められ た。(2)細胞数50個以上の大集塊は, 乳癌に最も高 率に認められた。(3)核の大きさは, 肺癌, 大腸癌, 卵巣癌が大型, 胃癌, 膵胆管系の癌では小型であ った。(4)核小体は, 肺癌, 大腸癌で比較的大型の あのが, 膵胆管系の癌では小型のあのが目立った。 (5)核縁の肥厚，クロマチンパターンについては原 発臟器別に有意な差異は認められなかった。以上 の様に原発蔵器別に計測した結果, その特徴から 若干の差異を認め, ある程度原発巣の推定は可能で あった。更に免疫学的検索も診断する上で, 補助 的役割として有用であった。 
III -5.

婦人科悪性腫痬にわける腹腔洗浄細胞

診の意義

近畿大学医学部産料婦人科学教室

O池田正典(MD), 小畑孝四郎 (MD), 吉岡忠亮 (MD), 伊藤耕造 (MD), 井上芳樹 (MD), 野田起一郎 (MD)

近年, 腹腔洗浄細胞診 (以下P. C.と略) は卵栄 癌, 子宮体癌においてはその臨床的意義が認めら れつつあり, 臨床進行期分類にも取り入れられて いる。しかし子宮䫇癌においての P. C.の臨床的意 義についての検討はあまりなされていない。そて で今回, 当科で開腹手術を行った卵巣癌 112 例, 子宮体癌 95 例, 子宮頸癌 185 例についてそのP.C. の成績と長期予後との関連を調べ, 予後の推測あ るいは治療方針の決定におけるP. C.の有用性につ いて検討した。その結果, (1)卵巣癌においては, I 期 29 例中 P. C. 陽性例は 6 例でそのうち 3 例が再 発, 死亡した。一方 P. C. 陰性例 23 例中再発, 死亡 した症例は 1 例であった。(2)子宮体癌症例 95 例 中 P. C. 陽性例は 28 例であり, 陰性例 67 例に比し, 長期予後は不良であった。組織学的分化度との関 係についてみると低分化型が $50 \%$ と最も陽性率が 高かった。さらに筋層浸潤の程度と P. C. 陽性率と の関係をみると, 浸潤 $1 / 3$ 未満の症例においても 53 例中 13 例 $(24.5 \%)$ r.C. 陽性例が認められた。 (3)子宮頸癌 Ib, II 期症例のうち p TNM 分類で $\mathrm{T}_{1}$ に 属するものには P.C.陽性例はなかった。浸潤様式 との関係をみるとCPL分類では L 型にP.C.陽性例 が多い傾向がみられた。リンパ節転移との関係を みるとリンパ節転移のない症例でも P. C. 陽性例が 認められた。そして P. C. 陽性例の長期予後は陰性 例に比し不良であり, 再発例の病態は癌性腹膜炎 の再発様式をとる症例が多かった。

以上, P. C. は卵巣癌, 子宮体癌のみならず子宮 頸癌においても, その予後の推測あるいは治療方 針の決定に重要な臨床的意義を有すると考えられ た。

\section{〉教育シンポジウム}

教シ-1.

疑陽性と判定された肺非癌症例の細胞

形態学的検討

北海道大学医学部附属病院病理部

○遠藤隆志 ( C T ), 井上和秋 (MD)

北海道大学医学部第 1 内科

阿部庄作 (MD )

呼吸器細胞診の診断技術は年々向上している。 しかし, 疑陽性の判定基準は不明確な点が多く, 統一されたものがなく，施設によってさまざまで ある。特に非癌肺疾患にみられる異型細胞の判定 は困難な場合があり, 時に癌細胞と疑診されるこ ともある。実施臨床細胞診断の場では, このよう な細胞のより明確な判定基準の確立が望まれる。 今回, 我々は細胞診で疑陽性と判定されたが, 臨 床診断, 病理組織診断で明らかに非癌とされた肺 疾患 137 例 (昭和 54 年〜 63 年度 )についてそ の細胞形態を分析検討した。

（対象）：A群：炎症性肺疾患 56 例, B群：慢 性閉塞性肺疾患 39 例, C群 : 間質性肺炎 17 例, $\mathrm{D}$ 群：良性腫瘍 4 例, $\mathrm{E}$ 群 : その他 21 例の喀疢, 気管支擦過標本を用いて検討した。

（成績）：A群からE群に分けて，その細胞診所 見を分析すると, 異型扁平上皮化生細胞と異型過 形成細胞が各群に共通して認められた。異型扁平 上皮化生細胞は喀痰に多く認められ，その中に， 散在性に出現し，核は増大ぎみで類円形から不整 形を呈し, クロマチンの増生, 不均一な分布, 胞 体はエオジン, オレンジに好染しやや重厚感を示 したものなど扁平上皮癌と粉らわしい細胞は特に A群に多かった。

一方, 異型過形成細胞は, 喀痰と気管支擦過標 本に共通して認められ，その中に，比較的細胞密 度の高い集団が出現し，腺様配列，核の増大，小 型の核でも大小不同，不整（きれ込み状）を示し， 明瞭な核小体を有し, クロマチンは徵細から細顆 粒で増生ぎみのものなど腺癌と粉らわしい細胞は 特にA群とB群にみられた。これらの細胞のNucleolar Organizer Regions (NORs) の染色 性についても検討したので併せて報告する。 
教シ-2.

喀痰における腺型細胞の判定困難例

（誤 (疑) 陽性、誤陰性) について

藤田学園保健衛生大学衛生学部 病理 ${ }^{1}$, 同大学 病院 病理 $^{2}$, 同 総医研病態細胞学 ${ }^{3}$, 愛知県 がんセンター病院 ${ }^{4}$,

舟橋正範 $(\mathrm{CT})^{1}$, 平沢 浩 $(\mathrm{CT})^{2}$, 黒田 誠 $(\mathrm{MD})^{2}$ 溝口良順 $(\mathrm{MD})^{2}$, 社本幹博 $(\mathrm{MD})^{3}$, 田嶋基男 $(\mathrm{MD})^{3}$ 蒲 貞行 $(C T)^{4}$, 栗田宗次 $(M D)^{4}$

喀痰細胞診における良性の腺型異型細胞は肺梗 塞症、肺結核症、慢性気管支炎等で出現し、特に 高分化型の乳頭状腺癌、細気管支肺胞上皮癌細胞 と鑑別困難な細胞像を呈することがある。

我々は喀痰細胞診で誤陽性あるいは疑陽性、誤 陰性と診断した症例の腺型異型細胞について検討 をした。

症例 : 症例は臨床的に肺炎、肺癌の疑いとされ、 胸部X線は肺野に異常陰影像を全例に認めた。誤 陽性とした症例は治療により異常陰影が消失し、 症状が改善し、その後異型細胞が出現しなくなっ た 11 例、誤陰性とした症例は症状が改善されず 繰り返し検査した結果、細胞診および組織診によ り腺癌と確定した 10 例である。

結果 : 誤陽性とした症例の最終診断は肺結核症 2 例、気管支炎 8 例、肺梗塞症 1 例であった。誤 陰性とした症例は高分化型の乳頭状腺癌、細気管 支肺胞上皮癌であった。䛊陽性とした細胞は変性 異型円柱上皮、基底細胞增生、肺胞上皮細胞の過 形成（腺腫様増生）等を誤認していた。主な細胞 所見 : 誤陽性例はN/C 比大、核の大小不同、核縁 の肥厚、不整核小体等を認めたが、明らかな細胞 相互のクロマチン像の差は見られなかった。誤陰 性例ではN/C 比は小さく、核の大小不同やクロマ チン増量は軽度で、核縁の切れ込み等の不整は少 なく核異型に乏しかった。異型性が弱い症例は疑 陰性になることが多く高分化型腺癌を念頭に置き、 細胞配列、核、核小体等について細胞相互を比較 し、細心の注意を払い観察する必要がある。
教シ-3.

\author{
喀痰における扁平上皮型細胞の判定困 \\ 難例について
}

大阪府立羽曳野病院病理診断科

○横山朝夫, 相野美栄子。竜野由美子

細野芳美, 森野英男, 菊井正紀

呼吸器系細胞診においてあ疑陽性の報告をでき

るかぎり少なくすべきである。

今回私に与えられたテーマは「喀痰における扁 平上皮型細胞の判定困難例について」である。

悪性腫瘍のスクリーニングに際して、検鏡時ス ライド中に存在する腫瘍と思われる細胞が変性し ていたり、数が少なかったり、組織学的にも境界 病変であったり、又、悪性細胞であるのに確定で きなかった場合がある。

当院の S 63 年 ( $1 \sim 12$ 月) の喀痰細胞診の 件数は 4,651 件で、その内訳は陰性 4, 250 件 ( 91 \% )、疑陽性 122件（ $3 \%$ )、陽性279件（6\%) で あった。

今回、疑陽性 122 件中扁平上皮型と思われる73 件について、一定の条件をきめ、当院の 4 名のス クリーナが、同一のスライドを再検鏡し、陰性、 疑陽性、陽性に区分した。

条件としては、特に重要と思われる、細胞の多 形性、細胞質の染色性、N/C比、核クロマチン 像、背景などについて検討した。

尚、陰性、疑陽性、陽性に区分した細胞につい て、組織診との関係屯調らべたい。 


\section{教シ-4.}

気管支擦過標本に於ける疑陽性例の

検討

長崎県総合保健センター 浦上具子

喀痰細胞診は検体採取の容易な事などにより、 肺癌の検查に欠かせないが、気管支内腔の狭窄、 閉塞がある場合、腫場があったとしても陽性率は 低く、他の方法に診断を委ねなくてはならない。 これに対し、気管支ファイバースコープによる検 索は、禁忌、合併症の問題があり、施行するため の設備、技術などを要するが病巣擦過細胞診、経 気管支肺組織生検、気管支洗浄細胞診などが肺疾 患の確定䛦断を行う上で必須のあのとなっている。 今回気管支ファイバースコープ下より得られた気 管支擦過細胞診標本に抢いて、疑陽性（Ｃ１ａｓ s III) と診断された症例の細胞学的検討と診断精 度上の問題点の検討を試みた。症例は最終結果が 非癌例 7 例（結核 4 例、肺炎 3 例) 癌例 19例（扁平 上皮癌 8 例、腺癌 7 例、他 4 例) 計 27 例である。

精度上の問題点として検査サイドと臨床サイド に分ける事ができる。検査サイドでは標本作成行 程での過染、脱水不良、自動染色装置を使用した 場合では器械のメンテナンスなどが考えられる。 鏡検については個々の能力向上を目指し研修に励 み鏡検体制の充実を計る。臨床サイドにおいては 内視鏡操作に熟達した医師が正確に病変部より細 胞採取を行う技術や適切なガラスへの塗抹、固定 が要求される。また両サイド間の問題としては相 互の理解、協力及び情報交換などが必要である。

細胞所見では癌例及び非癌例において、異型を 認めた細胞は扁平上皮化生細胞、再生上皮細胞、 活動性気管支上皮細胞之思われた。細胞像の特徴 は化生細胞では細胞質の染色性の増強、核不整、 核濃染が目だつ所見であった。再生上皮及び活動 性気管支上皮では細胞及び核の増大、核の大小不 同、核小体の増大、増加が認められた。細胞以外 の誤診因子として塗抹に於ける固定不良による細 胞の膨化変性や細胞の出現数がそしいことであった。
教シ-5.

\section{肺癌集検における喀疢細胞診の誤陰性 誤陽性、疑陽性例についての検討}

宮城県対がん協会細胞診センター ○中嶋隆太郎（C T ）、佐々木麻弥 ( C T )

伊藤 圭子 $(\mathrm{CT})$ 、東岩井 久 $(\mathrm{MD})$ 東北大学抗酸菌病研究所外科

佐藤 雅美 $(M D) 、$ 斎藤 泰紀 $(M D)$

藤村 重文 (MD)

南東北病院

佐藤 博俊 $(\mathrm{MD})$

短期間に多数の検体を取り扱う集団検診におい て、判定の精度を維持することは極めて困難であ る。まして、婦人科領域にみられるような系統的 な考え方の確立していない呼吸器ではなおさらで ある。

演者等は、老健法の肺癌検診と同様に結核検診 の一般住民検診に、肺門部肺癌の高危険群に対す る喀痰細胞診の併用による検診を、昭和 57 年度よ り開始し現在にいたつている。

検診は、昭和 57 年度より 61 年度までの 5 年間に 延べ45,865名に喀痰細胞診を施行し、Class I 848 名(1.8\%)、II 34,742名( 97.6\%)、III 146名(0.3\%) IV 54名(0.1\%)、V75名(0.2\%)であつた。

Class III 以上と判定された症例については、受 診歴を調査し前回までの標本を再度検鏡している

また、ClassIV・V と判定され癌が確定されな かった症例については追跡調査を行っている。

その結果、扁平上皮癌と確定した症例のうち 32 例の前回受診時喀痰標本を再評価し 5 例に誤陰性 が、また、ClassIV・Vと判定された 149例中23 例の未確定例についてその理由を調查し11例が過 大評価の可能性が示唆された。

誤陰性、誤陽性の原因としては、標本そのもの によるもの、人為的なもの、系統的な考え方が確 立していないこと等が考えられる。

早期癌を多く発見するためには、異型の弱いも のでも積極的に読み込む必要がある。 
教シ-6.

集細胞法における誤陽性例の解析

東京都予防医学協会細胞診断科 ${ }^{11}$,

東京医科大学外科 ${ }^{2)}$.

名古屋第二赤十字病院検査部 ${ }^{3)}$

○杉山田隆男 (CT $)^{11}$, 武智昭和 (CT $)^{11}$,

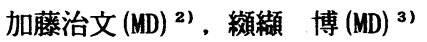

肺門部早期肺がんの発見のために喀痰細胞診検 查が第一次スクリーニングの基礎であるばかりで なく, 欠かせない要因の一つであり, 日常診断業 務において大いにその価値を発揮している。しか し, その反面各種要因により誤診は免れ得ず，い かにして減少させるか, その際路を打開すべく今 回は誤陽性と考えられる扁平上皮, 腺上皮系細胞 を中心に細胞の解析を試みた。判定はA〜 E 5 段 階分類を用い集細胞法処理により Pap染色を施し た。対象は当施設における会員制検診（I群）。 医療機関施設依頼検診 (II 群) , 行政・事業所等 の集団検診（而群）において喀痰細胞診判定 Dお よびEについて, I 群からの検討症例は, 全例国 立がんセンターの精査により異常のないことが確 認されており，その他の症例は追跡結果報告書に より異常なしとの結果を得ているもので, その後 3年以上経過し特に異常を認め得ないものを対象 に1975年〜1986年の12年間について検索した。

総検査実施数 50,441 件中, D 543 (1.08\%), E 478 (0.95\%) の結果を得，Dについては悪性疑いとし た22例（I 群11例・II群 7 例・III群 4 例）, E 13 例（I 群 1 例 - II 群12例）について解析した。そ れぞれの標本について標本背景, 出現様式, 核お よび細胞質所見, その他について日常の診断業務 に応用できるようにとの立場から細胞学的解析を 試み, 陽性症例細胞像との比較検討も合わせて報 告する。
৩ワークショップ[I]

ワ I -1.

ヒトパピローマウィルス感染の細胞診 判定基準

癌研究会附属病院婦人科 1), 同細胞診断部 2 )

○手島英雄 $(\mathrm{MD})^{1)}$, 2), 古田則行 $(C T)^{2)}$

ヒトパピローマウィルス (Human Papillomavirus, 以下 HPV) は, 尖圭コンジローム・子宮頸部 および胵・外陰の前癌病変, 子宮頸癌および胵癌 ・外陰癌に関係するウィルスとして近年注目され ている。細胞診断上, HPV 感染を示唆する所見と しては(1) Koilocytosis, (2) Parakeratosis, (3) Smudged nucleus, (4) Giant cell, (5) Multinucleation, (6) Condylomatous parabasal cell, (7) Amphophilia 等が挙げられている。細胞診で HPV感染を推定 する際に, どの所見を重要所見とするのか, どの 所見の組み合わせがあれば HPV感染と診断可能か についての consensusが現在得られていない。例 えば, HPV 感染細胞所見として特徴的な Koilocytosis の出現率は我々の検討では $60 \%$ であるのに対 して, 数\%２5\%とする報告す散見される。そて で, Southern blot hybridization法をはじめとす る分子生物学的手法でHPVゲノムの証明された症 例について, その細胞像を評価し, 各HPV感染細 胞所見の出現率を検討した。対象は尖圭コンジロ 一ム, 子宮頸部の mild severe dysplasia とした。 parakeratosisは100\%出現し, koi locyt os is $60 \%$, smudged nucleus $60 \%$, multinucleation $63 \%$,

giant cell $21 \%$, condylomatous parabasal cell 28 \%, amphophilia 55\%であった。てれらのてとか ら HPV 感染を細胞診で診断するための組み合わせ の検討や score化あ試みた。又, HPVゲノムの証明 されない症例に明らかな HPV感染細胞所見があり, これは現段階での分子生物学的手法の限界のため と考えられる。細胞診ではHPV感染を広く screening 出来る可能性があり, 細胞診と分子生物学的 手法による結果とを対比し, HPV 感染細胞像の基 準を確立することは意義あるものと考えられる。 
ワ I -2.

子宮顠部病変におけるHPV DNAの存 在とその細胞像

\section{佐賀医科大学産婦人科学教室}

○岩坂 剛(MD), 横山正俊 (MD), 原 浩一 (MD)

，林 嘉信(MD)，大隅良成(MD)，蜂須賀徹 (MD)

, 杉森 甫 (MD)

HPV感染症の細胞学的および組織学的診断には koilocytosis が特徵的所見として取りあげられ ているが、その出現頻度やHPV感染症検出上の意 義について詳細に検討した報告はまだ少ない。 今回、我々は以下について検討を加えた。1）細 胞診、組織診の両者におけるkoilocytosisの出 現頻度の比較。2) in situ hybridization法に よるCIN病変におけるHPV DNAの局在。3）HPV D NA陽性および陰性のCIN病変から採取された細胞 像の比較。（対象亡方法）佐賀医科大学産婦人科 において1986年以降に取り扱ったCIN患者を対象 とした。in situ hybridizationにはビオチン標 識HPV 6/11,16/18,31/33/35型DNAを用い、細胞 診標本中のHPV DNAの検出には $\mathrm{P}^{32}$ 標識HPV 6/11 /16/18/31/33/35型RNAを用いたdot blot hybri dizationを行った。（成績およびまとめ）(1)組 織標本におけるkoilocvtosisの出珼頻度はCINの gradeが進むにつれて低くなることが観察され、 HPVのlytic infectionからlatent infectionへ の移行が示唆された。(2)koi locytosisは細胞診 標本より組織標本に、逆にdyskeratosisは組織 標本より細胞診標本に多く出現する傾向がみら れ、HPV感染症診断におけるdyskeratosis検出の 重要性が示唆された。(3)in situ hybridizati onでは主に表層から中層におけるkoilocytosis の核に一致してHPV陽性所見がみられた。さらに 同じCIN病変であ koilocytosisで代表される HPV 感染に特徴的とされる細胞所見はHPV DNA陽性の 細胞診標本において高頻度に認められた。この 観察事実はこれらの細胞所見がHPVの増殖による 二次的変化であることを示唆している。
ワ I -3.

尿中に出現するパポバウィルス感染細 胞について

久留米大学第二病理 ${ }^{1}$, 聖マリア病院 ${ }^{2}$

○入江康司 $(M D)^{1}$, 伊藤園江 $(C T)^{2}$

尿中にみられるウィルス感染細胞の多くはパポ バウィルス群のポリオーマゥィルス属といわれ, ヒトから分離されたポリオーマウィルスにはBKV, $\mathrm{JCV}$ およびSV - 40がある。今回, 尿中ウィルス 感染細胞につき検討する機会を得たので報告する。

対象および検索方法: 対象は尿沈渣の

Sternkeimer染色で異型細胞とされ, 更にパパニ コロウ染色でウィルス感染細胞と同定された 40 例 で，5例は 5 才以下の小児例，35例は成人で，そ の半数は 60 才以上の人間ドック例である。細胞診 的検索に電顕的観察を行い, さらにSV-40のT 抗 原に対する免疫酵素抗体法执よび分子生物学的 DNAの検討を併せ行った。

結果 : ウィルス感染細胞の細胞質はライトグリ 一ンに淡染し，核は11〜 18 $\mu \mathrm{m}$ で円形〜類円形, $\mathrm{N} / \mathrm{C}$ の増大を認めた。核内はスリガラス状を呈 し, 鳥の目状, 核崩壊状のあのあ散見され, また 細胞質内封入体をもつ細胞が全例に認められた。 電顕所見では30 40 nmのウィルス粒子が核内に 結晶様配列, 索状〜渦巻状配列でみられ, 高度変 性細胞では細胞質内空隙にも認められた。脱色標 本によるSV-40のT 抗原に対する酵素抗体染色で は，小児の 3 例が細胞質に陽性(核内は不明)で, 残る全例陰性であった。分子生物学的には，尿沈 椬を使用し，20merのオリゴヌクレオチドを作製 し，PCR法によりBKV(Dun)の 4392〜4567 領域 の増幅を 4 例に行い， 170 塩基相当のDNAを全例 に得た。 
7 I -4.

リンパ節のウイルス感染症

藤田学園保健衛生大学医学部病態細胞

○社本幹博 $(M D)$, 伯野 卓 $(M D)$, 中村耕治(MD), 野本和孝(MD)

リンパ節のウイルス感染について次の 4 項目に ついて述べる。1）種々のウイルス感染によるウ イルス性リンパ節炎，2）ウイルスもその原因の 一つ之考えられてはいるが原因不明の壊死性りン パ節炎，3）AIDSウイルス感染時の腫脹リンパ 節，4）ウイルス感染がその原因と考えられてい る悪性リンパ腫 $(M L) 。$

1)についてはEBウイルスによる伝染性単核症 ( IM)，ヘルペスウイルス (HV)，サイトメガロ ウイルス (CMV) 等が代表的なあのである。共 通な所見としては免疫芽球の増加, 異型リンパ球 の出現があったが, 異型リンパ球については I M おいて最も顕著であり，悪性リンパ腫との鑑別を要 した。喀痰, 尿細胞診等でしばしば認められる HV, CMVによる核内封入体像の検出は極めて稀であり, また細胞診標本のみから病原ウイルスを同定するこ とは不可能であった。2)ではやや異型性のある Tリ ンパ球の出現が特徴であり, MLとの鑑別が時とし て困難であった。壊死物質の存在，リンパ球自体に あ変性のあること, 好中球浸潤の認められないこと 及び, 年令, 性, 腫脹リンパ節部位を十分考慮する 必要があった。3)急性リンパ節炎, 亜急性・慢性リン 八節炎があり，また種々の日和見感染が認められ， さらにはカポジ肉腫, 悪性リンパ腫の発生あある とされている（HE 標本を京大花岡名誉教授, 東 大森教授より借用)。4）EBウイルスによるバー キットリンパ腫, HTLV-1 ウイルスが原因とさ れる成人 $\mathrm{T}$ 細胞リンパ腫, 白血病がある。後者之 I M 細胞の核の不規則性については, 核の切れ込 み，核縁の彎曲性に相異があり注意して観察する 必要があった。

免疫学的, 電顕学的検索についても併せて報告 する。
7 I -5.

\author{
S T Dの細胞診 \\ 一 ヘルペス感染症を中心に -
}

産婦人科領域には，サイトメガロ，伝染性軟属 腫, 尖圭コンジローマ, ヒトパピローマ, AIDS, ヘルペス (HSV)ウイルスなどの感染症があり, これらは，またSTDの原因とあ考えられている。 これら疾患の多くに出現する細胞内封入体に関 して, 疾患に伴ういくつかの特徴が存在するため, 日常の臨床レベルにおいては，STDの診断には 細胞診があっとあ実用的であろう。

とくにHSVは，重篤で多彩な臨床症状に加え， 急性および再発感染, 産道感染や新生児ヘルペス の原因であり，性風俗を反映する疫学的関心から あ, 重要なSTDである。HSVの診断基準となっ ている巨大細胞の出現, 核内クロマチンの grey degeneration，核内封入体の形成などにつき， in vitroの実験を行ったところ, HSV感染細盷 は bionecrosis に至るまでに，これらのCPE を示すととを確認した。

HSV 感染細胞に対する抗ウイルス剂 (アシクロ グアノシン)，消毒剤(ポビドンョード夜）など の治療効果の機序を検討した。さらに，細胞にお ける感染防御のメカニズムとして考えられる内因 性インターフェロン（INF）の産生について, 治 療を目的として添加する場合の影響，および抗ウ イルス剤との併用におけるINFの効果について あ, 経時的, 形態学的な立場からいくつかの試み を行っている。 
ワ I -6.

眼科領域におけるウイルス感染の 細胞診

済生会滋賀県病院 検查部、眼科

○小林忠男 (CT)、植田正己 (CT)、佐藤史郎 (MD)

東京女子医大病院 眼科 高村悦子 (MD)

国立栃木病院 眼科、産婦人科

坪田一男 (MD)、長谷川寿彦 (MD)

関西医科大学 産婦人科 椹木 勇(MD)

【目的】眼科領域におけるウイルス感染症の診断 は臨床的にきわめて重要であるがその細胞学的検 索は比較的少ない。今回、我々はウイルス感染症 の内特に角膜へルペス ( H S K ) および流行性角 結膜炎 (E K C) の細胞学的診断について調べた ので述べる。

【方法】臨床的にH S Kの疑いのある 29 症例に ついて細胞学的および䣼素抗体法を用い検討した。 細胞材料は点眼麻较後頸管用ブラシ (サイトブラ シ、帝国䑏器）で潰場部を擦過しスメアを作成し パパニコロウ染色にて調べた。またヘルペス感染 細胞を有する所見また疑いを示す細胞に酵素抗体 ( HSV-PAP、オルソ社)にて確認した。E K C 1 0例に関しては結膜よりブラシで細胞採取 しパパニコロウ染色で観察し、一部材料はアデノ ウイルスのD N A 検索をインサイツ法で検討した。 又、同時にアデノウイルスの抗体検索も行った。 【結果】HSK 2 9例の内 20 例はへルペスの細 胞学的所見を認めたが䣼素抗体による検討では2 3例に陽性反応を認めた。陽性例の内訳は上皮型 潰掦（20例）、実質型（3例）であった。また、 $\mathrm{EK} \mathrm{K}$ 例ではリンバ球及び上皮変性像を中心とし た細胞反応で一部に明瞭な封入体も認めた。イン サイツ法でD N A 2 2例で確認された。

【まとめ】角結膜におけるウイルス感染症特に $\mathrm{H}$ S Kの免疫細胞学的診断は適切な細胞採取を行之 ば有効な方法と思われる。しかし、アデノウイル スのD N A 検索は細胞塗抹条件などを更に検討す る必要があろう。
ワ I -7.

各領域におけるウイルス感染症の細

胞診

国立循環器病センター病理

O岩 信造 (CT)、由谷親夫 (MD)、 今北正美 (MD) 、佐伯和則 $(M D)$ 、

栗島節子 (MD)，田原義孝 ( C T )

ウイルス感染細胞は各領域の臨床材料に出現し 封入体の特街所見からウイルスの類推が可能であ るが、より確定的にするには酵素抗体法、電顕等 の手法が有用である。今回、我々は臨床材料を用 い、各種ウイルス感染細胞の特徴所見について検 討を行った。

対象 : 婦人科 (HSV, HPV)、呼吸器 (HSV) 、胸水 (パルボウイルス)、尿（ヒトポリオーマウイル ス）、皮膚（伝染性軟属腫ウイルス）からのウ1 ルス感染練胞所見、酵素抗体法ならびに電顕学的 にも検索を行った。

結果：HSV感染細胞は多核巨細胞、スリガラス状 の核、cowdry A type 核内封入体が出現した。 HPV感染細胞は koilocytosis, smudged nucleus, dyskeratosisがみられ、酵素抗体法で抗原を検出 し、電影学的にもウイルス粒子を確認した。胸水 中に核内封入体を持ったパルボウイルス感染細胞 が出現し、モノクロナール抗体 (東北大学菅村和 夫博士より分与)により特異抗原を検出し得た。 尿中のポリオーマウイルス感染細胞は多彩な核内 封入体の出現が特徵的であった。伝染性軟属胜ウ イルスは細胞質内封入体が認められ、ホイルゲン 反応が陽性であった。

以上の如く、各種ウイルスにより特徵的な所見 がみられたが、䣼素抗体法や電影的観察を実施す ることにより確定的になると考えられる。 
৩ワーショップ[II]

ワ II $-\mathbf{1}$.

\section{膀胱腫瘍に対する細胞診の評価}

\author{
千葉県がんセンター 泌尿器科, 細胞診 \\ 長山忠雄 (M D) ， 池田栄雄 ( C T ) \\ 平田哲士 ( C T ), 宮内博幸 $(\mathrm{C} \mathrm{T})$
}

膀胱腫瘍の診断は、ほとんどが内視鏡的になさ れており，一般に細胞診は補助的手段として実施 されているにすを゙ない。従って, 泌尿器科医の細 胞診に対する関心は, 極めて低いと言わざるを得 ない。しかし，次に述べるような場合には，非常 に有用な診断方法である。第 1 は職業性膀胱癌で あり, high risk group $の$ screening 飞於ける 細胞診の有用性はすでに認められている。

第 2 は, いわゆる上皮内癌である。原発性上皮 内癌は稀な疾患であり, 膀胱鏡的には膀胱炎に類 似しており, 生検をしてる上皮の剥離が著しいて とが少くないため, 組織診断が困難なととがあり, この診断には細胞診が不可欠である。

第 3 は, 膀胱鏡検査が不可能な場合である。即 ち, 高度の膀胱出血を伴っていたり, いわゆる腫 瘍性膀腅炎などで膀胱容量が著しく減小している 例や尿道狭窄などの合併している例である。

第 4 は, 細胞診と生検結果に矛盾のある場合で ある。即ち, 生検診断が G1 であるにるかかわら ず, 細胞診で悪性度の高い細胞が認められる場合 である。同一膀胱に分化度の異なる腫瘍が同時に 存在していることがあり, 膀脱鏡的には良性の腫 瘍が優勢であるため, 過小評価されて治療適応が 決定される。第 5 は, 膀胱腫瘍治療後の follow- up である。膀胱保存的治療を実施した患者の30 50\%に 再発が認められるため, 定期的な注意深いfollow-up が必要である。しかし, 膀胱保存的治療の対象となる 腫瘍は, low grade 腫瘍が多く, 膀胖鏡的に腫瘍の存 在を確認でをても, 大部分は細胞診陰性false negative である。この false negative は臨床的に非常に意義 のあるものであり, 治療適応決定の際の重要な基 準の一つであると考える。最後は腫瘍類似疾患であ り，その鑑別診断には，細胞診は有用である。
ワ II -2.

膀腅腫瘍における尿細胞診の有用性

東京医科歯科大学泌尿器科 1 、帝京大学溝口病院

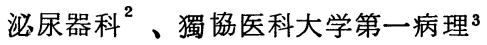

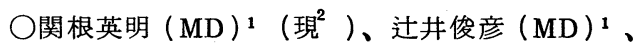
福井 䍩 $(M D)^{1}$ 、大島博幸 $(M D)^{1}$ 、横川正之 $(\mathrm{MD})^{2}$ 、山田 喬 $(\mathrm{MD})^{3}$

膀胱腫瘍における尿細胞診の重要性は既に広く 認識されているが、今回その有用性について改め て検討を加えた。対象は、最近 8 年間の膀胱腫 瘍で病理組織型が移行上皮癌であった 183 例で ある。方法は、自然尿約 $50 \mathrm{~m} \mathrm{l}$ をニュクリポア フイルターに吸引しパパニコラウ染色を施した。 尿細胞診判定基準はパパニコラウのクラス分類を るとにしたが、さらに核異型の程度、剝離細胞の 出現様式、大型悪性細胞の有無などを考慮してク ラスIII、N、Vkそれぞれ $\mathrm{a}$ と b の亜分類を設け た。クラス III a 以下を陰性、クラス III b 以上を陽 性とした。

(結果と考察) 尿細胞診陽性率は、腫瘍の grade あるいはstageとある程度相関したが、特に grade とクラス分類の相関が強く認められた。 $\mathrm{p} \mathrm{T}$ is 症例は $100 \%$ 陽性で、そのうち8 0 \%以 上がクラス $\mathrm{N} \mathrm{b}$ をたは V aであった。 $\mathrm{p} \mathrm{T} 2$ 以上 の浸潤癌ではクラス V a と V b が過半数を占め、 表在癌に比してV b の占める割合が高かった。 以上より、尿細胞診によって膀脱腫瘍の病理組織 像をかなりの程度まで推測でをると考えられた。 さらに、表在性膀脱腫瘍における悪性進展の予測 あるいは化学療法の効果判定などにおいてす尿細 胞診の有用性が認められたので併せ報告する予定 である。 
ワ II -3.

尿細胞診の診断的有効性とその限界

国立病院四国がんセンター臨床研究部

$\mathbf{O}$ 元井 信 (MD), 万代光一 (MD), 森脇昭介 (MD)

山内政之 (CT), 住吉義光 (MD)

尿細胞診は検体が得やすく, 反復して検査でき るため繁用される癌診療上重要な検査法の一つで

ある。当院において尿細胞診のおこなわれた症例 をもとにその意義と限界について解析したので報 告する。

検査方法はサコマノ液を用いて固定後Pap 染色 を施し, 陽性, 疑陽性, 陰性の判定をした。当院 で5年間(1985-1989年) に 565人 1484 検体の尿細 胞診がなされた。その目的は膀胱および上部，下 部尿路系腫瘍の発見, 治療後の追跡, 治療効果の 判定や前立腺その他の悪性腫崵の尿路系への波及 の有無の判定等を目的として検査されていた。

尿細胞診陽性は97例でその内訳は膀胱癌65例, 他の尿路癌, 尿路関連窝13例, 転移性癌11例, 誤 陽性8例であった。膀胱癌ではほとんどが移行上 皮癌で異型度 G2,3 の例は高率に陽性で, G1 で は細胞診陰性ないし疑陽性が多い傾向があった。 上皮内猺 6 例は全例陽性, 膀胱鏡検査では発見で きない症例が多かった。また、治療後の追跡では 細胞診は重要な役割をはたしていた。放射線療法 や化学療法の治療効果の細胞学的判定には森脇の 基準を利用しておこない有効であった。

上部尿路癌では尿管癌 $5 / 6$ (CIS 1 例), 腎孟癌

$1 / 1$ 陽性と高率であったが, 腎癌は 13 例全例陰性 であった。また，前立腺癌は $4 / 16$ 陽性で尿細胞診 陽性率は極めて低かった。下部尿路では尿道癌の 2 例で陽性であった。

他臟器の悪性腫瘍では骨盤内臓器である子宮頝 癌 $4 / 31$, 直腸癌 $1 / 7$ 陽性, 子宮体癌, 卵巣癌は全 例陰性であつた。骨盤外の臓器でも低率であった。 誤陽性例は尿路の炎症, 結石などの症例で 8 例 にみられ, 癌例で翼陰性の7例とともに細胞形態 を検討し診断成績向上に努めたい。

\section{II -4.}

自然尿細胞診と病理及び臨床所見

の対比

市立堺病院 中央検査部病理

花井 淳 (MD)

尿中の剥離細胞は，尿の高張性や含有物質の影 響を受け，細胞形態は変化し，かつ変性し易い。 その為，一般に尿細胞診の正診率は他領域のそれ と比べ必ずしも高くなく，殊に偽陽性グループの 正診率は問題として残されている。演者は 1980 年に自然尿細胞診の多数例について検索し，核の 大きさを尿細胞診断の際の主要因子として日本臨 床細胞学会雑誌に報告した。その際核クロマチン 構造や核小体も参考因子となるとするデータも加 えている。以来当院では原則的にはその報告に示 した判定基準により，診断を行ってきた。今回最 近 2 年間の自然尿細胞診の結果をまとめ, 病理組 織診断及び臨床記録との対比により尿細胞診の評 価を行った。尚当院では細胞診に際し 5 段階評価 を行っていて，吕度については悪性側の印象のも のを III b, 良性側を III a としている。今回検索対象 とした陽性症例は 161例である。V 度は49例(正 診率 $92 \%$ )，IV 度は 25 例( 正診率 $64 \%$ ), III b は5 5 例（正診率 $36 \%$ ) であった。尚残り 32 例は調査中 である。さてV度の誤陽性の症例では 4 例中 3 例， IV 度では 9 例中 6 例, IIIb で 36 例中 17 例に尿路結 石症や尿道カテーテル使用が認められた。残りの 誤陽性例は, 膀胱炎, 尿管, 尿道狭窄症, 良性腫 瘍などであった。従って尿細胞診の際かかる臨床 情報があれば判定に役立ち, 正診率の大巾な改善 が期待できる。尿細胞診の組織型では大多数が移 行上皮癌であるが，他では腺癌(前立腺癌 5 例， 大腸癌 3 例など）が多い。これら腺癌細胞をしば しば移行上皮癌と誤認する例があったが，標本の どこかに腺癌細胞の特徵を示す集団があり腺癌の 疑いの所見を記載した。その中で前立腺癌はク口 マチン掞く，核壮異型性が少い。大腸癌はクロ マチンが粗悎で, ときに細胞極性が認められた。 
ワ II -5 .

尿路系細胞診における新Sternheimer 染色法の再評価と技術的諸問題について

\section{国立熊本病院研究検査科}

○西 国広 (CT), 城後 博康 (CT), 小山 保廣 (CT) 佐々木 康雄 $(\mathrm{MT})$, 待鳥 泰浩 $(\mathrm{MT})$, 曾我 錠 $(\mathrm{MT})$

尿の細胞診は，尿沈渣の観察から先ず始めなけれ ばならない。何故なら, 沈渣の鏡検段階では出現し ていた細胞がパパニコロウ染色した標本では見られ ないといった事が非常にしばしば経験されるからで ある。

この細胞流出は, 乾燥メタノール固定によるギム ザ染色においても若干見られる。そこで, 尿沈渣中 の上皮細胞を観察する場合は新Sternheimer 染色( 新 $\mathrm{S}$ 染色) による鏡検で異型細胞の多くが診断可能 である事実より, 細胞診検査室での尿細胞診には尿 沈渣の見方（円柱の見方も合わせて重要）の再教育 と効率的な標本作製法の確立が重要と思われ，マニ ュアル化についての試みを報告する。

【方法】一般検査室および細胞診検査室に提出さ れた膀胱の移行上皮癌患者の尿を1500rpm (500G), 5 分間遠心後その沈渣を $10 \mathrm{ul}$ とり, 未染色生沈渣, 新 $S$ 染色, 迅速ギムザ染色, $Y \cdot M$ 固定Papanicolaou染 色 (Y·M·Pap.)，スプレー固定Papanicolaou染色 (S·P ap.) . 95\% エタノール固定Papanicolaou染色 (E·Pap ）につき癌細胞の標本付着率 (細胞保持率) を検討 した。

【結果】癌細胞保持率の最も良いのは新 $\mathrm{S}$ 法で, 次 に未染色生沈渣, 迅速ギムザ染色であった。 $\mathrm{Y} \cdot \mathrm{M} \cdot \mathrm{Pap}$. 法では保持率 $46 \%, \mathrm{~S} \cdot \mathrm{Pap}$. 法では $32 \%, \mathrm{E} \cdot \mathrm{Pap}$. 法では25\% であり湿固定によるパパニコロウ染色が いかに細胞の剥奪が多いかがわかった。 新 $\mathrm{S}$ 法で 診断可能であった尿路系の癌は, 移行上皮癌, 腺癌 (腎癌, 大腸癌からの転移, 胃癌からの転移)，徧 平上皮癌 (子宮頝癌からの浸潤) の細胞であった。

スライドにて, それら癌細胞の観察のポイント紹 介と尿細胞診の標本作製マニュアルについても述べ る。
ワ II -6.

膀脱腫瘍の尿細胞診の評価

\author{
北海道大学医学部第一内科 \\ ○宮本宏 (MD), 部宏 (MD) \\ 中島功雄 $(\mathrm{MD})$, 小倉滋明 $(\mathrm{MD})$ \\ 阿部庄作 $(\mathrm{MD})$ ，川上義和 (MD) \\ 北海道大学医学部必尿器科富樫正樹 (MD) \\ " 附属病院病理部 遠藤隆志 (CT), 荒川 \\ 三紀雄 ( $\mathrm{CT}$ ), 井上和秋 (MD) \\ 国立療養所道北病院 坂井英一 (MD)
}

過去 10 年間 (1977-1986) とおいて手術が行 われた膀胱腫場は 372 例 (乳頭腫 31 , 移行上皮

癌 321 , 扁平上皮癌 10 ，その他 10 ) で男 289 例, 女 83 例, 平均年㱓 62 歳である。その 5 ち 1 回以上, 尿細胞診が行われた（平均 5.9 回） 356 例の細胞診成績を解析した。

陽性率 (クラス V ) は平均 $48.9 \%$ あり 1977 -1981 ( $n=141)$ では 40.4\%, 1982-1986 （n=215）では $54.4 \%$ \%った。陽性症例の 91 \%が3回までの検查で陽性とされた。腫瘍深達度 別の陽性率は Tis $88.9 \%$, Ta $12.0 \%, T 1$ $41.2 \%$, T2 $75.8 \%$, T3a $71.0 \%$, T3b 9 $5.0 \%$, T4 $90 \%$,であった。 組織学的異型度別ではG1 $27.5 \%$, G2 $66.7 \%$ , G3 $85.3 \%$ \%むった。G1症例の判定クラス内 訳は I , II $27.5 \%$, III a $22.1 \%$, III b 22.9 \%であった。G1の III a および III b 判定が多 いことは，腫瘍細胞自身の異型度が少ないことを 示しており，これらの細胞の扱いを考慮する必要 がある。

尿中の腫瘍細胞に対して核小体形成部位蛋白( AgNOR）染色法を施行したところ, 組織学的異型 度が増すにしたがって染色数が増加した。 本染色法は膀胼腫瘍の細胞診の補助診断に有用で ある。さらに腫瘍の核DNA量を測定し, 細胞診 成績と比較する。 
৩ワクショップ[III]

7 III-1.

非腫瘍性の肺腫瘤性病変に由来する

異型細胞

筑波大学付属病院呼吸器外科 1 , 病理部 2 ○赤荻栄一 1 ( MD ), 木下朋雄 1 ( MD ), 湯浅洋司 1 (MD), 藤原 明 1 ( MD), 小川 功 1 ( MD ), 鬼 塚正孝 1 (MD), 三井清文 ${ }^{1}$ (MD), 深沢政勝 2 (CT), 小形岳三郎 2 (MD)

【はじめに】胸部 X 線写真上腫瘤陰影を呈する肺 病変は, すべて末梢型肺癌との鑑別が必要であり, その中には細胞所見も肺癌との鑑別が問題となる ものがある。従って, その細胞像を検討すること は重要である。

【対象と方法】当施設で経験した非腫瘍性の肺腫 瘤性病変のうち, 異型細胞を認めた 3 病変につい て擦過あるいは切除材料の直接塗抹標本を用い, その細胞像を検討した。

【結果】1）器質化肺炎：擦過標本上, 正常の円 柱上皮細胞に混じり，結合性に富む異型細胞集団 を認めた。異型細胞は淡い細胞質を持ち，核は類 円形やや大型で大小不同があり, 肥大した核小体 が目立った。腺癌を疑い開胸肺生検を施行し, 器 質化肺炎と診断された。2）肺硬塞症：擦過標本 にて, 平面的に配列する組織修復細胞様の異型細 胞集団を認めた。異型細胞は境界明瞭で厚みのあ る細胞質を有し，核は棈円形ないし類円形で，クロ マチン増量は軽度であったが, 明瞭な核小体を持 つものが多かった。肺血流シンチグラムにて肺硬 塞症と診断, 抗凝固剂投与で軽快した。3）炎症 性偽腫瘍: 切除肺からの直接塗抹標本上, リンパ 球や組織球に混じり, やや大型で核形不整があり 長円形核を持つ, 腺維芽細胞と思われる異型細胞 を認めた。組織診にて炎症性偽腫瘍と診断された。 【結論】腫瘤状陰影を呈する非腫瘍性の肺病変の らち, 器質化肺炎に認められた異型細胞は, 悪性 細胞との鑑別が最も困難であった。肺硬塞症では 組織修復細胞, 炎症性偽腫瘍では腺維芽細胞と思 われる異型細胞がそれぞれ認められた。
ワ III-2.

肺炎患者の喀痰に出現した診断困難で あった腺系良性異型細胞

国立療養所福岡東病院 ${ }^{1)}$, 九州大学医療技術短期 大学部 $^{2)}$

添田恭弘 $^{1)}(\mathrm{CT})$, 香月耕多 ${ }^{1 ｝ \text { ( } \mathrm{MT}) \text { ， }$ 境 $\left.\quad{ }^{1}\right)(\mathrm{CT})$, 豊原 弘 ${ }^{1)}(\mathrm{MD})$, 松崎義和 ${ }^{1)}(\mathrm{MD})$, 河野淳二 $\left.{ }^{1}\right)(\mathrm{MD})$, 前野茂樹 ${ }^{1)}(\mathrm{MD})$ ，石井 寛 ${ }^{2}$ (MD)

日常の喀疢細胞診において腺癌との鑑別が困難 な異型腺細胞に遭遇することがしばしばある。当 院にて昭和 59 年から平成元年までの喀疢細胞診 6827 例の中で経験した, 肺炎患者に出現した 良性異型腺細胞について, 画像解析装置での解析 を含めて検討したので報告する。症例は 6 例。2 例は肺化膿症で, クラスIVの腺癌を薙う細胞が出 現したが，その後軽快となり退院。現在まで 3 年 以上経過良好。他の 4 例は肺炎の臨床診断で経過 中。クラスIIIの異型細胞が出現したが，その後肺 炎は治癒し，2 年半から 10 ケ月にわたり経過良 好である。検討した母集団は良性対照として，異 型のない腺細胞集団から 22 個。悪性対照として 腺癌 154 個。良性異型細胞 132 個である。画 像解析の結果は, 良性群の平均核径 $9.9 \mu \mathrm{m}$, $\mathrm{N} / \mathrm{C}$ 比 $38 \%, \mathrm{~N} / \mathrm{N}$ 比 $3.9 \%$ 。悪性群では 同様に $11.5 \mu \mathrm{m}, 46 \%, 5.3 \%$ ，良性異型 細胞群では, $11.2 \mu \mathrm{m}, 47 \%, 6.3 \%$ あっ た。良性群と良性異型細胞群には， T検定で $3 つ$ の所見とも有意差があった。良性異型細胞群と悪 性群では核径， N/C 比には有意差がなかった。 $\mathrm{N} / \mathrm{N}$ 比では良性異型細胞群が悪性細胞群を軽度 であるがらわまわり, 統計学的には有意であった。 このように良性異型細胞は, 良性とは比較的容易 に鑑別はついたが, 悪性との鑑別は核径， N/C 比， N/N比のみでは鑑別が不可能であった。今 後更に細胞配列，核縁の所見，クロマチンの所見， 核小体関連クロマチンなどについて検討する。 
ๆ III-3.

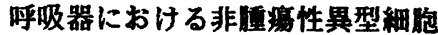

\section{国立療養所東京病院}

O小松彦太郎 (MD)，田岛紹吉（C T)，佐

藤紋二（MD），米田良藏（MD）

呼吸器疾患における非腫埥性異型細胞は、多岐 に渡っており、しばしば癌細胞との鑑别を要する ことがある。そこで今回は、疑陽性例を中心に最 近注目されてきている免疫組織化学所見および画 像解析を用い鑑別診断の問題点およびこれらの細 胞がどの様な背景で出現してきているかについて 検討したので報告する。

対象および方法 : 疑陽性例 9 例、疑陰性例 8 例 およびクラスIII 174例を対象にした。免疫組織 化学的娭討は、肺胞のII型細胞のマーカーとして サーファクタント.アポ蛋白（S A P ）に対する 抗体 ( PE-10, 帝人提供) を用い A B C 法に て行なった。画像診断はファインテック．ＩＭS を用い細胞および核の周镹，面積，円形度を測定 し、鑑别診断上特に問題となる杯細胞型の腺瘦に ついて多変量解析をおこなった。

結果 : 疑陽性例の最終診断は、肺炎 4 例、肺結 核 3 例、気管支炎 2 例である。腺癌としたものが 7 例で多くはS A P 抗体に陰性で細気管支の遇形 成と思われる。しかし、クラスIII としたものの 中に肺線維症、硬化性血管腫の症例が見られ、こ れらはS A P 抗体に陽性であった。また扁平上皮 癌としたものが 2 例である。また疑㓌性としたも のは大部分が腺癌で特に杯細胞型腺癌であった。 画像診断からは、核形の不整が相関係数0.57 と最も大きく、そのほか細胞の重㮴性、棱小体、 クロマチンの所見などが重要であった。

まとめ:呼吸器の非腫演性疾患に見られる異型 細胞を免疫組織化学所胃および画像解析を用い検 討することは肺癌との鑑别診断の精度向上および これらの異型細胞の起源を知るのに有用である。
ワ III-4.

呼吸器感染症に伴う特異的異型細胞

JR東京総合病院中央検查室 同胸部外科*

○早川欽哉(MD)、三宅紀子(ID)、宇佐美一彪(CT) 今野久美子(CT)、深井光一郎( MT)、村上正直 (MT) 大塚俊通(ND)*

呼吸器感染症に伴って出現する非腫瘍性異型細 胞には、一次的な封入体細胞、反応性巨細胞、微 生物の菌塊等之、二次的な炎症の各段階に伴う変 性・壊死細胞、修復細胞、肉芽等進行性病变細胞、 化生細胞、異形成細胞等の 2 種類に分けられる。 ここでは、一次的、特異的な異型細胞の鑑別点に ついて症例を呈示しながら触れたい。

先ず、ウイルス感染症では代表的なものとして サイトメガロウイルス肺炎、ヘルペス肺炎、巨細 胞性肺炎としての麻疹があり、いずれも核内、あ るいは細胞質内の封入体としてウイルスの存在が 証明されるが、時として異型を伴って鑑別に苦慮 する場合がある。特にサイトメガロウイルスでは 基礎疾患に悪性腫瘍を合併していることが多いの で注意を要する。細菌性肺炎では特異的な細胞の 出現は少なく、結核時の多核巨細胞、類上皮細胞、 非特異性の肺線維症で出現するマクロファージ等 があるが、比較的容易に判定できる。肺真䒩症は 近年増加の傾向にあり、ここではアスペルギルス 症、カンジダ症、ムーコル症、放線菌症について 検索したい。全て粘液染色或いはグロコット染色 等により同定は容易、確実であり、出現する細胞 にも特異性はなく、二次的な炎症反応のものが多 い。カリ二肺炎は原虫本体の出現と共に形質細胞 の反応を伴う場合が多い。

その他肺感染症は多岐にわたっており、その細 胞像も多彩であるが、出現細胞の異型度という点 では比較的低く、鑑別に悩む場合でも特殊染色、 或いは酵素抗体法等の免疫学的手法を用いれば容 易である。 
ワ III -5.

呼吸器における非腫瘍性異型細胞

一一肺癌疑診例における異型細胞の検討——

県西部浜松医療センター 胸部外科 ${ }^{1}$, 呼吸器科 ${ }^{2}$ 検査科細胞診 ${ }^{3}$. 同病理 ${ }^{4}$, 独協医科大学病理学教室 ${ }^{5}$ O半澤 㑺 $(M D)^{1}$. 由佐俊和 $(M D)^{1}$, 佐々木一義 $(M D)^{1}$ 橋爪一光 $(\mathrm{MD})^{2}$, 笠松紀雄 $(\mathrm{MD})^{2}$, 滝口恭男 $(\mathrm{MD})^{2}$ 土井久平 $(\mathrm{CT})^{3}$. 川根一哲 $(\mathrm{CT})^{3}$, 阪本勝美 $(\mathrm{CT})^{3}$ 岡本一也 $(\mathrm{MD})^{4}$, 小澤享史 $(\mathrm{MD})^{4}$, 山田 喬 $(\mathrm{MD})^{5}$

【研究の目的】細胞診断の主たる目的は、悪性腫場の 形態学的確定診断を得ることにあるのは言をまたない が、境界領域にあると思われる細胞に遭遇した場合、 その良悪性の判断に戸惑う事が少なくない。この検索 では肺癌疑陽性の診断根拠となり得る細胞の形態所見 と由来を追究することを目的とし、臨床細胞学的、実 験的検討を行った。【方法】(1) 過去 2 年間に、細胞 学的に肺癌の存在を否定し得ないとされた 38 症例につ き、その診断根拠となった細胞をPap 染色により再検 討した。（2）雑種成犬12頭に自己皮下移植気管支を作 成し、これに外来刺激物として $\mathrm{Fe}_{2} \mathrm{O}_{3}$ またはMNG（NMethyl-N $\mathrm{N}^{\prime}-\mathrm{Nitro}-\mathrm{N}-\mathrm{Ni}$ trosoguanidine) を接触させ、気 管支粘膜上皮の変化を経時的に、細胞学的組織学的に 観察した。【結果】(1) 肺癌疑診例にあって、その診 断根拠となった細胞は異型扁平上皮化生細胞とされる べきだったものが最も多く、次いで異型腺腫様増生細 胞、異型多核巨細胞、増生した基底細胞の順に多く見 られ、夫々により扁平上皮癌、腺癌、低分化癌、小細 胞癌等の存在が疑われた。更に悪性腫瘍の存在を疑う 根拠として、所謂癌真珠を形成するかに見える細胞集 団や、幼若組織球、変性を来した気管支粘膜上皮細胞 と思われるものが認められた。(2) 皮下移植気管支に あっては、 $\mathrm{Fe}_{2} \mathrm{O}_{3} 、 \mathrm{MNNG}$ 投与後4週迄の急性期には、 赤血球白血球の他、杯細胞が多く検出されたが、8週 乃至24週目からは、上皮細胞の線毛の消失や扁平上皮 化、基底細胞、腺系の異型細胞等が認められるように なり、これらの細胞の由来は組織所見により裏付けら れたが、癌組織は認められなかった。以上の結果につ き免疫組織学的、電顕形態学的所見も加え報告する。
ワ III-6.

肺非腫瘍性異型細胞への $\mathrm{Ag}-\mathrm{NORs}$ の臨床病理学的応用

北海道大学医学部第一内科 小倉滋明 (MD), 阿部庄作 (MD), 中島功雄 (MD) 国兼浩嗣 $(\mathrm{MD})$, 須甲憲明 (MD), 渡部直已 (MD)

磯部 宏 $(\mathrm{MD})$, 川上義和 $(\mathrm{MD})$

同付属病院病理部

遠藤隆志 ( CT)

Nucleolar organizer regoins は, 核小体の形成 に関与している ribosomal DNA が書き込まれて いる染色体上の部位である。その数と形状は, 細 胞の活動性を反映しているといわれている。近年, 鍍銀染色法により比較的容易にその部位を染色で きるようになった ( $\mathrm{Ag}-\mathrm{NORs}) 。 今$ 回, 私たちは 経気管支鏡的擦過法により採取された検体で，良 性疾患でありながらパパニコロー染色で疑陽性と 診断された 13 例の標本 ( 結核症 8 例, 気管支肺 炎 3 例, SLE 1 例, 器質化肺炎 1 例) の核内 $\mathrm{Ag}$ NORs の観察を試みた。各症例につきパパニコロ 一染色で疑陽性と診断された細胞の核内 $\mathrm{Ag}-\mathrm{NORs}$ の個数を計測しその平均を求めたところ，最小の 症例では $1.6 /$ nucleus で, 最大は $4.0 /$ nucleusで あった。 13 例すべての平均は $2.3 \pm 0.7$ /nucleus であった。この結果は，当科でおこなった肺腺癌 細胞の核内 $\mathrm{Ag}-\mathrm{NORs}$ の平均值 $4.7 \pm 0.5 /$ nucleus と比較して明らかに少なく, 核内 $\mathrm{Ag}-\mathrm{NORs}$ の計 測は良性・悪性の判断根拠として利用し得ると思 われた。 


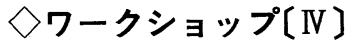

\section{ワ IV-1.}

子宮内膜増殖症と高分化型体内膜腺 癌の細胞学的鑑別点につんて

東京都がん検診センター検査科, 婦人科* ○石井保吉 ( CT), 佐久間市朗 ( CT ), 若林富枝 ( CT), 深堀世津子 ( CT), 小宮山京子 ( CT), 藤井雅彦 ( MD ), 杉下 匡 (MD), 石田禮載 (MD)*

てれまで我々は, 内膜細胞診における良・悪性 の判定基準の設定, さらには前癌病変とされる子 宮内膜增殖症の診断の精度向上を目的に, 組織構 造を重要視した三次元的な細胞集塊の読み方, 特 に集塊の形態とその分岐について検索し報告して をた。今回は細胞集塊中に介在する間質様成分に つんて詳細な検討を行ったので報告する。

[材料および方法］

全面搔爬による組織診で確認された腺腫性増殖 症 15 症例 (26 検体) と術後の組織診で確認された 高分化型体内膜腺癌 16 症例 (26 検体) を対象とし て用いた。方法は, 内膜吸引法にて採取された材 料の生食水洗净によって作成された細胞標本を用 々, 細胞集塊中の間質様成分の有無、その形態, 分岐について検討した。なお、対照として正常増 殖期内膜につんても同様の検索を行った。

[ 結果]

正常内膜の細胞集塊におらては、集塊の周囲に 濃染性の間質細胞が付着して認められたが, 増殖 症や腺癌例の絨毛様ないしは乳頭状集塊には間質 細胞の付着は見られなかった。

一方，紡錘形の核を持った間質様細胞の束を中 心に有する細胞集塊は正常内膜においては見られ なかったが, 腺腫性増殖症では 26 検体中 5 検体 (19.2\%), 高分化型体内膜腺癌では 26 検体中 25 検体 (96.2\%)に認められた。をた, 腺癌において は間質様成分の分岐的高頻度に認められた。

以上ょり, 内膜細胞診におらては細胞集塊周囲 の間質細胞の有無や集塊内の間質様成分の介在に 注目する必要があると思われる。
ๆ IV-2.

\section{子宮体内膜増殖症の細胞診の分析}

慶應義塾大学医学部産婦人科学教室

○和泉 滋(MD), 渡辺豊治( $\mathrm{MD})$, 鈴木キクエ(CT), 鈴木順子( $\mathrm{CT})$, 西村久美子(MT), 三上幹男 $(\mathrm{MD})$, 太田邦彦(MD), 佐久間達朗(MD), 飯野孝一(MD), 木ロ一成(MD), 野澤志朗(MD), 筒井章夫(MD)

〔はじめに〕子宮体がんのスクリーニング 検査法と して, エンドサイト採取による細胞診は, 検体の採 取時の患者の苦痛を考えると, キュレットによる組織 診より有利である。しかし, 体内膜病変とくに, 前癌 病変, 初期癌の細胞診断学は, 子宮頸部病変に較べ て充分に確立されていない。また, 子宮体内膜の細胞 診は, 子宮腔内よりの直接採取法の開発により, 従来 の剥離細胞診とは多少異なり, microbi opsyの診断 亡あいえる。今回は, 正常体内膜, 増殖症の細胞診 分析を行てなったので報告する。〔材料と方法〕増 殖期後期(P), 囊胞状腺増殖症 ( CGH ), 腺腫性増殖症 $(\mathrm{ADH})$, 異型増殖症 $(\mathrm{AH})$ と組織学的に診断された 症例を対象とした。細胞診標本は, エンドサイトにて 採取し, 塗料固定後, Pap. 染色した。核面積を planimetsyにて計測した。〔成績〕クラスターの構造 の分類 : (1)棍棒状, (2)辺縁が明暸な類円形, (3)突出 像をもつクラスター, (4)辺縁が不明瞭なクラスター, (5)乳頭状クラスター等に別けた。Pは(1), CGHは(1) (2), $\mathrm{ADH}$ (2)(3)(4), AHは(3)(4)(5)の頻度が多かった。 全体的に, 細胞質は境界不明であるが保たれ, ク ラスター辺緑の核突出はAHに誌めた。核: 円形と 棈円形の頻度が CGH, ADH, AH になるに従い後者 が増加した。核面積は, CGH 28〜30 $\mu m^{2}, \mathrm{ADH} 30$ 〜 46, $\mathrm{AD}$ 40〜59 と大きくなる傾向があり，核の大小 不同は AHに目立った。また，核濃染性が目立った。 核小体：全体の出現頻度は $\mathrm{CGH}, \mathrm{ADH}, \mathrm{AH}$ に従 って増加し, 大型 (直径 $\geqq 2.5 \mu$ )は, $\mathrm{AH}$ によ めた。その他, 孤立散在性の裸核様細胞は $\mathrm{AH}$ に押 いて異型性がみとめられた。〔結語〕クラスターの 構造, 細胞質, 核の細胞診所見亡正常体内膜の所 見を対比し， deviationを検討した。 
ワIV-3.

\section{子宮内膜増殖症の細胞診}

北里大学病院病理部細胞診、1) 同医学部病理 ${ }^{2)}$ 同医学部産婦人科 ${ }^{3)}$

○大野英治 $(\mathrm{C} \mathrm{T})^{1}$ ) 大野めぐみ $(\mathrm{C} \mathrm{T})^{1}$ 、 能勢富佐子 $(\mathrm{C} \mathrm{T})^{1}$ 、出村裕子 $(\mathrm{C} \mathrm{T})^{1)}$ 、 横山 大 $(\mathrm{C} \mathrm{T})$ ) 桑尾定云 $(\mathrm{MD})^{2}$ 、 蔵本博行 $(M D)^{3)}$ 、森沢孝行 $(M D)^{3)}$ 、

細胞診による子宮内膜增殖症の正診率は報告者 により区々であり、必ずしも満足すべき診断成績 とは言い難い。異型内膜増殖症 (A E H) と分化 型（G I ）体癌との鑑別についても、これまで多 くの研究者が悲観的な見解をとってきた。

そこで、このような命題に対処するため、エン ドサイト法による内膜細胞診標本を検索した結果 当院では以下のような診断基準を定め、一応の診 断成績を得ている。

腺腫性増殖症 (ADH) 所見; (1)背景に多数の増 殖期様内膜細胞および間質細胞、(2)核腫大、核の 大小不同を示す集塊、(3)集塊の形は乳頭状、類円 形、不整形で、重積、配列の乱扏を示し、ときと して腺構造の增強、腺上皮の多層化、(4)これら集 塊にしばしば半島状ないしは乳頭状の突出、(5)核 小体、クロマチンの増量は大前提

A E H所見 ; (1)A D Hの所見が強度でかつ細胞 異型も強度、(2)集塊の辺縁はスムーズで、核は集 塊辺縁内に収まるか、または軽微の核突出

G I 体癌所見；A E Hの所見に加え、(1)集塊の 辺縁は不整樹枝状、(2)集塊辺縁の核突出、(3)核形 の不整化、(4)複数の小型核小体、(5)尰瘍壊死

今回、子宮筋腫症例に内膜增殖症様の細胞が多 々出現していることに着目し、平成元年 6 月から 10 月までの手術例にて子宮筋腫と診断された 64 例の組織学的診断結果を検討したところ、増殖症 が 12 例、増殖症梯変化を示す症例が 12 例、これ ら子宮筋腫例に認められたため、現在詳細な組織 学的再検討を行っている。さらに、襄胞性腺増殖 症の細胞所見も併せて報告したい。
ワ IV -4.

\section{子宮内膜増殖症の細胞診}

九州大学医学部婦人科学産科学教室

O井町正士 (MD), 塚本直樹 ( $M D)$,

松山敏剛 (MD), 中野仁雄 (MD)

子宮頸癌においては、その前癌病変として子宮 頸部上皮内腫瘍 ( CIN) の病態は十分解明され、 CIN の自然史が明確にされている。そのため子宮 頸部の細胞診の結果が、その後の治療方針を決定 する重要な因子となり、子宮頸部細胞診の普及に 伴い子宮頸癌の治療成績は向上した。しかし、子 宮体癌においては従来より前癌病変として子宮内 膜増殖症が考えられてきたものの、その病態およ び自然史は未だ解明されず、問題点が多い。また、 昭和 62 年度から老人保健法による子宮癌検診に新 たに体癌検診が加えられ、子宮体癌の検診におい て細胞診の果す役割は益々重要となってきたが、 細胞診で子宮内膜增殖症を診断するてとは難しく、 その細胞学的特徴の解明が急がれている。

そてで今回われわれは、当科で病理組織学的に 診断された子宮内膜増殖症の内膜細胞診を、後方 視的に検討し、さらに筋層に浸潤を認めない子宮 体癌（筋首非浸潤癌）の細胞所見と比較した。子 宮内膜增殖症は囊胞性腺增殖症 ( $\mathrm{CGH}$ )、腺腫性 增殖症 ( $\mathrm{ADH})$ 、異型增殖症 (ATH) 飞分類した。 これら症例の細胞診標本について、異型細胞の量 および出現形態、細胞集団の重積性、核所見(形 大きさ，核縁の所見)、核内所見 (クロマチンの 性状, 核小体の数・大きさ)、正常内膜細胞の混 在、標本背景等を調べた。CGH ではやや重積性が 增加するのみで、正常内膜細胞とほぼ同様の細胞 所見で、細胞誩で䛦断するてとは困難と考えられ た。ADHでは重積性が増し、クロマチンは細顆 粒状に増量し、核小体がやや目立ってきた。また 細胞集団辺縁からの乳頭状あるいは棍棒状突起が 增加した。ATHではさらに重積性が増し、核異型 が目立った。しかし、筋層非浸潤癌と異なり背景 はきれいであった。 
ワIV -5 .

子宮内膜増殖症の細胞診

国井産婦人科病院

O国井勝昭 ( $M D$ )、国井兵太郎 ( MD )

大橋洋子 ( C T )、草裕子 ( C T )

国立栃木病院

長谷川寿彦 ( M D )

我々は、第 30 回本学会総会において、子宮内 膜増殖症 37 例 (Cystic glandular Hyperpla sia 以下 C.G.H. 22 例、Adenomotous Hyperpla sia 以 下Ad.H. 10 例、At ypical Hyperplasia 以下 A.H. 5 例）の細胞像と増殖期 10 例、GI Adeno ca. 11 例の細胞像について比較検討を行ない報告し た。

今回は更に例数を追加し、C.G.H. 28例、Ad.H. 18 例、A.H. 6 例について検討を行なった。

細胞診判定は、C.G.H.28例中 17 例 ( $60.7 \%$ ) が陰性、11例（39.3\%）が疑陽性であった。 Ad.H. 18例では、8 例 $(44.4 \%)$ が陰性、9 例 ( $50.0 \%)$ が疑陽性、1 例 $(5.5 \%)$ が陽性だっ た。A.H.では 2 例 $(33.3 \%)$ が陰性、3例 $(50.0 \%)$ が疑陽性、1 1 例 $(16.6 \%)$ が陽性だった。

てれらの細胞像を比較するため、以下の項目に ついて検討を行なった。

1. 背景 2. 出現細胞数 (腺細胞、間質細胞)

(孤立、散在) (正常、異型細胞)

3. 集塊の細胞数、集塊の形、集塊の辺縁状態、極

性、核の大小不同、重積、集塊中の腺腔構造、 集塊の分岐数

4.細胞質の染色性、大きさ、 N/C 比

5. 核形、核の大きさ、核縁、クロマチンの状態、

核分裂の数

6. 核小体の数、大きさ、形状

又、偽陽性、偽陰性に判定された症例について、 ぞういう所見から判定されたのか、その原因につ いても検討を行なった。
ワ IV -6.

\section{子宮内膜増殖症の細胞診}

近畿大学医学部産婦人科学教室

O小畑孝四郎 (MD), 井上芳樹 (MD), 山本嘉一郎 (MD), 堀井高久 (MD), 野田起一郎 (MD)

子宮内膜増殖症は, 子宮体部の前癌病変として 取り扱われているが, 子宮内膜癌に比べ細胞診に よる診断は困難と言われている。そてで, 内膜増 殖症についてその内膜細胞診成績を分析し, それ らの細胞異型の程度, 及び細胞集団における核の 大小不同性, 核形不正, 核間距離, さらには, 細 胞集団の辺縁像について詳細に検討したので報告 する。

吸引細胞診で，陽性及び疑陽性であったものは 体癌では $92.5 \%$, 異型増殖症では $49.3 \%$, 腺腫性增殖 症では $21.6 \%$, 囊胞性腺増殖症では $17.6 \%$ であり, 内膜増殖症では体癌と比べて細胞診で check up される頻度は低い。核過染性を認める細胞の頻度 は, 雯胞性腺増殖症及び腺腫性増殖症で, $0.0 \%$, 異 型増殖症で $6.9 \%$, 高分化型腺癌で $14.3 \%$ であり, 核小 体 2 個以上を認める細胞の頻度は，それぞれ $5.3 \%$, $5.3 \%, 13.8 \%, 40.0 \%$, 核小体 $2 \mu$ 以上を認める細胞 の頻度は,それぞれ $0.0 \%, 1.8 \%, 5.5 \%, 34.9 \%$, ク ロマチンの不均等分布を認める細胞の頻度はそれぞ れ $0.0 \%, 0.2 \%, 13.9 \%, 60.0 \%$, 襄胞性腺増殖症で は核異型はなく, 腺腫性増殖症では核異型がない か, あっても軽度である。核の大小不同性, 核形不正. 核間距離の変動は, 病変が高度になる程, 増大する傾 向が見られた。さらに, 細胞集団の長径の単位長さを 当りの突起数は, 病変が高度になる程増加する傾向が 見られ,腺腫性增殖症では, 整の桿棒状乳頭状の突起が 多く, 異型增殖症では不整乳頭状の突起が多く見られ, 高分化型腺癌ではその程度はさらに強くなった。

以上の上うに, 核異型の他に, 核の大小不同性, 核形不正, 核間距離の変動, さらには辺縁像も加 味して判定することにより, 内膜増殖症を細胞診 で check up する率を高めるととができると思わ れる。 
ワIV-7.

\section{子宮内膜增殖症の細胞診}

長崎大学医学部産婦人科学教室

O行徳 豊 (MD)、福居兼実 (MD)、 中島久良 (MD)

子宮内膜增殖症は子宮体部における境界病変と みなされているが 自然史の解明などが十分でな いことむあり、その分類や取扱いなどに関して必 ずしも統一的見解は得られていなかった。わが国 では、1987年にその取扱い規約が示され、組織学 的に囊胞性腺增殖症 $(\mathrm{C} \mathrm{GH})$ 、腺腫性增殖症 (ADH) および異型增殖症 (A T H ) に分類さ れた。子宮内膜增殖症は細胞診による診断が困難 なことも多く、その細胞学的診断基準の確立が望 まれている。

最近7年間に長崎大学で経験した子宮内膜增殖症 は55例（C GH25例，ADH22例およびATH8例) で、平均年踰はそれぞれ47.6歳 50.4 歳および 49.6歳である。まだ閉経後婦人の割合はそれぞれ 24\%、45.5\%および37.5\%であった。これらの症 例のうち、頸部細胞診で内膜增殖症または腺疸が 疑われたむの（疑陽性および陽性）はC G H0\% (0/25)、A D H22.7\% (5/22) およびATH $50 \%(4 / 8)$ 、一方、内膜細胞診では、それぞれ $42.9 \%(6 / 14) 、 70.6 \%(12 / 17)$ および $80 \%$ (4/5)であった。

内膜細胞診では、 C G H は增殖期に比しやや細 胞の重積が增し、乳頭状集塊を示すすのむみられ た。 ADHおよびATHではその程度が強くなり、 また集塊辺縁の不整および集塊内の腺管様構造が ややめだつ傾向がみられた。さらに A T Hでは腺 瘦と同様、集塊周辺での細胞の離散、核クロマチ ンの增加および核小体の肥大が琶められた。しか し、腺癌ではその程度が強く、また腫瘍背景およ び白血球領食像がみられることが多かった。なお、 画像解析装置による核面積の比較では、C GHは 增殖期と大差なく、ADH、A T Hおよび腺癌の 順に增大する傾向が認められた。 
1. 南小国町の子宮癌集団検診 (施設検診)

とサイトブラシの使用について

熊本県阿蘇郡南小国町 室原医院

O室原 博 ( MD)

南小国町町民課保健衛生係

南小国町は人し約5200の過疎の農林業の山村だが 、町当局の理解によりS 41 年より当医院で、子 宮癌集団検診を全額町の負担で実施して 23 年を 経過した。検診期間は原則として農閑期の12 2 月の 3 ケ月の金、土曜日、木製へラを使用、59 年中期よりサイトブラシを併用、スライドは 1 人 2 枚採集、可能な限りコルポ診、内診を行う。S 63 年度現在、延べ 15,162 人を検診、細胞診判定は 良性 $14,939(98.53 \%) 、$ 疑陽性 II a ; 186、III b ; 19 (計 $1.35 \%$ )、悪性 $18(0.12 \%)$ )、癌患者 20 例 $[0$ 期；6、I 期；11、I 期；1、林期 ? 1、胵癌 1 ]で全国の集検と大差ない。うち頸癌19例のうち III 期の 1 例が 1 年後再発死亡、他は永久治癒した が 10 年後乳癌、肺癌で 2 例死亡、12年後乳癌手術 1 例である。S63年の窑癌は子宮筋腫全摘術後 12 年目の発生である。

受㟝率は検診台帳完備により検診日以外いっであ 住民の希望のとき受け付ける為汃、S49年より 30 \%、S 52 年より $40 \%$ 台である。S 6 亿年度は 5 年以 上未受診者に受診锤奨通知を役場より発送したの で最高の50\%を超えた。な书去去10年間の未受診 者は約 $5 \%$ である。

高齢化による S C J の樑部移行、外子宮口の縮小 硬化でサイトブラシを必要とした例は S 60 年度 876 例中 133 例（14.8\%)、殊に60才代173例中54例 $(31 \%) 、 70 才 以 上 83$ 例中 43 例（52\%）に達した。 その後は閉経者には全例にへラとサイトブラシを 併用してスメアの採集ミスに注意している。 医師の努力は当然であるが、住民の癌に対する正 しい認識、行政の強力な援助の 3 者協力で高い受 診率、早期癌発見を可能にしている。
2. 子宮頸癌集団検診の経済効果に関する

検討

大阪医科大学産婦人科

$\bigcirc$ 植木 実 (MD) 山田隆司 (MD), 岡本吉明 (MD, ) 柳川泰彦 (MD)，杉本 修 (MD)

子宮頸癌早期発見のための集団検診が普及し， その意義が認められているにもかかわらず，その 事業にかかる多額の費用との経済効率が論議され ている。そこで兵庫県の山間部 (一宮町 ) で過去 17 年間に行ってきた婦人集団検診において子宮 頸癌のみの費用便益について検討した。

集団検診は同町の 30 才以上婦人（ 3,705 3,975 人) を対象とした。昭和 47 年から 63 年 までの受診率は, 当初 $19.5 \%$ から最近では 39 〜 $41 \%$ に増加した。この検診によって頸癌は 0 期 23 , I a 期 2, I b 期 1, II 期 1, III 期 1 の 計 28 例があり，17 年間における子宮癌による 死亡率は 17 名 (検診受診者は 2 名) 見られた。 今回は, これらの実績 (異形成 98 , 体癌 2 , 卵 巣癌 2 の検出例は除外)をもとに, 検診を行った 場合と, 行わない場合の経済的損失 (検診費用, 医療費、休職・死亡による損失)した。 その結果, 総検診費用は 65,230 千円 1 人 2,927 円）の検診費用に対し，検診により得ら れた便益は 115,665 千円と費用対便益費は 1 ： 1.7 となった。この検診による経済的便益は検診 を行わない場合の治療費と経済的損失 203,870 千円から検診を行った場合のそれは 88,204千円 をさし引いたもので, 総費用との経済的損失は $75.3 \%$ に抑制された。即ち, 検診を行うことに より, 約 $40 \%$ の受診率でも, 町全体として年間 約 2,967 千円の経済的利益があり,これに体癌, 卵巣癌の発見を含めるとこの利益はさらに増加す ると考えられた。 


\section{3. 老人保健法施行後における 大分県の子宮癌検診の現況}

大分県立病院産婦人科

O谷口一郎(MD), 宇津宮隆史(MD), 寺脇信二(MD) 岩里桂太郎(MD), 溝口洋一(MD), 肥田木孜(MD)

同 病理 辻 浩一(MD), 玉井重信(CT), 後藤英雄 (CT), 豊田 長 (CT), 鷲見悦子(CT), 上野正尚 $(\mathrm{CT})$, 阿南知子(CT)

大分県の子宮癌の死亡率が高い事は従来より指 摘されている所であり, 厚生省の統計によれば, 昭和 41 年よりほとんどワースト 5 以内にランク されてきた。子宮癌検診は昭和 58 年 2 月より実 施された老人保健法下での検診体制によりいくつ かの点で大きく異なってきた。また昭和 62 年 4 月より肺癌, 乳癌検診の導入及び子宮体癌検診を 新たに導入した第 2 次 5 力年計画が実施されてい る。大分県においては昭和 62 年 3 月に日本臨床 細胞学会大分県支部が発足し, 県当局との共催に よる細胞診従事者研修会が開催され今年は第 6 回 目となったが昨年度より大分県が当支部に全面委 託する形で運営され，その受講者より昭和 60 年 2 名, 同 61 年 2 名, 同 62 年 7 名, 同 63 年 3 名, 合計 14 名のC Tを誕生させた。平成元年に おける当県の C T の総数は 38 名である。各県の 総人口と各県のC $\mathrm{T}$ の比を出すと（平成元年 9 月 21 日現在）, 宮城県 85 名（1:25600 ), 石川県 43 名 (1:26791), 群馬県 70 名 (1:27443) 等となり, 大分県は ( 1：35714）で, 第 13 位に位置している。 また老人保健法による子宮癌検診の受診率は昭和 62 年度では宮城県 $27.3 \%$ 京都府 $23.2 \%$, 福島県 $22.9 \%$ 等となり, 大分県は $21.0 \%$ で 第 9 位となっている（昭和 59 年度 $16.4 \%$ ）。 今回は当県の子宮癌検診の大部分を占める対ガン 協会の成績を中心に, 当県の現況とその問題点に ついて報告する。
4. 島根医大学産科婦人科初診患者の子宮 頝部擦過細胞診の臨床統計

島根医科大学医学部産科婦人科学教室 ○高橋健太郎 (MD)、吉野直樹 (MD)、柳光宽仁 (MD) 森山政司 (MD)、岩成 治 (MD)、北尾学 (MD) 島根県環境保健公社 石飛恭子 (CT)、錦織二三枝 (CT)、磯田理恵 (CT) 高橋淳子 (CT)

島根医科大学産科婦人科を受診する初診患者の 数は年間（昭和63年） 698 名で 1 力月平均58名で ある。当科においてはその $99.4 \%$ に対して子宮頝 部擦過細胞診を施行している。そこで我々は外来 患者初診時の子宮頚部擦過細胞診について 1) class I , class II 2) class III a 3) class III b class IV, classVの 3 群に分類し、紹介の有無、 妊娠との合併等について昭和57年の 1 力年と比較 検討した。また島根医科大学産科婦人科を中心に 行っている島根県の車検診による子宮癌検診とも あわせて比較検討したのでその結果についても報 告する。

昭和 63 年に島根医科大学産科婦人科を受診した 初診患者は698 名で、子宮䅡部擦過細胞診の結果 は、1)群625名 (89.5\%)、2) 群22名 (3.2\%)、3) 群 47 名 (6.7\%)であった。昭和 57 年の初診患者は 1138名で子宮䅡部擦過細胞診施行患者は99.2\% で ありその結果は、1)群1074名 (95.2\%)、2) 群32名 (2.8\%)、3) 群23名 $(2.0 \%)$ であった。妊娠と合併し た子宮䅡癌患者は昭和 63 年に 1 名認められた。昭 和 57 年より昭和 63 年のほうが 3 ) 群の数が多く認め られるが、これは他施設からの子宮䝺部擦過細胞 診の異常をみとめた紹介患者が多くなったためで ある。その他詳細についても報告する。 
5. 当科治療症例における子宮頸癌発見 の端緒について

香川医科大学母子科

O塩田敦子(MD), 藤田和之(MD), 佐々木敏江(MD)，広川雅晴(MD)，山崎俊彦(MD) 黒瀬高明(MD), 大野正文(MD), 半藤 保(MD)

香川県における子宮癌検診は主に検診車により 行なわれているが、その集検受診率は非常に低い ものとなっている。昭和 58 年開院以来 63 年までに 当科で治療した子宮頸癌患者 202名について、癌 発見の端緒別にわけ、それぞれのグループの特徴 について統計的考察を加えて報告したい。

202例の内訳は、CIS 35例、Stagela 45例、1b 38例、2a 7例、2b 36例、3a 1例、3b 32例、4a 6例、 $4 \mathrm{~b} 2$ 例となっており、年令は25歳から89歳 である。これらを集団検診でみつかったもの、妊 娠、腰痛、排尿異常等で婦人科を訪れた際、念の ため検診してみつかったもの、不正出血等発症し てから受診したものにわけると、それぞれ40名、 49名、113名となり、当科では集検でみつかった ものは全体の $20 \%$ を占めるにすぎないことがわか った。また、いわゆる早期癌とされる CIS、1aの 、全体に占める割合は $40 \%$ に満たないことがわか り、昭和 60 年の全国統計 $44 \%$ に及ばず、早期癌発 見率はあまり芳しくない。一方、集検受診者では その $85 \%$ CIS、1aであったが、残りの $15 \%$ は進 行癌で、50歳代の初めて受診したものが多かった 。年令的な特徴は特に顕著ではないが、やはり集 検受診者は30～50歳代に多く、念のため検診した ものの中には、進行癌の多い60～80歳代であるの に早期にみつかっているものが多い。

子宮癌死亡率は、年々減少の一途をたどってい るが、それには治療の進歩のみならず、検診の普 及、精度の向上に依るところも大きい。検診受診 者の拡大、さしあたって特に 60 歳以上の受診者を 増やすことで検診の効果を高める必要がある。
6. 子宮頸部擦過細胞診における腺系異型細胞 （III 腺）の意義

宮城県対がん協会細胞診センター 近畿大学医学部産科婦人科学教室

○及洋恵 $(C T)$, 金野多江子(CT), 岩㴊一夫 (CT), 伊藤圭子 (CT), 那須一郎 $(M D)$, 佐藤 滋 $(M D)$, 金田尚武(MD), 東岩井久(MD), 野田起一郎(MD) *

宮城県対がん協会で発見された子宮頸部腺癌例の 細胞像の retrospectiveの検討では癌が発見される 数年前から癌の基準をみたさない腺系の異型細胞の 存在が認められる例が多い。現在, 腺系異型細胞に対 する適切な判定基準がないので子宮頸部腺癌のfalse negative を最小限にくい止めるために当センターで は，腺上皮系の細胞に腺癌細胞の基準をみたさない 異型が認められた場合, スクリーニング上III腺と判定 し, 原則として腟部, 頸管, 体内膜（体内膜に由来す る場合)の 3 筒所から組織診を行うことにしている。

当協会において，昭和56年から63年までの 8 年間 に実施した子宮頸がん検診総数は $1,069,516$ 例であっ た。この細胞診成績はclass I, II 1,054,453例(98.59 $\%)$, III 14,755例(1.38\%), IV152例 (0.014\%), V155 例(0.014\%)で,さらにclassIIIをこれまで発表して きた当センターの基準に従い細分類すると III $\mathrm{A} 11,736$

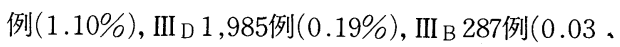
$\%)$, III腺747例 $(0.07 \%)$ であった。III腺747例の組織診 断の内訳は異常の認められなかったもの461例(61.71 $\%)$, 軽度一高度異形成147例(19.68\%), 上皮内癌·扁 平上皮癌例 $(0.80 \%)$, 腺異形成 61 例 $(8.17 \%)$, 内膜 増殖症35例 $(4.69 \%$ ), 頸部腺癌12例( $1.61 \%$ ), 体部腺 癌24例 $(3.21 \%)$ であった。腺系の病変の発見率を細 胞診class 分類毎に比較すると $\mathrm{III}_{\mathrm{A}} 164$ 例 (1.40\%), III D 24例(1.21\%), III B 9例(3.15\%), IV5例(5.05\%), V 18例(15.38\%)でIII腺からは132例(17.68\%) と高 率に発見された。この細分類は腺系病変の検出に関 し false negative を防ぐのに有用でありべセス多 方式の原因不明の異常腺上皮細胞に対応するものと 思われる。宮城県の子宮がん検診成績を詳細に報告 するとともに, III腺の細胞像, follow up 成績につい ても述べる。 
7. サイトブラシと木製スパーテル採取に よる子宮頸部細胞診の比較検討

東北大学産婦人科 ${ }^{1)}$, 宮城県対がん協会 ${ }^{2)}$ 仙台市立病院産婦人科 ${ }^{3)}$

○葉英俊 $(\mathrm{MD})^{1)}$, 伊藤 潔 $(\mathrm{MD})^{1)}$, 牧野浩充 $(\mathrm{MD})^{1)}$ 今野 良 $(M D)^{1}$, 遠藤 敦 $(M D)^{1)}$, 八重慗伸生 $(M D)^{1)}$ 鹿野和男 $(\mathrm{MD})^{1}$, 堀口正之 $(\mathrm{MD})^{1}$, 佐藤信二(MD) ${ }^{1)}$ 中名生裕子 $(\mathrm{CT})^{1)}$, 矢島 聰 $(\mathrm{MD})^{1)}$, 及川洋恵 $(\mathrm{CT})^{2)}$ 金野多江子 $(\mathrm{CT})^{2)}$, 伊藤圭子 $(\mathrm{CT})^{2}$, 東岩井久 $(\mathrm{MD})^{3)}$

子宮頸部細胞診の細胞採取を行う際, 現在, 木製 スパーテル, 綿棒が使われるととが多い。今回, 子 宮頸部細胞診の細胞採取を, サイトブラシ之従来の 木製スパーテルの 2 つの採取法を用いて行い，比較 検討を行った。対象は，宮城県対がん協会子宮癌検 診の受験者 400 名で, 同一受験者に対して, サイト ブラシと木製スパーテルの 2 回採取を行い, 更に, 採取の順番を変え比較検討した。比較はまず, (1)診 断結果, (2)背景について, (1)出血の程度, (2)粘液の 有無, (3)乾燥の有無, (4)細胞破壊の程度, (3)細胞成 分については, 以下の 5 項目について出現程度を比 較検討した，(1)円柱上皮，(2)集塊，(3)シート，(4)孤 立, (5)扁平上皮。結果は, 木製スパーテル, サイト ブラシの順に採取した群で, 診断結果に扑いて, サ イトブラシの方で, 扁平上皮領域の診断の疑陰性が あったほか，サイトブラシの方が木製スパーテルよ りも背景に扔いて, 出血が軽度, 細胞成分出現程度 において，円柱上皮の出現が多い傾向がみられた。 そして木製スパーテルで陰性, サイトブラシで III腺 であったものを認めた。また採取の順を変えた両群 の間は，同様の結果であった。サイトブラシは，比 較的容易に子宮頸管内に挿入可能であり, 頸管内の 病変の検診飞有効之思われる。採取側として, サイ トブラシが木製スパーテルより，手技的に苦慮した ということはなかった。一方, サイトブラシで採取 する際, 子宮頸管内のみの細胞採取に留まり, 扁平 上皮領域の細胞採取を怠る危険性があるととを考え る必要があると思われた。
8. 精検対象者におけるサイトブラシ採取の 有用性について

東北大学産婦人科

○遠藤 敦(MD), 八重樫伸生 (MD), 今野 良(MD) 鹿野和男 (MD), 千葉英俊 (MD), 堀口正之(MD) 佐藤信二 $(\mathrm{MD})$, 中名生裕子 $(\mathrm{CT})$, 矢嶋 聰 $(\mathrm{MD})$ 宮城県対がん協会

及川洋恵 $(\mathrm{CT})$, 伊藤圭子 $(\mathrm{CT})$, 東岩井 久 $(\mathrm{MD})$

近年頸部腺癌の割合が増加傾向にあるととが指摘 されており, 頸部腺癌に対する効果的対応が必要と されている。今回我々は, 腺癌の基準を満たさない 腺細胞の異型が認められた症例 (以下亚腺と亜分類 する)についてサイトブラシと従来からの木製スパー テル採取法と比較して，その有用性を比較検討した。 対象は宮城県対癌協会における要精検者でかつ腺 之診断された 100 例である。乙れらの症例において, 細胞は最初に木製スパーテルで引き続きサイトブラ シで採取した。また外頸部, 内頸部からの組織学的 検索も行った。

木製スパーテルでは, 細胞成分のうち扁平上皮の 占める割合が多く, 円柱上皮の量は少なく腺異型細 胞の判定が困難な例があった。一方, サイトブラシ では, 円柱上皮, 扁平上皮共に多い傾向がみられた。 また細胞の出現様式む円柱上皮細胞で集塊, シート 状, 孤立性と多彩であった。腺異型の細胞出現様式 は集塊状で核の過染性, 核の大小不同がみられ, 組 織診断の推定により有用と思われた。 スパーテルで吕腺の 100 例の組織診は, 正常73例, 腺異型 1 例, 子宮頸部異型性 24 例 (軽度 10 例, 中等 度 9 例, 高度 5 例) 上皮内癌 2 例であった。サイト

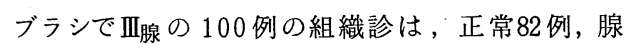
異型10例, 子宮頸部異型性 7 例（軽度 2 例, 中等度 4 例, 高度 1 例) であり, サイトブラシで腺異型の 一致例が多かった。

サイトブラシ法での精検対象者の組織診との高い 一致率は, 頸管内病変の細胞診でのサイトブラシの 有用性を示してると思われた。 
9. サイトブラシ法による頸部細胞像の分析 北里ヘルスサイエンスセンター ${ }^{1)}$, 北里大学産婦人科 ${ }^{2)}$ 北里大学病院病理部 ${ }^{3)}$

○林 玲子 $(\mathrm{MD})^{1)}$, 蔵本博行 $(\mathrm{MD})^{2)}$, 上坊敏子 $(\mathrm{MD})^{2)}$ 角田新平 $(\mathrm{MD})^{2}$, 岩谷弘明 $(\mathrm{MD})^{2)}$, 能勢富佐子 $(\mathrm{MT})^{3)}$ 出村裕子 $(\mathrm{MT})^{3)}$, 横山 大 $(\mathrm{CT})^{3)}$, 大野めぐみ $(\mathrm{CT})^{3)}$, 大野英治 $(\mathrm{CT})^{3)}$

子宮頸部腫瘍がこれまでの扁平上皮采ばかりでな く, 腺采腫瘍が増加していることから, 頸部細胞診 での診断には多彩な対応がせまられている。第28回 細胞学会秋期大会で, サイトブラシ法と綿棒法によ る頸管細胞診を比較検討し，述べてきた。今回はさ らに各々の細胞像を詳しく分析した。

細胞診陰性例 ( 両採取法) 飞招いて, 採取細胞量 及び細胞の出現様式をみた。扁平上皮, 頸管腺細胞 共に, サイトブラシ法は綿棒法に比し多量であった。 頸管腺細胞を認めないものは綿棒法の 372 例中 49.2 \%に比しサイトブラシ法では 392 例中 $2.3 \%$ と明ら かに少なかった。綿棒法では小型シート状又は孤立 散在性の出現が多いのに対し, サイトブラシ法では 様々の大きさのシート状集塊が多く, 孤立性の出現 も少なくない他, 集塊状での出現もあるなど多彩な 出現様式をとっていた。孤立性頸管腺細胞は over一 viewでは $\mathrm{N} / \mathrm{C}$ 比が大となりやすい。綿棒法に比 しサイトブラシ法は背景に粘液が目立ち, 又粘液豊 富な腺細胞も多かった。扁平上皮化生細胞はサイト ブラシ法では綿棒法に比し多く, 幼若化生細胞の核 の大小不同，核小体は目立った。頸部異形成，上皮 内癌, 微小浸潤癌ではサイトブラシ法は集塊状で出 現しやすいためoverdiagnosis としがちであった。 以上, サイトブラシ法は扁平上皮ばかりでなく頸 管腺細胞の収量も多いととから，腺系も含めた頸部 腫瘍の検出という現在の二ーズに対応しうる採取法 と判断された。
10. 子宮頸部初期病変 (特に頸管内病変) に対する円錐切除施行時に扔ける t ouch smear 併用の有用性の検討

大牟田市立病院産婦人科 ${ }^{1)}$, 病理 ${ }^{2)}$

○蓮尾泰之 $(M D)^{1)}$, 三田村民夫 (MD $)^{1)}$. 富田利紀 $(M D)^{1)}$,

粕方享亘 $(\mathrm{C} \mathrm{T})^{2)}$, 大德光信 $(\mathrm{C} \mathrm{T})^{2)}$, 中原俊尚 (MD ) 2 )

子宮頸部初期病変, 特に扁平上皮系の可視病変 の診断, 治療については細胞診, コルポ診, 狙い 組織診の普及, 精度の向上により, 確立された感 がある。しかし、腺癌や頸管内病変に対してはま だまだ検討すべき問題が数多く存在しているのが 現状である。顒管内病変に関しては細胞採取時の 問題, コルポ診上U.C.F 症例が増加することによ る狙い組織診の精度の低下, 頸管搔爬の不確実性 などがあげられる。これらの事より最終的には円 錐切除の結果に頼らざるを得ない症例も少なくな い。さらに, 円錐切除標本に拁いても最強病変の 確実な把握は必ずしも容易ではない。実際の臨床 では円錐切除標本の再切り出しで初めて病変を確 認し得る症例む経験するところである。我々は, 最強病変の把握, 再切り出しの省力化を目的とし て円錐切除施行時に切除切片に対し, t o u ch sme a r 施行し最強病変の予想マップを作成して 扣り，この方法が有用と思われる症例も経験して いる。今回, これらの実際の方法, 及び症例につ いて発表する。 
11. 子宮頚癌二次検診時における細胞診 の正診率について

一綿棒とサイトピックの比較（第 2 報）—

\section{東京都予防医学協会細胞診断科}

○武智昭和 (CT), 土屋菊枝 (CT), 野口美果 (CT) ,

筑場久美子 (CT), 土屋正和 (CT), 栗原操寿 (MD) , 東京母性保護医協会精検センター

長峰敏治 (MD) , 伊藤良弥 (MD)，

コルポ診を用いて狙い組織診を主体とする子宮 頚癌二次検診 (精検) 時の細胞診は, 従来コルポ 診の観察に支障をきたさないという理由から綿棒 法が賞用されてきたが, 吾々はサイトピック法を 用いた二次検診時の細胞診はコルポ診の障害にな らないこと, 綿棒法に比べ under diagnosisが少 なく、細胞診の信頼性がより高いことを両採取法 で同一患者から同時に採取した細胞診の成績によ って明らかにし、第29回本学会で報告した。

今回は, 綿棒で実施した昭和 61 年 11 月〜 62年 10 月までの 1 年間 $(372$ 例) とサイトピックにて実 施した昭和 63 年 5 月〜平成元年 4 月までの 1 年間 （484 例）における両法の成績を比較検討したの で報告する。各病変に対する細胞診断と組織診断 との一致率は、綿棒採取法で良性 $91.4 \%$,

$(53 / 58)$ ，軽中等度異形成 $94.1 \% ，(128$ $/ 136)$ ，高度異形成 $34.8 \%(16 / 46)$, 上 皮内癌 $58.8 \%(30 / 51)$ ，微小浸潤癌 76 . $2 \%(32 / 42)$ ，浸潤癌 $93.1 \%(27 / 29)$ であるのに対し、サイトピック採取法では 良性 $90.4 \%(123 / 136)$, 軽中等度異形成 $88.2 \%(120 / 136)$, 高度異形成 55.3 $\%(26 / 47)$, 上皮内癌 $79.7 \%(51 / 64)$, 微小浸潤癌 $88.4 \%(38 / 43)$, 浸潤癌 89 . $4 \%(42 / 47)$ であり, 高度異形成, 上皮内癌, 微小浸潤癌においてサイトピック採取法がより正 診率が高率であった。また。両採取法における各 病変のover daignosis, under daignosis などに ついても詳細に検討したので報告する。
12. Interferon による子宮胵部・胵壁 Condyloma の治療経過

大阪市大産婦人科, 城北市民病院産婦人科* O中村哲生(MD), 松本義隆(MD), 田村一富(MD), 土田茂( $\mathrm{MD})$, 伊藤文博(MD), 山片重房( $\mathrm{MD})$, 須川 佶 $(\mathrm{MD})$, 山本久美夫(MD)*

子宮腔部および胵壁のコンジローマ病変に対し て interferon (IFN) $\alpha$ による治療を試み、その効果 について形態学的ならびにHPV-DNAの copy 数の変 化に関し検討した。まず細胞診、組織診にて異角化細 胞、空洞化細胞など condyl oma tous change を示し た 40 症例に対し、IFN $3 \sim 6 \times 10^{6}$ IUを尖圭コンジ ローマ直下 (胵壁病巣) または子宮腟部の 8 ポイント (flat condyloma) そコルポスコピー下に局所投与 した。注射は隔日に計10 回施行し、治療前後の組織・ 細胞の変化、HPV抗原の免疫組織化学的変化ならび にHPV-DNA の copy 数の変化を調べた。DNA 検索 は、病巣外の細胞の混入を避けるため、特製のブラシ を用いて目的細胞を採取し、nylon membrane 上で dot blot hybridization 行った後、各dotの放射 活性を液体 scintilation counter 亿て測定し、標準 曲線より 1 細胞あたりのHPV-DNA の copy 数を算 定した。治療効果は、コルポ診上 $86 \%$ 、細胞診では $73 \%$ 、組織診では $50 \%$ \%でった。また酵素抗体法で はHPV陽性率が治療前 $77 \%$ であったものが治療後は $13 \%$ に減少していた。とてろが、治療症例の大部分 でHPV-DNAの copy 数の低下が観察された。形態学 的変化が消失しない例では、全例HPV-DNA が治療 後も検出されたうえに、形態学的に治療効累的認 められた症例でも、 5 例に virus DNA の遺残が 確認された。乙のととは、形態学的に病変が消失 しても、HPV-DNAがかなりの頻度で遺残してい るととを示している。その原因の一つは interferon の投与期間が短いためと思われたが、しか し、これらの遺残 virus が本病変の高い再発率の 原因となるものであろうと推察された。 
13. Koi locytosis とその関連病変に関す る子宮頸部剥離細胞の電顕観察所見

札幌医科大学産婦人科学講座

宿田孝弘（ＭD）, 伊東英樹（M D ), 熊井健得 ( M D ), 田中 恵 ( M D ), 三好正幸 ( $\mathrm{M} \mathrm{D})$ ，工藤隆一（ M D ）， 橋本正淑 ( M D )

近年, 子宮頸部尖圭コンジローム病変や扁平上 皮異型性病変とHPV感染症との関連性に関する報 報が数多くなされている。剥離細胞の形態学的変 化としては, Koilocytotic atypia, 二核, 多核 細胞, smudged nucleus, dyskeratotic cells, parakeratotic cells, 細胞質の多染性などが挙げ られている。しかしながら，これらの多くの所見 はHPV感染症以外の病変において屯認められてい る。これらの所見の中で, 今回我々はKoilocytotic atypiaを中心に, HPVが検出された症例と 検出されていない症例の異型細胞間に, 超微形態 学上, 相異点が存在するか否かを検討するため, 各細胞を電子顕微鏡にて観察したので報告する。

観察方法は, 当科が開発, 報告してきた同一細 胞の光顕－走査型電顕 (SEM) - 透過型電顕 (TEM) 連続観察方法を用いた。

観察結果

Koilocytotic atypiaを伴う細胞では, 光顕上, 核周囲の細胞質があたかも抜けた様に観察される 所見は, SEM上, 種々の程度の細胞表面の陥凹と して, またTEM上は細胞質が存在するあのの, 極 めて薄くなっている事が認められた。この現象は HPVの検出の有無には無関係であった。一方HPV 検出症例からの剥離細胞においてTEM上, 核内に virus particleの集団を認める細胞が多く観察 された。
14. 子宮頸部におけるヒトパピローマウ ィルスD NA検出キットによる成績と細胞および 組織像の比較

長崎大学医学部産婦人科学教室

O宮崎正浩 (MD) 、行徳 豊 (MD) 、村上俊 雄 (MD) 、福居兼実 (MD) 、中島久良 (MD)、 山辺 徹 (MD) 、馬場寿美子 (CT)

近年、分子生物学的手法の発達にともないた卜 パピローマウィルス（HPV) と子宮頸癌発生と の関連が注目されている。私どすはH P V6、11、 16、18、31、33、35型D NA検出キット（Filter DNA hybridization法) によりHPVゲノムの 有無を調べ、陽性例における細胞および組織像に ついて検討した。対象は当科腫瘍外来および入院 患者147例で、年齢は18〜7歳であった。HPV陽 性率は27\%（40/147人）で、20歳代50\%、30歳代

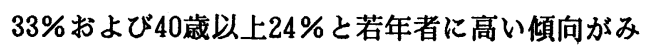
られた。組織学的に H P V 陽性率は慢性頸管炎25 $\%(8 / 32)$ 、軽度異形成 $18 \%(3 / 17)$ 、中等度 異形成 $42 \%(5 / 12)$ 、高度異形成 $57 \%(4 / 7)$ 、 上皮内癌 $50 \%(2 / 4)$ および微小浸潤癌および明 瞭な浸潤癌67\% (4/6) であった。また、細胞診 のクラス吕次上における陽性率は49\%（33/68）、 クラスIおよびாでは $9 \%$ (7/79) であった。 H P V 陽性例の細胞診では、koi locytosisを示し たすの71\% (27/38) 、角化異常（異角化および

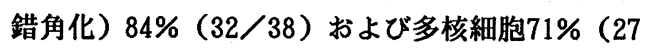
/38) であり、組織診ではそれぞれ64\%（16/25）、 $72 \%(18 / 25)$ および $36 \%(9 / 25)$ に認められた。 なお細胞診、組織診ともに明らかなkoi locytosis が認められなかった例は16\% (4/25) 、角化異常 が認められなかったのは8\% (2/25) および多核 細胞が認められなかったのは $24 \%(6 / 25)$ であっ た。徉来からいわれているこれらの所見が $\mathrm{HPV}$ 感染を示唆するものとして有用かどうか、H P V 陰性例と対比して検討した。 


\section{5. 子宮頸部 H P V 感染症の細胞像}

\section{久留米大学医学部産婦人科学教室}

$\bigcirc$ 高村邦子(CT), 田中博志(MD), 田崎民和(MD)

森一朗 $(M D)$, 福富 毅 $(M D)$, 蓮尾泰之 $(M D)$

葉 清泉 $(M D)$ ，薬師寺道明 $(M D)$

子宮頸部 HPV 感染症の診断は新しいHPV-DNA 検出法の開発により, より簡便, 正確となってい る。スクリーニング法である細胞診の特徵は, koilocytotic atypia, parakeratosis, multinucleus, smudged nucleus, giant cell よ゙と言われてい るが, HPV-DNA 検出症例の細胞像を把握し, 組 織診との不一致の原因を知るために HPV タイピン グキットFOー8830にてHPV-DNAを検出した40例 (組織診; cervicitis 10例, condyloma 2 例, mild dysplasia 8 例, moderate dysplasia10例, severe dysplasia 10例)について, koilocytotic atypia, paraker atosis, multinucleus, smudged nucleus, giant cell, metaplastic cell, koilocytosisとはできない vaculolization, nuclear enlarged endocervical cell の有無について検討し, koilocytotic atypia $6 / 40(15 \%)$, parakeratosis $23 / 40(57.5 \%)$, multinuclus $24 / 40(60 \%)$, smdged nucleus $3 / 4(7.5 \%)$, giant cell $6 / 40$ (15\%), metaplastic cell $35 / 40(87.5 \%)$, vaculolization $11 / 40(27.5 \%)$, nuclear enlarged endocervical cell 7/40(17.5\%)の結果を得た。 乙のように, 従来いわれている H P V 感染症の検 索に扣いて koilocytotic atypia は最も診断的価 值が高いとされていたがその頻度は比較的低く, H P V 感染を細胞診にて診断する上でてれ以外の 所見についても十分な注意を払う必要があるあの と思われた。さらに組織診との不一致例について や，HPV-DNAのタイプ別による細胞像の差につ いて検討したので合わせて報告する。
16. 子宮頸部上皮内新生物（CIN）にお ける HPV 陽性例の細胞像の検討

\section{佐賀県総合保健協会}

○中村清子 ( C T ), 大塚桂子 ( C T ), 本田敦子

( C T ), 古賀順子 ( C T ), 北島理恵 ( C T )

佐賀医科大学産婦人科教室

岩坂 剛 (MD), 杉森 甫 (MD)

HPV 感染症の細胞学的診断には, koilocytosis および dyskeratosis がその特徵的所見とされてい るが, 今回我々は, HPV DNA 陽性および陰性の CIN 病変から採取された細胞診標本の細胞像につ いて比較検討した。

(対象と方法) 佐賀医科大学産婦人科において 1986年以降に取り扱った CIN 患者68例および佐 賀県総合保健協会子宮頸がん検診受診者のなかか ら, 細胞診陰性であった20例を対象とした。これ らを以下の 4 群に分けて検討した。(A) in situ hybridization で HPV DNA 陽性であった CIN 18 症例, (B) dot brot hybridization で HPV DNA 陽 性であった CIN 25 症例, (C) HPV DNA 陰性で あった CIN 25症例および(D)細胞診陰性かっ HPV DNA 陰性であった対照群20症例。HPV DNA 検 出には HPV 6，11，16，18，31，33，35型 DNA あるいは RNA をプローブとして用いた。これら A, B, C, Dの各群について, koilocytosis, dyskeratosis (hyperkeratosis, parakeratosis を含 む), 両染性, multi-nucleation の有無を観察し, その出現率を検討した。

(結果) HPV 感染を示唆する細胞診所見は, A 群， B 群， C 群の順に出現率が高かった。中でも， A 群では, koilocytosis 所見を高頻度に認め, B , C 群では, koilocytosis 所見は少なかったが, dyskeratosis の所見の出現率に違いがみられた。 
17. 子宮頸部病変における $\mathrm{H} \mathrm{P} \mathrm{V}-\mathrm{DNA}$ の局在

\section{愛知医科大学産婦人科学教室}

O樋口和良 (MD) , 中西正美 ( MD )

愛知医科大学中央臨床検查部

小枝吉紀 (MT), 水野義已 (CT), 杉浦 浩(MD)

愛知医科大学第 1 病理学教室

原一夫 (MD)

ヒトパピローマウイルスが子宮頸部異形成 $(\mathrm{d}-$ ysplasia)や上皮内癌(CIS) に打いて高頻度に 認められるようになり、注目を集めている。

今回、われわれは、Dot blot Hybridization法で 確認した症例 13例之病理診断にて dysplasia, CIS , SCCを確認した症例12例についてHPVタイプをビ オチン標識DNAプローブを用いた In situ hybridization 法により検討した。

材料と方法：1989年 2 月から 1989年12月までの 期間に愛知医科大学附属病院産婦人科を受診し、

細胞診で、異常を指摘され、HPV-DNAをDot blot hybr idization法にて確認された13例と病理診断 にて dysplasia, CI S, SCC を確認した12例につい て検討した。その内訳は、mild dysplasiaが8例、 modenate dysplasiaが 4 例、CISが 9 例、SCC が 4 例であった。ホルマリン固定、パラフィン包埋 した標本を用いIn situ hybridization法を行った。 このHPVプローブはHPV - DNA 6, 11 と HPVDNA 16，18 と HPV-DNA 31，33，35の 3 タイプ が分けてあるため、タイプ別に局在を知るてとが 可能となる。

結果 : mild dysplasiaは 8 例中 4 例 ( $50 \%)$, moderate dysplasiaは 4 例中 1 例 $(25 \%)$, CISは 9 例 中 3 例 $(33 \%), \operatorname{SCC}$ は 4 例中 1 例 $(25 \%)$ で陽性 であった。

考察 : mild dysplasiaは50\%と高く、moderate dysplasia, CIS, SCCと比べ高い傾向を示した。 てのてとより H P Vが子宮頸癌に強く関与してい るととが示唆された。
18. Polymerase Chain Reactionによる 子宮顓部擦過細胞におけるHPV DNAの検出

広島大学医学部産科婦人科学教室

$O$ 太田さなえ $(M D)$, 永井宣隆 $(M D)$, 谷本博利 $(M D)$ 藤本英夫 (MD), 木岡寛雅 ( $\mathrm{MD})$, 松田 博 (MD) 藤井恒夫 $(\mathrm{MD})$, 上馬場是美 $(\mathrm{CT})$, 藤原 篤 $(\mathrm{MD})$

【目的】 Polymerase Chain Reaction (PCR) 法 は, 微量な D N A から目的とする領域を増幅し, D N A の検出感度をあげる新しい診断法である。 今回我々は, 子宮頸部擦過細胞を用いて, 子宮頸 癌と関連深いHPV 16型, 18型 DNA の検出を P C R 法より検討した。また，同時に採取した細 胞を用いて, Vira Pap ${ }^{\mathrm{TM}}$ (Dot blot)法(トーレ) より HPV DNA の検出も試みた。

【方法】1) PCR 法: 子宮頸部異形成, 上皮内癌, 浸潤癌の擦過細胞よりDNA を抽出し, HPV 16型, 18型初期遺伝子 E 7 領域に特異的な20bp oligonucleotide primer とし, DNA amplification systemより E 7 領域を増幅した。また, 対照群 として, 16型 DNA を含む Ca Ski 細胞, 18型 DN A を含む HeLa 細胞を用いた。HPV DNA の検 出は, アガロースゲルで電気泳動後, ethidium bromide 染色下の発色反応上り検討した。 2)Vira $\mathrm{Pap}^{\mathrm{TM}}$ (Dot blot) 法: 子宮頸部病変をキ ット専用綿棒にて擦過し, ${ }^{32} \mathrm{P}$ で標識した $\mathrm{H} \mathrm{P} \mathrm{V}$ RNA 混合プローブを用いた dot blot hybridizationよりHPV DNA を検出した。

【成績】CaSki 細胞で $115 \mathrm{bp}, \mathrm{HeLa}$ 細胞で $158 \mathrm{bp}$ の特異的 16 型, 18 型 $\mathrm{E} 7$ 領域の D A A 検出した。 また, 異形成 7 例中 4 例に, 上皮内癌を含む扁平 上皮癌 5 例中 3 例に 16 型 DNA 認め, 現在症例 を追加検討中である。一方, Vira Pap ${ }^{\mathrm{TM}}$ 陽性率 は $28.0 \%(28 / 100)$ であった。

【結論】 P C R 法は， H P V 感染の D N A 診断に おいて重要な検査法の一つであると考えられ， Vira Pap ${ }^{\mathrm{TM}}$ 法同様マススクリーニング的 DNA 診断への応用が期待された。 
19. 子宮䅡部病変におけるHPV-DNA タイプ 別の細胞診によるFollow up 成績

順天堂大学浦安病院検查科 ${ }^{11}$ 、同産婦人科 ${ }^{21}$ 、

$\bigcirc$ 喜納勝成 $(C T)^{11}$ 古谷津純一 $(C T)^{11}$

川島 徹 $(M T)^{11}$ 霜多 広 $(M D)^{11}$ 石 和久 $(M D)^{11}$

宇津野博 $(M D)^{2)}$ 高田道夫 $(M D)^{2)}$

(はじめに)

子宮頝部 HPV感染と関連した病变には、Condylo$\mathrm{ma}, \mathrm{CIN}$ ，扁平上皮癌及び腺癌がある。これら $\mathrm{HPV}$ 感染症を夕イプ別にみるとHPV 6,11 は、退行消 失する群、HPV16,18 は、病変が存続あるいは悪 性へと進行する群、HPV31，33，35 は、その中間群 とされている。今回我久は、各夕イプ別陽性例を Follow up し、KoilocytesをはじめHPV 感染に特 徵的とされている細胞学的所見の経時的変化につ いて検討したので報告する。

(材料と方法)

各種子宮䅡部病変 120 例中上記 7 種類のDNA プロ ーブを用いたSouthern blot 法にてHPV-DNA 陽性 となった 25 例を最短 1 年、最長 4 年半Fol l ow up しtype別における細胞所見を観察した。

(結果と考察)

タイプ別では、HPV6,11 は主にCIN I と診断され た症例でありKoilocytesは出現と消失を繰り返し 認められたが最終的に慢性頸管炎に移行したもの が6 例中4 例みられた。

全体的にKoilocytesの1 年後の出現頻度は、低く なったが、Dyskeratocytes, Binuculeated cells, Metaplastic cells の出現頻度に変化はなく、

Follow up 期間中継続してみられた。即ち、細胞 診においてKoilocytesの出現を認めなくとも、

Dyskeratocytes, Binucleated cells等の所見を認 める場合、十分注意し積極的にFollow up する必 要があると思われる。
20. 産婦人科外来におけるヒトパピロ一 マウイルス検出キットの有用性

大分医科大学医学部産科婦人科学教室 ${ }^{1}$, 同附属病 院検查部 2

○松 敬文 $(M D)^{1}$, 薬師寺喜八郎 $(M D)^{1}$, 早田 隆 $(\mathrm{MD})^{1}$, 林田蓉子 $(\mathrm{CT})^{2}$, 長浜純二 $(\mathrm{CT})^{2}$, 横山繁生 $(\mathrm{MD})^{2}$

ヒトパピローマウイルス $(\mathrm{HPV})$ は性行為感染症 のひとつである尖圭コンジロームの原因ウイルス であるが, 近年, 子宮頝癌との関連についてもに わかに脚光を浴びてきた。

又, 臨床的にもHPVの簡便な検出法の出現以来, 日常外来診療時の細胞診と同時に施行し得るとい った便利さとも相まって, 産婦人科外来において HPVのスクリーニングキットを行なら頻度が增加 しつつある。

今回, 我々は, 初診患者32例を対象として, HPV スクリーニングキット・Vira Pap ${ }^{\mathrm{TM}}$ (Life Technologies, Inc., USA)を用いてHPVの検出を試み， 本法が初期子宮頝癌の検出に寄与し得るか否かを 同時に施行した子宮䅡部細胞診と比較, 検討して みた。

その結果，日母分類 Class I 及び Class II では 全例で本法陰性であり，Class III 以上では本法陽 性及び境界領域が混在する事が判明した。

従って, 我々の用いた HPVスクリーニングキッ トは細胞診陰性群をスクリーニングする事に極め て有用であり，本法で境界領域以上の結果が得ら れた場合は, 子宮頝部の精查をする必要性がある 事が判明した。 
21. 子宮頸部病変とHuman Papilloma Virus (H.P.V.) の関連について

一新しい簡易検出法を用いてー

\section{久留米大学医学部産婦人科}

$\bigcirc$ 田中博志 $(\mathrm{MD})$, 高村邦子 $(\mathrm{CT})$, 蓮尾泰之 $(\mathrm{MD})$

藤吉啓造 (MD), 森 一朗 (MD), 福富 毅 (MD)

田崎民和 (MD), 葉 清泉(MD), 薬師寺道明(MD)

近年, Human Papilloma Virus(H.P.V.)と子宮 頸部病変の関係が注目されている。特に子宮頸癌 発生との関連が指摘され, H.P.V.症例の follow upが重要な課題となっている。H.P.V.の診断に は各種の検出法があるが特異性, 感受性に問題が あり, 最終的には組織より抽出したH.P.V.DNAに て同定するのが確実である。しかし本法は多量の 検体処理は不可能でスクリーニングには適してい ない。

今回, 子宮頸部より採取した剥離細胞よりH.P. V. DNAを検出およびスクリーニングを行ない, またDNA type まで検討可能なH.P.V.タイピング 用試薬キット FO-8830を使用する機会を得たの で，すでに市販されているVila Pap との比較も 含めて検討した。

対象は久留米大学産婦人科で follow upあるい は治療を施行した condyloma acuminatum 3 例, 軽度及び中等度 dysplasia 71例, 高度 dysplasia 20 例, 上皮内癌 4 例, 浸潤癌 13 例の計 111 例で ある。細胞診採取後に綿棒にてVira Pap 用の検 体採取, 最後にサイトブラシにて FO-8830 の検 体採取を行なった。

H.P.V. DNA 陽性症例は condyloma 3/3(100 \%)，軽度および中等度 dysplasia 30/71(42.3\%), 高度 dyaplasia $9 / 20(45 \%)$, 上皮内癌 3/4 (75 \%), 浸潤癌 8/13 (61.5\%)であったので, Vira Papの成績との比較扔よびH.P.V. DNA type の 成績も合せて報告する。
22. 子宮頚部病変における HPV DNAの局 在とタイプ別頻度 一Vira Type ${ }^{\mathrm{TM}}$ を用いて一

堀内文男 $\mathrm{CT}^{11}$, 大木昌二 $\mathrm{CT}^{11}$, 武田 敏 $\mathrm{MD}^{11}$, 米満 博 $\mathrm{MD}^{11}$,

岩崎秀昭 $\mathrm{MD}^{2)}$, 高見沢裕吉 $\mathrm{MD}^{2)}$, 計良恵治 $\mathrm{MT}^{3)}$,

白沢 浩 $\mathrm{MD}^{4)}$, 富田善身 $\mathrm{MD}^{4)}$, 清水文七 $\mathrm{MD}^{4)}$

1) 千葉大学附属病院検査部 ${ }^{2)}$ 千葉大学 産婦人科 ${ }^{3)}$ 千葉大学第二解剖学教室

4) 千葉大学第一微生物学教室

目的 子宮䅡部病変 (CIN) における HPV 感染 を知る目的でin situ Hybridizationを行い、HPV DNAの局在と HPV Typeの頻度を検索した。

材料 病理組織学的にCIN と診断された 131 例, Mild dysplasia 33 例, Moderate dysplasia 33 例, Severe Dysplasia 36例, Ca in situ 29 例,である。また 16 例の Condyloma も検討した。

方法 Human Papillomavirus Tissue Hybridization kit (Vira Type, トーレフジバ イオニクス（株））を用いた。

成績 CIN 全体における HPV DNA の陽性率 は61/131 46.6\%であった。Type別頻度では、 6. 11 型は Mild dysplasiaで $3 \%$, その他の病変 では認められなかった。16.18 型は、Mild dysplasia $15.2 \%$, Moderate dysplasia 18. $2 \%$, Severe dysplasia $16.7 \%$, Ca in situ $17.3 \%$,であった。31. 33. 35 型では Mild dysplasia $21.2 \%$, Moderate dysplasia 33.3 $\%$, Severe dysplasia $22.2 \%$, Ca in situ 41 . 4\%であった。Mild dysplasia全体における HPV DNA の検出率は $39.4 \%$, Moderate dysplasia $51.5 \%$, Severe dysplasia $38.9 \%$, Ca in situ $58.6 \%$ あった。16例のコンジローマでは 6.11 型が 9 例 $56.3 \%$,にHPV DNAが検出された。

結語 本 Hybridization 法は操作が比較的簡単 で一般の検査室で実施することが可能である。ま た従来の䤃素抗体法に比へ感度が高く HPV DNA の検出に有用と思われた。 
23. 子宮頸部におけるHPV (human papillomavirus) 感染検出法の比較検討

-FO-8830 法とViraPap 法の比較一

東北大学産婦人科, 宮城県対がん協会

○今野 良(MD), 鹿野和男(MD), 牧野浩充 (MD), 伊藤 潔(MD), 八重樫伸生(MD), 遠藤 敦(MD), 千葉英俊 $(M D)$, 堀口正之 (MD), 佐藤信二 (MD), 矢嶋 聰 $(M D)$, 東岩井 久 $(M D)^{*}$

HPV 感染の検出には種々の方法が行われている が, 今回, 我々はビオチン標識プローブを用いた HPV DNA 䛦断キットFO-8830 (藤沢薬品) により 子宮頸部の HPV-6, 11, 16, 18, 31, 33, 35 の検出を 行った。本法は，1）上記DNA 混合プローブによ る Dot blot hybridizationでスクリーニングを行 った後，2）陽性例について Southern blot hybridization で HPV DNA の型判定を行うとい う2段階加成っている。

対象は宮城県対がん協会がんクリニックで異形成 上皮追跡中の 187 症例とし, うち60例については ViraPap法と併用し両者の検出頻度を比較検討した。 また, 細胞診, 組織診との関係も検討した。

HPV DNA は，スクリーニングでは 187 例中 56 例 (30.0\%)に検出された。陽性例について Southern hlot hybridizationを行った成績は, HPV DNA型 が判定されたもの $51.8 \%$ ，型は判定不能ながら HPV 陽性と確認できたもの17.9\%, Dot blot hybridi zationでは陽性だったものの偽陽性と判定せざるを 得なかったあのが30.3\%であった。FO-8830 スクリ ーニング群 ( $\mathrm{F}$ 群) とViraPap 群 ( V 群)の比較では, 60 例中両群之む陽性が 3 例, F 群のみ陽性が29例, $\mathrm{V}$ 群のみ陽性が 1 例, 両群之も陰性が27例であった。 V 群で陽性率が著しく低かった原因は採取検体中に 血液の混入があると判定不能となってしまうととに よると思われた。

また，本法を用いて行った子宮頸癌集団検診時の 正常婦人を対象にした検査では 180 例中 5 例 (2.8\%) にHPV DNAが検出された。

\section{4. 各種HPV検出法の比較検討}

千葉大学産婦人科1), 同第 2 解剖2), 同中検細胞 彰3), 千葉県対がん協会4), 千葉市立海浜病院産 婦人科 5$)$

O岩崎秀昭 (MD)1), 白沢 浩 (MD)1), 深沢一雄 (M D)1), 小川雅利(MD)1), 稲葉憲之(MD)1), 武田 敏 (MD)1), 高見沢裕吉 (MD)1), 計良恵治(MT)2）, 堀内文男(CT)3), 大末昌二 (CT)3), 石川 明(CT) 4), 河西十九三(MD)5), 久保田浩一(MD)5)

従来より, 我々は子宮顕部病変におけるHuman papil lomavi rus (HPV) の存在様式を, 簡易的検出 法であるVira Pap TM, Vira Type TMにて検討し ている。Vira Typeは HPVの型を 3 群 (6/11， 16/18,31/33/35) にわけたタイピングキットであ る。またVira Type と同群のプローブを用いたin situ hybridization もあわせて行つた。今回こ れら種々の検出法の比較検討の成績についても報 告する。

1) Vira Type と細胞像：Vira Type の陽性率は 細胞診疑陽性例で最も高値を示した。6/11陽性は 1例で細胞診Class II，16/18陽性は29例で， class II 5例，IIta 17例, IIIh 7例，31/3.3/35 陽性は18例で class I 1例, II 3例, IIIa 11 例 , IIIb 2例, IV 1例であつた。

2 ) in situ hybridization : Vira Pap陽性, サ ザンブロット法にて HPVの型が同定された症例の in situ hybridization の陽性率は20/27(74\%)で ，同時に型も一致していたのは16/27(49\%)であつ た。Vira Type陽性例のin situ hybridization の陽性率は11/21(52\%)で，それらは型も一致して いた。

以上の事より，各種検査法による相互の信頼性 が確認された。またタイピングキットによる follow-up 成績もあわせて述べる。 
25. ヒト子宮須部におけるHPV DNA の検出。 Southern blot 法とin situ ハイブリダイゼーシ ヨン法との比較

千葉大医学部解剖1)，同大医学部産婦人科2），同 大医学部微生物 3)，同大附属病院中検 4)，千葉県 対がん協会5)

O計良恵治(CT)1)，岩崎秀昭(MD)2)，深沢一雄(M D)2），武田敏(MD)2），高見沢裕吉(MD)2），白澤浩 (MD)3)，冨田善身(MD)3)，清水文七(MD)3），堀内 文男(CT)4), 石川 明(CT)5), 田口明美(CT)5)

子宮癌とHuman papillomavirus(HPV) 感染との 関係が重要視され，その形態変化と HPV DNAとの 関連が注目されている。今回我々は，HPV遺伝子 をSouthern blot(SBH)法とin situ ハイブリダイ ゼーション(VIISH) 法とを比較検討した。

症例：子宮癌検診時に採取した生検組織より, SBH法で HPVのタイプ $(6,11,16,18,31,33,35$ 単 独）が確認された 34 症例についてパラフィン包埋 組織よりVTISH 法（東レ）でHPV DNA（6/11,16 /18,31/33/35の3種）の検出状況を調べた。

成績：SBH法での HPVタイプは31が13例，16が10 例. 11が 4例、33が 4例，6．18．35が条々 例 の合計34例であつた。この34例中VIISH 法でHPV DNA が検出された症例は28例で，非検出が 6例見 られた。検出例のタイプ別出現状況は $6 / 11$ が 3 例, $16 / 18$ が 8 例, $31 / 33 / 35$ が15例, タイプ不明 が 2例であつた。これらVIISH 法でHPV DNA が検 出された28例中, SBH法と不一致の31/33/35の 1 例とタイプ不明 2例の計 3例を除く25例はSBH法 の成績と一致していた。VTISH法でのHPV DNA の 分布は核異型を伴う扁平上皮の表層からかなり深 層の主に核内に見られ，この部位は連続切片での H\&E 標本でコイロサイトーシス等の HPV感染に特 有の変化がみられた。
26. 子宮癌集団検診におけるヒトパピロー マウイルスの出現率（Vira Papを用いて）

鹿児島県民総合保健センター, 鹿児島大学産婦人科 O花田正二 (C T), 堂園晴彦(MD), 池田俊一 $(M D)$, 鵜木康資 $(M D)$, 中村行彦 $(M D)$, 松元 保 $(M D)$, 三輪勝洋 $(M D)$, 永田行博 $(M D)$, 岡 上慎一 $(\mathrm{C} \mathrm{T})$, 折田利秀 $(\mathrm{C} \mathrm{T})$, 下川幸弘 ( $\mathrm{C} \mathrm{T})$, 東郷ゆ加り $(\mathrm{C} T)$, 今井悦子 $(\mathrm{C} T)$, 内田達也 ( C T )，平原寿美( $C \mathrm{~T})$ ，新田耕一 $(M T)$ ，前田 孝之 $(\mathrm{C} \mathrm{T})$ ，尾辻義人 $(\mathrm{MD})$

子宮頸癌発生とパピローマウイルスとの関連性 が最近注目を集めているが，本邦での研究は殆ど 細胞診や組織診陽性症例に対してである。今回集 団検診に Pap スミア検査と同時に HPV-DNA 検査を併用しパピローマウイルス感染の実態を検 討した。また，1988年，89年におけるkoilocytosis の出現率を検討した。対象症例はバス検診受診者 156名之, 外来受診の子宮癌検晾希望者30名, 合 計 186名である。また，koilocytosisは，1988年バス 検診受診者 67,234 名, 89年46,693名である。検索 方法は，まず綿棒ないしはサイトブラシで VCE ス ミアを採取後 HPV-DNA 検索をVIRA PAP HPV kit (Vira Pap)を用い検索した。 koilocyto$\operatorname{sis}$ の診断は 2 以上のスクリーナーと指導医の判定 で行なった。HPV-DNA 陽性者は186名中 4 名, $2.1 \%$ あ゙あった。また，乙の 4 例すべてにkoilocytosis は認めなかった。集団検診での koilocytosis の 出現率は1988年は67,234名中41名，0.06\%，89年は 46,693名中 20 名, $0.06 \%$ であった。また，両年とも 30才代と60才代にピークを認めた。子宮頸癌の発 生にパピローマウイルスが関連してるとの報告が 多数なされているが，集団検診で HPV-DNA 検 索報告は少ない。今回の検索では2.1\%であり， koilocytosis 出現率 $0.06 \%$ に比烄し高率であった。 今後 HPV-DNA 検査法が料金的に安くなるか, あるいは，老健法に組み入れられるとしたら，集 団検診であ積極的に用いる有用性が示唆された。 
27. フローサイトメトリーを用いての

子宮頸癌のDNA 解析之組織所見との検討

\section{慶應義塾大学医学部産婦人科学教室}

国立東京第二病院臨床研究部産婦人科*

○渡辺豊治 $(\mathrm{MD})$, 和泉滋 $(\mathrm{MD})$, 筒井章夫 (MD),

田村昭蔵(MD),

和田之も美 $(M T) *$, 新井宏治 $(M D) *$,

宇田川康博 $(M D)^{*}$, 山岡完司 $(M D)^{*}$,

栗原操寿 $(\mathrm{MD})^{*}$

[目的 ] FCMによる固形腫瘍の DNA 合成の生長 解析は, 最近臨床的に注目されている。われわれ は，厳密な $\mathrm{FCM}$ 解析を目標に基礎的検討を行っ てきた。今回は, 子宮頸癌に扔ける,DNA Aneuploidy (DA)の出現頻度, および DNA Index (DI) について, 組織および臨床所見との関連に おいて検討をくわえたので報告する。

[万法]子宮頸癌の生検材料及び手術摘出標本 80 例を対象とし，採取した組織をMEM·イーグル培 羕液中で, $4{ }^{\circ} \mathrm{C}$ 亿保存, 組織を細切し, $0.1 \%$ 卜 ライトンX-100にて裸核化, RNAse $(1 \mathrm{mg} / \mathrm{ml})$ 処理後, Propidium Iodide $(50 \mu \mathrm{g} / \mathrm{ml})$ にて 蛍光染色し, FACS tar (BD社) にて測定した。 [成績 ] 1) $\mathrm{CV}$ 值: 平均 $3.66(1.8-6.4), 2) \mathrm{D}$ $\mathrm{NA}$ 解析： 80 例中 54 例 $(67.5 \%)$ 飞 DAを認めた。 臨床進行期について, DAの出現率は, CIS 68.1 $\%$ ( 15 例 $/ 22$ 例中), I a $80.0 \%(8 / 10)$, Ib 75.0 $\%(15 / 20)$, II a $66.7 \%(2 / 3), \mathbb{I}$ b $62.5 \%$ $(10 / 16)$, III 以上 $44.4 \%(4 / 9)$ であった。組 織型別では, 扁平上皮癌 64 例中 39 例に DA を認 めた。そのDIは，CIS および Ia 期では， 1.05 から 1.25 の階級への集積がみられた。Ib期以上で は， 0.90 から 2.57 亿分布していた。また, 腺癌 では 13 例中 11 例之高頻度にDAを認め，そのDI は, 1.07 から 2.50 であった。

[結語 ] 1）子宮形癌の $67.5 \%$ 亿NA 異数体をみ とめた。2）扁平上皮癌の早期症例では, 近高二倍体 が多く出現した。さらに症例を加え，検討し報告する。
28. 婦人科癌培養細胞における $\mathrm{c}-\mathrm{myc}$ 遺层 子産物の発現とその解析

\section{大阪医科大学産婦人科学教室}

O植田政嗣 (MD), 岡本吉明 (MD), 山田隆司 (MD), 清木康雄 (MD), 御前 治 (MD), 鶴長建充 (MD), 岩井恵美 (MD), 植木 実 (MD), 杉本 修 (MD)

〔目的 最近, 癌遺后子産物と細胞の癌化過程や 腫瘍の悪性度との関連性が注目されており，中で も $\mathrm{c}-\mathrm{my}$ 蛋白は, DNA 合成開始因子として腫愓細胞 の增殖動態に密接に関与するとされている。そと で, $\mathrm{c}-\mathrm{my} \mathrm{c}$ 蛋白を婦人科細胞診における異型細胞 の質的判定に応用する前段階として，まず培養細 胞における発現を検討した。〔方法〕 OMC-1 (頸 部扁平上皮癌株), $\mathrm{OMC}-2$ (内膜腺癌株) , $\mathrm{OMC}-3$ (卵巣 ムチン性腺癌株), OMC-4 (頸部腺癌株)を 用いた。95\% e thanol, $10 \%$ formalin または 10,1000 $\mathrm{mM} \mathrm{NaCl}$ 添加 4\% para for maldehyde (PFA) で固定 後,抗 $c-m y c$ 蛋白モノクローナル抗体を一次抗体と して種々の反応条件で酵素抗体 $\mathrm{ABC}$ 法を行った。一 方, $1 \times 10^{7}$ 個の培盖細胞の抽出核蛋白に対し同抗体を 用いて western blotting を, また抽出 DNA 亿対し c-myc probe を用いて slot blot hybridization 行った。〔成績〕 $95 \%$ e thanol, $10 \%$ formalin 固 定では核と細胞質が染色された。 $\mathrm{NaCl}$ 添加 4\% PFA では, $10 \mathrm{mM}$ では細胞質も染色されたが $1000 \mathrm{mM}$ は核が特異的に染色された。反応条件は 500,1000 倍稀釈の一次抗体で $4^{\circ} \mathrm{C}$ over night, 発色は 1 分前後 が適当と思われた。使用した抗体は $\mathrm{OMC}-1$ では 66 kd, OMC-2,3,4では $62 \mathrm{kd}$ の蛋白を認識しており, ま た OMC-2,4で gene amplificationがみられた。

〔結論〕 OMC - 1,2,3,4 亿おける $c-m y c$ 蛋白の発現 が形態学的, 生化学的に確認され,てれらを positive control として臨床細胞診検体への応用が可能と思 われた。しか儿通常の e thanol, formalin 固定や低塩濃 度下では $\mathrm{c}-\mathrm{myc}$ 蛋白の細胞質への redis tribution が生じたととから, 染色結果の判定には固定法に 十分留意すべきである。 
29. Vira papを施行した $\mathrm{CO}_{2}$ laser conization症例の検討

\section{島根医科大学医学部産科婦人科学教室}

○中山 理 (MD)，岩成 治 (MD)，伊達美江 (MD)

吉野直樹 (MD) , 柳光寛仁 (MD) , 森山政司 (MD)

北尾 学 (MD)

近年、子宮頚癌と human papilloma virus (HPV) との関連を示唆する報告が数多く見られる。今回 HPV のDNA を検出するキット (Vira pap) を使用し た $\mathrm{CO}_{2}$ laser conization 症例について検討した ので報告する。

【対象】 $\mathrm{CO}_{2}$ laser conizationを施行する前に、 病変部位より採取した剥離細胞より Vira pap を 用い、HPV の検索をした15例を対象とした。

【成績】Vira pap陽性例は、 $\mathrm{CO}_{2}$ laser conization を行った症例15例のうち4 例であった。15例 のconization施行前の細胞診の内訳は, class III a :7例、class $\mathrm{III}_{\mathrm{b}}: 7$ 例、class IV : 1例であり、 conization施行後の組織診の結果は、moderate dysplasia: 3 例、 severe dysplasia: 3 例、CIS: 9 例であった。陽性例 4 例の conization 施行前の 細胞診の内訳は、class III $_{\mathrm{a}}: 3$ 例、class III $_{\mathrm{b}}: 1$ 例であり、conization 施行後の組織診の結果は moderate dysplasia:1例、CIS: 3 例であった。

【考察】Vira pap 陽性の4 症例のうち、細胞診 が classIIIa だった 3 例は2 例がCIS であり、 class III。の1 例はCIS であり、細胞診で推定し た以上に組織はより高度な病変であった。症例数 は少ないが、これにより細胞診だけでなく、HPV の局在を示す事は、更に詳しい組織の推定も可能

性も示唆された。また、 $\mathrm{CO}_{2}$ laser conization後 も細胞診だけでなくVira papにてもfollowしてい るのでその結果も細胞診と比較して報告する。
30. レーザー円錐切除法後に発見された 上皮内癌合併微小浸潤腺癌の一例

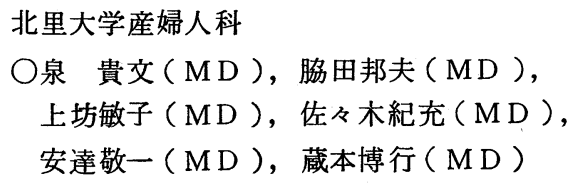

昨今, 子宮癌検診の普及により, 子宮頸部異形 成や早期癌の発見率が, 高まってきている。一方, 頸部腺癌は近年増加傾向にあると報告され, しか も, その早期発見は困難で, 予後も悪い。そこで 今回, われわれはレーザー円錐切除法を行ったと ころ, 切除標本で上皮内癌に加え, 微小浸潤腺癌 を認めたので, その術前細胞診を再検討し，臨床 経過も含め報告したい。

症例は 50 才, 3 経妊 3 経産婦, 不正出血を認め たため, 集団検診を受け, 細胞診では上皮内癌で 精密検査が必要と報告された。そのため, 当科を 受診し, 細胞診では上皮内癌, コルポ診では I 型 で，厚い白色上皮を認め, 同部の狙い組織診では 高度異形成と診断された。細胞診と狙い組織診が 不一致のため, $\mathrm{C} 02$ レーザー円錐切除法を施行し たところ, 切除標本で上皮内癌に加え，その頸管 側に微小浸潤腺癌を認めた。そのため, 準広汎性 子宮全摘出術, 両付属器切除術, 及びリンパ節郭 清術を施行したが，手術標本では，病変の遗残及 び転移は認めなかった。再度術前細胞診を検討し たところ，背景はきれいで，散在性の深層系 dysplastic cellに加え，シート状の細胞集塊を認 めた。後者では, 細胞質は淡くレース状で，核は 偏在し, 円形 類円形, 大小不同は軽度 中等度, クロマチンは, 軽度腫大し, 微細顆粒状だった。 核小体は，1～ 2 個の小型核小体を認めるのみで, 異型度は強くはなかった。結果的には腺異型細胞 と判断されたが，術前は上皮内癌と判定され，鑑 別に注意が肝要と思われた。以上より，子宮頸部 腺癌の早期診断の困難さを再認識すると共に, 細 胞診と狙い組織診の不一致例に対するレーザー円 錐切除法の有用性が確認された。 
31. 子宮顓部の小細胞非角化型扁平上皮癌 9 例の細胞像

九州大学医学部婦人科学産科学教室

O松村真理子 (MD), 井町正士 (MD), 塚本直樹 $(\mathrm{MD})$, 中野仁雄 (MD)

子宮頸部の小細胞非角化型扁平上皮癌は稀で、 子宮頸癌の 1 ～2\%といわれている。臨床的には リンパ節転移や遠隔転移を起てしやすく、 5 年生 存率が約 $20 \%$ と予後不良である。なかには ACTH, インスリン,カルシトニンなどのホルモン産生能 を有し、それらのホルモンによる特徴的な症状を 呈した症例の報告むある。診断に際しては腫瘍が 内向性に発育するむのが多く、コルポ診で病巣が とらえにくく、さらに細胞診でむ他の扁平上皮癌 と異なり特徴的所見に乏しい。しかし、早期に治 療すれば予後は良く、早期発見が望まれる。そこ で、今回われわれは子宮頸部の小細胞非角化型扁 平上皮癌の細胞所見および組織所見について、当 科で治療した 9 例ひついて検討した。

年跘は $23 \sim 76$ 歳で、臨床進行期は I b 期 3 例、 IIIb 期 2 例、IV a 期 1 例、IVb期 2 例、再発 1 例で あった。

組織学的には小型で大小不同に乏しい腫韵細胞 が、索状ないしは㖪様性に増殖し、間質へのびま ん性浸潤を認めた。核は円形または類円形で、細 胞質はわずかで、多数の核分裂像を散見した。

細胞学的には小型で大小不同に乏しい腫煌細胞 が、散在性あるいは細胞間結合のゆるい小集塊を 形成して出現した。細胞質は狭小で、 $\mathrm{N} / \mathrm{C}$ 比が 大きく、裸核状のものも認めた。核は円形または 類円形で、クロマチンは粗顆粒状に増量、核小体 はときに認めるが比較的小型で、核縁の肥厚は目 立たなかった。また、腫煬性背景を認めた症例は 少なかった。

\section{2. 子宮頸部扁平上皮癌の細胞診成績}

\section{長崎大学医学部産科婦人科学教室 \\ O馬場寿美子(CT), 福居兼実(MD), 森山伸吾(MD) \\ 村上俊雄(MD), 行徳 豊(MD), 中島久良(MD) \\ 山辺 徹(MD)}

長崎大学において 1985 年から 1989年の 5 年間に 治療した子宮頸部扁平上皮癌 229 例 ( 0 期96例, I a 期38例, I b 期46例, II期38例, III期 7例お よびIV期 4例）の細胞診成績，とくに浸潤の有無 が予測できたかどうかについて検討した．0期で はクラスIII，INおよ゙Vと判定されていたすのは 16例 $(16.7 \%) ， 52$ 例 (54.2\%) および28例 (29.1\%) であった．Ｉａ期ではクラスIII，IVお よびVと判定されていたすのは，8例（21.1\%）， 9例 (23.6\%) および21例 (55.3\%) であった. そして I b 期以上の進行例95例では, クラス且, IVおよびVと判定されていたものは，1例 (1.0 \%)，7例 (7.4 \%) および87例 (91.6\%) であ った. また, 104例 ( I a 期36例, I b 期41例 お よび【期27例）の摘出子宮における癌の間質浸潤 度と細胞診の結果を比較した. 浸潤度 $3 \mathrm{~mm}$ 以内の 癌は51例あったが, 微小浸潤癌および組織学的に 明嘹な浸潤癌に分けるとそれぞれ21/36例 (58.3 \%) および11/15例 (73.3\%) がクラスVであっ た.これに対して，浸潤度 3 mmを超える53例では 49例 (92.5\%) がクラスVと判定されていたが, クラスVと判定されなかった 4 例のうち 3 例が浸 潤度 $5 \mathrm{~mm}$ 以内であった。したがって, 浸潤度が增 すにしたがい細胞診で浸潤があることを予測でき る頻度が高くなる傾向にあった。 
33. クラミジアザイム陽性例の細胞所見

自治医科大学産婦人科

○関口 勲 (MD), 鈴木光明 (MD), 赤堀彰夫（MD），玉田太朗（MD）

Sexually transmitted diseasesのひとつである クラミジア感染は頸管炎, 付属器炎さらには卵管 性不妊の原因として注目されている。当科では 1987 年より不妊症あるいはクラミジア感染疑い婦人に 対しクラミジアザイム（EIA）を施行している. 今回, EIA陽性例の細胞診を検討したとてろ若 干の知見を得たので報告する. [対象・方法] 最 近 3 年間にEIAを施行した 669 例を対象とした。 細胞標本は綿棒にて子宮頸部および頸管より擦過 採取した.クラミジアの細胞診にあたっては, 細 胞標本に星雲状封入体（NB）もしくはcoccoid bodyを認める細胞質内封入体（ICI）を有する 細胞が出現した場合, クラミジア感染陽性とした。 また, 細胞異型, 炎症所見などああわせ検討した。 ［結果］1）EIA 陽性例は36例で，陽性率 5.3 \%であった。2）EIA 陽性例中，EIA と同時 に子宮頸部細胞診を施行した症例は17例であり， 細胞診でのクラミジア感染陽性例は 17 例中 12 例 （陽性率70\%) であった。3）NB陽性例は 5 例 (29\%)，ICI 陽性例は10例（59\%）であり， NB，ICI と屯に陽性は 3 例（18\%）であった。 NBあるいはICI は全体でそれぞれ 11 個，33 個 であった，NB，ICI は基底・傍基底型扁平上 皮細胞, 化生細胞および円柱上皮細胞に認められ た。核所見については 6 例（35\%）に核の軽度腫 大を認め，また，1例は上皮内癌を合併していた。 炎症所見としては白血球浸潤著明なすのが 11 例 (65\%) に認められたが, 組織球の出現は 3 例 (18\%) にみられたのみであった。[まとめ] 細胞診によるクラミジア感染の診断はかなり困難 なあのであると考えられたが，そのスクリーニン グにあたっては，NBに加え，ICIの同定が有 用であることが示唆された。
34. 老人性胵炎に対するエストロゲン製剤 投与前後の細胞診変化

\section{島根医科大学医学部産科婦人科学教室 ○森山政司 (MD), 岩成 治 (MD), 吉野直樹 (MD), 伊達美江 (MD), 中山 理 (MD), 柳光寛仁 (MD), 北尾 学 (MD)}

子宮頚癌による死亡率は順調に減少してきた が, 最近, 微增の傾向にある。その原因のひとつ として高歯者に進行子宮䅡癌患者が多いことが指 摘されてきており, 高歯者の子宮頚癌検診が重要 となってきた。しかし, 高齢者の子宮頝部擦過細 胞診は老人性胵炎による变化のため細胞診の判定 に苦慮することが多い。今回, 我々は初診時胵鏡 診によりあるいは子宮頝部擦過細胞診により, 老 人性胵炎と診断した患者22例（37才〜 82才, 平均 63.8才）に対して, エストリオール $2 \mathrm{mg} 2$ 週間 経口投与し, その変化を検討した。その結果, 老 人性胵炎の治療前 classII とした13例中, 治療後 では12例が classII であった。1 例は classIIIb となり, 組織診は軽度異形成であった。治療前 class III a と判定した 6 例では, 治療後 5 例が class II であり， 1 例が classIIIa であり，その 組織診は軽度異形成であった。残りの 3 例は治療 前 classIIIb であり, 治療後も classIIIb ないし は classIVであり, 組織診では中等度異形成 1 例 上皮内癌 2 例であった。老人性胵炎による萎縮上 皮を過大評価したり過小評価したりすることがあ るが, エストロゲン投与により判定の誤りを減ら すことができた。 


\section{5. 妊婦の細胞診}

東京慈恵会医科大学柏病院産婦人科, 同病理科 * ○小林重光 (MD), 山田恭輔 (MD), 渡辺明彦 (MD) 青木雅弘 (MD), 高山慶一郎 (MD), 神谷直樹 (MD) 安田 允 (MD), 寺島芳輝 (MD), 鯉沼博美 (CT)* 小野安雄 $(\mathrm{CT})$ * 猪股 出 $(\mathrm{MD})$ *

1987 年 4 月より 2 年間に, 慈恵医大産婦人科を 受診した新患々者を, 妊娠群と非妊娠群に分け, 両群の細胞診の結果を比較し, 妊娠時における細 胞診の特徵につき検討したので報告する。

当科では, 新患々者全例に胵細胞診検査を施行 しており，2 年間に打ける新患々者総数は8858名 であった。このうち, 妊娠群1803名, 非妊娠群 7055名のなかの class IIb 以上の要再検者数は, そ れぞれ，24名(1.3\%)，283名(4.0\%)であった。妊 娠群に打ける要再検例24例のclass分類は, class II b18例 (75.0\%), class IIla 6例 (25\%)であり,class IIIb 以上の症例は認められなかった。一方, 非妊 娠群要再検例 295例では, class IIb 160例 (54.2\%), class III a67例 (22.7\%), class IIb15例 (5.1\%), class N 20例 (6.8\%)， classV 33例 (11.2\%) といら結果で あった。両群を比較すると, 非妊娠群では, 症例 は class Ib-Vk広く分布するのに対し，妊娠群で class IIb， IIa に分布の片よりがみられ, class IIIb 以上の症例は存在しなかった。この差は, 1.両群 間に打ける年令構成の差 2 .非妊娠群では, 2 次 検診を目的とした新患々者が多く含まれていたた めと思われる。また, class IIb の症例数を比較 すると, 妊娠群 18 例 (75.0\%), 非妊娠群 160 例

(54.2\%) と，妊娠群における class Ib 症例の占め る割合は高く，妊娠時合併することの多い腟炎も， 診断をする上で重要な foctor であると推察さ れた。
36. 妊娠中の異型細胞の検討

東京慈恵会医科大学 産婦人科学教室 中野真 (MD), 崎平公子 (MD), 清水良明 (MD) 落合和彦 (MD), 安江育代 (MD), 株本和美 (CT) 寺島芳輝 $(M D)$

子宮頸癌は細胞診診断学の進歩・普及にょり早 期発見が可能となった。これは，たとえ妊娠中で あっても同様であり，近年妊娠に合併した子宮頸 癌の報告も散見される。我々は過去 2 年間に外来 受診した新患妊婦 1048 例中 12 例儿C I Nを 認め, その発見率は非妊娠時の細胞診異常出現頻 度と比較して決して少ない頻度ではなかった。 そてで, これらの症例の妊娠・産裖を通しての変 化を細胞・組織学的に検討したので, 若干の文献 的考察を加え報告する。

症例は, 奷娠初期の細胞診で c las s III a $\sim \mathrm{IV}$, 組織診でMild dysplasia 〜 I S の診断を得た もので, 産褯期まで経過を観祭し得た 5 例, 現在 妊娠経続中 6 例及び迁娠中絶 1 例の計 12 例であ る。

各症例壮, 1 3 力月毎 V Colposcope, 細胞 診を施行, 必要に応じPunch biopsyを施行し厳 重に経過観察を行った。妊娠中にはdecidua 1 cell, trophoblast, syncytiotrophoblastic cell, navicular cell などの妊娠に特徵的な 細胞の出現や,ホルモンの影響により中滴細胞が主 体を成すなどの細胞学的な変化が認められるが, Screening てあたっては, 特に困難はないと思 われた。又，妊娠中は免疫能の装化等に上り， progressive な経過をとる報告も認められるが， 今回の 12 症例はいゔれも安定した経過をとり， 逆に産裖期にはregressionする症例も認められ た。

以上の事より奸娠という産科的主訴での来院に 際しても細胞診の施行が重要であるととが再確認 された。 
37. 子宮頸部 のTissue Repair Cel1の 細胞学的検討（第二報）一その由来について一

大阪医科大学産婦人科, 同中検病理 ${ }^{*}$

O植木 実 (MD) , 黑川彰夫 (MD) *

森川政夫 (CT) * , 日下部正 (CT)* 木附公介 (MD) , 御前 治 (MD) , 清木康雄 (MD) , 後藤真樹 (MD) , 植田政嗣 (MD) ，前田隆義 (MD) ，杉本修 (MD)

子宮頸部初期病変に対するlaser cone後の創傷 治癒時の擦過細胞中にみられる Tissue Repair ce11は Papanicolaou 染色で形態的に, 上皮由来 (ETR)，間質由来 (STR) ならびに両者とも判別出 来ない由来不明 (UTR) 群に分けられるが, さらに EMA およびVimentinの両免度染色における染色態 度からもその分類の妥当性を既に報告した。

今回, これら TR細胞の由来, とくにSTR とUTR が創傷治瘾過程の肉芽組織に由来する細胞ではな いかとの観点に立って検索を行った。

10 例の laser cone施行後の創部より 2 5 週 目に綿棒にて細胞採取し，1枚はエーテル・アル コール固定後Pap 染色, restaining method によ るEMA およびVimentin免疫染色を, 他の 1 枚は Znker 液固定によるPTAH染色をそれぞれ行った。

その結果, STR およびUTR と判断される細胞に は細胞質に青黒色に染る数本の縦走する細線維, 即ち筋細線維 (myofibrile) が観察された。これ によって間質由来の特徵を持つTRは肉芽組織の myofibroblastであることが強く示唆された。

以上の証明から，全てのTRは，上皮由来と考え る報告者が多い中で，証明は出来なかったものの その存在を推察したBibbo の説を裏ずけたと考え られる。
38. 子宮頸部 Tissue Repair Cell の細胞 学的検討(第三報)一頸癌放射線治療例について一

\author{
大阪医科大学中検病理, 同婦人科 ${ }^{*}$ \\ 森川政夫 (CT)，植木 実 (MD) * , 黑川彰夫 (MD)， \\ 日下部 正 (CT), 岡村信介 (MD) *, \\ 前田隆義 (MD) *, 後藤真樹 (MD) *
}

我々はTissue Repair Cell (TR) を「組織修復 に由来する異型或は活性核を有する細胞」と規定 し，検討している。既報では子宮頸部の laser coneの創傷治瘾時における T Rには，上皮由来 (ETR)と間質由来(STR) が存在することを明ら かにした。今回, 婦人科領域で同様にTRがよく出 現するとされる頸癌の放射線治療患者を対象と して,それらの種類, 形態, 放射線影響の出現時 期, 頻度さらにPIDや残存癌, 再発に由来する異型細 胞との鑑別について検討した。対象は, 頸癌の進 行期 II b IV 期の放射線治療 (非手術施行)の延心 65 例である。外照射(Tel ecobalt)中の $2,000 \mathrm{rad}$ 頃より 6,000 rad 迄と,その後局所照射 (Radium) $2,000 \mathrm{mg}$ を加えた終了後の約 1 年間の follow up 期間に, $1 \sim 2$ 力月毎に頸部より擦過（綿棒） 採取し、2 枚に塗沫した。1 枚はエーテル・アル コール固定後 $\mathrm{Pap}$ 染色を行い，その一部に restaining methed によるEMA とVimentinの 免疫染色を行い, 他の 1 枚は Zenker液固定後 PTAH 染色を行った。その結果，放射線治療後に みられるTRはほとんど ETRであり,わずかにSTR がみられた。T Rは 2,000 rad頃では出現例は少な いが，治療後数力月の間は多数の例に認められた。 これらには放射線による細胞への影響は少ないが。残 存癌による癌や異型細胞には明らかな変化が認め られた。このような所見や異型度の差から T R と 他の異常細胞との鑑別は可能と思われた。 
39. 細胞診を契機として診断された子宮 頸部悪性リンパ腫の 1 例

福井医科大学医学部産科婦人科学教室

O佐々木博正（MD）, 吉田 好雄（MD） 福野直孝 $(M D)$ ，竹内 譲 $(M D)$ 紙谷 尚之 $(M D)$, 富永 敏朗 $(M D)$ 福井医科大学医学部附属病院検查部病理 森 正樹 (C T) ，三宅 敏彦 (M D)

悪性リンパ腫はリンパ組織を構成する細胞成 分に由来する悪性腫湯の総称で、その診断は生 検組織像による。一方、スタンプ細胞診は、補 助診断として有用であることが知られているが 今回、我々は、擦過細胞診である子宮腔部、頸 管細胞診を契機として確定診断に至った子宮頸 部原発と思われる非ホジキン性悪性リンパ腫の 1 例を経験したので、その細胞像を中心にして 供覧したい。

症例は、 58 歳、 5 回経妊 2 回経産婦、月経 周期は 30 日型、整、中等量。昭和 63 年 11 月 29 日、淡赤色帯下を認めたため、福井成人 病センター受診、子宮腔部、頸管細胞診より精 查勧められたため当科受診した。当科にて再検

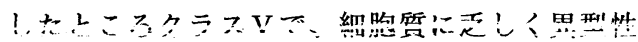
の強い円形細胞の集団を認めた。さらに精查 のため、子宮鏡を施行、子宮頸管後壁に白色隆 起性、比較的表面平滑な病変部を確認、同部位 からの生検標本を通常染色および免疫組織化学 的な方法にて検索した結果、非ホジキン性悪性 リンパ腫、B c e 11 t y p e と診断した。 これより、平成元年 1 月 10 日、腹式単純子 宮全摘術を施行、切除標本についても、同様に 検索、診断を確定し、術後の回復を待って、化 学療法追加のため本院血液内科転科となった。

本症例より、子宮頸部の擦過細胞診は上皮性 悪性腫瘍以外に、希ではあるが非上皮性腫瘍の 早期発見にも有用であると思われた。
40. 妊娠に合併した子宮頸部腺癌の一例

東京都立府中病院 病理 O庄野幸恵 (CT) 佐藤保男 (CT) 藤ノ木淑子 (CT) 古田深雪 (CT) 小金井真理子 (CT) 福留伸幸 (CT) 水口國雄 (MD) 同婦人科 桑江千鶴子 (MD) 大塚晴久 (MD)

はじめに) 子宮頸癌が妊娠に合併する症例の報告 はあるが、そのほとんどが扁平上皮癌である。今 回我々は、子宮頸部腺癌と妊娠が合併した症例を 経験したので、その細胞像を中心に報告する。 （症例）27才女性・初めての妊娠で外来受診し、 妊娠 6 週と診断された。診察時頸部に易出血性部 分があり、細胞診でClass(2b) と判定され経過観 察していた。正常分娭後 1 か月検診で頸部に隆起 性病変を発見、同部の細胞診でClass (4)悪性が薙 われた。生検の結果、頸部腺癌と診断され広沉子 宮全摘術を施行し、現在経過観察中である。

(細胞所見) 初診時の細胞診では、採取細胞量が 少量で、少数の中層細胞とごく少数の腺系の軽度 異型練胞を認めたが、臨床所見及び妊娠による腺 上皮の增殖性変化を考えて積極的に悪性との診断 はできなかった。分娭後 1 か月の細胞診では、腫 瘍性背景にシート状又は乳頭状に核小体著明でク ロマチンの増量をみる細胞集塊が認められ、細胞 の大きさや核所見等より腺癌を疑った。

(組織所見) 摘出された子宮頸部には $1 \times 1 \times 2$ cm大の乳頭状腫瘍があり、組織学的に深達度 $3 \mathrm{~mm}$ 以内の高分化子宮内膜型腺癌であった。

(まとめ) 当院で過去10年間の子宮頸癌は193 例 で、妊娠との合併例は 3 例で上皮内癌 1 、浸潤癌 1、腺癌 1 であった。頸癌と妊娠との合併例の報 告は多いが、大部分が扁平上皮癌で腺癌は少ない

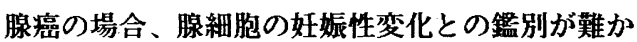
しいことがあるので慎重なスクリーニングが必要 と思われた。 
41. 細胞診で初期頸部腺癌と誤認された症例

札幌医科大学産婦人科学講座

藤井美穂 ( $M D$ ), 寒河江悟 ( $M D$ ), 早川 修 (MD), 工藤隆一 ( MD ), 橋本正淑 (MD)

北海道対がん協会 清野邦義 ( C T )

釧路がん検診センター 白川洋三 ( C T )

細胞診で初期の子宮頸部腺癌を疑う細胞像を呈する にもかかわらず, 生検組織診あるいは術後の組織診で 頸部腺癌か認められない症例を時に経験する。これら の症例の中で今回は“atypical reserve cell hyperplasia” とされている 3 組織背景によって出現したと考えられ る症例についてそれらの細胞像と組織形態について報 告する。

経験した症例は 3 例で，いずれあ集団検診時の細胞 診で class IV又は class Vと診断されていた。これらの 細胞質はレース状で薄く, 又細胞質が乏しく裸核状の 細胞屯認められた。核の大小不同㑇認めら，それら の核小体は多くの細胞で顕著であった。核クロマチン は微細顆粒状のものが多いが，中には粗顆粒状のもの 濃染する核を有する細胞む認められた。細胞の集団は 柵状, rossete様の小集団のものが多く, 散在性に出 現する細胞には上皮型のdy splasiaの存在を示唆する様 な dyskaryotic cells屯認められる症例ああった。これ らの症例の生検では腺癌は認められなかったが他の疾 患屯あった事から子宮全摘出術を行った疾例や生検組 織所見から“atypical reserve cell hyperplasia”とされ る組織背景より出現した細胞所見と考えられた。これ らの組織は 3 層から時に 6 層以上の細胞からなり, 円形 又は長円形の核を有し，それらは肥大した核を有する 細胞で占められていた。細胞質は淡青色で扁平上皮へ の分化傾向はほとんど認められない細胞で構成された 上皮であった。集団検診では前述した如く腺癌を疑っ たが組識学的に初期の頸部腺癌と誤認された症例と今 回の症例の細胞像を retrospectiveに比較検討した結果, 細胞の集団, 核の計測值, クロマチンの増量の程度な ど若干異なり，これらが細胞診断時の参考所見となり うるあのと考えられた。
42. 子宮賈部adenoma mal ignumの 1 例

千葉大学産婦人科 1$)$, 同中検細胞診2), 同第 2 解 剖3), 千葉県対がん協会4)

O深沢一雄(MD)1), 岩崎秀昭(MD)1), 小川雅利 (M D)1), 武田 敏(MD)1), 高見沢裕吉(MD)1), 堀内 文男(CT)2), 大椙二(CI)2), 計良恵治(MT)3), 石川 明(CT)4)

子宮顠部腺癌の中でいわゆるadenoma malignum は診断困難な疾患とされているがその1例と思わ れる症例を経験したので報告する。

症例は49才, 妊 3 産 1 , 既往歴, 家族歴に特記す べき事なし。とくに症状はなく集団検診にて細胞 異常を指摘され近医受診。細胞診, 組織診の結果 adenoma malignum疑いにて当科に紹介された。

〈コルポ所見〉子宮顠部は易出血性で異型血管を 伴う軽度異常隆起がみとめられた。〈細胞所見〉 きれいな背景の中に比較的多数の顠管腺細胞の出 現が見られた。細胞集団は一部不規則重積性を認 めたが大半は平面的, シート状眍列で side view に塗抹されている部位では核の偏在傾向がみとめ られた。それらの細胞質は豊富で明調, 粘液を多

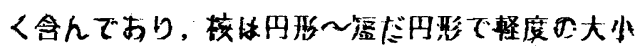
不同を伴うがクロマチンの増量は認められなかつ た。核小体は1つ明瞭に認められ肥大しておら好 酸性を呈している。この核小体肥大がなければ良 性細胞との籃別が非常に困難であると思われた。 〈組織所見〉頸管腺は核異型がそしく細胞質内に 著明な粘液がみられる一層の高円柱上皮細胞で構 成され，大小不規則な腺腔を形成していた。 


\section{3. 子宮頸部腺様囊胞癌の一例}

東海大学医学部 産婦人科 1 ), 同 病理診断科 2 ), 同 病理3)

$\bigcirc$ 宮本 壮 ${ }^{1)}(\mathrm{MD})$, 村上 優 1$)(\mathrm{MD})$, 篠塚孝男 1$)$ $(\mathrm{MD})$, 藤井明和 1$)(\mathrm{MD})$, 赤塚由子 2$)(\mathrm{CT})$, 篠田玲子 2) (CT), 長村義之 3$)(\mathrm{MD})$

腺様囊胞癌は主として唾液腺, 気管支, 乳房, などに発生する比較的稀な腫瘍であるが, 子宮頸 部に発生するあのは，極めて稀である。今回我々 は子宮頸部に原発した腺様蓑胞癌を経験したので こてに報告する。

症例は 53 歳, 0 妊 0 経, 17 歳より分裂病の診断 で36年間入院加療中であった。平成元年 8 月, 月 経後の出血が見られたが, 放置していた。その後 あ性器出血が認められたため, 11月16日近医受診 し子宮癌の疑いで当院紹介され, 性器出血, 又貧 血も見られるため入院となる。入院時診断は子宮 頸癌 II b 期, 病理組織診断は腺様囊胞癌であった。 11 月 17 日当院入院し, 12 月 20 日手術療法施行する。 子宮頸部より綿棒擦過にて採取した細胞診標本 には, 出血性背景の中に重積性をむった細胞集塊 が見られる。細胞は比較的小型で円形〜楕円形の 大小不同性に乏しい濃染核を有するが，クロマチ ンは微細顆粒状で均等分布し，肥大核小体は全く 見られず時に小型の核小体を有する細胞が散見さ れる程度で全体として異型性にそしい。

しかし, 本症例の特徴的な所見として, 細胞が 一層または数層のリング状に配列しその中に粘液 様物質を含んだ䙵胞状構造が見られたととである。 組織学的所見としては, 腺様囊胞癌に特徵的な異 型細胞が大小様々の囊胞状構造を呈し, その内部 に粘液様物質を有する, いわゆる篩状構造 (cri briform pattern) を呈していた。本症例の細胞 像, 組織像につき文献的考察を含めて報告する。
44.上上皮内癌に出現する裸核状基底型細胞 と子宮頚管腺細胞について

佐々木研究所附属杏雲堂病院 婦人科 ${ }^{1)}$ 、細胞診 2$)$ ○室谷哲弥 1 ）（MD）、作永穂高 1 ）（MD）、 伊藤良弥 1$)(\mathrm{MD})$ 、杉田道夫 ${ }^{1)}(\mathrm{MD}) 、$ 杉下 匡1）（MD）、天神美夫1）（MD）、 長島義男 2$)$ (CT)

【目的】上皮内癌の細胞像に、頚管腺細胞に類 似した裸核状基底型細胞が出現することがある。 これらの細胞を杉下が” $\mathrm{S}$ 細胞”と名付け、上皮 内癌の手がかりとして注目している。 $\mathrm{S}$ 細胞が扁 平上皮系の細胞のN/C比がほぼ100\%に上昇して 裸核状になったものか、あるいは頝管腺細胞の形 態に類似していることから頝管腺上皮に由来する ものかは今だに明らかではない。そこで今回我々 は、上皮内癌及びA.I.S.、頝部腺癌を中心に慢 性頝管炎の頝管腺細胞の細胞像との比較検討を目 的とした。

【方法】慢性頝管炎の症例を含めた正常症例20 例、異形成 (軽度 - 高度) 各8例、C.I.S. 30例、A.I.S. 2例、子宮頝部腺癌2例につき、通常の綿棒採取後、 頝管腺細胞がよく採取されるcytobrushを用い細 胞像及び、病理組織学的検討を加えた。

【結果】一般にcytobrush標本では頝管腺細胞が 多数採取され、正常例特に頚管炎の合併例では、 頝管腺細胞の軽度の核腫大、大小不同がみられ、 また炎症による再生や扁平上皮化生を伴う症例で は核小体も目立っている。C.I.S.やA.I.S.では 慢性頚管炎の時に出現する頝管腺細胞よりさらに 核の腫大、大小不同が目立つ傾向があり、 $\mathrm{S}$ 細胞 として認識可能と思われる。組織学的に、扁平上 皮内にも裸核状基底型細胞が存在する例もある が、同時に頝管腺内にも $\mathrm{S}$ 細胞類似の細胞像をみ ることが多い。A.I.S.にはC.I.Sがよく合併するこ とが知られているが、C.I.S.でも頚管腺細胞に炎 症性ないしは腫瘍性（特にA.I.S.様）の変化が生 じている可能性が示唆された。 
45. 子宮頸部腺癌の細胞形態学的解析

鳥取大学医学部産科婦人科学教室 ${ }^{1)}$ 同 検查部 病理 $^{2)}$

○金森康展 (MD) ${ }^{1)}$, 石原 浩 (MD) ${ }^{1)}$, 森 下嘉一郎 (MD) ${ }^{1)}$ ，皆川幸久 (MD) ${ }^{1)}$ ，紀川 純三 (MD) ${ }^{1)}$, 前田一雄 (MD) ${ }^{1)}$ ，永見光子 $(\mathrm{MT})^{22}$, 松井克明 (MD) ${ }^{2)}$

（目的）子宮頸部腺癌は子宮内膜癌、腺侵襲型の 扁平上皮癌病変との鑑別が困難な事が多い。今回 我々は子宮頸部腺癌の細胞形態学的特徴を数量的 に評価することを目的として本研究を行った。 （対象と方法）子宮頸部腺癌症例 8 例の細胞標本 を検討対象とした。組織分類は 8 例すべて内頸部 型腺癌であった。白黒写真上で癌細胞の核の短径、 長径、核間距離をマニュアル計測し、各々の絶対 值と変動係数および核短径と長径の比を算出し、 先に報告した分化型内膜癌および子宮頸部扁平上 㾨の計測結果と比較検討した。また、癌細胞の出 現形式、核の重積性についても検討した。なお、 細胞採取は綿棒擦過法によった。

(結果) 核の長径は症例ごとの平均值で 10.82 14. $43 \mu \mathrm{m}$ 、全平均が $12.39 \mu \mathrm{m}$ であり、先に本 学会で報告した内膜癌のそれ（8. $96 \mu \mathrm{m} ）$ より大 きい傾向が認められた。核の短径と長径の比は全 平均で0.72であり、先に報告した子宮頸部微小浸 潤癌のそれ (0.76) よりやや小さい㑯向が認めら れた。核間距離は症例ごとの平均が 9. 7〜17.0 $\mu \mathrm{m}$ 、全平均が $12.29 \mu \mathrm{m}$ であり、内膜癌の平均 9. $97 \mu \mathrm{m}$ より大きく、またその変動係数は平均 0.233 であり、内膜癌の0.189 より大きい傾向を 示した。

（結論）内頸部型頸部腺癌の癌細胞は内膜癌に比 し大型で、子宮頸部扁平上皮癌に比べて、棈円形 に近い核を有することが確認された。また、頸部 腺癌の癌細胞集塊は内膜癌のそれに比して疎で不 規則な細胞配列を示す可能性が示唆された。
46. 子宮全摘出術後に発生した肉腫様変化 を示した胵原発性扁平上皮虚の一症例

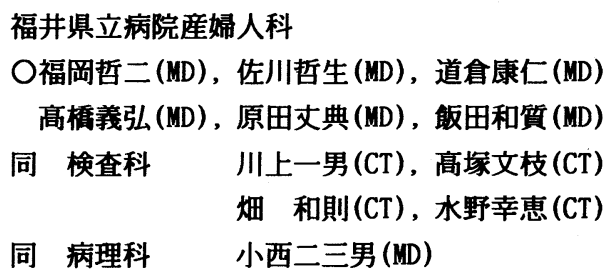

原発性腔密は全婦人科悪性腫湟の $1 \%$ 前後を占 める比較的稀な疾患である。その大多数が扁平上 皮癌であるが、今回、我々は子宮全摘出術後に発 生した肉腫様変化を示した胵原発性扁平上皮虞の 一例を経験したので報告する。

症例は 54 才、 4 回経妊 2 回経産婦。42才の 時、某医で子宮筋腫にて単純子宮全摘出術を弓け る。平成元年 7 月に車集団検診にて、腔断端細胞 診クラス III b と診断され、当科受診。左腛断端に 直径 4 mm大の肉芽様腫笛を認め、組織診にて肉腫 が疑われた。8月 24 日、胵壁切除術施行す。

細胞所見 : 炎症細胞を背景に散在する類円形の 肉腫様巨細胞之非角化型扁平上皮癌細胞集塊を認 めた。巨細胞の細胞質はライトグリーン淡染性、 核は類円形で 2 ～ 3 個認め、核緑は薄くクロマチ ンは細顆粒状で、不整形の大型の明暸な核小体を 認めて。他方、非角化型扁平上皮癌細胞は、 $\mathrm{N} /$ $\mathrm{C}$ 比大の類円形で大小不同に乏しく、核クロマチ ンは細〜粗顆粒状で、核小体は不明暸であった。

組織所見：狙い組織診標本では、正常胵扁平上 皮下に核浱染し大小不同の著しい、一部多核の多 角形または紡鉷型異型細胞がびまん性に稆な増殖 を示し、肉腫様であった。手術摘出標本では胵後 壁に胵上皮内窝を認め、一部に上皮下への肉腫様

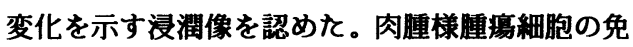
疫組織化学染色では、Keratin (+)、S $100(-)$. EMA (-) 、Vimentin $(-) 、 M T 1(-)$. M T $2(-)$ であった。以上より、肉腫様変化を

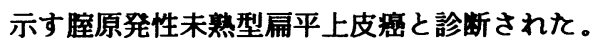




\section{7. 胵原発悪性黒色腫の 4 症例}

\section{札幌医科大学産婦人科講座}

竹原正輝 $(M D)$, 早川 修 (MD), 伊東英樹 $(M D)$, 寒河江俉 $(\mathrm{MD})$, 藤井美穗 (MD), 佐藤賢一郎 $(\mathrm{MD})$, 水内英充 $(M D)$, 工藤隆一 $(M D)$, 橋本正淑 $(M D)$

腔原発悪性黒色腫は, 国内では安達らの報告に 始まり, その後, 文献上, 散見されるが, まだ稀 な疾患の 1 つである。また, その予後は非常に悪 く, 原因の 1 つとして, 早期発見が困難であり, 初診時, すでに病期が進行している点があげられ る。我々はこれまで 4 症例を経験, 症例 $1 \sim 3$ は 以前報告した。今回症例 4 に関して, 光顕, 電顕, Masson-Zinmmermann染色, Berl in Blue 染色, $S-100$ 蛋白を施行, 以前報告した結果とあわせ て検討したので報告する。細胞診上の特徵として, 細胞の多くは散在性であり細胞質は卵円形 紡錘 形, 出現の頻度は極めて少い症例ああったが, 全 例にメラニン色素を有する腫痬細胞を認めた。

$\mathrm{N} / \mathrm{C}$ 比は高く, 核の多くは円形〜惰円形で, 偏在 傾向が強く, 核膜の肥厚は認められないが, 核縁 の不整を認め,クロマチンは顆粒状であった。核 内空胞は全症例においてみられなかった。

症例 4 に扔いて, 当科で行っている同一剥離細 胞の光顕一走査型電顕 - 透過型電顕, 連続観察法 を用いた結果, 走查型電顕上, 腫痬細胞表面に $0.3 \sim 0.5 \mu$ 大の顆粒を認め, 透過型電顕にて, メラノソームIVであることが確認された。

同症例の子宮胵部の摘出標本で, $\mathrm{HE}$ 染色上 amelanotic な部分と同一部分に各段階のメラノ ソームを確認することができた。

症例 $1 \sim 3$ は, 冷凍, 化学療法を施行したが全 例, 死亡。症例 4 は手術施行, 現在, 再発徴候を 認めず, 化学, 免疫療法のため入学経過観察中で ある。
48. 子宮体癌 8 年後汇発生した胵原発無色 素性悪性黒色腫の一例

京都第二赤十字病院中央検査部病理検査室 ${ }^{1)}$ 同婦 人科 ${ }^{2)}$ 滋賀医科大学 3$)$ 京都病理研究会 ${ }^{4)}$

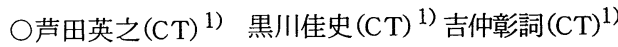
池田 守 $(M T)^{1)}$ 加藤元一 $(M D)^{1)}$ 加藤慶子 $(M D)^{2)}$ 岡部英俊 $(\mathrm{MD})^{3)}$ 木村和郎 $(\mathrm{MD})^{4)}$

窑原発無色素性悪性黒色腫は極めてまれな疾患 である。メラニンを有していない点や、弱い結合 性があったため剥離細胞診では非角化型扁平上皮 癌との鑑別が困難であり、今回の症例のように子 宮体癌の病歴がある場合再発む考虑しなければな らない一例を経験したので報告する。

〔症例〕 67才女性。昭和55年子宮体癌(高分化型 腺癌）により腹式子宮全剔、両側付属器剔除術施 行。その後細胞診、諸検査にて経過観察。

昭和63年不正性器出血にて近医受診、胵内腫瘤、 臸細胞診Class IV の指摘を受け当院受診。受診時 細胞診 Class IV 非角化型扁平上皮癌、生検組織診 未分化型扁平上皮癌にて腔部分切除術施行。

〔細胞所見〕ライトグリーン淡染の紡鍾形細胞で 弱い結合性があり、クロマチン濃染で胞体が豊富、 メラニン色素及び核内空胞の所見は明瞭でなかっ た。

〔組織所見〕上皮基底層に沿って異型の強い紡錘 状細胞が増殖するいわゆる Junctional activityを 認めたことにより、悪性黒色腫を疑い Masson Fontana 染色を行いメラニン色素を確認して診断 を確定した。S-100 蛋白は陽性であった。

以上本症例の子宮体癌の細胞像、経過観察中の 細胞変化、悪性黒色腫の細胞像を中心に報告する。 
49. 子宮内膜細胞診で異型細胞が認めら れた原発性卵管癌の一例

\author{
金沢大学医学部産科婦人科学教室 ${ }^{1}$ \\ 金沢大学医学部第一病理学教室 ${ }^{2}$ \\ 舞鶴共済病院臨床検查科病理検査室 ${ }^{3}$ \\ O杉山裕子(MD), 富松功光(MD), 川北寛志(MD),

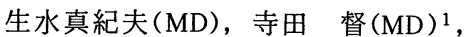 \\ 上田善道 $(M D)^{2}$, 岩猗由恵 $(M T)$, 山口直則 $(M T)^{3}$
}

今回我々は子宮内膜細胞診で軽度〜中等度の異 型細胞をみとめ, 子宮内膜組織診で子宮内膜腺癌 (中等度分化型) と診断され, 子宮体癌として手術 をしたが，左原発性卵管癌であったきわめてまれ な症例を経験したので以下報告する。

症例は 57 才主婦 ( 4 妊 2 産)。既往歴上高血圧症 をみとめる。15才初経，52才閉経であった。1988 年6月より不正出血をみとめ 1989 年 5 月 2 日初診。 内䛦, 超音波像上異常をみとめず。頸管細胞診で はクラスII, 内膜細胞診ではクラス III a で体部内膜 上皮型と思われる細胞に軽度ないし中等度の異型 性をみとめた。子宮内膜細胞診で子宮内膜腺癌の 報告をうけたため子宮体癌 ( I 期) と診断し，1989 年 5 月 18 日広汎子宮全摘術を施行した。手術中左 卵管膨大部部分が約 $1.5 \mathrm{~cm}$ 大に腫大していた。腹 水はなく, 大綱, 腹膜, 子宮, 両側卵巣, 右卵管 には異常はなかった。術後病理診断は左原発卵管 癌であった。又子宮内膜には異常をみとめなかっ た。

術前の細胞診にて原発性の卵管癌を示唆する所 見をみとめたとの報告が発表されている。今回我 我が経験した症例では, 術前に子宮体癌と診断さ れ, 術後早期卵管癌であったというきわめて興味 ある経験をした。その理由についても若干の考察 を加える。
50. 胃細胞診への抗fibronectin 抗体を応 用した免疫細胞化学的研究

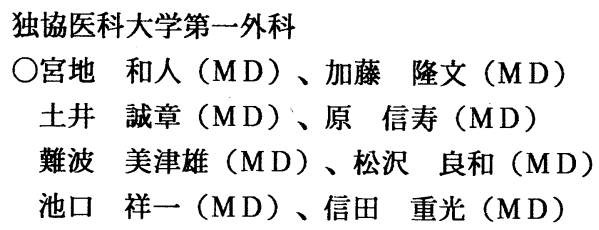

Fibronectin(以下 F N) は、細胞の接着・細胞 形態の維持・細胞分化の調節・癌細胞の転移を抑 制するなどの機能を有する糖タンパク質である。 尿中 F Nが、悪性疾患で増加しているとの報告や 細胞中 F Nが癌細胞で減少しているとするものや、 F Nの細分化が生じているとする報告もある。今 回、我々は胃内視鏡下に採取した生検組織より塗 抹細胞標本を作製し、これに抗 F N 抗体を用いた 免疫細胞化学を行った。

症例は、悪性30例・良性50例の計80例である。 抗F N抗体は、宝酒造製の抗 F Nモノクローナル 抗体で、抗 F N抗体8-12（以下 F N 8) と抗 F N 抗体12-8（以下F N12）を用いた。F Nは、6つ のdomeinから構成されていて、各々のdomeinが特 有の結合性を有している。F N 8 は、domeinVI（ ヘパリン結合性）に対応し、F N12は、domeinTV （細胞接着性）に対応している。

良性疾患（class I・II）の細胞標本上での抗 F N抗体による染色性は、F N 8・F N12ともに 陰性の症例が約半数を占めていた。再生上皮等の 增殖性の症例では、細胞質内に網状の染色性を認 めたが、染色性の程度には症例毎に差を認めた。 悪性症例では、ほぼ全例でF N 8・F N 12ともに 細胞質内に網状又は顆粒状の染色性を認めた。染 色強度は、F N12の方がF N 8 よりも、組織型で は高分化型の方が低分化型よりも強い染色性を示 す傾向にあった。

Fibronectin のdomeinに関しては増加傾向を認 め、その意義については検討を要するが、以上の 知見を得たので報告する。 
51. 大腸癌細胞（原発巣、転移リンパ節） におけるHLA抗原発現とDNA量との相関性について

長崎大学第一外科教室

○林宗榮 (MD)、田川泰 (MD)、岡田代吉 (MD)、 山口広之 $(M D)$ 、中崎隆行 $(M D) 、 川$ 副直樹 $(M D)$ 、 安武亭 (MD)、草野裕幸 (MD)、富田正雄 (MD)

（目的）癌免疫は主に細胞性免疫が担って拈り、 effector細胞による癌細胞の認識にはHLA抗原の 発現が必要ではないかと考えられている。このよ らな自己認識抗原としてのHLA-class I の出現や 免疫系細胞との相互作用に打いて重要とされる HL A-class II 抗原にて大腸癌の進行に伴ら発現の変 化 (原発巣とリンパ節) を確認する目的で免疫組 織染色を行ない、HLA-class I、II 抗原の発現を 検討した。な㧍、大腸癌ではDNA aneuploidyが悪 性度の指標になると報告されたが、今回核DNA量 を測定し、HLA抗原の発現との相関性について検 討した。（方法）切除大腸癌15例と転移リンパ節 6 例のAMex法にて固定後、パラフィン包埋し、HL

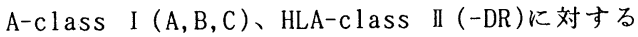
MoAbを用いて、ABC法による組織染色を行った。 核DNA量の測定はパラフィン包埋材料よりSchutte らの方法に準じ、Flow Cytometoryにて核DNA量を 測定し、DNA indexを算定した。D. I.=1.0をDiploidy (D)、それ以外をAneuploidy (A)とした。 (結果および考察) HLA-class I にて原発巣で80 $\%$ 以上の症例は”++"以上である。”+++"の10例に $\mathrm{A}: 8 / 10 、 \mathrm{D}: 2 / 10$ である。転移リンパ節にて 6 例 とも”+++、A:4／6、D:2/6であった。HLA-class IIについて原発巣は”土”:3/15、”一"は12/15、 ”土”の 3 例ともA。転移リンパ節は" $+": 1 / 6$ 、 "士”:2/6、"-":3/6、"+"の 1 例はA、"士”の 2 例ともA、"一”の 3 例に $\mathrm{A}: 1 / 3 、 \mathrm{D}: 2 / 3$ であっ た。以上より原発巣にHLA抗原と核DNAとの相関は なく、転移巣ではDiploid症例のHLA-class II の 発現は低下することを示唆される。今後症例を增 やし、検討していく必要があると思われる。
52. pm胃癌のDNA ploidy patternの 検討

獨協医科大学第一外科学教室

$\bigcirc$ 西川眞史 (MD), 東 宗徳 (MD), 難波美津雄 $(\mathrm{MD})$ 池口祥一 $(\mathrm{MD})$, 信田重光 $(\mathrm{MD})$

同病院病理

正和信英 $(M D)$, 滝本寿郎 (MD)

B M L

田中昇 (MD), 大塚重則 ( CT), 上野喜三郎 ( CT)

胃癌の中で深達度 pmのものは, 予後が様々であ り,その推測が難しいとされている。今回我々は 予後推定の試みとして, 予後のわかっている pm胃 癌についてDNA ploidy patternを分析し,若干の 知見を得たので報告する。

【対象】昭和 49 年以降当教室で入院手術したpm 胃癌のうち, 組織学的分化度が中分化型 (tub 1,2) のものを選び, 早期死亡群として, 術後 2 年以内 に死亡した 7 例と, 5 年以上生存した 13 例, 計 20 例を対象とした。

【方法】固定標本より細胞単離塗沫標本を作製し, DAP I にてDNA染色を行い, 僄本中の正常リン パ球を対照 $(2 \mathrm{C})$ として, 200 個以上の癌細胞 DNA 量を, 蛍光顕微測光法にて測定した。

【結果】早期死亡群では 7 例中全例が aneuploid, 5 年生存群では 13 例中 8 例 $(61.5 \%)$ が dipioid， 5 例 ( $38.5 \%)$ が aneuploid であった。両群の間で, 平均 DNA 量, 標準偏差, $4 \sim 6 \mathrm{C}$ 細胞の出現率, $6 \mathrm{C}$ 以上の細胞の出現率を比較したが, 早期死亡 群のほうがいずれも高値を示した。また, 両群の a neuploid症例どうしを比較しても同様の傾向が みられた。次に両群の a neuploid症例について臨 床病理学的観点から比較を行ったが, 両群の間で 最も差がみられたのは $1 \mathrm{y}$ 因子で, 早期死亡群の 陽性率が高かった。

【結語】DNA ploidy patternの分析は, pm胃 癌の予後を推測する上で有用であると思われた。 
53. "Interphase Cytogenetics"による 胃癌の染色体異常の検出

長崎大学第一外科

○山口広之 (MD), 田川泰 (MD), 岡田代吉 (MD), 川副直樹 (MD), 中崎隆行 (MD), 林宗榮 (MD), 安武 享 (MD), 石川 啓 (MD), 原 信介 (MD), 宮下光世 (MD), 下山孝俊 (MD), 三浦敏夫 (MD), 富田正雄 (MD)

近年、癌の分子生物学的解析のめざましい進歩 により癌化と染色体異常との密接な関連性が一段 と論じられるよらになってきたが、胃癌に関して 染色体の数的異常の娭討を行った報告は少ない。 最近、染色体特異的DNAプローブを用いたFluorescent in situ hybridization(FISH) により間期 の細胞において染色体の数的異常を検出すること が可能となった。そこで、本法を用いて胃癌細胞 の染色体異常について調べ、進行度、分化度、核 DNA量との関連、さらに原発巣と転移巣との関連 性について検討を行い報告する。

FISHは各染色体のcentromere近傍にそれぞれ特 異的に存在する反復配列である $\alpha$ seterite DNA に対するプローブでビオチン標識したものを用い て行った。当科で切除された胃癌の新鮮僄本を材 料とし、これを細切して得られたsingle cellを 低張処理後、酢酸エタノール固定を行った。固定 細胞の浮遊液をスライドグラス上に展開し熱変性 を加え、同じく熱変性させたプローブをスライド グラス上に加えて $37^{\circ} \mathrm{C}$ over nightで hybridizationを行った。 非特異的反応物は洗浄にて除去 し、FITC標識アビヂンを用いてhybridization し ているプローブを発色させ蛍光影微鏡にて観察し た。核 1 個当りの鸴光 spot数を約 400 個の細胞に ついて数えた。核DNA量はやはり新鮮標本を用い Taylorらの方法に準じフローサイトメトリーにて 測定した。
54. "Interphase Cytogenetics"による大 腸腫瘍の染色体異常の検出

長崎大学第 1 外科

○安武 亭 (MD)、田川泰 (MD)、山口広之 (MD)、 宮下光世 $(M D) 、$ 石川啓 $(M D) 、$ 原信介 $(M D) 、$ 岡田代吉 $(M D)$ 、清水輝久 $(M D)$ 、中越享 $(M D)$ 、 平野達雄 $(M D)$ 、下山孝俊 $(M D) 、 三$ 浦敏夫 $(M D)$ 、 富田正雄 (MD)

大腸腫漡に関し、制限酵素多型性 (RFLP)を用い てへテロ接合性の欠失等を検討した報告はみられ るが染色体の数的異常を検討した報告は少ない。 最近、染色体特異的DNAプローブを用いたFluorescent in situ hybridization (FISH)により間期 の細胞において染色体の数的異常を検出すること が可能となった。そこで、本法を応用し、大腸腫 瘍の悪性度と染色体異常の関連、DNA量と染色体 異常との関連、及び大腸癌の原発巣と転移巣に拉 ける染色体の数的異常等に関し検討を加え報告す る。

FISHは各染色体の $\alpha$ satellite DNAに対するプ ローブ、すなわち、centromerek対するプローブ でビオチン標識したものを用いた。まず、臨床検 体を細切しsingle cellにした後、低張処理し酢 酸エタノールにて固定した。固定細胞をスライド グラス上に展開しheat denatureを加え、同じく heat denature したプローブとover night でhybridizationさせた。洗いの後、FITC-avidinに て発色させ、蛍光顕微鏡にて観察した。核 1 個 当りのspot数を約 400 個の細胞につき数えた。DNA 量は Taylorらの方法に準じて、Triton X-100、 RNase、Propidium Iodideを使用しフローサイト メトリーにて測定した。

これまでに、末血リンパ球、培養細胞、臨床肺 癌細胞に関する検討を発表しているが、今回、大 腸腫湯に関する検討を行いたい。 
55. 『レーザー治療後の胃癌細胞診』

-1 報...残存癌細胞の細胞学的検討一

秋田中通病院 臨床病理科

$\bigcirc$ 今野稔子 (CT), 石井 明 (CT), 熟谷清忠 (CT) 佐藤 昭 $(\mathrm{CT})$, 小野 玈 (MD)

「はじめに」近年、高齢者や手術不適応な主に 早期胃癌患者に対して、レーザー治療が導入され てきている。当院は昭和 61 年から施行している が、レーザー照射後の胃生検組織の捺印細胞診を 併用し10〜15分以内にその結果を返して臨床に役 立てている。迅速細胞診でclass $V$ の症例は、す ぐに再照射を行い、後日同材料の生検組織診で確 認している。しかしレーザー照射対象の早期胃癌 は、高分化型腺癌が多く異型性に乏しいため判定 に苦慮することが少なくない。そこで第 1 報とし て、レーザー照射後に胃生検組織診で陽性の症例 を細胞学的に再検討したので報告する。

「方法」1986年 1 月から1989年 9 月までに行った レーザー照射後の胃生検捺印細胞診50例中、組織 診陽性の14例を対象とした。年齡は53〜85才で、 レーザー照射前の組織診断はすべて高分化型腺癌 である。尚レーザーはNd：YAG光線を使用した。

「結果」悪性 14例の細胞診断は、陽性10例、疑陽 性 1 例、陰性 3 例だった。背景はいずれにも出血 炎症壊死等が多く、癌細胞は散在〜小集塊に出現 し核は類円〜棈円形で、クロマチンは微細顆粒状 で濃染し、明瞭な核小体を 1 〜 個認めるものが 多かった。照射前の癌細胞とも比較したが、両者 にはあまり差異がなかった。疑陽性例は、見直し 後陽性にできた。陰性 3 例は、細胞が少なく異型 が弱いもの 2 例、再生上皮としたもの 1 例だった。

「まとめ」YAGレーザー照射後の細胞診は、出 血炎症壊死等の変性像を認めるが、細胞像は照射 前と基本的に変わりがない。従って、胃の分化型 腺癌の特徵をよく把握することにより、診断の向 上がはかれると考える。レーザー後のブラシ擦過 細胞診も今後全例に施行し更に検討していきたい。
56. 早期胃癌 ( m ) 45例の出現細胞

中野共立病院 病理、外科 ${ }^{*}$

○川地素崇 (CT) 藤林 寛 ${ }^{*}(\mathrm{MD})$

上尾中央臨床検査研究所 病理

熊川睦美 (CT)，中島清美 (CT)、菊地和枝 (CT)

日赤医療センター 病理 藤原睦憲 (MD)

東京医科歯科大学第一病理 青木 望 (MD)

東京都予防医学協会 内科 原島三郎 (MD)

第27回秋期大会にて「胃の生検塗抹細胞診にお ける出現細胞」について発表した。今回 $m$ 癌にお ける細胞像について検討を加えたので報告する。 $\mathrm{m}$ 癌 45 例のうち、tub1は18例、 tub 2 は 12 例、 sig 3 例、 por 12例であった。

double 5 例、triple 2 例で隆起型 (type I な ど ) 9 例、平担型 (Ib) 6 例、陷凹型 (I cなど ) 30例であった。又最大径でみると、 $1.0 \mathrm{~cm}$ 以下が 12例、 $1.0 \sim 1.9 \mathrm{~cm} 17$ 例、 $2.0 \sim 2.9 \mathrm{~cm} 8$ 例. 3.0 $\sim 3.9 \mathrm{~cm} 6$ 例、 $4.0 \mathrm{~cm}$ 以上 2 例であった。

(方法) 生検時塗抹されたATP 様腫瘍細胞、裸核 腫瘍細胞、大型腫瘍細胞（100 $\mu$ 以上）、印環（型） 腫瘍細胞、再生上皮、間質細胞を各組織型別に出 現頻度について検討した。

\begin{tabular}{|c|c|c|c|c|c|c|}
\hline & ATP样 & 袖枟 & 大刑 & F几 環 & 再生 & 閒啠 \\
\hline tub 1 & 67 & 89 & 33 & 0 & 56 & 44 \\
\hline tub 2 & 8 & 75 & 25 & 25 & 83 & 58 \\
\hline p or & 0 & 17 & 8 & 83 & 92 & 58 \\
\hline s i g & 0 & 33 & 0 & 100 & 100 & 33 \\
\hline
\end{tabular}

ATP 様腫瘍細胞は tub 1 で多く認められたが低 分化型では見られなかった。間質細胞は組織型に よる差は見られなかったが、進行癌でみられるよ うな線維束のあのは少なく、free cell あるいは 小集塊状のものであった。

(まとめ)

1.組織型により出現する細胞に差が見られた。

2. $\mathrm{m}$ 癌で高分化型では結合性が強くユニフォーム を呈するものが多くみられた。 
57. 胃・十二指腸粘膜下腫瘍における内 視鏡下穿刺吸引細胞診

聖マリア病院病理部, 内科消化器科 * ○大田喜孝 (CT), 伊藤園江 (CT), 原武晃子 (CT), 森塚祐子 (CT), 大田桂子 (CT), 中村康寛 (MD), 自見厚郎 $(M D)$, 伊藤裕司 $(M D)$, 井手耕一 $(M D) *$

【はじめに】消化管領域における粘膜下腫場の術 前診断は直視下組織生検が普及した現在であなお 困難なものとされている。

今回, 我々は胃・十二指腸の粘膜下腫瘍に対し 内視鏡下穿刺吸引細胞診による組織型の推定を試 みたので報告する。

【対象および方法】対象は1985年 7 月〜1989年 11 月までに行なった胃・十二指腸内視鏡検查で肉眼 的に粘膜下腫場之診断された21例のうち生検組織 診で陰性であった16例である。

方法は内視鏡下に生検鉗子で腫瘤部粘膜上皮の 一部を除去し, 同部に局注針 $(\mathrm{NM}-3 \mathrm{~K}, \mathrm{OLY}-$ MPUS) を挿入。針を $4 \sim 5$ 回細かく上下させ 粘膜下の組織をある程度挫滅し, 局注針のチュー ブラインを介して $15 m \ell$ の注射器で吸引。細胞をス ライドグラスにふきつけ, 圧平塗抹し, 細胞の観 察は主に Papanicolaou染色, May-Giemsa染色で 行った。また症例によってはさらに針を $5 \% \mathrm{FCS}$ 加生食的 PBSで洗浄。cytospin で細胞塗抹し, 免疫組織化学的検索を行った。

【結果】対象とした16例のうち手術により組織診 断が確定したあのは11例であった。てのうち穿刺 吸引細胞診による推定組織型と一致したものは 6 例 (54.5\%)であり, その内訳に平滑筋肉腫 $2 / 3$, 平滑筋芽細胞腫 $1 / 2$, 平滑筋腫 $1 / 3$, 脂肪腫 $0 / 1$, 異所猝 $1 / 1$, 転移性腎癌 $1 / 1$ であった。

【結語】局注針による内視鏡下穿刺吸引細胞診は 特別な機具を必要とせず，また患者に対する苦痛 を加重することなく, 積極的な組織型推定が可能 であり, 粘膜下腫瘍およびその類似病変の術前診 断に有効な方法と考える。

\section{8. 胃癌手術中腹腔内洗浄細胞診成績}

国立がんセンタ一病院細胞診1、外科 ${ }^{2}$ ${ }^{1}$ O山岸紀美江 (CT)，渡部㡺一（CT），日吾雅 宜 (CT)，岸紀代三 (MD)，上井良夫 (MD)， ${ }^{2}$ 岡林謙蔵 (MD)，丸山圭一 (MD)，木下平 (MD) 笹子三津留 (MD)

当院で1980年より1985年の6年間に扱った胃癌 症例1499例のうち、術中腹腔内洗浄練胞診を施行 した235例について検討した。

結果

1 全235例のうち細胞診陽性 $37.0 \%$, 疑陽性

7.2\%であった。

2 切除例195例では細胞診晹性 $31.8 \%$, 疑陽性

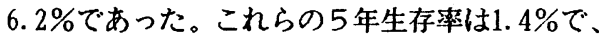
細胞診陰性例の同率 $37.2 \%$ と比較し有意差を認め た。

3 治忿切除例82例では紐胞診陽性6.1\%, 疑陽 性3.7\%であった。これらの5年生存率は $0 \%$ で、 細胞診陰性例の同率59.5\%と比較し有意差を認め た。

4 肉眼的漿膜面浸潤 $\mathrm{S}_{0}$ で $14.9 \%, \mathrm{~S}_{1}$ で8. $3 \%$, $\mathrm{S}_{2}$ で33.3\%, $\mathrm{S}_{3}$ で49.1\%が細胞診陽性で、 $\mathrm{S}_{2}$ の 1 例以外 5 年以内に死亡した。

5 肉眼的腹膜転移 $\mathrm{P}_{0}$ で $14.9 \%, \mathrm{P}_{1}$ で50.0\%, $\mathrm{P}_{2}$ で52.6\%, $\mathrm{P}_{3}$ で80.3\%が細胞診陽性で、 $\mathrm{P}_{1}$ の 1 例以外 5 年以内に死亡した。

6 組織学的深達度 $\mathrm{m}$ で33.3\%, seで30.9\%, si で $49.6 \%$ が細胞診陽性で、seの 1 例以外 5 年以内 に死亡した。

7 陽性率の高い組織型は腾様腺癌、印環細胞癌、 中分化型管状腺癌、低分化腺癌であった。

85 年以内死亡例の死因は澏性腹膜炎が最も多 かった。

まとめ

胃痁手術中腹脭内洗浄細胞診は、陽性の場合予 後不良であり、虑性腹脱炎の予測に有用であり、 予後的漿膜面因子として重要であると思われた。 


\section{9. 胃癌術中採取腹水の細胞診と予後}

宮城県立成人病センター

O小室 邦 子 (CT) . 長谷 とみよ (CT)

大沼 真喜子 ( C T ) , 佐藤 裕美子 ( C T )

武田 鉄太郎 (MD) ，小野寺 博義 (MD)

桑島 一 郎 (MD), 松田堯 (MD)

斎藤 博 之 $(M D)$ ，中村 克 宏 (MD)

われわれの施設で手術を施行した胃癌症例のう ち、術中に腹水を採取し、その細胞学的検索を行 つた75例について、術後の生存月数、癌梁達度、 墏膜浸洞範囲との相関を検討した。

対象とした75例を深達度別に分類すると、sm 4 例、pm 2例、ss 6例、seおよび sei36例、試験開 腹27例であるが、腹水の塗抹およびセルブロック 標本中に癌細泡を検出したのは、sm 1例、 pmおよ びss 0、seおよび sei22例、61.0\%、試験開腹 26 例、96.3\%であった。

深達度se以上の死亡 32 例について、術後生存月 数と墏膜面での癌浸潤最大径を対比した。6r月 以内死亡 12 例の癌浸洞径は $2.5 \mathrm{~cm} \sim 14.0 \mathrm{~cm}$ と巾が あり、一定の傾向はみられなかった。6r月〜12 ヶ月生存11例ではほとんどが 4〜 6 $\mathrm{cm}$ 径であった。 13 ヶ月〜24ヶ月生存 5 例は $1.0 \mathrm{~cm} \sim 9.0 \mathrm{~cm} 、 25$ ケ 月〜 68ヶ月生存 4 例は、 $13.5 \mathrm{~cm}$ 以内であった。

生存月数と細胞所見との関係をみると、16r月 以上生存の 10 例はいずれも腹水中に癌細胞を認め なかった。

se、sei36例中癌細胞陰性であった14例では、 4例は現在なお生存中で、残る10例の平均生存月 数は22.0ヶ月であり、癌細胞陽性22例では、7.7 ヶ月であった。

組織型別にみると、分化型癌 9列では 4例に癌 細胞を認めたが、いずれも癌細胞は少数で、集塊 として出現した。低分化型癌では26例中17例に癌 細胞を検出した。細胞量が多く孤在〜大小集塊形 成など多彩な像を示す例ほど予後不良の傾向が認 められた。
60. 胃悪性リンパ腫の検討

一その診断における細胞診の役割一

獨協医科大学第一外科、同病院病理部 O東 宗徳(MD)、藤田茂信(KD)、倉山英生(KD)、 難波美津雄(MD)、池口祥一(MD)、信田重光(MD)、 山田 喬(HD)*、正和信英(HD)*、佐壂豊彦(CT)* 小池史子(CT)*、佐々木英夫(CT)*

〔目的〕胃癌の診断は早期診断も含めてほほ確立 されているが、胃悪性リンパ腫の診断は、内視鏡 をはじめとする各種の診断法が発達してもなお、 その診断は容易ではなく、一般には生検診断に頼 らざるを得ないのが現状であるが今だ問題点も多 い。教室では生検時細胞診の併用を行って正診率 の向上を計っており今回その成績に挨討を加えた。 〔対象〕当科で胃内視鏡下生検・細饱診がなされ た胃悪性リンパ腫は14例であるが、うち胃原発悪 性リンパ腫は13例 (切除例10例、非切除例2 例、 他院切除例 1例）と全身悪性リンパ腫の部分症と しての胃悪性リンパ腫 1 例である。

〔結果〕初回内視鏡肉眼的診断で、悪性リンパ腫 を疑ったものは9/14例 (64.2\%)で胃癌と読まれた もの2/14例（14.2\%）、胃漬場と読まれたもの2/14 例(14.2\%)、RLHと読まれたもの1/14例(7.1\%)であつ た。初回生検診断による正診率は8/14例 (57.1\%) で、一方初回細胞診による正診率は12/14例(85.7 \%)であった。両者を合わせた正診率は12/14例 （85.7\%）であった。生検診断で正診できなかった 6 例の理由としては、(1)低分化型腺虞と読まれた もの 4例。(2)組織挫堿所見 1 例。(3) Group II と読 まれたもの 1 例であった。一方細胞診断で正診で きなかった2 例の理由はすべて Class II と判定さ れたものであった。

〔まとめ)胃悪性リンパ腫の像は多彩であり、肉 眼診断は歎しく、術前に確診することがしばしば 困晎であるが、生検と細胞診の併用により正診率 の向上が計られると考えた。 
61. 鉗子生検捺印細胞像により診断し得 た胃悪性リンパ腫の 4 例

鎗田病院検査科 ${ }^{12}$ 、同外科 ${ }^{2)}$ 、千葉県予防衛生 ${ }^{2}$ 協会）、国立習志野病院研究検查科4)、 同外科 ${ }^{5}$ 、千葉大学看護学部病㷫学6)

○岩谷まり子 $\left.(\mathrm{CT})^{D}\right)$ 、古川敦子 $(\mathrm{CT})^{D}$ 、 鎗田努 $(\mathrm{MD})^{2)}$ 、神木弘子 $(\mathrm{C} \mathrm{T})^{3)}$ 斎藤博子 $(\mathrm{CT})^{4)}$ 、花輪孝雄 $(\mathrm{MD})^{5)}$ 、 君塚五郎 (MD)

胃悪性リンパ腫は、比較的稀な腫瘍であり胃 の悪性腫瘍の 0、3\%-2\% とされている。我々は、 今回、鉗子生検の捺印標本による細胞像から、 術前に診断し得た、胃の悪性リンパ腫を 4 例経 験したので、その細胞像を中心に報告する。

[症例 1］50才、男性。得られた腫瘍細胞は リンパ球に類似し、上皮性結合を示さず、 monotonousな像を呈していた。個々の細胞はN C 比が大きく、核に異型を有し核小体が明暸で あった。

[症例 2］７0才、女性。腫瘍細胞はリンパ 球様でNC比が大きく、単独に出現していた。 核は概わ円形で一部にはくびれ、切れ込みを有 し、核小体の増大と増加を認めた。

[症例 3］65才、女性。出現した腫瘍細胞 は、リンパ球よりやや大型で散在傾向を示して いた。核は類円形で、一部には核縁の不整を認 め、核小体は肥大していた。

[症例 4］49才、女性。腫瘍細胞は比較的 小型であり、中に大型の細胞を混在していた。 核は類円形が多く、一部には切れ込みも認めら れたが、核小体は小さく R L H との鑑別を要し た。然し、全体にmonotonousな像を呈し、個々 の細胞境界は明暸で、核分裂像も散見された。

[まとめ] 胃の悪性リンパ腫は、monotonous な像を示すことが特徴的であり、更に核縁の切 れ込み、核小体の所見などに注意をすることで、 R L H との鑑別も可能であると考える。
62. 髄液細胞診で判明した胃癌による癌性 骮道膜炎の|例。 釧路学災病院病理, 同脳外科, 同産婦人科,
網走厚生病院内科

○小島英明 $(\mathrm{MD})^{1)}$, 斉藤隆二 $(\mathrm{CT})^{1}$, 久未浩街 $\left.(\mathrm{CT})^{1}\right)$, 本田千恵子 (MT), 大里孝夫 $\left(\mathrm{MD}^{2}\right)$, 宝金清博 $(\mathrm{MD})$ ), 井須豊彦 $(\mathrm{MD})$ ), 竹林克重 $(\mathrm{MD})$ ), 山崎知文 $(\mathrm{MD})$,

転移性脳腫瘍は脳腫瘍の14\%を占め, そのうち 白血病等は癌性髄膜炎をおこしやすく, 固型癌は 実質内に腫湯塊を形成しやすいといわれている。 しかし, 固型癌転移でも $2.7 \%$ は癌性䯣膜焱をお としらるとされ，それはmalignant melanoma， 乳癌, 肺癌の順にであるという。我々は, 胃癌術 後 3 年で癌性䯣膜炎を来をした症例を経験したの でここに報告する。

症例: 59 才男性。 3 年前に胃癌にて胃全摘術を 受けた。組織型は低分化型腺癌でsci rrhous type, se, 腹膜播種あり stage N であった。

本年 6 月頃より難治性頭痛出現し来院。強度の うっ血乳頭を認めるも， C T 上有意な結節性病変 はなかった。䯑道液穿刺にて初圧 $600 \mathrm{~mm} \mathrm{H}_{2} \mathrm{O}$ と異 常高值を示し, タンパク $52 \mathrm{mg} / d \ell$, 糖 $80 \mathrm{mg} / d \ell$,多 核球, 単球リンハ球は各々0/3で弱いキサント クロミーであった。

細胞診では $\mathrm{N} / \mathrm{C}$ 比の高い，核縁不整のある大 小不同の核を有する細胞が検出され，核小体も明 瞭で核は偏在傾向を示し, 腺癌の所見であった。

A B C 法の免疫組織化学では, 摖過採取による 正常口腔粘膜を陰性対照として, との異型細胞を 検索すると，C E A 陽性所見を得た。

以上加ら, 胃癌による癌性䯣膜炎と診断し, ᄀ イルタ一付の V-Aシャント術を施行した。症状 は改善し，現在経過観察中である。

固型癌の leptomeningial involvement次 き，文献的考察を加えて報告したい。 
63. 脳脊䯣液細胞診で疑われた䯣膜癌腫 症の 2 例 その転移経路に関する考察

長崎大学医学部病理学第 2 教室 ${ }^{1)}$, 長崎市立市民 病院検查部 2 ）, N T T 長崎病院臨床検查科 3 ) ○入江準二 $(\mathrm{MD})^{1,2)}$, 浦壁順一郎 $(\mathrm{CT})^{2)}$, 松江圭子 $(\mathrm{CT})^{2)}$, 柴原好彦 $(\mathrm{CT})^{3)}$

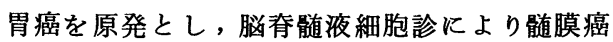
腫症の疑われた 2 例を相次いで経験したので, 剖 検所見と併せて報告し, その転移経路について考 察する。

症例 1：56才, 男性。3 か月前に胃癌の切除 術を受けた。組織像は低分化型腺癌であった。

症例 $2: 55$ 才, 男性。約 9 年前飞胃癌の切除 術を受けた既往がある。組織像は印環細胞癌であ つた。いずれる, 髄膜炎症状で入院し, 脳脊䯣夜 細胞診が行われた結果, 陽性で, 䯣膜癌腫症が薙 われた。治療が行われたが死亡し，剖検が行われ た。

細胞診所見：胞体は狭く, N $/ \mathrm{C}$ 比大の異型細 胞が多数見られ, 核はしばしば偏在性で, 核小体 が目立つものが多かった。又胞体には空胞をもつ ものが見られた。全体的に結合性は低く，低分化 型腺癌または印環細胞癌が推定された。

剖検時所見：両例とも，広範な臟器転移が見ら れた。脳は肉眼的に腫瘤の形成はなく, 組織学的 飞, 細胞診と同様な細胞が, クモ膜下腔, 軟膜, Virchow-Robin腔飞認められた。

考察：髄膜癌腫症の経路については, 種々の報 告がある。今回の 2 例は, 椎骨または傍椎骨りン パ節に転移が見られ，癌細胞は，まずこの部位に 転移し、それから，神経索をたどってクモ膜下腔 へ侵入したものと考兄られた。
64. 若年者にみられた骨髄癌腫症（胃癌） の一例

松江赤十字病院検査部病理 ${ }^{1}$, 内科 ${ }^{2}$

島根医科大学附属病院検査部病理 ${ }^{3}$

O松浦幸浩 $(\mathrm{CT})^{1}$, 荒木弘江 $(\mathrm{CT})^{1}$, 今田和典 $(\mathrm{MD})^{2}$ 井上.勝美 $(\mathrm{MD})^{2}$, 三浦弘資 $(\mathrm{MD})^{3}$, 板垣哲朗 $(\mathrm{MD})^{1}$

骨髄穿刺が発見のきつかけとなった稀な若年者 胃癌を経験したので報告する。

〔症例〕17墄, 女性, 高校 3 年生。既往歴, 家族 歴に特記すべきことなし。生来健康であったが, 平成元年 5 月頃より全身倦总感が出現し, 同年 8 月自転車で転び腰痛のため近医の整形外科を受診。 $\mathrm{X}$ 線写真上特に問題なく, 採血時の出血が止まり にくいことに気づき紫斑も出現するようになった ため当院内科入緊急入院となった。入院時の骨髄 穿刺では, 多数の腫瘍細胞がみられ腺癌の転移を 疑う所見を呈した。その後諸藏器の検査が行なわ れ, 胃生検より signet ring cell carcinoma がみら れ胃癌の骨髄転移 (癌腫症) と診断された。化学 療法を試みるも病状は悪化し, DIC によるくも膜 下出血で同年 10 月死亡となった。

〔骨髄穿刺細胞所見〕不規則重積性を示す集団と 孤立散在性で結合性にそしい腫瘍細胞が混在して いた。 N/C 比高度大, 細胞質は小空胞状〜レース 状, 核は多くの細胞で類円形を呈し, 核内には細 顆粒状クロマチンが充満していた。一部では腺管 様配列や核の位置とは正反対に粘液を思わせる淡 い橙色の偽繊毛構造が認められた。PAS 染色は偽 纎毛構造に一致して滴状陽性, Alcian blue 染色 はわずかの細胞で陽性を呈した。

〔病理解剖所見〕胃壁は全体に肥厚し Borrmann IV 型の胃癌 (poorly differentiated adenocarcinoma)と診断された。骨髄は広範に地図状の転移增 生が認められ, 癌性腹膜炎及び両側卵巣の Krukenberg 型転移巣もみられた。その他肝臓・胃周囲 リンパ節への多数の転移巣を認めた。 
65. 骨骾転移をみた直腸原発平滑筋肉腫 の一例——骨䯣狳抹標本における腫瘍細胞の細胞像

名古屋大学医学部附属病院検査部病理室

O長坂徹郎 $(\mathrm{MD})$, 中島伸夫 $(\mathrm{MD})$,

白井孝夫 (CT), 大岩 昇 ( $M D)$,

奈良佳治 $(M D)$, 竹内 純 $(M D)$

癌腫, 悪性リンパ腫の骨髄転移は日常の細胞診 そおいてしばしば経験するとてろであるが, 肉腫 の骨䯣転移は稀である。最近, 我々は直腸原発の 平滑筋肉腫の骨髄転移例を経験したので, 骨髄塗 抹標本における腫瘍細胞の細胞像を呈示するとと もに, その細胞学的特徵を報告する。

症例：47才,女性。

病歴: 昭和 60 年より, 時々下腹部痛があり, 精 查の結果, 骨盤内に腫瘤を認め, 経過観察されて いたが，増大傾向のため手術目的で昭和 61 年 8 月名大病院分院外科飞入院。腫瘤は子宮と直腸の 間に位置し, 生検にて平滑筋肉腫と診断された。 Miles's opeが施行され, 病理診断は直腸原発の平 滑筋肉腫であった。術後経過は良好であったが, 平成元年春頃より肛門痛が出現, 同部に径 $3 \mathrm{~cm} の$ 腫瘤を認めたため, 7 月に腫瘤摘出術が行なわれ た。腫瘤の病理組織診断は平滑筋肉腫の再発であ った。さらに, 9 月頃より末梢血の汎血球減少が 出現したため, 骨䯣穿刺が施行され, 塗抹標本の 細胞診が依頼された。

細胞像: ギムザ標本では, 造血細胞に混じって, 巨核球程度の大きさの単核の異型細胞が少数, 散 在性に認められた。核は類円形から長円形でク口 マチンの增量を認め, 明瞭な核小体を数個認めた。 胞体は弱塩基好性で広, やや不規則に伸展するも のが多かった。PAS染色は陰性であった。平滑筋 肉腫細胞と考えられた。

まとめ：骨髄組織標本においても平滑筋肉腫の転 移が確認されたが, 腫瘍細胞と反応性に増殖す る骨䯣間質細胞との鑑別が難しく，腫瘍細胞の同 定に細胞診が有用であった。
66. 子宮腔内細胞診にて診断された大腸 癌再発転移性子宮癌の 1 例

$$
\begin{aligned}
& \text { 東京都立府中病院産婦人科 }{ }^{1} \text { ) } \text { 同検査科病理 }{ }^{2} \\
& \text { ○桑江千鶴子 }{ }^{1)}(\mathrm{MD}) \cdot \text { 佐藤保男 }{ }^{2}(\mathrm{CT}) \\
& \text { 庄野幸野 } \left.{ }^{2}(\mathrm{CT}) \cdot \text { 藤の木淑子 }{ }^{2} \text { ( CT }\right) \\
& \text { 水口国雄 }^{2}(\mathrm{MD}) \cdot \text { 大塚晴久 }^{1}{ }^{2}(\mathrm{MD})
\end{aligned}
$$

大腸癌術後 3 年目に再発, 転移部位の子宮空内 より細胞診にて診断された症例を経験したので報 告する。症例は, 54 才無職, 主訴は帯下。家族歷, 既往歴には特記すべき事なし。I G I P. 現病歷 では, 1986 年 4 月大腸回盲部癌の為に右半結腸切 除術を受けている。1989 年 9 月より帯下出現, 同 11 月当科初診, 内診上子宮は正常大, 付属器は触 知せず, 帯下は水様であり, Sonde 診は $7 \mathrm{~cm}$ あった。P S, E C, EM (Endocyte) S mear 採取したところ，E C , EM Smearに丈の高い 異型円柱上皮細胸が棚状配列にて出現。クロマチ ンは豊富で, 大小不同あり内膜由来細胞とは異な り腸上皮由来の悪性細胞と考えられた。診断は class V (Metastatic Colon Ca.) 内膜 部位 別リーハにて体部, 頸部内膜いずれにも高分化 型の腺癌組織を得, 転移性大腸癌と診断された。 $\mathrm{CEA} 215 \mathrm{mg} / \mathrm{m} \ell$ と高值。注腸検査では異常を 認めず, 12 月開腹術施行。開腹所見では子宮は正 常大だが体部後壁よりD oug 1 as 窩腹膜にかけて 超拇指頭大の癌性硬結認められ, Doug 1 as 窩腹 膜への転移による子宮浸潤と考えられた。又原発 巣近くの腸間膜リンパ節にも拇指頭大の硬結認め たため, 術式を腹式単純子宮全摘術十両側付属器 切除術十横行結腸回腸端々吻合術を行なった。肝 には異常を認めなかった。摘出物の検索では子宮 は体下部後壁正中より頸部にかけて, 獎膜より内 膜まで癌組織が貫通しており内膜に癌性潰瘍を形 成していた。同部位より剥離細胞診にて診断され たと思われる。病理組織は高分化型管状腺癌であ った。 
67. 術前に穿刺吸引細胞診で診断しえ た肝血管腫の 1 例

徳島大学医学部第 2 病理学教室

O山本洋介 (MD)

徳島厚生連麻植協同病院検査室

$$
\text { 大久保 岩雄 (CT) }
$$

【症例】53才, 男性。貧血の精查中偶然に肝 左葉の腫溜が発見され, 超音波検查, CI, 血管 造映にて肝細胞癌, 肝血管腫, 肝内胆管癌など が疑われた。肝炎, 肝硬変の既往はなく, $\alpha-$ フェトプロテインは正常範囲内。確定診断のた め穿刺吸引細胞診がおこなわれた。

【細胞診所見】血液成分が豊富で, 壊死細胞は みられない。肝細胞は少数で異型に乏しく, 肝 細胞癌の所見はない。これらに混じて, 短紡錘 形細胞がシート状に集合してみられる。核の大 小不同は乏しく核クロマチンの増加は軽度で, 細顆粒状均等に分布する。核縁の肥厚や核小体 の腫大はみられない。細胞質はライトグリーン に染まり細胞境界は不明暸。悪性と判断される 所見はない。胆管上皮系の高円柱上皮細胞はみ られない。

【肉眼所見】肝左葉の腫瘤は割面で約 $6 \times 3.5 \mathrm{~cm}$ の大きさで境界明暸, スポンジ状で多量の血液 が流出する。周囲の肝実質に硬变所見はない。 【組織所見】1層の内皮細胞でおおわれ, 内腔 に血液を入れた小血管が密在し，その間には比 較的厚い結合織が存在し, 典型的な海綿状血管 腫の所見であった。

【まとめ】肝左葉腫瘤の穿刺吸引細胞診を行な い,異型の乏しい紡鍾形細胞のシート状出現に より術前に肝血管腫の診断が可能であった。肝 細胞には異型がなく，壊死性細胞所見のないこ とや, 肝炎・肝硬変の既往がなく, $\alpha$ ーフェト プロテイン陰性の成績も診断の助けとなった。

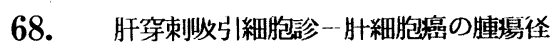
と細胞所見の比較検討一

沼津市立病院臨床検查科

川川詳司 ( C T ), 近藤恵子 ( C T ),

野坟謙：(MD)

同内枓簙猗正美 (MD)

カーネギー産婦人科医院印牧義孝 (MD)

困像診断の発達により、肝臟の小腫瘤 (肝紐胞 癌など）の確定診断のために肝穿刺吸引針による 組織学的、細胞学的晾断が行われている。 小肝細胞癌 (特に $\phi 2 \mathrm{~cm}$ 以卜) は、組織学的には 買型度が弱い分化型肝細胞䄆が多いと言われてお り、われわれは肝細胞嵒の各大きさについての細 胞像を所見別に比較検討した。

対象は $1988 ， 89$ 年に超音波映像下に 21 ゲージ吸引生検針を用いて組織。細胞採取を行い 病理診断及び細胞㟝で肝細胞䙖と診断された 20 症例を対象とした。細胞観察はパパニコロウ染色 のみで行った。

検討方法は、堙場径の大きさ・〜 $2 \mathrm{~cm} ・ 2 \sim 4$ $\mathrm{cm} \cdot 4 \mathrm{~cm}$ 以上の 3 群に分けて、(1)細胞の出現性(2) 細胞結合の強さ(3)多形性(4) N / C 比(5)核の大小不 にににクロマチンパターンク核不整(8)核内封入体(9) 核小体の大きさ10細胞の大型化の 10 項目につい て検討した。

結果は腫煬径の小さい群では、細胞の結合性が 強く、集団で出見しやすく、核の大小不同は余り なく核不整は腫場径の大きい群より少なかった。 腫瘍径の大きい群では、細胞が大型化及び平面的 散在性に出現するすのが多く、核不整が強く、核 小体の大型化が高率に見られた。核内封入体は著 明な変化は見られず、 $\mathrm{N} / \mathrm{C}$ 比及びクロマチンパ ターンについては比較検討が非常に難しく詳しく 分析するのが望まれた。 
69. 細胞診が有用であった肝細胞癌・胆 管細胞癌の混合型

大阪労災病院臨床病理科

○川野潔 (MD), 过村 俊 (MD), 田中育子 (MT), 古田美知子 (MT), 橋野義信 (MT ), 石谷 智 (MT)，和田 昭 (MT)

単一腫瘍内に肝細胞癌と胆管細胞癌が種々の割 合で混じているものを混合型という。てのような 腫搷は原発性肝臟癌の数パーセントを占めるとされる か、外科手術材料们於ける細胞学的診断の試みは甚だ 少ない。われわれは、切除腪崵の擦過細胞診により肝 細胞癌 ( HCC) ・胆管細胞癌 ( C C ) の混合型と想 定しえた症例を経験したので報告する。

【症例】73才、男性、平成元年 4 月頃より閉塞性黄疽 を来し、US, CT, ERCP等で肝左葉 S 2 亿 $4 \mathrm{~cm}$ 大の腫 瘤を確認。11月2日、HCCかCCか確定しえないまま左 葉切除が施行された。A F P，CEAは正常範用。

【手術所見】S 2 k $4.1 \times 2.3 \times 3.3 \mathrm{~cm}$ 大の突出 した乳白色の腫煬が認められ、左肝管起始部内は 腫瘍が允填していた。

【細胞学的所見】ホルマリン固定後、擦過細胞診 を施行した。大部分の腫煌細胞は結合性が弱く、 著明な核小体をもつ類円形の核が紡鍾形の広い細 胞質のやや辺縁に位置していた。それ以外にも、 やや小型の細胞よりなる集団が散見された。それ らの細胞はシート状に配列し、やや不整形の核が 細胞の中央に見られ、核内空胞を有する細胞も散 見された。

【組織学的所見】腫場は高度の好中球浸潤を伴い 結合性の弱い乳頭腺管状癌を示していた。腫瘄細 胞は CEA, Al cian-Blue 陽性であった。さら に同一腫焅内に約 $4 m m$ 大の線維性結合織に囲まれ た肝細胞癌の存在を認めた。

【結語】 HCC・CC混合型の診断には H C C の偽 腺管型を否定し、 $\mathrm{C} \mathrm{C}$ として粘液を証明しなけれ ばならない。本症例は細胞学、組織学的にも混合 型に一致し、細胞診でそのととが想定できた。
70. 胆汁細胞診における疑陽性例の検討

山梨矢科大学附属病院検查部

O石井喜雄 (CT) 中澤久美子(CT)

弓納持 勉(CT) 早川直美(CT)

小山敏雄 (MD) 久米章司(MD)

山梨医科大学病理学教空

三俣昌子(MD) 須田耕一(MD)

〔目的〕胆汁細胞診は良悪性の判定の困難な例 が少なくない。そこで今回疑陽性判定例を再検討 し、その原因について考察した。

〔方法〕当施設の最近 6 年間における胆汗細胞 診例から判定不能例を除いた 359件を対象とし、 臨床細胞学的に検討した。

〔結果および考察〕 359件の Class分類は I : 156 、II $: 51$ 、II $: 35 、 \mathrm{~V}: 8 、 \mathrm{~V}: 109$ 件であ る。Class III : 35件のうち組織診の裏付けのある のは27件 (21例) で、その内訳は胆管癌13例、脺 癌 6 例および十二指腸乳頭部癌 2 例であった。

疑陽性 (ClassIII) の異型細胞は次の 3 つに大別 された。すなわち、(1)孤立散在性あるいは数個の 細胞が少数出現し、クロマチンはオパーク状不均 一で、核小体が明膫なもの、(2)細胞力密で、配列 が乱れた重積性のある小集団で、クロマチンが漕 縮し、核小体も不明瞭な变性像を呈しているもの、 および(配列の整った平面的シート状集団でク口 マチンはオパーク状均一で、核小体が明膫なもの、 である。(1)(2)異型細胞を同一症例の別回提出の Class VP腫塲捺印標本の像と比較すると、それ は腫場由来と考えてよい細胞像であった（検索可 能14例中 9 例)。したがって、(1)(2は今後の胆汁 細胞診において、より積極的な判定に参考となる 細胞所見と考えられる。(3はその由来が腫場細胞 であるか周辺反応上皮の集団であるのか判定か困 難て、それぞれの組織像との比較の上報告する。 
71. 膵癌の細胞診の検討

浜松医療センター検查部 消化器科*

O土井久平 $(\mathrm{CT})$, 川根一哲 (CT), 村松一已(CT)

阪本勝美 (CT), 倉形順子(CT), 岡本一也(MD)

小沢享史 (MD), 室久敏三郎(MD)* ${ }^{*}$, 竹平安則(MD)* 川西幸衛(MD)*

独協医科大学第一病理 山田 喬(MD)

私共は、第2 7 回広島秋期大会において胆道領 域の炎症性疾患における胆道の良性異型細胞の形 態について発表してきたが、今回私共は膵㖪疾患 である膵癌を、臨床的, 組織学的に癌と診断し た73例について、採取方法による診断率，採取 方法の細胞の出現状態と、それによる細胞の良悪 性の問題ならびに細胞衫で陰性, 疑榢性と診断し た細胞について組織像と比較しながら検討したい。

採取方法別によると、P T C 3 例中陽性 1 例, 陰性 2例, P T C D 23 例中陽性 19 例, 疑陽性 1 例, 陰性 3 例, E R C P 36 例中陽性 28 例, 疑陽性 3例, 陰性 5例, E R B D 4 例中陽性 3例, 疑陽性 1 例, エコ一下穿刺 3 例中陽性 2 例, 陰性 1 例，その他4例中陽性4例であった。

また陰性とした細胞は、細胞数が少なく小型で 平面的な配列を示すものが多く、一部には核小体 の増大, クロマチンの増量等も目立ったが、中に は変性を伴う大型な核異型練胞もみられた。

疑陽性とした細胞は、 $\mathrm{N} / \mathrm{C}$ 比の増大とクロマ チンの増量, 異常重積むあるが、全体にスムース なことと採取方法によっては細胞数が少ないため 悪性と診断しえなかったものもあった。

これらを、再検討して組織像と対比しながら检 討したい。
72. A F P 産生胃癌の細胞学的検討

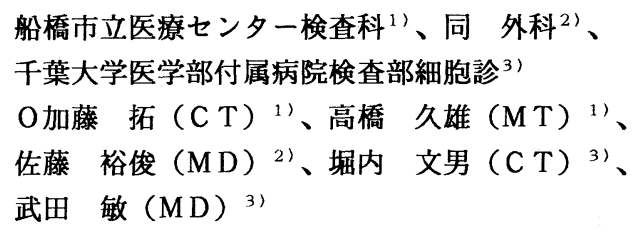

胃癌の中で A F P を産生するものが近年注目さ れ、報告されるようになってきたが、その産生機 序や局在部位についてはいまだ、明確にされては はいない。そこで今回我々はA F P 高值胃癌20例 を免疫細胞化学的に検討し、その細胞像について 報告する。

昭和 58 年 10 月から 62 年 3 月までの 3 年 5 か月間 に当センターで経験した胃渻は 191 例であり、う ち血中 A F P 值が $20 \mathrm{ng} / \mathrm{ml}$ 以上示したものは20例 (10.5\%) あり、この中で実際に免疫細胞化学的に 癌細胞内に A F P 陽性を示したのは9 例(4.7\%)で あった。その A F P 陽性細胞の細胞形態は円柱細 胞夕イプ(22\%)、肝細胞夕イプ(67\%)、小円形細 胞タイプ(11\%) の 3 タイプ認められた。その染色 パターンは細胞質辺縁型、細胞質内顆粒型、細胞 質内びまん型、細胞質内封入体型の 4 種類に分類 することができ、血中AF P 値が高くなると数種 類が混在してくる傾向にあった。細胞質内封入体 は卵黄震腫または肝細胞癌に見られる eosinophilic hyaline globulesとよく類似していた。 
73. Ki-67抗体及びPIを用いた抗癌剤5-Fu が細胞動態に与える影響の検討

長崎大学第一外科

$\bigcirc 川$ 副值樹 (MD)、田川泰 (MD)、宮下光世 (MD)、 石川啓 (MD)、山口広之 (MD)、岡田代吉 $(M D)$ 、 中崎隆行 $(M D) 、$ 林宗榮 $(M D) 、$ 安武享 $(M D) 、$

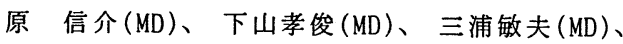
富田正雄 (MD)

[目的] 5-Fuが癌細胞の增殖活性と細胞回転に 与える影響を明らかとする目的で、モノクロ一ナ ル抗体 Ki-67 を用いて免疫染色法にて labeling index（以下LI）を、またflow cytometryにて細 胞周期の測定を行った。 Ki-67抗体はGerdesらに より開発されたものでcycling sells（G1，S， $\mathrm{G} 2 / \mathrm{M}$ 期） の核内に存在する核蛋白を認識する モノクローナル抗体である。

[方法]対数增殖期にあるヒト大腸癌培養細胞 であるWidr細胞に、0.1,0.5,1.0,5.0 $\mu \mathrm{g} / \mathrm{ml}$ の 4 濃度の5-Fuを、接触時間を $1,12,24,48$ 時間の 4 種 に変化させて接触させ、接触後の細胞をKi-67抗 体と60分間反応させた後 ABC法を用いDABにて発色 させる免疫染色を行い、核全体あるいは核小体が 褐色に染色された細胞を陽性細胞とし、細胞 1000 個あたりの陽性細胞の数をLIとして表わした。ま た接触後の検体にKi-67抗体を反応させた後、FI TC僄識抗 $\gamma$ グロブリン抗体にてK়i-67抗体をFITC 染色し、Propidium iodideにて核DNAを蛍光染色 し、FACSNにて細胞周期および陽性細胞率の計測 を行った。

[結果]LIはコントロールである5-Fu非接触Widr 細胞では70\%程度であるのに対し、5-Fu接触Widr 細胞では接触時間が長くなるにつれて $90 \%$ 以上に 上昇した。またflow cytometryでの細胞周期の計 測では、5-Fu接触により $\mathrm{S}$ 期（特にearly $\mathrm{S}$ 期） の細胞の割合が増加する傾向が認められた。
74. 化学療法が著効を奏した進行胃癌の 一例

鳥取大学第一外科 西江浩(H. D. ) 系原志津子(C. T. )塩田摄成 (H. D. ) 松井孝夫(M. D. ) 広岡保明 (M. D.) 村田陽子(M. D. ) 木村章彦(M. D. ) 具原信明 (M. D. )

くはじめに＞癌に対する制癌化学療法が進歩しつ つある今日においても、切除不能胃癌に対する成 績は極めて不良である。今回、我々は、62歳の 男性で、切除不能胃癌に対し、E t o p o s i $\mathrm{de} \cdot \mathrm{Adr}$ i a my c i n C i s - p 1 a t i n u mの 3 剂を用いた E A P 療法を施行し、 著明な腫瘍縮小効果を得、 2 期的に切除可能となっ た症例を経験し、その治療経過中、細胞診により 経時的に治療効果を観察しえたので報告する。 <症例>（患者） 62 歳・男性（主訴）心窝部痛・ 食思不振 (現病歴) 1989 年1月より上記症状 が出現し、胃の精查にて胃癌と診断され、1月 1 7 日当院入院よなった。（検査所見及び経過）胃 $\mathrm{X}$ 線・胃内視鏡検查にて、前庭部大弯側にボルマ ン 2 型の癌を認め、腹部 C T ・ U S にて肝両葉と 腹腔内リンパ節に多発性の転移を認めた。2月 7

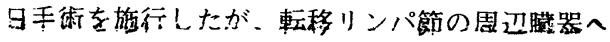
の浸潤のため切除不能であり、術後より E A P 療 法を施行したが、腫場の著明な縮小を認め、再手 術により原病巣及び所属リンパ節の切除が可能で あった。（細胞所見）胃内視鏡下生検の捺印細胞 診により、制癌剤の効果を経時的に観察し得、特 に1クール施行後に、核の膨化、核小体の腫大・ 二核化などの著明な变性所見が認められた。また、 初回手術時の腹腔内洗浄細胞診で多数認められた 癌細胞も、2 回目の時には消失していた。肝の穿 刺吸引細胞診でも、術前には陽性であったが、穿 刺すべき腫瘤を同定しなかった。

くまよめ> E A P 療法により、著明な腫湢縮小の みられた切除不能進行胃癌の一例を経験し、その 効果を細胞形態学的に観察しえたので報告した。 
75. 胃生検塗抹標本によるCampy lobacter Pyloriの検出と細胞所見について

常滑市民病院中央検査科 ${ }^{1)}$ 、名古屋市立大学中央 検查科 ${ }^{2)}$ 、同 第 2 病理 ${ }^{3)}$

O榊原英一 $(\mathrm{C} \mathrm{T})^{1)}$, 来海節夫 $(\mathrm{C} \mathrm{T})^{1)}$

柴田偉雄 $(\mathrm{MD})^{2)}$, 立山 尚 $(\mathrm{MD})^{3)}$

吉田雄一 (MD) ${ }^{1)}$

はじめに : Campylobacter pyloriは長さ $3 \mu \mathrm{m}$ 、 幅 $0.5 \mu \mathrm{m}$ で、複数の鞭毛を有するグラム陰性 螺旋状菌であり、胃粘膜から高頻度に検出され、 胃炎や胃潰瘍など胃疾患との密接な関係が問題と なっている近年話題の微生物である。

今回我々は、胃生検塗抹標本によるこの菌の検 出と細胞所見について検討したので報告する。

方法 : 胃生検時に細胞診・組織診・培養の 3 法 が行われた 91 症例について、塗抹標本を用いた 細胞診での菌の検出と培養の成績を比較すると共 に、出現細胞所見について検討した。また、併せ て組織標本により、本菌の局在と病理組織所見に ついても観察した。

結果 : 細胞診での検出率は $53.8 \%$ (49 例) 、培養では $51.6 \%$ （47 例）、一致率は 80 。 $2 \%$ （７３例）であった。細胞診陽性例は全て組 織の特殊染色標本にて菌体を確認することができ た。

菌を認めた症例では、腺窩上皮細胞が正常上皮 細胞より大きくなり、核・核小体の肥大が認めら れ、同時に好中球・好酸球・リンパ球などの炎症 性細胞が種々の程度に出現していた。再生上皮細 胞は炎症の強い症例にしばしば観察された。

組織標本での菌の局在は、腺窩上皮細胞間隙と 粘液中であり、腸上皮化生・再生上皮細胞間陌に は見られなかった。また、組織学的に腸上皮化性 の著しい症例では、菌は殆ど認められなかった。

結語 : 胃生検塗抹による細胞診で、培養検査と ほぼ同等のCampylobacter pylori検出成績が得ら れ、迅速性にも優リ、細胞所見と併せて胃疾患に 関する有力な情報を提供しうることがわかった。
76. 細胞診により診断し得たヘルペス食道炎 の 1 例

名古屋市立城西病院 内科, ${ }^{1)}$ 中検 ${ }^{2)}$

○佐宗克久 $(\mathrm{MD})$, 小塚正雄 $(\mathrm{MD})$, 蜂矢 化 $(\mathrm{MD})$ 中尾春寿 $(\mathrm{MD})$, 平野朝光 $(\mathrm{MD})^{1)}$

早瀬妙子 $(\mathrm{CT})$, 鈴木孝幸 $(\mathrm{CT})$, 神谷増三 $(\mathrm{MD})^{2)}$

食道擦過細胞診よりヘルペス食道炎と診断し， 早期治療により良好な経過を示した食道潰瘍の 1 例を経験したので報告する。

症例は 76 才，女性で子宮癌のため子宮全摘術 をうけて 2 日後, 吐下血を来し上部消化管内視鏡 検査を施行。胃幽門部に新鮮な潰瘍を認めたが, 同時に食道中・下部に白苔を有する境界明瞭な多 発性潰瘍が広範にみられ，同部よりの擦過細胞診 によりヘルペス食道炎と診断した。

ヘルペス感染細胞は好中球が散在する炎症像を 背景に多核のライトグリーンに濃染した細胞集塊 とオレンジ Gに染った細胞集塊とに認められる。 標本上の食道上皮細胞は傍基底細胞から中層細胞, 表層角化細胞までの扁平上皮細胞と再生上皮まで 多彩で, 細胞の巨細胞化と細胞質の崩壊もみられ, 単核から 10 個程の核を有する多核のものまで種 々で，核は中心性に存在し類円形，楕円形を呈し， 大小不同性が強く, 相互圧排像やクロマチンが核 縁へ凝集した鋳型状核もみられる。核内はスりガ ラス状を呈し，わずかにクロマチンの顆粒状凝集 をみるものもあるが, 大部分は無構造である。ま た，細胞質が濃染して核周に明底を認める Koilocytosis もみられる。

本例は免疫抑制剤の投与は行っていないが, 子 宮癌の基礎疾患に手術侵襲が加わって免疫力の低 下が生じ，さらに胃管挿入などの機械的刺激が重 なって発症したと考えられる。また, 本症は従来, 剖検時に偶然発見されるてとが多く, 本例のでと く細胞診によって診断された症例は極めてまれで ある。ときに大出血を来す本症の早期発見は臨床 上とりわけ有意義である。 
77. イムノグラムによる組織球性壊死性 リンパ節炎（HNL）の診断

点共済病院臨床病理科

○青木 潤(CT)，山本津由子(CT)，佐々木なおぬ(MD) 広島大学総合科学部 難波紘二(MD)

【はじめに】HNLは1972年、菊池に上り発見された。 核片を貪食した組織球と大型の異型的な幼若リンハ球が 多数出現するため、組織標本ですら悪性リン八腫との鑑 別に苦慮する場合がある。形態学的細胞診による診断は 従来ほとんど不可能とされてきた。我々はリンパ節スタ ンプ標本を用い 5 種CD抗原を免度染色し、イムノグラム （青木ら, 日臨細胞誌, 28:727,1989）を作成したところ、特 有のパタンが検出されることを発見したので報告する。

【材料と方法】1988年3月～89年12月の間化当科へ提出 されたリンパ節生検材料のうちHNL と組織学的に診断され た10例（平均年齡 26.2 歳）についてリンパ節のスタンプ 標本を作製し、CD3, 4, 5,8,20に対する免疫染色を難波法

(難波ら,病理と臨床, 5:333,1987) で行なった。病巣部の 大,中,小リンパ球について $\mathrm{CD}$ 別の陽性率を求めイムノグ ラムを作成した。

【結果】10例中8例のスタンプ標本に組織球、リン八球、 壊死物からなる病巣部が含まれていた。病巣部のリンパ 球はCD3(+),5(+)の成熟 $\mathrm{T}$ 細胞が多く、さらにそのサブセ ットについてみると CD4(-),8(+)のサプレッサ-細胞( T $\mathrm{s} / \mathrm{C})$ が多かった (CD4/8 $=0.63 \pm 0.28)$ 。 $\mathrm{T}$ 細胞のらち中,大 リンパ球だけをみるとCD8(+)細胞が圧倒的に優位をしめ た (CD4 / 8=0.21士0.16)。これらのデータに基きイムノグ ラムを作成したところ、CD8(+)のコラムは大リンパ球を 含み、高く、CD4(+)のコラムは低くほとんど小リンハ球 からなるといら、パタンが検出された。

【考察】リンハ節の凍結切片でのCD抗原の免疫染色では、 病巣部はCD8(+)の T s / 細胞が優位といら報告がある。我 々の結果はこれを確認するものである。しかし凍結切片 法は標本作製に手間がかかり、通常の日常診断法として 用いるには必ずしも適さない。イムノグラムによる解析 は日常業務に組み入れることが可能である。また一つ一 つの細胞が正確にカウントでき、細胞のサイズ判定も容 易である。さらにリンハ節吸引材料についてる原理的に は応用可能である。HNLは若い女性の䅡部リンパ節に好発 し予後良好であるので、生検によらず細胞診のみで正確 な診断ができれば、その方がよい。今回、スタンプ標本 での検討で特徽的パタンを示すことが判明したことから、 今後穿刺吸引材料によるHNLのイムノグラムについて検討 する予定である。
78. 免疫の個体発生よりみた新生児リンパ 球subpopulationの研究

\section{岩手医科大学医学部産婦人科学教室}

O松田 玩磨 (MD)、利部 輝雄 (MD) 西谷 䉷 (MD)

[目的] 免疫系の個体発生を検索する目的て新生 児䐮帯血リンパ球についてTCR $\gamma / \delta$ 陽性T細 胞、成人においてそのNK様活性の注目されてい るdouble negative T (DN T) 細胞（成人は TCR $\gamma / \delta$ 陽性細胞がその多くをしめる)、 $\mathrm{CD} 5^{+} \mathrm{B}$ 細胞（個体発生初期に多く、自己の抗原 にも高度の反応性を有する）数を測定した。また NK細胞についてLeu11,NKH-1を用いてその subpopulationを、アトピー体質との関連を Fc $\varepsilon$ R II陽性B細胞の比率より検討した。

[方法] 成人末梢血 (䏬帯血)をへパリンを添加 して約 $10 \mathrm{ml}$ 採血、Ficoll-Paqueを用いた比 重遠沈法により単核球層を分離、 $2 \times 10^{6}$ 個 $/ \mathrm{ml}$ に調整、FITC,PE標識モノクローナル抗体 (CD3,CD4,CD8,TCR $\delta-1, C D 5, C D 20, C D 23$, CD16,NKH-1)を用いて二重染色しSpectrum III,DS- 1 にて解析した。成人 10 例、胼帯血 20 例、以下数值はこの順。

（成績） $\mathrm{CD}^{+} \mathrm{TCR} \delta-1^{+}: 4.2 \pm 1.3(\%, \mathrm{SD}), 4.6$ $\pm 2.0 \mathrm{CD}^{+}{ }^{+} \mathrm{CD}^{-}{ }^{-} \mathrm{CD} 8^{-}: 4.5 \pm 1.4,4.3 \pm 2.0$ $\mathrm{CD}^{+}{ }^{+} \mathrm{CD} 20^{+}: 1.5 \pm 0.3,4.8 \pm 1.5, \mathrm{CD}^{2} 3^{+}$ CD20+:0.4 $\pm 0.1,0.4 \pm 0.2 \mathrm{CD} 16^{+} \mathrm{NKH}^{-1}{ }^{-}$: $6.5 \pm 2.0,4.8 \pm 1.2 \mathrm{CD} 16^{+} \mathrm{NKH}-1^{+}: 18 \pm 4.2$, $17 \pm 3.6 \mathrm{CD}^{1} 6^{-} \mathrm{NKH}-1^{+}: 4.2 \pm 1.8,3.2 \pm 1.5$

[結論] TCR $\gamma / \delta$ 発現細胞は成人と新生児に おいて差を認めず、出生時すでに $\alpha / \beta$ 鎖 $\mathrm{T}$ 細胞 が主になっているものとおもわれた。DN T細胞 もほぼ同数であった。 $\mathrm{CD}^{+} \mathrm{B}$ 細胞は成人におい て有意に低值をしめした。NK細胞の subpopulationは特に差を認めなかった。 
79. マウス白血病性脾腫における $\mathrm{ABC}$

埼玉医科大学病理 ${ }^{1)}$ 日本細胞病理ボラトリー2) O大友幸二 $(\mathrm{CT})^{1)}$ ，西辺泰夫 $(\mathrm{MD})^{11}$ ， 片山熟(MD) ${ }^{1)}$, 坂井義太郎(MD) $)^{2)}$

目的: Aspiration biopsy cytology(ABC)は, 諸臓器において盛んに行なわれるようになったが, 脾臓とくに白血病性脾腫においては, 出血の危険 性が高いため, $A B C$ 澿忌とされている。白血病 性脾腫には，ABCのみならず摘脾術も禁忌とされ るむのが多いが，逆に摘脾術が効果的治療法とな る “Surgical Leukemia”む知られている。ABCの 安全性が認められれば, 摘脾術適応性の鑑別法と してABCが賞用されるものと予測される。

材料・方法：4匹づつ3群のマウス [CBH/He$\mathrm{NJCl}$ に, thymic Iymphoma( I 群), non-thymic lymphoma( II 群), lymphatic leukemia(III群〉のマ ウス由来細胞株を $2 \times 10^{6} \mathrm{cel} 1 \mathrm{~s}$ づつ静注, $2 \sim 3$ 週 間後, 明らかな脾腫の形成を確認して, 経皮的に 脾藏の $A B C を$ 行なった。その10〜15分後に開腹し， 直接的に $A B C$ を施行した。ついで脾臓を摘出し分 割して, 組織標本(10\%ホルマリン), スタンプ, オートスメアを作製した。細胞診標本はPapanicolaou染色またはGiemsa染色を行なった。

結果及び考察：各群において，3週後には明ら かな脾腫が触指された。開腹すると, 黄色の腹水 が少量みられるのみで，血液の混人はなかった。 亚群のみ腸間膜リンパ節が腫大していた。細胞診 所見では, 約14 $\mu$ m前後の細胞が多数みられ，そ の半数以上に核の切れ込みと著明な核小体が 1 〜 3個みられた。病理組織像でも同样の細胞が脾組 織を置換していた。

まとめ：実験動物の白血病性脾腫に，経皮的に $\mathrm{ABC}$ 施行したが, 出血などの合併症なしに摘脾 標本の病理組織像を正しく予测する穿刺細胞像が 得られた。
80. 血中細胞診で癌細胞は見つけられるか。 一剖検への細胞診の।つの応用の試み—

北大第二病理, 美呾学㷋病院中検病理, 釧路労災病院中検病理, 同産婦人科

○小島英明( $\left(\mathrm{MD}^{1}\right)$ ), 古田 康 (MD), 竹林克重 (MD) 石田 匠 $\left(\mathrm{C} \mathrm{T}^{2}\right)$, 松崎純和 $(\mathrm{CT})$, 斉藤隆二 $\left(\mathrm{CT}^{3}\right)$, 久末浩樹 $\left(\mathrm{CT}_{4}\right)_{4}$, 本田千恵子( $\left(\mathrm{MT}_{4}\right)$, 森下奈緒美(MD) 早川和彦(MD), 山崎知文 $(\mathrm{MD})$

\section{〔はじめに〕}

癌の転移の有無は重要な問題であり，特に癌末 期には，大なり小なり carcinocythemia がおき ている可能性がある。その検索のためと，剖検時 そ血中細胞診を試みた。

\section{〔方法〕}

末期癌で亡くなった方の剖検に際し，開胸し心 外膜に切開を入れ心臟を露出してから, 大動脈基 部と下大静脈より，へパリン加採血を $20 m l$ 行ない， $2000 \mathrm{rpm} / 5$ 分間遠心分離した。上清は $-70^{\circ} \mathrm{C}$ 凍 結保存し, バッフィーコートをピペットで吸いあ げて塗抹し, PapanicolauとGiemsa染色を行っ た。死後剖検時間は 2 時間以内とした。

〔結果〕

現在 5 例（総胆管癌, 前立腺癌, 大晹癌 2 例, carcinoid）を検索した。いずれる全身性の転移 を認めたが，血中細胞診で陽性所見をみたのは， 総胆管癌（低分化型腺癌）の症例の大動脈採血の 例だけであった。

\section{〔まとめ〕}

腫瘍の細胞学的性格の差異の問題, 症例数の問 題, 方法論上の問題等があり, 今後の検討課題と したい。 
81. Sjögren症候群で胸水細胞診により悪 性リンパ腫を発見した一例

新潟県立中央病院病理検査科

$\mathrm{O}$ 鏡十代栄 $(\mathrm{CT})$, 建部勝彦 $(\mathrm{CT})$, 山田恭子 $(\mathrm{CT})$ 浅野ツ中子(CT). 関谷政雄 $(\mathrm{MO})$

[緒言]Rothmaの報告以来, Sjögren症候群は悪性 リンパ腫を高率に合併することが知られている。 今回我々は, 胸水細胞診により悪性りンパ腫の合 併を診断しえたSjögren症候群を経験したので報 告する。

[症例]69歳女性。昭和36年頃より口腔内乾燥症状 があった。昭和63年10月頃より側胸部痛が节り胸 部X線で右胸水を指摘され当院内科入院となった。 ANA 1280倍, SS-A 16倍ですり, 耳下腺造影で典 型的なapple tree formationが見ら机Sjögren症 候群と診断された。胸水細胞診では大型異型りン パ球が多数見られ, $\operatorname{CD2}(H), \operatorname{sig} G \kappa$ で悪性り ンパ腫細胞と診断した。この後Cたよる精査で, 綎隔・肺門部リンパ節の腫脹が認められた。さら に触診により, 䫫部リンパ節に軽い腫脹があり, 生検で悪性りンパ腫が確認された。

[胸水細胞所見] $N / C$ 大て好塩基性の細胞質を有す る大型のリンパ球系細胞が多数認められた。核型 の不整や核の切れ迈みも見られ，クロマチンは， 細顆粒状で核小体やカリオゾームが1-2個見られ るものもあった。その他CD2(H), CO4(H)の小型り ンバ球や好酸球も多数出現していた。 [生唡リンパ節所見]non-Hodgkin lymphoma, diffuse lymphoma, large cell type。免疫組織 化学ではMT1(-), SL-26(+)で, B cell Iymphoma であった。

[結語]Sjögren症候群では悪性りンパ腫の合併す る危険率恃，43.8倍といわれている。本症例のご とく体腔液中に悪性りンパ腫細胞が出現すること は稀であるが，多数の大型りンパ球が認められる 場合にはモノクロナール抗体による検索が重要と 思わ机た。

\section{2. 距骨に発生した軟骨芽細胞腫の一例}

\section{関東労災病院検査科病理}

○柿沼良子 ( CT ) , 井上正年 ( CT ) , 田村浩章 $(\mathrm{MT})$ ）村尾陽子 ( MT ) , 江口正信 (MD)

軟骨芽細胞腫は比較的稀な骨腫瘍で, Dahlin の 報告に上ると原発性骨腫場中 $1 \%$ を占め, 主飞長 管骨の骨端部を主体とする腫瘍形成を示す。今回 我々は距骨飞発生した軟骨芽細胞腫を経験したの で，その择印細胞像を中心に報告する。

症例は 16 歳, 男性。昭和 62 年近医々て, 距骨 骨腫場の手術施行。その後当院受診し，X線，骨 シンチ, MRI などで腫漡の残存を認め, 本年 7 月 再手術施行。腫瘍は左距骨後内側飞あり, 黄色お よび一部は褐色調を示した。病理組織学的には, わずかに分葉状構造がみられ，紡錘形から多角形 を呈する腫瘍細胞の比較的密な增殖を示し，多核 巨細胞の出現するが，全体的に異型性は乏しく 腫瘍細胞間《はAlcian-Blue陽性を示す軟骨基質 の形成と不規則な石灰沈着が認められた。をた腫 瘍の周囲には肥厚した骨梁構造からなる骨硬化性 病変がみられた。同腫瘍の捺印細胞像で, 細胞 密度が高く, 結合性の乏しい小型の紡鏵形細胞が 認められた。核は渒㴽類円形で一部にくびれるみ られ, 小型の核小体を有し, クロマチンは顆粒状 で均一に分布していた。交た，その中に2核标よ び多核の巨細胞が認められたが, 全体的には原济 均一な腫瘍細胞像を呈していた。P A 染色では 細胞質内に陽性像がみられ, ギムザ染色では一部 スメタクロマジーを示す軟骨基質と思われる像が 認められた。以上の所見に加え, 免疫組織学的検 索結果につんても報告する。 
83. 穿刺吸引細胞診にて診断しえた腹壁 皮下アニサキス症の一例

\section{国立習志野病院外科 O山本和夫(MD)}

伊藤文雄(MD)、花輪孝雄(MD)、获部喜一(MD)

吉岡 茂(MD)、

同研究検查科斉藤博子(CT)、山田敏也(CT)

飯島謙二(CT)

千葉大学医学部寄生虫学教室 小島荘明 (MD)

アニサキス症は胃をはじめとして消化管内に 多くみられる疾患であり、時に大網、腸管膜など の腹腔内にみられることがある。しかし皮下にみ られることはきわめて稀であるとされている。今 回我々は、腹壁皮下に形成された腫嘴に対する穿 刺吸引細胞診で診断可能であったアニサキス症の 一例を経験したので報告する。

〈症例〉39才男性、生来健康であった。主訴 は腹壁の皮下睡㿇である。現病歷、以前より腹壁 正中に小さい腫瘤があり、平成元年 10 月頃より 次第に増大し、また軽い痛みがあるため、同 11 月当科受診。初診時、剣状突起と翢のほぼ中間の 腹壁正中に直径 $2.5 \mathrm{~cm}$ の腫瘤あり、弾性硬で、皮 简との痣着はないが可動性はなく筇膜との痹着が 考えられた。全身的な理学的所見では特に異常を 䜑めなかった。穿刺吸引細胞診を施行したところ、 白色系状、長さ $3 \mathrm{~cm}$ の虫体が採取された。

〈細胞像〉 虫体の断片と思われる構造物が見ら れる他、リンパ球、好中球が、極く少数見られる のみで、好酸球の増加は見られなかった。

〈組織像〉肉来組織の形成があり、多数の好酸 球とリンパ球、形質細胞の浸潤がみられ、炎症は 周囲の脂肪組織に及んでいた。

〈その他の検査〉血液像では白血球増多はなく 好酸球の増加も見られなかった。免疫学的検査で は患者血清中にアニサキス抗体の増加が䋟められ た。また虫体はアニサキスであることが判明した。
84. 左大腿軟部組織原発と思われる肺転移 性悪性顆粒細胞腫の一例

福島県立大野病院外科11 福島労災病院病理2 磐城共立病院中央検查部3) 江東微生物研究所4

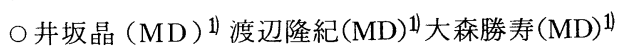
箱崎半道 $(\mathrm{MD})^{2}$ 大槻文子 $\left.(\mathrm{CT})^{3}\right)^{3}$ 蛭田道子 $(\mathrm{CT})^{3)}$ 吉田京子 $(\mathrm{CT})^{3}$ ) 益子真由美 $(\mathrm{CT})^{4}$

本邦における悪性顆粒細胞腫の報告例は今だ 20 例にすぎない。我々は、59歳の女性に左大腿部の 軟部組織原発と思われる肺転移性覀性顆粒細胞腫 の一例を経験したので報告する。

症例は胸部検診で異常陰影を指摘され精查の目 的で入院し、両側肺に腫瘤影を認め、特に右肺門 に大きな数個の腫瘤があるため気管の圧迫による 症状がみられた。気管支擦過および経皮的生検を 施行し、Papanicolaou 染色にて胞体内に好酸性の 顆粒をもつ悪性細胞を認めた。症状改善の目的で 右中葉切除術を行い、現在化学療法を継続中であ る。

組織診の結果、悪性顆粒細胞腫と診断された。 本症例は、55歳および58歳のときに左大腿部腫瘤 を摘出しており、その組織標本の照合により当部 位を発巣と診断した。

細胞診、組織診断の要点は、細胞質内に多数の 顆粒を認めた点で、特に神経組織特異蛋白といわ れるS-100蛋白染色を行ない、茶褐色に染まった 顆粒を認めたととである。さらに電顕像による細 胞所見も比較検討し、あわせて報告する。 
85. 脂腺癌の細胞学的検討

\section{大阪医科大学 中検病理}

○日下部正 (CT) 森川政夫 (CT) 山本隆一 (MD)

橋本和明 (MD) 黒川彰夫 (MD) 稲井真弥 (MD)

脂腺癌は主として眼瞼に発生する比較的稀な疾 患で, 時として基底細胞上皮腫や扁平上皮癌との 鑑別が問題となる。

今回我々は脂腺癌の細胞像をより明確にする目 的で, その特徵を細胞学的にさらに免疫細胞化学 的に検討を行なったので報告する。

[対象] 過去 3 年間に脂腺癌 (眼瞼) と診断され た 3 例を対象とし，その術中迅速診断時の捺印細 胞を材料とした。

[細胞所見］腫瘍細胞は集合性に出現し，異型性 の強い小型細胞と泡沫状の大型細胞が見られた。 小型の細胞は $\mathrm{N} / \mathrm{C}$ 比大, 核の大小不同を示し, クロマチンは増量, 著明な核小体を認めた。 大型の細胞は泡沫状の細胞質を有し, 核は類円形 でクロマチンの増量も認めなかった。

[免疫細胞化学的所見] 脂肪染色, P A S 染色で 陽性を示し, とくに泡沫状の大型細胞は脂肪染色 で強く染色された。免疫染色では E M A は小型 および大型細胞ともに陽性を示したが，泡沫状の 大型細胞がより多く陽性を示す傾向にあった。C E A は少数ながらいずれの細胞も陽性を示した。 [まとめ] 1 ) 脂腺癌では異型性の強い小型細胞 と異型性の乏しい泡沫状の大型細胞が認められた 。2 ) 免疫染色で E M A は異型性の強い小型細胞 に比し、泡沫状の大型細胞により多く陽性を示し た。3）脂腺癌では E M Aが陽性を示し, 基底細 胞上皮腫ではEMAが陰性。4）EMAの免度染 色を用いることは, 脂腺癌の診断に際し有用な方 法と思われた。
86. トリコスポロン属真菌と他の真菌と の細胞彭における菌形態の比較

国立大阪南病院臨床検查科 ${ }^{1)}$, 近畿大学医学部第 2 病理 ${ }^{2}$

○木村雅友 $(M D)^{1)}$, 2), 酒谷邦康 $(M D)^{1)}$,

丹司 紅 $(M D)^{2}$, 蛭間真悟 $(C T)^{2)}$, 前田光代 $(\mathrm{CT})^{2)}$, 佐藤隆夫 $(\mathrm{MD})^{2)}$, 橋本重夫 $(\mathrm{MD})^{2)}$

皮覤の常在菌の 1 つであるトリコスポロン属真 菌による日和見感染症が近年増加している. 我々 は播種性トリコスポロン症の 1 例を経験し, トリ コスポロン菌要素の細胞診での特徵を他の真菌の あのと比較検討したので報告する。患者は 75 歳 男性で薬剤性肺炎の疑いで副腎皮質ホルモンを投 与されていたが, 呼吸不全のため死亡した。生前, 血液及び尿培養から Trichosporon beigelii が分 離されていた。剖検により，心・腎・肺・甲状腺 にトリコスポロンの菌要素が見い出された。すり 合わせ法による病巣組織の細胞搒で菌系・酵母 · 分節型分生子等を認め, 各要素と鑑別すべき他の 真菌を比較した。結果は以下のでとくである. 酵 母状要素は大小不同があり表面不整で, カンジダ の醉母状要素のように大きさが均一で平滑な表面 ではない。またクリプトコッカスのように莢膜は 有さない，菌系は的じれを伴った有隔性分岐性で, カンジダ仮性菌系のようなソーセージ様形態は示 さず，アスペルギルスのように菌系壁の幅が一定 ではない。本たムーコルとはスクリウ様形態を 菌系が示すことで類似しているが，ムーコルのよ うに無隔性菌系ではない。分節型分生子にっいて は上記のすべての真菌にはなく，トリコスポロン のみに認められた。 
87. 尿膜管由来の膀脱原発小細胞癌

福井医科大学病理学教室

O白石泰三 (MD), 斉藤由美(MT), 中久木和也(MD)

福井赤十字病院検査部

吉森哲夫 ( C T )

福井赤十字病院泌尿器科

西川忠之(MD), 塚原健治(MD), 南後千秋(MD)

膀胱原発の小細胞癌は稀な腫痬であるが，尿膜 管由来と考えられ，しかも粘液腺癌を合併した症 例を経験したので，その細胞像を中心に報告する。 [症例] 29 才男性, 平成元年 6 月頃上り血尿が出 現し, 同10月初診。膀胱鏡にて頂部に広基性の隆 起性腫瘤を指摘され，同月膀胱部分切除術施行。 膀胱頂部に壁内を中心とする $5 \times 4 \mathrm{~cm}$ 大の腫瘤形 成がみられ，正中臍索に浸潤性増殖を示していた。

臨床的には他臓器に腫痬はみられず，原発性膀 胱腫瘍と考元られた。

[尿細胞診所見]背景は比較的きれいで, 孤立散 在性汃集塊を形成する $\mathrm{N} / \mathrm{C}$ 比大の小型円形の 異型細胞が多数出現していた。細胞質は少なく辺 縁は明膫で, 核は不整形濃縮状, 中心性に配列し, 大小不同性を示していた。細胞質内に粘液はみら れなかった。

[腫瘍組織像] 腫瘍の膀胱内胿側 $1 / 2$ は小細胞 性未分化癌の像で，辺縁部では円柱状で管腔形成を 示す部分があった。膀胱深部から正中臍索にかけて は大量の粘液に少数の腫痬細胞が浮遊しており粘 液腺癌の像を示していた。免疫染色では膀胱内腔 側の小細胞性腫瘍はN S E 陽性, C E A 陰性であり, 粘液腺癌の部分では逆のパターンであった。 [まとめ] 尿膜管上皮および尿膜管癌には神経分 泌顆粒含有細胞が存在するとの報告があり，同細 胞が本腫湯の発生母地と考えられる。膀胱原発小 細胞癌の症例報告は数十例みられるが，本例は若 年で，尿膜管由来，しかも粘液腺癌を合併してお り,てれまでにない特異な例と考えられた。
88. 尿中に出現した悪性黒色腫の一例

久留米大学病院病理部 ${ }^{11}$ 同ハートセンター ${ }^{21}$ 同泌尿器科 ${ }^{3}$ 同第一病理 ${ }^{41}$ 同第二病理 ${ }^{51}$

O杉島節夫 (CT $)^{11}$, 横山俊朗 (CT ${ }^{11}$ 吉田友子 (CT) ${ }^{11}$, 金原正昭 (CT ${ }^{21}$ 大薮裕司 $(\mathrm{MD})^{31}$, 江藤耕作 (MD) ${ }^{31}$ 自見厚郎 $(M D)^{4}$, 荒川正博 $(M D)^{41}$ 森松 稔 $(M D)^{5}$

悪性黒色腫についての細胞学的報告は比較的多 くみられるが、尿道に発生した悪性黒色腫は極め て稀である。今回われわれは尿中に出現した尿道 原発性悪性黒色腫を経験したので報告する。

症例：64歳、男性。昭和63年12月10日頃より血 尿があり、排尿困難、頻尿が認められ、同年12月 22日開業医を受診し治療を受けた。この時尿道出 血を指摘された。平成元年 3 月 31 日排尿困難持続 のため前立腺肥大の臨床診断にて経尿道的前立腺 切除術が施行された。その後も尿道出血が持続す るため、同年 8 月某病院へ転院、9月7日尿道止 血と生検術が施行され生検組織診断にて悪性黒色 腫が疑われ、同年 9 月 25 日久留米大学泌尿器科を 受診し、入院後尿細胞診が施行された。

細胞所見 : 腫瘍細胞は孤立散在性あるいはシー 卜状細胞集塊で出現していた。核の腫大がみられ N/C 比の増加を呈し細胞質は比較的狭小であり、 核縁は不整で切れ込みも認められた。また、著明 な核小体の出現があり、核クロマチンは微細顆粒 〜網状で非上皮性細胞を思わせる様な細胞所見を 呈していた。細胞診においてはメラニン色素の出 現に乏しく、シート状細胞集塊で出現した細胞で は移行上皮癌細胞との鑑別も必要と思われた。こ れらの細胞所見に病理組織所見、免疫組織化学的 所見ならびに電顕所見を併せ報告する。 
89. 男子尿道炎症例のChlamydia trachomatis とUreaplasma urealyticumの検討

鹿島労災病院 検査科病理 1 ), O長坂宏一 $\left.(\mathrm{CT})_{1}, 3\right)$, 石川昌文 $(\mathrm{CT})_{1}$ ), 岩桷裕郷 (MD) 1 )

千葉大学病院中検細胞診 2 ), 杏林大学保健学部 31 武田敏 $\left.(M D)_{2}\right)$. 椎名義雄 $(\mathrm{CT})_{3}$ )

『はじめに』今回我々は尿道炎患者の尿道擦過材 料か 5 Chlamydia trachomatis とUreaplasma urealyticum の検出を行い、この細胞形態と兔疫細 胞化学を以下の方法で行い訩断的意義を検討した。

『対象・方法』143例の尿道炎患者の尿道摖過材 料から塗抹標本を作成し、Papanicolaou染色と免 疫細胞化学的方法 (IF法: Micro Trak Chlamydia trachomatis Direct Test, Syva社, PAP法: クラ ミジア同定用キット, Or tho 社, IF・PAP 法 : IF 法観察後二次抗体以降を反店させたPAP法, MT ・ PAP 法：IF法の蛍光抗体を一次抗体とした PAP法) を143例に施行した。またこのうち32例にクラシジア 广社 $n^{\circ}$ 听, (:TP法, DAINABOT 社) 行った。Ureaplasma の検索にはMYCOFAST(:MF法, DBV社) とMYCOTRIM-GU(:MG法, Hana Media社) を使用し10例検 討した。

『結果』Papanicolaou標本から星雲状封入体細胞 は認められなかった。IF法, IF・PAP 法, MT・PAP法, PAP 法の 4 法一致率は $40.0 \%$ で、IF法 $(+)$, IF - PAP 法(-), MT - PAP 法(-), PAP 法(-) は17.7 $\%$ で、IF法(-), IF ・ PAP 法 $(+), M T \cdot P A P$ 法 $(+), P A-$ P 法 $(+)$ は $15.4 \%$ であった。IF法では基本小体の レベルで明確に認められるのに対してPAP 法では 核の反対侧に陽性所見が諰められた。またU.urealyticum の検出率は 40.0\% でMF法とMG法の全例が 一致していた。陽性例の75.0\% Kは C. trachomatis, N. gonor rhoeae, Hemophi lus 等の混合感染が認 められた。

『まとめ』IF法, IF ・ PAP 法, MT ・ PAP 法, PAP 法陽性パターンは一致せず、陽性形態とTP法の結 果を考虑するとPAP 法は C. trachomat is以外のも のと反応が示睃された。U.urealyticum は高率に 検出され、混合感染例が多く㳏められた。これら の検討に症例数を追加し報告する。

\section{0. 検体採敢法別に見た尿細胞診の検討}

群馬県健康づくり財団対ガン事業部病理 ${ }^{11}$

群馬大学医学部中検病理 ${ }^{2)}$

上毛泌尿器科病院 ${ }^{31}$

O関本 弘 $(\mathrm{CT})^{11}$, 木村 茂 (CT ${ }^{11}$

城下 尚 (MD) ${ }^{2)}$, 簙䛴忠利 (MD) ${ }^{3)}$

今回我々は、検体採取法別（自然尿・カテーテ ル尿・膀胀洗浄液）の差異による尿路系腫堭の正 診率と細胞像について検討したので報告する。

当健康づくり財団で経験した過去 3 年間の尿細 胞診症例数は、 2,462 例で総件数 7,58 6 件 であった。2, 462 例の内訳は、非腫煌 2, 22 6 例, 乳頭腫 18 例, 墨性腫㾤 158 例, 経過観 察 6 0例であり、尿細胞診の結果は、非腫煌症例 2,226 例中偽陽性 58 例 (26\%)，疑陽性 76 例 $(3,4 \%)$, 乳頭腫は、1 8 例で正診 8 例 $(44.4 \%)$, 陰性 5 例 (27.8\%)，隄性 2 例 (11.1\%)，疑陽性 3 例 (16.7\%), であった。

墨性腫瘍は、158例で内 151 例が移行上皮 癌であった。移行上皮癌 151 例の尿細胞診は、 正診 118 例 (78.1\%), 偽陰性 18 例 (11.9\%), 疑 陽性 15 例 $(9.9 \%)$ であった。移行上皮癌正診例

118 例を、検体採取法別に娭討すると自然尿で 此誩できたものは、99例 (83.9\%) であった。こ れを分化度別にみると、分化型 12 例中 4 例 133 $3 \%$ ), 中分化型 51 例中 43 例 (84.3\%), 低分化型 55 例中 52 例 (94.5\%) であり、残り 19 例 (16. 1 \%) は、カテーテル尿・膀胱洗浄液緗胞診ではじめ て正診したものである。すなわち組織分化が低い ものほど自然尿で正診できるものが多く、逆に分 化度が高いものは、カテーテル尿・膀肶洗浄液で 正診される率が高かった。尚細胞像についても報 告する。 
91. 尿細胞診の臨床的意義

一細胞診分類に於ける臨床的及び形態的

意義, 異型細胞の由来についての検討一

\section{京都民医連病理センター}

O堀隆(CT), 藤元里美(CT), 稲本和男(CT)

矢野由佳(CT), 若田 泰(MD),

安田産婦人科医院

安田廸之(MD)

尿細胞診が手軽に行える形態的検查として今日 沉用されていることを今更強調する必要はない。 しかし, 形態上明らかな悪性細胞はよいとして, 細胞異型を認めるが悪性と判断できないむのに対 して，その細胞がどのような疾患或は病変に由来 しているかを知る事は練胞診の判定を評価するう えで，湢床的にも形態的にも重要と考える.

そこで，今回我々は，1985年 1 月から1989年3 月までの 4 年 3 力月間に尿細胞診で一度でもクラ ス II Repeat（以下 II R) 以上の判定を受けたこと のある 185症例に対し, その後の精查追跡実態を 調べ，出現する異型細胞の由来（原因疾患或は病 変)について検討したので報告する.

䊅果：185例のうち臨床的に悪性であったもの は44例で，それらは細胞診の結果ではクラスIV・

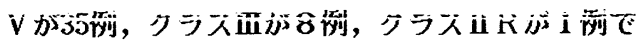
あった。クラスIIやII Rとされた症例の細胞像は 小型の悪性細胞が孤立散在性に少数個出現したも のが多かった。185例のうち臨床的に良性であっ たものは 103例で，細胞診の結果ではクラスIV・ $\mathrm{V}$ が9例，クラスIIIか26例，クラス II Rが68例で あった. 異型細胞が出現した原因としては導尿変 化, 結石, 炎症, 卧疾患等が考えられた。それら の症例では，依頼書に導尿採取を始めとして臨床 情報の記載のないものが多く見られた。

尿細胞診の正碓な判断には臨床側の協力が不可 欠で, また, 細胞診の正確な判断は臨床側の細脆 診への信頼を高め, それらは患者の病態の正しい 把握の一助になると考えられた。

\section{2. 前立腺分泌液細胞診の評価}

福島県立医科大学泌尿器科学教室

一条貞敏 ( MD )、白岩康夫（MD）

我々は独自の方法で前立腺分泌液細胞診を行 ってきた。本細胞診法は極めて確度が高く、治 療効果の判定、ひいては予後の推測、鑑別診断 にも有効であることが判明した。

症例は 1980 年 12 月より 1989 年 5 月まで に施行した前立腺疾患である。この内訳は、臨 床診断が前立腺肥大症 234 例、前立腺癌の疑 W 141 例、前立腺癌 76 例、前立腺炎 83 例、 前立腺症 32 例、血精液症 34 例で総計延べ 600 例である。細胞診は独自に開発した前立 腺液採取用カテーテルによるものである。この カテーテルは尿道に留置した場合、先端の穴が 尿道前立腺部に位置する。これを尿道に留置、 前立腺マッサージの上、前立腺液を吸引㭘索す るものである。細胞判定は癌細胞陽性、疑陽性 及び陰性の 3 段階とした。

臨床的に前立腺肥大症とされた 234 例の内 12 例（ $5 \% ）$ が細胞診陽性であったし、この 内 6 例 $(2.5 \%)$ に癌組織を確認し得た。前 立腺癌とされた 74 例では 45 例（59\%）が 細胞診陽性、24例（３２％）が陰性であった が、陰性例はほとんどが既に内分泌療法を施行 されていた。これら内分泌療法後の陰性例を除 き、いずれかの時点で癌組織の存在を確認した 55 例についてのみみると、陽性例は $82 \%$ と 高率で、陰性例は $4 \%$ にしかみられなかった。 すなわち、本細胞診は極めて確度の高い癌診断 法といえる。一方、内分泌療法施行例に陰性例 が頻発したことは治療効果の判定に有効であっ たし、この様な症例の生存率は高く、予後の推 測にも効果的であった。前立腺液所見から炎症 その他、他疾患の診断もなし得た。

以上の如く、本細胞診法は簡便かつ安全な上、 極めて効果的な前立腺疾患診断法といえる。 
93. 前立腺穿刺吸引細胞診による前立腺炎 診断の試み

三信会原病院臨床病理部1)、泌尿器科2)

$\mathrm{O}$ 藤 利夫 $(C T)^{1)}$ 野坂綾子 $(M T)^{1)}$ 手島軍児 $(C T)^{1)}$ 、川岸淳子 $(C T)^{1)}$ 、金城 満 $(M D)^{1)}$ 、 䉆山和幸 $(M D)^{2}$ 、 、山口秋人 $(M D)^{2}$ 、原 三信 $(M D)^{2)}$

【目的】泌尿器科では前立腺炎には穿刺吸引細胞 診は禁忌であるといわれているが、実際は理学的 所見や超音波検查のみでは前立腺炎の診断はきわ めて困難である。今回、われわれは当院で昨年実 施された穿刺吸引細胞診 (FNA) と組織学的検查か ら、前立腺资の診断への応用について検討したの でその結果を報告する。【対象及び方法】昭和 63 年 1 月から 12 月までの 1 年間に当院泌尿器科で は479回のFMAが行われたが、そのうち175件に ついては同時に針生検または経尿道的前立腺切除 (TUR-P)が行われた。てれらのうちで、両者か沲 行された 105 件について臨床的、病理学的及び細 胞学的所見を対比、検討した。細胞学的判定には Maksemらの方法を改良して基準を作製してみた。 標本上で白血球数が20個未満を陰性と判断し、20 個以上 100 個未満を+、 100 個以上 200 個未満を +十、200 個以上を+++として細胞診標本上で 判定した。病理学的には同一の病理医が全症例を 判定した。臨床的事項は病歴の記載を参照した。 【結果及び考察】検討した 105 件は全例好中球、 リンパ球、組織球が標本上にみられたが、上記の 判定基準で判定すると、急性前立腺炎が 6 件、慢 性活動性前立腺炎が 14 件、慢性前立腺が 4 件であ った。肉芽腫性前立腺炎は 1 件のみであった。前 立腺上皮細胞の異型を示したものも見られたが、 腺癌との鑑別については今後の検討課題にした。 また組織学的検討結果とは大きなずれがみられた が、これは入院後術前に行われた化学療法による 修飾の結果と考えられた。今後ての結果を検討し 臨床的に診断困難な慢性前立腺炎の診断に応用す る予定である。

\section{4. 前立腺穿刺吸引細胞診の陽性率}

帝京大学市原病院病理部 ${ }^{1}$ 同泌尿器科 ${ }^{2}$ 千葉大学病理学教室 ${ }^{3}$

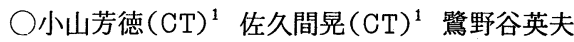
$(M T)^{1}$ 松齐 理 $(M D)^{1}$ 菅野 勇 $(M D)^{1}$ 中島 透 $(M D)^{1}$ 長尾孝一 $(M D)^{1}$ 山口邦雄 $(M D)^{2}$ 伊藤晴夫 $(M D)^{2}$ 小松悌介 $(M D)^{3}$

本邦における前立腺癌は未だ欧米に比較して少 ないむのの、近年になって臨床癌としての前立腺 癌が著名に増加してきた。また、従来行われてき た内分泌療法に加えて前立腺全摘などの外科的治 療法の発達などから、より確実な診断が必要とな ってきた。欧米では、従来から前立腺穿刺吸引細 胞診（FNA）が盛んに行われており、穿刺組織 診に劣らない好成績が報告されている。今回、我 々は、当院で行われたF N A の結果について、前 立腺癌の臨床病期と比較検討して報告する。

検索対象は1987年12月から1989年11月までに頻 尿や排尿困難等の排尿障害を主訴として本院泌尿 器科を受診した 45 才から95才までの男性で、触診 - 経直腸的超音波断層診断・腫㰾マーカー等の検 索により前立腺癌や前立腺肥大症の疑われた 263 例で、F N A と生検組織診または経尿道的前立腺 切除術が行われた。穿刺吸引は、前立腺の左右各 葉加 $3 \sim 4$ 籄所行い、吸引物之針・注射筒内容 は生食浮遊液として遠心沈澱後、沈查物をスリ合 わせ方により塗抹標本を作製した。95\%エタノー ル固定後、Papani colaou染色を行い、Kline らの判定基準に従って細胞診的判定を行った。

(結果) 263 症例中前立腺癌は48症例で、その臨 床病期による内訳はStage A 13例、Stage B 7 例、Stage C 7 例、Stage D 21例で、F NA 陽性または偽陽性と判定出来たすのはStage A 5 例(38.5\%)、Stage B 4 例 (57.1\%)、Stage C 4 例 (57.1\%)、Stage D 18例 (85.7\%)で前立腺癌 48 症例 全体で65\%の陽性率であった。病期の低い前立腺癌の 細胞殿的診断の陽性率の上昇が今後の課題と思われる。 
95. Membrane filter の尿細胞診への応用

慶應義塾大学病院中央臨床検査部病理

○深町茂( CT), 田中陽一(DDS),

田代征夫 (MD), 大宮恕子 ( CT ), 山崎優子 ( CT ), 松井栄美 ( CT), 津田隆洋 ( CT ), 佐藤文夫 (MT), 柴田一成( MT), 杉浦 仁 (MD), 入 久巳 (MD)

オートスメアが開発されて以来, 尿を中心とし た液状検体の検体処理にオートスメアを使用して いる施設は数多い。細胞診全検体の半数近くを占 める自然尿をはじめとした液状検体にはオートス メアを多用しているが, 細胞回収率は必ずし屯高 くなく，日常スクリーニング検査に扣いて数回の 検査後に陽性化する例にあ遭遇している。また従 来のミリポアフィルター法は細胞回収率は高いが 操作が煩雑なととや，鏡検の際，pore が気になる など実用的ではなかった。そこで今回新たに開発 された membrane filter (ニコン社製)を用いて， 細胞診液状検体特に自然尿のスクリーニング検査 において応用可能であるか従来のオートスメア法 と比較検討した結果を報告する。

【症例及び方法】当検査室に提出された自然尿検 体から無作為抽出した 40 症例を対象とした。今回 は細胞回収率, 操作性, 細胞保存状態等を中心に オートスメアによって作製した標本と対比し, 臨 床応用の可能性を検討した。

【結果及び考察】細胞回収率はオートスメアに比 べ高率であった。オートスメア作製標本では陰性 であったが, 本 membrane filter 法で Class III 上と診断された症例が 2 例あり, 診断的価值にお いても有用性が示唆された。現段階の操作性には 若千の改良が望まれるが, 上述のようなメリット からあ日常検査への応用は充分可能である。特に 細胞数極少の検体に対しての有用性は高いと思わ れた。
96. In situnybridizationを用いての尿 中polyoma virus 感染細胞の検出.

\section{山口大学医療技術短期大学部}

○上田順子（C T)，岩田隆子（M D)

山口大学医学部病理学第一講座

石原得博（MD），横田忠明（MD）

山下吉美 (MD) , 権藤俊一 (MD)

山下 勝 ( C T ), 村上喜信 ( C T )

ヒトポリオーマウイルスはヒトでの腫瘍形成の 報告は見られないが, 免疫不全患者の日和見感染 を起こすことが知られている. しかし, ウイルス を細胞学的に証明するのは容易ではない，我々は ヒトポリオーマウイルスであるICウイルス (JCV) 及びBKウイルス (BKV) のD N A プローブを用いて In situhybridization により尿中のウイルス感 染細胞を検出したので報告する.

材料は腎移植（18例），血液疾患（27例），一 般検查（27例）の尿計72例. JCV 及びBKV のD N A プローブはENZ0製キットを使用した。ポリLリ ジン処理のスライドグラスに尿沈查を塗抹し，95 \%エタノール固定を行った. パパニコロー (Pap) 蒤色にて核腫大が目立ち，核全体を占める均翼な 好塩基性の封入体を特徴とする細胞のみられた症 例（10例）についてInsitu hybridizationを行 った。その結果陽性は 4 例のみで, 腎移植患者が 3 例（2 例がJCV 及びBKV 共に陽性 1 例がBKV の み陽性），糖尿病患者 1 例（JCV 陽性）であった。 血液疾患患者には感染細胞は認められなかった。

陽性細胞と感染が疑われながら陰性であった細 胞とを比べてみると, 陽性細胞はクロマチン顆粒 が核膜に付着してみられたが, 陰性細胞はクロマ チン顆粒が核内に分散しており, カリオゾーム様 のものが認められ, 均質・好塩基性に欠けている ように思われた. しかし,Pap 形態像だけではポ リオーマウイルス感染細胞の同定は難しいと思わ れた。 
97. Polyoma virus感染尿中異型上皮の 10 例 札幌医大病院病理部, 北里大学衛生学部微生物学教 室, $^{2}$ 国立予研腸内ウイルス部 ${ }^{3}$

$\bigcirc$ 室谷光三 ${ }^{1}(\mathrm{MD})$, 成松英明 ${ }^{1}(\mathrm{MD})$, 若林淳一 ${ }^{1}(\mathrm{MD})$, 佐藤昌明 ${ }^{1}(\mathrm{MD})$, 矢吹泰行 ${ }^{1}(\mathrm{MD})$, 山本英彬 ${ }^{1}(\mathrm{MT})$ 岸 谊博 ${ }^{1}(\mathrm{CT})$, 佐々木雅博 ${ }^{1}(\mathrm{MT})$, 林 広子 ${ }^{1}(\mathrm{CT})$, 菅原清美 ${ }^{1}(\mathrm{MT})$ ，田口文章 ${ }^{2}(\mathrm{MD})$ ，

原 和矢 ${ }^{2}(\mathrm{MD})$, 加藤賢三 ${ }^{3}(\mathrm{MD})$

新生児マウスに癌や肉腫を造るPolyoma virus (PV)はPapova virus科に属し、1970 年に剖検PML 脳(JC virus) と腎移植患者尿(BK virus) に人体 $\mathrm{PV}$ 発見後、腎・骨髄移植、貧血、悪性リンパ腫、白血 病、糖疗病、妊娠、悪性腫瘍など、主に免疫抑制例 の尿中上皮の核内封入体中にBK virusが主に証明さ れ、最近は康中 JC virus もあるといら。本邦では、 13 件 121 人の症例報告あり、第 28 回日本臨床細胞学 会秋期大会(1989) に自験 7 例とともに総括発表。そ の後 3 例の経験を加え今回発表する。P V は腫瘍性 ウイルスであるが、人体腫瘍発生との関連は明確で ない。今後、P Vの種類の同定と分布につき検索を 要する。【症例】昭和 61 年以来悪性リンパ腫 $4, \mathrm{C}$ L L 1 , 腎腫瘤 1 , 尿道癌 1 , 肺癌 1 , ネフローゼ 症候群 1 , 天疮瘡 1 例で、抗癌剤投与が多い。ネフ ローゼではEndoxan 投与で出血性膀胱炎併発。【細 胞所見】尿中好中球と赤血球は多少とも出現。異型

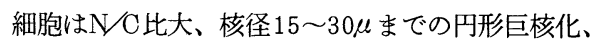
クロマチン不整粗化・辺在化 $\rightarrow$ 濃淡スリガラス状均 質化 (核内封入体)、核小体肥大あり癌などとの鑑 別要するが、胞体有尾状傾向とも比較的特徵的形態 示し、移行上皮由来と見る。一部電顕像で、主に核 内に $30 \sim 38 \mathrm{~nm}$ のウイルス粒子を分散〜結晶状に認 めた。な挍、抗SV40 VP 1 抗血清(国立予研より供 与。SV 40 の抗原性は PV と交叉)での酵素抗体法で 核内陽性別に、変性細胞に異型細胞増減と関連して、 細胞質内封入物様顆粒 (Giemsa染色で淡青染, $\mathrm{Pa}$ pani col aou 染色ではOg 好と Lg好 2 種）も認めた。
98. 細胞診によって術中迅速診断が可能で ちった甲状腺乳頭癌, follicular variantの 1 例

${ }^{1}$ 石川県立中央病院病理科, ${ }^{2}$ 同中央検査部,

3 金沢大学医学部付属病院病理部

$\bigcirc$ 車谷 宏 $(\mathrm{MD})^{1}$, 奥本正光 $(\mathrm{CT})^{2}$, 太田浩一 $(\mathrm{CT})^{2}$, 林 守源 (MD) ${ }^{1}$, 水上勇治 $(\mathrm{MD})^{3}$, 松原藤継 $(\mathrm{MD})^{3}$

Follicular variantの甲状腺乳頭癌は, 細胞形 態学上, 乳頭癌の特徵をよく表わす癌であり, 構 造的には, 濾胞性腫瘍の形態を示す。今回, 我々 は, 乙の腫瘍に対し, 細胞診と組織診を併用する ことによって術中迅速診断が可能であった 1 例を 経験したので報告する。

〔症例〕 39歳, 女性。平成 1 年 9 月中頃より咽頭 異物感があり, 近医受診, 右頸部に腫瘍を指摘さ れ，9月27日，当院耳鼻科受診，エコーにて右甲 状腺の乳頭癌を疑われた。10月27日，同院外科に て甲状腺右葉切除術施行。

〔肉眼所見〕右葉上極に，1×1 cmの結節をみる。 割面では，周辺部に石灰化がみられ，中央部は淡 褐色, 骾様。

〔凍結組織所見〕小型濾胞の密な増生をみた。濾 胞上皮細胞は軽く腫大し, 核密度も増加, 一部に 核内封入体様構造物をみた。また，わずかに核に しわを認めた。

〔細胞所見〕腫大した濾胞上皮が多数認められた。 これら細胞の核はクロマチンが微細で明るく，小 さな核小体を 1 ないし 2 個認める。核のしわが多 く認められた。また少数の核内封入体を認めた。 〔考察〕本例は, 永久標本で乳頭癌の follicular variantと確認されたが，術中迅速診断の際に細 胞診がきわめて診断に有用であった。凍結組織診 は, 組織構築をみるのに絶対的方法であるが, 微 細な細胞観察に耐えないことが多々ある。本腫瘍 のように詳細な細胞観察が診断の決めてとなる病 変に関しては, 術中迅速診断での凍結組織診と細 胞診の併用が必要であると考えられた。 
99. 対側癌性胸膜炎を契機として発見され た甲状腺癌の 1 例

高岡和夫 $(\mathrm{MD})^{1}$ ， 植村弘幸 $(\mathrm{CT})^{1}$

井上勝一 $(M D)^{2}$, 五十嵐毅 $(M D)^{1}$

花野正則 $(C T)^{1}$, 牟禮一秀 $(M D)^{1}$

川村光弘 $(\mathrm{MD})^{1}$ ，

${ }^{1}$ 日鋼記念病院, ${ }^{2}$ 北海道大学環境医学

左側癌性胸膜炎で発見され，胸水細胞診で甲状 腺癌が推定され，確診に至った右甲状腺癌の 1 例 を経験した。本症例では, 肺転移拉よび胸腔内甲 状腺を臨床上認めないにも拘らず, 対側の癌性胸 膜炎を併発した腫瘍発育上非常に稀な症例で，な お且つ細胞診の有用性が認められた症例であった ので報告する。

症例は66才，女性。主訴は息切れ，咳嗽。1988 年12月に左胸水貯留を指摘され, 胸水細胞診で乳 頭状腺癌と診断され, 甲状腺癌の存在が推定され た。精査の結果, 直径 $1.5 \mathrm{~cm}$ 大の右甲状腺癌が発 見された。全身検索を行ったが，他蔵器に癌は認 められず, 肺にも原発ないしは転移巣と考光られ る所見はなかった。また, ${ }^{131} I$ シチグラムでも縦 隔内の取り込文は認められなかった。1989年 3 月 に甲状腺全摘手術を施行した。病理診断は乳頭状 腺癌でリンパ節転移（\# 5 ）を認めた。8月に胸 水の再貯留を認め, 胸腔穿刺を施行したところ前 回と同様の乳頭状腺癌を認めた。この時の血中拉 よび胸水中のサイログロブリン值は, それぞれ 87. $8 \mathrm{ng} / \mathrm{ml}, 1549 \mathrm{ng} / \mathrm{ml}$ と著増していた。胸水中の 悪性細胞の所見は, 乳頭状重積性であり漏胞状構 造もみられた。細胞の大小不同は比較的乏しかっ た。細胞は比較的小型で $\mathrm{N} / \mathrm{C}$ 比は大きく, 核の 偏在, 核形の不整, 核縁の切れ込及, 細顆粒状の クロマチン, 1 数個の核小体がみられ，核内封 入体・砂粒体も認められた。以上の検査結果おょ び臨床経過上り右甲状腺原発の左転移性癌性胸膜 炎と診断した。
100. 胞体内に豊富な脂質様物質を認めた 甲状腺低分化癌の一症例

名古屋大学医学部臨床検查医学講座 名古屋大学医学部附属病院検査部病理 O大岩 昇 $(M D)$, 中島伸夫 $(M D)$, 長坂徹郎 $(M D)$ 白井孝夫 $(\mathrm{CT})$, 奈良佳治 $(\mathrm{MD})$, 越川卓 $(\mathrm{MD})$ 竹内 純 $(\mathrm{MD})$

甲状腺の癌で, 腫瘍細胞の胞体内に豊富に脂質 様物質を認める稀な症例を経験したので, その細 胞, 組織所見および電顕所見を供覧したい。

〔症例】 53 才, 女性。1981 年より頸部腫脹に気ず き, 近医にて経過観察をしていた。細胞診は陰性 であった。次第に頸部が腫脹し,1989 年 1 月 細胞 診を施行し, 陽性の診断をうけ, 名大病院にて手 術を施行した。

〔絸胞所見】腫瘍の術中择印細胞診で, 比較的豊 かな胞体を有する細胞がシート状にみられた。腫 瘍細胞の核は比較的大きさは揃っており, 核小体 が明瞭である。核の切れ込みがみられる。胞体は 泡末状で, ズダンIII儿染色される脂質様物質が認 められる。腫瘍細胞の核所見は, carcinoma の核 所見に類似する。同時に施行した術中組織診では 甲状腺の癌と診断した。

〔肉眼所見〕割面において腫瘍は境界明瞭で, 黄 色調を呈した。

〔腫瘍組織所見〕線維性被膜を有する境界明瞭な 腫瘍である。腫瘍細胞は索状に配列して増生し， 所々に小さい囊胞をまじえる像であった。いわゆ る, 低分化腺癌の像であった。細胞の胞体内に空 胞を認めてれはズダン吕にて, 脂質様に染色され た。

電顕所見とともに，文献的考察を加え報告する。 
101. 核内封入を認めた甲状腺良性疾患の 2 例

秋田中通病院 臨床病理科

○佐藤 昭 $(C T)$, 石井 明 $(C T)$, 今野稔子 (CT)

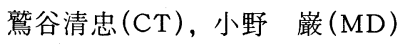

甲状腺穿刺吸引細胞診で、核内封入体の出現は 癌判定の大きな手掛かりとして重視されてきた。 最近、当院において、核内封入体を認めた瀘胞腺 腫と橋本病の 2 症例を経験したので報告する。

[症例 1] 31歳、男性。慢性腎不全のため、 外来で経過観察中、甲状腺右葉の腫瘤を指摘さ れ、穿刺吸引細胞診で瀘胞癌を疑った。諸検查の 結果、甲状腺機能低下症および甲状腺癌と診断さ れ、甲状腺业全摘術を施行。

（細胞所見）血性背景で泡沫細胞が多数みら れた。また、核増大した瀘胞上皮由来の細胞集塊 がみられ、細胞質はやや広く好酸性であるものの 核内封入体の出現がみられ瀘胞癌を強く疑った。

（組織所見） 結節性病変部は瀘胞腺腫で、周 辺の組織は、著明な異型性を示す小型瀘胞のびま 几性増殖から成っている。瀘胞腺腫に随判した Dyshormogenetic goiter に相当する像であった。

[症例 2] 51歳、女性。当院外来で癌検診 受診時に甲状腺腫瘤を指摘され、穿刺吸引細胞診 を施行。諸検查で、T 3、T 4、TSHいずれも正 常。サイログロブリン高值。シンチで左右両葉に 欠損部あり、甲状腺癌と診断され甲状腺全摘術を 施行。

（細胞所見） 背景はリンパ球を主体とした炎 症性であり、穿刺吸引により剥離細胞量が多く、 軽度な核の大小不同を示す瀘胞上皮が出現し、明 瞭な核内封入体が著明であり、瀘胞癌を疑った。

（組織所見）腺腫性過形成に橋本病が随判し た像であった。
102. 名古屋大学病院での穿刺吸引細胞診に 拈ける甲状腺炎の診断成績について

$*$ 名古屋大学医学部病態研、 $* *$ 同中検病理、 $* * *$ 同 第一病理、****同第二外科

$\bigcirc$ *越川卓 $(\mathrm{MD}) 、 * *$ 白井孝夫 $(\mathrm{CT})$ 、長濱大輔 ( $\mathrm{MT})$ 、吉田泰彦 (MT) 、中島伸夫 (MD) 、***浅井 淳平 $(M D) 、 * * * *$ 佐藤康幸 $(M D)$ 、舟橋啓臣 $(M D)$

名古屋大学付属病院中央検査部において検査さ れた甲状腺穿刺吸引細胞診の中で、最近2年間に甲 状腺炎と診断された38例について、臨床所見、臨 床診断、病理組織診断などとの関連を検討した。 症例：17才から76才までの男女38名 (平均年齢 : 48.9才、令／우：1／37）の患者に対し、1回か ら3回まで（1回：29名、2回：8名、3回：1名）の 穿刺吸引細胞診が行われた。

結果：1回目の診断結果は、分類不能の甲状腺炎 ：4例、亜急性甲状腺炎：1例、慢性甲状腺炎：33 例であった。分類不能の甲状腺炎4例は、再検査の 結果、1例は亜急性甲状腺炎、1例は慢性甲状腺炎、 さらに1例は、2回目て慢性甲状腺炎、3回目で乳頭 癌と診断された。従って、38名の最終的な診断結 果は、分類不能の甲状腺炎：1例、亜急性甲状腺炎 ：2例、慢性甲状腺炎：34例、乳頭癌：1例となっ た。これらの細胞診断と臨床診断あるいは病理組 織診断とが一致したものは、分類不能の甲状腺炎 : $0 / 1$ 、亜急性甲状腺炎 : $2 / 2$ 、慢性甲状腺炎 :

$27 / 34$ 、乳頭癌：1／1であった。細胞診で慢性甲 状腺炎と診断されたが臨床診断とは一致しなかっ た7例中4例については、病理組織検査の結果、2例 は乳頭癌、1例は悪性リンパ腫、1例はバセドウ氏 病と診断された。なお、細胞診で慢性甲状腺炎と 診断された34例中31例に対LMCHAが検査され、そ の内24例が陽性であった。

まとめ：細胞診で慢性甲状腺炎と診断される症 例の中には、乳頭癌や悪性リンパ腫が含まれるこ とが希でない。これらの症例の細胞所見を提示し、 診断上の注意点について検討する。 
103. 甲状腺滤胞型腫瘍の細胞学的検討

$$
\begin{aligned}
& \text { 大阪府立成人病センター 細胞診断科 }{ }^{1)}, \text { 内科 }{ }^{2)} \\
& \text { 病理診断科 }{ }^{3)}, \text { 外科 }{ }^{4)} \\
& \text { O止藤幸子 }(\mathrm{CT})^{1)} \text {, 南雲サチ子 }(\mathrm{CT})^{1)}, \text { 松田 実 } \\
& (\mathrm{MD})^{2)} \text { 和田 昭 }(\mathrm{MD})^{3)} \text {, 伊藤良治 }(\mathrm{MD})^{3)}, \\
& \text { 辻 直子 }(\mathrm{MD})^{3)}, \text { 小山博記 }(\mathrm{MD})^{4)}
\end{aligned}
$$

甲状腺濾胞型腫煌は, 通常, 組織学的に被膜浸 潤, 脈管侵襲, 転移巣の有無により悪性と診断さ れる。従って, 細胞学的には良性悪性の判定が困 難であるてとが多い。穿刺吸引細胞診の精度を向 上させるために, 組織標本と細胞診標本との対比を 行ない滤胞型腫痬の細胞所見について再検討した。 特に今回, 観祭された集団の細胞密度に着目して, 滤胞腺癌と濾胞腺腫を比較した。

【対象および方法】当センターにおいて, 術前に 穿刺吸引細胞診が施行され, 切除された甲状腺濾 胞腺癌 8 例, 滤胞腺腫 16 例のパパニコロウ染色標 本及び, 手術材料における HE染色標本を用いて比 較検討した。また, 滤胞型細胞集団の細胞密度を 測定する指標として, パパニコロウ染色標本上に観 察された集団の面積を測定し, 集団を構成する核 の数を計測した。

【結果】滤胞腺腫では sheet 状の集団が出現し易 い傾向にあり, 濾胞腺癌では, 大小多彩な集団が みられるが, とりわけ重積性を示す小 cluster 及 び孤立散在性の腫瘍細胞が出現し易い傾向にあっ た。さらに, 集団の細胞密度は滤胞腺腫に比べ高 い傾向がみられた。乙れらは, 組織学的に濾胞腺 腫では大型の濾胞が多くみられるのに対して, 濾 胞腺癌では小型の濾胞が多くみられるととに対応 していると思われた。又，個々の細胞については, 濾胞 腺癌ではクロマチン増量か溡に目立った所見であった。 【考察】甲状腺滤胞型腫演の判定には, 小 cluster あるいは孤立散在性の腫煌細胞の出現頻度と集団 における細胞密度の増大の有無が重要であり, 細 胞異型の観点からはクロマチン増量の有無が大切 であるととが示晙された。

\section{4. 甲状腺濾胞状腫演の細胞学的検討}

帝京大学医学部附属病院中検病理 ${ }^{1}$, 同第 2 病理 ${ }^{2}$, 同第 1 外科 ${ }^{3}$

O照井仁美 $(C T)^{1}$, 島田智子 $(C T)^{1}$,

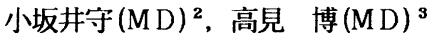

甲状腺濾胞状腫瘍 (湽胞癌と滤胞腺腫の総称)の 細胞学的診断はしばしば困難であり, 組織学的診 断と一致しないことも少なからず見られる。濾胞 癌及び濾胞腺腫の細胞像は, 比較的小型の集塊を 形成する腫瘍紼胞がその中に小濾胞構造をもつと いう共通した特徽がある。濾胞状腫場については 細胞診での推定診断基準が不明確のままである。 今回我々は, 昭和 62 年から平成 1 年の間で, 術前 穿刺吸引細胞診が施行され，組織学的に診断の 確定している濾胞癌 10 例. 溘胞腺腫10例を対照に パパニコロウ染色及びGiemsa染色標本をもとに， 細胞像の特徴について比較検討を行ったので報告 する。

腫瘍細胞の1)細胞採取量, 2)集団の形態,3)細 胞の過密・重積性，4）核径，核形不整，5)核の大 小不同性，6）クロマチンの分布，7)核小体につい て細胞像を比較した。

滤胞癌の細胞像は濾胞腺腫に比べ細胞採取量及 び小集塊の数が多く, 又小濾胞構造は, はっきり しない傾向にあった。細胞集団において配列の乱 れ、大小不同があった。核は一部重積するところ もあり, クロマチンの増量及び核径も増大傾向に あった。

濾胞癌と濾胞腺腫は, 時に, 細胞所見において 大きな差が見い出せないことが多い。今回の検討 においても，濾胞癌を港胞腺腫とした症例が 1 例, その反対が 1 例あった。濾胞状腫場の細胞診にお いては，組織診断基隼に細胞異型が良・悪性の判 定には関与していないことを充分に認識した上で, 良・悪性判別の推定診断基準を考える必要がある と思われた。 
105. 甲状腺良悪性病変におけるレクチン 結合反応

杏林大学保健学部細胞診断学教室

○嶋村 順（MT） 椎名 義雄（CT）

沢田 好明 (MD)

杏林大学医学部第二外科学教室

$$
\begin{aligned}
& \text { 福島 久喜 (MD) 関原 正 (ID) } \\
& \text { 花岡 建夫 (MD) 鍋谷 欣市 (ID) } \\
& \text { 杏林大学医学部第二解剖学教室 } \\
& \text { 平野 寛 (MD) }
\end{aligned}
$$

甲状腺における細胞診は、乳腺・子宮内膜等の ホルモン依存性臟器と同様に異型の之しい癌細胞 の出現によって診断に苦虑する事が少なくない。 そこで今回我々は、細胞膜表面に存在する糖鎖と 特異的に結合するレクチンを用いて細胞の悪性化 化に伴う糖鎖構造の変化を観察しその細胞診断学 的価値について検討した。

（材料・方法）検索材料は、手術摘出後の捺印標 本および捺印部分の組織切片である。そ扎らの組 織学的診断の内訳は良性例、硬化性腺腫5 例、濾 胞腺腫10例、癌例は乳頭癌7 例、濾胞癌5 例、䯣 様癌3 例である。捺印標本はブアン固定後従来の 処理を行ない、組織はホルマリン固定後通常のパ ラフィン切片を作成しそれぞれにレクチン染色を 行なった。使用したレクチンはP N A ( Peanut agguluitinin・Vector社製) レクチンで0.1\%BSA -PBSで $25 \mu \mathrm{g} / \mathrm{m} 1$ に調整したものを用いた。検出は A B C 法 (Avidin Biotin Complex) で行なった。 （結果）良性例の組織レベルでは滤胞上皮の細胞 質に微慢性弱陽性、一部分泌側に陽性、塗抹細胞 では均一パターンのHwp 型と細顆粒状型のFg型が 主体であった。癌例の組織では微慢性弱陽性の中 に強陽性を示す細胞が見られた。症例によっては 陰性細胞が増加していた。淕抹細胞ではHwp 型、 $\mathrm{Fg}$ 型に加えて一部に粗顆粒状型のCg型抗よび均一 型強陽性のHsp 型が出現した。
106. 甲状腺未分化癌の細胞内骨格蛋白とサ イログロブリンの局在について

八木クリニック

○八木幸夫 $(\mathrm{MD})$, 八木俊一 $(\mathrm{MD})$, 潮田勇治 $(\mathrm{MT})$ 鹿児島市医師会病院

下津高志 (CT)

甲状腺末分化癌は臨床的に著しく予後不良なこ そが知られているが，その細胞生物学的特性なぞ についてはよく知られていない。

今回, 細胞診レベルで 3 種類の細胞内骨格蛋白 とサイログロブリン（T）の局在について検索を 行ない，その特性について検討を行った。

[方法]甲状腺未分化癌の術中スタンプ標本を対 象とした。細胞内骨格蛋白のうちケラチン $(\mathrm{K})$ は人足底部皮膚より，アクチン（A）とミオシン （M）はニワトリの砂囊よりそれぞれ蛋白抽出を 行ない，ウサギに免疫して抗体作製を行なった。 兔度染色は P A P 法にて検索した。

〔結果・考察〕未分化癌細胞はいづれも Tに染ま る細胞はなく，AやMおよびKなどの細胞内骨格 蛋白を豊富に有していた。すでにわれわれは組織 レベルでの甲状腺の各種癌について同様な検索を 行ない，すでに報告しているが $\mathrm{T}$ 消失化と骨格 蛋白の増量が予後不良な因子と相関している。 
107. 胸, 腹水中の反応性中皮細胞と癌細胞 の腫瘍マーカー染色

埼玉県立がんセンター臨床病理部 ${ }^{1}$, 同検查部 ${ }^{21}$ ○松井 武寿 (CT) ${ }^{11}$, 田久保海誉 (MD) ${ }^{11}$ 譜久山當晃 $(C T)^{11}$, 高山昇二郎 $(M D)^{11}$ 石井 勝 $(\mathrm{MD})^{21}$

前回我々は腫湯細胞と反応性中皮細胞の鑑別を 目的として、睡瘍マーカー(CEAおよびBFP)を用い た免疫染色を行い、中皮細胞は異型度に関係なく CEA に対して陰性であり、腫愓細胞と反応性中皮 細胞の鑑別にCEAは極めて有用であることを報告 した。今回我々は前回同様に腫場マーカーを用い て、腫瘍細胞と反応性中皮細胞との鑑別を酵素抗 体法を行い検討したので報告する。

〔材料および方法〕良性疾患 3 例を含む45例から の胸, 腹水を用い、間接法で染色した。用いた腫 瘍マーカーは、 secretory component(SC)、CEA、 CA19-9、CA-50、扁平上皮癌関連抗原 $(\mathrm{SCC}) 、 お よ$ びST-439の6種頑である。

〔結果および考察〕反応性中皮細胞が全く陰性を 示した腫場マーカーは、SC、CEA、CA19-9および CA-50であり、SCCに対しては弱陽性を示すものが あった。またST-439では弱陽性を示す症例と明ら かな陽性を示寸肝硬変症例があっだ。腫愓細胞と 反応性中皮細胞の鑑別に今回用いた腫瘍マーカー では、SCCは反応性中皮細胞に弱陽性となる症例 があったが、腫瘍細胞との鑑別はできると思われ た。しかし陽性症例数が少ないため単独で用いる ことはできないと思われた。ST-439は腫瘍細胞の 陽性症例が比較的多いが、反応性中皮細胞も陽性 を示すことから、他の腫瘍マーカーと併用するこ とが望ましいと考兄られた。しかし、SC、CEA、 CA19-9およびCA50は腫瘍細胞に陽性を示す場合が 多く、反応性中皮細胞との鑑別には有用と思われ た。中でもSCとCEAは腫瘍細胞陽性症例数が多く、 また反応性中皮細胞には陰性であることから腫瘍 細胞と反応性中皮細胞の鑑別に極めて有用である と思われた。
108. 覀性中皮腫細胞の培養系に打ける 形態学的変化阮

滋賀医科大学病理学第二講座

O片岡秀夫（C T), 天野殖（MD）,

行岡直哉 (M D)

悪性中皮腫の生物学的特性を探るため、腹膜及 び胸膜よりの悪性中皮腫細胞の細胞培養を行って いる過程で、形態学的に興味ある所見を認めたの で報告する。

材料は腹膜 $($ 症例 -1 ), 及び胸膜 $($ 症例 -2$)$ より発生した悪性中皮腫（上皮型）例で、2症例 とも細胞診断にて悪性中皮腫を疑われ、アルシア ンブルー $(\mathrm{A} \mathrm{L}-\mathrm{B})$ 染色、免疫組織化学、及び 透過型（TEM）・走查型（SEM）電子顕微鏡 により悪性中皮腫と診断された。無菌的に採取さ れた腫煌細胞は F-10 培地 ( $15 \%$ 馬血清 +2 . $5 \%$ 牛胎児血清）及びR P M I - 1640 （20 $\%$ 牛胎児血清）の二種類の培地を用いて細胞培養 を行った。第 $2-5$ 継代の細胞にて位相差顕微鏡 $\mathrm{P}$ a p, A L - B 染色、免疫組織化学、拈よ゙ $\mathrm{T}$ EM・S E M 亿て観察を行い、培地の違いによる 細胞の形態学的変化を中心に検索した。

症例一 1 では、F-10 培地を用いた系では広 い細胞質を持ち上皮性性格を有する細胞のシート 状增殖を示し、R P M I 培地を用いた系では非常 に細長い線維状細胞の束状增殖を示した。二種類 の培地により細胞形態に差異が認められた。一方 症例一 2 では、いずれの培地でも広い細胞質を持 ち上皮性性格を呈する細胞がシート状に増殖して いた。二種類の培地の違いによる細胞形態の差異 は認められなかった。

以上、二種類の悪性中皮腫を異なった培地にて 培養したとてろ、培地の違いにより形態的に差異 を生じたものと生じなかったものがみられた。悪 性中皮腫細胞には培地という微小環境に対する多 様性があると考えられ、との多様性の原因につい ては現在検索中である。 
109. 心震液細胞診にて心膜悪性中皮腫を 疑った一症例

$J R$ 東京総合病院病理 ${ }^{1}$ 循環器内科 ${ }^{21}$ 胸部外科 ${ }^{31}$ $\bigcirc$ 宇佐美一虎 $(\mathrm{CT})^{11}$ 村上正直 (MT $)^{11}$ 深井光一郎 (MT) ${ }^{11}$ 今野久美子 (MT $)^{11}$ 三宅紀子(MD) ${ }^{11}$ 早川欽哉

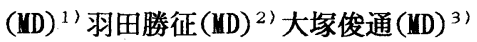

近年, 悪性中皮腫の報告は増加傾向にあるが, 心膜原発の悪性中皮腫は比較的稀である。一般に 細胞診での悪性中皮腫の診断は容易ではなく, 腺 癌との鑑別が困難な場合が少なくない。今回我々 は, 心夕ンポナーゼを来し, 心震穿刺細胞診にて 腺癌または悪性中皮腫と考えられた症例を経験し たので報告する。

〔症例〕71歳女性。37歳結核, 40歳左乳癌切除。 昭和63年 6 月, 浮腫等心不全状態にて来院。胸部 X線，画像診断等にて癌性心膜炎を疑い，心囊液 細胞診を施行, 腺癌または悪性中皮腫と診断。そ の後も心タンポナーゼ改善のため心震液を持続吸 引したところ，腫瘍細胞は陰性化したが心不全状 態は改善せず同年11月, 肝不全を併発し死亡。

〔細胞診所見〕まりも状, 乳頭状集塊および単一 型異型細胞を多数認めた。異型細胞は大型で大小 不同性。核は単〜多核で類円形のものが多く．ク ロマチン増量, 大型核小体を認めた。Alcianblue陽性, PAS陽性, diastase および hyaluronidase で消化された。

〔剖検所見〕心は650g。び慢性，充実性，腫慯性 に心外膜が肥厚, 心全体を被覆。一部心筋および 縱隔に浸潤。組織学的には中〜小型の腫瘍細胞が 充実性, 一部乳頭状に増殖, 一部線維性間質の增 生を伴っていた。Alcian-blue陽性, PAS 陽性, diastaseおよび hyaluronidaseで消化された。

〔電顕像〕腫場細胞は微䄉毛に富み, デスモゾー 么様結合を認めた。

〔まとめ〕悪性中皮腫と腺癌の鑑別は困難な場合 が多くみられ, 粘液染色, 免疫組織化学, 電顕的 検索の併用が望まれる。
110. 卵巣癌と術前診断された悪性中皮畽の 一例

$$
\begin{aligned}
& \text { 北里大学病院産婦人科 同細胞診 }{ }^{1)} \text { 同病理 }{ }^{2)} \\
& \text { 立岡和弘 }(\mathrm{MD}) \text {, 下田隆夫 }(\mathrm{MD}) \text {, 岩谷弘明 }(\mathrm{MD}) \text {, } \\
& \text { 篠原洋介(MD), 上坊敏子 (MD), 蔵本博行(MD), } \\
& \text { 大野英治 }{ }^{1}(\mathrm{CT}) \text {, 岩㴊啓一2) }
\end{aligned}
$$

婦人科領域で悪性中皮腫を経験することは非常 に稀である。また生前に診断を確定することは困 難とされている。今回我々は卵巣癌の疑いで手術 を施行し，摘出標本から悪性中皮腫と診断しえた ものの，急激な経過で死亡した一例を経験したの で報告する。【症例】71歳主婦。【主訴】右下肢 腫張。【月経歴】53歳閉経。【職業歴】アスベス 卜との接触歴なし。【経過】平成元年 6 月より右 下肢腫張あり, 当院外科受診, 精查後, 左卵巣腫 瘍が疑われ，婦人科紹介受診となる。10月 17 日卵 巣癌の診断で初回手術 ( 単純子宮全摘術, 両側付 属器切除術, 大網切除術）施行。開腹時, 大網が 内性器全体を被っていた。術後イレウスを併発し， 11月14日, 第 2 回目手術（腸㜢造設術）を施行し たが，12月13日消化管出血より，DICを併発し永 眠した。【腹腔洗浄液細胞像】好中球や中皮細胞 に混在して大型の核及び細胞質を有する腫瑒細胞 を散在性に認めた。単核のものも多核のものもあ るが，いずれも核小体を 1 数個認めクロ゙マチ ンは粗顆粒状であった。【畽瘍捺印細胞像】腫湯 細胞は散在性, 一部集合性に存在し, 細胞質はラ イトグリーンに濃染し, 核クロマチンは粗〜粗大 顆粒状，核は類円形で大小不同を認めた。【摘出 病理組織像】(初回手術) 線維状に配列し核の多 形性に富む腫瘍細胞がびまん性に認められた。

（第 2 回目手術）立方状腫瘍細胞がびまん性に浸 潤する像を認め, 一部は索状及び管状構造を呈し ていた。特殊染色の結果, 文献的考察も合わせ報 告する。 
111. 体沿液細胞診におけるAD 117m 検出の 意義について

\author{
杏林大学保健学部細胞診断学教室 \\ ○飯島淳子（CT）椎名義雄（CT）沢田好明（ID） \\ 資生堂安達研究所

$$
\text { 土田一雄安達健二 (ND) }
$$ \\ 大阪医科大学産婦人科教室 \\ 岡本吉明（ID）山田隆司（MD）植田政嗣（ID） \\ 植木，実（ID）
}

体腔液細胞診における腫演マ一カーの検出の意 義は、転移性悪性腫瘍の多くが腺癌であることか ら、上皮性の腫煬マーカーであり、かつ中皮細胞 に反応しないことが重要であると思われる。我々 は大阪医科大学産婦人科教室で樹立した、子宮頸 部腺癌細胞 (ONC-4) に対するモノクローナル抗 体を作成しているが、今回は体腔液細胞診に有効 と思われるAD $117 \mathrm{~m}$ と他の腫瘍マーカーと比較検 討した。

【検索材料および方法】

検索対象は転移性腺癌 50 例、良性体腔液 20 例の 計70例である。対象とした腫瘍マーカーはCA $125 、$ CA 15-3、CEA 、EMA であり、検出方法は酵素抗 体間接法によった。

\section{【結果】}

AD 117m は中皮細胞に反応を示さず、また癌細 胞における陽性率は約 $90 \%$ でEMA よりやや低いが、 CEA より高値であった。

以上の成績より、AD $117 \mathrm{~m}$ は体腔液細胞診に応 用価値を認めた。今回はさらに、組織レベルでの 検討も加え報告したい。
112. 体腔夜中の疑陽性細胞における $\mathrm{Ag}$ NORs の診断的意義

北海道大学医学部第一内科 ${ }^{11}$

同附属病院病理部 ${ }^{21}$

$\bigcirc$ 須甲憲明 $(M D)^{1)}$, 阿部庄作 $(M D)^{11}$, 渡部直巳 $(M D)^{11}$, 国兼浩嗣 $(M D)^{11}$, 小倉滋明 $(\mathrm{MD})^{1)}$, 中島功雄 $(\mathrm{MD})^{11}$, 磯部 宏 $(M D)^{1)}$, 川上義和 $(M D)^{11}$, 遠藤隆志 $(\mathrm{CT})^{2)}$

\section{【目的】}

Nucleolar organizer regions (NORs)は, 核小体 中の rRNA 遺伝子の DNA loopsであり，その数は 細胞の活動性を反映している。最近では, 癌細胞 でNORsの数が増加しているとの報告もあり, 注 目されている。そこで今回，体腔液中における疑 陽性細胞の NORs を測定し, その体腔液が癌性か 否かの診断に利用できないか検討した。

\section{【方法】}

対象は癌性胸・腹膜炎 21 例, 非癌性胸 - 腹膜炎 14 例。パパニュロー染色にて細胞診上疑陽性と判 定された体腔液中の細胞を脱染色し, Plotonらの 方法 Argyrophilic methodにより NORsを特異的に 染色し( Ag-NORs), 細胞形態学上疑陽性と判定 された細胞についてのみ，NORsの平均個数を測 定した。

\section{【結果】}

NORs の平均個数は, 癌性胸・腹膜炎では 2.2 か ら5.0に分布し，Mean士SDは3.5土0.6であった。 一方非癌性胸・腹膜炎では 1.3 から 3.8 亿分布し, Mean士SDは2.1士0.6であり，両者の間には有意 差が認められた。

\section{【結論】}

非癌性胸・腹膜炎に比べ, 癌性胸・腹膜炎でみ られる疑陽性細胞の NORs の平均個数は有意に大 きく, Ag-NORs は体腔液が癌性か否かを判定する 際に診断的意義が高いものと考えられた。 
113. 温熱化学療法による腹㓐内遊離癌緗胞 の変化

\section{鳥取大学第一外科}

O広岡保明(MD)、西江 浩(MD)、塩田掑成(MD)、 松井孝夫(MD)、村田陽子(MD)、木村章彦(MD)、 貝原信明(MD)

〈はじめに>腹膜播種巣に対する腹腔内温熱化学 療法において、計删可能病変 (腹水詝留、体表面 腫瘤形成）のない例ではその治療効果を判定する ことは困難である。今回我々は温熱療法による腹 腔内遊離癌緗胞の変化を钼察し、その治療効果判 定における細胞診の有用性を検討した。 <対象と方法>腹膜播種巣 8 例（胃癌 7 例、大腸 癌 1 例) に対し抗癌剂 (CDDP腹腔内投与或いは MMC静眽内投与) を併用した局所温熱療法(RF)を 1〜 7回施行し（治療前に腹水胡留を認めない例 では生食を腹腔内に注入）、その前後で腹水中或 いは腹胫内灌流液中の緗胞所見を検討した。すな わち、(1)背景に出現する各種緗胞の出現頻度、(2) 癌細胞の出現数、(3)癌細胞の出現形態、(4)癌細胞 の変性所見、につき検討した。

〈結果>治療によって局所のコントロールが可能 であった例（腹水減少や䀦床症状好転）では、そ うでなかった例に比べて癌細胞はほとんど単離し た状態で出現し、その数も著明に減少していた。 また、多核巨細胞化、核の膨化、クロマチンの粗 造化、胞体内空胞等の変性所見も顕著であった。 治療によって腹水の減少した例では、腹水中のリ ンパ球出現頻度が增加する傾向にあった。しかし ながら、治療によって腹水が一旦減少し、その後 再び眝留した例では好中球が增加し、変性の少な い癌細胞が集塊をつくって出現していた。 くまとめ>腹膜播種巣に対する治潦効果判定は。 細胞診を用いれば腹水非肪留例においても可能て あった。細胞学的には、癌細胞の変化のみならず 背景緇胞の所見も効果判定上重要と思われた。
114. 担癌患者体望液中の腫瘍細胞とサプレ ッサーTとの関係

藤田学園保健衛生大学医学部病態細胞

○金子千之 (CT), 新里昌功, 社本幹博 $(\mathrm{MD})$

田嶋基男 (MD)

愛知県がんセンター病院

栗田宗次 $(M D)$, 蒲 貞行 (CT)

我々は昨年本学会で胸・腹水の眝留をみた進行 癌患者体挖液中でサプレッサーTの比率が高い事 を報告した。今回担癌患者体挖液中に認められた 腫瘍細胞とサプレッサーT 係があるのか検索したので薬剤投与例屯併せて報 告する。

材料及び方法: 胃癌, 乳癌等の担癌患者 82 例, 肝硬变症等非癌患者 20 例，及び薬剤投与例 13 例を

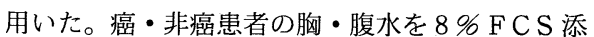
加P BS で洗浄後細胞遠心標本を作製し，ギムザ 染色及びモノクローナル抗体による免疫染色を行 い，各種細胞を算定した。モノクローナル抗体は， Leu 4, B 1, Leu 3a，OKT 8 を用いた。

結果及び考察：担癌患者82例中54例 $(65.8 \%)$ はサプレッサー Tの比率が高く, 残りの 28 例 （34.1\%）はへルパーTの比率が高かった。また 対照として用いた非癌患者20例中，18例 (90.0\%) はヘルパーTの比率が高かった。な捄薬剤を投与 した症例で，13例中 7 例は，投与前ではサプレッ サーTの比率が高かったが，投与後ではへルパー Tの比率が高かった。即ちサプレッサーTとへル パーTの比率が逆転している事が判明した。

以上の結果から, 担癌患者体腔液中に㧈いてサ プレッサーTの比率が高い事は，免疫能の低下を 示しているのか, あるいは腫場細胞に存在する何 らかのファクターがサプレッサーTを誘導してい るあのと考えられる。また薬剤を投与する事によ り,ヘルパーTの比率が増加する事は，抒そらく 患者の免疫能の改善を反映しているあのと思われ る。 
115. エンドブラシ (Endobrush) による 内膜細胞診の試み

東北大学産婦人科

○鹿野和男(MD), 牧野浩充(MD), 伊藤 潔(MD),

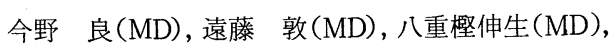
千葉英俊 $(\mathrm{MD})$, 堀口正之 (MD), 佐藤信二 (MD), 中名生裕子 (CT), 矢嶋 聰 (MD)

高齢化社会の進行により, 子宮内膜細胞診は 今後ますます施行される事が予想される。この 度我々は, 内膜細胞診採取器具である Endobrush を使用する機会を得たので, Endocyte との比較 を含め報告する。

対象は当科外来受診または入院患者で, 主訴 より内膜細胞診が必要と思われた者に施行した。 Endobrush 群 (A群) は1989 年 5 月より 7 月 までの60例で, 対照としたEndocyte 群 (B群) は 1987 年 1 月より 3 月までの 60 例とした。 対象の年齢は A 群で $45.3 \pm 9.31$ 歳, B 群で $46.7 \pm 9.71$ 歳で両群間で差はみられなかった。 また両群共に挿入不能例は認めなかった。

細胞診の結果では A 群で偽陽性 1 例, 陽性 1 例, 判定不能 1 例を, B 群で偽陽性を 2 例認め た。判定不能例は内膜細胞を認めない症例であ つた。

$\mathrm{B}$ 群の細胞像は $\mathrm{A}$ 群に比して集塊状に採取さ れ, 採取される細胞の量屯多い傾向がみられた。 一方, 扁平上皮の混入は $\mathrm{A}$ 群で少ない傾向が認 められた。

また Endobrushは，挿入時やスライドグラス への塗布の際にやや腰が弱い印象があるが軽度 であり, 内膜細胞採取に团難を感じるととはな かった。

Endobrush は採取される細胞数等より, 内膜 細胞診には有用であると思われた。
116. 新しい内膜細胞探取器具

- Endosearch - そついて

（第四報，診断精度）

大阪がん予防検診センター 検診第二部 ${ }^{1)}$, 検查部 ${ }^{2)}$

O布引 治 $(\mathrm{CT})^{1)}$, 田路英作 $(\mathrm{CT})^{2}$, 国藤憲子 $(\mathrm{CT})^{2}$, 山本倫子 $(\mathrm{CT})^{2}$, 潘 静 $(\mathrm{MD})^{1}$, 甲斐一郎 $(\mathrm{MD})^{2)}$, 野田 定 $(\mathrm{MD})^{1) 2)}$

北野病院 産婦人科 ${ }^{3)}$, 病理 ${ }^{4)}$

井上欣也 $(M D)^{3)}$, 向野 晶 $(C T)^{4)}$, 平野耕一 $(C T)^{4)}$

われわれは新しい内膜細胞探取器具 “Endosearch” を開発し，その有用性につきすでに本学会で報告 してきた。今四注同様な内膜擦過器具であるEndocyte とその診断精度について比較検討し若干の知見を 得たので報告する。検討対象は 1989 年 1 月より同 年 12 月までの間大阪がん予防検診センター, 大阪 府医師会臨床検查センター及び北野病院産婦人科 で二次，または三次 (精密) 検診の目的で受診し た患者のうち, 組織診が得られた Endocyte 使用 58 例, Endosearch 使用 60 例, 計 118 例である。各 々の検出率は[( ) 検討症例数]

I. Adenocarcinoma: Endocyte $80.0 \%$ (8/10), Endosearch $100.0 \%(10 / 10)$ 。

II. Hyperplasia: Endocyte $62.1 \%(18 / 29)$, Endosearch $88.8 \%(24 / 27)$ 。そのうち訳は

(1) Cystic glandular hyperplasia: Endocyte $63.2 \%(12 / 19)$, Endosearch $84.2 \%(16 / 19)$ 。

(2) Adenomatous hyperplasia: Endocyte 100.0 $\%(4 / 4)$, Endosearch $100.0 \%(6 / 6)$ 。

(3) Atypical hyperplasia: Endocyte $33.3 \%(2 /$ $6)$, Endosearch $100.0 \%(2 / 2)$ 。

III. Benign: Endocyte $63.2 \%(12 / 19)$, 不一致の 7 例はCystic glandular hyperplasiaとした。 Endosearch $65.2 \%(15 / 23)$, 不一致の 8 例は Cystic glandular hyperplasia とした。

以上の結果より, hyperplasia 以上の所見につ いては Endosearch の方が Endocyteより検出率が 高かった。 
117. 内膜スミアでのクラス分類特に II R ついて

関西医科大学産科学婦人科学教室

$\bigcirc$ 椹木 晋 (MD), 寺西二郎 (MD), 北田光美 (MD) 西川正博 (MD), 加藤 明 (MD), 中島徳郎 (MD), 椹木 勇 (MD)

子宮内膜癌の増加に伴ない，日産婦子宮癌登録 委員会に打いても, ハイリスクグループの設定と, その集団検診としての細胞診による一次スクリー ニングが老健法を主として実施され，その効果む 見られるようになってきた。

我々の教室でも, 臨床上明らかに子宮体部括よ び付属器に病変が疑われる場合, 積極的に子宮内 膜細胞診を施行し，昭和 61 年 1 月より平成元年 11 月末までの総数はのべ5656例であった。またその 間での治療体癌総数は36例であった。実施当初よ りこれ等の症例から単に陰性, 疑陽性, 陽性の 3 段階法だけではその内容に含まれる疾患として不 満足な乙とから, 我々は 5 クラス分類法を仮に採 用し，さらに細胞診所見として異型性を軽度有す るが, 悪性を比較的強く否定できる，しかし再検 を要する場合を II R として分類してきた。それ等 から 2,3 の知見を得たので，反省を踏まえて報告 する。

約 4 年間での II R とされたのは 402 例 $7.1 \%$ で, その原疾患は，子宮筋腫，ホルモン剂投与を含む 機能性出血, 子宮内膜増殖症, 内膜萎縮, 流産拉 よび子宮内操作後, 子宮脱, 他臟器からの転移, 卵巣のう腫, 結核性内膜炎の他子宮内膜癌の誤陰 性 2 例が含まれていた。さらに疑陽性とされるの う胞性腺増殖症はいずれもクラス II とされ， II R の増殖症は腺腫性であったことから，その診断の 困難さが指摘された。また性周期, 年齢, 子宮内 操作等の臨床からの情報の重要なととも再認識さ れ，それ等の少ないスクリーニングでの集団検診 では一層の注意が必要と考えられた。
118. 子宮内膜細胞診偽陽性例の再検討 一特に細胞集塊の構造に着目してー

\author{
東京都がん検診センター婦人科 ${ }^{1)}$, 検査科 ${ }^{2)}$ \\ ○藤吉啓造 $(\mathrm{MD})^{1)}$, 石井保吉 $(\mathrm{CT})^{2)}$, \\ 鶴岡三知男 $(M D)^{1)}$, 柳沢弥太郎 $(M D)^{1)}$, \\ 藤井雅彦 $(\mathrm{MD})^{2)}$, 杉下 匡 $(\mathrm{MD})^{2)}$, \\ 石田禮載 $(M D)^{1)}$, 天神美夫 (MD ${ }^{1)}$
}

子宮内膜細胞診の判定において, 細胞異型等の 細胞所見とともに, 組織構築を反映すると考えら れる細胞集塊の構造を観察するととが高分化型腺 癌の診断に重要であると思われる。をた，最近の 検討により，細胞集塊の中の間質様細胞の出現形態 の観察が, 子宮内膜増殖症と高分化型腺癌の鑑別 に有用であると思われた。

そこでこの細胞集塊の構造や間質様細胞の出現形 態を retrospective飞観察し, その有用性につい て検討を行った。

対象：当センター婦人科集団検診受診し子宮内 膜細胞診で class II b 以上と判定され, 組織検査 施行し異常なしと診断された 26 例。

方法：增淵式吸引法で採取された材料を生食で 洗浄し, 遠沈塗洙された細胞診標本を再検鏡し, 細胞集塊の絨毛様分岐や孚頭状分岐の有無, 腺腔 の有無, 腺腔内乳頭状増殖の有無, 間質様細胞構築 などについて検討を行い再診断を試みたのでこて に報告する。 
119. コンピューターによる「細胞配置」の 計測と子宮体癌の診断

東北大学病院病理部 ${ }^{2}$ 、国立仙台病院検査科 ${ }^{2}$ 、 同 産婦人科 ${ }^{3}$ 、宮城県対がん協会 4 $\mathrm{O}$ 手塚 文明 (MD $)^{1}$ 、並木 恒夫 (MD) ${ }^{2}$ 、 森塚威次郎 $(M D)^{3}$ 、東岩井 久 $(M D)^{4}$

子宮の早期体癌は「内膜に限局する癌」と定義 するのが適当であると考えられるが、この際境界 病変とくに内膜增殖症との鑑別が困難で従来から 診断基準となるべき所見の模索がいろいろと試み られている。私どもは、癌において「細胞配列」 の乱れが現れることに着目し、これを定量化する 理論とコンピューターにより自動計測するプログ ラムを開発した。そして子宮内膜増殖性病変の細 胞診に応用し、本方法の有用性を検討した。

(1) 基礎理論：標本表面に分布する細胞核の配列 の規則性は $\overline{\mathbf{r}} \cdot \sqrt{\mathrm{n}_{\mathrm{o}}}$ で表され、この定量值を DP indexと呼ぶ。ここで $\mathbf{n}$ 。は核の密度、 $\overline{\mathbf{r}}$ は任意の最近核間距離の平均である。 DP index は無作為な配列をとれば 0.5 、等間隔の規則的 配列に近付くにつれ 0.5 より大きくなり、正六 角形格子の交点の配列をとれば 0.877 、正方格子 の交点の两列で 1 となる。(2) 紼朐計湘：コンピ ユーターによる自動計測のため、ライズ社と共同 で、「細胞診画像計測プログラム」を作製した。 顕微鏡を介してモニターテレビに取り込まれた細 胞画像をデイジタイザーによりプロットし自動的 に最近核間距離の計測、ヒストグラムの抽出、DP index の計算を行った。

子宮内膜から採取された細胞集塊について DP index の平均值は、正常で 0.85 、内膜增殖症て 0.76 、分化型腺癌で 0.66 となり、三群間で明 らかな有意差が認められた。( $\mathrm{P}<0.001)$ 。

子宮内膜増殖性病変の定量的な診断では、核サ イズなど複数のパラメーターを組合わせ用いるべ きであるとされるが、その一つに「細胞配列」を 加えることは精度向上を図る上で有用である。
120. 集団検診において内膜細胞診より検出 された子宮体部腺癌の細胞学的検索とその有用性

千葉県対がん協会,

O梅原有子 (CI), 早田篤子(CT), 角 敏子 (CI)

石川 明(CT)

千葉大学医学部産婦人科

深沢一雄 (MD), 岩崎秀昭(MD), 武田敏(MD),

高見沢裕吉 (MD)

老人保健法に子宮体癌検診が追加され当協会で も積極的に施行してきたが，集団検診という立場 より昭和63年度と平成元度の 2年間にわたる正確 な内膜検診率, 精検率そして体癌の診断率を含め 子宮体部腺癌と確定した症例の細胞像について報 告する。

63 年度 $(1988,4 \sim 1989,3)$ の集検受診者は, 114, 526件でそのうち内膜細胞診を施行したのは 736例であり全体の $0.645 \%$ である。さらに内膜 細胞診要精検数は69例で内膜細胞診における精検 率は $9.375 \%$ であつた。また子宮体部腺癌は 6 例 で内膜細胞診における検出率は $0.815 \%$ であつた 。また平成元年度 $(1989,4 \sim 1990,3)$ の統計につ

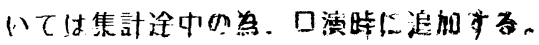

子宮体部腺癌細胞は，いずれもエンドサイトに よる採取の為に比較的採取細胞量が多いので重積 が強いが良性のものに比べ不規則な配列, 核の突 出, 核の大小不同, 核膜肥厚が強く, 核小体の大 きさ数ともに目立つてきている。また，比較的高 分化な異型のおとなしい病変においては,これら 異型の全体のバランスと集魂のほつれ具合が着目 点になるといえよう。

以上より集団検診における内膜細胞診で一次検 診の段階において癌, 異型病変の高い検出率を示 し得たことの有用性と検診のコルポ診, 組織診を 加えより深い細胞学的検討ができた事を報告する 。 
121. 子宮内膜細胞診飞おける集塊内腺腔 様構造につんて(第 2 報 組織学的検討)

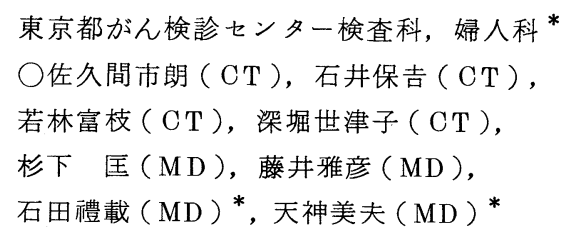

子宮内膜細胞猃ておらて，てれまで我々は細胞 個々の所見のみではなく, 細胞集塊の分岐や集塊 中の腺腔様構造など細胞構築の観察が高分化型腺 癌や腺腫性增殖症の判定・鑑別に重要であるとと を報告してをた。特に腺腔様構造においては正常 增殖期, 腺腫性增殖症, 高分化型腺癌となるにつ れて腺腔数および腺腔面積の大小不同が大きくな る傾向を認めている。今回は, 細胞標本上にみら れる集塊内腺腔様構造についての測定結果を組織 学的に裏付けるため, 組織標本を用いて腺腔形態 の検討を行なったので報告する。

[検索対象および方法]

対象として, 東京都がん検診センターにおいて 細胞診と同時に行なわれたキュレッテージないし は細胞標本作製後の材料で作られたセル・ブロッ ク標本の組織診で判定された高分化型腺癌 10 例, 腺腫性增殖症 10 例を使用した。方法は, オリンパ ス製カラー画像解析システムを用い, キュレッテー ジまたはセル・ブロックでの組織標本中にみられ る腺腔の数, 面積和よび形の不整について検討し た。をた，対照として増殖期内膜 10 例飞ついても 同様の検索を行なった。

\section{[結果 ]}

組織標本上における腺腔様構造は, 増殖期内膜 に比べて腺腫性増殖症で数が増える傾向がみられ た。高分化型腺癌では腺腔数は著しく多く, また 腺腔面積の大小不同も強くなる傾向が認められ た。これらの成績は細胞標本における成績とょく 一致しており, 細胞診における腺腔様構造の観察 の重要性が再確認された。
122. high grade endometrial stromal sarcoma， 3 例の細胞学的検討（平滑筋肉腫との 相違を中心に)

\section{国立熊本病院産婦人科}

○三森寛幸 $(M D)$, 徳永達也 $(M D)$, 柚原健男 $(M D)$

小山秀樹 (MD), 松山茂麿 (MD)

国立熊本病院研究検查科

三浦和典 $(\mathrm{MD})$, 小山保廣 $(\mathrm{CT})$, 城後博康 $(\mathrm{CT})$

（目的及び方法）子宮に発生する Pure homologous sarcomaとしてのendometrial stromal sarcoma（以下ESSと略）は稀な疾患で, 組織学 的に細胞分裂数により low grade と high grade とに分類される。我々は現在までて3例のhigh grade ESSを経験し, 細胞病理学的検討を行ったので, その細胞学的特徴を，他の代表的子宮肉腫である leiomyosarcoma（以下LMS と略）3例と比較検 討し報告する。尚乙れ等 6 症例は全例子宮摘出術 を施行し摘出標本で組織診断を行いさらに捺印細 胞診を行い, 術前細胞診陰性であった症例はこれ を用いた。

（結果）(1)術前細胞診陽性率はLMS では 3 例中 1 例のみであったが E S S では 3 例共陽性でしか も出現腫煌細胞数も多い傾向にあった。(2)出現様 式は主として孤立散在性(ESS), LMS では重積性 cluster 屯目立つ。 (3)裸核状細胞は特にESSで目 立つ。(4)ESS では核の大小不同は認めるものの bizarreな核, 多核; 巨細胞の出現は主にLMSで 見られ，特に $20 \mu$ 以上の巨核細胞はLMS では全 例出現するもESS例ではみられない。(5)核径計測 平均値でもESS例はLMS例に比べ小型。(6)クロマ チンパターンはいずれあ主に細顆粒状で核縁も平 滑であるが, ESS 例では一部粗顆状クロマチンや, 核縁の肥厚を認める。(7)大型核小体はESSでは少 なくLMSで目立つ。

（まとめ）ESS 3 例の細胞学的特徴をLMS例之の 比較を中心に検討したが, 両者に肉腫としての共 通所見を認める一方，上述したような相違がみられた。 
123. 筋層浸潤を認めない初期子宮体癌の 細胞像

九州大学医学部婦人科学産科学教室

○舟越邦明 (MD), 井町正士 (MD), 重松敏之 (MD), 鶴地伸宏 $(\mathrm{MD})$, 斎藤俊章 (MD), 嘉村敏治 $(\mathrm{MD})$, 塚本直樹 (MD), 渡辺寿美子 (CT), 中野仁雄 (MD)

近年子宮体癌は増加し、当科では最近 5 年間の 全子宮癌の $15.5 \%$ が子宮体癌である。また老健法 により細胞診が子宮体癌のスクリーニングとして 採用され、初期の子宮体癌の細胞学的診断基準の 確立が必要となってきた。しかし子宮体癌におい ては初期癌の定義がされておらず、細胞診で前癌 病変や初期病変を診断するととは困難な現状であ る。一方、子宮体癌の予後判定の重要な因子とし て筋層浸潤の程度がいわれており、特に筋層浸潤 を認めない癌（筋層非浸潤癌）は完全治癒が期待 できる。そこで、今回われわれは筋層非浸潤癌の 細胞診を後方視的に観察するとともに、筋層浸潤 癌の細胞所見と比較検討した。

対象は 1979 年から 1989 年 8 月まで当科で治療し、 摘出標本の病理組織学的検索で診断を確定された 筋層非浸潤癌 28 例と筋層浸潤癌 97 例である。採 取法は吸引法あるいはエンドサイト法によった。 これら症例の細胞診標本てついて、異型細胞の量 および出現形態、細胞集団の重積性、核所見 (形, 大きさ, 核縁の所見), 核内所見 (クロマチンの 性状, 核小体の数・大きさ)、細胞質所見 (染色 性, 空胞形成, 細胞境界)、正常内膜細胞の混在、 標本背景等を調べた。また筋層非浸潤癌の症例の なかで、子宮内膜増殖症を伴ったものと、伴わな いむのとで細胞所見に違いがあるか否かむ検討し た。その結果、筋層非浸潤癌は筋層浸潤癌と比べ て核の大小不同や核縁の不整が少なく、クロマチ ンは細顆粒状のむのが多く、巨大核小体が少ない など、全体として核異型が軽度であった。細胞質 所見では、筋層浸潤癌で空胞形成が多くみられる 傾向にあった。
124. 子宮体癌に対する黄体ホルモン療法中の 細胞像の推移

北里大学医学部産婦人科

○上片平昭二(MD)，下田隆夫(MD)，上坊敏子(MD), 大河原聡 (MD), 秦 宏樹 (MD), 根本玲子 (MD), 佐藤倫也 $(\mathrm{MD})$, 蔵本博行 $(\mathrm{MD})$

近年, 若年子宮体癌は増加する傾向にあるものの, 30 歳未満の発生は極めて稀である。我々は, 20 歳 代の体癌症例にMPA (Medroxyproge sterone ace ta te) の大量投与を施行し, 治療経過を細胞診を用いて 追跡したので報告する。症例 1 は29歳, 症例 1 は 29 歳, 症例 2 は 28 歳で共に 0 経妊。月経は規則的で, 不妊・不正出血を主訴に来院。いずれも不妊の一般 検查である内膜組織診で異常が見られたため精査 施行, G1 腺癌と診断。症例 1 はI a 期, 症例 2 は II 期であったが, 強い挙児希望のためMPA療法(400 $\mathrm{mg} /$ 日 )を施行した。症例 1 では, 投与後 3 か月よ り細胞診はクラスII となったが，10か月の投与終 了後 2 か月で核異型を示す細胞集塊が出現，つい で組織診でも体癌の再発が確認できたため投与を 再開した。症例では 6 か月投与したものの効果不 良と判断し, 広汎子宮全摘術を施行。細胞所見： 症例 1 ではMPA投与開始後 1 か月では, 核, 細胞 質ともに腫大した細胞集塊や萎縮した内膜腺細胞 集塊を, 混在して認めた。前者の細胞では, 核ク ロマチンは細顆粒状で小型の核小体を有し, 多少 の大小不同性を示し，後者ではクロマチンは濃染 し，核の大小不同性や異型性を認めなかった。投 与開始 2 か月以後では, 萎縮内膜のみとなり, 採 取細胞数も極端に減少した。症例 2 でも萎縮を思 わせる所見は出現したが，ほとんどホルモンの影 響を受けない細胞が投与開始 2 か月の時点でも出 現していた。しかし, 摘出標本では腫瘍の残存は ごく僅かであった。妊孕性の温存が求められる 若年体癌例においては, 黄体ホルモン療法も試み られるべき方法と考えられる。その経過観察にお いては細胞診が有用であるとの結論を得た。 
125. MP A 投与に上る子宮内膜癌の組織 学的細胞学的影響

\author{
京都府立医科大学産婦人科学教室 \\ 伊藤良治（MD），藤田宏行（MD） \\ 山本 宝 (MD), 岡田弘二 ( $M D)$ \\ 京都第一赤十字病院産婦人科 \\ 中田好則 (MD)
}

(はじめに) 子宮内膜癌に対する内分泌療法とし てプロダストーゲン療法による抗腫瘍効果が知ら れているが、その組織学的、細胞学的な効果判定 についてはまだ十分な理解が得られていない。今 回プロゲストーゲン剤として medroxy progesterone acetate (MP A) を術前投与した症例に 対して投与前後の組織学的、細胞学的变化につい て比較検討した。

(対象および方法) 1987 年6月から1989 年 2 月までの当科にて手術を施行した内膜癌症例 の5ち 6 例 (高分化腺癌 1 例、中分化腺癌 3 例、 低分化腺癌 2 例）を対象とした。術前にMPAを 1 日 $600 \mathrm{mg}-800 \mathrm{mg}$ を $8-50$ 日間経口投 与し、MP A 投与前の生検組織、MP A 投与前後 の内膜スメフ標本および摘出子宮より得られた $\mathrm{M}$ P A 投与後の組織像を比較検討した。

（結果および考祭）高分化腺癌では上皮細胞の偽 重層性の消失、管腔の払張、分泌物の貯留、胞体 の淡明化等が見られた。中分化腺癌では上皮細胞 の重層性の低下、管腔内の debris の出現、胞体 の腫大および淡明化、相対的 $\mathrm{N} / \mathrm{C}$ 比の低下、核 分裂像の減少が見られた。低分化腺癌では充実性 管状に配列する上皮細胞密度の低下、管空内の lebris の出現、核の heterogeneity の増加、 single cell necrosis の出現等が見られた。これ らの変化はMP A のプロゲストーゲン剤とし:の 黄体ホルモン効果に加え、抗腫湯効果を含めた組 織学的、細胞学的表現型であると考えられた。
126. 抗BrdUモノクローナル抗体による子宮 内膜癌の Labeling Index (L.I.) と細胞診所見につ いて

癌研究会附属病院婦人科 ${ }^{1}$, 同細胞診断部 ${ }^{2}$, $\mathrm{SRL} \cdot$ 研究部 ${ }^{3}$

藤本郁野 $(\mathrm{MD})$, 横須賀薫 $(\mathrm{MD})$, 手島英雄 $(\mathrm{MD})$, 荷見勝彦 $(\mathrm{MD})$, 增淵一正 $(\mathrm{MD})$, 都竹正文 $(\mathrm{CT})$, 池永素子 $(\mathrm{CT}))^{2}$ 平田守男 $\left.(\mathrm{CT})\right)^{2}$ 名取恒夫? 高橋正宜 $(\mathrm{MD})^{3}$

（目的）Bromodeoxyuridine (BrdU)に対するモ) クローナル抗体の出現により, $\mathrm{S}$ 期細胞の同定が 可能となった。我々は子宮体癌組織の $B r d U$ 標識 率と子宮内膜細胞診所見との関係につき検討した。

(方法) 子宮体癌18例につき摘出子宮より可及的 儿内膜癌組織を採取。BrdU 添加 HamF12 培地溶 液中にて $37^{\circ} \mathrm{C} 60$ 分間反応 $10 \%$ ホルマリン固定後パ ラフィン切片作成, $\mathrm{HCl}$ 処理後抗 $\mathrm{BrdU}$ 抗体を用 いた醉素抗体法 (ABC 法)染色を施行し BrdUを捕 捉した細胞数の割合 (L.I.)を任意の 5 視野にて測 定した。同一症例の内膜細胞診所見は核小体数 大きさ・分布状態・核クロマチン所見, 細胞質染 色性などを中心に検討し, L.I.との関係をみた。 （成績） L.I. の平均值は I 期（8 例）17.3\%, II 期 （5 例） $10.9 \%$, III 期（5 例） $9.5 \%$ で全体の平均 值は $13.3 \%$ であった。L.I.が16\%以上を示したも の（5 例）を $\mathrm{H}$ 群とし, $15.9 \sim 10.0 \%$ （7 例）をM 群とし, 10\%未満群 (6 例) をL 群とし, 組織分 化度との関係をみると, $\mathrm{H}$ 群では $\mathrm{G}_{1}$ が $80 \%$ を占め たのに対し，M〜 L群では $\mathrm{G}_{1}$ が $33.3 \%$ であった。 細胞診所見としては核小体数が 4 個以上のあのが H群で100\%であったのに対し, 3 個以下のものは $\mathrm{M} \sim \mathrm{L}$ 群の方に多く認められた。核小体分布状態 については分散型が H群で高かったのに対し, 傍 中心型はL 群に多く認められた。核小体の大きさ. クロマチン状態などもL.I. と相関を認めた。 
127. FCM に括ける固定標本に対する細胞 分散法の検討とその細胞形態

佐々木研究所附属杏雲堂病院、婦人科 ${ }^{1}$ ) 、細胞 診 $^{2}$ ) 、 FCM 研究室 ${ }^{3}$ )

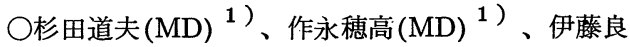

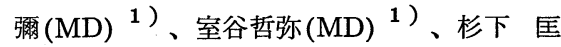
$\left.(\mathrm{MD})^{1}\right)$ 、天神美夫 $(\mathrm{MD}, \mathrm{FIAC})^{1)}$ 、長島義男 $\left.(\mathrm{CT})^{2}\right)$ 、有馬美和 $(\mathrm{MT})^{3}$ )

近年フローサイトメトリー (FCM)は、その普及 にともない各研究分野で広く応用されるようにな ってきたが、何といっても DNA Aneuploidyの検 索が主体である。DNA Aneuploidyの検索におい ては、新鮮材料のほうが低い $\mathrm{CV}$ 值が得られるが、 retrospective な検討あるいは時間的余裕を得る ためには固定した検体を使用することが多い。

パラフィンブロックから DNA Aneuploidyを検 討する場合、ペプシンを用いて分散させる方法が 一般的であるが、細胞質が消化されることと蛍光 量の減少が強く、sorting 後の細胞形態とDNA ヒス トグラムを比較検討している我々の研究には適さ ない。そこで、今回我々はトリプシン、dispase を用いて固定材料に対する細胞分散法の改良を試 みた。

摘出子宮より得られた正常子宮内膜を $10 \%$ フォル マリンもしくは70\%エタノールにて固定し、トリ プシン(Difco, 0.25\%)、dispase (500〜2,000unit/ $m \ell)$ にて分散させ、高速ブレンダーを追加させ、 R Nase $(1 \mathrm{mg} / \mathrm{ml})$, , P I $(50 \mu \mathrm{g} / \mathrm{ml})$ にて染色し、そ の DNA ヒストグラムと細胞形態を比較した。

結果はトリプシンによる分散法が良く、フォル マリン固定標本では細胞の分散も細胞質の保存も 良好であったが、蛍光量の減少が強かった。アル コール固定では蛍光の減少は認められなかったが、 細胞形態に扣いては、細胞質はかなり保存されて いるものの、細胞辺縁がやや不鮮明になる傾向が 認められた。
128. F low cytometry による子宮内膜癌、 子宮内膜增殖求：正常子宮内膜の D N A 解析

鳥取大学医学部産科婦人科 ${ }^{1)}$, 同検查部 ${ }^{21}$

O石原 浩 $\left(\mathrm{MD} ;{ }^{1}\right)$, 金森康展 (MD) ${ }^{1)}$, 森下嘉一郎 $(\mathrm{MD})^{11}$, 皆川幸久 (MD) ${ }^{1)}$, 紀川純三 (MD) ${ }^{1}{ }^{1}$, 前田一雄 (MD) ${ }^{11}$, 永見光子 $(M T)^{2)}$, 松井克明 $(M D)^{2)}$

目的：前回、子宮内膜癌、子宮内膜增殖症、 正常子宮内膜の細胞診による鑑別を数量化するこ とを試みた。しかし、細胞診所見の中で核所見は その客観化が困難であった。 そこで、F l ow cytometry を用いて子宮内膜癌、子宮内膜增殖症、 正常子宮内膜の核D N A ヒストグラムの解析を行 なった。

対象：鳥取大学医学部産科婦人科を受診し、 組織検查で確定診断され、組織の保存状態の良好 な子宮内膜癌 16 例、子宮内膜增殖症 8 例、正常子 宮内膜10例の計34名である。内膜癌はすべて高分 化型 (G 1) 、内膜増殖症は3 例が異型增殖症、 5 例か腺腫性增殖症であった。正常内膜は 4 例が 増殖期、6 例が分泌期であった。

実験方法： 組織検查で確定診断されたものと 同一のパラフィン包埋組織ブロックから50 $\mu \mathrm{m}$ の 薄切片を数枚切り、xylen 、ethanol で脱パラフ インし、0.25\% trypsin で酵菜処理、 $50 \mu \mathrm{m}$ の nvlon meshで濾過後、Dronidium iodideで染色l、 FACS CAN (Becton Dickson)に供し、ヒストグラム とサイトグラムを描かせ、それらの解析を行なっ た。

結果：DNAヒストグラムでは、内膜癌のう 与5例 (31.3\%) がaneuploidr、11例 (68.7\%) が eup loidyであり、異型增殖症では、3例中 1 例が aneuploidyであった。DNA indexは、内膜癌で 1. $51 \pm 0.17$ 、異型增殖症の 1 例では1.71であった。 腺腫性增殖症と正常内膜では全例e u p l o i d y であり、 aneuploidyは認められなかった。Proliferative indexは、正常内膜、内膜增殖症、内膜癌の順に 增大傾向が認められた。 
129. 子宮体内膜糖脂質測定法による子宮 体癌の診断への応用：フローサイトメトリーとの 比較検討

慶應義塾大学医学部産婦人科学教室 ○小林陽一(MD), 野澤志朗 (MD), 柳沢かよ子, 進 伸幸 $(M D)$, 酒依元子 $(M T)$, 田中 淳 $(M D)$, 太田邦彦 $(M D)$ ，佐久間達朗 $(M D)$

【目的】子宮体癌の診断は主として細胞診や組織 診により行われているが，一般的に高分化型腺癌 は細胞診上判断に苦慮する場合がしばしばあり, より客観的な補助的診断法の出現が待たれている。 我々は体癌に特異性の高いモノクロナール抗体 （MSN-1）を作製しフフローサイトメトリー（FCM） に応用して正常内膜と体癌細胞との鑑別への有用 性について検討してきた。今回は MSN-1の認識抗 原が細胞膜の糖脂質上の糖鎖に存在する事に着目 し, 子宮体癌細胞より抽出した糖脂質の MSN-1 との 反応性を測定し, FCMの結果と併せて比較検討を行っ たので報告する。【方法】エンドサイトあるいはエン ドサーチを用いて採取した体癌細胞の糖脂質をク ロロホルム:メタノール $1: 1$ 混液により抽出し, 細 胞乾燥重量 $50 \mu \mathrm{g}$ 当たりの糖脂質を薄層クロマトグ ラフィー（TLC）上に展開し, MSN-1を第一抗体と した間接抗体法により染色し, 染色されたバンドを デンシトメーターにより測定した。標準物質として $\mathrm{MSN}-1$ の免疫原であるS NG-2 細胞の糖脂質を用い た。【結果扣よび考察】SNG-2 細胞の乾燥重量 $100 \mu \mathrm{g}$ 当たりの糖脂質とMSN-1との反応性をデンシ トメーター乾燥重量 $1 \mathrm{mg}$ 当たりの反応性を換算し たところ cut off 值以上の症例が体癌 16 例中 11 例 $(68.7 \%$ )に認められた。また同一症例につき FCMにより反応性を測定したところ, 陽性例が 68.7\%に認められ，どちらか一方が陽性の例は， $81.3 \%$ であった。これらの結果より, 体内膜糖脂 質測定法は, 子宮体癌の診断に执いて有用であり, また FCMと組み合わせる事によりさらに診断効率 が上昇する事が示唆された。

\section{0. 子宮内膜細胞診の免疫染色所見}

島浪医科大学医学部産科婦人科学教室

○伊達美江 (MD) , 岩成治 (MD), 吉野直樹 (MD) 中山 理 (MD), 柳光寛仁 (MD), 森山政司 (MD)

飯田幸司, 北尾 学 (MD)

島根医科大学付属病院検査部病理

三浦弘資 (MD)，小池美貴男 (CT)，長岡三郎 (MD)

子宮体癌検診が老人保健法により実施されるこ とになり、子宮内膜細胞診による子宮体癌、子宮 内膜增殖症の診断が重要になってきている。しか し実際は、月経周期、炎症などに伴って、細胞診 上に核の大小不同、核・核小体の腫大した間質細 胞が出現し、腺細胞との鑑別に苦慮することが多 い。そこで、我々は免疫染色を用いて、両者の鑑 別を試みた。

まず、正常子宮内膜増殖期 - 分泌期、腺腫性增 殖症、異型内膜增殖症、分化型子宮体癌の組織を Biotin-streptavidin 法により免疫染色し、ケラ チン（KL-1)、ビメンチンについて検討した。 $\mathrm{K} \mathrm{L}$ - 1 は腺上皮全層で、陽性だった。ビメンチ ンは、内膜腺、間質両方に陽性であった。以上よ り、内膜腺細胞と間質細胞の鑑別には K L - 1 が 適していると判断し、内膜細胞をパパニコロー染 色にて判定後、脱色、 KL - 1 にて染色した。今 回、その結果について報告する。 
131. セル・ブロック法による子宮内膜增殖 症の細胞診

倉旉成人病センタ一臨床検査部

O森 真理子 (CT), 藏重 亮 (CT)

国立病院四国がんセンタ一臨床研究部

元井 信 (MD)

子宮体癌の増加傾向とともにその前癌病变とし ての子宮内膜増殖症の重要性が高まってきた。そ の診断には細胞診でスクリーニングを行ない, 組 織診で精密検査をする方法がとられている。しか し, 子宮内膜細胞診は変性も加わり判定に難渋す ることが多く, 診断の向上には従来から種々の試 みがなされているが, 我々もその一端として, 本 症の細胞診にセル・ブロック法の併用を試み, 良 好な結果を得ているので報告する。

方法：エンドサイト法により採取した内膜組織 は通常の如く塗抹標本を作製した後, エンドサイ ト内芯の上端で切り落とし内芯内に付着残存した 組織をそのまま20\%ホルマリン液で固定し, 寒天 を用いるセル・ブロック法で組織標本を作製した。 塗抹標本を優先する約 $20 \%$ の症例では検体不足に より標本作製が困難であった。

結果 : 過去 4 年間（1986-1989年）に当院で内 膜細胞診 250例に対し塗抹細胞診にセル・ブロッ ク法を併用して検討し, 囊胞性腺增殖症18例, 腺 腫性增殖症 4 例, 異型内膜增殖症 8 例, 子宮体癌 11例を診断した。本法の利点は細胞集塊に対して 組織診断に準じた観察が可能となり, 塗抹標本で は細胞集塊が大きく，厚くなると染色性が低下し 内部構造の観察が困難となる欠点を補うことがで きた。その結果, 塗抹細胞診で軽度の細胞異型を 認め, 内膜増殖症を確診できない症例でも組織構 築を加味して判定でき, 特に襄胞性腺增殖症の診 断が容易となり, さらに内膜增殖症と子宮体癌と の鑑別に構造異型を組織診の基準と同様に適用で きることは診断に有用であった。また, 多数の標 本が作製でき特殊染色に利用できた。
132. 子宮内膜增殖症により癌化した 4 症例

北里大学産婦人科

O大河原聡 (MD), 上坊敏子 (MD), 坂本伊豆美 $(M D)$, 秦宏樹 (MD), 森沢孝行 (MD),

蔵本博行 (MD)

子宮体癌の発生にはエストロゲンが関与して拉 り, また, 高エストロゲン環境に起因する内膜増 殖症はその前癌状態と考えられている。この増殖 症から体澏が発生して行く過程は, いまだ明らか にされていないが, 我々が現在までに経験してい る 187 例の体癌の中に, 内膜増殖症からの癌化 例と考えられる 4 症例を経験したので, その臨床 経過と細胞像を検討し報告する。増殖症診断時の 年齢は, 33 歳〜 45 歳で 2 例は経産, 他の 2 例 は未婚, 未妊であり, 月経歴は, 整が 2 例, 稀発, 頻発各 1 例であった。また, 主訴は全例不正出血 であった。癌化前に診断されていた子宮内膜増殖 症は, 異型 2 例, 腺, 囊胞増殖症各 1 例であった。 癌発見までに要した期間は 1 年 4 カ月〜 6 年 2 力 月, 平均 3 年 6 力月であった。これら 4 症例は, いずれも内膜細胞診, 内膜組織診, 子宮鏡診で経 過観察し，2例には黄体ホルモンによる治療を施 行した。摘出標本の検索において, 組織型は $\mathrm{G} 1$ は 2 例, $\mathrm{G} 2$, 腺棘癌は各 1 例であり, 筋層浸潤 は残存なし 2 例, 粘膜内, $1 / 3$ 未満各 1 例であ った。子宮内膜増殖症から癌の診断に打ける細胞 診と組織診の推移は, 1 症例では細胞診において 陰性であったが, 組織診で異型増殖症見出され, 子宮子宮鏡診, 全面搔爬で体癌と診断された。他 の 1 症例では, 細胞診で経過中に疑陽性がでたた め, 再検を繰返したところ体癌の診断となった。 ホルモン療法を行った 2 症例は, 細胞診で治療中, 後の経過観察を行い, 疑陽性及び陽性の所見にて 精査で体癌と診断。癌化過程に扣ける細胞診を再 検して, 細胞学的推移てついて報告したい。 
133. 子宮内膜間質細胞の出現形式と細胞 形態学的特徵に関する研究

鳥取大学医学部産科婦人科学教室 ${ }^{1)}$, 同 検查部 病理 ${ }^{2)}$

○皆川幸久 (MD) ${ }^{1)}$ ，金森康展 (MD) ${ }^{1)}$ ，石 原浩 (MD) ${ }^{12}$, 森下嘉一郎 (MD) ${ }^{1)}$, 紀川純 三 $(\mathrm{MD})^{1)}$ ，前田一雄 $(\mathrm{MD})^{1)}$ ，永見光子

$(M T)^{2)}$, 松井克明 (MD) ${ }^{2)}$

（目的）細胞標本における子宮内膜腺細胞と間質 細胞の鑑別は必ずしも容易ではない。子宮内膜間 質細胞の出現形式と細胞形態の特徵を明らかにす るために本研究を行った。

(対象と方法) 子宮内膜に悪性病変が否定された 10 例のエンドサイト採取による内膜細胞標本を ビメンチンにて染色した。ビメンチン陽性細胞に ついて、その出現形式を検討すると共に、核の短 径と長径、核間距離をマニュアル計測し、各々の 变動係数、核の短径と長径の比を算出した。

（結果）ビメンチン陽性細胞の集塊は孤立散在性 の集塊を形成して出現するものと内膜腺細胞の集 塊と一塊となって出現するものがあった。また、 後者の中には細胞集塊の辺縁部に存在するもの、 腺細胞の表面を被覆するもの、腺細胞の集塊に介 入するものが存在した。先に本学会で発表した正 常内膜腺細胞の核径は、增殖期で5. $76 \pm 0.81 \mu \mathrm{m}$ 、

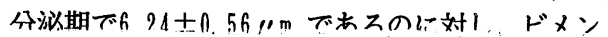
チン陽性細胞においては、総平均で核の短径は $5.57 \pm 3.96 \mu \mathrm{m} \quad$ 核の長径は $7.39 \pm 1.79$ $\mu \mathrm{m}$ であった。細胞の長軸方向の核間距離は 11. $74 \pm 4.46 \mu \mathrm{m}$ であり、正常分泌期腺細胞のそ れ $(9.80 \pm 1.21 \mu \mathrm{m})$ より大きい傾向があった。 また、核間距離の変動係数は0.379 であり、正常 分泌期腺細胞の0.138 に比して、著しく大きかっ た。また、核の短径と長径の比は平均で $0.57 \pm$ 0.19であり、分布図上には $0.42 \sim 0.52$ と 0.62 〜0.72の二つピークが認められた。

（結論）ビメンチン陽性細胞は内膜腺細胞に比べ、 細長い核を有し、㻋でかつ不規則な分布を示す傾 向が確認され、さらに、核の形態には二つのタイ プがあるものと考えられた。
134. 更年期・老年期における子宮出血と . 子宮内膜組織像との関連

岩手医大産婦人科学教室

$\bigcirc$ 鈴木浩基 (MD)，利部輝雄 $(M D)$

井筒俊彦 $(M D)$ ，西谷 䉷 $(M D)$

[目的]老人保健法の改正により50歳以上の饘人 で最近 6 ケ月以内に性器出血を見たものを対象に, 子宮体癌検診が，内膜細胞診を主体に実施される ようになった。しかし，更年期から老年期にかけ て子宮出血を来たす婦人の内膜病理組織像に関す る報告は少ない。そてで我々は，1985 年より1988 年までに，40歳～89歳の婦人で子宮出血のみられ た 651 例を対象に, 内膜病理組織像を検討したの で報告する。〔方法〕子宮出血をみとめた婦人よ り, 子宮内腔全面择爬を行い, 内膜を採取し，固 定後, 通常の方法で薄切, 染色, 鏡検した。

〔成績〕 対象を40〜 49歳 ( A 群：273 例 )，50 59 歳 ( B 群：307 例)，60歳以上 ( $\mathrm{C}$ 群：71例) の 3 群に分け，A群を対照とし，乙れと B，C群 を比較した。子宮内膜の組織像は, 萎縮又は静止 期内膜, 機能異常内膜, 囊胞性腺増殖症, 腺腫性 増殖症, 異型增殖症, 腺癌に分類し, 各群の頻度 を比較した。萎縮または静止期内膜は A 群 $12.8 \%$ B群 $22.1 \%$ であり，C群 $60.6 \%$ 之著増した、機能 異常内膜は, A 群 $57.5 \%$, B群 $58.3 \%$ と差はなく C群では $5.6 \%$ と低頻度であった。囊胞性腺增殖 症は, A 群 $14.7 \%$, B 群 $8.4 \%$ であり，C群 5.6 $\%$ 之著減した。腺腫性増殖症, 異型増殖症は, そ れぞれ，A群 $3.3 \% ， 1.8 \% ， \mathrm{~B}$ 群 $4.8 \% ， 2.3$ \%であり，C群では $12.6 \% ， 5.6 \%$ と有意の増加 をみとめた。内膜癌は $\mathrm{A}, \mathrm{B}$ 群とも $0.7 \%$ と差は なく，C群では $8.4 \%$ と著増した。〔結論〕子宮 出血の背景としての内膜病変は，40歳代と50歳代 に差がなく, 60歳以上では, 菱縮性病変, 増殖性 病変, 内膜癌の頻度が有意任高く, 子宮内膜癌の 発生には二型がある可能性がえられた。 
135. 子宮内膜細胞診疑陽性及び陽性例への hysterofiberscope $の$ 応用

\section{富山県立中央病院産婦人科}

○佐竹紳一郎 (MD), 舟本 寛 (MD),

南 幹雄 (MD), 舘野政也 (MD)

同 中検病理

宮本藤之 (CT), 福村 健 (CT), 三輪淳夫 (MD)

子宮鏡は近年, 子宮内病変が疑われる場合の routineな検查となりつつあるが, 内膜細胞診・疑 陽性以上の病変に対する内視鏡的検索は未だ一般 化していないのが現状と思われる。

当院では昭和 61 年 5 月より元年 6 月まで，フジ ノン観察用及び処置用ヒステロファイバースコー プを使用し, 計 502 例に対して子宮鏡検查を行っ てきたが，今回我々は，そのうち内膜細胞診・疑 陽性例41例及び陽性例23例に対して検討した。

内膜細胞診・疑陽性例のうち, 子宮鏡で子宮体 癌及び hyperplasia と診断した12例については, 組織診で萎縮内膜と診断された 1 例を除いて, 正 診率は $91.7 \%$ であった。特に子宮鏡で子宮体癌と 診断した 5 例のうち 2 例は, biopsy 及び abrasio で atypical hyperplasia と診断されたが術後診断で adenocarcinoma が確認された。子宮鏡診断で carcinoma 及び hyperplasia を共に否定した29例につい ては，組織診で $\mathrm{ADH}, \mathrm{CGH}$ を計了例認めたが他の 26例は, いずれも内膜の neoplasmaを認めなかっ た。さらに内膜細胞診・疑陽性例全体についてみ ると，子宮鏡診断の正診率は 41 例中 29 例， $70.7 \%$ であった。

内膜細胞診・陽性例について見ると, 子宮体癌 18例, hyperplasia 2 例, 子宮頸癌 2 例, 卵巣癌 III 期の正常内膜 1 例で, 子宮鏡の正診率は $100 \%$ で あった。

以上より, hysterofiberscope は子宮内膜細胞診 - 疑陽性及び陽性症例の診断に有用であり, routine 亿行われるべき検査であると思われた。
136. 子宮内膜細胞診に㧍けるクライテリ ア作成の試み

久留米大学産婦人科

○森一朗 (MD), 田中博志 (MD), 藤吉啓造 (MD), 福富 毅 (MD)，田崎民和 (MD)，葉 清泉 (MD)， 薬師寺道明 (MD)，高村邦子(CT)

目的：近年, 子宮体癌および増殖症の発見は増 加傾向にあり, 内膜細胞診にて, 増殖症之高分化 型腺癌の鑑別の重要性が指摘されている。そてで 我々は，それぞれの細胞個々および集塊について 比較検討した。方法: 増殖期, 分泌期, 月経期, 閉経後 5 年末満, 閉経後 5 年以上, 腺腫性增殖症, 体内膜腺癌症例についてNIKON コスモン゙ーン $1 \mathrm{~s}$ 二次元解析装置を用いて，1 症例につき 100 個の 細胞核について核面積, 核長径, 核短径, 核周囲 長を測定し，核クロマチン，核小体数を比較した。 細胞集塊については, 重積性, 形態抢よび分岐数 なぞ組織構築について比較検討した。成績：細 胞核面積については, 増殖期, 分泌期, 月経期に 有意の差を認めず，閉経後は縮小傾向にあった。 また, 腺腫性增殖症, 高分化型腺癌之核面積は增 大し，大小不同も認められた。また，核クロマチ ンや核小体数のみでは，鑑別困難であった。重積 性については，正常性周期では，ほぼ 2 層までの 重積性を認めるのみであるが，月経期に 3 層以上 の重積を認める症例むあり, 重積性のみでは腺癌 との鑑別は困難であった。集塊の形態特に分岐に ついて検討すると, 正常内膜では 1 次分岐までし か認められないのに対して，増殖症および高分化 型腺癌では分岐数は増加した。また，高分化腺癌 や月経期においては，樹枝状集塊が認められるが， その集塊内の間質細胞の形態に相違が認められた。

結論：細胞個々の所見では, 軽微の差を認める のみで, 結果的に偽陰性, 偽陽性率が高くなる之 思われる。しかし今回我々の検討した集塊の形態 や分㞳など組織構築を加えることにより，より正 確な診断が可能であると考えられた。 
137. 子宮体部腫瘍症例における腹腔洗浄 細胞診の娭討

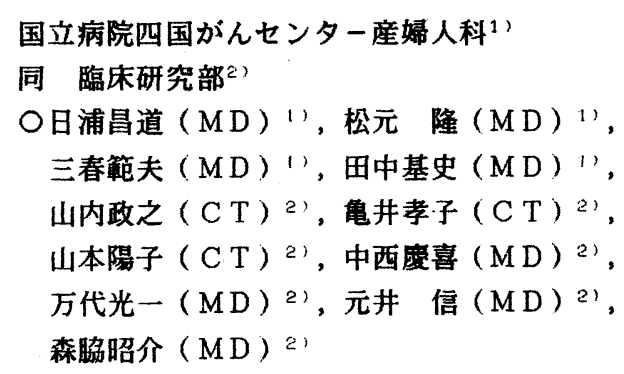

子宮体癌の予後因子 (病期分類)の 1 つとして前 臨床的腹膜播種が重要視され，腹腔洗浄細胞診の 意義が強調されてきた。今回子宮体部腫瘍症例に ついて開腹時の腹腔内播種を確認するため腹腔洗 浄細胞診を検討したので報告する。

対象は1986年12月より1989年11月までに当院で 開腹治療した子宮体癌44例(Ia:31例, Ib:6例, II : 7 例)でダグラス窩, 回盲部, S字状結晹および横隔 膜下の洗浄細胞診を施行した。また当院の子宮体 癌の再発様式についても検討する。

細胞診陽性率は 5/44(11.4\%)で部位別ではダグ ラス筥 4 例, 上行結腸外䆟 1 例にみられ, 病期别では I a期 2 例 $(6.5 \%)$, Ib 期 1 例 $(16.7 \%), \mathrm{II}$ 期 2 例 $(28.6 \%)$ と 病期の進行につれて陽性率が高く，組䄉型别では 内膜型腺癌 $3 / 25(12 \%)$, 腺徧平上皮癌 $1 / 7(14.2 \%)$, ミュラー管混合腫湯 $1 / 2$ で漿液性腺癌2例, 腺棘細 胞癌 5 例, 明細胞 (類中腎) 腺癌 2 例, 扁平上皮癌 1 例 においては陰性であった。筋層浸潤の程度をみる と表層型; $0 / 17(0 \%), 1 / 3$ 以下;0/10 $(0 \%), 1 / 3-2 / 3$; 1/8(12.5\%)，2/3以上;4/9(44.4\%), 表層型を除いた 子宮腔に対する同方向の腫場の艮さでは $1 / 3$ 以下; $1 / 5(20 \%), 1 / 3-2 / 3 ; 2 / 18(11.1 \%), 2 / 3 以 上 ; 2 / 4(50 \%$ )と筋層浸洞の增加につれて高陽性率がみられた。 それ以前の開腹治療75例(非再発5年生存 58 例 - 再 発17例)では22.7\%に再発,そのうち5/17(29.4\%)に 腹膜播種が珰められた。子宮鏡施行群20例と非施 行24例の細胞診陽性率は各々 5\%,16.7\%であった。
138. 子宮腔部擦過細胞診で子宮頸部腺癌と 診断された子宮体部粘液性腺癌の一例

国立杤木病院産婦人科

○秋葉隆三(MD), 芝 徹(MD), 長谷川寿彦(MD) 同検查科病理

宇賀神作次郎 $(\mathrm{C} T)$ ，小島 勝 (MD)

子宮体部粘液性腺癌は稀れであるとされている。 今回われわれは子宮胵部・頸管擦過細胞診で、子 宮頸部腺癌と診断された子宮体部粘液性腺癌の一 例を経険したので報告する。

症例は63才、閉経46才、帯下感を主訴に来院し た。初診時コルポスコープはU C F 、子宮腔部は 年令に比して大きく、頸管からは多量の粘液分泌 を認めた。子宮胵部・頸管擦過細胞診では多量の 粘液様背景のなかに $/ \mathrm{N}$ 比の高い、類円形の濃染し た核とライトグリーンに染まる高円柱状の細胞質 を持つ細胞が出現しており、一部の細胞では細胞 質内粘液分泌を著明に認めた。同時に施行した子 宮体内膜組織診では、高円柱状の腺癌細胞が乳頭 状に増殖した組織が得られ、内頸部型腺癌と診断 されたため広汎子宮全摘術を施行した。摘出標本 の肉眼所見では子宮頸部は所見なく、子宮体内膜 の著明な肥厚を認めた。病理組織診では子宮頸管 腺には異常なく、子宮体内膜はほほ全域にわたり 乳頭状、管状構造の明らかな分化型腺癌細胞で置 換され、筋層内にわずかに浸潤を認めた。リンパ 節、卵巣には浸潤を認めなかった。腺癌部分は PAS, Alucianblue の粘液染色に陽性、酵素抗体 法によるCEA 染色も陽性であった。

以上の所見より本症例は子宮体内膜粘液性腺癌 と診断された。 
139. 3 重複癌 (子宮頸癌・体癌・卵巣癌) の 1 症例

秋田大学医学部産婦人科学教室 ${ }^{1)}$

同中央検查科 ${ }^{2)}$

○兽我賢次 $(M D)^{1)}$, 五十嵐信一 $(M D)^{1)}$, 真木正博 $(M D)^{1)}$, 藤原登美子 $(C T)^{2)}$, 藤田 彬 $(\mathrm{CT})^{2)}$, 提島真人 $(\mathrm{MD})^{2)}$

3 重複癌の 1 例を経験したので報告する。 【症例】 47 才 1 妊 1 産 独身

左下腹部痛を主訴として来院。内診では子宮は 玨卵大・右附属器の腫瘤を認めた。超音波検査で 一部充実性・一部囊胞性の卵巣腫瑒（悪性疑い） を認めた。同時に頸部擦過細胞診, 内膜細胞診を 施行したところ各々(V)怙よび(II)であった。コルポ

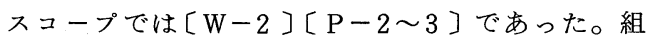
織検査ではCISであった。C I S 扣よび卵巣癌疑 いの診断で当科へ入院した。

【頸部擦過細胞像】きれいな背景の中に $\mathrm{N} / \mathrm{C}$ 比 （80\%以上）の基底型悪性細胞が clusterで出現。 核は類円型で張りがあり, 核周囲は一条の線でな ぞったよらな所見であった。また，核小体拈よび 中層型悪性細胞を認めたことから I a 疑った。

【子宮内膜細胞像】重積性のある clusterを認める。 核は類円形で大小不同, 核の配列不整, cluster 辺縁部の核の乫出も認め分化型腺癌を疑ら所見で あった。一方,ぶどら房状の cluster も一部認め た。核は類円形で重積性があり, 細胞質内空胞も 明瞭であった。

\section{【組織検查】}

頸部は微小浸潤癌 (Ia)の診断であった。子宮体 部は高分化型腺癌(Ia)の診断であった。右卵巣は atypical cell が tubullo-papi 11 ary 飞增殖する adenocarcinoma がみられ, PAS 陽性・Alucian blue 陽性であり mucinous cyst-adenocarcinoma の診断であった。

\section{【治療および経過】}

腹式子宮全摘, 両側附属器摘出, 大網切除, 骨 盤リンパ節郭清術を施行した。術後, C D D P, $\mathrm{ADM}, \mathrm{VP}-16$ 療法を 5 回施行し治癒退院した。
140. 術前診断が困難であった子宮原発中胚 葉性混合腫瘍の 1 例

日鋼記念病院産婦人科、同呼吸器内科、同検査部 川村光弘 $(M D)$ ，牟禮一秀 $(M D)$ ，西野共子 $(M D)$, 斎藤裕司 $(M D)$, 高岡和夫 $(M D)$ ，植村弘幸 $(C T)$

子宮に原発する中肧葉性混合腫瘍（MMT）は 比較的希な疾患であるが, 進行, 再発例では予後 が悪いことが指摘されている。また組織, 細胞学 的には上皮系の成分と間葉系の成分が混在してみ られることが特徴とされている。今回我々は術前, 細胞診とパンチバイオプシーを施行したものの診 断が困難であったMMTの一例を経験したのでそ の組織像と判胞像を中心と報告する。

〈症例〉 54 才，昭和63年10月より月経に引続き大 量の性器出血が持続し, 同11月15日他院より紹介 されて当院を初診した。内診, 窑鏡診では腫瘍は 子宮頸部全体を占め, 白色を呈し, 表面は壞死状, 易出血性であった。直ちに細胞診と組織診を施行 したものの, 易出血性であるため検体の採取は困 難であった。細胞診では, 大半を壞死像と出血像 が占め, 明らかな腫湯細胞をみることは出来なか った。また病理組織学的にも, 大部分が壊死組織 であり,ごく一部に間葉系悪性腫瘍の像を得たも のの確定診断には至らなかった。同年12月 2 日準 広沉子宮全摘術を施行した。腫瘍は子宮頸部に由 来して招り病理組織学的には上皮系成分と間葉系 成分の悪性腫湟が混在して括り, MMT と診断し た。また捺印細胞診にては, 一部腺様の構造を有 する多数の細胞集塊が見られた。これらの細胞に はクロマチン増量, 著明な核小体の増大がみとめ ら腺癌由来の細胞と考光られたが，あきらかな肉 腫由来と考えられる細胞はみとめられなかった。 本症例は初田治療後10力月で骨盤内に再発を及と めたため, 再度腫塲の摘出を行っており摘出腫瘍 の組織像, 細胞像の検討も行ったので併せて報告 する。 
141. Danazol 投与下の子宮体内膜の経時的 変化について一その細胞像と組織像の比較検討一

北里研究所病院産婦人科1), 同 臨床研究検査科 ${ }^{2}$, 慶應義塾大学医学部産婦人科学教室 ${ }^{3)}$

$\bigcirc$ 福田良夫 $(M D)^{1)}$, 田村昭蔵 $(M D)^{3)}$, 和泉 滋 $(M D)^{3)}$, 渡辺豊治 $(M D)^{3)}$, 藤田則子 $(M D)^{3)}$, 筒井章夫 $(M D)^{3}$, 森下春枝 $(\mathrm{CT})^{2}$, 根津義広 $(\mathrm{CT})^{2)}$

【目的】子宮内膜症 danazol (以下 D) 療法時に扰ける 子宮体内膜組織像に関する報告はあるが, 内膜細胞 像の報告はない。子宮内膜症病巣により近い反応性 を示す子宮体内膜細胞の変化を詳細に観察し, D の効果を細胞診レベルで検討した。【方法】子宮内 膜症患者 19 名にD 200 または $400 \mathrm{mg} /$ 日を月経第 5 日 より 4 6 カ月投与し, 投与前卵胞期, 投与開始後は 4 週毎, 投与終了後は 3 力月後の卵胞期にエンドサ イトにより子宮体内膜細胞を, キュレットにより内膜 組織を採取し, 細胞診はPap. 染色標本を, 組織診 はH.E. 染色標本を作製鏡検し，前者にはプラニメ トリーによる核面積の計測も行った。【結果】Dの 投与週数に伴い, (1)細胞像：スライドグラス上の細 胞数は減少し, 細胞の重積性は低下, 核間距離が 明瞭となり, 核は縮小する傾向がみられた。核面積 $\left(\mu^{2}\right)$ の平均值は投与前 29 , 投与 2 週 22,4 週 21 , 8 週 20,12 週 22, 16 週 22, 20 週 21, 24 週 23 であ った。(2)組織像：採取される組織片は小さくなり，投 与 24 週では採取不能例もみられた。腺管の数は減少, 形は円形となり, 上皮細胞は立方形を呈し, 重層化 が減少して一層となり, 分泌は減少, 核の大きさい小 さくなり,クロマチンパターンは小胞状構造が失わ れ, 間質が粗になる萎縮像を示し, この程度は症例 により多少の差がみられた。【結論】D投与下に拉 ける細胞診は組織診を概ねよく反映しているが， 投与 24 週の組織採取不能例に怙いて観察可能な 細胞が得られ，核面積がやや増大したことは興味 深い。今後採取容易な内膜細胞診はD D 効果判定 に有用なパラメーターとなり得る可能性が示唆さ れた。
142. 乳癌手術後に長期 Tamoxifenを服用 した患者に発生した子宮体癌

癌研究会附属病院婦人科 ${ }^{1}$, 同細胞診断部 ${ }^{2}$, 研究所病理部 ${ }^{3}$

手島英雄 $(\mathrm{MD})^{1,2}$, 池永素子 $(\mathrm{CT})^{2}$, 横須賀 薫 $(\mathrm{MD})$, 藤本有野 $(M D)^{1,2}$, 山内一弘 $(M D)^{1}, 2$, 荷見勝彦 $(M D)$, 平田守男 $(\mathrm{CT})^{2}$, 增淵一正 $(\mathrm{MD})^{1}$, 坂元吾偉 $(\mathrm{MD})^{3}$

Tamoxifenは乳癌手術後患者の術後補助内分泌 療法として用いられる薬剤である。婦人科領域で もその抗エストロゲン作用とプロゲステロンリセ プタ一誘導作用に注目して, 子宮体癌の治療に用 いられ始めている。我々は乳癌手術後長期 Tamoxifen 服用患者 (服用期間 2 年 8 年) に発生し た子宮体癌 4 症例を経験したので報告する。 又,Tamoxifen 長期服用により, 血中Estrogenレべ ルが上昇し, estrogenie 効果によって子宮体癌が 発生したととが想定されたので腔ホルモン細胞診 を施行し, 成熟指数 (Maturation Index, MI) で, エストロゲン効果を評価した。

【対象】(1)閉経後の乳癌患者で手術後 Tamoxi fen 单独服用患者 13 例：60才以上を対象として平均年 齢 67 才, 閉経後平均 17 年, Tamoxifen 服用期間平 均 2 年 11 ケ月。服用量は $20 \sim 40 \mathrm{mg} /$ 日。

(2) contro1 として閉経後乳癌患者で,Tamoxifen 非服用, 化学療法未施行患者 10 例：平均年、秢 65 才, 閉経後平均 16 年。

【結果】 Tamoxifen単独服用群ではM.I・は8/74/8 であり, control 群は 96/2/2であった。

【結論】Tamoxifen 長期服用は閉経後の手術後乳 癌患者にエストロゲン効果を示す。 
143. 茨城県総合健診協会で実施した喀痰 検診 5 年間の成績

\section{茨城県総合健診協会検查部}

O鈴木優子 $(\mathrm{CT})$ 、赤城弘文 $(\mathrm{CT}) 、$ 桧山浩一 (CI)

阿久津真奈 (CI)、相馬雅行 (CT)、柴田文雄 (CT)

同 診断委員会

赤荻栄一(MD)

【はしめに】 我々は、昭和60年度より肺がん検 診の一環として喀痰細胞診検查を実施してきたの で、平成元年度までの5ヶ年の成績について報告 する。

【対象と方法】対象者は、肺癌高危険者 (問診 により、50歳以上で契煙指数が 600以上、又は血 痰や 1 ヶ月以上持続性の喀痰の有る者）及び希望 者である。喀痰処理法は、マルチブレンド式集細 胞法（抗研式変法 II）を用いた。判定基準は、日 本肺癌学会肺癌細胞診判定基準改訂委員会の基準 に準して行った。

【結果】検診者数 (喀痰容器提出者数) は、平 成元年11月現在、延34, 168名であった。有効検体 数は33,851であり、有効検体率は、99.1\%であつ た。有効検体中、判定区分Cは $347(1.03 \%) 、 D$

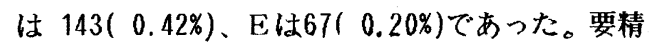
検者 (D+E) 210名中、精検受診者は 177( 84.3\%) 名であった。そのうち発見された䖈は、Dより13 名、Eより52名、計65名であった。有効検体に対 する癌発見率は、0.19\%であった。癌例65名中、 腺癌の 1 例のみ女性で、他は全て男性であった。 年齢は52 82歳 (平均67.9) 、肺癌高危険者 (喫 煙指数 600 以上) は57名であった。血痰の自覚症 状のあった症例は無かった。間接X線写真で異常 なしとされた症例は、51例( 78.5\%)であった。病 期別では、I期が43名と最も多く、そのうち早期 癌は18名であった。組織型は、中枢ないし末梢気 管支発生の扁平上皮癌が54名と最も多かった。

【結論】咯痰検診は、早期気管支扁平上皮癌の発 見に有効であった。
144. 宮城県肺癌集検における喀痰細胞診の 成果

東北大学抗酸菌病研究所外科, 仙台厚生病院 2 盛岡県立中央病院呼吸器外科, 南東北病院 4 , 大 田総合病院呼吸器外科 5 , 青森県立中央病院呼吸器 外科 ${ }^{6}$, 宮城県対がん協会 ${ }^{7}$

○高橋里美 $(M D)^{1}$, 薄田勝男 $(M D)^{1}$, 菅間敬治 $(M$ $\mathrm{D})^{1}$, 佐川元保 $(\mathrm{MD})^{1}$, 佐藤雅美 $(\mathrm{MD})^{1}$, 太田伸一 郎 $(M D)^{1}$, 永元則義 $(M D)$, 斎藤泰紀 $(M D)^{1}$, 藤村 重文 $(M D)^{1}$, 仲田 祐 $(M D)^{2}$, 橋本邦久 $(M D)^{3}$, 佐 藤博俊 $(M D)^{4}$, 須田秀一 $(M D)^{5}$, 今井 督 $(M D)^{6}$, 東岩井 久 $(\mathrm{MD})^{7}$

宮城県の肺癌検診は, 従来の胸部 X線写真によ る結核検診に喀痰細胞診を導入する形で昭和 57 年 度より開始された。肺癌検䧐におりる喀痰細胞診 の成果を報告する。

昭和62年度までの延へ肺癌集検受診者 $1,080,009$ 名中問診により高危険群とした 72,829名 (6.7\%) 亿喀痰処理容器を配布し, 58,057名 (5.3\%) から 回収した。そのうち細胞診断が可能であったのは $56,603$ 名 ( $5.2 \%)$ であった。咯疢細胞診の結果, 350 例を気管支鏡検査を含めた要精査とし, 131 例（受㟝者 10 万対 231）の原発性肺癌を発見した。 131 例中 107 例は喀痰細胞䛦のみによる発見であ った。喀痰細胞診のみによる発見 107 例は全例男 性で, 103 例は扁平上皮癌で 4 例は腺癌であった。 喀痰細胞診のみによる発見 107 例中88例 (82\%) を切除し，その 5 年生存率は $88 \%$ であった。乙れ は, X線のみによる発見の切除例 180 例 (切除率 67\%)の 5 年生存率 $47 \%$ 之比較し, 有意に良好で あった。 
145. 病変の深達度別にみた気管支早期扁平 上皮癌の擦過細胞像の検討

東北大学抗酸菌病研究所外科 ${ }^{1}$, 仙台厚生病院 ${ }^{2}$, 南東北病院 ${ }^{3}$, 宮城県対がん協会 ${ }^{4}$

O佐藤雅美 $(M D)^{1}$, 斎藤泰紀 $(M D)^{1}$, 永元則義 $(M D)^{1}$, 薄田勝男 $(M D)^{1}$, 高橋里美 $(M D)^{1}$, 营間敬治 $(M D)^{1}$, 佐川元保(MD) ${ }^{1}$, 太田伸一郎 (MD $)^{1}$, 仲田 祐 $(M D)^{2}$, 藤村重文 $(M D)^{1}$, 佐藤博俊 $(M D)^{3}$, 関口礼子 $(C T)^{2}$, 本多昌子 $(\mathrm{CT})^{2}$, 黒川典子 $(\mathrm{CT})^{2}$, 中嶋隆太郎 $(\mathrm{CT})^{4}$

喀痰細胞䛦で発見されるX線無所見肺癌には, 浸 潤が上皮内に限局するものから, 気管支壁外に及 ぶもの, リン八節転移を伴う症例までが存在する。 上皮内癌では，区域切除であ十分に根治性が維持 される。一方, 浸潤が軟骨外に及ぶ症例では, レー ザー治療は適応とならない。従って, 治療前に病変 の深達度を推定する事は治療法選択に重要である。 演者らは, 先の本学会で, 肺癌検診宮城方式におけ る喀痰細胞診陽性例を検討し, 喀痰細胞像により 有る程度, 病変の進行の程度が推定可能である事を 報告した。すなわち, ClassV (E判定) 症例にはX線 有所見肺癌を含む進行例が多く, Class III ( D 判定) 症例には, 異形成, 上皮内癌, $\mathrm{X}$ 線無所見の早期浸 潤癌が多く見られた。またClassIV (E判定)症例の80 \%はX線無所見肺癌であった。しかし，喀痰細胞診 のみにより, X線無所見肺癌の病変の深達度を推定 する事は必ずしあ容易ではなかった。そてで，擦過 細胞像による深達度推定の基礎とするため, 深達 度別の擦過細胞像を検討した。対比として, 異形成, $\mathrm{X}$ 線有所見肺癌の細胞像屯検討した。検討項目は, 異型細胞数, 異型細胞集団数, 細胞の染色性, 集団 を形成する細胞の核面積, 核形不整の程度, 核 1 ケ あたりの核小体数である。その結果, 異型細胞数, 異型細胞集団数は異形成，上皮内癌で有意に浸潤 例より少なく,核面積は異形成, 上皮内癌で浸潤例 より有意に小さかった。核形不整の程度は浸潤が 平滑筋層を越えると有意に不整となっていた。核 小体数は浸潤が進むにつ増加する傾向にあった。

\section{6. 肺滤手術時の洗浄細胞診の意義}

神奈川県立がんセンター外科1),検査第一科2)， 神奈川県立循環器呼吸器病センター検査科3) O諸星隆夫 (MD) 1)，石橋 信 (MD) 1), 中村満美子 (C T ) 2), 神溒光代 (C T ) 2), 飯田萬一 (MD ) 2), 亀田陽 (MD ) 2) 早㴊洋子 (CT) 3)

はじめに : 進行肺虏においては、手術後の再発 形式を予測し、術後補助治療䘮する必要がある。 われおれは胸膜浸潤例 (P2以上) にお汁る癌性胸 膜炎再発と手術時の病巣の洗浄細胞診結果の関連 性を知るため、1987年より手術時に洗浄細胞診を 行っているが、今回は洗浄細胞診を施行した全例 について、胸膜浸潤と洗浄細胞診の結果について 検討を加えた。

対象と方法：1987年1月から1989年11月までに 肺癌の診断で肺切除術を受けた156例中、肺野発 生で、悪性胸水芯認力なかった88例（腺癌66例、 扁平上皮癌17例、小細胞癌4例、力ルチノイド1 例）について、開胸直後に50m10生理食塩水で、 胸膜㿟口の見られる部分ないし病巣より最も近い 胸膜を洗浄し、その回收液の細胞診を行った。

結果: 88例中18例がclassIII V、70例がclass $\mathrm{I} \sim \mathbb{I}$ 之診断された。前者では 0 , 3例、p1，2例、 p2,7例、p3,6例で、組織型は腺癌15例、扁平上皮 癌了例であった。後者では、p2,10例、p3,5例であ ったが、洗浄しても悪性細胞は認力られなからた。

観察期間方短いが、前者では5例の死亡があり、 そのう方3例に癌性胸膜炎荄認力、この他担癌生 存中の癌性胸膜炎症例が 1 例ある。後者では死亡 例は9例であるが、癌性胸膜炎の発症流なく、7 例には血行性全身転移を認めている。なお 0 0, p1 でありながら classIII〜Vと診断された5例のう ち2例は標本作成時の contaminationがあったと 思われるが、その他の3例、およびp2, p3でも class I〜I と診断された15例についても検討を 加之る。 
147. 肺癌手術患者における胸腅洗浄液の検討 一術前経皮穿刺吸引細胞診施行による影響一

国立姬路病院内科 ${ }^{1)}$ 、研究検査科 ${ }^{2)}$

O中原保治 (MD) ${ }^{1)}$ 、中原由紀子 (MD) ${ }^{1)}$ 、 西園寺正士 $(C T)^{2)}$ 、木下晴希 $(C T)^{2)}$ 、 桂栄孝 (MD) ${ }^{2)}$

肺癌症例において胸膜浸潤の有無はその予後に 与える影響が大きいため、われわれは肺嵒手術に 際し胸胫洗浄液あるいは胸水中の悪性細胞の有無 を検討している。今回、経皮穿刺吸引細胞診が行 われた症例についてまとめ報告する。

経皮穿刺吸引細胞診は肺癌診断において重要な 位置を占めているが、一方で、腫瘍を穿刺した針 を抜去する際、胸膜、胸膜腔、胸壁を経由するた め、腫瘍細胞が正常組織に播種される可能性が危 惧される。そこでわれわれは、経皮穿刺吸引細胞 診施行により胸膜腔に悪性細胞が移行するか否か をみることを目的として、術前経皮穿刺が行われ た症例の胸胿洗浄液の検討を行なった。

対象は昭和 63 年 5 月から平成 1 年 9 月までの間 の肺癌手術症例98例のうち手術時胸腔洗浄あるい は胸水採取の行なわれた44例である。うち術前に 経皮穿刺吸引細胞診が施行されたのは15例である。 方法 : 開胸時、胸水の認められなかった症例に ついては生食20m1にて胸胫を洗浄し洗浄液を回収、 胸水のみられた例では胸水採取し細胞診を行った。 成績 : 胸胿洗浄を行った 2 症例、胸水採取の 3 例が細胞診陽性であり、いずれも腫場の胸膜浸潤 が認められた。術前に経皮穿刺吸引細胞診を施行 した15例については病理診断にて胸膜浸潤度は11 例がp0、4例がp1と診断され、2例に胸水貯留が 認められたが、胸胿洗浄液、胸水の細胞診陽性例 はみられなかった。

結語 : 今回の検討では経皮穿刺吸引細胞診施行 により悪性細胞が胸膜㓐に播種したと考えられる 例はなかった。今後さらに症例を追加し検討する。
148. 肺結核診断における細胞診の有用性 について

坂総合病院病理科, 内科*, 細菌検査室 ${ }^{* *}$

神馬 悟 (CT), 岡本 聡 (CT), 岩間憲行 (MD) 高橋 武 $(\mathrm{MD})^{*}$, 歌川睦子 $(\mathrm{MT})^{* *}$

近年、肺結核の罹患率や死亡率は著明に改善し たが、今なお年間約 6 万人もの患者が新たに登録 されている。そこで、1989年 1 月から11月まで、 経気管支的擦過細胞診で肺結核が疑われた 4 症例 について、細胞診の有用性と、又どのような細胞 所見を示しているか検討した。

〔症例 1 〕 75 歳、男性。臨床診断 : 胸膜炎、肺炎。 細胞所見〜壊死物質、類上皮細胞を認めた。

〔症例 2 〕 57 歳、男性。臨床診断: 肺結核疑い。 細胞所見一壊死物質、類上皮細胞を認めた。

〔症例 3 〕 80 歳、女性。臨床診断：器質化肺炎。 細胞所見～壊死物質、類上皮細胞、Langhans 型 巨細胞を認めた。

〔症例 4 〕5 歳、男性。臨床診断: 肺癌疑い。 細胞所見～壊死物質、類上皮細胞、Langhans 型 巨細胞を認めた。

【まとめ】 Gaffky (一) の症例で、細胞診上結核 の疑われたケースが 3 例中 2 例にみられ、他の検 查に先がけて結核の可能性を強く示唆する所見を 得ることができた。また細胞所見では(1)背景の壊 死物質の存在、(2)類上皮細胞の存在、(3) Langhans 型巨細胞の存在など見られたが、特に(1)、(2)が重 要であると思われた。

以上の結果から、細胞診が肺結核診断上でも、 重要な検査であると思われた。

細菌検査の結果

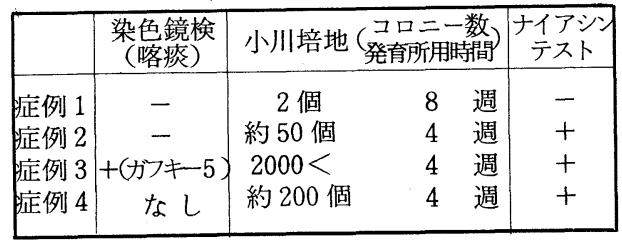


149. 肺癌外科治療成績からみた喀痰細盷 診の重要性

\section{東京医科大学外科}

河手典彦 $(M D)$, 三浦弘之 (MD), 池田徳彦 (MD), 高橋秀暢 $(M D)$, 中嶋 伸 $(M D)$, 山本秀樹 $(M D)$, 石井正倫 $(M D)$, 小中千守 $(M D)$, 加藤治文 $(M D)$, 早田義博 $(M D)$

肺癌の各種診断法の進歩によって，その治療成 績は年々向上しているが，今な扰発見時に既に進 行癌である症例が全体の約 $70 \%$ 占めている。ま た, 外科的に根治切除可能の状態で発見される症 例は約 $20 \%$ 亿過ぎない。

肺癌の治療成績を外科治療の立場からみると, その予後を左右する因子は主として病期と組織型 である。我々の教室に於ける肺癌切除 1376例の病 期別の 5 年生存率をみて 病期 I $: 74.8 \%$, 病期 II $: 57.5 \%$, 病期 III : $21.0 \%$, 病期 $N: 15.0 \%$ で, 当然の如く発見時病期の早いものほど手術によ る延命効果が期待できる。

教室におりる早期肺癌の治療成績は, 病期 I 症 例に比較して更に良好であり，5年生存率は中心 型早期肺癌では $98.3 \%$, 末梢型早期肺癌では 86.4 \%である。

最近, 病期 III の進行肺癌に対して術前化学療 法を施行して根治切除を可能とすることを目的と した neoadjuvant chemotherapyの試みが行われ ているが, てれらの治療上の価值判定には更に検 討が必要であろう。治療成績向上のためには治療 法の改良と同様に, 病期のはやい肺癌を発見する ことが極めて重要である。そのための一手段とし て胸部 X線検診があり, 集検群の治療成績は優れ ている。しかし, 早期中心型肺癌はX線像として 捕えるととは困難であり, 喀痰細胞誩によって補 う必要がある。米国で行われた, projectでは喀 疢細胞彮之X線写真による検晾の有効性は否定さ れたが, 今回は教室の外科治療成績を紹介し, 改 めて略痰細胞診のあり方を検討したい。
150. 肺癌N因子確定診断における胸部 $\mathrm{C} \mathrm{T}$ と T B A C の比較検討

\section{東京医科大学外科学第一講座}

○石井正憲 (MD)、三浦弘之 (MD)、斎藤 宏 (MD) 平栗俊介 (MD) , 高橋秀暢 (MD)、河手典彦 (MD) 小中千守 (MD)、加藤治文 (MD)、早田義博 (MD)

肺癌の病期分類のN因子を判定するために， 現在胸部CTの結果が最す信頼されているが, 術後の組織診断と術前の胸部CTの結果と比 較すると,その正診率は約 $60 \%$ 程度である。 このため我々は, 術前に胸部CTおよび経気管 支鏡的吸引細胞䛦 (TBAC)を施行し, 術後組織 学的にN因子を検索できた症例について検討 した。胸部CTは直径 $1 \mathrm{~cm}$ 以上リンパ節腫脹を 転移陽性とし，それ以下を転移陰性と判定した。 TBACは, Class I II III までを転移陰性ClassIV V を転移陽性とした。対象とした症例は，腺癌 26 例, 扁平上皮癌 12 例, 大細胞癌 4 例, 小細胞癌 1 例 の 43 症例であった。術後病期別ではstage I 10 例, stage II 9例, stage III 15例, stageIV 9 例で あった。胸部CTとTBACの結果の一致率を見る と胸部CT TBAC共に昌性であったのけ11例。 胸部CT陽性TBAC陰性は13例, 胸部CT陰性, TBAC 陽性は7例, 胸部CT陰性, TBAC陰性は9例であった。 術前にN因子を決定することは予後判定の上です 重要であり画像診断のみではなく，術前に質的 に診断することが必要と思われた。 またTBACは, 安全かつ簡便であり，胸部CTと共に N因子確定のために必須の診断法と考えられる。 


\section{1. 喀痰細胞診疑陽性例の検討}

\section{東京医科大学 外科、同 病院病理"} 0 三浦弘之 (MD), 加藤治文 (MD), 小中千守 (MD), 河手典彦 (MD), 石井正憲 (MD), 古川欣也 (MD), 山本秀樹 (MD), 早田義博 (MD), 三浦玲子 (CT), 海老原善郎 (MD) ${ }^{*}$, 越川真理子 (CT) ${ }^{*}$

【目的】近年早期肺癌の症例が増加しており、各 症例の細胞を retrospectiveに観察すると非常に 異型の弱いむのがある。そこで逆に喀痰細胞診で 疑陽性とされた細胞はいかなるものか検討し、診 断に役立てんことを目的とした。

【対象】1987年1月から12月までの一年間に東京 医科大学病院で行われた喀痰細胞診は2005件で疑 陽性は122例 (6.1\%)であった。このうち細胞検查 士、指導医ともに疑陽性と判定した症例が98あり、 保存のよい88例を対象とした。

【結果】扁平上皮系の細胞 73 例、腺系の細胞 9 例、 そのほか 6 例であった。扁平上皮系の細胞 73 例の うち、扁平上皮癌を疑える細胞は25例に出現して おり、出現細胞数や異型度の弱さから陽性と出来 なかった症例であった。うち 2 例は早期癌であっ た。確定診断は肺癌が 40 例、うち扁平上皮癌が 26

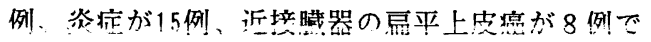
あった。腺系の細胞 9 例のうち 1 例は腺癌が疑わ れ、8 例は円柱上皮の異型增殖が疑われた。確定 診断は肺癌 3 例、炎症が 2 例であった。

核クロマチンの増殖が軽度でもN/C 比が大きく、 核異型のある細胞、小型でN/C 比が小さくとす彩 度が高くクロマチンの高度增量のある細胞を有意 に拾うと癌の診断がより高率的に行えた。

【考察】喀痰細胞診疑陽性の中には良性域の異型 細胞と、悪性域の異型細胞が含まれているのが実 状であるが、癌病巣由来の細胞です異型の弱いむ のがあり、いずれる厳重にfollowする必要がある。 したがって程度に応じてコメントに加えて○カ月 後再検や要精查と指導区分を設けるととあに、各 施設間の判定基準の統一が必要である。
152. 呼吸器細胞診の誤陽性例の検討

大阪府立成人病センター 細胞診断科 ${ }^{1)}$, 呼吸器科 ${ }^{2)}$ ○南雲サチ子 $(\mathrm{CT})^{1)}$, 福原直美 $(\mathrm{CT})^{1)}$, 伊藤幸子 ${ }^{1)}$, 宝来 威 $(M D)^{2}$, 松田 実 $(M D)^{2)}$

肺癌の診断には病巣の直接擦過や穿刺細胞診が 有用である。今回は呼吸器細胞診をより正確に判 定するために誤陽性であった症例の細胞所見につ いて検討を行った。

対象は 1981 年から 1988 年の間に大阪俯立成人 病センター呼吸器科で検查された気管支擦過, TV ブラシ, 肺穿刺材料で, 陽性, 疑陽性と判定した 症例のうち非癌と確診された 26 例である。結核症 10 例, 肺炎 8 例, 気管支炎 4 例, 硬化性血管腫 2 例, その他 2 例で，陽性と判定した例は 18 例，疑 陽性 8 例であった。結核症 10 例では, 陽性と判定 したものが 6 例（腺癌 5 例, 非角化扁平上皮癌 1 例 ) で, クロマチンが増量し, 核小体が著明な異 型の強い細胞を認めた例は 2 例で, 他はやや増生 した異型細胞の Over diagnosisであった。また

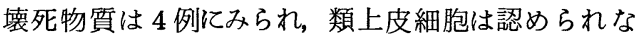
かった。肺炎 8例では, 陽性と判定したものが 6 例 (腺癌 2 例, 非角化扁平上皮癌 1 例, 大細胞癌 2 例, 小細胞癌 1 例) で, 細胞も核も大きく, 著明な核小体 を有する異型の強い細胞が5例認め, てれらは癌 細胞との鑑別がむつかしい細胞であった。気管支炎 4例では, すべて扁平上皮癌と判定しており, 角化型 の異型細胞や增生した基底細胞が認められた。と のように太い気管支の病変では異型扁平上皮化生 細胞が出現すると考元られ，乙れらは扁平上皮癌 細胞との鑑別が困難な場合があり, 厳重な follow up が必要と思われた。また肺の末梢の感染症に 出現する異型細胞は, II 型肺胞上皮細胞の増生し たものと考えられ, 癌細胞との鑑別には N/C, ク ロマチンの所見が参考となる。硬化性血管腫の症 例では癌細胞との鑑別は困難であった。 
153. 細胞診からみた肺腺癌の鑑別診断 につhて

千葉県がんセンター呼吸器科, 細胞診

○沢田勤也 ( M D ), 池田栄雄 ( C T )

平田哲士 $(\mathrm{C} \mathrm{T})$, 宮内博幸 $(\mathrm{C} \mathrm{T})$

胸部検診の普及に伴って, 集検 $\mathrm{X}$ 線上, 結節影を示 す症例が急速に増加しつつある。乙れらの病変は細胞 診からみて肺腺癌と鑑別の求められる場合が多い。

検討対象は, 高中分化型肺腺癌 24 例, 硬化性肺血 管腫 7 例, 気管支カルチノイド 8 例, びをん性悪性胸 膜中皮腫 2 例の計 41 例である。全例, 病理組織学的 䛦断がえられている。肺腺癌を中心とした鑑別上の 類似点と相違点についての主要所見について報告する。 硬化性血管腫につんて類似点は, 細胞の大小不同性 と核内封入体の存在であるが，相違点は紡錘型細胞， 2 核立方状細胞の出現と細胞腫の多いととで，P A S 染色ではグリコーゲン顆粒陽性，Al－B染色は陰性 である。乳頭状配列所見のみに把われないように注意 すべをである。気管支カルチノイドは，肺腺癌との 類似点として立方状細胞で， $\mathrm{N} / \mathrm{C}$ も同程度であるてと が挙げられるが，柵状，ロゼット様配列が時にみられ， 腺癌より細胞異型が低い。末梢例では紡鍾型細胞が多 く認められる。核クロマチンは細, 粗顆粒が混在し, 核小体も $2 \sim 3$ 個認められる。P A S 染色怪度陽性, $\mathrm{A} \boldsymbol{l}$ - B 染色は陰性である。

悪性胸膜中皮腫は肺腺癌と最も鑑別が困難である。 乳頭状配列を示し, 細胞は立方状で大小不同も著しく, 核クロマチンは細顆粒状で濃染し核内封入体もしばし ば認められる。核の折れ込み所見も肺腺癌と同様, 時 々観察される。核小体时に異常に大なることがある。 P A S 染色は核周㘫に好染し，A $\boldsymbol{l}$ - B 染色は陽性で 表面型である。相違点としては, PA S 染色所見と散 在性に大型細胞が認められ，しばしば 2 核形成を伴っ ている。また，小型細胞が集団を形成して観察される ことが挙げられる。

今後は, 肺胞II型細胞の増生を伴らようを疾患を対 象に,さらに検討していく必要があると考える。

\section{4. 単純ヘルペスウィルス肺炎の一例}

\author{
済生会下関総合病院 病理検査室 \\ ○岩崎史夫 (CT) 福間冨士美 (CT) \\ 川内野和孝 (CT) 和田知里 (CT) \\ 呼吸器内科 \\ 藤田博司 (MD) 中島明雄 (MD) 池田賢次 (MD) \\ 池田顕彦 $(\mathrm{MD})$ 月野光博 $(\mathrm{MD})$
}

単純へルペスウィルス（H S V ）は口唇や性器 に皮膚粘膜病変を起こすウィルスとして知られて いるが、免疫機能低下の宿主では肺炎の原因とな るととも報告されている。我々は、悪性リンパ腫 の治療中に呼吸不全状態となった患者でPneumoー cystis carinii れる肺炎の一例を経験したので文献的考察を加え 報告する。

症例：3 3 歳 女性。昭和 63 年 12 月初めより 悪性リンパ腫の再然のため化学療法 (Cyclophosphamide, Adoriamycin, Vineristin, Pepreomycin, Predonisolone)を受けていた。12月12 日には 白血球が $1800 / m^{3}$ と減少し、1 2 月 21 日より咳 嗽が出現し $38{ }^{\circ} \mathrm{C}$ をてえる発熱を認めるようにな った。抗生剤の投与により 1 月 5 日には解熱傾向 が認められたが、呼吸困難を生じ呼吸器内科に紹 介された。胸写では両側肺野に彌慢性浸潤影をみ とめた。著明な低酸素血症のため気管内捰管が行 われ人工呼吸が施工された。気管チューブより採 取された気道内分泌物の塗洙標本でH S V 感染細 胞と考えられる核内封入体を有する細胞が検出さ れた。患者は 1 月 13 日に呼吸不全の為永眠した。 剖検肺の組織学的検索で肺胞上皮細胞に好酸性の

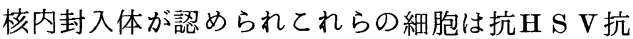
体を用いた酵素抗体法（ＡＢＣ法）で陽性を呈し た。一方、同時に行ったグロコット染色で Pneumo cystis carinii が検出され混合感染と考えられた。

H S V は従来免疫能の低下した患者の重症肺炎 で他の病原菌と混合感染をきたすことが報告され ており本例もその一例と考えられた。 
155. 肺の腺扁平上皮癌の 2 例

鎗田病院検査科 ${ }^{\prime \prime}$ 、同外科 ${ }^{2)}$ 、千葉県予防衛生 協会3)、国立習志野病院研究検査科 ${ }^{4}$ 、 千葉大学看護学部病態学 5)

○岩谷まり子 $(\mathrm{C} \mathrm{T})^{1)}$ 、古川敦子 $(\mathrm{C} \mathrm{T})^{1) 、}$ 鎗田努 $(M D)^{2)}$ 、神木弘子 $(\mathrm{C} \mathrm{T})^{3 !}$ 、

斎藤博子 $(\mathrm{C} T)^{4)}$ 、君塚五郎 $(M D)^{5)}$ 、

肺の腺扁平上皮癌は、腺癌部分と、扁平上皮 癌部分とからなる、比較的稀な腫瘍である。我 々は、今回、気管支擦過、T B A C および客痰 の細胞所見から、retrospective には、組織型 の推定が可能であったと思われる2例を経験し たので、その細胞像を中心に報告する。

[症例 1] 34才、男性。1988年4月4日、検 診にて肺の異常㓌影を指摘され、同19日、当院 を受診。精査のため客痰細胞診およびT B A C を行った。客痰標本には壊死物質と共に角化型 の扁平上皮癌細胞が忍められた。又、T B A C 標本では腺癌由来と思われる細胞が出現した。 5月11日、手術が施行され、摘出標本の病理診断 では、腺扁上皮漓であった。

[症例2］59才、女性。1988年 8月頃より 血痰が出現、次第に増量したため、同10月29日、 鎗田病院を受診した。精査の目的で茖痰細胞診、 気管支擦過およびT B A C を行った。客痰標本 では、Pap V 角化型扁平上皮癌とされたが、気 管支擦過、T B A C 標本には明暸な悪性細胞は 認められなかった。11月9日 手術が行われ、摘 出標本の病理診断は腺扁平上皮癌であった。細 胞診標本をretrospectiveに見直した結果、腺 癌を疑わせる細胞が認められた。

[ま之め]腺癌之扁平上皮癌では、1)治療法 が異なる場合や、2)転移形態が異なる場合があ るため、術前に組織型を適確に推定することが 重要であると考える。
156. 呼吸器細胞診にアスベスト小体の認め られた癌症例 -2 例

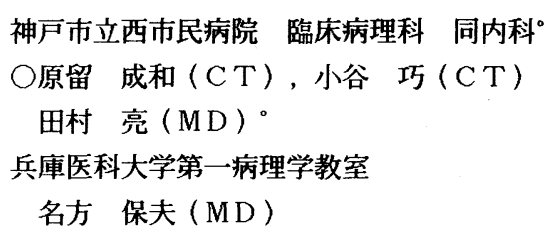

アスベストの刺激により悪性腫檺が発生する事 実が注目されているが，1988年5月から 19 89 年 11 月末迄 19 力月間の, 当院における呼 吸器細胞診検体総数は, 1944 で, その内 11 症例 18 検体（約0.93\%）にアスベス卜小体 が見られた。そして 11 症例の内 2 例が担癌例で あったので，組織所見を加えて報告する。 症例 1:87才男 アスベス卜曝露歴 無 1987 年 11 月 左上顎癌 (高分化型扁平上皮 癌）にて放射線療法，1989年4月右肺門部異 常陰影出現, 化学療法後, 現在外来にて経過観察 中。

症例 2:66才男 アスベス卜曝露歴 無 1988 年6月頃より狭心症で治療中。1989 年6月から胸痛があり, 左 $\mathrm{S}^{6}$ に異常陰影出現。 化学療法を行っていたが. 狭心症の発作が激しく なり, 同9月23日死亡。

職業性アスベスト曝露だけではなく, 生活環境 として，アスベスト製品からの吸入が問題視され ているが，一般病院として当院でのアスベスト小 体の検出率はかなり高率であると考えられる。今 後も增加傾向を示すことが予想されるので，検出 方法と，検出者の経過観察の方法の検討が, 今後 の課題である。 
157. 限局性肺アミロイドーシスに拉ける細 胞診所見について

香川県立中央病院 内科1）検查科 2 )

$\bigcirc$ 亀井雅 $(\mathrm{MD})^{1)}$, 白井求 $(\mathrm{CT})^{2}$ ), 下浦泰昌 $\left.(\mathrm{CT})^{2}\right)$ 岡根倫代 $(M T)^{2)}$, 角谷昌代 $(M T)^{2)}$, 桑島実 $(\mathrm{MD})^{2)}$, 藤田甫 $(\mathrm{MD})^{2)}$

香川医科大学第一病理学教室 ${ }^{3}$ 荻野哲朗 $(\mathrm{MD})^{3)}$ N T T 高松病院内科4）岡田宏基(MD) ${ }^{4)}$

原発性結節性肺アミロイドーシスは稀な疾患で あり, 我々の調べ得た範囲では本邦で15例の報告 をみるのみである。今回我々は, 胸部レントゲン 上多発結節影を呈した限局性肺アミロイドーシス を経験したので，細胞診所見を中心に報告する。 【症例】60歳女性で, 既往歴として50歳時に子宮 癌にて子宮全摘術を受けている。56歳頃より胸部 異常影を指摘され，じん肺症疑いにて経過観察さ れていたが，集検にて異常を再指摘され当科紹介 となる。血液学的検索では異常を認めなかった。 経気管支肺生検を施行し H・E染色標本にて多量の エオジン淡染性の均一物質の小血管への沈着を認 め, Congo-red染色にて緑色偏光を示し, 過マン ガン酸処理に抵抗性であった。抗 A A タンパク陰 性で non A A タンパクの性質を有していた。肺以 外飞病変はなく限局性肺アミロイドーシスと診断 した。

【細胞所見】Papanicolaou 染色では, 悪性細胞は なく, 壊死椂無構造物質を認め, 偏光顕微鏡にて 偏光を示し, Cong-red 染色にて強い偏光を有し, アミロイド物質と診断された。

【結語】Papanicolaou 染色儿て壊死性無構造物質 が認められた場合は, 偏光顕微鏡による検索をき っかけにアミロイドと診断される場合もあり, ア ミロイドーシス診断に有用と思われた。
158. いわゆる肺硬化性血管腫の経皮的肺針 吸引細胞像の検討

国立療養所道北病院内科

○藤田結花 $(M D)$, 清水哲雄 $(M D)$, 坂井英一 $(M D)$

国立がんセンター臨床検査部細胞検查室

上井良夫 $(\mathrm{MD})$

いわゆる肺硬化性血管腫の術前診断は細胞診に よるところが大きいが，術前に診断された報告は 少ない。今回われわれは, 本腫瘍の術前診断を目 的として経皮的肺針穿刺吸引細胞像 (穿刺細胞像) と肺末梢型腺癌との鑑別点について検討したので 報告する。

【対象】1981年から1989年まで国立がんセンター にて摘出され肺硬化性血管腫と診断された11例の うち，術前に穿刺細胞診が行われた 8 例である。

【検索方法】穿刺細胞診は成毛生検診を用い，染 色はパパニコロウ染色とギムザ染色, アルシアン 青染色を用いて細胞像を検討した。

【成績】細胞診陰性と診断した 5 例と偽陽性とし た1例では採取された細胞数が少なく，陽性と診 断した 1 例と陰性とした 1 例では多数の細胞を認 めた。出現している細胞は多種類であり，大別す ると小型類円形細胞, 大型多辺形細胞, 組織球, リンパ球などの炎症性細胞であった。小型類円形 細胞は，N/C 比は大小様々であるが，核にシワ を認めず，クロマチンは微細顆粒状で全体に異型 に乏しかった。この細胞は散在性あるいは数珠状 に配列し, 時に乳頭状集塊を形成していた。また, 乳頭状集塊の内部に紡鍾形の核を認めた。大型多 辺形細胞は類円形細胞に比して少数で, 細胞質が 広く核も大きく,クロマチンはやや粗粘のものも あり，大型円形のよくめだつ核小体を認めた。

【考察】大型多辺形細胞は腺癌細胞との鑑別がむ ずかしいが少数であり、採取細胞が十分である場 合には小型類円形細胞, ヘモジデリン領食組織球 などの多彩な細胞像に注目すれば診断は可能であ ると思われた。免疫学的検討も加えて報告する。 
159. 肺癌についての Epidermal growth factor receptor (EGFR) 免疫化学的染色の検討

埼玉医科大学第二病理学教室

O藤田 勝 (CT), 宮下ひとみ (CT), 則竹澄子 (MT) 高浜素秀 (MD)

Epidermal growth factor receptor (以下EGFR) は、細胞の癌化およびその増殖に際して著しい増 加を示し、特に扁平上皮癌系の腫瘍マーカーとし て有力とされている。今回我々は、肺癌について 組織ならびに喀痰細胞診検体についての抗EGFRモ ノクロナル抗体を用いた $\mathrm{ABC}$ 法醭素抗体染色を試 み、その固定条件、抗体の種類、染色法などを評 価したので報告する。

材料と方法：1）先ずEGFRに関する至適固定条 件を求めるために培養扁平上皮癌細胞 (A 431) を 用い、喀痰細胞診用の各種固定液で数日間固定し、 抗EGFR一次抗体に引き続き、FITC標識の二次抗体 による蛍光免疫染色を施し、flow cytometryで測 定して蛍光強度を比較検討した。2) 組織染色で は肺癌手術症例の各種癌組織を液体窒素凍結して cryostat切片を作製し、ethanol 系、paraformaldehyde系、formalin系の各種固定液で固定し、固 定条件および抗体の種類による染色性の差異につ いて検討した。3) 喀痰細胞診用固定液 (スプー トル）で固定した肺癌症例の喀痰および擦過材料 につき、ABC法酵素抗体染色を検討した。

結果：1）それぞれの固定液により、培養扁平 上皮癌細胞 (A 431) の蛍光強度に差異を認めた。

2 ) 凍結切片用固定液では我々が考案した4\%paraformaldehyde/40\%ethano1/PBS solution (PEPS) お よび70\%ethanol、中性formalinで優れた固定効果 がみられ、一次抗体では OSI社モノクロナル抗体

（Ab-1）が癌細胞に対し優れた陽性所見を示した。 3 ) 喀痰中の癌細胞では強い陽性所見を示す細胞 もみられたが、一部微弱な所見のみの検体も認め られたので、その原因等の考察も含めて報告する。
160. 浸潤性胸腺腫の細胞像とDN A 分析 一気管支内、心衰内に浸潤した 2 症例を対象に一

栃木県立がんセンター 研究検査部 11 、娭査技術 部

O島村香也子 (MD) " 種二 (MD) " 、鈴木恵子 (MD) "

悪性胸腺腫が浸潤とともにどのように細胞像と DNAバターンを変えて行くか、浸閏先でどこま で細胞診断が可能かなどを明らかにするため、気 管支内、心曹内等に進展した浸潤性胸腺腫の 2 症 例を対象に、細胞像とDNA分析を行った。

[症例] 1.59藏女性。模診で前絿隔から左肺 上葉にかけての異常陰影を指摘され入院。緹隔生 娭により胸腺腫と判明し、手術が施行された。睡

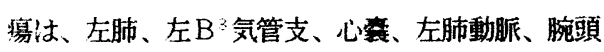
静脈等に浸潤していた。2.69歳男性。上大静脈 症候群のため他院より転院し、絴隔生検により胸 腺腫と診断され手術。上大静眽、睕頭静脈、右心

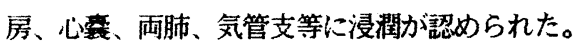

[細胞像] 症例 1 では、胸腺穿刺、気管支擦過 及び心囊水吸引細胞診標本で、多数のック゚ 球に混 在して少数の上皮細胞が認められた。上皮細胞に は、勫胞筫が広く、明るい大型核と腫大した核小 体老持つ細胞と、細胞質力狭く、暗い核と小さな 核小体を有する細胞があり、浸潤先では後者が多

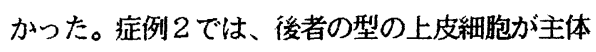
をなした。心異水吸引標本では上皮細胞が小型円 形化し、川的球との鑑別か難しかったが、核の大 きさと形の不同、核小体の存在、ギ却染色での細 胞質の染色性などが鑑別点になると思われた。

[DN A 分析] 胸腺、気管支内腫瘤、心震内腫

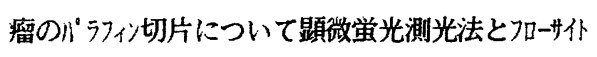
外リーを、また胸腺穿刺、気管支擦過及び心䟺水吸 引細胞診標本については、矰微栄光測光法を施行 した。原発巣、浸閏先ともにdiploid patternを 呈し、SG2M期の細胞の比率は、浸潤部位に拘わら ず、症例 1 で約 $36 \%$ 、症例 2 で約18\%であった。 
161. 肺大細胞癌飞打けるDNAーploidy と 細胞所見の関連についての検討

千葉大学医学部肺癌研究施設外科、千葉大学附属 病院中検細胞診 1

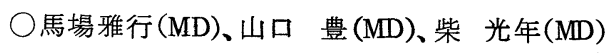

山川久美 $(M D) 、$ 飯筑俊彦 $(M D) 、$ 藤沢武彦 $(M D)$

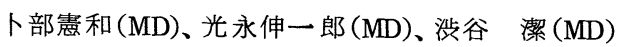

小高恵美子 $(\mathrm{MD})$ 、堀内文男 $(\mathrm{CT})^{1}$ 、大木昌二 $(\mathrm{CT})^{1}$

肺の大細胞癌はホルモン産生能あるいは高度の 化学療法感受性を有するるのなどその生物学的特 性は多様であり、形態学的にも種々の所見を呈す る。今回は細胞䛦による本腫瘍の生物学的特性の 推定の可能性を検討する目的で DNA-ploidy と 腫瘍細胞所見の関連性について検討した。

材料拈よび方法：1978年1月から 1989年11月ま でにわれわれの施設で切除を行つた肺大細胞癌の らち切除標本割面の捺印あるいは経皮的針生検飞 よる細胞所見の解析が可能であつた 13 例である。 年令は 35〜80才、平均 59才で男女比は $12: 1$ であ る。DNA-ploidyの解析は腫瘍のパラフイン包埋 ブロックから厚さ $30 \mu$ の薄切組織を作製し、FACS によるパターン解析を行つた。

結果抢よびまとめ：DNA一ploidy の解析の結 果では diploid (D群) が 8 例、aneuploid (A 群)は5 例であつた。細胞所見ではいずれの群も明らかな 腺癌あるいは扁平上皮癌の分化傾向は認められな かつたが多変量解析による判別分析の結果、 $\mathrm{A}$ 群 では濃縮核の出現、N/C大、高度の hyperchromasia がみられ、核小体は $2 \sim 5$ 個と D群に比して多く、 核小体周囲明庭飞乏しく、核分裂像は低頻度など の特長があり、また壊死が高度であつた。肺大細 胞癌の細胞学的特長とされる豊かな細胞質、明る い大型核、分葉核ないし多核、核分裂像などの所 見を呈する症例は 5 例であつたが、いずれるDNA -ploidy は diploid patternであつた。

以上、上記の 6 種の細胞所見の検討にょりDNA 一ploidyを推定することが可能と考元る。
162. 肺腺癌における組織学的因子と核 D N $\mathrm{A}$ 量、核蛋白量との関連に対する検討

\section{東京医大外科学教室}

池田徳彦（M D) 、三浦弘之（M D ）、伊藤哲 思 (MD) 、奥沢 健 (MD) 、田中浩一 (MD) 、石井正憲 $(M D)$ 、高橋秀暢 $(M D)$ 、河手典 彦 $(M D)$ 、小中千守 $(M D)$ 、加藤治文 $(M D)$ 、早田義博 (MD)

肺の腺癌は症例により生物学的悪性度が異なって おり、各種治療法に対する反応す多岐にわたって いる。一般に、組織学的に未分化な症例は高分化 な症例より予後が不良で、リンパ管侵襲、血管侵 襲陽性の症例は陰性の症例に比し予後不良とされ る。今回我々は、東京医大外科で切除された腺癌 $\mathrm{T} 1$ 症例 27 例につき細胞化学的に核 D N A 量、核 蛋白量を測定し、組織学的分化度、リンパ管侵 襲、血管侵襲との関連に付き検討した。27例のう ち、 2 年以内に死亡した症例が14例、 5 年以上生 存した症例が13例である。切除標本より、

B. Shut teの変法により細胞を単離し、Feulgen Naphthol Yellow $S$ 染色後、定量細胞診断TV力 メラシステムにより核D N A 量、核蛋白量を測定 した。癌細胞增殖の指標として核蛋白量の核 D N A 量に対する比 ( $\mathrm{P} / \mathrm{C}$ 比)、 $\mathrm{P} / \mathrm{C}$ 比が1.8 以 上の細胞の割合 $(\mathrm{P} / \mathrm{C}>1.8)$ と組織学的因子、検 討した結果、高分化症例（17例）と低分化症例 (10例)ではP/C比、P/C>1.8において有意差を 認めなかった。一方、リンパ管侵襲、血管侵襲陽 性の症例（各々13、9例）は陰性の症例（各々 14、 18例）に比し $\mathrm{P} / \mathrm{C}$ 比、P/C>1.8 のいずれす有意に 増加していた。以上の検討より、細胞增殖が増加 した状態では、生物学的悪性度が高く転移を助長 していることが推察された。 
163. 肺癌の原発巣とリンパ節転移巣の D N A ploidy pattern の比較

東京医科大学外科、同病院病理部・

○伊藤哲思 (MD), 池田徳彦 (MD), 田中浩一 (MD)， 三浦弘之(MD)，土田敬明(MD)，平野隆 (MD), 河手 典彦(MD), 小中千守(MD), 加藤治文(MD), 早田義 博 (MD), 海老原善郎 (MD) *

（目的）腺癌と扁平上皮癌は、肺癌の代表的な組 織型であるが、その性格は大きく異なる。本院で 切除された症例においてす、その両者では縦隔り ンパ節転移（ $\mathrm{N}_{2} ）$ の頻度に有意差を認めた。そこ で、これを定量細胞化学的に解析した。

（対象及び方法）1982年1月〜1987年12月に本院で 切除された肺癌症例のうち、腺癌 175 例、扁平上皮 癌118例で、このうち $\mathrm{N}_{2}$ 症例は各々50例（29\%）、 17例（14\%）であった。この中から無作為に10例ず つを選び検討した。各症例のパラフィン包埋材料 より細胞を単離させ、Feulgen-Naphthol Yellow $S$ 染色を施し、一例につき 100 個の癌細胞と対照 となる同一標本上の小リンパ球 20 個を無作為に 抽出し、547 nm と $436 \mathrm{~nm}$ の波長で核D N A 量と 核タンパク量を計測した。

(結果) 原発巣とリンパ節転移巣での D N A ploidy pattern を比較すると、両組織型とも転移 巣において aneuploid pattern が増加した。腺癌 では転移巣において核タンパク量が有意に増加し たが、扁平上皮癌では有意差を認めなかった。 D N A ヒストグラム相互の類似性を多変量解析に て分析したところ、腺癌では原発巣と転移巣とは 1 例を除き全て類似していると判定された。扁平 上皮癌では 1 例を除き全て類似性がないと判定さ れた。この結果 Fischer 法により、腺癌は原発巣 と転移巣とが類似し、扁平上皮癌は類似していな いと考元られた。（ $p=0.0019 ）$
164. Ag-N O R 染色を細胞診に応用するた めの基礎的検討 1 ．細胞分散法による影響

\author{
杏林大学保健学部細胞診断学教室 \\ ○名古屋美智 (学生) 椎名義雄 (CT) \\ 飯島淳子 (CT) 沢田好明（MD)
}

NOR（nucleolar organizer resion）は蛋白 合成に関係する核小体の形成部位として考えられ、 また、細胞增殖と密接に関係することも諸家の報 告から明らかになってきた。また、最近の報告を 見ると、細胞診における良悪性の鑑別診断におい てN O R 染色が極めて有効な方法であると述べて いるものが多い。しかしながら、我々の数少ない 経験から、塗抹標本、特に細胞重積性の強い集団 では周囲と中央部で染色性に差があり、検討の必 要性を痛感した。そこで我々は、蛋白分解酵素を 用い細胞分散を試みた。今回は、細胞分散処理に 伴うN O R 染色の局在性、および染色性への影響 を観察したのでその成績を報告する。

\section{【方法および材料】}

検索材料はEeagle's MEM倍地で72時間培養した HeLa 229 細胞と、手術摘出胃粘膜をメスで擦過し て得た細胞である。それら細胞は $37^{\circ} \mathrm{C} に$ 加温し酵 素液に直ちに浮遊させ、経時的に固定標本を作成 した。 細胞分散のために使用したトリプシンは Difco 社而の (1:250) を最終㴗度がU. Ub\%、之 $0.25 \%$ に調製した。固定は95\% エタノール、 $\mathrm{Ag}$ N O R 染色は 1 step法で行った。

\section{【結果】}

細胞分散は $0.25 \%$ では数分、 $0.06 \%$ でも 10 分以 内に完了した。また、光顕レベルの観察において、 細胞形態およびN O Rに及ぼす影響はないと思わ れた。但し、消化後の細胞成分の洗浄が重要と思 われた。また、粘液成分を除去することが課題と して残った。 
165. 細胞集団における $\mathrm{S}$ 期細胞の分布と良 悪性との関係

\begin{tabular}{|c|c|c|}
\hline & & \\
\hline ○椎名義雄（CT） & 飯島淳子 & \\
\hline 稲垣伸介（NT） & 沢田女 & ( \\
\hline 林大学医学部第 & 学教 & \\
\hline 関原 正 (ND) & 福島久 & \\
\hline 网垏圭 & & \\
\hline
\end{tabular}

細胞の增殖性をより客観的に評価できる方法と して抗-bromodeoxyuridine(BrdU) モノクローナ ル抗体を用いた酵素抗体法は、 ${ }^{3} \mathrm{H}$ サイミジンを 用いたオートラジオグラフィーに比べ細胞診にお いても容易に応用可能な方法である。In vitoro による方法はすでに当学会でも報告しているよう に、比較的安定した成績が得られるようになった。 今回は、細胞標本における $\mathrm{S}$ 期細胞の分布と良悪 性の関係を検索した。

【検索材料および方法】

今回の検索には正常各周期の子宮内膜 15 例、子 宮内膜腺癌 8例、adenomatous hyperplasia 5 例、 乳癌 7例、乳腺良性病変14例、胃癌15例、胃非癌 部11例を用いた。

全ての症例は、手術摘出後速やかにBrdUの取り 込みを行った。その条件は $37^{\circ} \mathrm{C} 、 3$ 気压、60分間、 $5 \% \mathrm{CO}_{2}, 95 \% \mathrm{O}_{2}$ の環境下である。染色は4N-HClで DNA の单鎖化を行い、中机伐、睬系㧈体間接法“゙ 検出した。

\section{【結果】}

$\mathrm{S}$ 期細胞の分布は良悪性で異なり、悪性例では $\mathrm{S}$ 期細胞が密に接するように出現した。また、悪 性例では、細胞集団間でlabeling indexがかなり かなり異なった。
166. Cytometry:同一検体によるUV-顕微分 光測光とflow cytometry-routine への導入(V)

相互生物医学研究所 病理 · 細胞診セン夕 ${ }^{*}$ 社会保険山梨病院 病理、金沢医大 病理 ${ }^{* * 1 *}$ O田中 昇 (MD, DDS) 、大塚重則 (CT) , 小俣好 作 $(M D)^{* *}$, 上野喜三郎 $(C T)^{*}$ 、松山みどり $(C T)^{*}$, 今 野千賀子 $(\mathrm{Cr})^{*}$ 、武川昭男 $(M D)^{* * *}$ 、上妻喜勝 $($ CT $)$

形態学的知見にだけ頼る組織学的診断、細胞診 は主観的見解、経験の累積に依存する所が大であ り、しばしば境界領域病変の範疇を脱し得ない。 腫瘍の良性、悪性のparameter の一つとして、形 態学に細胞生物学的知見を加味して客観的表現を することは価値のあることで、従来より核 DNAploidy解析が導入されている。その際, 裸核にし てFeulgen 反応、PI/FITC など種々な方法が実施 されているが、裸核にすることによって細胞の大 きさ、N/C 比などの知見を全く儀牲にしてしまい 、形態分析を主流とした我々の細胞診断自動化装 置CYBESTへの導入は不可能である。

そこで塗抹標本は勿論, 生検、手術材料、ホル マリン固定材料、更にはパラフィンブロックより

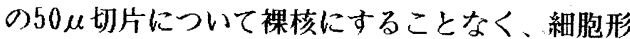
態、成分を良く保つベく trypsin処理、機械的細 胞分散法を工夫し、細胞浮遊液から塗抹標本を作 製、HP/DAPI 法 (高浜) 染色公施L、目的細胞を 確認しつつ、独自に開発したソフトを用いオリン パス 0SP-1で紫外部顕微分光測光、同一検体の細 胞浮遊液についてFACStar Plusによるflow cytometry, cell sortingを行って検討、現在まで 200 例以上を検索し発表してきた。CYBEST集検検体八 の応用例のほか、実際的に価値ある症例の中から condy loma，消化管腺腫、甲状腺リンパ腫、また予 后の明らかな羘癌、肺癌、などを提示、また手術 例、剖検例の解析データについてploidy pattern のみによらず蛋白量などとの関連についても報告 する。 
167. Multicellular Tumor Spheroids (MTS )とFlow Cytometry（FCM）を用いた新細胞株樹立 の確認

${ }^{1}$ 北海道大学大学院環境科学研究科、 ${ }^{2}$ 日鋼記念病 院、 ${ }^{3}$ 北海道大学齿学部付属病院検査部、“ 北海道 大学医学部付属病院病理部、 ${ }^{5}$ 中央医院

$\mathrm{O}^{1}$ 井上勝一 $(\mathrm{MD}) 、{ }^{2}$ 高岡和夫 $(\mathrm{MD}) 、{ }^{3}$ 水 野重孝、“遠藤隆志 ( C T )、 ${ }^{5}$ 伊藤正美 (MD)

最近の細胞培養技術の進歩により、細胞株の樹 立も比較的容易になった。また、新細胞株は抗癌 剂の感受性テストなどに有用である。しかし、新 細胞株樹立の確認のためには、1) ヒト細胞由来の 確認、2)細胞病理学的な原発巣との一致性の証明 、3)腫瘍原性の確認、4)他の細胞の混入の否定等 が必要である。このため、従来、染色体分析、ヌ 一ド・マウスへの移植などが行われてきた。しか し、ヌード・マウスの飼育、維持は必ずしあ容易 ではなく、これに替わる万法が啒望されている。 そこで、われわれは、MTS とFCM を用いて、新樹 立細胞株NPC-1 の確認を行ったので報告する。

MTS はYuhas の方法により作製した。FCM によ る腫瘍関連抗原の測定は、間接法による抗原物質 のFITr染色とDNA のPI染色の同時染色により行な った。MTS を圧挫し、パパニコロウ染色し、凍結 切片をH. E. 染色し、パラホルムアルデヒド固定後 走査型電䫓で、また、パラホルムアルデヒド・オ スミゥム酸二重固定後透過型電顕により形態学的 検討を行った。

パパニコロウ染色では、腺癌細胞の極性、扁平 上皮癌細胞の流れ状構造、小細胞癌の結合性の欠 如等細胞型の特徵がよく現れていた。H.E. 染色で あ組織型の推定は容易であり、電顕像であ細胞表 面微細構造および細胞間結合方式の観察に優れて いた。また、FCM の測定により、他細胞の混入の 有無は容易に判定できた。

新細胞株樹立の確認は、染色体分析にMTS と FCM を加えることにより可能と考えられた。
168. 細胞増殖過程における $\mathrm{Ki}-67$ 抗原量 の変化

北海道大学医学部第一内科

○磯部安 $(\mathrm{MD})$, 清水透 (MD), 羽田均 $(\mathrm{MD})$, 石黒昭彦 $(\mathrm{MD})$, 原田真雄 $(\mathrm{MD})$, 小倉 湤明 $(\mathrm{MD})$, 宮本宏 $(\mathrm{MD})$, 川上義和 $(\mathrm{MD})$

近年, 増殖相細胞の核抗原を認識するモノクロ 一ナル抗体 Ki-67を用いて, 免度組織学的に各 種腫瘍を対象に, その染色性と腫瘍覀性度, 予後 等との関連の検討が行われてきている。しかし， 細胞周期や細胞増殖過程での $\mathrm{Ki}-67$ 抗原量の変 化の検討は少ない。今回フローサイトメトリー を用いて，培養細胞を対象に細胞増殖過程におけ る Ki-67 抗原量の変化を測定した。

対象と方法：ヒト肺癌培養細胞株 PC-3（腺癌） , PO-6（小細胞癌）を対象とした。細胞成長 曲線はTrypan blue dye exelusion法に よって計測した。モノクローナル抗体 $\mathrm{Ki}$-67 の 染色は以下の様に行った。対象検体を $95 \%$ ア セトン, $-20^{\circ} \mathrm{C}$ で固定した後, PBS で洗浄し， モノクローナル抗体 $\mathrm{Ki}-67(20 \mu \mathrm{l} / \mathrm{ml})$ を $4{ }^{\circ} \mathrm{C}$ , 30 分間反応させた。次いでPBSにて再洗浄

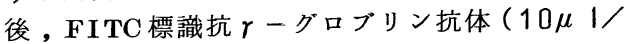
ml ) で $4{ }^{\circ} \mathrm{C}, 30$ 分間処理し，Ki-67 抗体を FITC染色した。さらにPBSにて洗浄後, RNa se 加Propidiam i odide $(50 \mu \mathrm{g} / \mathrm{ml})$ で核DNAを染色し,二重染色とした。螢光量の 測定はFACScs n を用いた。

結果：対数増殖期に打いては $\mathrm{PC}-3, \mathrm{PC}-6$ とも $\mathrm{G}_{1}, \mathrm{~S}, \mathrm{G}_{2} / \mathrm{M}$ 期で $\mathrm{Ki}-67$ 抗原陽性細胞を認 めた。一方, 静止期に抮いては，PC一ろでは $\mathrm{S}$ お

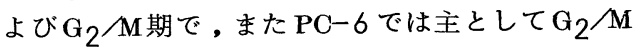
期で, Ki-67 抗原陰性細胞の出現を認めた。ま た静止期細胞を新鮮培養液下に戻すと，Ki-67 抗原陽性細胞の再出現を認めた。

結論 : Ki-67 抗原の発現は細胞増殖過程で大き く変化して打り．特に細胞の栄養状態, 細胞密 度に関連していた。したがって Ki-67抗原量 は腫瘍細胞の増殖度の指標と考えられた。 
169. 乳腺集検における分泌物細胞所見の検討 一石灰化像について一

宮城県対がん協会細胞診センター

水戸協同病院 $*$

○松井 昭義 ( C T ), 佐藤 由紀 ( C T ), 長谷川清美 $(\mathrm{C} \mathrm{T})$ ，伊藤 圭子 $(\mathrm{C} \mathrm{T})$, 武田鉄太郎(MD), 金田 尚武(MD), 東岩井 久 $(M D)$, 石岡 国春 $(M D)$ \%

宮城県対がん協会では，昭和52年乳腺集検の開 始当初から，一次検診に May-Grünwald-Giemsa 染色による分泌物細胞診を併用している。細胞所 見としては, 赤血球, 乳管上皮細胞集塊, 異型細 胞の 3 所見を重視してきたが，昭和62年度からは, 石灰化像もチェックすべき必須所見に加えている。 昭和 62 年 4 月から, 平成元年 9 月までに分泌物 の細胞診を施行した10,596件中，86件，0.81\%に 石灰化像を認めた。

石灰化像はすべて乳管上皮細胞集塊中に検出さ れた。色調は無色あるいは淡紅色で, 性状は, 無 構造, 顆粒状, 屈折性, 層状などを示した。

石灰化像を認めた 86 件(69例)のうち， 1 標本上 石灰化像 1 個のみは 37 件, 2 個は 8 件, 3 個は 13 件， 4 個以上は 28 件であった。石灰化像を伴った 細胞集塊を検索すると, 大集塊では時々 2 個以上 出現した。また, 色調は, 1 個のみの場合は, 大 半は無色で, 複数個では, 無色と淡紅色の混在傾 向がみられた。大きさは, $10 \mu \mathrm{m}$ 以上が77件と大 多数を占め, チェックされる限界と考之られた。

石灰化像を認めた69例のうち，58例にマンモグ ラフィーを施行したが, 墨性石灰像とされたもの 3 例, 良性石灰像 5 例, 所見を認めなかったもの 50例であった。

分泌液細胞診で石灰化像を認めた 69 例中, 癌 5 例（Tis 2 例，To 2 例含む），境界病変 1 例， 乳頭腫 7 例, 過形成 4 例が病理組織学的に確認巳 れた。
170. 乳頭分脑細胞診による乳癌の細胞像 と病理組織学的背景

\author{
大分県立病院 病理 $^{1}$ 、外科 ${ }^{2}$ \\ O辻浩一 $(M D)^{1}$ 、豊田長 $(C T)^{1}$ 、睍悦子 $(\mathrm{CT})^{1}$ 、 \\ 上野正尚 $(\mathrm{CT})^{1}$ 、後藤英雄 $(\mathrm{CT})^{1}$ 、阿南知子 \\ $(C T)^{1}$ 、玉井重信 $(C T)^{1}$ 、中村泰也 $(M D)^{2}$
}

乳頭分泌細胞診は、乳癌訅断の簡便な検査法で あり、また微小癌の発見に有力な手段とされ、 再評価されつつある。今回われわれは異常乳頭分 泌を主訴とした乳癌の細胞像と病理組織学的背景 について検討したので報告する。

材料および方法：細胞診材料は、乳頭分能物で、 術後病理組織学的に乳癌と診断した 15 症例であ る。細胞所見はパパニコロー染色によった。

結果 : 乳汁分泌口は常に特定の部位より生じ、 その流出口が 1 個のものが 13 例に、 2 個、4 個 が各 1 例にあり、自然流出は 13 例にあった。

細胞標本中の細胞量の多い症例は 4 例に、 少ないのものは 10 例であった。癌細胞の集塊の 状態は、大（30個以上の細胞よりなる）が 12 例に、小 (10 個以下) が 12 例に、中等度が 10 例にあり、それぞれ混在していた。立体的な 細胞集塊は 3 例のみであった。小の集塊は孤立細 胞と混在する頻度が高く、8例にあった。集塊を 作る癌細胞の核間距離の不整、細胞核の大きさ、 核形、クロマチンの増量、核小体などの所見は症 例によって種々であった。孤立細胞は9例にあり、 6 例にはなかった。对細胞は 12 例にあり、3例 にはなかった。石灰化は 4 例に見られた。

病理組䄉学的には非浸潤癌 7 例（充実型 1 例、 乳頭型6 例)，浸潤癌 8 例で、1 5 例の乳癌のう ち 1 例を除いてすべて乳頭型の増生を示していた。 面疮癌、硬癌、管内乳頭腫などとの合併が各々 1 例ずつに見られた。 
171. 乳腺の良・悪判定困難例に対する免 疫組織化学的染色の応用の可能性（第 1 報）

一癌胎児性抗原 $(C E A)$-孚癌関連抗原 $(B C A)-$

板橋中央釉合病院: 研究所 (IML), 外科

O畠山重春 $(\mathrm{CT})$ 、後藤恵子 $(\mathrm{CT})$ 、熊谷智子 $(\mathrm{CT})$ 、 高桑妃佐子 $(\mathrm{CT})$ 、渡辺哲弥 $(M D)^{*}$ 埼玉医科大学第 二病理：鈴木雅子(MD)、塩田 敬(MD)

東邦大学医学部第二病理 : 辻本志郎(MD)

佼成病院病理科：三浦妙太(MD)

乳癌の増加傾向と共に、形態学的な判定困難例 に遭遇する機会が多くなり、免疫組織化学的手法 の導入も盛んになっている。中でも乳癌のための 代表的腫掦マーカーの一つとして CEA をあげる ことが出来るが、今回 BCA(Bio Genex社) を CEA と併用し、判定困難例への応用の可能性を見出す ことを目的に検討を試みた。

対象は良性病変10例、癌40例の捺印標本である。 良性細胞は CEA が細胞集団の辺縁をふちどるよ うに染まるが、癌細胞では細胞個々が全周性に、 あるいは細胞質内がビマン性からドット状陽性を 示した。すなわち後者の局在性が癌細胞に特徽的 であるが、このような局在を示す緇胞が出現した のは全乳癌例の40\%であった。したがって、癌例 の半数以上は CEA 陰性であるが、陽性の場合は 特異性が高いといえる。一方、BCAは良性細胞、 悪性細胞間で局在性に著明な差はなく、細胞個々 が全周性からビマン性の局在を示し、癌例の約75 \%、良性例の約10\%が陽性であった。萁管上皮の 增生を伴う良性病変が陽性を呈した。陽性率の高 い $\mathrm{BCA}$ は CEA よりも癌例に特異性の低い傾向が 伺われた。良性例には CEA によって細胞質がビ マン性陽性を示す細胞は認められず BCAだけが陽 性であったが、癌例では両者に陽性の症例を多数 認めた。

判定困難例に於いて CEA、BCA の両方にビマン 性陽性を示す細胞を混在した場合、悪性の可能 性が強く示唆される。
172. 腫瘤触知不能 ( $\mathrm{To}$ ) 孚癌における病 理 - 細胞学的検討

東京都がん検診センター検査科1)，乳房科 ${ }^{2)}$

○藤井雅彦 $(\mathrm{MD})^{1)}$, 石井保吉 $(\mathrm{CT})^{1)}$,

後藤昭子 $(\mathrm{CT})^{1)}$, 佐久間市朗 $(\mathrm{CT})^{1)}$,

桐谷寿子 $(\mathrm{CT})^{1)}$, 野口正之 $(\mathrm{MD})^{2)}$,

松永忠東 $(\mathrm{MD})^{2)}$, 萩原 勁 $(\mathrm{MD})^{2)}$

腫瘤触知不能 ( $\mathrm{To}$ o) 乳癌のより効果的な検出法 老検討するため, To 乳癌の病理学的背景, 理学的 所見, 乳頭異常分泌ならびにその細胞学的特徵に つんて検索したので報告する。

[対象末よび方法]

1985年から 1989年までの 5 年間に東京都がん 検診センターで見つかったTo乳癌 15 例 ( P age t 病の 1 例を除く) を用いて, 腫瘍径, 組織型など の病理形態学的検索を行った。むた, 乳頭分泌の 有無, 分泌物細胞診の成績, その細胞像, および マンモグラフィーや超音波検査などの理学的所見 について検索し, 各種診断法に和ける精度の比較, 組織形態との関連性,さらには腫瘤触知例との差 異につんて検討した。

\section{[成績]}

$\mathrm{T}$ o 乳癌 15 例の組織型は非浸潤性乳管癌 4 例 $(26.7 \%)$, 乳頭腺管癌 10 例 $(66.6 \%)$, 硬癌 1 例 $(6.7 \%)$ で乳管内進展型の癌が大部分を占めた。 腫瘍の大ささについては, 最大径 $2 \mathrm{~cm}$ 以下のもの が10例（66.7\%）と多かったが，かなり広範囲 飞広がる症例も認められた。リンパ節転移は 1 例 (6.7\%) に見られたのみであった。

理学的検査では 7 例 ( $46.7 \%)$ にマンモグラフ イーで微小石灰化像などの異常所見が認められた。 一方, 乳頭異常分泌の見られた症例は10例 (66.7 $\%$ ）で, このらち9例 $(60.0 \%)$ は蓄乳法を用い た細胞診で陽性，1例（6.7\%) は疑陽性と判定 された。さらに, 分泌物中の細胞像について腫瘤 触知例との比較を行ったが, To乳癌飞特徽的な 細胞所見は見出せなかった。 
173. 乳腺細胞診疑陽性例における Peanut aggulutinin(PNA)結合パターンの分析とその診断 的意義について

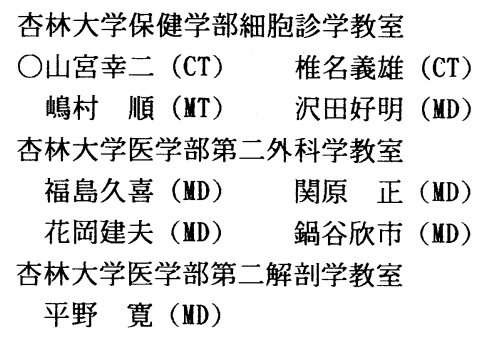
疑陽性と判定した 5 例で、それらの組織型は線維 腺腫 1 例、管内乳頭腫 2例、孚頭膘管癌 2例で る。使用したレクチンはVctor 社製で、0.1\%BSAPBS に2 $5 \mu \mathrm{g} / \mathrm{m} 1$ の濃度に調整したものを用いた。 検出は A B C 法で行ない、発色はジアミノベンチ ジンを使用した。

（結果）癌例と非癌例ではその結合パターンおよ び染色性の強さにおいて異なった。しかし、それ ら結合反応の評価を、個々の細胞について行なう より、細胞集団全体を評価対照にした時、診断的 効果を認めた。
174. 乳腺疾患にお污る穿刺吸引細胞診の 検討

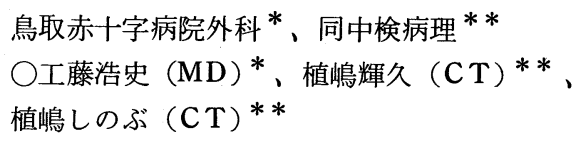

乳腺疾患に対する穿刺吸引細胞診はその普及とと もに診断率も向上しているが、稀に、その診断に苦 慮する症例も見られる。今回我々は本法施行例の成 績を分析し、誤診の要因について検討し、診断能向 上の一助とすべく若干の文献的考察を加えて報告す る。〔対象と成績〕症例は 1986年4月から 1989 年 11 月までに当院で本法が施行された乳腺疾患 241 例で ある。性別内訳は男性 8 例、女性 233 例。良、悪性別 内訳は癌 55 例、組織学的良性疾患 28 例、細胞診の結 果からみた良性疾患は 158 例である。癌例の組織型 別内訳は充実腺管癌 32 例、乳頭腺管癌 13 例、硬癌 4 例、非浸潤癌 3 例、小葉癌 2 例、粘液癌 1 例である。 細胞診の成績を組織型別にみると充実腺管癌は陽性 30 例、 $94 \%$ 、陽性疑 2 例、 $6 \%$ 、乳頭腺管癌、粘液癌及 び小葉癌では全例陽性とされていた。しかし、非浸 潤癌では 2 例、67\%が陽性、1例、33\%は陽生疑とさ れ、硬癌では陽性、陽性疑、陰性、判定不能がそれ ぞれ1例、25\%となっていた。この結果、陽性とされ たもののみを正診とすると $89 \%$ の正診率となるが、 陽性疑も正診とすると正診率は $96 \%$ に向上し、悪性 疾患に関しては極めて良好な成績と思われる。一方、 組織学的良性疾患 28 例をみると 2 例、7.1\%で陽性、 4 例、 $14.3 \%$ で陽性疑、 1 例、0.5\%で判定不能と されていた。しかし、細胞診で陰性として経過観察 している良性疾患 158 例も含めるとそれぞれ $1.0 \%$ 、 $2.1 \% 、 0.5 \%$ となる。すなわち、良性疾患では、陽 性とされたもののみを誤診とすると $1 \%$ 、陽性疑も 含めると $3.1 \%$ の誤診率となり、ほぼ満足のいく結 果と思われる。以上のように比較的良好な成績が得 られているが、誤診例の細胞像を分析することによ り、さらなる正診率の向上が期待できるものと思わ れるので、各症例の細胞像を合わせて供覧したい。 
175. 乳腺穿刺吸引細胞診による細胞像と その組織型の相関

慶應義塾大学病院中央臨床検査部病理

○松井栄美(CT), 田中陽一( DDS), 田代征夫(MD), 大宮恕子 (CT), 山崎優子 ( CT), 津田隆洋(CT), 深町 茂( CT), 佐藤文夫 (MT), 柴田一成( $\mathrm{MT})$, 杉浦 仁 $(\mathrm{MD})$, 入 久巳 $(\mathrm{MD})$

乳腺穿刺吸引細胞診 (以下 FNAC) は良悪の判 定む比較的容易で, ある程度組織型む推定できる 事から乳癌診断上の重要性が高く評価されている。 しかしながら細胞像による推定組織型之組織診断 は必ずしあ一致しない。

我々は 1986 年 7 月から 1989 年 9 月の約 3 年間 に行なわれた乳腺 FNAC 807 症例, 1161 件をむ とに両者がどの程度一致するかを検討している。 今回は組織学的最終診断が確定し, 細胞が充分採 取された浸潤性腺管癌, (1)乳頭状管腺癌, (2)充実性 腺管癌, (3)硬癌, (4)粘液癌計 47 症例を対象とした。 細胞像と組織像が一致したものは(1) 12 例中 7 例 ( う5面疮癌 5 例 ), (2) 17 例中 10 例, (3) 12 例 中 3 例, (4) 6 例中 5 例でいずれも他の組織型の混 合しない単一組織型によるあのであった。(1)の細 胞像は, 乳頭状, 立体的な集塊が多数出現し核の 突出や対細胞が, 又面疮癌はサイズが大きく核異 型の強い細胞が小集塊状や平面的に見られ, 背景 には多量の壊死物質を認めた。(2) 喵道様, 平面的 な重積を示す集塊, 細胞質辺縁が濃く染まり境介 明瞭な集塊之核異型の強い単個の細胞が多数散在 性に出現, (3)では細胞サイズが比較的小さく, 平 面的で小さい集塊が索状, 小集塊状に見られク口 マチン増量核, 細胞質内小腺腔む認められた。(4) では 6 例中 5 例に粘液が認められ, 判定に極めて 有効だった。組織型が混合しているすのでは相対 的細胞所見が優位な組織像を示すあの之, 不統一 な出現の仕方で特有な所見が得られず組織型推定 まで致らなかったものがあった。
176. 術前穿刺吸引細胞診に括ける乳腺疾患 の核異型度の客観的評価一画像解析装置を用いて

千葉大学医学部第一外科, 增田病院* (以下MD)

○宮内 允, 花輪孝雄, 堀中悦夫, 足立武則, 石毛英男, 山本尚人, 奥井勝二, 増田 豁 ${ }^{*}$

穿刺吸引細胞診法による乳腺疾患の診断の際, 核異型度の評価が重要であるが，その評価は時に 主観的な判断によるところが大きい。今回は核異 型度因子の詳細な検討の後, 画像解析装置を用い て核異型度を客観的に評価したので，その有用性 について報告する。

【対象】病理学的検索のなされた, 線維腺腫14例, 乳腺症 13 例, 乳管内乳頭腫 6 例, 浸潤性乳管癌 (5 5 5 年以上健存例 45 例, 再発例29例）を対象とした。

【方法と結果】術前穿刺吸引細胞診 Pa panicolaou 染色材料に括いて, 核䱋型度因子として核径, 核 形不整, 核大小不同性, Chromatin所見など10項 目に関して3段階評価を行い, 核異型度決定に関する 各因子の重要性を多変量解析により検討した。その結 果核異型度の評価には, 核形不整, Chromatin所 見に加え, 核の大小不同性がきわめて重要な因子 であることが判明した。次いで同Giemsa 染色材 料を用いて画像解析装置による核形態学的計測を 行い, 核大小不同性の指標として核面積変異係数 Coefficiency variant of nuclear area (NA. $\mathrm{CV}$ ) =核面積標準偏差/平均核面積 (\%)を算出した。 その結果NA.CVはとれぞれ，線維腺腫18.9 土5.0\%, 乳腺症 $22.4 \pm 5.2 \%$, 乳管内乳頭腫 $19.7 \pm 6.0 \%$, 浸潤性乳管癌 $30.9 \pm 9.4 \%$ (健存例 $25.2 \pm 4.7 \%$, 再発例 $39.9 \pm 7.9 \%$ ) であった。

【結語】乳腺疾患に括ける核大小不同性は, きわ めて重要な核異型度因子であり, また画像解析装 置を用いた NA. CV 值の算出は核異型度を客観的に 評価しらるのみならず, 乳腺疾患の良悪性診断や, 浸潤性乳管癌の予後に関しても, 良好な評価法で あることが示唆された。 
177. 乳腺穿刺吸引細胞診における 液状試料について一第 2 報，性状と細胞所見一

浜松医科大学病院病理部 O中島 昭 (CT), 原田英一(CT), 川端弥生 (MT), 中村真一(MD)

同 第一病理学教室

森田豊彦( $M D)$, 甲田賢治 (MD), 喜納 勇( MD), 同 第一外科学教室 馬場国男 (MD),

同 微生物学教室 松尾哲道 (CT),

乳腺穿刺吸引細胞診における液状試料について の成績は, 本学会 (第 28 回秋期大会) で報告し た。今回は, 試料の性状と細胞所見について検討 した。本院での過去約 10 年間における, 乳腺穿 刺吸引液状試料 360 例を対象とした。また組織診 断 42 症例の細胞所見について検討した。試料の 性状を 6 種類に分けた。1)灰白色 $118(32.8 \%)$. 2 )灰黄色 $122(33.9 \%) .3$ )灰褐色50 (13.9\%). 4 )チョコレート色 $30(8.3 \%) .5)$ 血性 35 ( 9.7 $\%)$.6)その他 $5(1.4 \%)$.である。

【悪性症例 12 例 】血性 7 .チョコレート色 3 . 灰 黄色 2 . 霊胞性病変を形成するものは, 通常の吸 引試料と比較すると悪性細胞の出現が少ないこと が多い，また変性所見も強い。

【良性症例】乳腺症（14例）。灰白色 8 .灰黄色 2 . チョコレート色 3 .血性 1 。細胞所見, a )泡抹細胞 64 \% . b ) アポクリン化生上皮細胞 $64 \%$.C )腺上皮細 胞の增殖性所見 $14 \% て ゙ ， a ， b ， C$,すべて認められた 症例は 2 症例と少なかった。管内乳頭腫（4例）。灰黄 色 2 .血性 2 .細胞所見の特徵は, 泡抹細胞の中等量 の出現と腺上皮細胞の増殖性所見, 細胞異型が認 められることである。炎症( 3 例). 灰白色 1 . 灰黄色 1. 血性1. 臨床的に腫瘍性病変を指摘され, 細胞診 では，いずれも強い炎症性所見を呈し，䛦断とし ては容易である。腫瘤の鑑別に細胞診の有用性が 示唆された。

考察 試料の性状で特に悪性症例では, 血性， チョコレート色が多く認められることは, 病巣が 出血性であることが推測された。
178. 乳腺の良性悪性判定基㔼の検討（特に 乳腺上皮細胞と筋上皮細胞の2細胞性について)

昭和大学藤

O斉藤多紀子 ( CT) , 菅原和子 ( CT) 光谷俟幸 $(M D) ，$ 佐川文明 (MD)

従来乳腺の良性悪性の判定の際、構造的観察と して、乳腺上皮細胞と筋上皮練胞の 2 細胞性が良 悪の鑑別に重要視されている。特に練胞颜におい て、乳管乳頭腫症、乳頭腺管癌の篮別か困難であ るが、今回良・悪性病变の判定基準、特に 2 細胞 性の有無とその他の所見について検討した。

class III診断した症例には、良性症例と悪性 症例が見られるが、これらの診断には、2練胞性 以外の所見を重要視しなければならない。今回我 タはclass III症例を中心にして、2緗胞性とそ の他の所見について、練脆診、組䋨診、電䫓を用 いて観察した。検索症例は125 例 (乳腚症24例お 上び良性疾患13例、乳頭腺管密36例およびその他 の癌62例)である。紐胞診で大部分の良性症例で は、筋上皮紐胞が多数認められ、良性と診断する のに容易であったが、class III 診断した症例に は、細胞集団の基底部に筋上皮練胞と診断する細 胞が少なく、組織診では乳管膈頭腫症と診断され た症例が比較的多かった。このような症例を電顥 て観祭すると、筋上皮細胞の発達力悪いという所 見を示した。細胞診でClass II と診断され、組織 診て永頭腺管癌と診断された症例の中には、細胞 診て筋上皮様練胞と思われる緗胞が基底部に認め られ、電影観察でも、明らかな箭上皮様練边力認 められた。このようなclass III診断には、2細 胞性による良・悪性の鑑別診断は困難で、その他 の所見、すなわち腫湯背景における腫場細胞の散 在性、塤死物質、組糡球の多察、クロマチンの增 量する細胞の割合、核の切れ込み、重積性、化生 の有無等の組合せによる診断が必要と思われた。 
179. 乳腺乳頭状疾患の術前細胞診の検討

千葉大学医学部第 1 外科 (以下 MD)

○石毛英男, 堀中悦夫, 花輪孝雄, 足立武則, 宮内 充, 奥井勝二

（目的）乳腺乳頭状疾患は, 術前細胞診による診 断がしばしば困難なととがある。そこで乳管内乳頭 腫, 非浸潤性乳管癌, 乳頭腺管癌について細胞診断 学上の諸因子を比較検討し診断に有用な因子につい て考察した。（方法）当科找いてS 57年より S61年までに手術を行なった乳管内乳頭腫 7 例（6 症例で 1 例に再発 $(H)$, 非浸潤癌 6 例, 乳頭腺管癌 4 例について検索した。乳管内乳頭腫はいずれも 3 年以上 follow up され, 1 例に癌化がみられた。乳 管内乳頭腫群を $\mathrm{A}$ 群, 非浸潤癌群を $\mathrm{B}$ 群, 浸潤癌群 をC 群とした。細胞診断上の因子として背景, 穿刺 吸引された細胞数および細胞塊の大きさ, 配列, 細 胞間の結合性, 重積性, N/C比, クロマチン量および その分布、核の大きさと形, 核の大小不同, 核小体 について検討し $\lambda^{2}$ 検定を行ない統計処理した。

（結果） 細胞診上の各因子のうち, A 群よりもB 群さらにC 群へとしだいに増す傾向のある因子とし て細胞塊における細胞配列の乱れ, 細胞の結合性の 減弱, N/C 比の増大, クロマチン量の増加およびクロ マチン分布の不均一化がみられた。しかし (B 群vs C 群）の統計処理を行なうと $\mathrm{N} / \mathrm{C}$ 比,クロマチン量お よび分布に関して有意差が認められた。NC比やク ロマチン量やその分布など一般的な細胞診断学上の 悪性の指標とされている因子は, C 群で有意に多く みられた。乙のてとは, A 群とB 群の鑑別には, そ れ以外の因子あ考慮する必要があるととを示唆して いる。(A群vs B 群)で各因子を比較するとB群で は有意に細胞配列の乱れ, 結合性の低下, cluster の小型化認められた。（まとめ）乳管内乳頭腫 と非浸潤癌の鑑別には細胞の配列, 結合性, cluster の大きさが有用な因子であり，クロマチン量やN／ $\mathrm{C}$ 比など一般的な乳癌の特徵は浸潤癌によくみられ た。
180. 乳腺非浸潤癌の細胞像

宮城県立成人病センター

○大沼真喜子（ C T ），小室邦子（ C T ）， 長谷とみよ（ C T ）, 佐藤裕美子（ C T ）, 武田鉄太郎（MD）, 松田 堯 (MD), 小野寺博義 ( MD ), 桑島一郎 ( MD ), 斎藤博之 $(M D)$, 中村克宏 $(M D)$

宮城県立成人病センターで経験した乳腺非浸潤 澏22例を対象として、摘出標本タッチ・スメア を中心に、穿刺吸引スメアを参考にその細胞所見 を検討した。

切除標本の組織像はすべて乳頭腺管㴦で、充実 性あるいは等状構造を示した。その塗枺細胞像は、 概して細胞量豊富で、集塊は大小多様だが、乳頭 状あるいはまりも状の結合性密な大型集塊を認め るものが多かった。シート状集塊として観察され、 辺縁細胞が散在傾向を示すものもあった。軽度の 配列異常があり、不均等重積、核間距離の不均等 性を呈した。細胞集塊にいわゆるtuicall patternは みられなかった。散在細胞も多数出現したが、そ のほとんどは細胞質の保持が明瞭で、裸核は少な

く、また二層構造の反映とおもわれる2個の細胞 が対を成すパターンは観察されなかった。

個々の細胞は比較的に小型均一だが、細胞質に 富み、核は一部に大型核、核不整がみられたが、 基本的には、小型均一、円〜類円形で、核径は

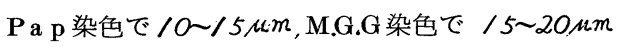
の幅があったが、主体は P a p 染色で $/ O \mu \cdot m$ 内外、 M.G.G 染色で/5Mm内外であった。核小体は/ $/ \mathrm{m}$ 程度の小型なものだが、目立つ例が多かった。 form cill の出現した例もあった。明瞭な石灰化像、 I CLを認めた例はなかった。

22 例中9例に乳頭分泌物を認め。その5ち5例 に癌細胞を検出した。その細胞像は、配列異常、核 形不整、核の大小不同など異常所見の顕著なものが 少なくなかった。また全症例に赤血球を検出した。 
181. 乳腺原発之考えられた悪性リンパ腫の 一例

静岡市立静岡病院臨床検查科

O伊藤忠弘 $(M D)$, 荒井知子 $(M T)$

鈴木三佳 $(\mathrm{MT})$, 堂下浩二 $(\mathrm{MT})$

静岡市医師会付属臨床検查センター

青木健治（C T)

乳腺の悪性リンパ腫は極めて稀で、乳腺腫瑒の 0.09\%あるいは乳癌の $0.18 \%$ という報告がある。 乳腺の悪性リンパ腫は乳癌よりあ予後が良い之言 われている。乳腺原発と考えられた悪性リンパ腫 の一例を経験したので報告する。

症例は65才女性で、左乳房に腫瘤を触知し、生 検され、悪性リンパ腫之診断され、左乳房切除術 が行われた。腫瘍は約 $5 \mathrm{~cm}$ 径で、黄白色、弾性軟 で、乳腺組織内にみられた。所属リンパ節の腫大 はみられなかった。

組織学的所見：腫揚細胞は類円形で、核は血管 内皮細胞の核より大きく、細胞質は狭い。腫掦細 胞はびまん性に浸潤增殖し、壊死細胞が多数混在 している。腫瘍内には既存の線維組織が断片的に 残存し、腫場辺縁部には少数の乳管上皮が認めら れる。

腫場の捺印細胞診 : パパニコロウ標本では、壊 死細胞や小リンパ球と混在して、それらより数倍 大きい類円形細胞が孤立散在性にみられる。ギム ザ標本では、細胞質が好塩基性で、核形不整の少 ない類円形核の $\mathrm{N} / \mathrm{C}$ 比大の細胞が孤立散在性に みられる。

腫腸の電顕所見：核は円形ないし棈円形で、核 形不整は少なく、クロマチンは核縁に凝集する傾 向がみられる。核小体は比較的小さく、1〜2個 みられる。細胞質には遊離リボゾームが豊富であ るが、他の小器官は乏しい。細胞間のデスモゾー ム結合はみられ学い。

以上の所見から、本症例は乳獥原発の悪性リン 八゙腫、びまん性、大細胞型の一例と考えられた。
182. 胸水中に悪性細胞を認めた乳腺覀性 葉状肉腫の 1 例 一原発巣と胸水中の腫湯細胞の 細胞像およびD N Aパターンの比較

栃木県立がんセンター 娭查技術部”，研究娭查 部2!

O鈴木兼一 $(C T)^{1}$ ，岩谷靖央 $(C T)^{11}$ 、笠倉貞男 $(M T)^{11}$ 、福永義一 $(C T)^{11}$ 、井村穕二 (MD $)^{21}$ 、鈴 木恵子 (MD) 2)、島村香也子 (MD) ${ }^{2)}$

胸水中に乳腺要性葉状肉腫の腫湯細胞が出現す ることは稀であり、細胞像の報告は、調べた範囲 内では未だ 1 例をみるに過ぎない。今回われわれ は、乳腺悪性葉状肉腫の 1 例について、原発巣と 胸水中の腫場細胞の細胞像およびD N Aパターン を比較したので報告する。

[症例] 48葴女性。7年前より右乳房外上部領域 に腫瘤あり、徐々に増大したため来院。超音波で 管胞内癌を疑われ、1987年11月に腫瘤摘出術を受 けた。1988年肺転移、1989年1月5日、胸水穿剌施 行。1989年1月21日、呼吸不全により死亡した。

[乳腺の病理所見] 線維性被膜を有する4.7x

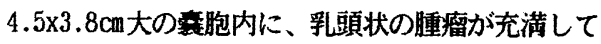
いた。組織学的には葉状肉腫で、約半分が線維肉 腫梾、軟骨肉腫侎の像を呈する悪性部分から成り 一部で被膜に浸潤、細胞異型が著明で、核分裂像 もしばしば観察された。

[細胞所見] 乳腺择印標本では、壊死性背景の もとに、上皮細胞のクラスターと单離性に存在する多彩 な間葉系細胞か認められた。上皮細胞には異型が 乏しく、間葉系細胞には、泡抹細胞、妆”球のほ か、核及び核小体の睡大、核異型、核分裂像、多 核化等を示す肉腫細胞力”観察された。一方、胸水 では腫瑒細胞は小型円形化してツ川゙ 球と混在して おり、2-3核を有する肉腫細胞が主体であった。

[DNA分析] 上記 2 検体の細胞診標本及び原 発巣のベラフイ切片について、顕微緹光測光法によ る腫减細胞のD N A 分析を行った。原発巣では20 Cに及ぶhigh ploidyの腫場細胞か認められた。 


\section{3. 乳腺葉状囊胞肉腫の 4 例}

河北総合病院外科 ${ }^{1)}$, 病理 ${ }^{2)}$

内山雅之 $(\mathrm{MD})^{1}$ ), 団野誠 $(\mathrm{MD})^{1)}$, 杉戸弘司 $(\mathrm{CT})^{2)}$ 本多邦子 $(\mathrm{CT})^{2)}$, 海老原善郎 $(\mathrm{MD})^{2)}$

関東中央病院病理

入江宏 $(\mathrm{MD})$ ），坂巻明子 $(\mathrm{CT})$ ，佐藤千香子 （CT），貝塚美佐子（CT)

今回我々は, 乳腺の葉状囊胞肉腫を 4 例経験し たので報告する。年令は $43 \sim 51$ 歳, 平均 48 歳で, 全例女性で, 左乳房 3 例, 右乳房 1 例であり, 悪 性 2 例, 良性 2 例であった。腫瘤の大ささは 5.2 $\times 5.1 \sim 12 \times 9 \mathrm{~cm}$ であった。穿刺吸引細胞診が 2 例, 捺印細胞診が 2 例飞施行された。

葉状霊胞肉腫は管内型線維腺腫の一覀型とされ. 間質結合織の増殖が極めて強く，しかも間質細胞 成分飞富むととが特徽で, 良性, 境界病変, 悪性 飞分類される。臨床的特徵として, 腫瘤が急速に 増大するととがある。本症の多くは良性であるが， 稀に悪性化を来えすと言われ，多くは間質細胞の 悪性化であ。葉状囊胞肉腫内ての悪性の割合は $7 \%$ 前後である。

細胞像は, 良性葉状囊胞肉腫は腺維腺腫と基本 的な差はなく，上皮細胞集団と異型性に乏しい間 質細胞の出現で, 境界病変では多数の間質細胞が 認められ, 異型性は強くなり, 更に悪性では細胞 の大小不同，多核細胞及び核分裂像がみられ，血 管を中心とする放射状配列を示すと言われる。

葉状囊胞肉腫の良性例, 悪性例の細胞像を比較 し，若干の文献的考察を加えて報告する。
184. 血中 A F P 高値を示した前䙕隔顺絀胞 性緟場の一例

大宮市医師会サイトロジーセンター1)

日本大学第 2 外科 $^{2}$ )、同第一病理 3 ) 、

慈恵会医科大学 ${ }^{4}$ )

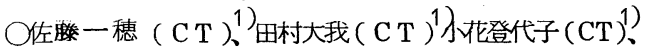
関 保 $(\mathrm{MD})$ ， 伊良子光正 $(\mathrm{MD})^{2)}$ ， 大烟正昭 $(\mathrm{MD})^{2)}$ 、

岡野匡雄 $(\mathrm{MD})$ ）岩田正青 $(\mathrm{MD})^{4}$ )

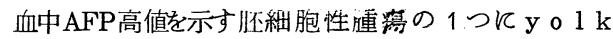
s a c t umorがあり、主に卯巣や精巣の生殖器に好 発 することが知られている。また頭蓋内、縦隔、 後腹顺腔扰よび仙骨などでも見られるが、

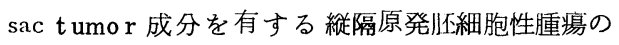
報告は少ない。今回我々は血中 A F P 高值を示した 前縱隔顺細胞性腫場を経駾したので報告する。 症例は 45 才男性、昭和 63 年 10 月腧部圧迫感を主 訴飞当院内科を受診し、同年 11 月胸部X線上異常 影を指摘され精查目的にて入院。経皮的生検及び

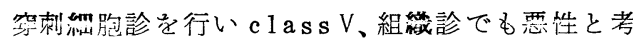
えられた。生化学検查では血中AFP27.600 $\mathrm{ng} / \mathrm{ml}$ 、

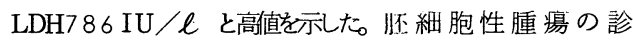
断化て化学療法を行った後、平成元年 2 月 15 日手 術施行。腫瘍は大動脈、肺動脈周国飞浸琵してい たため不完全摘除飞終った。術後 AFP 値は漸減す るも 7 週間後には $389.500 \mathrm{ng} / \mathrm{m} \ell$ と再び高值となり、 画像上飞子再発像を認め同年 4 月 12 日死亡。 生検の細胞所見は腫煌細胞が㧓立散在性飞出現 し核は偏在、クロマチン密で浱く、核小体著明で非上 皮性悪性腫焬を疑ったが組織型の推定は困難であ つた。組織所見では線維性組織に混在し $\mathrm{N} / \mathrm{C}$ 比大、 円又は楕円でクロマチン密な核の悪性細胞の增生 を認めたが組樴型の判定は困難であった。

手術材料の組織検査で seminoma、inmature tera toma, yolk sac tumor 々診断し、免疫組織化学的 飞悪性紲胞内の AFPを認め、複合組織型清細胞性 腫場と診断された。 
185. び慢性肺転移のみで発見された胸腺力 ルチノイド

\author{
網走厚生病院内科 \\ $\mathrm{O}$ 竹林克重(MD), 持丸隆一(MD), 助川 真(MD), \\ 渡辺 豊(MD), 高野宏平(MD), 佐藤泰男(MD), \\ 岡本宗則(MD), 水野 均(CT) \\ 国立札幌病院病理科 \\ 山城勝重(MD)
}

胸腺カルチノイドは稀な疾患であり、全カルチノ イドの $5 \%$ 、全縦隔腫瘍の $1 \%$ を占め、本邦では 1988 年まで約 80 例の報告にすぎない。又その生物 学的悪性度の指標は一定しておらず、臨床的、細 胞学的に興味がある所である。今回我々は検診で 偶然、び慢性肺転移が発見され、超音波エコー下 生検により確定診断のついた症例を検討した。

（症例）58才、女性、主婦。

平成元年 7 月 26 日、検診にて胸部異常陰影を指摘 され、当院内科 9 月 7 日入院にいたる。入院時の 哅部X-Pでは両肺にび慢性の粒状陰影が認められ 、転移性肺腫瘍と診断した。腫瘍マーカーは陰性 、全くの無症状であった。その後全身検索が行わ れ、肺 C T で胸壁直下の前縦隔腫場が発見された。 不正形の充実性パターンを示し、肺や他の臟器浸 潤は不明瞭であった。超音波エコー下に肺生検を 行い細胞組織学的検索を行ったところ、細胞はシ 一ト状配列を示し、一部ロゼット様配列を示す部 分屯認められた。核は類円形から卵円形で、胞体 は境界不明瞭でややレース状、クロマチンパター ンは濃焱様々に混在していた。核小体は $1 \sim 2$ コ 認められた。又紡鍾形細胞や核分裂像、出血、壊 死等は認められなかった。兔疫組織学的検索では EMA(-),Keratin(+ - ), E GC(+),NSE(+), Lact opherin (ーで診断は胸腺カルチノイドとした。G rimelius (-), Fontana-Masson( （CDDP.Vinblastin, Bleomycin）を継続中である。
186. 多形性の顕著な心原発性平滑筋肉腫の の 1 剖検例

\author{
東京慈恵会医科大学 付属柏病院 病理科 \\ O猪股 出 (MD) \\ 同 中央検查科 小野安雄 ( C T ), 鯉沼博美 \\ （C T ），相曾正義 (C T)
}

心蔵には血管肉腫・横紋筋肉腫・中皮腫などの 原発性悪性腫瘍, 及び転移性腫瘍がみられる. 最 近, 心蔵に原発した平滑筋肉腫の稀な 1 剖検例を 経験したので報告する。

症例：53才男. 死亡 2 ケ月前より背部痛・関 節痛があり，1 ケ月前より咳嗽・発熱も出現し， 近医を受診. 胸部し線で左胸水を認め, 当院内科 八紹介入院. 検查所見は軽度貧血とL D H D高値 であった・心エコー図・MRIでは右房内に巨大 な mass lesionを, また, CTスキャンでは心周 囲・上行大動脈を取囲む椂に腫颤陰影を認めた。 3 回の胸水細胞診は陰性. MR I 下に死亡9日前

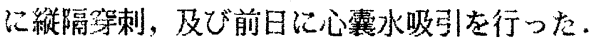

細胞像: 炎症性背景て，睡㕫細胞を孤立散在性 に認めた。胞体は豊富で多形性て，一部は紡鍾型 であった。ラ仆グリーンに好染し，空胞や硝子 滴様物質む散見した。核虫不整一類円形で，ク口 マチンは顆粒粗網状で，㤥縁拄や肥厚し，核小 体はやや大型一小で, 好酸性・不整型であった。 診断は, 特定出来ないが, 肉腫を強く疑った。

組織像：検体は極少量で, 多形性・短紡鍾形の 細胞が密に増生し, 肉腫が疑われた。

患者は右胸水・呼吸困難の増強, 発熱 - 頻脈の 持続と, 一般状態が悪化し, 放射線や化学療法无 出来ず, 心夕ンポナーデによる両心不全で死亡.

剖検所見：赤褐色調で自壊性の顕著な腫場が心 外膜の全周性, 及じ右心房後壁に全層性, かつ, 右房内腔に径 $3.5 \mathrm{~cm}$ 大のポリープ状に発育してい た. 組織学的には異型性・多形性・变性の目立つ 末分化な腫場組織で，一部で平滑筋組織を模倣し ており，muscle-actinを強陽性に認めた。 
187. 小児外科一特に悪性㣫瘍一における細 胞診の意義

猲協医科大学、第一外科*、病院病理部"* O藤原利男 (MD)、土岡 丘(MD)、黒須祐作(MD)、 木島金夫(MD)、町田尚美(MD)、野中康子(CT) 高山松子(CT)、池口祥一(MD)、信田重光(MD)、佐 藤豊彦**(CT)、小池史子(CT)、佐々木英夫(CT)

小児の外科的悪性腫怚の治療成績は早期発見と 診断技術の進歩および治療学の発達により著しく 向上しつつある。しかしながらその診断は症例に よっては画像診断および洍床検査結果からのみで は極めて困蓄な場合がある。今回私どもの施設で 経駼した小児の悪性湩場を中心に細狍診の面から その診断と意義について検討し報告する。

過去15年間に当科で細胞診を施行した15才未满 の小児は150例で、合計228検体であった。採集方 法は生椮豚涑法、穿刺吸引法、尿遠沈法で行った。 228検体中ClassIV、Vと診断したのは46検体、約 20\%であった。正診率は95.6\%であった。陽性例 の疾患は卵黄囊癌(1検体)、横文筋肉腫(3検体)、

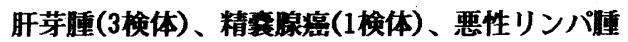
（4検体）、悪性間葉㯵(2検体)、神経芽腫(15検体)、 Wilus腫汮(7検体)、胎览性癌(6検体)、悪性奇形 腫(2検体)であった。考按)小児の悪性腫瘍の治

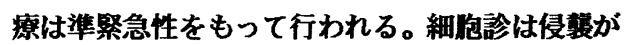
少なく比較的短時間に結果が判明し、また直接病 理診断が可能な場合がある。手術が不可能な症例 また画像診断、距床検查から診断が困羅な場合、 超音波下または直接穿剌吸引細脃診を行い、病理 診断と治療方針を決定できる可能性がある。しか し小坚の場合、穿刺吸引診断をするまでもなく診 断可能な症例もあることより症例を選択すること が重要である。
188. 細胞診液状検体細胞収集用容器 （IL 化 ッッ：MSと略）の考案と、その使用結果

愛知県がんセンタ一病院臨床検查部細胞診室 O蒲貞行 (CT)、作田一実(MT)、鈴木亮而(MD)、 栗田宗次 (MD)、須知泰山(MD)

[目的］1988年の1年間に、当施設で実施し た液状検体(Solと略) の細胞診件数は996件 であり全体( 8,545 件)の $11 \%$ でっっが、容量 、性状はもとより提出用容器も様々であり、液 の移し替え、遠心処理から細胞採取に至る作 業に手間がかかり、处理の能率化並びに効率 的細胞採取可能な容器の開発が望まれる所て ある。そこで今回、現状の調查分析をし、MSC 村角KK)を考案し、その使用結果を報告する。 [現状調查の方法］1989年6月から1か月間、 当施設で扱ったSol.89件(吸引痰 30 、その他 59)の検体の全容量、全沈渣等を調べた。液は 主に15m1量不 ッ州分注後 $2,500 \mathrm{rpm} 、 5$ 分遠心 した。[全検体量(その他の59件)] 10ml未満 $: 29$ 件 (49.2\%)、11 20m1: $12(20.3 \%) 、 21 \sim 40 \mathrm{~m}$ $1: 10(16.9 \%) 、 41 \mathrm{~m} \mid$ 以上: $8(13.6 \%)$ 。[全沈渣量 （全検体量が $20 \mathrm{~m} 1$ 以上の場合は $20 \mathrm{~m} 1$ として換 算)] $0.05 \mathrm{~m} 1$ 末満: 33 件 $(55.9 \%) 、 0.06 \sim 0.8 \mathrm{ml}$ $: 23(39.0 \%) 、 0.9 \mathrm{~m} 1$ 以上: $3(5.1 \%)$ 。[MSの形状] 管底からの容量は、第1層0.05m1、第2層まで $0.8 \mathrm{~m} 1$ 、第3層まで $9 \mathrm{~m} 1$ 、第 4 層まで $12 \mathrm{~m} 1$ 、全 $25 \mathrm{~m} 1$

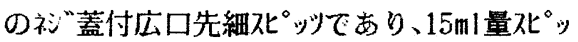
ソの遠心用川゙スケ外で遠心できる。[使用結果( 16件)] 沈渣は8件 (50\%)が第1層内、6(37.5\%) が第2、2(12.5\%)が第3層に至る量として各々 遠沈した。[まとめ] 日常のSolの 90\%以上の 例が40ml以内で提出され、MSの1〜2本で提出 されればべッドサイトかから遠心・細胞採取に至る まで同一容器で行うことができ、加えて少量 の沈渣も特に工夫した先端部で効蜜的に採取 可能てあり、検查室ひいては病院全体の中で の業務改善の一助になる事が期待できる。 
189. パソコン上での細胞診、組織診デー タファイルと細胞診精度管理

八戸市立市民病院病理

O方山揚誠(MD), 高坂公雄(MT), 熊谷幸江(CT), 十文字文男(MT), 佐藤啓子(MT), 川嶋 博(MT)

我々は細胞診台帳、病理組織台帳、組織診断報 告書をパソコン上で処理するシステムを作り既に 2 年以上活用しており、組織診処理の詳細は既に 発表した。（病理と臨床 6(11):1349-1356,1988）

緗胞診データファイルは検体コード（臓器コー ド）と診断コードを組織診と共用している。臟器 コードはS NOPコードを簡易化した 3 杵のコー ドで、藏器コードで性採取法により組織診の藏器 コードと区別している。診断コードは独自の简易 化した 3 桁のコードを用いているが、この中にパ パニコローのクラス分類む含まれている。

コード以外の部分むできるだけ組織診とファイ ル構造の共通化を図り、個人情報検索として患者 のI D番号ないしカナ氏名より一回の検索で特定 患者の細胞診と組織診の検索結果が一度に表示で き、日常業務の中で頻繁に使用される。診断情報 娭索ではクロスファイルの作製ができ、検索を複 合させて細胞診と組織診の不一致例を捜すことも できる。また、検索結果をフロッピーディスクに データとして落とすことができ、落としたデータ より特定の疾患の患者名簿を作製している。

以上のように紐胞診と組織診とを結合したコン ピューター台帳処理は練胞診精度管理の大きな威 力を発揮する。細胞診と組織診の両方の業務を行 なっている施設では細胞診単独のコンピューター 処理ではなく、組織診デー夕処理も平行して行い 両者を結合できる形にすべきである事を特に強調 したい。
190. 口㓐 Verrucous carcinomaの3例

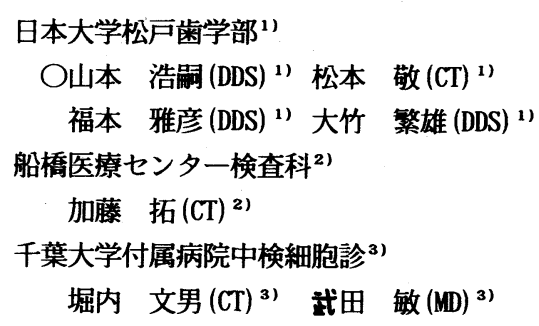

Verrucous carcinoma は扁平上皮癌の特殊型で主 に臨床学的及び組織学的な観点からの報告が多く, 細胞学的な観点からの検索は比較的乏しい。今回, 我々は口脆 Verrucous carcinomaの3 例を経験し, その細胞像及び組織像について報告する。

[症例] 症例 1 は77歳女性, 発生部位は $\overline{2+7}$ 部齿肉の乳頭状腫瘤, 細胞診の結果 class II. 症例 2 は70歳女性, 発生部位 $7-4$ 部歯肉の乳頭状腫瘤 , 細胞診の結果 class II. 症例 3 は74歳女性, 発生 部位 $4-1$ 歯槽頂歯肉〜口蓋側の乳頭状病変, 細胞 診では classIIIであった。

[細胞所見］ 全症例で著明なオレンジG好染性 の細胞質を有する角化型扁平上皮細胞が主にみられ , ghost cell, 核周囲明庭も一部にみとめた。核は 腫大し, クロマチンの濃染化, 2 核化, 軽度〜中等 度の大小不同等がみられた。

[組織所見］腫瘍実質 hyper\&parakeratosis, acanthosisを呈する重層扁平上皮が主に外方へ乳頭 状增殖を示し, 増生する細胞の核は濃染化し, 明暸 な核小体を有し, 一部では核分裂像もみとめられ。 individual cell keratinization, horny pearl, 極 性及び配列の乱れも散見され, rete pegsは棍棒状で あった。

[結果] Verrucous carcinoma の細胞診による 診断は困難であったが著明な角化傾向を呈し，濃染 化クロマチン,ghost cell 等の出現した乳頭状病変 の症例では, 臨床所見を参考に乳頭腫や高分化型扁 平上皮癌との鑑別を十分に考慮すれば，細胞診が同 病変に対して補助的診断になりうるものと考える。 


\section{1. 耳下腺の壷腫状腺房細胞䍃の 1 例}

\author{
横浜赤十宇病院中央検查部病理 \\ O山村信一 ( C T ) 、鈴木洋子 ( C T ) \\ 横浜市立大学医学部第 2 病理学教室 \\ 北條晴人 (MD) \\ 横浜市立大学医学部病院中央検查部病理 \\ 桔梗辰三 (MD)
}

【始めに】今回我々は、耳下腺に発生し零腫 状に発育した腺房細胞癌を経験し、細胞学的及び 組織学的検索をしたので報告する。

【症例】39f 男性 1984年頃より左耳下 脉部の腫脹に気付くも放置。1988年頃より増大し 始めた。1989年6月当院受診し超音波等の検查に より内腔に乳頭状発育を示す囊腫状に発育した病 変が考えられた。同日実施された穿刺吸引により 黄色に混濁した嶈液性の液体が得られた。細胞学 的検索が実施され、悪性を否定できず同年7月耳 下腚を摘出した。

【細胞所見】乳頭状の発育を示す緗胞集団が散 見された。細胞質は、ライトグリーンに淡染し比 較的厚く細胞の境界も比較的明暸であった。核は 侢在傾向にあり蛏度大小不同が見られた。核ク口 マホンはやや濃染し小型の核小体が1個見られた。 その他に異物巨細胞、泡沫細胞等が見られたが明 らかな腫焬性背景は見られなからた。非定型的な 多形性腺腫を考えた。

【組織所見】摘出検体は、黄色混濁した液体を 入れた露腫 $(5.0 \times 2.8 \mathrm{~cm})$ で、踣腫壁は組織学的 に一部にへモジデリンやコレステリン結晶の沈着 を伴う厚い線維性の組織からなり、囊腫内面は1 層の立方ないし円柱上皮に覆われ、しばしば内腔 に小さな乳頍状增殖が見られた。腫湯細胞は濃染 する核と、時に胞体内空胞を伴う比較的異型性の そしい細胞で一部で売腫壁に浸潤し、また血管侵

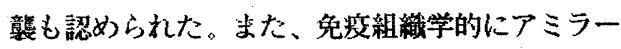
ゼが証明されることから唾液腺由来の腺房細胞䍃 (papillocystic variant)と考えられた。
192. 鼻・副鼻腔・Small cell tumors $の$ 細胞学的検討

順天堂大学附属病院中央臨床検查室病理 ${ }^{11}$, 同耳鼻科 ${ }^{2)}$, 同臨床病理学教室 ${ }^{3)}$

○鈴木節子' 1) $(\mathrm{CT})$, 笠原健弘 ${ }^{12}(\mathrm{CT})$, 安藤一郎 ${ }^{2}(\mathrm{MD})$, 丹野正隆 ${ }^{2}(\mathrm{MD})$, 齊藤 脩 ${ }^{3}(\mathrm{MD})$

鼻, 副鼻腔悪性腫瘍は多種多様であり, 生検組 織の採取は部位的制約のため充分でないてとが多 く, 採取時のアーチファクトも著しく, 組織病理 学的診断の困難な症例が少くない。我々は術前或 いは生検術施行時に細胞学的検索を併用して組織 診にまさる情報を得る事が少くない。特に小型覀 性細胞を主体とする Small cell tumors の鑑別診 断は組織学的には難しい症例が多い。確定診断に 困難を要した 3 症例に参考例を加えて報告する。

症例 $1:$ 未分化癌・34才, 女性, 左鼻腔打よび 上顎洞腫瘍の診断で入院。生検を繰り返しながら 遠隔転移により経過 5 年で死亡。組織診は未分化 癌, 横紋筋肉腫の疑い, 嗅神経芽腫, 悪性 amelanotic melanoma などと变転し, 判定に困 難な症例であった。

症例 2: Nasal-T-cell-lymphoma・28才, 男性, 臨床的にはWegener 肉芽腫を疑われて入 院, 反復生検してす確定診断を得られず, 経過 3 年で下腿皮膚などの遠隔転移にて死亡。

症例 3 : Nasal Cylindroma・78才, 女性, 右 上顎癌の診断にて入院, 生検にて未分化扁平上皮 癌とされたが細胞学的には合致せず, 最終診断は Adenoid cystic carcinoma であった。

以上の症例は何れも経過中の臨床細胞学的所見 と組織診断との間に充分な一致性はなく, 最終診 断から retrospective に考察するとむしろ細胞情 報により優れた示唆的所見が見られたあのである。 その他, 横紋筋肉腫, 富細胞性神経鞘腫, Ewing 腫瘍, 咱神経芽腫等の Small cell tumorsについ て細胞学的鑑別の要点を述べる。 
193. 副鼻鲑原発孤立性形質細胞腫の 2 例

\author{
順天堂大学浦安病院検查科 ${ }^{1}$ 、同耳鼻咽喉科 ${ }^{2}$ 、

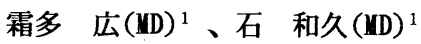 \\ 古谷津純一 $(\mathrm{CT})^{1}$ 、喜納勝成 $(\mathrm{CT})^{1}$

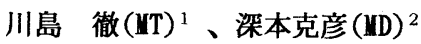 \\ 杉田麟也(ID $)^{2}$
}

副鼻胚原発孤立性形質細胞腫は、極めて稀な疾 患の一つである。今回我々は 2 例経験したので、 その細胞所見を中心に組織学的および免疫組織化 学的検索結果を含めて報告する。

症例 $1: 31$ 才男性。

既往歷、家族歷に特記することなし。

現病歷: 昭和62年 2月右鼻出血、鼻閉、右頑部 のしびれを自覚し,3月当院受診し、穿刺細胞診を 行ない、右上顎洞腫瘍の疑いで手術を施行した。

症例 $2: 15 才$ 女性。

既往歷、家族歴に特記することなし。

現病歴 : 平成元年 1 月左鼻閉感、鼻汁があり、 症例 1 と同様に穿刺細胞診にて非上皮性悪性腫瘍 を疑い手術を施行した。

細胞所見 : 症例 1,2 とに、壊死物質と大小不 同を伴う裸核状の細胞を背景に細胞質の良く保存 された類円形の異型細胞を散在性に認めた。これ らの異型細胞はPapanicoloau染色で胞体は泡沫状 でlight green に好染性を示す。Giemsa染色では、 胞体は強い好塩基性を示し、一部にGolgi 野をみ る。核は偏在性で多くは単核であるが一部で 2 核 細胞も認められる。核クロマチンは、明らかな車 軸状構造を示すものは少なく、明瞭な核小体を有 していた。

組織所見および免疫組織化学的所見：症例 1 は、 未熟な形質細胞がび慢性に增殖し織細な間質を伴 い、酵素抗体法にてIgA， $\ltimes$ が陽性となった。また 症例 2は、車軸状構造が不明瞭な核偏在性の異型 細胞が増生し、䣼素抗体法にてIgG, 入が陽性とな った。従って、症例 1 はIgA, $\kappa$ 型の、また症例 2 はIgG, $\lambda$ 型の形質細胞腫と診断した。
194. 鼻悪性黒色腫の細胞像と鑑別診断

\author{
白河厚生総合病院検査科 *同耳鼻咽喉科 ** \\ O高木尚広 $(\mathrm{CT})$ * 樋口 豊 $(\mathrm{CT})$ * 尾股丈夫 (MD) ** \\ 福島県立医科大学第一病理 \\ 阿部正文 (MD) 浅野重之 (MD) \\ 順天堂大学浦安病院順天堂大学臨床病理 \\ 古谷津純一 (CT) 齊藤 觔 (MD)
}

鼻・副鼻腔の悪性腫瘍は $90 \%$ 以上が扁平上皮 癌であり、残る $10 \%$ は多種多様で鑑別に苦しむ 症例が少なくない。悪性黒色腫は嗅神経芽細胞腫。 胎児性横紋筋肉腫、1ethal midline granuloma、悪 性リンパ腫、未分化癌と共に組織診断の難しさと 予後不良なためsinonasal sma11 ce11 tumorとし て纒められ、早期確定診断が望まれている。

我々は鼻・副鼻㸆の悪性腫渲の自験例 2 例を中 心として、その細胞像を検討し、上記の各種疾患 の細胞像と比較し、鑑別診断の要点を述べる。

症例 1：72歳女性、3ケ月前より鼻出血あり、 下甲介にできた Polyp 状悪性黑色腫

症例 $2 ： 46$ 歳女性、左側鼻閉出血の主訴で来院 悪性黑色腫の細胞像: 両例共にN/C が高く、し ばしば大型の腫瘍細胞がある。核は偏在性のこと が多く 円〜卵円形で微細不均等な核クロマチン を有し、大型好酸性核小体が目立つ。時に多核、 巨大核もあり、また核内に打ち抜き空胞が認めら れる。細胞質はPap 染色で黄褐色、Giemsa染色で 青黒色に染まるメラニン顆粒を認めた。

鑑別診断：メラニン色素が豊富であれば何らの 問題はない。色素産生がそしく、細胞性に富む場 合には多くの悪性腫瘍との鑑別が必要になる。最 も紛らわしいのは少数のメラニン色素含有細胞の 混在しうる嗅神経芽細胞腫であり、S-100 蛋白陽 性は区別の根拠にならない。胎児性黄紋筋肉腫は グリコーゲン顆粒陽性の所見が有力な手掛かりに なる。その他の疾患においても、形態学的検索の 他、電顕、免度染色を含めた検索が必要であろう 
195. 新しいヒト卵巣ムチン性囊胞腺癌培養 株（MN I）の樹立とその性状について

奈良県立医科大学産婦人科学教室

○丸山雅代(MD)，清塚康彦(MD), 斉藤兹(MD),

加藤由美子(MD), 別府謙一(MD), 島本有子(MD),

一條元彦(MD)

東大阪市立中央病院産婦人科

安達進(MD), 野田恒夫(MD),

奈良県集団検診センター

河野貢(CT)

（樹立の経過）1989年5 月9 日、66才の卵巣ムチ ン性囊胞腺癌患者の手術時摘出腫演組織を用い、 細胞分散法に従い15\%FCS加ダルベッコ・イーグル 変法培地中、 $37^{\circ} \mathrm{C} 、 5 \% \mathrm{CO}_{2}$ 下にて初代培養を開始 した。継代培養時の細胞分散は0.125xトリプシン - EDTAにて行った。 （株細胞の特性）培養開始後20日目に第一回目の 継代後、良好な增殖を示し、現在までに第50代を 経過した。第10代における倍加時間は16.9時間、 紐胞密度は18. $7 \times 10^{4}$ 個 $/ \mathrm{cm}^{2}$ 之高密度を示した。 核型分析における染色体数は56〜107 に分布し77 のpseudo-triploidy領域にモードを認めた。異種 移植能につつきードマウス背部皮下に $\times 10^{7}$ 㑑の 培養細胞を接種後、2 週間目から腫瑝発育か認め られその組織像は腺腔形成、ムチン産生を認め るムチン性囊胞腺癌で原腫瑝之類似していた。無 血清培地(ASF102)で培養可能であるか壁付着能は 低下しmirror ball patternを呈した。初代培養時 、CEA 及びCA 125の産生を確認した。培養10代の クローニングにて、敷石状の形態を有する細胞集 団 (MN I-A) 之紡鍾状の形態を有する細胞集団（ MN I-B）に分離、継代することに成功した。位相 差顕微鏡およびHE, PAS, Papanicolaou 染色を用い 、形態観察を行ったところ、いずれの細胞集団で も紐胞質内にPAS 陽生顆柆を認めた。MN I および その亜株 IN I-A, Bにつき、その細胞特性を比較検 討し報告する。
196. 卵巣由来明細盷癌培養株の樹立とその 性状

癌研究会付属病院婦人科 ${ }^{1}$, 同病理部 ${ }^{2}$ O山川義寛 $(\mathrm{MD})^{1}$, 河口徳一 $(\mathrm{MT}){ }^{2}{ }^{2}$ 手島英雄 $(M D)$, 横須賀 薰 $(M D), 1$, 中山一武 $(M D),{ }^{1}$ 荷見勝彦 $(M D)$, 増淵一正(MD) ${ }^{1}$

手術後 3 年目に再発した卵巣明細胞癌患者の腹 水加ら腫瘍細盷を採取し, 継代可能な細盷株の樹 立に成功した。本株を細胞生物学的, 免疫組織学 的に検討したので報告する。

1987 年 4 月, 無菌的に腹水を採取してGIT培養 液で培養を開始し, 種々の培養液を試みたが安定 增殖に至らず， $3 \%$ 胎児仔牛血清加Waymouse MB 752/1 とMCDB 152 の等量混合液に ITS, EGF を加えた培地が最適であり, 約 6 力月で増殖が安 定した。1989 年12月現在, 56 代目を継代中である。

原腫瘍の病理組織像は, 豊富で淡明な細胞質を 有する細盷がシート状に配列する solid type の明 細盷癌であり, 明らかな hobnail cell は認められ なかった。腹水細胞診では, 細胞境界は明瞭で細 胞質が豊富な悪性細胞が乳頭状集塊として認めら れた。PAS染色は陽性であり,アルシャンブルー 染色は陰性であった。

培養細盷では, 大小不同が著明で, 多棱形ない し短紡鍾形の細胞がシート状僧殖している。培 養当初は, mirror ball patternを呈したが, 現 在は認められない。PAS 染色は陽性で, ジアス ターゼ消化試験では消化されグリコーゲンである ことが確認された。56代目培養細盷の増殖曲線よ り算出した倍加時間は約 53 時間で, 細盷密度は $6.3 \times 10^{4} \mathrm{ce} 11 / \mathrm{cm}^{2}$, 染色体数は異数性に分布し, モードは 4 倍体付近にみられた。異種移植能につ いては, 移植後 2 力月を経過したがいまだ腫瘤は 認められない。本株の腫瘍マーカーは, CA 19-9, CA $72-4, B F P$ が培養上清中で各々, $67 \mathrm{u} / m \ell$, $5.4 \mathrm{u} / m \ell, 210 \mathrm{ng} / m \ell$ 之高值を示し, 免疫細胞化学 的染色でも確認された。 
197.卵巣腫瘍細胞診における ras $\mathrm{p} 21$ おょ びmyc 産物発現の免疫組織化学的検討

広島大学医学部産科婦人科学教室

○谷岡慶英 (MD), 松田 博 (MD), 谷本博利 (MD)

藤本英夫 (MD), 太田さなえ (MD), 木岡寛雅 (MD)

今城雅彦 $(M D)$, 永井宣隆 (MD), 藤井恒夫 (MD)

上馬場是美 $(C T)$, 藤原 篤 $(M D)$

卵巣腫瘍において癌遺伝子ras, mycの発現が報 告され, 腫瘍の悪性度や分化度との関連が注目さ れている。今回細胞診標本について ras, myc 発現 を免疫組織学的に検討したので報告する。

【方法】上皮性卵巣腫瘍 27 例 (将液性囊胞腺癌6例, ムチン性囊胞腺癌 6 例, 類内膜癌 5 例, 類中腎癌 4 例, 浆液性囊胞腺腫中間群 2 例, ムチン性囊胞腺腫中 間群 3 例， ムチン性囊胞腺腫良性群 1 例）より得ら れたパパニコロウ染色择印細胞診標本を脱色し, ras p 21 およびmyc産物について A B C 法による免 疫組織化学的染色を行ない, その陽性率を検討し た。用いた抗体は抗Ha-ras p 21抗体 (T B I 社) ならびに抗ヒト c-myc 抗体 (Oncor社)である。

【結果】悪性群に抢いてはras $70.0 \%$, myc 64.3 \%, 中間群に扔いてはras $60.0 \%$, myc $25.0 \%$ の 陽性率であった。更に組織型別には浆液性囊胞腺 癌で ras $66.6 \%$, myc $50.0 \%$, ムチン性囊胞腺癌 でras $66.6 \%$, myc $50.0 \%$, 類内膜癌で ras 50.0 $\%$, myc $66.6 \%$, 類中腎癌で ras $100 \%$, myc 100 \%の陽性率であった。ras 扔よびmycとも主として 細胞質に陽性所見を認めたが, mycの一部では核 に陽性所見を認めた。染色強度は悪性群において 強陽性例が多い傾向にあった。

【考察】ras 打よびmyc 発現に関する免疫組織化学 的検討が細胞診標本においても可能であった。ま た, 悪性度が増すにつれて陽性率, 染色性ともに 高度となる傾向が示唆された。
198. 漿液性・ムチン性卵巣腫場組織の悪 性化に伴うレクチン反応性の変化(第4 報)

東京慈恵会医科大学 産婦人科教室

O株本和美(CT)、清水良明(MD)、落合和彦(MD)、 佐々木寛(MD)、寺島芳輝(MD)

杏林大学 保健学部 細胞診断学教室

椎名義雄(CT)、沢田好明(MD)

【目的】卵巣腫瘍において腺細胞の悪性化に伴 いレクチン反応性がどの様に変化するか漿液 性及びムチン性腫瘍につき腺腫、境界覀性、腺 癌に分けて検討した。

【方法】10\%ホルマリン液で固定した病理組織 パラフィン切片を用い、レクチン免疫染色を行 った。用いたレクチンはベクター社のビオチン 化レクチン 7 種(Con A, DBA, SBA, WGA, RcA, UEA-I, PNA)で、対照として0.2Mの阻害糖夜を各々作用 させた。

【結果】漿液性腫瘍では腺腫、境界悪性、腺癌 共にCon A, WGA, RcAで100\%の染色率が見られた。 DBA, SBAにおいて腺腫ではほぼ100\%の染色率で あったが悪性化に伴い染色率の低下を認めた。 PNAでは悪性化に伴い染色率の増加を認めた。 ムチン性腫瘍ではDBA、PNAにおいて悪性化に伴 い染色率が低下する傾向が現れた。また他のビ オチン化レクチンにおいて 3 者間に大差は見ら れなかった。

【結論】以上の成績より漿液性腫瘍では、DBA, SBA, PNAにおいて悪性化に伴い変化が涩められ た。またムチン性腫瘍では、DBA, PNAに変化が 認められた。 
199. 新規腫瘍マーカーC A 54/61 の婦人科 領域における免疫細胞・組織化学的検討

香川医科大学母子科

O黒瀬高明（MD）、塩岡るみ (C T)

藤田和之 $(M D)$ 、塩田敦子 $(M D)$

佐々木敏江 (MD)、広川雅晴 (MD)

山崎俊彦 (MD) 、大野正文 (MD)

半藤 保 (MD)

[目的］肺腺癌由来細胞株を免疫原として野 沢らにより作成された 2 種類のモノクロナル抗体 M A 54、およびM A 61を認識する抗原 C A 54/61 は卵巣ムチン性癌において高陽性率を示すとされ 新しい腫瘍マーカとしての有用性が示唆されてい る。今回我々は C A 54/61 の婦人科領域における 局在を、それら 2 種の抗体を用いて免疫細胞・組 織化学的に検討した。

[対象および方法］卵巣腫瘍 6例（浆液性囊胞 腺癌 2 例、ムチン性囊胞腺癌 1 例、類皮囊胞腫悪 性変化 1 例、ムチン性囊胞腺腫 2 例 ）、子宮腫 瘍 7 例（内膜癌 2 例、肉腫 1 例、筋腫 2 例、腺筋 症 2 例）、正常子宮内膜 2 例（産裖期、閉経期） を対象とした。組織はホルマリン固定標本を、細 胞は捺印細胞標本または擦過細胞標本 (95\% アル コール固定）を用いた。免疫染色はMA54、61の 2 種の抗体を用いてPAP 法に準じて行なった。

[結果] 卵巣腫瘍では漿液性腺癌では陰性であ ったが、ムチン性腺癌ではM A61に強陽性を認め た。類皮囊胞腫悪性変化の 1 例でも間質に索状に 浸潤した未分化扁平上皮癌部分でM A 54、61 とも 強陽性を示した。ムチン性囊胞腺腫では 2 例と もM A 54,61 の両者に弱陽性を認めた。子宮腫瘍 では内膜癌の 1 例にM A61が陽性であった。中胚 葉性混合腫瘍の 1 例はM A 54,61 とも強陽性とな った。子宮筋腫、腺筋症はいずれも陰性であっ た。正常子宮内膜は細胞標本のみの検討であった が、いずれも陰性の結果であった。

[結論] 抗原 C A 54/61 は卵巣ムチン性腺癌のみ にとどまらず、各種悪性腫瑒を中心に広く存在し ているものと考えられた。
200. 卵巣癌由来培養細胞に対するモノクロ ナール抗体の作製とその認識抗原の扁平上皮癌にお ける局在

慶應義塾大学医学部産婦人科学教室

○木ロ一成(MD), 野澤志朗(MD), 崔 永喜(MD), 柳沢加子, 高松 潔( MD), 長谷川清志 (MD), 佐々木宏輔(MD)，三上幹男(MD)

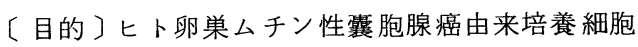
株( RMUG-L)を免疫原として得られたモノクロナー ル抗体を用いて, 各種婦人科腫瘍培養細胞株, 及 び子宮頸部・体部の正常・癌組織について免疫組 織化学的染色による比較検討を行ったとてろ, 組 織型及び組織の癌化に伴う局在の変化が見られた ので,こてに発表したい。

〔方法及び結果〕免疫原としてヒト卵单ムチン性 囊胞腺癌由来培養細胞株(RMUG-L)を用い, 常法に よりモノクロナール抗体を得た。又, その認識抗 原の局在部位をI 型 (核周辺の限局性染色) , II 型 (細胞質内ビマン性染色) 及び III型 ( 細胞間の 染色）に分け分析した。染色はハイブリドーマの 培養上清を第一抗体として用い, 免疫組織化学的 染色 $\mathrm{ABC}$ 法によった。(1)正常頸部扁平上皮では III 型に高い陽性率が見られた。一方，正常頸管腺で はむしろII型に高い陽性率が見られた。(2)子宮頸 部扁平上皮癌組織に扎いては染色部位が多彩とな り, I 型・II型・III型共に同程度の陽性所見が見ら れた。(3)子宮体内膜については, 増殖期内膜ではI 型が压倒的に陽性率が高く, 一方, 分泌期内膜に ついては殆ど染色されなかった。(4)子宮体内膜腺癌 についてはI型が比較的多く見られ，さらに分化度 による検討では，高分化型に高い陽性率が見られた。 (5) RMUG-Lを含む当研究室で樹立した 10 種の培養細 胞株については，RMUG-Lのみに I 型がみられた。 〔結論〕当モノクロナール抗体により認識される 物質は，正常・悪性及び組織の違いにより細胞内 での局在が変化するという興味ある結果が得られた。 
201. 当科における卵巣低悪性度裹胞腺腫の 組織細胞学的検討

大阪市立大学産科婦人科学教室

$\mathrm{O}$ 松本義隆(MD), 伊藤文博(MD), 田村一富(MD), 中村哲生 $(\mathrm{MD})$, 川村直樹 $(\mathrm{MD})$, 山本 彰 $(\mathrm{MD})$, 土田茂( $\mathrm{MD})$, 山本啓司(MD), 田村明敏(MD), 山片重房(MD), 須川 佶(MD)

大阪市立城北市民病院産婦人科

山本久美夫 $(\mathrm{MD})$

卵巣低悪性度囊胞腺腫（LPM）は、良性腺腫と 癌との中間に位置する腫瘍であるが、組織学的に は、良性の囊胞腺腫に近い腫瘍から悪性の囊胞腺 癌に近い腫瘍まで広い範囲の腫瘍を抱括しており、 診断上の問題点も残されている。そこで今回我々 は、当院で昭和 47 年より平成元年まで、低覀性度 囊胞腺腫と彰断された 20 例について、臨床的及び 組織細胞学的検討をおてなった。

この20例は同時期における卵单悪性腫演 (日産 婦分類での中間群を含む）の約 $10 \%$ を占めた。臨 床進行期別に分類すると、I a 期 13 例、 I b 期 2 例、 I $c$ 期 3 例、II b 期 1 例、III期 1 例で、III 期症例の み術後 3 年 9 カ月で死亡している。他は現在のと ころ再発を認めていない。また組織型では漿液性 囊胞腺腫が 3 例、ムチン性囊胞腺腫が 17 例を示し、 他の組織型は認めなかった。漿液性及びムチン性 の各々をさらにその上皮の重層化、乳頭状発育、 核異型、異常核分類像などの所見を細分類化し、 組織学的に検討を行なった。間質への細胞浸潤は 示さないものの、組織構築像は腺癌類似の特徴を そなえていた。細胞学的には腺癌細胞と良性上皮 性腫煌細胞との中間的な特徵を有しているものの むしろ良性細胞との鑑別が重要であると思われた。 上記の各視点に関する検討から L PM と良性腺腫 および腺癌との鑑別点について報告する。
202. 卵巣漿液性のう胞腺腫、境界悪性、 腺癌の捺印細胞診における核面積、核周囲長、 切れ込み指数、核長径短径、最小核間距離につ いて

東京慈恵会医科大学 産婦人科教室

O瀬尾宏(MD), 厚川裕志(MD), 渡辺明彦(MD), 株本和美(CT), 落合和彦(MD), 岸野喜保(MD), 佐々木寛(MD), 寺島芳輝(MD)

【緒言】卵巣癌の根治術は近年拡大手術の傾向 にあるため術中の良悪性診断は過度の手術を避 けるうえで重要である。そこで上皮性卵巣腫瘍 の中で頻度の高い漿液性腫瘍につき術中捺印細 胞診における形態学的差について検討した。

【方法】卵巣漿液性のう胞腺腫10例、境界悪性 6例、腺癌24例の術中摘出組織捺印細胞診を用 いた。顕微鏡により500倍拡大スライド写真を 作製後投影描写法により核周囲図を描く。ポラ リメーターおよびキリメーターにより核面積、 核周囲長、核長短径、最小核間距離を求めた。 同時に切れ込み指数 $\alpha$ を次式で求めた。 $\alpha=\mathrm{L} / \sqrt{\mathrm{A}}(\mathrm{L}$ : 核周用長、 $\mathrm{A}:$ 核面積 $)$

【成績】測定した細胞数は、腺腫937個、境界悪 性769個、腺癌2112個であった。各計測項目に つき腺腫、悪性境界、腺癌の順に示すと核面積 : 28. $7 \pm 38.0 ， 24.0 \pm 21.8 ， 50.2 \pm 130.0$ 核周囲 長: $57.7 \pm 13.8 ， 53.1 \pm 10.8 ， 70.7 \pm 20.0$ 核長径 : 21. $3 \pm 5.7,19.2 \pm 4.2,25.5 \pm 7.2$ 核短径: 14 . $5 \pm 3.7,13.2 \pm 3.6,17.0 \pm 5.4$ 最小核間距離: 12. $3 \pm 4.5,11.2 \pm 4.5,14.6 \pm 5.4$ であった。各項目 についてWelchのT検定により有意差検定をす る亡、核面積、核長径、核短径、核周用長、核 切れ込み指数は、各 3 病変間に $P<0.01$ と有意差 を認めた。しかし最小核間距離に関しては有意 差を認めなかった。

【結論】漿液性卵巣腫瘍においては、腺腫、境 界悪性、腺癌の 3 病変間の鑑別上、核の大小不 同性が有用であることが示唆された。 
203. 婦人科悪性腫痬細胞における multiparameter解析と予後との関連性

\section{岩手医大産婦人科学教室}

$\bigcirc$ 金子重信 (MD)，井筒俊彦(MD)，小山俊司(MD) 福島明宗 (MD), 松田壮正(MD), 利部輝雄 (MD) 西谷 嚴(MD),

岩手対ガン協会

高橋利成 $(\mathrm{CT})$, 片島淳巨( CT)

（目的）悪性腫瘍の増殖動態さらには腫瘍の担 体となっている患者の予後を推定する手段として 癌細胞の核D N A 量の測定は有効な手段である。

しかし、DN A量のみを parameter としての細胞 の悪性度の評価にはおのずと限界がある。われわれ は、従来の臨床進行期、組織型等にくわえて婦人科 腫瘍の増殖動態と予後推定を目的として癌細胞の DNAmul tiparameter (MP) 解析を行った。（方 法）子宮頝癌17例、子宮内膜癌18例、卵单癌21例、 計56例の婦人科悪性腫瘍症例を対象とした。これら の症例より採取した悪性細胞中のDN A 合成細胞の 割合すなわちBrdU labeling index (B. L. I. ) とF CMによるD N A index および画像解析装置 を用いての $5 \mathrm{~N}$ 以上の aneuploid cell の頻度 ( $5 \mathrm{~N}$ ER ) のMPにより婦人科悪性腫瘍の増殖動態とそ の予後について検討を加えた。（成績）子宮頚癌で は大細胞非角化癌、小細胞非角化癌が大細胞角化癌、 腺癌に比しB.L.I . が高かったが、他の parameter では一定の傾向をみなかった。子宮内膜癌で はB. L. I.が高く、 5 NERが高く、aneuploid を示した症例は予後不良であった。卵巣癌では胎 児性癌、分類不能癌で高いB. L. I. を示し、5 N E R の高い症例で予後不良の傾向が見られた。 しかし、DNA index, B. L. I . は予後とは相 関しなかった。( 結論) 婦人科悪性腫瘍細胞のD N A multiparameter解析から子宮内膜癌では、 B.L.I., DNA index, 5 NER が予後推定の 指標として有用であった。卵巣癌では、 $5 \mathrm{NER}$ が予後と関連しており、子宮頝癌ではB. L. I. が 細胞増殖動態の指標として有用であった。

\section{4. 卵巣癌の細胞診}

国立がんセンター病院病理 ${ }^{1}$, 細胞診 ${ }^{2}$, 婦人科 ${ }^{3}$ $\mathrm{O}$ 松本武夫 $(\mathrm{CT})^{1}$, 吉川英一 $(\mathrm{MT})^{1}$,

日吾雅宣 (CT $)^{2}$, 渡部庸一 (CT $)^{2}$, 山岸紀美江 (CT $)^{2}$ 岸紀代三 (MD) ${ }^{2}$, 上井良夫 (MD) ${ }^{2}$, 恒松隆一郎 (MD) ${ }^{3}$

国立がんセンター研究所病理 手島伸一 (MD)，下里幸雄 (MD)

卵巣癌の細胞診は、主に、1)腟・及び子宮腔内 細胞診、2)腹水細胞診が多用され、その腫瘍の良 悪性の診断、術後のfollow up 及び化学療法の効 果等の判定に用いられ、臨床的にも重要視されて いる。そこで今回は、1963年から1988年までに国 立がんセンター病院において、病理組織学的に検 討可能であった卵巣癌手術例（上皮性 common type ) 125例について、臨床病理学的・細胞形 態学的な検討を行なった。125例の卵单癌は、 Serous (S) 46例、Mucinous (M) 40例、 Endometrioid (E) 15例、Clear cel1 (C) 18例、Undifferentiated（U） 6 例であった。

1 ) 評価可能な 78 症例における 5 年生存率は $51 \%$ \%りその内訳は、S (35\%)，M (67\%), E $(56 \%), C(44 \%), U(25 \%)$ と Serous. Udifferentiated で低かった。

2）125例中の細胞診陽性例（腟及び子宮腔内 細胞診十腹水細胞診) は75例、それぞれの陽性率 は、 $\mathrm{S} ; 37(80 \%), \mathrm{M} ; 13(33 \%), \mathrm{E} ; 8(53 \%)$, C ; 14 (78\%)，U; $3(50 \%)$ で、mucinous例の陽性率 が低かった。

3 ) 術前の腟及び子宮腔内細胞診に悪性細胞の 出現する頻度は $18 \%$ であり、その内訳は、S (28\%), M (3\%), E (13\%), C (22\%), U (33\%) で、 mucinous例で悪性紐胞を認める症例が少なかっ た。

4) 腹水中の細胞形態学的特徵は、Clear ce11 においては重積性の弱い細胞集団で出現し、大き く、且つ泡沫状の細胞質が特徵的であり、比較的 その推定は容易であったが、他のタイプの組織型 推定は困難であった。 
205. シスプラチン耐性卵巣癌細胞のフロ ーサイトメトリーによる検討

防衛医科大学校産科婦人科学教室

O笹 秀典 $(M D)$, 菊池義公 $(M D)$, 喜多恒和 $(M D)$, 永田一郎 $(\mathrm{MD})$

佐々木研究所附属杏雲堂病院婦人科

杉田道夫 (MD), 杉下 匡 (MD), 天神美夫 (MD)

卵巣癌の早期診断は困難なことが多く, 発見の 時点ではすでに進行していることが多い。シスプ ラチンを主とした多剤併用化学療法が行われるよ うになり, その予後は改善されつつある。しかし, 化学療法によく反応し完全宽解が得られた症例で も, $2 \sim 3$ 年後には再発し抗癌剤に抵抗性を示す 症例がみられる。したがってこのような症例では, 抗癌剤, 特にシスプラチンに対する耐性の克服が 大きな課題である。今回我々は, シスプラチン耐 性卵巣癌細胞をフローサイトメトリーを用いて分 析検討したので報告する。

対象は, 七上卵巣漿液性囊胞腺癌由来の $\mathrm{KF}$ 細胞 と我々が樹立したシスプラチン耐性細胞株 KFr 細 胞である。培養したおのおのの細胞群を $70 \%$ エタ ールにて固定した。次に高速ブレンダーで分散さ せ, PBS洗浄後Propidium Iodide (PI, $50 \mu \mathrm{g} / \mathrm{ml}$ ) にて染色し,フローサイトメーターを用いてDNA分 析を行なった。 $\mathrm{KF}$ 細胞群, $\mathrm{KFr}$ 細胞群との間には DNA 量のピークの相違が認められた。その他, 両 群のいくつかのピーク領域を sorting し, パパ= コロ染色にて形態を観察し比較検討したので報告 する。
206. 卵巣癌における多剂耐性因子(MDR)の 免疫組織化学的検討

東海大学医学部産婦人科 11 , 同 病理診断科 2$)$, 同 病理 3$)$

$\bigcirc$ 平園賢一 $(M D) 1)$, 篠塚孝男 $(M D)^{1)}$, 藤井明和 $(\mathrm{MD})^{1)}$, 伊藤 仁 $(\mathrm{CT})^{2)}$, 川井健司 $(\mathrm{CT})^{2)}$, 覚道健一 $(\mathrm{MD})^{3)}$, 長村義之 $(\mathrm{MD})^{3)}$

化学療法に対する癌の耐性の獲得は, 治療の成 否を決定する因子である。最近，抗癌剤に対する 多剂耐性機構の研究が進み, 乙の遺伝子産物であ る P-glycoprotein (P-G) が耐性細胞に存在する てとが判明してきている。

今回, 我々は人卵巣癌に対してP-Gに対するも ノクロナール抗体 (JSB -1) を用いて多剤耐性の発 現の有無を免疫組織化学的に検討した。症例は14 例の卵巣癌で, 術前に CAP 療法を施行し, それ らのパラフイン切片を材料とした。また，予後か ら以下の 3 群に分けた（I：無効 II : 中等度有 効 III : 有効)

従来, JSB-1 亿よる免疫組織化学的な検討には新 鮮凍結標本を用いてきたが, 我々は薬剤治療成績 の明らかな症例を用いるためパラフィン切片標本 を用い検討を加えた。その結果 P-Gが膜局在物質 であることが明らかであるため陽性反応が細胞膜 に認められるものを陽性とした。その陽性率は I

: 3/6 II : 0/3 III : 0/5であった。

以上より, JSB - 1 亿よる P-G の検出はパラフ ィン切片での検討であその治療成績と良く一致し, 特に化学療法有効例では全例陰性と判定できた。 従来, 固定標本作成過程に扔いて抗原性が失活す るととが知られている P-Gの検出にも, その感度 は低下するがホルマリン固定パラフィン切片での 実際的な応用の可能性が期待された。 
207. 卵巣癌治療後 follow-up に抢ける腹腔 鏡下採取細胞診, 組織診の有効性

東海大学医学部産婦人科 1$)$, 同 病理診断科 2 )

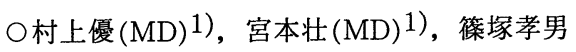
$(\mathrm{MD})^{1)}$, 藤井明和 $(\mathrm{MD})^{1)}$, 篠田玲子 $(\mathrm{CT})^{2)}$, 赤 塚由子 $(\mathrm{CT})^{2)}$, 伊藤仁 $(\mathrm{CT})^{2)}$, 川井健司 $(\mathrm{CT})^{2)}$

卵巣癌治療後follow-upでの腹腔鏡検查 (LS) の 応用は, 患者に対する手術侵襲が少なく, しかす くり返し行なうことができるという利点がある反 面，病巣の見落としや腸管損傷の危険性など予想 される demerit 屯多い。我々は卵巣癌治療後症例 で, 画像診断や腫瘍マーカー検査では再発の診断 の得られない症例に対し，昭和57年10月より定期 的な LS を応用し，現在までに90例に対し合計 231 回の LS を行なってきたのでその有効性について 検討し報告する。その検查内容は L S 下での肉眼 診と異常所見部位からの組織診。細胞診では腹水 細胞診, ダグラス窩および腹腔内洗浄細胞診を採 取した。L S 診断は陰性, 疑陽性, 陽性の 3 つに 分け, 疑陽性とは肉眼診が疑陽性又は陽性であ細 胞診と組織診がともに陰性のもの, 又は細胞診が クラスあのとした。

90 例飞対する 231 回の LS で陰性 175 回, 疑陽 性19回，陽性37回（20例）となった。乙れら37回 の陽性例につき, 組織診, 腹水細胞診, 洗浄細胞 診と検査項目別に陽性率をみると, それぞれ, 70.3 $\%, 80.0 \%, 75.0 \%$ と腹水細胞診が最も高い陽性率を 示した。2 nd - look LS 陰性でその後の follow up 中に腹腔内に病変の出現したもの 5 例, 同様に 2 nd-look LS 疑陽性から陽性となったものが 3 例みられた。LS による腸管損傷は 8 例 (3.5\%)に みられたが，いずれむL S 施行中に気づき大事に 至ったあのは 1 例むない。

これらにつきさらに詳細な分析を加えて報告す る。
208. 子宮䫫部擦過細胞晾で陽性となつた 卵巣明細胞癌の 2 例

\author{
島根医科大学医学部産科婦人科学教室 \\ O柳光寛仁(MD), 都 仁哉(MD)，吉野直樹(MD)， \\ 岩成 治(MD), 森山政司(MD), 北尾 學(MD) \\ 島根医科大学医学部附属病院中央検查部 \\ 三浦弘資(MD)
}

卵巣癌は子宮䫫部擦過細胞診で発見されること は稀であるが，経卵管的に癌細胞が出現したと思 われる卵巣明細胞癌の 2 例を経験したので報告す る。

\section{症例 $1: 48$ 歳, 主婦}

現病歴: 集団検診にて class IIIb (腺系異形細 胞）と判定され, 当科初診となる。

(子宮䫫部擦過細胞診) 背景は炎症性で, 一塊と なって存在する多数の腺癌細胞群がみられ, 中心 に psammoma bodyが認められた。細胞は $\mathrm{N} / \mathrm{C}$ 比 が軽度増大, 核形やや不整, クロマチン軽度増量, 増大した核小体を $1 \sim 2$ 個認めた。卵巣明細胞癌 が推定された。

\section{(子宮内膜擦過細胞猃) 陰性}

（腹水細胞診）変性は強いが子宮顠部擦過細胞診 所見と同様な像を認めた。またコッサ染色にて psammoma body中のカルシウムが染色された。

症例 2:40歳, 主婦

現病歴：発熱を主訴に近医受診し, 腎孟炎とし て抗生剂投与されるも軽快せず, 婦人科的精査目 的で当科紹介となる。

(子宮頢部擦過細胞診) きれいな背景で, 正常な 扁平上皮系細胞の中に核形不整, 核小体の目立つ 変性腺癌細胞集団を認めた。

(子宮内膜擦過細胞診) きれいな背景の中の正常 内膜細胞に混して核形不整、核縁肥厚し比較的胞 体の保たれた腺疻細胞を認めた。

（腹水細胞診）分葉状あるいは切れ込みのある核 を持つ異形細胞が重積性あるいはシート状に配列 していた。 
209. 腟, 子宮内膜スミアに認められた卵 巣原発 embryonal carcinoma の一例

関西医科大学産科学婦人科学教室

O神谷敬雄 (MD)，岡村芳郎 (MD)， 中島徳郎 (MD)，椹木 勇 (MD)

腔，及び子宮内膜細胞䛦において背景が比較的 きれいで，腺癌細胞などの悪性所見を認めた場合， 子宮外悪性腫瘍の転移を考慮する必要がある。我 々の教室でむ，乙の 10 年間で約 90 例の転移性腺癌 を経験し，その約15\%が嘼巣原発であった。しか し，このような子宮外悪性腫瘍の中であ embryonal carcinoma の転移による腟, 及び子宮内膜細胞診 の報告は少ない。今回, 我々は日産婦分類の $\mathrm{em}-$ bryonal carcinoma C 群の 1 例を経験し, 転移に よる腟, 及び内膜細胞診を得ることができたので, その細胞診所見を中心に臨床病理学的考察を加え て報告する。

症例：17歳, 昭和63年 8 月末より, 腹部膨満感 を訴え, 9 月20日当科受診し, 大量の腹水之下腹 部に児頭大の腫瘤を触知した。AFP : $21735 \mathrm{ng} / m l$ であり, 腔, 及び内膜細胞診ではきれいな背景の 中に, 重積性の著明な腺房状細胞集塊を形成する 転移性覀性腫瘍細胞が観察され, 卵巣腺癌を疑。 た。10月 3 日, 開腹術では, 腹水は約 $3000 c c$, 右 卵巣には新生児頭大の充実性腫瘍を認め, ダグラ ス窩を充満し, FIGO 分類 3 C 期の状態であった。 腫瘍細胞の割面の捺印細胞診では, 腟, 及び内膜 細胞診で認められたような腫瘍細胞集塊とともに, 重積性を示さず，やや間隔をあけて配列する細胞 集塊を認めた。病理診断では, 細網状構造, 不規 則な腺様囊胞状構造, 及び血管周囲の星状配列之 と屯に, 表皮, 皮脂腺, 軟骨といった三肧葉性組 織が認められ embryonal carcinoma C 群と診断さ れた。術後は, VAB-6 療法にて管理し,平成元年 12 月現在再発徴候は認めていない。

\section{0. 最近経験した白血病性卵巣腫瘍}

船橋市立医療センター産婦人科, 同検查科, 千葉大学医学部附属病院検査部細胞診 3 )

○林 敏 (MD), 清川 尚(MD), 高橋久雄 $(\mathrm{MT})^{2)}$, 加藤 拓 $(\mathrm{CT})^{2)}$, 武田 敏 $(\mathrm{MD})^{3)}$

【意義】白血病は近年化学療法の進歩で宽解率が 向上し, 初発の急性白血病では60 80\% が寛解 すると言われる。これに伴い寛解症例での腫瘍形 成性白血病も増加傾向がみられる。こうした症例 では骨髄・末梢血検查とは別に細胞診の重要性が 生じる。今回我々はA ML 寛解が 6 年余経過した のちに卵巣腫瘤形成し,さらに子宮への浸潤と腹 水を生じて再発した稀な一例を経験したので報告 する。

【臨床症例】39才女性。'83.6. AML 初発し BHAC-DMP 療法 1 回で完全寛解し, その後地 固め・維持療法を'88.4 まで反復し, 以後の経過 観察では異常を認められなかった。'89.8. 急性腹 症にて当院来院し, 卵巣腫瘍茎揄転の診断で開腹, 子宮腫大もあり子宮全摘術十左付属器切除術を行 なった。この時黄色膿様で細胞成分が $50 \%$ よぶ腹水をみた。

【細胞所見】腹水細胞診にて骨䯣芽球様細胞を認 めた。ギムザ染色で細胞は中等大・成熟度による 多少の变化をみるが大部分は円形〜類円形。核も 円形〜類円形のものが大部分で $\mathrm{N} / \mathrm{C}$ 比大きく, 一部に切り込みをもつものや, 軽度の不整, 裸核 のものもある。核質は微細で豊富, 薄い核膜と 2 〜 3 個の大型核小体をもつ。胞体はやや青みをお び,アズール顆粒やアウェル小体もみられる。

【病理所見】卵巣および子宮の浸潤部ではこらし た腫瘍細胞に大部分置換され, 蜂墖状一索状に配 列し，緘維性間質の介在をみる。

【まとめ】腫湯就よび腹水細胞は骨䯣検查より

F A B 分類 $\left(M_{2}\right)$ と診断された白血病由来と考え られた。 
211. 豊胞性成熟奇形腫より発生したと考え られた脂肪肉腫の 1 例

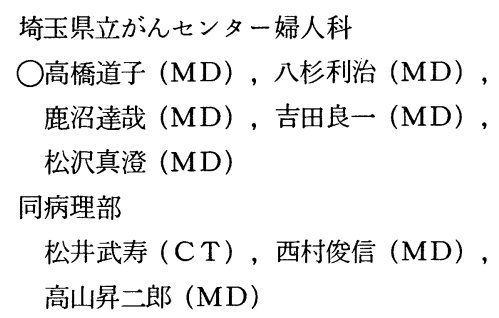

卵巣の襄胞性成熟奇形腫の $2 \%$ 程度に悪性腫啺 との合併が存在するといわれており、合併腫瘍の らち最も多いものは扁平上皮癌であるが、腺癌、

肉腫などの合併例も報告されている。

我々は、最近、19才女性の右卵巣腫場で、襄胞 性成熟奇形腫と脂肪肉腫の合併した症例を経験し、 その捺印細胞診所見と、病理組織学的所見につい て検討したので報告する。

右卵巣は、最長径20cm、重量 $1100 \mathrm{~g}$ に腫張して おり、大部分は充実性腫瘤であったが一部は霊胞 性であった。組織学的には、囊胞性部分は成熟奇 形腫の像を示し、皮盧附属器や骨、線毛上皮等を 認めた。この囊胞壁に発育したかたちで充実性の 部分が存在し、円形から紡錘形の異型細胞が粘夜 性の間質内に浮かぶように出現していた。これら の異型細胞の胞体はやや好塩基性で、核は腫大し、 大型核小体が 1 個から数個みられた。脂肪染色で 細胞質内に脂肪滴を多数認めたため、豊胞性奇形 腫より発生した脂肪肉腫之考光た。

腫場の捺印細胞診では、大型の円形から紡鏵形 の核を持ち、クロマチン粗大顆粒状の核異型の強 い細胞が多数認められ、核小体も円形、大型で、 各細胞に 1 個から数個明膫に認められた。又、 $\mathrm{P}$ A S 染色では、細胞質内に顆粒状に強陽性が認め られ、これら細胞集団の所々にはリンパ球の出現 も認められ、末分化肧細胞腫と類似様部分子存在 した。

\section{2. 後腹膜悪性神経鞘腫の 1 例}

千葉市立病院㭘査科病理

鈴木 博 ( CT) 井浦 宏 (MT)

武田敏 (MD)

同院産婦人科

田中 圭 (MD) 加藤喜市 (MD)

帝京大学市原病院病理部

長尾孝一 (MD) 松菩 理 (MD)

菅野 勇 (MD)

悪性神経鞘腫は後腹膜に原発する腫痬では稀で ある。最近我々は本症の 1 例を経験したのでその 細胞像と組織像について検討を加えたので報告す る。

<症例 >：45才 4 回経妊 2 回経産

平成元年 7 月集検にて貧血を指摘され近医受診。 子宮筋腫にてFollow upと言われ精査を希望し当 院当科受診。C T スキャンにて骨盤内に腫瘤を確 認。同年 10 月子宮筇腫 + 後腹膜腫瘍の診断にて手 術を施行し子宮及び後腹膜腫痬を摘出した。摘出 物の総重量は $253 g$ でそのうち後腹膜腫痬は $43 g$ 、 大きさは $6 \times 8 \times 1 \mathrm{~cm}$ で表面は平滑でやわらかい ものであった。

インプリントスメアでは紡錘状の細胞が束状の 集団を形成し、一部に渦巻型や柝状配列を示すも のもあった。その細胞境界は不明瞭である。核の クロマチンは比較的 fine で核縁の肥厚や切れ込み なども認られない。核長径が短径の 3 倍に達する細 胞が少なくなかった。核小体は目立たないものが 多く核小体のある細胞では Nucleolus associated chramatin が豊富であり好酸性を示すものは極めて 桸であった。

組織学的所見で腫瘍細胞注紡錘型で束状の配列 を示している。組織学的に Spindle cell Sarcoma (low grade) と診断され細胞所見と対応した病理 組織像であった。N S E， S-100,ビメンチン 等の免疫染色の検討も加えて報告する。 
213. 䯣膜腫の細胞学的検討

組織型と悪性度の推定の試み

順天堂大学中検病理 ${ }^{1)}$, 同臨床病理 ${ }^{2)}$, 同第 2 病 理学教室 ${ }^{3)}$, 船橋二和病院 ${ }^{4)}$

○竹田桂子 $(\mathrm{CT})^{1)}$, 大沼八千代 $(\mathrm{CT})^{1)}$, 須藤嘉子 $(\mathrm{CT})^{3)}$, 坪内弘行 $(\mathrm{MD})^{4)}$, 齊藤 脩 $(\mathrm{MD})^{2)}$

〔目的〕近年, 脳外科領域の術中迅速細胞診が 重要視されるようになってきており, 良覀の判定 のみならず, その組織型や悪性度の推定む望まれ る。今回, 我々は䯣膜腫の細胞学的特徵とともに 組織严型と悪性度の推定について報告する。

〔症例と方法〕最近 5 年間に提出された 50 例の 䯣膜腫について, 手術時捺印標本 (Pap 染色・M $-\mathrm{G}$ 染色) を用いて細胞学的には, 細胞成分・細 胞配列・血管成分とと屯に核型・核クロマチンパ ターン及び巨細胞・核分裂像・砂粒体の有無など をチェックした。組織の覀型分類は WHO 分類 に従った。

〔結果〕䯣膜腫を構成する細胞は, 基本的には 2 種類の細胞よりなるもので, 一つは arachnoid cell に類似するあの, 他の一つはfibroblast cell に似ているものである。乙の量的比率で, 組織亜 型分類がほぼ可能である。移行型は, てれらの細 胞がほぼ同等に混合したあのであり, 砂粒体の目 立つむのは砂粒腫型と判定出来る。血管腫型は他 の症例にくらべて血管が特に目立つわけではなく, 細胞診での判定は難しい。悪性䯣膜腫では cellularity が高く, 核の異型性・大小不同及び異型巨 細胞の出現, 壊死物質などがある。

悪性度の推定に必要なチェックポイントは, 腫 瘍細胞の核径差・核の大小不同・巨大核・核分裂 像である。

【考察】細胞像から組織学的亜型分類を推定す ることは, ほぼ可能であると考えられる。又細胞 学的異型度と組織学的悪性度の間にも充分な相関 が見られた。

\section{4. 脳神経外科領域の細胞診 \\ 第 2 報 脳腫瘍の免疫細胞化学的検索}

長崎大学医学部第 1 病理学教室、同附属病院検査 部*

○松尾 武 (MD) 、竹島史直 $(\mathrm{MD})$ 、穴見正信 (CT) * 津田暢夫 (MD) * 、池野雄二 (MD)、柴田正則 (MT)、 高島一彦 (MD) 、梶原義史 (MD) 、岩崎啓介 (MD)

先に我々は第 1 報にて、脳腫瘍の細胞像につき 検討し報告した。各々の脳腫瘍の種類での細胞像 の特徴はみられたが、それのみでは全例の細胞診 断は難かしい。今回はとくに脳腫瘍の種類の鑑別 に当たり、免疫細胞化学的手技を応用し、その結 果につき報告したい。

対象 : 本大学脳外科にて1981年より今日まで手 術された症例のうち、細胞診標本で免疫細胞化学 的検索が可能であった 102例。内訳はグリオーマ 系腫瘍33例、髄芽腫10例、髄膜腫32例、神経鞘腫 14例、下垂体腺腫 4 例、血管芽細胞腫 3 例、悪性 リンパ腫 3 例、転移性腫瘍 2 例、その他である。

方法: 手術時採取された組織切片よりスタンプ 標本をつくり、その標本に、また一旦 Pap染色さ れた標本を脱色してGFAP、ビメンチン、S-100、 NSE 、Leu7、フィブロネクチン、EMA 、LCA など を用いA B C 法にて染色した。

結果：GFAP にて陽性を示した腫瘍は星膠腫、 膠芽腫、混合膠腫、血管芽細胞腫であった。ビメ ンチン陽性例は膠芽腫、髄芽腫、神経鞘腫、䯣膜 腫。S-100陽性例は神経鞘腫、星膠腫、㵦膜腫。 NSE 陽性例は喵芽腫。Leu7 陽性例は混合膠腫、 上衣腫、神経細胞腫。フィブロネクチン陽性例は 髄膜腫。EMA陽性例は転移性癌。LCA陽性例は悪 性リンパ腫であった。

まとめ: 脳腫瘍ではいくつかのマーカーを組合 わせた免疫細胞化学的検索を行えば、脳腫瘍の種 類を鑑別するに充分有用な結果が得られる。 
215. 抗 BrdUモノクローナル抗体を用いた 頭頸部腫煬の細胞動態解析

青森県立中央病院放射線科 1), 臨床検查科 ${ }^{2)}$ $\mathrm{O}$ 真里谷靖 $(M D)^{11}$, 渡辺定雄 $(M D)^{1}$, 貝森光大 $(M D)^{2)}$ 菅三千夫(MD) ${ }^{2)}$, 今井 督 $(\mathrm{MD})^{2}$ )川本真由美 $(C T)^{2)}$ 竹越美佐江 $(\mathrm{CT})^{2)}$

【目的】腫煌の細胞動態は，臨床的悪性度あるい は放射線感受性を考元る上で重要である。我々は， 抗BrdUモノクローナル抗体を用いた腫瘍細胞動 態解析を行い，その臨床的有用性について検討し たのでてれを報告する。【対象】対象は，当院に て放射線治療を行った頭頸部腫煬15例である。組 織診断の内訳は, 扁平上皮癌が12例のほか, 腺様 囊胞癌，悪性リンパ腫，髄外形質細胞腫が各 1 例 ずつである。【方法】治療開始前に, BrdU を持 続動注カテーテルから $100 \mathrm{mg}$ あるいは経静脈的に $250 \mathrm{mg}$ 投与し, 約 30 分後に生検を施行した。 $\mathrm{H}-\mathrm{E}$ 染色と共に抗BrdUモノクローナル抗体を用いた 免疫組織染色を行った。【結果】1）BrdU labeling cell(BLC; S期細胞) の多宾と腫瘍の進展 度（病期, T因子, N⿴囗大必）には明らかな関連を認 めなかった。2) 扁平上皮癌では BLC の多塞と分 化度に関連を認めた。分化度が低いほど BLC が 多い傾向があった。3）BLC の多塞と放射線感受 性に関連を認めた。扁平上皮癌では, BLC が多 いものほど感受性が高い傾向を示した。しかし, 悪性リンパ腫と髄外形質細胞腫の 2 例では, BLC は比較的少なかったにも関わらず高感受性であっ た。4）BLCの分布からみた血管分布パターンと BLCの多寡に関連が認められた。また当然のこ とながら, Mitosis とBLCに数的関連が認められ た。【考察】本法を従来の病理組織診断と併せて 検討することで，単なる動態解析溜まらない多 面的な評価が可能である。現在我々は, 本法を腫 瘍の放射線感受性を判断するPredictive assayの 一法として用いており，その臨床的有用性を確認 しつつある。
216. 若年性子宮体癌の一症例

大阪府済生会野江病院 病理 ${ }^{1}$, 産婦人科 ${ }^{2)}$ 田附興風会北野病院 病理部 ${ }^{3)}$

大阪大学医学部附属病院 病理部 ${ }^{4)}$

$\mathrm{O}$ 全 恵子 $(\mathrm{CT})^{1)}$, 田中佐知子 $(\mathrm{CT})^{1)}$,

石川 行良 $(M D)^{2)}$, 高村 伸雄 $(M D)^{2)}$,

村田 匡好 $(M D)^{2)}$, 大林正 $(M D)^{3)}$,

桜井 幹已 (M D $)^{4)}$

若年性子宮体癌,特に 40 才以下は比較的まれな 疾患であるが, 今回 35 才の子宮体癌例を経験した ので, その細胞像と組織像を中心に報告したい。 症例は, 35 才, 妊娠歴なし, 月経周期は不整。 1 年前よりの下腹部痛と不正出血を主訴に, 平成 1 年 3 月当院受診。子宮と右附属器が一塊となり 成人手挙大以上に腄大しており, 超音波検査にて 子宮溜血腫が認められ, 覀性腫瘍が疑われた。子 宮体部からの細胞診標本上には，腫瘍性背景のな かに, 多数の小型で核小体著明な腺系の異型細胞 と, 少数の角化を伴う異型細胞が出現しており, クラス $\mathrm{V}$, 子宮体部の腺棘細胞癌と診断された。 なお, 子宮䐋部からの細胞診標本上にも，体部と 同様の異型細胞が少数出現していた。体部からの s mear 採取時に排出された組織片より作製した組 織標本では, 高分化型内膜型腺癌組織と扁平上皮 成分とが連続してみられ, 腺棘細胞癌と診断され た。準広沉子宮全摘術及び両附属器摘出術, リン パ節郭清術が施行され, 摘出臟器からの組織標本 では, 体部原発の腺棘細胞癌で, 子宮㓐部への浸 潤, 両側卵巣への転移, 骨盤内リンパ節への転移 が認められ, 臨床進行期分類 III 期の子宮体癌であ った。

本症例の患者は, 当院受診の半年前に近医にて, 子宮腟部の細胞診検査を受けているが, 異常は発 見されなかった。子宮癌に於ける子宮体癌の占め る割合は, 増加の傾向にあり, 若年者に対する体 部細胞診の必要性も増すものと考えられる。 
217. 若年性子宮体癌の一例

佐々木研究所附属杏雲堂病院細胞診 1 , 同婦人科 2$)$ $\bigcirc$ 長島義男 $(\mathrm{CT})^{1)}$, 作永穂高 $(\mathrm{MD})^{2)}$, 伊藤良弥 $(\mathrm{MD})^{2)}$, 杉田道夫 $(\mathrm{MD})^{2)}$, 室谷哲弥 $(\mathrm{MD})^{2)}$, 杉下 匡 $(\mathrm{MD})^{2)}$, 天神美夫 $(\mathrm{MD})^{2)}$.

日本通運東京病院検查部

野本雅弘 (CT)

40才以下の子宮体癌は若年性子宮体癌と定義さ れている。最も若年での発生年令は欧米では 16 才，本邦では18才の報告があるが、その中でも20 代前半や10代の子宮体癌は極めて稀である。最近 我々は19才の若年性子宮体癌を経験したので文献 的考察を加え、報告する。症例; 19才、未婚、月 経歴; 初潮17才で生理不順であり昭和63年近医に て一度ホルモン治療の既往あり、その後不規則な がら月経の発来をみた。臨床経過; 平成元年 5 月 17日に不正出血にて近医受診、ホルモン治療を受 ける。7月10日 EMスメアにて、C-III b診断。 7 月 24 日内膜の生検にて低分化型腺癌と組織診断 され当院を紹介される。 8 月 7 日当科受診、 $\mathrm{EM}$ スメア C - V、8月 9 日 4 万向の内膜生検にて、 低分化型腺癌と診断。8月16日準広沉子宮全摘術 および両側附属器摘出術施行。手術材料にて EM A d - C a .(G-3)。腫瘤は内腔発育型の tumorで 組織学的にも筋層内への浸潤はみられず、リンパ 節への転移もみられなかった。術後、化学療法も 検討したが、本人の希望もあり維持化学療法のみ とし9月 7 日退院、経過観察とした。しかしなが ら11月 1 日頃より風邪症状あり、その後数日間で 急激な腹満感出現し、11月13日来院、大網に tumor 形成し腹水の貯留がみられ癌性腹膜炎の診断(腹 水細胞診Class V) そて入院、現在 C A P F 療法中 である。
218. 若年者にみられた無症状子宮内膜癌の 一例

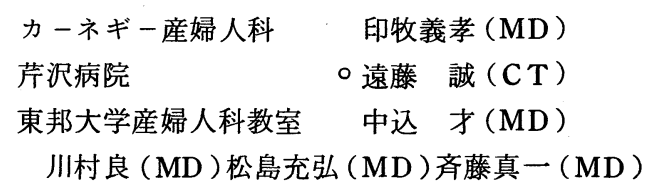

子宮体内膜癌の若年者に見られる頻度は、極め て稀れである。

今回我々は、不妊を主訴として来院し子宮卵管 造影写真 (以下ヒステロと略)にて内膜肥厚を認 め、全面ソー八を施行し内膜細胞診クラス $\mathrm{N}$ 、病 理組織診も内膜癌であった症例を経験したので報 告する。

症例 : S.K. 26 才、結婚は 63 年 5 月、 63 年 10 月より B B T 測定全く二層性であったが、 排卵期頃極々少量毎月出血をみたが異常とは思わ なかった。初潮は中 1 年、高 3 年頃より月経痛あ り時々市販の鎮痛剂の服用もあった。月経量は友 達に比べてや〉多いとは思っていた。

平成元年 11 月 16 日不妊を主訴として初診、 11 月 30 日ヒステロ、12月14 日全面ソ-八 を施行子宮内容や〉多量、その)タッチスメア所見 は正常分泌期像と異型增殖症像と一部に重積性、 極性の乱れ、核クロマチンの増量、核の大小不同 等を示す子宮内膜腺癌細胞が認められた。 
219. 過去の内膜細胞猃所見に增殖性の推移 が反映されていたと考えられる子宮体癌の一例

\author{
九段坂病院産婦人科 ${ }^{2}$, 同 中検病理 ${ }^{2)}$ \\ 東京医科歯科大学病理 ${ }^{3)}$

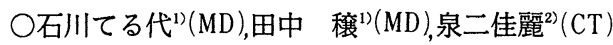

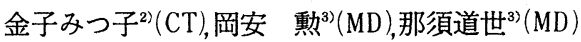

2 年 8 ケ月の検診過程で内膜細胞診所見に増殖 性の強くなる過程が反映されていたと考えられる 子宮体癌例を経験したので報告する。

症例 : 62 才未妊婦。家族歴, 既往歴に特記事項 なし。49才にて閉経した。1987年 2 月（当時 59 才）に不正出血を主訴として当科を受診した。初 診時の内膜細胞診では陰性と判断し，以後定期的 に検診を受けるよう勧めた。11回の内膜細胞診と 7 回の内膜組織診を行い, 1989年 10 月 28 日に子 宮内膜癌と診断した。血中CA $12-5$ 値は 1989 年 5 月には $13.3 \mathrm{U} / \mathrm{ml}$ と正常值であったが, 11 月 11 日には $57 \mathrm{U} / \mathrm{ml}$ と軽度上昇していた。 11 月 27 日 に子宮及び両側付属器を摘出した。摘出子宮内腔 に突出して発育した子宮体癌を認めた。

細胞像 : 1987 年 2 月の子宮内膜細胞診では核異 型のない細胞がシート状集団となり重積性を認め なかった。1987 年 7 月より軽度の重積性が出現 し, 1987 年 9 月ょり核縁肥厚, 細胞集団辺縁の核 の突出, 腺腔様構造が出現した。1988年6月には 軽度の核大小不同を認めた。1988年 12 月には細 胞集団の辺縁に突起を認めた。1989年 10 月の所 見では背景に好中球が多数出現し, 細胞集団には 不規則な重積性を認めた。核の大小不同は目立た ずこごく少数の大型核を認めた。

組織像：1987年 7 月より 1989 年 5 月までは核 異型のない内膜の小片が採取されたのみであっ た。1989年10月の内膜組織診では, 高円柱状の異 型腺上皮細胞が多層化し, 腺管はback to backの 像を示す高分化型腺癌であった。摘出子宮には高 分化型腺癌が広範囲に見られ,一部には異型の乏 しい部分もあった。
220. 術前、一部充実性部分をともなった 卵巣囊腫と誤認した子宮体癌の 1 症例

$$
\begin{aligned}
& \text { 青森県立中央病院 産婦人科! 病理 } 2 \text { 放射線科 }{ }^{3)} \\
& \mathrm{O} \text { 高村郁世 }(M D)^{1)} \text { 、貝森光大 }(M D)^{2)} \\
& \text { 菅三知雄 }(M D)^{2)} \text { 、真理谷靖 }(M D)^{3)} \\
& \text { 川本真由美 }(\mathrm{CT})^{2)} \text { 、竹越美佐江 }(\mathrm{C} \mathrm{T})^{2)} \\
& \text { 青森県成人病予防協会 } \\
& \text { 一戸志津子 (C T) 、小野雅子 (C T) }
\end{aligned}
$$

子宮頸癌についで、子宮体癌の細胞彰断基準も 確立されつつあるが、私達は下腹部腫瘤を主訴と し、開経後出血のEpisodeもなく、術前子宮腟部 およびEndocyte法細胞診は陰性であり、画像剅断 によって、一部充実性部分を有する卵巣囊腫と診 断し、開腹手術を行った結果、術中迅速診断で多 彩な細胞組織像を呈したが、子宮体癌と診断され た症例を経験したので報告する。

症例：75歳、2 妊 2 産、原因不明の発熱が続き 、内科医より下腹部臍下全体を占拠する腫瘤を指 摘され当科纪紹介された。超音波抢よび C T 検查 で、単房性、一部内腔に突出充実性部分を認め卵 巣腫瑒を示唆する所見であったため、開腹手術を 行った。しかし開腹所見では両付属器には異常な く、超小坚頭大の筋腫様外観を呈した子宮腫場が みられ、腹腔内には播種や腹水貯留の所見なく、

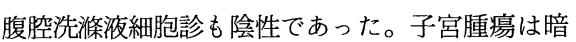
赤色の内容液を満たした囊腫状で頸管より子宮ゾ ンデの挿入を試みたが挿入できなかった。囊腫内 腔突出充実部位はBizarre な肉腫焃所見もみられ る低分化型腺癌で構成され、その他内腔壁にみら れた小結節部位は分化型内膜型腺癌の所見であっ た。両者の移行像もあり子宮体癌と診断された。 子宮囊腫様変化の原因としては老人性変化によ り頸管内か滧着、完全閉鎖状態となって子宮腔内 に分泌物が貯留したものと思われ、臨床上みられ た発熱の一因とも考えられた。以上の状態に加え て画像所見の誤認が術前診断上の落し穴となった 。その結果術中迅速診断の重要性を再認識した。 
221. 子宮体部高分化型腺癌の細胞像

一特に判定困難であった症例について -

近畿大学医学部附属病院 病院病理部

O渡邊利津子 $(\mathrm{CT})$, 京田明子 $(\mathrm{CT})$, 岡村綾子 $(\mathrm{CT})$, 山本良子 $(\mathrm{CT})$

同 産婦人科

小畑孝四郎(MD), 井上芳樹 (MD), 野田起一郎 (MD)

近年，子宮体癌は増加傾向にあり，その早期診 断には, 子宮内膜細胞診が, より重要となってき ている。しかし, 子宮体癌のうち高分化型腺癌の 永離細胞像は, 個々の細胞の異型が弱いため, 時 として，陰性として判定されることがある。

そこで, 我々は, 今回陽性と判定できなかった 高分化型腺癌の初回内膜吸引細胞診において, ど のような点から異型細胞を check up できるかを retrospectiveに検討してみた。

対象は, 過去 5 年間において, 病理組織学的に 子宮体部高分化型腺癌と診断された患者 48 例のう ち, 初回内膜吸引細胞診で, 陽性と判定しえなか つたもの 8 例 (IIIA-3 例, $\mathrm{II}_{R}-3$ 例, II - 2 例 ) を用いた。

これらについて, 背景, 細胞の出現様式, 細胞 集団の形, および重積性, 核の大きさ, 大小不同, 核形, 核クロマチン, 核小体等の点を検討した結 果, 細胞集団の形, 重積性を重視すべきであると いう成績を得たので，その詳細を報告する。
222. 子宮体部 clear cell carcinomaの一例

新潟大学医学部産婦人科教室

○永井絵津子 $(C T)$, 児玉省二 $(M D)$, 吉谷徳夫 (MD), 本間 滋 $(M D)$, 金沢浩二 (MD), 田中憲一 (MD)

腫瘍で稀な腫瘍と言われている明細胞癌を最近 経験したのでその細胞像, 組織像について報告す る。

〔症例〕 62 才。 50 才で閉経し不正子宮出血を主 訴に当科を受診した。子宮頸部細胞診class II, 子 宮体部細胞診class Vで腺癌の診断, 内膜診にて clear cell adenocarcinoma hobnail typeの診断 で単純子宮全摘術を施行した。

〔細胞所見〕内膜細胞診は, 重積性が軽度の細胞 集団で出現し細胞質は比較的豊富で明るい。核は 円 類円型で中心性傾向が見られる。核の大小不 同大で, クロマチンは細顆粒状で明療な核小体を 数個もつあのが多い。clear cell carcinoma solid typeよりも重積性を認め $\mathrm{N} / \mathrm{C}$ あさいが，乳頭 状增殖を示す体部腺癌に比へて全体に核の大きさ が大きく著明な核小体，また細胞質も豊富なとと が特徴的であった。

〔組織所見〕子宮体部筋層内側 $1 / 3$ 亿浸潤した 腫瘍組織は, hobnail cellが管腔内に突出したtype および管状発育する typeが大部分を占め極く一部 に充実性に発育する明細胞typeが混在した。特殊 染色では, PAS染色陽性, ジアスターゼ消化抵抗 性を示した。 
223. 診断困難であった子宮体部扁平 上皮癌の一例

藤田学園保健衛生大学病院臨床検查研究部,

同 病理科 ${ }^{1)}$, 同 婦人科 ${ }^{2)}$,

同 医学部病理学教室 ${ }^{3)}$.

○平沢 浩 (CT), 舟橋正範 (CT), 伊藤 圆 (MD)，

黑田 誠 (MD) ${ }^{11}$, 溝口良順 (MD) ${ }^{1}$ ，澤田富夫 (MD)

${ }^{2)}$ ，廣田 鍫(MD) ${ }^{2)}$ ，笠原正男 (MD ${ }^{3)}$ 。

細胞診および組織診で診断困難であった、きわ めてまれな子宮体部原発性扁平上皮癌の一例を経 験したので報告する。

【症例】 80 歳、女性。初経 17 歳、閉経 50 歳。 昭和 63 年 12 月、性器出血を主訴に当院婦人科 外来受診。エンドサイト法による子宮内膜スメア、 子宮頸管スメアで中等度異形成があり、頸部およ び内膜生検では癌の診断は得られなかった。臨床 的に子宮体癌を否定できず平成元年 3 月 1 日、単 純子宮全摘術が施行された。

【細胞所見】好中球を主体とした炎症性背景で、 紡鍾形〜繊維状の異型細胞が散在、またはシート 状に多数認められ、繊維状異型細胞は著明な細長 い細胞質を有していた。細胞質はライトグリーン、 あるいはエオジンに好染し、核は濃縮状または融 解状で parakeratosisを呈していた。また中層〜 傍基底型の核異型細胞す少数認められた。

【組織所見】内膜生検では扁平上皮がコンジロー マ様に増殖し、軽度の異型性を有していた。摘出 子宮では、子宮体部は高度の parakeratosisを伴 う核異型性の乏しい扁平上皮組織で置換され、浸 潤は頸管部におよび、深達度は子宮底部では漿膜 面に露出していた。病理組織学的には体部原発性 扁平上皮癌, 深達度 $\mathrm{d}$ と診断された。

【まとめ】本症例はエンドサイトで角化異型細胞 が多数採取されたが、内膜成分がそしい点から内 膜病変としての診断は確定できなかった。また異 常な瀻維状異型細胞が出現したが、核異型に乏し く細胞診断は困難であり、verrucous carcinoma、 コンジローマ等との鑑別も考虑された。

\section{4. 若年者の子宮平滑筋肉腫の 1 例}

九州大学医学部婦人科学産科学教室

O木下秀一郎 (MD), 井町正士 (MD), 上平謙二 (MD),

塚本直樹 $(\mathrm{MD})$, 渡辺寿美子 (CT), 中野仁雄 (MD)

子宮平滑筋肉腫は主に閉経後の女性に発症する 稀な疾患で、若年者にはほとんどみられない。今 回われわれは、22 歳の子宮平滑筋肉腫の 1 例を経 験したので、その細胞所見および組織所見につい て報告する。

症例は 22 歳の、経妊 0 回経産 0 回の未婚女性で、 1988 年 11 月近医で子宮筋腫摘出術を受けた。1989 年 9 月から下腹痛および不正性器出血を認め近医 を受診、外子宮口から排出された組織片の病理組 織学的検索で肉腫を疑われ当科に入院した。子宮 は超手拳大に腫大し、形部細胞診、内膜細胞診と もと V 型 (肉腫疑) で、内膜組織診で内膜間質細 胞肉腫疑であった。11月6日単純子宮全摘術、両 側付属器切除術、大網切除術、骨盤リンパ節郭清、 傍大動脈リンパ節生検を施行した。摘出標本の検 索では子宮および大網に平滑筋肉腫を認めたが、 リンパ節転移はなかった。腹腔細胞診は陰性であ った。術後 2 週間目より化学療法 (VAC)を行った。 肉眼所見: 子宮体部前壁飞黄白色の径 $13 \mathrm{~cm}$ の 充実性腫瘤を認め、一部は子宮内腔に突出していた。 細胞所見：形部細胞診および内膜細胞診とも、 出血性の背景に多数の異型錇泡を認めた。異型細 胞とは、比較的均一な円～円形の核を有し集団 として出現したものと、孤立散在性に存在し紡鏵 形ないし長桿状の核を有し核小体の目立つ細胞の 2 種類を認めた。両者とあクロマチンは微細顆粒 状に増量、細胞質は菲薄であった。また核分裂像 が散見された。

組織所見：子宮内腔に突出した部分は内膜間質 細胞肉腫の像に類似し、多数 $(30 / 10 \mathrm{HPF})$ の核 分裂像がみられた。体部では紡鍾形の核を有する 異型細胞を認め、平滑筋肉腫の像で、前者との間 に移行像を認めた。 
225. 穿刺吸引細胞診にて診断しえた子宮 肉腫 leiomyosarcomaの 1 例

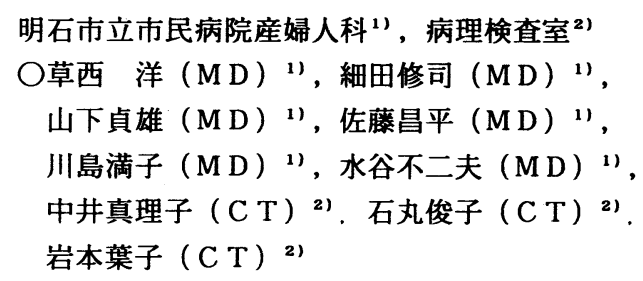

近年、穿刺細胞診が普及し、皮下、軟部組織の 肉腫組織の細胞所見の報告が見られるようになっ た。今回、腰部に転移再発を来した子宮肉種の症 例を穿刺細胞診で診断しえたので報告する。

症例は 55 才、 2 経妊 2 経産。昭和 62 年 3 月 子宮筋腫の診断の下に単純子宮全摘術と両側付属 器摘出術を受けたが、術後の病理組織検査で子宮 肉腫と診断された。C A P 療法を5クール行ない 退院後は外来にて 5 F U $200 \mathrm{mg} / \mathrm{day}$ の経口投 与を受けていた。

平成 1 年 5 月 9 日右腰部に弾性硬の腫瘤を触知 した。超音波検査にて hypoechoic massを認めた ので、骨盤 X 線 C T を行なったところ、腸骨に接 して腫瘤形成を認めた。そこで子宮肉種の再発を 疑い 超音波下に穿刺細胞診検查を行なった。

細胞診所見では、腫場細胞は主として緊密な細 胞結合を欠き、孤立散在性に出現し、シート状の 細胞集塊を認めるものもあるが、上皮性結合は認 めなかった。核形は類円形を示すものが多く、中 に bizzer なものも認めた。核縁は薄く、核小体 数個認められた。以上の細胞所見より子宮肉腫の 再発と診断し、入院のうえ、手術を行なった。 術後の病理診断は子宮平滑筋肉腫の再発であった。 H E 染色のほかに、免疫染色での検討も合わせて、 報告する。
226. 子宮体部ミューラー管混合腫瘍 の 3 例

都立墨東病院検査科病理

O三浦弘守(CT), 宮田清美(CT), 仁平博子(CT), 岩切重憲(MT), 鈴木不二彦(MD), 青木幹雄(MD)

子宮体部ミューラー管混合腫瘍は比較的希で 予後不良な疾患であり, 術前診断が得られるこ とは困難なことが多く, 細胞診での診断が重要 であると思われる．最近我々は、細胞診で診断 し得た 3 例の本腫瘍を経験したので, それぞれ の細胞像ならびに組織像について比較検討し報 告する.

【症例 1】67歳. 50歳閉経. 不正性器出血. 細胞所見：塤死背景に重積性を示す比較的小型 で N/C比大の腺癌細胞の集塊が数ケ所に, 肉腫 由来亡思われる核形不整, クロマチン堌量を伴 う裸核状や大型の細胞が孤立散在性に認められ た.これらの腫瘍細胞の内には腺僢または肉腫 由来かどうか判定困難な細胞も散見された。

【症例 2】54歳. 53歳閉経. 不正性器出血. 細胞所見 : 2 種類の腫瘍細胞が多数見られた。 1 つは重積や配列の乱れのある腺癌細胞の集塊 であり、もう1つは長棈円形の大型核を有する 紡錘形で結合性に之しい細胞集塊，奇異な形の 大型核を有し細胞質が豊富な細胞, 多核巨細胞 など肉腫由来と思われる細胞であった。

【症例 3】54歳. 52歳閉経. 癌検診.

細胞所見：クロマチンの増量した核小体明瞭な 腺癌細胞の集塊が多数散見された。これらの腺 癌細胞は症例1, 2と比較すると大型 $(50 \sim 70 \mu)$ で, 核腫大を伴うがN/C比は大きくなかった。また, 横紋様構造を認める紡錘形の細胞や，大型の多 核細胞など肉腫由来亡思われる細胞も認められ た.

以上の 3 例の組織診断は, 症例 1,2 は癌肉 腫, 症例 3 は中胚葉性混合腫瘍であった。 
227. 子宮体癌との鑑別が困難であった 原発不明転移性胎児性癌の一症例

東京厚生年金病院 病理科 ${ }^{1)}$, 産婦人科 ${ }^{2)}$ ○川口洋子 $(\mathrm{CT})^{1)}$, 菅沼麗桜 $(\mathrm{CT})^{1)}$, 金子 實 $(\mathrm{MD})^{2)}$

東京大学医学部病理学教室 石田 剛 (MD)

子宮胵部・頸部・内膜の細胞診及び内膜組織診 で子宮体部腺癌を疑い, 手術材料にて原発巣不明 の胎児性癌と診断された一症例を経験したので報 告する。

[症例] 84 才・女性。8回経妊 8 回産。不正性器 出血を主訴に来院。細胞診所見により腺癌 (C I ass N) と診断された。さらに細胞診、組織生 検を施行した結果、子宮内膜腺癌 (C I ass V) の臨床診断にて手術施行となった。

[細胞学的所見]年令に比し、表層細胞が多く観 察され、比較的きれいな背景に重積性を伴う異型 細胞集塊が認められた。この異型細胞は核の不整 大小不同、核縁の肥厚を示し、クロマチンは顆粒 状で、核小体を有するものも認められた。細胞質 は厚く、円形または類円形であった。

〔組織学的所見〕大型で卵円形、明るい核を有し、 豊かな胞体を持つ腫瘍細胞のシート状増殖が、子 宮体部、両側畞巣の漿膜側怤められた。組織学 的には胎児性癌が最も考之られた。また、子宮内 膜には異型細胞は観察されず、分泌期の内膜を呈 していた。

〔結語〕術前、分化度の高い表層細胞が年令に比 し目立つことからホルモン産生卵巣埂瘍が、最も 疑われた。しかし、卵巣には異常所見が認められ ず臨床的には子宮体部腺癌と判断されたが、切除 された手術材料により、胎児性癌と診断された。 術前細胞診に扔いては胎児性癌と診断することは 困難であったが、それを考慮に入れるべき細胞学 的所見を有している症例と考光られた。尚、原発 巣は、剖検が施行されなかったため確認でさてい ない。
228. 内膜細胞診にて他藏器由来の癌が疑わ れた一例

千葉大学產婦人科1), 春日部更生病院内科2) O小川雅利(MD)1), 深沢一雄(MD)1), 岩崎秀昭(M D)1), 武田 敏(MD)1), 高見沢裕吉(MD)1), 嶋田 園恵(MD)2)

内膜細胞診にて他藏器由来の癌が疑われた一例 を経験したので, 細胞像を中心に報告する。 症例: T.A,52才, 2G 2P, 䁘床経過: 1989年 7 月下旬腹部痛出現, 婦人科医受診, 細胞診の異常 を指摘される。8月5日内科を紹介され入院, 胸 水眝留のため胸腔穿刺施行, 胸腔内および全身性 に化学療法剂投与, 8 月 30 日当科入転院する。入 院後全身の精査を行う。胸部 X-Pでは陰影の縮小 が認められた。婦人科内膜細胞診にて, 他藏器由 来の悪性細胞が指摘される。腫瘍マーカ一値異常 CA125 701.00U/mI, CA19-9 124.60U/mI, 両側付 属器部位に腫瘤が触知される。原発巣不明にて 9 月28日開腹術施行 (単純性子宮全摘出術, 両側付 属器摘出術, 大網切除術) 開腹時所見: 腹水少 量, 子宮はほほ正常大, 両側卵巣側方に $30 \times 30 \times 40$ m。乳頭状增殖を示す睡瘦がみられた。大细に転 移腫篃と思われる小腫瘤が多数見られた。細胞診

1)内膜細胞診：比較的きれいな背景に中に多数 の組織球が出現しており, 乳頭状增殖を示す悪性 腫瘍細胞の集団がみられた。他に核は軽度肥大し , クロマチンは軽度増量のみられる腺細胞も見ら れた。2)腫瘤捺印細胞診: 多数の腺系の異型細胞 が多くは集塊にて出現している。細胞質はライト グリーンに濃染され, 核は大型で, 核型は円〜短 だ円形，核小体は増大しており，好酸性に染色さ れている。一部にPsammoma body が見られる。3) 胸水細胞診: 空胞をもち核増大の見られる腫瘍細 胞の集塊が見られた。組織診: Serous papillary adenocarcinoma with dissemination. 
229. Bartholin腺癌の一症例

豊橋市民病院桜ヶ岡分院 臨木検查科 ${ }^{1}$ )

豊橋市民病院 臨床検查科 ${ }^{2}$ 同産婦人科 $\left.{ }^{3}\right)$

○夏目篤二 $\left.(\mathrm{C} \mathrm{T})^{1}\right)$ 山本明美 $\left.(\mathrm{C} \mathrm{T})^{2}\right)$

有井吉太郎 $\left.(M D)^{3}\right)$

井沜産婦人科医院井鴆昭彦 (MD)

浜松医科大学 第 2 病理学教室. 室 博之 (MD)

外陰癌は少なく、その殆んどが扁平上皮癌であ る。今回我々は、バルトリン腺に発生した極めて 稀な腺癌を経験したので報告する。

「既往歴」/6歳：結核性腹膜炎、19歳：外陰部 の化膿のため治療を繰り返す。49歳：慢性腎炎、 $7 /$ 歳：狭心症、肺炎

「臨床経過」患者は 72 歳、昭和 63 年 7 月、性 器出血、外陰部腫張飞て他医受診。外陰部の擦過 細胞診検查および組織検查により、バルトリン腺の 腺癌と診断され、同年 10 月入院、化学療法受け るも白血球減少のため治療中止。紹介により平成 元年 7 月 / / 日豊橋市民病院産婦人科外来受診々 なつた。外陰部左尿道口付近より左臸口に沿い後 連合飞達する $1.5 \times 3.0 \mathrm{~cm} の$ 隆起性腫瘍を認め、擦 過細胞診検查および外陰部部分切除に伴ない、組 織検查を行なつた。その後、放射線療法により軽快 したため、同年//月退院。現在、外来にて経過観 察中である。

「細胞所見」腫瘍部摖過標本ではシート状および 重積性の不規則な細胞集団として認められ、一部 は乳頭状配列を示す円柱状の細胞集団を呈してい た。細胞質はライトグリーン好性、核は小型、類円 形〜棈円形で偏在し、大小不同が見られた。クロマ チンは細顆粒状〜顆粒状、核小体は/〜数個、少数 の細胞に核形不整、核小体の腫大が認められた。 「組織所見」真皮 皮下組織内に、中等度の細胞 異型を示す腺上皮が、乳頭腺管状に增殖した高分 化な乳頭状腺癌を認め、一部に粘液癌の像も見ら れた。腫瘍は周辺部で浸潤性が強く、境界不明瞭 であり、一部表面に露出していた。
230. バルトリン腺腺様囊胞癌の 1 例

岐阜大学医学部 1 産婦人科, 2 同第 1 病理, 3 同中央検查部

O丹羽憲司 $(M D) ! 1$ 横山康宏 $(M D)$ ，杉江茂幸 $(\mathrm{MD})^{2}$, 田中卓二 $(\mathrm{MD}, \mathrm{FIAC})^{2}$, 下中恵美子(CT), 下川邦泰 $(\mathrm{MD})^{3}$, 加藤一夫 $(\mathrm{MD}, \mathrm{FIAC})^{2}$

バルトリン腺腺様䘫胞癌は外陰癌の中でも非常 に稀な腫場である。今回，我々はその 1 例を経験 したので細胞所見を中心に報告する。

【症例】 71 歳, 女性。 2 妊 2 経。 $2-3$ 年前より 左外陰部の腫瘤に気付くも放置し,'89年 9 月 5 日 当大学産婦人科受診。初診時, 左胵壁に白色小指 頭大の硬結が認められ, 内診状, 径約 $3 \mathrm{~cm}$ の腫瘤 を触知した。膣スメアは陰性であったが, 生検に よりバルトリン腺由来の悪性腫湯が示唆されたた め, 10 月 30 日左外陰全切除術及び浅鼠径リン八節 の郭清術を施行した。摘出標本は直径約 $3 \mathrm{~cm}$ で, 割面は白色で一部に出血を伴っていた。摘出標本 より捺印細胞診を病理学的検索とともに行った。

【細胞所見】出血性の背景に, 重積性を有する大 小の clusterが多数見られ,ヒアリン様物質が認め られた。細胞はmonotonousで比較的小型であった。 核の偏在性を認め, クロマチンは微細で時に小型 の核小体が見られた。胞体は淡染性であった。整 液腺などの腺様霊胞癌に類似した所見が認められ た。

【病理組織所見】主としてcribriform パタンを示 す異型細胞が nest を形成し, 真皮下から筋層にま で浸潤性に増殖していた。以上, 細胞所見及び組 織所見により,バルトリン腺腺様襄胞癌と診断した。 【まとめ】バルトリン腺腺様囊胞癌は非常に稀で, しかも，病変が深部より発生するため進行例でな ければ剥離細胞診で見られるてとは少ない。今回 の症例でも, 病変が比較的小型であったため, 眰 細胞診では陰性であった。 
231. トリコモナス耗炎およびカンジタ胵炎 のスメアー細胞像の検討

\section{碧南市民病院中央検查室}

O吉田賢一（C T ）、生田美佐子（CT）

名古屋大学医学部臨床検查医学

中島伸夫（MD）

日常の細胞診スクリーニングでトリコモなス (以下TV) あるいはカンジダ様真菌（以下C V) に感染したスメアーを見ることは少なくない。 TVおよびCVに感染した場合この両者にはスメ ア一像において類似した点もあるが、明かな相逗 も認められる。また、細胞診の上で細胞の形態的 変化を伴う場合もあり、mild dysplasia との鑑別 を要することがある。

今回、TVを 28 例、CVを 22 例を用い、そ の細胞の形態的変化の特徵とスメアーの背景抢よ び Tricomonas 原虫と Candida 様真菌の出方など を比較検討し、また、mild dysplasia との鑑別に ついても調べた。

両者の相違点は、 $\mathrm{T} V$ の 細胞背景は好中球が多 く、ときに出血を見るが、CVでは背景はきれい である。Trichomanas 原虫は細胞外に散在性独立 してあるい纹一個の扁平上皮細胞の辺縁に付着す るように出現するが、Candida の場合、扁平上皮 細胞を串刺しにするようにして出現することが多 い。細胞の形態的変化としては、TVでは扁平上 皮細胞の胞体は伸びきって薄く、無核になる細胞 が多いが、CVでは胞体内にグリコーゲン顆粒を 持つ細胞が目立ち、しかも koilocytotic change が起こることがある。異型化生細胞はTVのスメ アーには多く出現するがCVの場合注少ない。共 通点は、 $\mathrm{N} / \mathrm{C}$ 比がやや上昇し、中層扁平上皮細 胞の核小体が目立つ傾向がある。クロマチンの增 量はなく顆粒状である。

以上 TVおよびC Vの細胞学的特徴に留意すれ ば、これらの細胞像と mild dysplasia との鑑別 は困難ではないと思われた。
232. 扁平上皮癌様細胞像を呈した腔異形 成の 1 例

癌研究会附属病院細胞診断部 1, 同婦人科 2

○佐野裕作 (CT $)^{1}$, 古田則行 $(\mathrm{CT})^{1}$, 平田守男 $(\mathrm{CT}) 1$, 手島英雄 $(\mathrm{MD}) 2$, 山内一弘 $(\mathrm{MD})^{2}$, 荷見勝彦 $(\mathrm{MD})^{2}$

今回, 我々は扁平上皮癌様の細胞像を呈した脺 異形成の 1 例を経験したので細胞像を中心に報告 する。

＜臨床経過＞集団検診でクラスIIIb のため当科受 診。細胞診 ( V, C, E, EM), コルポ診, 子宮胵部 生検組織診施行, 細胞診飞て扁平上皮癌と判定, コルポ診は特記すべき所見なし。生検組織診は慢 性頸管炎と猃断された。円錐切除標本も, 慢性頸 管炎であうた。病変が確認できないため, 細胞診, 組織診, コルポ診で経過観察, 初診時より約 6 ケ 月後飞右側胵壁飞病変を確認した。細胞診では軽 度異形成扔よびH P V 感染が示唆された。組織診 は臸異形成と診断された。

<細胞像〉初診時細胞像は比較的きれいな背景の 中に奇異な形態でオレンジ $\mathrm{G}$ 好染ないしェオジン 飞染まる細胞質を有し, Smudge 様濃染核を有す る悪性細胞を多数認めた。以後の細胞診は軽度異 形成一高度異形成を繰り返し毎回のよ 5 亿 P V 感染を示唆する細胞所見を伴っていた。

<組織像>円錐切除標本は慢性頸管炎, 胵壁組織 標本はKoilocytosisを伴う軽度異形成であった。 <結語>今症例は経過観察中の細胞診で毎回のよ 5 V H P V 感染を示唆する細胞所見が認められ， また胵壁病変擦過材料を用いたDot blot hybridi zation 法 (Vira typekit) でHPV 16/18 型 ゲノムが証明された。

以上より, 初回細胞診で扁平上皮癌と判定した細 胞像も, H P V 感染飞ょる細胞変化であろう事が 推定された。

本症例は 2 年以上の経過観察が行われ, 現在病変 は認めず, 細胞診, 組織診も陰性である。 
233. 腟原発悪性黒色腫の一例

神戸市立中央市民病院臨床病理科，同産婦人科* ○田中 敏憲 (CT) 杉田かよ子 (CT) 森田 恵美 (CT) 白根 博文 (MD) 内田 博也 (MD) 高島 英世 (MD) * 小野 吉行 $(M D) *$ 星野 達二 $(M D) *$

悪性黒色腫は発生が外胚葉由来の神経性悪性腫 湯で、メラニン色素を有し、一般に頭頝部と下肢 に発生しやすく、腟原発の悪性黒色腫は極めて稀 な疾患である。今回、我々は攃過細胞診において 診断し得た一例を経験したので報告する。

症例は63歳の未妊婦、閉経51歳。平成元年5月 以降より時々出血と帯下があり近医を受診、癌検 診異常なく senile colpitis としてfollowされ ていた。10月20日、患者が墫内の突出物を触知、 当院へ紹介され、11月15日産婦人科を初診した。

初診時所見 : 処女膜輪近くの9時、11時の部位 に褐色の小結節を認めた。12時の部位にはポリ一 プ状の突出が見られた。型の如く擦過細胞診を行 い悪性黒色腫と診断され、試験生検でも悪性黑色 腫と診断された。皮虐を含む他の部分に原発巣は 認められなかった。

細胞所見：異型細胞は主に孤立散在性に出現、 大小不同が著明。胞体は淡青緑色で、比較的豊か なものから乏しいものまで多彩な像を呈し、細顆 粒状のメラニン色素を有するものも散見された。 核は類円形ないし不整円形を呈し、核クロマチン は微細顆粒状で軽度增量、核小体の著明なものも 見られた。核内空胞を有する細胞も少数認められ 醭素抗体法で S-100は陽性、NSEは陰性であった。 組織所見：腫湯は上皮下に潭漫性に増殖し、腫 瘍細胞は多型性で大小不同が見られ、胞体は広く 種々の量のメラニンを含み、核は類円～多形、腫 大した核小体を有するものや核内空胞所見を認め た。核分裂像も散見され多核細胞の出現も認めら れた。醳素抗体法で S-100が陽性であった。
234. 臸原発悪性黒色腫の 3 症例

九州大学医学部婦人科学産科学教室 ${ }^{1)}$, 国立病院九州がんセンター婦人科 ${ }^{2}$, 国立病院九州がんセンター臨床検査部3) O西田 真 $(\mathrm{MD})^{1)}$, 井町正士 $(\mathrm{MD})^{1)}$, 塚本直樹 $(M D)^{1)}$, 中野仁雄 $(M D)^{1)}$, 自見昭司 $\left.(\mathrm{MD})^{2}\right)$, 園田文孝 $(\mathrm{CT})^{3)}$

臸原発悪性黒色腫は極めて稀な疾患であり, 胵 悪性腫㾨の $3 \%$ 以下といわれている。最近われわ れは 3 例の腟原発悪性黒色腫を経験したのでその 細胞所見について報告する。

症例 $1: 53$ 歳, 妊 2 産 1 , 不正性器出血および 胵腫瘤を主訴に昭和62年 1 月 7 日初診。胵左前壁 の入口部より約 $1 \mathrm{~cm}$ の部位に示指頭大暗赤色のポ リープ状に突出した腫瘤を認め, 同部の擦過細胞 診 $\mathrm{V}$ 型，生検組織診は悪性黒色腫であった。

症例 $2: 51$ 歳, 妊 1 産 1 , 不正性器出血, 水様 帯下および腔腫瘤を主訴に平成元年 1 月 31 日初診。 臸右前壁に長さ約 $5 \mathrm{~cm}$ 亿わたって黒色の色素沈着 を伴う噴火口状の腫瘤を認め, 同部の擦過細胞診 $\mathrm{V}$ 型, 生検組織診は悪性黒色腫であった。

症例 $3: 60$ 歳, 妊 7 産 3 , 平成元年 2 月頃より 右股関節痛および不正性器出血があった。うつ病 で九州大学医学部附属病院精神科入院中, X 線撮 影で骨転移像を指摘され原発巣検索のため 6 月 22 日当科初診。臸左前壁, 右後壁, 後陰唇交連の 3 ケ所飞暗青色隆起性病変を認め, 同部の擦過細胞 診 V 型, 生検組織診は悪性黒色腫であった。

細胞所見：腫瘍性背景の中に異型細胞が主に孤 立散在性に認められ，細胞質は好青性で菲薄であ り，N/C 比は比較的小さい屯のが多かった。細 胞質内には種々の程度にメラニン色素が細顆粒状 て認められた。核は偏在性でクロマチンは微細顆 粒状に増量，核小体は明瞭であった。巨大多核細 胞も認められた。 
235. 子宮内膜細胞診上り診断し得た卵宩 癌の一例

東京慈恵会医科大学産婦人科*, 美馬産婦人科** ○武田 修(MD)*, 落合和彥 $(M D)^{*}$, 恩田威一 (MD)* 北川道弘 (MD)*, 小室順義 $(M D)^{*}$, 安田 允 $(M D)^{*}$ 杉下、匡 $(\mathrm{MD}) *$, 寺島芳輝 $(\mathrm{MD}) *$, 美馬博史 $(\mathrm{MD}) *$

子宮内膜細胞診で卵巣癌細胞を認めるととは希 であり，報告例る少ない。特飞付属器飞明確な腫 瘤を認めない場合には，その originを特定するこ とは困難である。今回我々は卵巣腫痬を認めず， 内膜細胞診で卵巣癌と診断し得た症例を経験した ので若干の文献的考察を加え報告する。

症例は 69 歳, 3 経産。49歳飞て閉経。排氺時に 不正性器出血があり平成元年8月25日に受診した。 初診時の双合診所見は, 子宮鵎卵大で, 卵巣は触 知せず。超音波所見では付属器飞明かな腫大を認 めなかった。子宮胵部 smear は class I であった が, 子宮内膜細胞䛦では上皮性悪性細胞が孤立性 一小集塊を形成し, 粘液産生性空胞, 不規則重積 性も著明飞認められたが, 子宮内膜組織診では癌 組織が認められなかったため, 卵管癌もしくは卵 巣癌を疑い平成元年9月22日拡大全摘術を行った。 手術所見は子宮は正常大, 右卵巣は超母指頭大 で直腸飞癒着が認められたが, 左側卵巣は正常大 で,腹水は認められなかった。

病理所見 serous papillary cystadenocarcinomaであった。卵巣飞はserous な異型 円柱上皮が cystpapil1ary 飞增殖し, 残存する正 常卵巣組織とは連続性があり, 右側卵巣原発の卵 巣癌と䛦断された。卵管組織㤌深正常に残存し 子宮飞は筋腫を見るが, 内膜飞腫痬性変化は認め られず portio, cervixす正常であった。

今回経卵管経由にて内膜細胞診に出現したと推 定され得る卵巣癌の症例を経験したので報告する。
236. 急速な転帰をたどった卵巣clear cell adenocarcinoma の一例

$$
\begin{aligned}
& \text { 九州労災病院 } \text { 産婦人科, 病理 }^{2} \\
& \text { 柏村賀子 }(M D)^{1} \text {, 徳藤一真一郎 }(M T)^{2} \text {, } \\
& \text { 菊次 徹 }(M T)^{2} \\
& \text { 産業医大 病院病理, 産婦人科 } \\
& \text { 藤原 仁 }(C T)^{3} \text {, 佐藤 斎 }(C T)^{3} \text {, } \\
& \text { 柏村正道 }(M D)^{4}
\end{aligned}
$$

卵宩clear cell carcinoma他他の上皮性卵 巣悪性腫瘍と比べ予後が悪いとされている。 今回、骨転移で発見され、急速な転帰をたどっ た卵巣clear cell carcinomaを経験したので、 その臨床像、細胞像ならびに組織像について興 味ある所見を報告する。

症例は49才未妊婦。腰痛の為整形外科を受診 し、転移性癌と診断され、諸検査の結果、卵巣 腫瘍を指摘され、当科飞入院した。CA / 25 は / / OU / ml、AFP、CEA、CA/9-9 は正常值。 開腹したところ、腹水は少量で細胞診は陰性。 子宮は正常大、左卵巣は正常所見。右卵巣は $7 \mathrm{~cm}$ 大の可動性良好な充実性腫瘍で骨盤腹膜や 腸間膜への浸潤は見られず、子宮全摘ならびに 両側付属器切除術を行った。術後は腰痛に対し 放射線療法などを行ったが、急速な転帰をたど り、入院後 3 力月にて死亡。

細胞所見：卵巣の腫瘍スタンプでは、球状の集 団とシート状配列の集団とが見られた。球状集 団はMirror ball patternを呈していた。また シート状配列の集団は,ライトグリーン好性の円 形小体が多数認められ、Endodermal sinus tumor のhyaline globule に類似していた。 腹水貯留がなく、周囲臓器よりる広範な骨転移 が急速にすすんだ症例で、重腹癌も疑ったが、 卵巣原発のみであった。( 解剖所見) 絟織像は多形资明細胞からなる充実性胞巣、 hobnail pattern を呈する腺管状、乳頭状胞巣 が見られ、EST類似所見が見られた。 
237. 卵巣類皮囊腫より発生した悪性黒色腫 の 1 例

丸山記念総合病院 細胞診, 同婦人科 ${ }^{2)}$

埼玉県立がんセンター臨床病理 ${ }^{3)}$

○木村恒子 (CT) , 鈴木君義 $(\mathrm{CT})^{1,}$, 大野喜作 (CT), 塚原和夫 $(M D)$, , 大倉史也 $(M D)^{2)}$, 大野秀夫 $(M D)^{2)}$, 丸山正義 $(\mathrm{MD})^{2)}$, 田久保海誉 $(\mathrm{MD})^{3)}$

はじめに：今回われわれは、卵巣類皮囊腫より 発生した悪性黒色腫の 1 例を経験したので、細胞 学的拉よび組織学的所見を中心に報告する。

症例：65歳女性、8 妊 4 産、初経14歳、閉経46 歳。下腹部膨満感を主訴として他医を受診し、卵 巣腫湯を指摘され、平成元年 1 月 26 日当院婦人科 を受部した。超音波検查拉よびC T検査にて卵巣 囊腫を疑い、腹式単純子宮全摘術および両側付属 器切除術を施行した。病理組織診断は類皮囊腫と、 これより発生した悪性黒色腫であった。術後化学 療法を行い、現在通院にて経過観察中である。

病理学的所見: 肉眼的には囊腫の内側飞径 $2 \mathrm{~cm}$ 以上の黒色斑がみられた。組織学的にメラニン顆 粒を有する腫痬細胞の結節性增殖が数個存在し、 周囲上皮に腫瑒細胞の水平方向への伸展がみられ た。腫瘍細胞は深部において a typia が強く、核 は著しく不整形で、腫大した核小体を有していた。 時に核内空胞を認めた。グリメリウス、フォンタ ナマッソン法は陽性で、免度組織化学的に S-100、 N S E 、ビメンチン染色もまた陽性であった。以 上より悪性黒色腫と䛦断した。

細胞学的所見 : 震腫内容の捺印細胞診におりる 腫揚細胞は、大小の集団でみられた。細胞は類円 形からやや紡錘形を呈していた。細胞質はライト 緑好性に染まり、核は不整形で、偏在するものは 少なかった。クロマチンは微細顆粒状で増量し、 核小体を 1 個認めた。時に細胞質内に褐色の顆粒 を認め、メラニン色素と思われた。

まとめ：まれではあるが、類皮囊腫の悪性化に ついて注意する必要があると思われた。

\section{8. 卵巣腫湯の臸・頸管・内膜細胞診陽 性例の検討}

横浜市立大学産婦人科

O大山俊樹 (MD)，仲沢経夫 (MD)，平原史樹 (MD)，五来逸雄 (MD)，水口弘司 (MD ) 同中央検查部病理

津村みずえ ( CT ), 大津久美子 (CT), 北村和久 (CT), 竹律恵実子(CT), 下山 潔(MD), 桔梗辰三(MD)

卵巣腫揚はその解剖学的性格上, 細胞診陽性率 が他の婦人科腫瘍に比し低いと言われる。そこで 今回当院に乱ける過去 5 年間の卵巣腫瘍悪性群括 よび中間群の細胞診陽性例を検討した。

開腹手術によって組織型が明らかにされた卵巣 腫瘍 58 例中細胞診陽性例は 11 例 $(19.0 \%)$ であっ た。進行期別陽性率は I 期 9.1\%(2/22)，II 期 $14.3 \%$ ( $1 / 7)$, IIII $24.0 \%$ ( $6 / 25)$, IV 期 50.0 $\%(2 / 4)$ と進行期に伴なって增加傾向が認められ た。術前の胵・頸管・子宮内膜細胞診陽性11例の 万ち腹水細胞診陽性例は 8 例 $(72.8 \%)$, 同陰性 47 例のらち腹水細胞診陽性例は 27 例 $(57.4 \%)$ と腹水細胞診陽性例で術前細胞診陽性率がより高 い傾向を認めた。予後に関しては，死亡率は細胞 診陽性例では $45.5 \%$ ( $5 / 11)$ ，陰性例では $8.5 \%$ $(4 / 47)$ と術前の細胞診陽性例でより予後が不良 であった。組織別に見ると，漿液性およびムチン 性腺癌では $16.7 \%(6 / 36)$, 類内膜癌 $100 \%(1 / 1)$, 類中腎癌 $0 \%(0 / 5)$, 類皮囊胞癌 $33.3 \%(1 / 3)$, 転移癌 $100 \%(1 / 1)$, 中胚葉性混合腫瘍 $100 \%(1 / 1)$, 顆粒膜細胞腫 $50 \%(1 / 2)$ であった。

細胞像は, 内膜・頸部・菿への転移巣がなけれ ば, 腫瘍細胞が忽然として出現しその判定は易し いものが多い。しかし組織型の判定は原発巣が多 彩のため正確な診断は得難い。 
239. 原発性卵管癌の二例

聖マリアンナ医科大学産婦人科学教室

○斎藤 馨 (MD), 岩田正範 (MD)

林和彦 (MD), 浜田 宏 (MD)

同臨床検查部病理

星川咲子 (CT), 平野三重子 (CT), 森脇友子 (CT)

同病理学教室

竹内英子 (MD)，田所 衛 (MD)

原発性卵管癌は極めて稀で術前診断の困難な疾 患である。今回我々は開腹時に卵管腫瘍之診断し 病理組織学的に卵管原発の癌と確診された 2 症例 を経験したので報告する。症例 $1: 63$ 歳, 8 妊 4 産, 閉経51歳。主訴は不正出血之下腹痛。子宮胵 部・頸管擦過細胞診では出血性背景の中に高度異 形成の存在を示唆する細胞と一部集簇傾向をみる 腺癌由来を否定できない細胞が認められ, 腫瘍捺 印細胞診では比較的小型で異型性の乏しい腺癌細 胞を認めた。子宮単純全摘術之両側付属器切除術 を行った。肉眼的には左卵管の腫瘍 $(4 \times 3 \times 2 \mathrm{~cm})$ で, 病理組織学的には比較的異型性の乏しい乳頭状 腺癌であった。また子宮胵部には高度異形成を認め た。術後 4 年を経て患者は健在。症例 $2 ： 44$ 歳, 2 妊 2 産。主訴は腹部膨満 (腹水眝留)。腹水細胞 診では大小不同, 異型性の強い腺癌細胞の乳頭状 集塊を認め卵巣癌を疑った。子宮胵部・頸管擦過細 胞診ではclean な背景の中に核小体の目立つ腺癌由 来を示唆する細胞が少数認められた。患者は試験 開腹後, 化学療法を行った後, 再開腹し子宮単純 全摘術之両側付属器切除術および大網切除術を施 行し化学療法を追加した。肉眼的には右卵管原発 の腫瘍 $(3.5 \times 2.5)$ で病理組織学的にはより異型性 の強い乳頭状腺癌。対側卵管, 両側卵巣, 子宮筋 層, 大網への転移を認めた。患者は治療開始後 1 年で再発死亡した。今回の 2 症例のように原発性 卵管癌を術前に確診することは困難であるが, 術 前の子宮胵部・頸管細胞診の再検討にて本疾患由 来を示唆する細胞が発見された事は興味深い。
240.

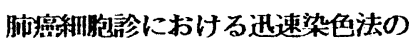
比較梌䣓

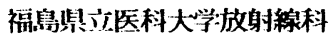 \\ O比仗純孝[MD]，森谷浩史 [MD]，鈴木茂媇 [MD]， \\ 橋本直人 [MD]，渋行広子 [MT]，木村和衞[MD] \\ 福島県保健简生協会 \\ 富H健 [MD] , 松川仴 [MD]
}

目的:我々は第28国日本臨床絒狍学会秋期大会に

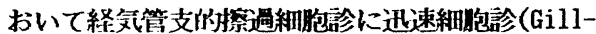
Shorr染色)を導入することにより患者の俱莇鞂 㳦し、検查の师滑化か泃上することを報告した。 今回はGill-Shorr染色以外に、迅速Papanicolaou 染色、Diff-quik染色も同封に行いこれらを比較 検䣓したので船结する。 方法:氮管支鏡を施行する際に湿微鏡と染色液を 用意し、採取した㭘体から通常のPapanicolaou染 色、Gill-Shorr染色、迅速Papanicolaou染色、Di ff-quik染色の4 種類の標本を作成しそれぞれの 比较检討を行った。进速Papanicolaou染色はメル ク社の迅速細抱診用サイトカラーを用いた。この 染色法は10ステップ、3分で染色か完了する。従 来の进速Papanicolaou染色より操作が简便て染色 時䦎海くなっている。

結果:染色までの所要侍間はGill-Shorr染色と迅 速Papanicolaou染色加約 3 分、Diff-quik染色か 約30-60秒であった。細粅所兒はDiff-quik染 色がGiemsa染色に類似しており、Gill-Shorr染色 と迅速Papanicolaou染色は通常OPapanicolaou染 色に類似した紼胞所見を呈した。当科では細胞診 診断はPapanicolaou染色を中心に行うことが多い 為、迅速染色法もPapanicolaou染色類似であるこ とが判定か容易にできる印象であった。Papanico laou染任類似の雨者を比較すると、Gill-Shorr染 色のほうが通常のPapanicolaou染色と類似した核、 和粅留所見を呈した。気管支鏡検查に導入する迅 速染色法としてはGill-Shorr染色か適切であると 思われた。これらの染色法の細胞所見を当日供覧 する预である。 
241. 大分県の喀痰細胞誩による肺癌集団 検診の状況と細胞判定の検討

財団法人 大分県対ガン協会

O櫛来英美 $(C T)$, 後藤亜紀 (CT), 工藤美喜 $(C T)$ 佐藤祐子 $(\mathrm{MT})$ ), 平丸正宣 $(\mathrm{MT})$, 諸井滋子 $(\mathrm{MT})$ 板井真由美 (MT)

財団法人 大分県対ガン協会診療所

上杉正見 $(\mathrm{MD})$

大分県立病院中央検査部病理

过 浩一 (MD)

大分県立病院胸部血管外科

内山貴克 (MD)

大分県対ガン協会では, 昭和 61 年度より喀痰 細胞診に上る肺癌集団検診を行っており, 過去 4 年の細胞診成績とその間に発見された癌症例の細 胞所見について報告する。

材料及び方法: 検診対象者は, 肺癌検診を希望 する 40 歳以上の男女である。受診者総数は, 昭 和 61 年 4 月より平成元年 9 月までの間に, 延べ 4,294 名であった。検体は， 3 日間蓄痰をし，粘 液融解法で処理を行った。細胞判定は, 肺癌学会 集団検誩咯疢細胞診の判定基準に従った。

結果: 判定結果は, [A] 173 名, [B] 3,897 名, [C] 214 名, [D] 10 名であった。精査の結果, $\mathrm{C}$ 判定より 2 名, D判定より 5 名, 計 7 名の癌が 発見された。癌症例中, 肺癌は 5 例, 喉頭癌 2 例 であり，その組織型は，いずれも扁平上皮癌であ った。癌発見率は, $0,16 \%$ であった。肺癌 5 例 は, 精査のための直接胸部X線写真では無所見 4 例, 異常所見 1 例であった。手術後の切除標本で は， 4 例が肺門型早期癌であった。

$\mathrm{C} ・ \mathrm{D}$ と判定した標本は, 高度異型扁平上皮化 生細胞と扁平上皮癌細胞を含んでいると思われ, その解析をした。また喉頭癌 2 例もあり, 肺扁平 上皮癌との細胞所見の差についても检討した。

\section{2. 末梢性肺癌の経皮的針穿刺細胞診の意義 立川共済病院 細胞診 ○薄田 正 (CT). 笹井 伸哉 (CT) 同外科 中山 光男 (MD). 佐藤 孝次 (MD) 防衛医科大学校病理学教室 中西 邦昭(MD).河合 俊明(MD) \\ 慶応義塾大学医学部病理学教室 鳥潟 親雄 (MD) \\ 浅野産婦人科 浅野 順二郎(MD)}

（目的）肺癌の末梢型は喀痰・気管支擦過 ·気管 支洗浄細胞診で、腫場細胞が得られ難く、診断困 難な場合が多い。我々は末梢性肺晸に対して診断 を確定する為に経皮的肺針第刺細胞診を施行し、 良好な成績を得たので報告する。

（材料と方法）材料は1980年から1989年 までの間に病理組織学的に診断が確定し、喀痰 . 気管支摖過・気管支洗浄細胞診で診断できなかつ た2 8症例を使用した。経皮的肺針穿刺は東京医 大式有䊂針を使用した。

(結果) 病理組織学的に診断された 28 例の内訳 は原発性肺癌 25 例、転移性肺癌3例であった。 転移性癌を含む肺癌 28 例中 27 例が細胞診陽性 であり、その正診率は96.4\%であった。陰性 例は 1 例で腫場細胞が採取されていなかった。 細胞診断学的組織型と病理組織診断を比較すると 扁平上皮癌 8 例中 6 例、腺癌 18 例中 1.6 例、大 細胞癌 1 例が一致していた。組織型一致率は 85 . $2 \%$ あった。

（結論）経皮的肺針穿刺細胞診は末梢性肺癌の診 断の為に有用な検查法であると考えられる。 
243. 好酸球性肉芽腫症と診断した 3 例の 臨床細胞学的検討

総合病院 鹿児島生協病院 病理科

○奥村晃久 ( M D )。神渡幹夫 ( MD )

衛藤政志 ( C T )

我々が経験した好酸球性肉芽腫症と診断し た 3 例 (肺病変 2 例、胸椎病変 1 例) を免疫 組織化学的に検索し、病変組織内の組織球の 性状を調べ、好酸球増多、I g E の変動など の臨床所見との関係を検討した。第 1 例 (胸 椎病変）８０才、男性、胸椎の陳旧性圧迫骨 折があり、未血や骨髓に好酸球増多、C R P 陽性、血沈元進、「ッ」反応陽性であった。 胸水には好酸球浸潤が著明で、榜の大きい、 胞体辺縁不明瞭な組織琭が多数認められた。 脊䯣液にも好酸球浸潤と組織球が散見された。 整形外科で椎体固定術を施行。病巣部の肉芽 組織に Muramidase、及び $\alpha$ IAntichimotry psin陽性の単球吞食細胞系組織球を多数証明 した。 S I O0蛋白陽性のTrane組織球は証明出 来なかった。従って、アレルギ一性慢性炎 症と診断し直した。第 2 例 (肺病変) 50 才 男性、胸部写真の異状結節陰影で、開胸肺生 検施行。肉芽組織の新鮮標本で $\mathrm{T}_{6}$ 抗原、及び

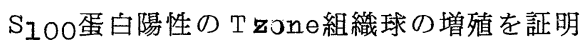
した。その後、TBLB標本を用いて検索し、同 様の結果を得た。第 3 例 (肺病変) 16 才、 女性、肺痤検のパラフィン標本で検索。肺実 質内に $\mathrm{S}_{100}$ 蛋白陽性の Tzono 組織球を集塊 状に証明した。従って、これら 2 症例は肺原 発好酸球性肉芽腫症と診断した。臨床検査所 見では末血の好酸球は軽度増加、IgE高值、 「ッ」反応陰性であった。3 症例とも細胞診で は診断出来なかった。臨床所見を重視し、疾 病の本質を表わすには好酸球性肉芽腫症は $\mathrm{T}$ zon日組織球腫症とし、アレルギ一性慢性资 症の場合に用いるべきではないかと思う。
244. 小細胞癌細胞と鑑別が困難であった 非小細胞性肺癌の 3 例

日立総合病院 臨床検査科病理部 ${ }^{1}$, 外科 ${ }^{2}$ $\mathrm{O}$ 根本昌夫 $(\mathrm{CT})^{1}$, 高橋 敦 $(\mathrm{MD})^{1}$, 神山幸一 $(\mathrm{MD})^{2}$ 日立総合健診センター臨床検査科高荷 恵 (CT) 筑波メディカルセンター病院病理科土井幹雄 (MD)

肺癌を治療の面から考慮すると小細胞癌と非小 細胞癌に大別することができる・小細胞癌細胞と 判別が困難であった肺癌 3 例の細胞像について 報告する。

症例 $1 ： 68$ 才, 男性。健診によって左上肺野に異 常陰影が指摘され, 細胞間結合性および一部に重 積性を示す腫瘍細胞が検出された。細胞径は小型 から中型で細胞質はほとんどみられず，核クロマ チンは粗く，不均等に分布していたてとにより低 分化型癌細胞が疑われた。しかし，核縁は整で核 小体は概ね 1 個であった。摘出された腫瘍は中等 度分化型腺癌之診断された。

症例 2 : 70才, 男性. 健診によって左上肺野に異 常陰影が指摘され, 孤立散在傾问あるいは細胞間 結合性を示す腫瘍細胞が検出された。細胞径は小 型であり, 裸核状の細胞が多くみられたことによ り小細胞癌細胞が疑われた。しかし, 核の大小不 同が目立ち, 核形は棈円形ないし不整形であり, 核縁は整であった。クロマチンは細顆粒状で均等 に分布していた。摘出された腫瘍は低分化型扁平 上皮癌と診断された。

症例 $3: 78$ 才, 男性. 感冒様症状によって来院し, 右肺尖部に異常陰影が指摘された。喀疢から検出 された腫瘍細胞は散在傾向が著明であり, 一部平 面的結合性もみられた。細胞径は極めて小型であ り, 裸核状を示したことにより小細胞癌細胞が疑 われた。しかし，核形は円形から卵円形であり， 核縁は整, クロマチンは顆粒状で均等に分布して いた。核小体は小さく概ね 1 個であった。剖検の 結果, 腫瘍は低分化型腺癌と診断された。 
245. 肺原発印環型細胞癌の 1 例

国立療養所沖縄病院 ${ }^{1 ）}$ 琉球大学第 2 病理 ${ }^{2)}$

○岸本明久 $\left(\mathrm{C} \mathrm{T}^{1}\right)^{1}$ 久場睦夫 $(\mathrm{MD})^{1)}$

石川清司 (MD) ${ }^{1}$ ） 源河圭一郎 (MD) ${ }^{1}$ )

岩政輝男 ${ }^{2)}$

最近我々は，粘液形成が著明な，肺原発のいわ ゆる印環細胞癌を経験したので報告します。

〔症例〕47歳, 男性, 集団検診にて胸部 X線像上, 右肺門部異常陰影を指摘され精查のため当院紹介 された。気管支鏡検查で右肺気管支 $\mathrm{B}_{3}{ }^{\mathrm{b}}$ 入口部に 腫瘤を認め, 同部の擦過細胞診より印環型の異形 細胞を認めた。

〔細胞所見〕異形細胞は, 散在性又は重積性に出 現し, 細胞質がわずかに赤染し粘液の豊富なこと が示唆された。核は偏在し印環型を示し,クロマ チン顆粒状で著明な核小体を認めた。細胞質内は, P A S 染色, アルシアン青染色にて染り粘液物質 が証明された。

〔組織所見〕いちじるしく大量の粘液を胞体内に 入れ, 小型類円形核が偏在する腫瘍細胞が気管支 壁にそって胞宩を作り増殖している。腫瘍の大き さは $2.5 \times 2.0 \mathrm{~cm}$ であった。

〔まとめ〕肺原発の印環型細胞を主体とする腫瘍 はまれであり，分類及び組織発生にも不明な点が 多い。本症例は肺門部付近に腫瘍を認め, 多量の 粘液を含む印環型細胞の充実性胞巣が主体をなし 気管支壁にそって増殖していた。
246. 気管支洗浄液細胞診で診断し得た気 管支腺型肺腺癌の一例

横須賀共済病院病理部

○川口幹夫 ( C T ) 石渡仁梁 ( C T )

栗原正美 ( CT) 浅見正敏 ( C T )

赤羽久昌（MD） 木村雄二 ( MD )

肺腺癌は多彩な細胞像を呈し、組織亜型の推定 に苦慮する事が多い。今回私達は気管支洗浄液の 細胞診で、気管支腺型肺腺癌と診断し得た症例を 経験したので、その細胞像について報告する。

症例 : 76 歳、女性、農業。既往歷、家族歷に特 記する事はない。1987 年近医で胸部異常陰影を指 摘され数力所の病院を転院後、1989 年 10 月嗄声を 主訴に当院内科を受診した。胸部XPで右上葉の腫 瘤影と縦隔、左肺門リンパ節の腫大を認め、血清 のCA 19-9が640u/ml と高值であった。

細胞診所見：気管支洗浄液に集合性で大型の異 型細胞が見られた。この細胞は類円又は不整形で 大型の核が偏在し、クロマチンは粗顆粒状で大型 の核小体を見る。豊富な細胞質に大型空胞を認め 時として、好中球の侵入を見る。

病理組織所見：気管支肺生検で腫瘍は、粘膜下 に増殖する腺癌で、一部は肺胞壁を這って発育し ていた。腫瘍細胞は多量の粘液を有し、電顕で細 胞質内に central condensationを持つ墏液顆粒と 粘液顆粒を認め、気管支腺型腺癌と診断した。

まとめ: 粘液産生性の肺腺癌には杯細胞型と気 管支腺型がある。杯細胞型の異型細胞は小型で核 異型が弱く、杯細胞や組織球に類似するが、気管 支腺型の異型細胞は大型で核異型が強く、粘液の 産生が著明であった。又消化管からの転移性腺癌 の異型細胞は小型で、気管支腺型腺癌との鑑別は 可能と思われる。私達の経験した気管支洗浄液の 異型細胞は比較的細胞の変性が少なく、気管支腺 型腺癌と細胞診で診断し得たが、腫瘍細胞の粘液 顆粒や漿液顆粒の電顕による検索が、最終的な診 断の根拠となった。 
247. A Case of Adenoid Cystic Carcinoma of the Relative Pheripheral Bronchus with Pleural Effusion

Department of Internal Medicine, Kaohsiung Medical College, *Yuan's Menorial Hospital, Kaohsiung, Taiwan, R.O.C. Ming-Shyan Huang, MD, MIAC. , *Ming-Chuan Yang, MD., Ping-Cherng Chiang, MD.

Adenoid cystic carcinoma is a rare tumor which occurs most in the trachea and large bronchi. We experienced a relatively rare pheripheral type with pleural effusion adnoid cystic carcinoma.

A case of 37 year-old male complained of dry cough for 4 months. Chest X-ray showed the left side pleural effusion. Bronchoscopy revealed a nodule with a smooth surface in left B3a. Thoracoscopy revealed tumor sheeting on the pleura. Both sites biopsy yielded a diagnosis of adenoid cystic carcinoma. Histological findings: The cribriform pattern and a tendency for cystic acellular spaces to form in the masses were noted. The tumor cells were ovoid and had little cytoplasm. Brushing cytological specimen : Ball -like and tight clumps of small polygonal cells were seen. Nuclei were round and almost uniform in size. Pleural effusion cytological specimens:The cells in ball-like clusters were small and rounded with little variation in size and showed a low degree of atypia. Cells containing mucin was also noted.
248. Sputum Cytology of Metastatic Choriocarcinoma -- A Case Report --

Department of Internal Medicine, Kaohsiung Medical College, Taiwan, R.O.C. Ping-Cherng Chiang, MD, Ming-Shyan Huang MD, Jhi-Jhu Hwang, MD.

Case: A 35-year-old female experienced vaginal bleeding, hemoptysis and cough for one month. she delivered a normal baby 2 months ago. Chest $\mathrm{X}$-ray revealed multiple opacities in both lung. $\beta$ - HCG level was up to $4000 \mathrm{IU} / \mathrm{L}$. The histology of uterine endometrium showed a diagnosis of choriocarcinoma. She died few days after chemotherapy .

Histological findings: The tumor was composed basically of two cell types. Cytotrophoblasts were represented by relatively little cytoplasm and clusters. The syncytiotrophoblasts were large, irregularly shaped cells, which were multinucleated with clusters and indistinct cell borders. The nuclei were large, hychromatic with marked pleomorphism.

Cytological findings: The sputum specimen contained blood and many clusters of cells with abundant, basophilic,vacuolated cytoplasm and round pleomorphic hyperchromatic nuclei with prominent nucleoli. Syncytiotrophoblastic cells were multinucleated with abundant cytoplasm and clustering of hyperchromatic nuclei.

It was difficult to diagnose it from sputum cytology. However, the raised $\delta$-HCG levels and malignant multinucleated gaint cells presented in sputum should take it into consideration. 
249. 気管支腺由来の唾液腺型腫痬と考元ら れる一切除例

弘前大学第二内科

○木村 隆 (MD)，高梨信吾 (MD)， 小野寺庚午 (MD)

青森県立中央病院臨床検查科 ${ }^{13}$, 呼吸器科 23 今井 督 (MD) ${ }^{1)}$, 竹越美佐江 (C T $)^{1)}$, 川本真由美 (C T $)^{1)}$, 田中正治 (C T $)^{1)}$, 貝森光大 $(M D)^{1)}$, 管三知男 (MD) ${ }^{1)}$ 高谷彦一郎 (MD) ${ }^{1)}$, 岡庭群二 (MD ${ }^{22}$, 蝦名昭男 (MD) ${ }^{23}$

比較的希な疾患である気管支腺由来と考えられ る喠液線型腫瘍の一切除例を経験したので報告す る。症例は57才の女性で集検にて胸部異常陰影を 指摘され入院した。胸部 $\mathrm{X}$ 線写真では左 $\mathrm{B}^{3}$ 入口部 に閉塞する半球状の腫瘤を恝めた。生検組織標本 では比較的小型で N/C比む小さく淡明な細胞質を 有する細胞が充実性に一部管くうを形成していた。 bronhial oncocytomatous adenoma と診断された が陰影の增大が認められ左上葉切除を施行した。 捺印細胞標本では $N / C$ 比が小で淡明な細胞質を 有する比較的小型の細胞が集魂を成し管くう様構 造もみられた。角化型扁平上皮細胞や硝子様物質 等も認められた。また組織像では小型で異型性の 低い細胞が管くう形成を主体に一部充実性、索状 に配列し間質の硝子化む目だっていた。被膜はな く一部で周囲組織への浸潤傾向がみられまたやや 異型の強い細胞も認められたため carcinoma in pleomorphic adenoma と診断された。また特殊染 色による組織標本や電子顕微鏡写真による検討も あわせて報告する。
250. 肺穿刺吸引細胞診で肉腫様細胞の 出現をみた扁平上皮癌の一例

聖マリアンナ医科大学病理学教室 $\bigcirc$ 竹内英子 $(M D)$ 須永達哉 $(M D)$ 田所 衛 $(M D)$ 聖マリアンナ医科大学病院病理部 星川咲子(CT) 平野三重子(CT) 森脇友子(CT)

扁平上皮癌は時に多様な綀胞形態を示し, 腫瘍の 一部の生検または細胞診では組織型の診断に困難 を来すことがある。今回, 我々は肺の穿刺吸引細 胞診で肉腫様細胞の出現をみ, 検索の結果扁平上 皮癌由来とされた症例を経験したので, 細胞像お よび組織像を提示する。患者は77才, 女性。近医 歯科にて抜歯後に発熱出現。内科受診し胸部 $\mathrm{X}$ -

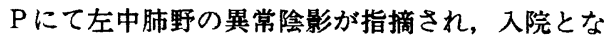
った。入院時歯肉の腫脤も認めた。精查の結果, 悪性腫瘍が疑われ，C Tガイド下での肺穿刺吸引 細胞詥及び歯肉の生検を施行。その後全身の衰弱 が強く死亡。剖検となった。〔細胞像〕出血性背 景に, 異型性が強く, 多形性に富む悪性細胞が散 在性ないし集塊状に認められる。細胞質は此較的 厚みがあり，辺縁明暸で類円形ないし紡鍾形また は不定形を示す。核は大小不同，核型不整が目立 ち，多核巨細胞が多くみられる。クロマチンは增 量し粗く, 核小体も目立つ。これらの像から肺の 巨細胞癌あるいはM F Hなどの肉腫の存在を疑つ た。〔菌肉の生検組織像〕大部分は紡錘形の腫瘍 細胞が束となって交錯している像で散在性に多核 巨細胞がみられる。一部に類冈形または多綾形の 細胞が敷石状に配列している。〔剖検所見〕下影 畨肉に $4 \times 4 \times 3 \mathrm{~cm}$ 大で，表面溃瘍状，割面 白色充実性の腫瘍, 肺には左上葉に比較的境界明 䊩な $4.7 \times 3.5 \mathrm{~cm}$ 大の一部壤死を伴う腫瘍を認 めた。転移巣は両側副叒, 右鎖骨上リンパ節, 及 び椎骨に認めた。組織学的には，腫瘍は生検の像 に加之明らかな扁平上皮㾂と考之られる像が存在

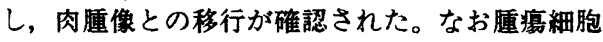
はKeratin陽性, Vimentin弱陽性であった。 
251. 発育形式・胸水細胞診で悪性中皮腫と の鑑別を要した肺の低分化類表皮䖈の細胞組織像

新潟市民病院 臨床病理部 $\bigcirc$ 田中伸子 (CT)， 荻部 豊 $(C T)$, 清野俊秀 $(C T)$, 涉谷宏行 (MD)，岡崎悦夫 (MD)

症例：83 歳女性。1986年11月より腰背部痛、咳 濑、喀痰あり。肺癌の疑いで当院内科に紹介入院。 胸部写真では右側の気胸と胸水貯留が示唆され、 $\mathrm{C} \mathrm{T}$ 上右肺絴隔側に腫㾇陰影あり。胸水細胞診で 悪性中皮腫または腺癌が考えられたが確診を得ぬ まま入院 $2 力 月$ 後に死亡。胸水細胞喰: 多数の反 応性中皮細胞を背景に、軽度の異型を示す細胞の 小集団ならびに核小体著明な孤立性細胞を認めた。 剖㛟・組織所見：前紛隔は灰白色板状に硬く、右 胸腔は胼胝状腫場性に肥厚した胸膜で覆われ、13 $00 \mathrm{~m} 1$ の血性液貯留あり。右肺は表面白色調で肺門 部に向って縮小し、胸壁、横隔膜との瘾着はなか つた。上葉肺門側に $3 \times 2 \mathrm{~cm}$ 大の腫㿔があり、肺実質 に浸潤すると共に壁側胸膜の腫湯性肥厚に連続し ていた。組織学的には、肺実筫内で粘液産生性の 細気管支肺胞型腺䄆が增殖。また硬く胼胝梯の部 分には小〜中型で円形の未分化腫煬細胞が肉腫様、 びまん性に增殖し、一部に角化傾向や稀に管腔形 成のみられる未分化類表皮癌を認めた。腺癌の間 質の一部には未分化腫湯細胞が浸潤性に広がり、 両者はよく混じりあっていた。未分化腫掦細胞は、 Vimentin (+), Keratin (+), CEA(-), PAS (-), Alcian blue (-)、角化を示す腫湯細胞は、Vimentin (-), Keratin $(+)$, CEA (-) , 管腔内粘液や胞体の一部と膜 表面はPAS(+), Alcian blue(+)で、ジアスターゼ、 ヒアルロニダーゼの消化に抵抗性であった。

まとめ: 胸水細胞診で悪性中皮腫との鑑別が難し い低分化類表皮滛の剖検例を検討した。この型の 特殊な癌でもジアスターゼ消化 PAS, ヒアルロニダ 一ゼ消化 Alcian blue染色が鑑別上有用であった。
252. 扁平上皮癌との鑑別を要した気管分支 部の異型を伴う扁平上皮病変

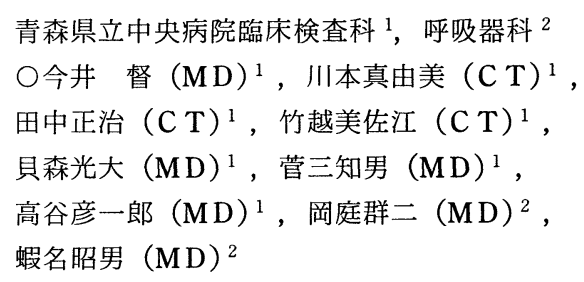

症例は 47 才の男性。昭和 63 年 11 月に血痰を 主訴として近医を受診し，気管支鏡検查で気管分 支部に発赤著明な軽度隆起性病変を認め, 生検に て扁平上皮癌と診断され当科へ紹介入院した。

擦過細胞診では，中等度の異型を伴う扁平上皮 細胞がみられ, 生検組織では, 粘膜下に炎症細胞 浸潤や血管新生を伴う異型性扁平上皮組織がみら れた。両者の所見より異型を伴う扁平上皮病変と 診断し, レーザー照射治療を行い現在経過観察中 である。

類似した経過をとった他の症例も含めて報告す る。 
253. 多数の多核巨細胞の出現を見た小細胞 癌の胸水細胞診について

\section{和歌山赤十字病院病理課}

O宮木康夫 (CT)，静木厚三（MD）

今回我々は，異型の強い多核巨細胞が多数胸水 中に喼められた小細胞溰の一例を経験したので報 告する.

【症例】69才，男性. 1989 年 9 月末より咳 と疢がひどく近医受晾。胸部レントゲン撮影にて 胸水眝留を指摘され同年 10 月中旬本院受診.

11 月 4 日死亡. (入院時検查所見の中で特に 血清NSEが $54 \mathrm{ng} / \mathrm{ml}$ と高值であった。)

【胸水細胞所見】異型細胞は孤立散在性に認めら れ単核細胞と多核巨細胞として出現している. 単 核細胞の核クロマチンは細顆粒状で核緑の肥厚は 目立たない。多核巨細胞の核は円形から奇怪な形 をしたタイプまでさまざまで核分裂像も認められ る. 核クロマチンは，細顆粒状で核縁の肥厚は目 立たない。核内封入体を有する細胞も認められる 核小体は，単核細胞，多核巨細胞ともに中型のも のが 1 2 認められた。

【組織所見】腫揚はほぼシート状に広がり，とこ ろどころに大きな凝固壊死菓が認められる. 間澌 は，ごく少量で胞隔状である. 腫瘍は血管周囲に 偏在する傾向を示すところもあるが，肺胞内への 浸潤も強い。腫煌細胞は一様に小型で細胞盺はき わめて少ない。核は濃染して核小体の認められな いものもあるか，比較的明るい核で核小体の認め られるものも多い，核分裂像は頻繁に認められる ところどころに散在性に異型の強い核が二核また は多核の状態になった巨細胞も認められる. 以上 の所見より小細胞澺と診断された。
254. 気管支洗浄液細胞診が有用であった気 管支カルシノイドの一例

中勢総合病院病理 ${ }^{1)}$, 同内科 ${ }^{2)}$, 回生病院病理 ${ }^{3)}$, 同胸部外科 ${ }^{4)}$, 三重大学医学部病理 ${ }^{5)}$

○井原慎司 $(\mathrm{CT})^{1)}$, 兽我俊彦 $(\mathrm{MD})^{1)}$, 牧野克俊 $(\mathrm{MD})^{2)}$, 山本伸仁 $(\mathrm{MD})^{2)}$, 留奥 誠 $(\mathrm{MD})^{2)}$, 玉井琢也 $(\mathrm{MD})^{2}$, , 西川恭弘 $(\mathrm{CT})^{3)}$, 服部良二 $(\mathrm{MD})^{4)}$, 矢谷隆一 $(\mathrm{MD})^{5)}$

症例：66才, 女性。主訴は乾性咳嗽, 胸部 X線 上右中下葉に異常陰影を指摘され, 肺炎の診断に て抗生剤投与により症状は改善されたが, 腫瘤様 陰影が残存した。喀痰細胞診は陰性。気管支鏡検 查にて, 右 $\mathrm{B}^{4,5}$ 分岐前に, 一部白苔の付着する表 面平滑で赤色調の腫瘤を認め, 経気管支的肺生検 (TBLB)，気管支洗浄液細胞診が施行された。生 検組織診断は陰性, 細胞診の結果, 非ホジキンリ ンパ腫, 小細胞性未分化癌およびカルシノイドの 疑いで右中下葉切除術が施行された。

細胞所見: 壊死物質のない出血背景に比較的大 きさの揃った小型円形の細胞が散在性, 平面的に 出現し, 細胞質はそしく N/C 比の大きな細胞, 裸 核状の細胞が多くみられる。核は円〜卵円形, 核 縁は均等で一部陥入がある。クロマチンは軽度増 量, 細顆粒状で均等分布し, 核小体は小型のもの が 2,3 個みられた。

肉眼所見: 腫瘍は $3 \times 2 \times 1 \mathrm{~cm}$ の白色䯣様の結節 で被膜はみられなかった。

病理組織所見：均一な円形あるいは卵円形核を 有する細胞の胞巣状増生がみられ, 細胞質は好酸 性であった。グリメリウス染色, フォンタナ・マ ッソン染色にて好銀顆粒がみられ, カルシノイド と診断された。以上の症例について TBLB後喀痰 細胞診の細胞像を加えて報告する。 
255. 喀痰中にアミロイド物質を認めた全身 性アミロイドーシスの 1 例

大阪警察病院 研究検査科病理 ${ }^{1)}$, 同院長 ${ }^{2)}$ O黒川和男 ( $\mathrm{C} \mathrm{T})^{1)}$, 辻本正彦 (MD) ${ }^{1)}$, 林 真奈美 $(\mathrm{CT})^{11}$, 吉川和弘 $(\mathrm{MT})^{1}{ }^{1)}$, 大西あゆみ $(M T)^{1)}$, 名古曽教彦 $(M T)^{1)}$, 宜野座安順 $(C T)^{11}$, 岡野錦弥 (MD ${ }^{11}$ 滰 一郎 $(M D)^{2)}$

アミロイドーシスは、線維構造をもつ特異な蛋 白が細胞外に沈着する原因不明の代謝性疾患であ る。アミロイドは、脾、肝、腎、副腎に好んで沈 着するが、肺に見ら扎ることは稀である。そして 喀痰中のアミロイドの報告例も少ない。今回我々 は、全身性アミロイドーシスの患者の喀痰中にア ミロイド物質の出現を認めたのでその検討を行っ た。

症例は67歳男性で、昭和60年12月下旬より軽い 感冒様症状と労作時前胸部痛が出現した。その後 尿閉も出現したため、当院に救急入院となった。 陳旧性心筋梗塞、労作性狭心症、塵肺、慢性気管 支资の診断がなされ、抗生剂投与により、呼吸苦、 咳は軽減したが労作時倦急感は持続。昭和 61 年 4 月20日呼吸不全にて死亡した。

剖検後の病理診断は、全身性アミロイドーシス で、肺に著明なアミロイドの沈着が認められ、そ の他、心、胃腸、前立腺、肝、脾、膵、副腎等に 血管周囲性に軽度のアミロイドの沈着が見られた。 喀痰細胞診のパパニコロウ染色標本では、资症 性の背景にライトグリーンに淡く〜濃く染まる壊 死様無構造物質を認めた。これらは簡易偏光装置 にて重屈折を示し、脱色後のコンゴレッド染色に おいても陽性を示した。これらの物質について詳 細に検討を加え発表する。
256. 肺腫瘍様病変の二例

兵庫医科大学第一病理 ${ }^{21}$, 神戸市立西市民病院臨 床病理科 ${ }^{21}$, 同内科 ${ }^{31}$

○名方保夫 (MD) ${ }^{11}$ ，森 睦子 (MD) ${ }^{1)}$ ，準田 彬(M D) ${ }^{11}$, 森 芳茂 $(\mathrm{MD})^{11}$, 原留成和 $(\mathrm{CT})^{21}$, 小谷 巧 $(\mathrm{CT})^{21}$, 田村 亮 (MD) ${ }^{3)}$

肺の腫瘍样病変には比較的まれなものが多く、 ときに悪性腫瘍との鑑別が問題となる。今回我々 は、肺腫瘍様病変の二例を経験したので、それら の細胞像および組織像に若干の文献的考察を加え て報告する。

症例 1 ; 炎症性偽腫瘍。63才男性。主訴は咳濑 と発熱。昭和 63 年 11 月下旬に咳濑、発熱および血 痰が出現し、胸部 X線で左中肺野に異常陰影を認 めた。断層写真およびCTで S4を中心に腫瘍様病変 を認め、喀痰および擦過細胞診で腺系異型細胞を 認めた。その後も陰影に変化が見られず、左肺上 葉切除術を施行した。腫瘤は $4 \times 4 \times 2.5 \mathrm{~cm}$ であった

細胞像 : 核は偏在傾向を示しクロマチンは均一 で、核小体明瞭、核縁は整でculster を形成する 腺系異型細胞が認められ、悪性細胞との鑑別が困 難であった。

組織像 : 肺胞構造は破壊され、線維化像を中心 にして多数の形質細胞や小リンパ球浸潤、また泡 沫細胞の集簇巣も認められた。

症例 2 ; 硬化性血管腫。48才女性。自覚症状は なし。昭和 63 年 10 月検診時の胸部 $X$ 線で右下肺野 S7にcoin lesoin を指摘されたが、細胞診は陰性 であった。12月初旬に右肺下葉切除術を施行。腫 瘤は $2 \times 2 \mathrm{~cm}$ で、比較的境界明瞭で暗赤色調であっ た。

捺印細胞像: 小型の肺胞上皮様細胞に加えて、 少数の線維細胞や炎症細胞が認められた。

組織像 : 内腔面を一層の扁平〜立方状細胞で覆 われ、赤血球を含む大小の血管腫様構造が認めら れた。間質の多くは硝子化し、リンパ球、形質細 胞や組織球の浸潤が認められた。 


\section{7. 多発性過誤腫の一例}

\section{群馬大学医学部附属病院中央唡査部病理 同大学第 2 内科* 同大学第 2 外科壮}

\section{O新井征夫(MT) 石原 力(CT) 清水和彦(MD) \\ 細村泰夫 (MD) 倉林良幸 $(M D)$ 城下 尚(MD) 大村 暁(MD)*小谷野哲也(MD)**安斎徹男(MD)**}

肺過誤腫のうちでも多発性肺過誤腫は極めて稀 な良性腫瘍で、今回我々は試験開胸にて生検及じ 捺印細胞診を施行し、多発性過誤腫と診断した症 例を経験したので報告する。

症例は47才、女性、昭和62年4月の集検にて肺 野異常陰影を指摘されたが自覚症状が無いため放 置。平成元年 4 月の集検での胸部 $X-P$ にて肺野 にmultiple coinlesion を認め、転移性肺癌が疑 われた。胃透視、注腸像影、胸部エコー、内視鏡 検查では特に異常は認めらなかった。肺の断層撮 影にて腫瘍を強く疑わせる所見が見られたため当 院にて原発巣の精查及び加療目的にて入院した。

入院時胸部 $X-P$ は昭和 62 年に比べ陰影の数は 増加しているが個々の大きさはあまり変化は無か った。同年10月11日、骨盤部C T-scanにて鼠径 部に異常集積像を認め、生検組織診断にてLeiomyomaと診断された。同年11月16日、肺の開胸生検 術中診にて既往症に子宮筋腫があり、鼠径部の所 見と同様のことからBinign metastasizing leiomyoma が疑われたが、捺印細胞診、生検組織診 にて多発性肺過詰腫と診断した。

摘出された腫瘍は暗褐灰白色充実性で一部霊胞性 な部分を認めた。

捺印細胞像は円柱上皮がシート状又は孤立散在 性に、線維状の平滑筋細胞が散在性に出現してい た。いずれも異型は認められなかった。

病理組織学的には、腫瘍組織は錯走する平滑筋 細胞束と震胞状拡張傾向を示すリンパ管ないし腺 管の増生がからみ合って認められた。内皮細胞と 円柱上皮細胞が同一露胞内に移行する形で存在す る部分も見られた。
258. 長期経過観察し得た肺の多発性軟骨性 過誤腫の 1 症例

一単発性軟骨性過誤腫との比較検討を加えて一

日本赤十字社医療センター中央検查部細胞猃 ${ }^{1}$,

同病理, 東京清瀬医学技術専門学院, 自衛隊中央 病院検査部病理 ${ }^{4}$

O稲木美保子 $(\mathrm{CT}))^{1}$, 高久忠一 $\left.(\mathrm{CT})\right)^{3}$, 橋本昭一 $(\mathrm{CT})$, 野口泰子 $(\mathrm{CT})^{1}$ ，馬洸基樹 $(\mathrm{MD})^{4}$ ，武村民子 $(\mathrm{MD})^{2}$

肺の軟骨性過誤腫は, 通常単発性である。今回 我々は, 初発から23年の経過を観察し得た, 多発 性軟骨性過誤腫の症例を経験したので報告する。

【症例】59歳男性。1966年 6 月, 集検にて肺の異 常陰影を指摘され, 自衛隊中央病院で腫瘍摘出。 過誤腫と診断された。1989年 5 月, 集検にて, 右 肺腫湯の増大を指摘され，8 月当院外科に入院。 胸部 X線, CTにて多発性肺腫瘍を認めた。穿刺 吸引細胞診により, 軟骨性過誤腫と診断され，9 月18日, 右肺最大径の腫瘍の摘出が行なわれた。

【細胞診所見】穿刺標本では, 多数の上皮様細胞, 脂肪細胞, 紡鍾形細胞の集簇, 少量の軟骨成分 を認め, 軟骨性過誤腫と診断された。上皮様細胞 は，よくそろったシート状配列を示す小型立方状 細胞之，散在性〜小集塊で出現するやや大型の細 胞から成っていた。後者の核は類円形，ク、ロマチ ンは細顆粒状, 時に核の大小不同を認めた。

【病理組織所見】摘出腫瘍は, $11 \times 12 \times 7 \mathrm{~cm}$, 線 維性被膜で包まれ，壊死とゼリー状内容物を含ん でいた。組織学的には, 未熟軟骨組織と, 脂肪組 織の中に，上皮様細胞の小結節が多数混在してい た。上皮様細胞は，好酸性の細胞質を持つ紡鍾形 〜多角形の細胞で, 渦巻状配列を呈する他, 散在 性に軽度異型を示すすのが見られた。

本症例については，特に上皮成分において通常 の単発性軟骨性過誤腫との間に大きな差が認めら れた。両者の細胞, 組織学的比較を, 免疫組織化 学的所見, ならびに電顕所見を加えて報告する。 
259. Pulmonary Endodermal Tumor Resembling Fetal Lung の一症例

倉敷中央病院病理検查科

○能登原憲司 (MD), 片山博正 (CT), 古谷満寿美 (CT), 則松良明 (CT), 香田浩美 (CT), 伊達晶子 ( CT),

野口秀樹 (MT)，伊藤隆志 (MT)

Pulmonary endodermal tumor resembling fetal lungは希な, 胎児肺に類似する特異な組織像を呈 する肺癌である。今回われわれは本腫瘍の一例を 経験し, 細胞診断に苦慮したので報告する。

【症例】46才, 女性。'88年12月より咳, 喀痰あり。 '89年 1 月近医受診し, 胸部レントゲン写真にて異 常陰影を指摘され，2月当院にて肺癌の疑いのも と, 左上葉切除術を施行された。術後 10 力月現在, 再発もなく，経過は良好である。

【穿刺細胞所見】気管支上皮細胞類似の細胞が重 積し, 腺腔形成を思わせる多数の集塊を形成して いた。乙れらの細胞の核はほぼ円形で,クロマチ ンは軽度増量し, 核小体は小さかった。胞体は淡 く不明瞭で, 線毛は認められなかった。集塊によ つては karyorrhexis が目だった。異型性, 核形不 整, 核の大小不同は乏しく, クロマチン分布も均 等であり, 術前には癌細胞と断定出来なかつた。

【組織所見】腫瘍は異型性の乏しい, 胞体の淡明 な高円柱状細胞からなり，樹枝状に分岐する管腔 を形成していた。部分的に, 腫瘍細胞が桑実状に 増生する部分があり，乙の部分は免疫組織化学的 に, Leu 7 , chromogranin が陽性であった。この 組織像は胎児肺構造に類似するものであった。腫 瘍の境界は明瞭であり, 辺縁においては萎縮した 非腫瘍性肺胞上皮の混在がみられた。

【まとめ】本腫瘍は細胞の異型性がそしいため細 胞診断が困難であり，線毛を有さない重積した細 胞集塊が多数出現する点が, 本腫瘍を疑うポイン トになると考えられた。本属瘍は希だが, 呼吸器 系細胞診検查の場合には, 念頭に押く必要のある 腫瘍と考える。
260. アミラーゼ産生肺小細胞癌の一例

愛知県厚生連渥美病院検査科病理 ${ }^{1}$ '同内科 2)

O夏目俊彦 ${ }^{1} （ \mathrm{C}$ T ） 塚䐗雅夫 ${ }^{2}$ （MD） 名古屋大学医学部臨床医学講座

奈良佳治 （MD） 中島伸夫 （MD）

愛知県がんセンター病院

栗田宗次 (MD)

高アミラーゼ血症を伴った肺癌の報告は, 19 51 年W e i s s らに始まるが比較的稀である. 今回, 我々は高アミラーゼ血症を伴った肺小細胞 癌を経験したので報告する。

【症例】 60 歳, 男性. 主訴, 咳. 既往歴, 45 歳より高血圧にて治療, 59 歳時胃潰瘍にて胃部 分切除. 喫煙歴, 20 歳より 56 歳まて 1 日 60 本. 現病歴, 昭和 63 年 5 月中旬より咳が出現, 当院受診, 胸部 $X$ 線にて異常陰影を指摘され, 同 年6月 22 日人院となる。入院時胸部 $X$ 線にて左 肺門部に腫瘤影を認め, 喀痰細胞診にて小細胞癌 と診断され，N S Eは $45 \mathrm{ng} / \mathrm{ml}$ と高值を示し， アミラーゼは血清2 $315 \mathrm{lU} / \mathrm{ml}$, 尿4190IU ノm1でともに高值を示した.アミラーゼアイソザ イムにおいてはP型に比して S 型が優位で西分画 を認めた。耳鼻科的には唾液腺には異常を認めず， 又腹部 C T, 腹部超音波にても膵臟には異常を認 めなかった。剖検時の肺腫瘍組織は, 小細胞癌, 中間型の像を呈した。畽場組織のアミラーゼ值は 正常肺組織比して高值でアミラーゼアイソザイム は S 型優位でそのS / P 比は一致していた。醅素 抗体法にて腫場細胞の胞体内にアミラーゼ陽性所 見を認め, 電顕において胞体内に分泌顆粒を認め た。以上によりアミラーゼ産生肺小細胞癌と診断 Uた. 
261. 穿刺吸引細胞診で診断しえた肺の悪性 黒色腫と思われる 1 例

賛育会病院 検査室 ○浦崎政浩 (CT), 野原キクエ $(\mathrm{CT})$, 佐々木陽一 $(\mathrm{MT})$

賛育会病院 外科

垣花昌彦 (MD)，仁瓶善郎 (MD)

独協医科大学第一病理 山田 喬 (MD)

肺の悪性黒色腫は転移性のものが多い, 今回我 々は穿刺吸引細胞診で診断しえた肺原発之思われ る悪性黒色腫を経験したので報告する。

症例: 41 才, 女性, 他院にて $2 \sim 3$ 年前より右胸 背部痛あり, 最近右顔面, 右上肢に発汗なく受診, この時肺腫瘍を指摘され，当院外科飞紹介された。 入院後肺の内視鏡的検索で TBLBを行ったが, 腫 瘤に到達できず, 癌は認められなかった。後日肺 の穿刺吸引細胞診と生検を行った。細胞所見 : 血 性所見の中に, 核の増大, クロマチンの増量及び 核小体の目立つ異型細胞の集団を認める。結合性 の弱い平面的な集団で, 腺癌を疑わせたが, 一部 の胞体内に黄褐色顆粒を認めた。乙の顆粒はギムザ 標本で青黒色顆粒としてみられメラニン顆粒と考 え, 細胞診では悪性黒色腫とした。組織学的所見 : 1 回目の肺の穿刺吸引生検では軟骨組織と共に 異型細胞巣が認められた。異型細胞は細胞質が豊 富で, 核小体の目立つ卵冈形の核をむつ多形細胞 が充実性に集合している。一部に胞体内に黄褐色 顆粒を有するむのがみられる。乙れはFe染色(一) で, メラニン顆粒が最も考えられるが, bile pigment の可能性むある, 組織学的に悪性黒色腫, 肝 細胞癌, 非角化型扁上皮癌等が考えられるが材料 が小さく決定は不可能とされた。2 回目の生検で 腫瘍細胞の多くにメラニン顆粒を胞体内に diffuse に含む類円形細胞と一部に紡鍾形細胞がみられ, 悪性黒色腫と診断された。結び : 肺原発の悪性黒 色腫は極めて希なため, 他に原発巣の検索を指摘 された, 眼科, 婦人科, 皮膚科の受診では原発巣 の病変は無く, 肝及び消化管等にも特に所見は無 いため, 肺原発の悪性黒色腫と考えられる。
262.甲状腺転移をきたした肺㾔の一例

東京都済生会中央病院臨床䬤查科，同病理科，同 外科

O降幡雅子 ${ }^{7}\left(\mathrm{C} T\right.$, I A C ) ，森永正二郎 ${ }^{23}(M D$

)，野守裕明 (MD)，木村 满 (MD)

甲状腺に他藏器の癌が転移する頻度は低く、特 に臨床的に原発性甲状腺癌との鑑別が問題となる ような単発の転移腫瘤を形成する症例は極めてま れである。我々は、街前の穿刺吸引細胞診により 甲状腺腫瘤が肺癌の転移であることを確診し得た 一例を経験したので報告する。

㱏例は 52 才男性。一ケ月前より左前胸・背部痛 を自覚し、左肺門・肺尖部の異常陰影を指摘され た。気管支擦過細胞診、生検により低分化な非小 細胞性肺癌と診断された。同時に、CTにて甲状 腺左葉に $1.5 \mathrm{~cm}$ 䅅の単一な腫瘤が発見され、原発 性甲状腺癌の合併が疑われたため穿刺吸引細胞診 が施行された。甲状腺腫場の細胞像は、多量の壊 死物質を背景に伴い、大型で $\mathrm{N} / \mathrm{C}$ 比が高くルーズ な結合性を有する異型細胞で、クロマチンは增量 し、数個の核小体が目立つが、核内封入体や核脱 宿入像は見られなかった。気管支擦過細胞診で得 られた細胞と同所見であったため、肺癌の転移と 考えられた。左肺上葉切除 (胸脱合併切除) と甲 状腺左葉切除が同時に施行された。肺腫瘍は左上 葉末梢原発の低分化腺癌て胸壁に直接浸潤し、絴 隔リンパ節にも転移が認められた。一方、甲状腺 腫瘍は腺内に限局しており、ほほ球状で境界明膫 であった。組織学的には肺虞と同一でその転移と 診断された。尚、甲状腺内の他部位や郭清された 䫫部リンパ節には転移は認められなかった。

甲状腺の潜在癌は稀ではないので、他炡器に既 に癌が確認されている場合でも、甲状腺腫瘤が見 出されると甲状腺癌の重複と考えられがちでらる が、他撼器からの転移性の可能性も考虑する必要 があると思われる。その診断には術前の第刺吸引 細胞診が有力と考えられた。 
263. 肺原発と考えられる悪性線維性 組織球腫の一例

国立療盖所福网東病院検査科 1), 胸部外科 2) 九州大学医療技術短期大学部 3)

○添田恭弘 $(\mathrm{CT})^{\mathrm{l}}$, 香月耕多 $(\mathrm{MT})^{\mathrm{I}}$, 境 $一(\mathrm{MT})^{\mathrm{I})}$ 河野淳二 $(M D)^{2)}$, 石井 寛 $(M D)^{3)}$

悪性線維性組織球腫 $(\mathrm{MFH})$ は中高年の四肢に好 発する肉腫であるが，肺原発のものは少ない。

今回我々は, 右肺上葉原発と考えられる一例を 経験したので, 細胞学的所見, 組織学的所見, 免 疫組織学的所見について報告する。

症例は64才男性。胸写にて右肺上葉の中枢域に 直径約 $1 \mathrm{~cm}$ の円形陰影を認め入院。気管支ブラッ シングでは陰性であったが, 肺癌の疑いで開胸, 術中細胞診が施行され, 右上葉摘出術が施行され た。尚, 術前の全身検索では他に異常は認められ なかった。

〔細胞所見〕弱拡大の所見は散在性の大きな集塊 を認めるが結合性は踈である。核は楕円形〜紡錪 形でクロマチンは顆粒状，しばしば核内空胞を認め る。核径は 10〜 15 $\mu \mathrm{m}$ のものが多く, 時に単核 〜多核の巨細胞を認める。榜縁は肥厚なく繊細で あった。細胞質は繊細でライトグリーン好性，核の 両端へ紡錘形に伸びている。核小体は核径に応じ て小型でュ個のものが多い。

〔組織所見〕腫瘍は境界明瞭で, 線維芽細胞様紡 鍾形細胞および組織球様異型細胞に混じって異型 核を有する多核巨細胞よりなっている一部には花 むしろ模様がみられ, staghorn 状の拡張した血 管を認めた。リンパ球, 好酸球等の炎症細胞浸潤 を伴っていた。

〔免疫組織学的所見〕 E MA, ケラチン, デスミン, Sー100 蛋白, アクチンは陰性で $\alpha_{1}$ ーアンチトリ プシン,リゾチームは陽性であった。

以上の所見及び他に原発と思われる腫瘍がない ことから肺原発の M F H 考えた。
264. 肺原発悪性線維性組織球腫の一例

神奈川県立循環器呼吸病センター検查科 1)

横浜市立大学医学部病理学第一講座 2)

神奈川県予防医学協会 31

$\mathrm{O}$ 早淵洋子 ( $\mathrm{C} T)_{1}$ ), 稲山 嘉明 $(\mathrm{M} \mathrm{D})_{2}$ ) 北村 均 (MD) 2)、松岡規男 (MD) 3)

軟部組織発生の悪性線維性組織球腫（M F H ）は比較的多いが、肺原発例は稀で報告例も少 ない。今回、我々は気管支擦過細胞診で肉腫を 疑い、組織学的にM F Hと診断された症例を経 験したので報告する。

症例；7 1才、男性。平成元年 10 月初旬頃 より胸痛、咳にて来院。胸部 X線で右肺上葉に 異常影有り、気管支肺生検及び擦過細胞診を施 行し肉腫が疑われたが、扇平上皮癌も否定し難 かった。1 1月、右上葉切除術施行された。腫 瘍はPancoast typeで、 $6 \times 6 \times 5 \mathrm{~cm}$ 大の黄白 色、壤死を呈する境界明暸な像を呈し、術後予 後良好で他部位に原発巣は見られない。

細胞所見; 背景は壤死を呈し污い。紡錘形の 線維芽細胞様の細胞が多く、核のクロマチンは 微細顆粒状、濃染性で増量し核形は楕円形、長 楕円形を呈し、一見扁平上皮癌のfibercell ty peの細胞と㘕別を要したが、細胞の一端が捻じ れ、細胞集団では storiform patternが多く見 られた。組織球様細胞、多辺形の胞体の細胞、 巨核、多核細胞も出現し多形性が見られた。

組織所見; 紡鍾形細胞が細胞束をなし、一部 s toriform patternを呈し増性、広範な壤死も 認めた。多核の腫場巨細胞も混在。

酵素抗体法で、vimentin, lysozyme , $\alpha_{1 \text { - anti }}$ trypsin, $\alpha_{1}$-antikimotrypsin陽性、keratin, desminは陰性であった。各種特染、免疫組織学 的検索によりMFHと診断された。 
265. 乳腺穿刺吸引細胞診の検討

淀川キリス卜教病院病理部

○葛西里美（MT）、西山哲穂（CT)、 福岛成之 ( C T )、吉沢里美 ( M T ) 、 武田善樹 (MD)

乳痴の診断法の中で、穿刺吸引細胞診の重要性 は高まりつつある。今回我々は、過去 4 年間に本 院で行われた細胞診と、その中の乳腺第刺細胞診 の比率、陽性率、正診率などについて検討を行つ た。年々增加する細胞診中での乳腺細胞診の比率 は增加しており、1989年度には細胞診全体の $2 \%$ に達している。

1988 年 4 月から 1989 年 11 月に本院で 行方れた乳腺細胞診は250件で、このうち50 件が陽性、186件が陰性、14仵が疑陽性（C1 assIII) と診断された。陽性 50 件中、誤陽性は 4 件で、その組織像は乳腺症が 3 件、乳頭腫が 1 件であった。これらの細胞像、竩織像に検討を加 え供覧する。

譟陰性は 8件で、いずれも維胞診標本に細胞の 乏しい不良嫩本例であり、見落とし例とは考えな い。我々の施設での正誼率注 $92 \%$ であった。

去た、乳癌細胞のエストロゲンレセプター(E R）について検郌を加えた。乳密組織の凍結切片、 脱パラ切片、捺印細胞標本について、P A P 法で ER染色を行い、これらの結果と生化学的方法( D C C 法)の結果とを比較した。脱バラ切片以外 の材料では、細胞、組織切片上の反応と生化学的 方法の結果は良い柏関を示した。迅速組織診時の 凍結切片や捺印細胞標本加ら、ERの正確な陽性 率を知り得るものと思方える。

（更に症例を加える予定のため、数値は多少变化 する予定です。）

\section{6. 乳腺穿刺細胞診の誤陽泩例の検討}

\section{横浜市大中検病理部}

O河野 敏郎 (MD)，藤井 勇一 (MD), 吳吉焕 ( MD), 下山潔 ( MD), 桔梗 辰三 ( M D ), 中野友由枝 ( C T ), 大津久美子 ( $\mathrm{C} \mathrm{T})$, 北村 和久 ( C T ), 津村反ず党 ( C T ), 竹津恵実子 ( C T )

乳癌の診断に扔いて穿刺吸引細胞診は重要な診 断法の一つであり，確定診断となることもあるの で，その正診率を向上させることが必要である。 特にその誤陽性例を減らすことが臨床的には重要 である。

当院に执いて過去 5 年間に, 穿刺吸引細胞診を 行った後組織学的に良性と診断された症例は 198 例であった。それらの内で，陽性と判断したもの 16 例 ( $4.7 \%)$, 陽性疑いとしたもの 16 例 (4.7\%), 陰性としたもの 166 例 (83.8\%)であった。

陽性と判断した症例の組織学的診断は, 乳腺症 8 例, 腺維腺腫 6 例, 乳管内乳頭腫 2 例であった。 以上の誤陽性例を再検討すると, 穿刺吸引細胞診施 行初期の症例は良性所見の見落しが多く, 後期の症例 の中には上皮性成分の増加した腺維腺腫や乳腺症など, 再検討飞执いても陽性と判定される症例があった。 しかし誤陽性例の内, 8 例は複数回穿刺して招り, 2 回以上陽性と判定された症例はなかった。

乳癌の診断に乱いては穿刺吸引細胞診は最も重 要な診断法の一つであるが，臨床的に疑わしい症 例の場合には複数回穿刺を行い, 時には陽性と判 定した場合でも，術前生検を行うことが必要と思 われる。 
267. 女性化乳房の細胞像

\section{東邦大学大森病院病院病理}

○小林照明 ( CT ), 前田陽子( CT ), 三宅洋子(CT),

影沢よりみ (CT)，石井真由美（CT），

辻本志朗 (MD), 工藤玄恵 (MD)

同婦人科

大村 剛 (MD)

社会保険蒲田総合病院検査科

清川秀昭 ( CT)

はじめに：女性化乳房は本邦においてもよく知 られた疾患であるが，細胞診の立場からの詳細な 報告はなき飞等しい。我々は女性化乳房の吸引細 胞材料を基に細胞学的特徵を把握すべく検討した。

材料：女性化乳房 15例 ( $40 \sim 82$ 才, 平均 64 ), で ある。さらに男性乳癌 3 例 $(41,80,81$ 才) と女性 の線維腺腫10例を比較対象として選んだ。

結果：採取量は症例により幅があるが，その多 少にかかわらず細胞数 10 個以上の大集団が多く, 線維腺腫に認められるような小集団は少ない。強 い結合性と重積性があり，細胞質は乏しい。核は 類円形で比較的揃っており $(6 \sim 9 \mu)$, 核縁の肥厚 はなく,クロマチンの分布は均等で，核小体は 1 〜 2 個で小型が主体。核分裂は 8 例飞認め，その 数は全視野で $1 \sim 20$ (平均 6 )。筋上皮細胞は全 例飞認め，5ち4例には双極裸核も認めた。一方 線維腺腫では， $7 \sim 8 \mu$ 径の核で， 3 例飞 $2 \sim 5$ (平均 3 ) の核分裂像を認めた。筋上皮細胞や双 極裸核は全例に認めた。癌例は，通例の如く採取 量が多く, 結合性は弱い。核は大小不同性が著し く $(10 \sim 20 \mu)$, 不均等なクロマチン, 大型核小体 を認めた。核分裂像はなかった。

まとめ：女性化乳房の特徴は，一般的に言われ ている女性の良性増殖病変の細胞像と基本的に同 じであるが，女性の線維腺腫と比べて，大集団が 多く小集団が少ない。さらに筋上皮細胞の出現頻 度や数，核分裂数，双極裸核の有無に拈いて差が みとめられる。一方䜿との鑑別は容易である。
268. 乳癌培養細胞に対するエストロゲン および抗エストロゲンの及ぼす影響

\section{東海大学病院病理診断科}

○伊藤 仁 (CT), 篠田玲子 (CT), 赤塚由子 (CT)， 覚道健一(MD), 長村義之(MD)

【はじめに】ホルモンによってその増殖が促進さ れる癌の中でも性ホルモン依存性の乳癌は数も圧 倒的に多くそれらの代表といえる，エストロゲン （E）により乳癌の増殖は促進され，また乳癌の内 分泌療法に用いられている代表的抗エストロゲン 剤タモキシフェン(TAM)はEとエストロゲンレセプ ター (ER)の結合を競合的に阻害するといわれてい る.また最近乳癌の培養細胞を用いたin vitroで の研究で，癌細胞にTAMを添加すると細胞内ER值 が増加するという報告があり，その治療効果発現 機序が注目されている，そこで今回我々はERを有 する乳癌細胞がEおよびTAM添加によりどのような 変化を示すかについて種々のマーカーを用いて免 疫細胞化学的に検討した。

【材料および方法】乳癌細胞はER陽性乳癌培養株 MCF-7, ZR-75-1， ER陰性培養株MDA-MB-231の3種 の培養細胞を用い，腫瘍マーカー (CEA, CA153)， 癌遺伝子産物 (c-myc gene product), 細胞增殖能 （BrdU標識によるS期細胞の同定），およびERの変 化について免疫細胞化学的に検討した.

【結果および考察】ER陽性乳癌細胞においてER陽 性細胞はエストロゲン添加により減少し，その染 色性も減弱したが, TAM添加により著明な染色性 の増強がみられた。これはこれまで報告された Enzyme immunoassay法による結果と同様であった。 BrdU陽性細胞はエストロゲン添加により増加し， TAM添加によりやや減少した。 またEおよびTAMに よる腫瘍マーカーCEA, CA153の変化はみられなか った。 ER陰性培養細胞においてはBrdUを含めたす ベてのマーカーにおいて変化はみられなかった。 以上により $\mathrm{E}$ ，TAMがERおよび増殖能に影響を与え ることが示唆された。 
269. 乳腺アポクリン化生癌の細胞診

\author{
大阪医科大学 中検病理 \\ O中塚裕之 (CT) 森川政夫 (CT) 山本隆一 (MD) \\ 橋本和明 (MD) 黒川彰夫 (MD) 稲井真弥 (MD)
}

乳腺のアポクリン化生癌は比較的稀な疾患で, 構成細胞が汗腺の細胞に類似しているところから 汗腺癌とも呼ばれている。

今回我々はアポクリン化生癌 4 症例を経験し, その捺印細胞像について特徵的な所見を得たのて 報告する。

[対象] 過去 5 年間に本学中検病理に提出された 乳癌 259例中 4 例 (1.5\%)のアポクリン化生癌を対 象とした。年令は52歳〜77歳, 平均63.5歳で全例 閉経後婦人であった。

[細胞所見］腫瑒細胞は平面的または重積性を示 し、一部で乳頭状の配列を示し出現していた。こ れらの腫瘍細胞は 2 種類に大別され,一方は豊富 な細胞質を有する大型の細胞で他方は偏在した類 円形核をもつ円柱状の細胞であった。大型細胞の 細胞質は豊富で好酸性の顆粒と, 硝子滴様の封入 物が見られた。これらはPAS染色で陽性を示し た。また細胞質辺縁の断頭分泌 (snouts projection)が見られ.アポクリン分泌を思わせた。

核は小型でクロマチンは微細顆粒状, 著明な核小 体を有していた。一方円柱状の腫瘍細胞は細胞質 が好酸性を示し,その自由縁には断頭分泌が認め られた。

[組織所見] 腫瘍細胞は大型立方状ないし円柱状 を示し，核は小型で細胞質はエオジン好性で管腔 内へ突出する断頭分泌を示していた。

[まとめ] アポクリン化生癌の細胞像の特徴的な 所見は好酸性の豊富な細胞質, 好酸性の顆粒, 明 らかな断頭分泌が見られることである。アポクリ ン化生癌は乳頭腺管癌の一部としてみられること もあり，その細胞像を十分把握しておくことは乳 癌の組織型診断の際有用なことと思われる。
270. 乳腺アポクリン癌の一症例

公立昭和病院病理科" 同外科"

○森一磿 (CT)" 乙幡由美子 $(\mathrm{C}$ ) $)$ "柏崎好美 (CT)" 濱川真治( MT)" 浜本鉄也(MD)"永山

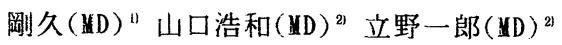
昭和大学医学部第一病理学教室 諸星利男 (MD)

乳腺のアポクリン癌は本邦においては極めて 稀で、その頻度は全乳癌中 $1 \%$ 以下であるとい われている。今回我々は典型的ともいえるアポ クリン癌を経験したので、細胞学的・病理像,

免疫組織化学, 電顕等の考察を加えて報告する。 <症例>女性68歳, 昭和 63 年 8 月頃より右乳房 CE領域の腫瘤に気づくが放置していた。平成元 年 8 月 3 日吸引細胞診にて乳腺症之診断。同年 8 局13日生検にてアポクリン癌と診断され、同 15日非定型乳房切除術を施行。

<細胞像>術前の細胞診ではN $/ C$ 比の低い細胞 が集塊で出現し、配列は平面的で僼富な細胞質 には好酸性顆粒を認め、核小体は目立つものの 全体的におとなしく、良性アポクリン化生細胞 とした。街後スタンプ標本でも基本的には同様 の所見であるが詳細に見ると、核の腫大・大小 不同・核小体の肥大等アポクリン癌を示唆する 所見であった。病理像>肉眼的に腫㢞は $2 \times$ $3 \mathrm{cn}$ 大で境界明瞭 $\mathrm{H} \mathrm{E}$ 染色では檤様に増生し、 浸潤も見られた。N/C 比は低く核小体は明瞭、 細胞質はエオジン好性に染まり顆粒状を示す部 分も見られた。配列は腺管・乳頭状であった。 <電顕像〉 T E M にて細胞質内好酸性微細顆粒、 他の微細構造の検索ができ、SEMにてアポク リン分泌像が観察された。

<良性アポクリン化生細胞との鑑別点>

(1)核の腫大(2)核の大小不同(3)核小体の大型化(4) 裸核細胞の出現(5)配列の不整等が挙げられる。 


\section{1. 乳腺アポクリン癌の一例}

聖マリアンナ医科大学横浜市西部病院病理部1'同 外科 ${ }^{2}(\mathrm{O} \text { 多田留美子(CT })^{11}$ 林菜穗子(CT $)^{11}$ 品川俊人 $(M D)^{11}$ 田中一郎 $(M D)^{21}$ 中野未広 $(M D)^{21}$ 金杉和男 $(M D)^{21}$ 片場嘉明 $(M D)^{21}$

聖マリアン十医科大学病理学教室 竹内英子(MD) 田所 衛 (MD)

乳癌の特殊型のひとつであるアポクリン虞は非 常に稀であり, 乳癌の $0.2 \sim 0.3 \%$ \%いわれてい る。今回, 我々は典型的なアポクリン癌を生検择 印細胞診で経験したので報告する。

〔症例〕72才，女性。胃潰湯による出血性ショッ クで他院より転院。入院時右乳房B領域に硬い可 動性の腫瘤を認め, 生検並びに择印細胞診を施行 した。浸洞虚の診断にて定型的右乳房切断術が施 行された。

〔細胞所見〕腫場細胞は細胞辺縁明膫で, 結合性 はゆるく，散在性または平面的配列をした集塊を 示す。N/C 比は低く，好酸性顆粒が著明に見られ る豊富な胞体を認めた。核は通常 1 ケの大型類円 形核で，中心性ないし偏在性に見られ，大小不同 を示した。核クロマチンは増量し, 粗顆粒状で不 均等に分布。殆どの核内には 1 ケの明燎な円形大 型核小体が存在。以上の所見からアポクリン虞が 疑われた。

〔肉眼所見〕腫裙は $1.3 \times 1.0 \mathrm{~cm}$ 大, 白色, 線 維性で硬く，微小囊胞状構造を呈していた。

〔組織所見〕腫場細胞は殆どが硝子化した結合織 中に見られ，好酸性で顆粒状の広い胞体を持ち， 核はやや大きく濃染し，核小体の目立つものを認 めた。断頭分泌を示す細胞も明らかである。組織 球样に大きく淡い胞体を持つ細胞も見られ，好酸 性細胞との移行的な像も認められる。これらの細 胞による䓀胞形成や間質への浸洞像も認めた。組 織学的には他の組織型を認めないアポクリン虎で あった。
272. アポクリン化生を伴う

非浸潤性乳管癌の一例

日野市立総合病院検查科 ${ }^{1}$, 慶應義塾大学医学部病 理学教室 ${ }^{2}$, 埼玉中央病院検查科病理検査室 ${ }^{3}$, 杏林 大学医学部病院病理部 4

○宮崎 進 (CT $)^{1}$, 山田健人 (MD) $)^{2}$, 吉村ゆかり (MD) 2 , 是松元子 $(\mathrm{CT})^{3}$, 米沢志生子 $(\mathrm{CT})^{4}$, 海野みちる (C T) ${ }^{4}$

乳腺細胞診で, 穿刺吸引や腫溜捺印標本中にア ポクリン化生細胞を認める場合, 良性病変のこと が多い. 今回, 線維腺腫の疑いで摘出された腫瘤 で, その擦過標本中にアポクリン化生を認め, か つ乳頭腫との鑑別が困難であった非浸潤性乳管癌 を経験したので報告する.【症例】 32 歳, 主婦, 経産婦 ( 2 児), 産後 2 年. 左乳房に腫瘤触知, 当院外科外来受診. 超音波検查にて C 領域に $5 \mathrm{~mm}$ 大の low echo massを認めた. 線維腺腫の疑いに て摘出.【細胞診】腫瘤割面より擦過標本作製.

低倍: 大小, 多数の集塊がみられ，乳頭状のもの からシート状のあのまで多様である。それらの間 には孤在性の上皮細胞を認める。高倍: 良性所見 : 集塊を構成する細胞は， N $/ \mathrm{C}$ 上昇はなく,ク ロマチン増量はごく軽度でおり，伭小休の咶太柰 示さない，集塊の外層には二相性を示唆するよう な構筑を認める部すあり, 核の飛び出しはなく, 核異型むみられない，乳管癌を疑い得る所見：孤 立散在性の上皮細胞が多数存在する。これらはい ずれすしっかりとした胞体を有し，集塊からほっ れた様に分布している. 結合織由来の細胞は認め られない，以上より，疑陽性（class III）と診断。 【組織診】非浸潤性乳管癌. 腫瘍は径 $7 \mathrm{~mm}$, 不 明瞭ながら線維性被膜を有する，中心には管状・ 乳頭状を示す上皮の強い増殖, 辺縁にはアポクリ ン化生をみる。一部では二相性が消失し, 堅固な bridgingを呈する.【まとめ】アポクリン化生細 胞が混在する場合, 引きガラス法による, 上皮細 胞の散在傾向の詳細な観察が重要と思われる. 
273. 乳腺乳頭部腺腫の 1 例一笌刺吸引 細胞像について一

松阪中央総合病院臨床病理科

○小山英之(CT)、上森 昭(CT)、木村多美子(CT) 石原明徳(MD)

(はじめに) 乳腺乳頭部腺腫は良性であるが、乳 頭部の発赤、ビランを生じ臨床的にPaget 病と誤 診されることがあり、組織学的に乳管癌との鑑別 が問題になる場合がある。今回我々は11歳女览に 発生した本症の 1 例を経験したので、その穿刺吸 引細胞像について報告する。

(症例) 11歳女児、1988年7 月1 日入浴時右乳房 の腫瘤に気付き同年7 月5 日当院外科を受診。触 診にて乳頭直下EC領域に母指頭大の腫瘤を触知し 腫瘤は境界明暸で可動性があった。乳頭の発赤、 ビランは認めなかった。直ちにエコー検査及びエ コー下穿刺吸引細胞診を施行。エコー娭查では線 維腺腫と診断。穿刺吸引細胞診では乳管内乳頭腫 が疑われた。同年7 月20日局所麻轵下に腫瘤を摘 出。組織診にて乳頭部腺腫と診断された。

(細胞所見) 粘調な液状物質及び泡沫細胞を背景 に多数の細胞が認められた。その多くはシート状 及び乳頭状集塊を形成し結合は強くほつれは認め なかった。一部の集塊辺緑には乳頭状突起像が認 められた。個々の細胞は類円～棈円形でN $/ C$ 比中 等度、細胞質はライト緑に淡染し核は類円形で均 一大であった。クロマチンは細顆粒状で均等に分 布し小型核小体が 1 ～個認められ、一部の細胞 には対細胞が認められた。

(肉眼及び組織所見) 腫留は黄桃色分葉状を呈し 管腔内に粘調な液状物質を認めた。光顕標本では、 管内乳頭腫症、乳頭腫様の像を主とする乳管上皮 の旺盛な增殖が見られ、上皮に異形性は見られず 2層性が保たれていた。

(まとめ) 細胞診断上、本症例は乳管癌との鑑別 は容易であったが、乳管内乳頭腫とは類似点が多 く鑑別困難であった。
274. 腺・扁平上皮癌を思わせた孚癌の 一症例

\author{
沖縄協同病院 \\ O仲宗根克 (CT)，濱元ちえみ (MT) \\ 内間良二 (MD)，屋良敏男（MD）
}

乳腺における扁平上皮澢の発生率は、全乳癌の $0.1 \sim 0.29$ 程度といわれ、腺・扁平上皮湂の発 生頻度はそれ以下である。我々は、乳腺の穿刺吸 引細胞診を施行し、細胞診て腺・扁平上皮癌を疑 い組織診で、扁平上皮化生を伴った浸潤性、充 実腺管癌であった一症例を経験したので、その細 胞像を中心に報告する。

（症例７0才。女性。左乳房内上領域に示指頭 大の腫瘤に気づき来院。穿刺吸引細胞診で、孚癌 が疑われ、定型的乳房切除術か施行された。

〔細胞像〕壊死性背景に 2 種類のMal ignantcellの混在が見られた。一方は、オレンジG好染 の胞体に濃染核を有する細胞で、小cluster ある いは、孤立散在性に見られた。もう一方は、大型 の核小体を有し、クロマチンは細顆粒状、核異型、 核の大小不同のみられる細胞が大小の腺様配列を 示すcluster でみられた。また、雨成分の細胞の 混在、とくに、腺癌細胞のcluster 内に角化した 細胞の混在がみられた。

〔組織像〕腫瘍の最大割面は $10 \mathrm{~mm} \times 7 \mathrm{~mm}$ で周 井軟部組織との境界は比較的明瞭。組織学的には 不規則な小腺管構造、一部角化傾向などを伴う充 実性の増殖がみられた。

〔まとめ〕全体的に腺系のMalignant cellの割 合が多く、また組織像を反映していると思われる 細胞所見、特に、腺癌細胞のcluster 内の角化細 胞の混在は、組織像を推定する上で、大切な所見 と思われる。 


\section{5. 乳腺扁平上皮癌の 1 例}

立川共済病院病理 O笹井伸也(CT), 薄田正 (CT) ; 町谷原病院 中西泉(MD); 埼玉医科大学 病理 本間富夫(CT), 片山熟(MD)

症例：39歳女性。平成元年10月末, 右乳房の儿 こりに気付き，近医を受診した。硬い $3.5 \times 4.0 x$ $2.5 \mathrm{~cm}$ 腫瘤が触知され，穿刺細胞診で, classV と診断された結果, 11月13日右乳房切断術が施行 された。

穿刺吸引細胞像：壊死物質を背景にシート状配 列を示す細胞集塊が多数認められた。細胞のN/C 比には幅があり，細胞質の染色性は多彩であった。 核は類円形・大小不整で， bizarreな巨大多核も 散見された。核クロマチンは粗顆粒状, 核小体が 1 数個認められた。以上, 穿刺標本では扁平上 皮癌成分のみが観察されたが, 純粋な扁平上皮癌 の可能性は少なくないと考え, classV(扁平上皮 癌巣を伴う通常型腺癌が予测される)と報告した。

病理組織像：切除標本では，扁平上皮癌が圧倒 的な優勢成分であったが, 精査により僅かながら 腺癌が認められた。

考察：穿刺細胞診の普及ととむに, 乳腺扁平上 皮癌の報告が增加しつつあり, 本学会においても 最近の 7 年間に 8 例が報告されている。しかし， 腺癌の存否に言及していない 1 例を除くと、6例 では多少の腺癌が混在し, 残る 1 例のみが純粋の 扁平上皮癌(全標本の検索で腺癌を認めない)であ つた。近年の報告例の増加は, 細胞診により化生 性扁平上皮成分が的確に見出されるためと考えら れる。

まとめ：本症例の穿刺細胞診には腺癌成分を欠 いていたが, 化生性の腺癌が予測されるとコメン トして報告(classV)した。その予测は切除標本 の精査により確認された。乳腺原発の純粋な扁平 上皮癌は極めて稀(文献上 $0.1 \%$ 以下)である。
276. 穿刺吸引細胞診で診断された乳腺腺 様赜胞癌の 1 例

日本医科大学第 2 外科 ${ }^{1)}$, 日本医科大学付属第一 病院病理部 ${ }^{2)}$, 日本医科大学付属多摩永山病院病

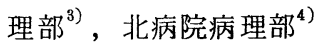

○渡边一彦 $(M D)^{1)}$, 秋丸琥甫 $(M D)^{1)}$, 小山寿雄 $(M D)^{1)}$, 朝戸健夫 $(M D)^{1)}$, 庄司 佑 $(M D)^{1)}$, 山田宣孝 $(M D)^{2)}$, 中川敬夫 $(\mathrm{CT})^{2)}$, 前田昭太郎 $(\mathrm{MD})^{3)}$, 飯島 正 $(\mathrm{CT})^{4)}$

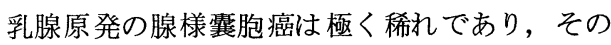
生物学的態度, 予後は他の乳癌の組織型と比し良 好とされている。

今回我々は, 術前穿刺吸引細胞診にて, 乳腺の 腺様翼胞癌と診断し得た 1 例を経験したので報告 する。

【症例】49歳, 女性。左乳房腫瘤を主訴として近 医を受診。穿刺吸引細胞診にて腺椂婯胞癌と診断。 手術目的で当科紹介入院となった。左乳房 $\mathrm{D}$ 領域 に母指頭大の表面平滑, 弾性硬, 可動性のある腫 瘤を触知。腋窩リンパ節は触知しなかった。精查 の後, 非定型的乳房切断術 $(\mathrm{Br}+\mathrm{Ax})$ を施行した。 【細胞像】標本中には細胞成分が豊富に採取され， 核型均一で, 粗顆粒状及び細顆粒状のクロマチン に富む小型の核と，小量の細胞質を有する小型細 胞がマリモ状集団を形成，その中心には P A S, alcianblue 陽性の粘液を認めた。また, 個々の 細胞の異型性は之しく, 腺様襄胞癌と診断した。 【組織像】異型性が少く，小型で大きさ均一，細 胞質の乏しい基底細胞様細胞の胞巣状增殖を認め, 周囲に硝子様結合織を認めた。胞巣内には多数の 装胞を認め, 穊状構造を呈した。麗胞内は好酸性 の粘液物質で満たされていた。乳頭腺管癌等の成 分を認めず，腺様製胞癌と診断した。

以上，典型的な細胞像，組織像を呈したと考元 られる乳腺原発腺様翼胞癌を若干の文献的考察を 加光報告する。 
277. 乳腺 lipid-rich carcinoma の 1 例

丸山記念総合病院 細胞診、同外科 ${ }^{2)}$

埼玉県立がんセンター 臨床病理 ${ }^{3)}$

O大野喜作 $(\mathrm{C} T)^{1)}$, 鈴木君義 $(\mathrm{C} T)^{11}$, 木村恒子 $(\mathrm{C} T)^{1)}$,

田林 晃(MD), 古川俊隆(MD), 丸山正董(MD), 田久保海誉 $(\mathrm{MD})^{3}$.

はじめに：今回われわれは、腫瘍細胞の細胞質 内に脂肪滴を多量に含んだ、乳腺の lipid-rich carcinoma の 1 例を経験したので、その穿刺吸 引細胞彰の細胞学的所見に加え、組織学的所見に ついて報告する。

症例：患者は58歳の女性で、他院の人間ドッグ にて左乳房腫瘤を指摘され、平成 1 年 5 月 15 日当 院を受診した。超音波検查および穿刺吸引細胞診 亿て乳癌之診断し、同年 5 月 22 日、非定型的乳房 切断術を施行した。琴在、術後 7 力月を経過し再 発の徴候なく通院中である。

病理学的所見 : 肉眼的に腫韵は乳頭から $1 \mathrm{~cm} の$ C領域にあって、 $2 \times 2 \times 2 \mathrm{~cm}$ の大きさで、割面は 白色を呈していだ。組織学的には、腫痬細胞は主 に乳管内に增殖し、明るく泡沫状を呈する豊富な 細胞質を有していた。核はほぼ円形で犬きく明瞭 な核小体を認めた。また、腫瘍細胞は脂肪染色に より、細胞質内に大小の脂肪滴が陽性を示した。 電顕的にあ脂肪滴が認められた。

細胞学的所見 : 背景には少数の白血球がみられ たが、壊死物質は認めなかった。腫瘍細胞は、ほ ぼ円形で大小不同を呈していた。核は円形〜類円 形で、偏在傾向を示していた。核のクロマチンは 増量し、明瞭な核小体を 1 数個認めた。また、 腫場細胞は明るく泡沫状の豊富な細胞質を有して いた。

結語：lipid-rich carcinomaは、極めてまれ である。その報告例あ少なく、その生物学的性格 は明らかではないが、前述の特徵ある細胞所見を 有し、ての症例に関しては十分、細胞診で組織型 の推定が可能であると思われた。
278. 乳腺・紡鍾細胞癌の 1 例

名古屋市立城西病院 中検 ${ }^{1)}$ 内科 ${ }^{2)}$ 外科 ${ }^{3)}$

O早瀬妙子 $(\mathrm{CT})$, 鈴木孝幸 $(\mathrm{CT})^{1)}$

小塚正雄 (MD), 佐宗克久 (MD ) ${ }^{2)}$

篠田憲幸 $(\mathrm{MD})^{3)}$

名古屋市立大学 中検 ${ }^{4)}$, 第二病理 ${ }^{5)}$

柴田偉雄 $(\mathrm{MD})^{4)}$, 神谷增三 $(\mathrm{MD})^{5)}$

乳腺原発の紡鍾細胞癌は肉腫樣組織像を呈する まれな腫瘍である。今回, 我々は乳腺の腫瘍穿刺 吸引細胞診にて上皮性および非上皮性と思われる 2 種の異型細胞を認め, 癌肉腫と診断したが, 切 除乳房の組織診より紡鍾細胞癌と診断した症例を 報告する。

症例は 31 才の女性で， 4 年前より左乳房の腫瘤 に気付くも放置していたが次第に増大するため来 院。穿刺吸引細胞診を受けた。

吸引塗洙標本には孤在性の異型細胞と上皮性結 合を示す異型細胞群の 2 種類の異型細胞がみられ, 前者の細胞形は円, 類円, 紡錘, 多稜と多形性に 富み $\mathrm{N} / \mathrm{C}$ 比は大きく, 細胞質は泡洙状で貧食細胞 や偽筧毛をもつもの，あるいは扁平上皮癌類以の 細胞等みられ，核形は類円形，長棈円形，紡錘形 など多彩で, 核縁の陥入, 不整が目立ち, 不均等 肥厚が顕著である。大部分の核は偏在し, クロマ チンは細網細顆粒状で, 核内空胞のみられるもの もある。一方, 後者は $\mathrm{N} / \mathrm{C}$ 比が大きく, 大小不同 のきわだつ細胞集団で, 細胞質は泡洙状, 核形は 類円形, 核像不整で不均等肥厚を認める。クロマ チンは粗網粗顆粒状である。

切除標本では大部分が充実性腫瘍であるが，一部に はのう胞の形成を認める。腫場細胞は紡鋛形または類 円形で, 細胞質はうすく, 核の大小不同, クロマチン の不均等增量を認め, 核分裂像も多数みられる。また, 腫瘍の中には著明な異型を呈する扁平上皮化生の島が あり，それからの肉腫様細胞への移行像を認める。腫 瘍細胞は免疫化学的にはEMA ( Factor VII ( - )である。 
279. 乳腺原発平滑筋肉腫の 1 例

大津赤十字病院病理

O今村真治（C T ）。雑賀興慶 (M D )

同外科 小川博睴 (M D)

大阪医科大学附属病院検査部病理

日下部 正（C T ）。森川政夫（C T)

乳腺原発の肉腫は一般に稀で、全乳腺悪性腫瘍 の $0.3 \sim 3 \%$ といわれている。今回我々は、乳腺 から発生した平滑筋肉腫を経験したので報告する。 （症例） 63 歳 女性。近医にて右乳腺腫瘤を 指摘され、生検の結果線維腺腫之診断。その後生 検部位に一致して再び腫瘤出現、急速に増大した ため当院へ紹介される。腫瘤は $7.5 \times 8.2 \mathrm{~cm} 、 \mathrm{~A}$

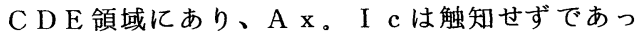
た。術中迅速病理診断は、Leiomyosarcoma? 摘出腫瘤は $7 \times 6 \times 5 \mathrm{~cm}$ 、重量 $120 \mathrm{~g}$ 割面は髄様 であった。

（捺印細胞所見）紡鍾状の腫焬細胞が散在性及 び集積状に出現。細胞結合は弱く、集団を構成す る細胞は束状に配列。核は紡錘形、卵円形ないし 円形、時に核膜の陥込。核縁は薄く平滑、クロマ チンは細顆粒状、核小体は小型で 1 〜数個、細胞 質は Light green 淡染性で境界は不明瞭。

（病理組織所見）腫瘍細胞は紡錘形で、細胞束 をなして密に増生し、互いに交錯する様な所見も 認められる。異常核分裂像や核の異型性も認めら れ、平滑筋肉腫と診断された。酵素抗体法では、 E M A 陰性, Desmin 陽性, Myoglobin 陰性で あった。

以上、本症例の細胞、組織形態像を供覧する。
280。著明な骨軟骨化生をみた乳癌の 1 例

帝京大学医学部附属病院中倹病理 ${ }^{1}$, 同第 2 病理 ${ }^{2}$, 同産婦人科 ${ }^{3}$

O島田智子 $(\mathrm{CT})^{1}$, 照井仁美 $(\mathrm{CT})^{1}$, 小坂井守 $(M D)^{2}$, 土橋一慶 $(M D)^{3}$

骨軟骨成分をみる乳癌は稀で報告例も少ない。 今回，我々は吸引細胞診でbizarreな核をもつ 大型細胞を認め, 精査の結果, 著明な骨・軟骨化 生を示した乳癌を経験したので報告する。

症例 : 31 歳, 女性。数力月前より左乳房の腫瘍 に気付き，吸引絊胞診が施行され，その結果，肉 腫 (class V) と診断され, 定型的左乳房切断術 とリンパ節郭清術が行われた。

吸引細胞診像：bizarreな核をもつ大型細胞 が目立ち、腫瘍繧胞はバラバラに存在し、癌腫を 思わせる細胞集塊はなく，肉腫と診断した。明ら かな骨 (類骨) 組織は見られなかった。

肉眼所見 : 腫瘍は左孚房上外 $1 / 4$ (C領域)にあり

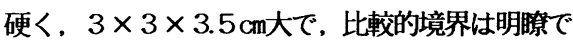
あった。割面では，骨軟搰形成か強く，散在性に 光沢のある軟骨組織で囲まれた小囊胞を形成し， 血性内容を入れていた。又, 骨軟骨成分の増加し ている部分と同等量に灰白色で充実性の腫痬部分 もみられた。

組織所見 : 腫瘍はその半分は明らかな腺管構造 を有する分化型腺窝像を示しており，残り半分は 類骨の著明な形成を見る骨肉腫様の部分で軟骨成 分も多かった。又，同時に僅かではあるが，両者 の移行と考えられる紡錘形細胞の集蔟巣もあった。 扁平上皮化生も小島状に僅かに見られた。

まとめ : 乳腺の吸引紐胞診において, bizarre な核をもつ大型紐胞の出現は, 肉腫状所見として 把握することが多いが, 化生性病変をまず第一に 考える方が良いと思われる。今回の症例について は, 電䫓, 免疫染色等の所見を合わせ考えると癌 腫が著明な骨・軟骨化生を示したものと思われた。 
281. 授乳期における乳癌の 1 例

前橋赤十字病院検査部病理 ${ }^{1}$ ，群馬県健康づくり 財団対ガン事業部 2), 群馬大学医学部第 2 病理 ${ }^{3)}$ 群馬大学医学部中検病理 4)

○松尾美智子 (CT ${ }^{11}$ ，諏訪幸子(MT) ${ }^{11}$ ， 中島俊江 $(\mathrm{CT})^{1)}$, 関本 弘 $(\mathrm{CT})^{21}$, 木村 茂(CT) ${ }^{21}$ 新開紘子 (MD) ${ }^{3}$, , 大野順弘 (MD ${ }^{3}$ ), 堀越美枝子 (CT) ${ }^{4}$ ，城下尚 (MD) ${ }^{4}$ )

妊娠・授乳期乳癌が、全乳癌に占める割合は、 およそ $1 \%$ 内外と比較的少ない。しかし、妊娠。 授乳期の乳癌は、発見が遅れ、予後が悪いとされ 臨床上問題となっている。今回我々は、授乳期に おける乳癌の 1 例を経験したので、その細胞像及 び組織像について報告する。

〔症例〕35才女性、授乳開始2週目頃より右乳房 腫瘾に気づき、平成元年1月21日 当院受㕫。大 きさ5. $1 \times 4.2 \mathrm{~cm}$ 境界明膫な弾性硬の腫瘤で、乳房 X線撮影・超音波検查では、悪性所見は認められ ず、第刺吸引細胞診が施行された。その後、腫瘤 は增大傾向 $(7.0 \times 6.2 \mathrm{~cm})$ にあるため 2月25日再度 穿刺吸引細胞診が施行され悪性細胞が多数出現し た。3月2日 試験切除で髄棣癌と診断され、右 乳房切除術が施行された。

〔細胞所見〕初診時 : 大型で核小体の目立つ異型 的な細胞が孤立散在性ないし小集塊を形成して、 比較的多数認められた。クロマチンは、細顆粒状 ないし中顆粒状で、核は類円形で大小不同や不整 形は少ない。背景には、多数の好中球が見られた。 再診時: 核小体明膫な大型異型細胞が、孤立散在 性ないしシート状集塊を形成し多数出現していた。 核の大小不同や不整形を示すものも見られ、ク口 マチンは、細〜粗顆粒状で、細胞質は、豊富。核 分裂像や多核巨細胞も散見された。

〔組織所見〕大型で胞体の広く、明暸な核小体を もつ異型細胞が、充実性胞巣を形成して增殖し、 間質にはリンパ球と共に、高度の好中球浸潤が見 られた。授乳期觹様癌と診断された。
282. 網膜下からの穿刺吸引細胞診で確認し えた進行乳癌の眼球転移の一例

都立大塚病院検查科

O石川幸恵 $(\mathrm{CT})$, 高山公孝 $(\mathrm{MT})$, 椎名京子 $(\mathrm{MT})$ 有輪六朗 (MD)

外科 関口令安 $(M D)$, 眼科 松島利明 (MD)

\section{症例. 65 才女性}

既往歴：昭和 47 年某病院で右乳癌手術及びコバ ルト 60 照射, 昭和 60 年 3 月都立大久保病院で右乳 癌手術，以後 $5 \mathrm{Fu}$ の投与を受けてる。

現病歴：昭和63年11月頃より息苦しさ, 咳, 腰 痛，背部痛を訴える様になり，平成元年 4 月，当 院での骨シンチにて長管骨, 頭蓋骨以外の多発性 骨転移が認められた。 5 月初旬より急激に右視力 障害を訴元, 当院眼科敒右下羊周の網膜剥離が

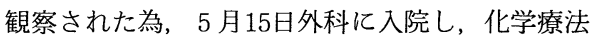
を開始した。尚 5 月には, CE A:6.9, C A:15-3 :127 亡上昇していた。6月1日, 右網膜下から, $27 \mathrm{G}$ の針を使用し，穿刺吸引細胞診を施行した。 細胞診所見：重積性を示す大型クラスターと散在 性又はシート状クラスターを示す 2 種類の細胞集 塊が多数出現している。腫瘍細胞は, 核の大小不 同が著しく，核形不整で出芽状を呈するものが認 められ, クロマチンパターンは粗〜微細顆粒状。 核小体は 1 〜数ヶ認められる。

以上から 充実腺管状の腺癌が考えられた。

脉絡膜転移性腫瘍では，女性の場合乳癌からの 転移頻度が高く, 網膜下からの穿刺吸引細胞診で 確認しえた症例は，本邦第一例目である。 
283. 小脳橋角部に発生した髄膜腫と神経鞘 腫の細胞学的比較検討

東邦大学大森病院病院病理

$\mathrm{O}$ 三上貴代 (CT), 前田陽子(CT), 井手 忠(CT),

佐々木久美子 (CT), 長嶺一夫 (CT), 清水雅子(CT);

辻本志朗 ( $M D)$, 工藤玄恵 (MD)

同第 1 病理学教室

前田明 (CT)

〔はじめに】脳腫瘍の術中迅速診断の際、有 力な補助診断として細胞診が注目されている。 今回我々は、凍結切片にて鑑別診断がしばしば困 難とされる小脳橋角部に発生した髄膜腫、神経鞘 腫の圧挫細胞診の細胞像を比較検討したので報告 する。

〔対象〕小脳橋角部に発生した髄膜腫 4 例、 神経鞘腫 4 例である。

〔細胞像〕1) 髄膜腫の細胞集団は神経鞘腫に 比べ辺縁のほつれが目立ち、散在性細胞がより多 く見られた。神経鞘腫は組織学的に多数の血管を 見るが、圧挫標本上では両者に有意の差は見られ なかった。

2) 髄膜腫の核形は神経鞘腫のそれに比べふっくらと したものが目立ち、よじれ等の不整も少ない。又 髄膜腫には核縁の軽度肥厚や、やや荒いクロマチ ンが観察された。

3) ギムザ染色において神経鞘腫の細胞質には随膜 腫に比べ、ピンク色に染まる細線維と青紫色の擞 細顆粒がより多く見られた。

[まとめ〕パパニコロウ染色による細胞所見 は、これまで報告されているすのとほぼ同じであ った。ギムザ染色は細胞集団中心部を見る上で不 利な染色ではあるが，血管や細胞質内線維や顆粒 を見る点においてかなり有力な染色であると考え られた。なおギムザ染色で認められた細胞質内線 維と顆粒の意義については現在検討を行なってい る。
284. パパニコロウ染色厅挫標本による䯣 膜䚽と神経鞘腫の細胞診断学的娭討

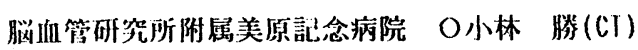

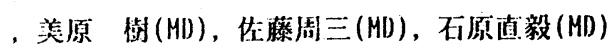

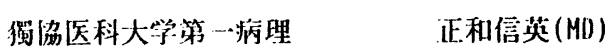
群馬大学附属病院叶検病理 城下 尚 (MD)

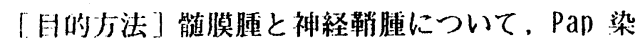
巴龙挫標本に上る腫癔紼胞の比較検討を行った。 刘象は随膜腫11例と神経鞘腫 5 例である。

これら諚例のP a p 染色圧挫標本の娭鏡を行い ，腄澺細胞集団の細胞，核の配列を観祭し，これ らの所見から連想出来る組織檴筑の検討および綝 胞集四周辺の細胞形態，核の形，大きさ，クロマ チンの满造や分布，核小体の大きさ，数，細胞質 内および周进の観察を行った。

[钼察結果]髄膜腫でも神経鞘腫でも典型的特徽 的な細胞配列や砂粒体などを多数認める場合は， 阿脯湯を䋥胞学的に鑑別することが容易であった 。その他のP a p 染色圧挫標本の所見としては, 以下の如くである。

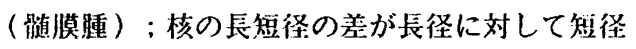
が1/3までのものが多い。核緣は肥厚し、クロマ ホン锲造はやや粗く, 㤥の染色性に湴淡を認め, 紐胞凬国《細線維が軖富で太く，不均一である。 また，紐胞集団周辺には腄湯細胞が孤放散在性に 認められた。

（神経夥腫）; 核は䯑道膜腫よりも長棈円形の㤥が 㤎められ，これらの快には波打ち形態を有するこ とも珍しくない。核緑は菲薄化し,クロマチンは 細顆精状で均等に分布, 核の染色性に濃淡を認め 尔い。細胞周目の)細線維性状は細く，均一である 。また，紼胞集団周辺には腫場細胞は殆ど認めら れない。

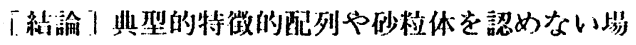
合でむ，P a p 庄挫摽本の闻嗹凛の細胞所見によ り練胞㖣澌学的に鑑別することが可能であると思 われた。 
285. 中枢神経原発悪性リンパ腫の 1 例

茅ヶ崎徳洲会総合病院中唡病理

O伊勢好之 (C T) , 大平嘉一 (MT)

松本竜一 (MT), 黒葛原伸 (MT)

東海大学医学部病理学教室

覚道健一 (MD)

原発性脳脊䈯腫瘍で悪性リンパ腫は、1〜2\% の発生頻度とされるまれな腫場である。

Radiculomyelopathyにて発症し、C S F 中に腫 瘍細胞を認めた 1 例につき報告する。

（症例）51歳女性。入院3ケ月前より右上肢の 筋力低下が出現し神経内科入院。莖椎レ線、C T MR I にてC $4,5,6 に M a s s$ lesionを認め、脳外n 転科となり精査の結果、頭蓋内テント上下にむ Multipile metastasis lesion を認めた。䯣液細 胞診でClass V “Malignat lymphoma疑い” の診断 を得、原発单を検索するも他臟器に異常は認めら れなかった。全脳及び頸部に放射線療法を施行す るむ、人院6ケ月で死亡し剖検された。

（細胞診所見）20 50 $\mu \mathrm{m}$ の細胞径で、核小体 が目立つ円形〜核縁不整を見る腫場細胞が認めら

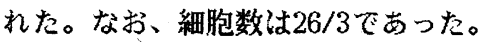

(病理組織所見) 春噵の病理組織所見。充実性 腫瘍は核異型の強い大型の類円形細胞からなり、 Perivascular growth patternが見られ、脊韫へ の浸潤も認められ、悪性リンパ腫、びまん性、大 細胞型と診断された。

腫瘍細胞の免疫組織化学的特徵は現在検索中て 剖検所見と合わせて報告する。
286. 第VIII（聴）神経より発生した悪性神経 鞘腫の 1 例

袋井市民病院病理 ${ }^{1}$ 脳外科 ${ }^{21}$ 浜松医大第 2 病理 ${ }^{31}$ O城崎俊典 $(\mathrm{CT})^{11}$ 市橋鋭一 $\left.(\text { ID })^{2}\right)^{2}$ 原野秀之 $(\mathrm{MD})^{21}$ 杉山忠光 $(\text { MD })^{21}$ 前多松喜 (UD $)^{31}$

県西部兵松医療センター胸部外科 半沢 㑺( UD) 豊橋市民病院臨床検查科䈖本明美(CT)

今回我々は第䧃神経より発生した悪性神経鞘腫 の 1 例を経験したので、腫晹捺印細胞所見と共に 組織学的検討を加えて報告する。

[症例] 38 才 男性。眩量、右側耳鳴、右側恥 力低下を主訴として、平成元年 4 月当院脳神経外 科に入院。諸検査の結果、小脳橋偶角部に第 VIII神 経由来と考えらる腫痬が認られ、同年 5 月、腫瘍 摘出術施行、約 $90 \%$ の亜全摘が行われた。その 後、腫崵の再発により、同年 7 月死亡、局所解剖 が行われた。

[解剖所見] 右小脳橋偶角部に $3 \times 4 \times 5 \mathrm{~cm}$ の暗 褐色の腫瘍組織が認められ、腫崵内血腫を伴い、 脳幹を圧迫していた。

[腫瘍捺印細胞所見］腫碭細胞は、紡鍾形や類円 形を呈し散在性に出現し、細胞質はライトグリー ンに淡染し、辺縁は不明暸であった。核は棈円形 もしくは類円形で、大小不同を呈し、一部の細胞 では核縁不整がみられ、核クロマチンは粗網状、 核小体は不明瞭であった。また、これらの細胞に 混じって大型多核細胞を認めた。

[病理組織所見］核が濃染し、N／Cの大きい異 型性を示す紡鍾型や多角形の腫場細胞が密に増殖 しているが、明らかなpalisadingは見られない。 膠原線維は少なく、粘液腫状の基質が見られた。 免疫染色では、S100(+)GFAP(-)NSE(+)であった。 [電顕所見］腫瘍細胞表面には、厚い基底膜様構 造物が見られ、腫場細胞は互いに接着装置でつな がっている。一部の細胞では、細胞突起のinterdigitationがみられた。 
287. 仙尾部脊索腫一症例の捺印細胞像

群馬大学医学部第二病理学教室

○葥藤まさ子 (CT), 福田利夫 (MD)

群馬大学医学部附属病院中央検查部

城下尚 (MD)

脊索腫は胎生期脊索の遺残から発生するまれな腫 瘍であり，局所再発を繰り返し，長期の経過後に は転移を生じることがある，今回，発症後6年めに 腫瘍全摘術を行った症例の择印細胞像について病 理組織像と比較検討して報告する．

症例は53才の女性. 昭和55年ころから仙尾部痛 が出現し, 昭和58年に仙尾部腫嘴の部分切除によ り脊索腫と診断され，化学療法と照射を行った. 61年2月に第2仙骨の一部から尾骨をふくめた腫掦 全摘術 $(8 \times 7 \times 8 \mathrm{~cm})$ をおこなった. 62 年4月には肺転 移が確認され，63年2月に骨盤全摘術を行ったが全 身転移を生じ64年1月に死亡した。

捺印細胞像：腫湯全摘時の新鮮な割面から捺印 標本を作製した，壊死性，粘液性背景の中に腫瘍 細胞が上皮様の集塊を形成して出現している，腫 瘍細胞は大型で細胞質は空胞状であり，その中央 部に小型円形の核がある。核形は整，クロマチン は顆粒状で，1-3個の小型核小体を持つ. PAS染色 では細胞質内にglycogenの沈着がみられた．以上 の細胞はphysaliferous cellsに相当する，一部の 大型円形の腫㙏細胞は核の肥大, 大小不同, 核縁 の不規則な切れ込みをしめしている.さらに一部 では細胞質は不規則星芒状となり， light greenに 好染している，このような腫湯細胞は大型円形の 核をもちstellate cellsに相当する.

病理粗織学的所見：腫痬は分葉状を呈し, 中心部 は壊死に陷っている．豊富で空胞状となった 細胞質を有する細胞 (physal iferous cells)が敷石 状に增殖している部分があり，一部では紡鏵形な いし星芒状の腫漡細胞 (ste1late cel1s)が豊富な 粘液性の基質の間に柾に浸潤している部分がある.
288. 乳頭型䯙朕腫の細胞像

聖マリアンナ医科大学病理学教室

$O$ 阿部光文 $(M D)$ 、天本大輔 $(M D)$

竹内英子(MD) 田所 衛(MD)

聖マリアンナ医科大学病院中央検查部病理

森脇友子(C T)、平野三重子 (CT)、

星川咲子(C T)

䯙膜腫は頭蓋内腫場の約20\%にみられ、膠腫群 に次いで多い。この中で乳頭型䯣膜腫は悪性の性 格を示すとされている。今回我々は中年男性の左 小脑天幕に発生。その後再発を繰り返し、組織学 的にも乳頭型䯙膜腫と確認された症例を経駼した ので報告する。

症例は37才男性。主訴は複視。昭和60年複視を 自覚し眼科受診。うっ血乳頭指摘され当院受診。 tentorial meningiomaの診断で50\%の部分切除が 行われ、残存した腫場に対して40Grの放射線治㞠 が行われた。その後神経症状の悪化は認めず、外 来にて経過観察されていたが、平成元年 4 月右耳 鳴が出現し聴力も低下したため再び当院入院。C $\mathrm{T}$ 上腫場の再発が認められ、急速に増大傾向見ら れたため再手術施行。その後更に 2 回の再発に対 して手術が行かれた。

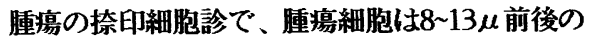
類円形の核を有する円柱〜多稜形の、比較的均一 な細胞であった。平面的一集族性に出現し、血管 を中心に乳頭状に配列したり、腺膯录の配列が認 められた。渦巻き状の配列は見られなかったが、 核分裂像は部分的に認められた。

組織学的には、腫湯は血管結合蟣性基質を伴つ て、比較的小型で均一な腫瘍細胞が乳頭状に增殖 し核分裂像も認められた。また一部では腫場細胞 が血管を中心とするロゼット様配列もみられた。

電䫓的には intermediate filaments、inter digitation、また細胞間にはtight junction,desmosomeも認めらん、これらの所見より、悪性性格 を有した梠頭状髄膜董と診断された。 
289. 脈絡乳頭癌と乳頭状上衣腫が混 在した脳腫瘍細胞診の一例。

聖マリアンナ医科大学第一病理学教室

$O$ 天本大輔 $(M D)$ 、阿部光文 $(M D)$ 、竹内英子 $(M D)$ 田所衛 (MD)

聖マリアンナ医科大学病院臨床検查部

平野三重子(CT)、森脇友子(CT)、星川咲子(CT)

脈絡顽頭癌 (Choroid plexus carcinoma) は、全脳腫瘍の $0.5 \%$ G 1 i iomaの1.6\%を占める脈絡 丵乳頭腫 (Choroid plexus papilloma) の $8 \%$ に認める悪性型である。今回、我々はこの稀な choroid plexus carcinoma と乳頭状上衣腫 （papillary ependymoma）を同一腫瘍内に認めた 症例を経験したので捺印細胞詥所見を中心に報告 する。

【症例】生後 2 ケ月、男児。妊娠経過中に異常は なく、生下時体重は3440g、Apgar score 10点で あった。1ケ月検診にて頭囲拡大 $(40 \mathrm{~cm})$ を指摘 され、さらに 1 ケ月後には頭囲 $45 \mathrm{~cm}$ とった。水 頭症疑いにて当院小児科入院となった。頭部 C T にて左側脳室に脳腫瘍を認め、腫瘍摘出術施行。

【細胞診所見】盾瘍の捺印により得られた細胞は およそ2つの夕イプに分けられた。ひとつは立方 状ないし円柱状の細胞質を持つ小型細胞で一部で は口ゼット形成も認められた。もう一方は小型類 円形核を有する細胞が、著明な乳頭状增殖を示す 集塊として得られている。この細胞集団は、血管 との関係を認める部分があった。

【病理所見】肉眼所見は、 $4.0 \times 4.0 \times 5.0 \mathrm{~cm}$ 大の境 界明膫な結節性病変で、割面は赤みを帯びた充寒 性腫瘍であった。光影所見は明らかに異なる2つ の特徵ある腫瘍が混在した。一つはpapil1ary な 形態を示すepedymoma の所見と、他は choroid plexusから発生した乳頭状腫瘍で、細胞異型と核 分裂像および一部に間質性浸潤を認める choroid plexus carcinomaの像であった。
290. 脳脊䯚夜細胞診で眽絡叢乳頭腫が 強く示唆された1症例

昭和大学藤が丘病院 病院病理科1

同組織化学研究室 ${ }^{2>}$

O中川信廣(CT $)^{13}$, 北村隆司(CT $)^{12}$, 神保容子(CT $)^{1)}$, 斉藤多紀子 $(\mathrm{CT})^{1)}$, 光谷俊幸 $(\text { MD })^{13}$, 佐川文明 $(\text { MD })^{13}$, 鈴木孝夫(CT $)^{2)}$

脈絡叢乳頭腫(Choroid plexus papilloma)は、 原発性脳腫瘍の約 $0.4 \%$ 、小览の脳腫瘍の約 $1.5 \%$ と極めて稀な睡瘍で、発生部位は、成人では、第 4脳室に多く、小児では、側脳室が大部分を占め

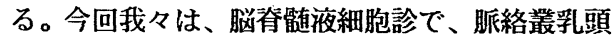
睡が強く示唆された1症例を経験したので報告す る。

【症例】生後4力月男児.平成元年、7月31日嘔吐、 意識障害により発症。近医受診、CT施行、睬室内 腫瘍が疑われ、同年9月8日当院脳神経外科受診。 CT、MRIを施行し、左側脳室三角部に腫瘤形成が 認められた。同年9月10日、娟迹液細胞診を施行. 眽 絡叢乳頭腫が強く示唆された。同年9月18日に腫 瘍摘出術施行。

【細胞所見】出血性背景に、少数の乳頭状集団 が見られた。腫場細胞は小型でN/Cが高く、胞体 はライドグリン好性で、核は小円型、核形不整、核加 マデは、微細顆粒状で軽度の増加を認めた。核小 体は、小型で比較的明暸であった。

【組織学的所見】(手術材料)主に円柱上皮より なる腫場細胞の著明な乳頭状増殖が見られ、間質 は血管に富んだ結合組織で、Choroid plexus papilloma と診断。悪性と断定できなかった。

【まとめ】4力月男児、脳脊髄夜細胞診でChoroid plexus papillomaが強く示唆された1症例を経験 した。爁別疾患としては、乳頭状上衣腫、Choroid plexus carcinoma、転移性腺癌等があげられ る。 
291. 脳内発生の悪性線維性組織球腫の 一例

聖マリアンナ医科大学臨床検查部、同病理学教室* ○星川咲子(CT)、平野三重子 (CT)、森脇友子(CT) 阿部光文 $(M D)$ ：天本大輔 $(M D)$ 、竹内英子 $(M D)$ * 品川俊人 $(M D)$ * 田所 衛 $(M D)^{*}$

頭蓋内に発生した悪性線維性組織球腫と考えら れる症例を経験したので報告する。

【症例】81才、女性。昭和63年 6 月下旬上り左 下肢のしびれ感、その後右顔面のしびれ感出現。 同年 9 月精查のため入院し、C T、M R I 等の結 果、脳腫瘍を指摘される。10月 7 日脳腫瘍摘出術 施行。凬瘍は左頭頂葉皮質下に存在し、境界明睹 な $2.5 \mathrm{~cm}$ 大の弾性硬で、割面は灰白色を呈してい た。腫㰾の一部には軟膜と接触がみられた。

【捺印細胞診所見】細胞質縁明膫な線維状一星芒 状の不規則な突起を有する多形性、異型性のみら れる腫瘍細胞が散在性一集簇性、集塊状に認めら れた。核形は類円～棈円、紡鍾形で不整もみられ 多形性に富むが、核構造は単調で核縁は明膫。 クロマチンは顆粒状で比較的均等に分布し、明瞭 な核小体が 1 個認められるものが主体であった。 同一の核所見の $2 \sim 3$ 核の多椟細胞が少数裙めら れた。

【病理組織所見】特徴的な storiform pattern をとる紡鍾形の線維芽細胞様細胞がびまん性に增 殖しており、そのなかに bizarreな核をもつ巨細 胞、sudan III染色で陽性顆粒を認める泡沫状細胞 を加えた多形性に富む組織球様細胞が混在した。 免疫組織学的には、いずれの細胞にも S-100、 G F A P、Neurof ilament は陰性、Vimentinはび まん性に陽性、 $\alpha_{1}$-antichmotorypsin、 $\alpha_{1}$-antitrypsin が組織球性と考えられる細胞の一部に陽 性所見を見た。しかし Isozymeは陰性であった。 以上の所見より striform-pleomorphic type の 悪性線䧴性組織球腫が考えられた。

\section{2. 髄液細胞診で推定された 脳軟膜黑色症の 1 例}

日本大学医学部付属板橋病院病理部 ${ }^{11}$, 同医学部病理 ${ }^{2)}$

稲庭義巳 $(\mathrm{CT})^{1)}$ ，関 利美 $(\mathrm{CT})^{11}$ ， 根本則道 $(M D)^{1>2)}$, 桂 義久 $(M D)^{2)}$, 田崎需一 $(\mathrm{MD})^{2>}$, 岡野匡雄 $(\mathrm{MD})^{2>}$, 桜井 勇 $(M D)$ 1) 2)

髄膜炎症状で発症し髄波細胞部より悪性黒色腫 が疑われ、多発する皮解色素性母珓の存在より神 経皮虔黒色腫症を背景に発生したと考えられたビ マン性髄膜悪性黒色腫を経験したので報告する。

[症例] 19 才、男性。昭和 63 年 7 月感冒様 症状が出現し、鲔膜炎の診断で治療を受けるも軽 快せず、同年 10 月当院へ転院した。入院後数回 の髄液細胞診が施行され、いずれにもメラニン色 素を含有する大型の異型細胞が認められ、悪性黑 色腫が考えられた。またCTでは小脸に露腫を疑 う低濃度域が認められ、クモ膜下囊腫の診断のも と平成元年 1 月 26 日、震腫内容穿刺ならびに囊 腫壁切除術が行われ悪性黑色腫と診断された。そ の後、頭蓋内圧の立進を認めたため脳室膜㚙シャ ント術施行したが症状発現後 8 力月目に死亡し、 病理解剖が行われた。[髄液細胞診所見]腫瘍細 胞は大型で細胞質内に褐色顆粒を有し、核は円形 〜類円形、一部切れ込みを有するものも認められ た。クロマチンは細顆粒状で軽度增量し、1〜2 個の核小体が認められた。褐色顆粒は漂白法で漂 白され、メラニン色素と考えられた。[生検なら びに解剖所見]震腫壁は抯道膜よりなり悪性黑色腫 細胞のビマン性浸潤を伴っていた。開頭時の肉眼 観察では髓膜は大脳、小脳半球は勿論のこと脳幹 から沓髄馬尾に至るまで組織学的には悪性黒色腫 細胞の浸潤が観察された。他の全身缄器の検索で は原発巣を示唆する部位は確認されず神経皮虔黒 色腫症を背景に発症したビマン性铕膜悪性黒色腫 と診断された。 


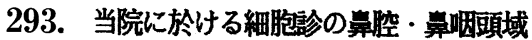
への利用

姫路赤十字病院病理

O山本繁秀 $(C T)$ 、春名勝也 $(M T)$

佐伯久子 (CT)、荻野哲也 (MD)

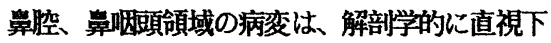
での組織採取力容易なため、組䋨検查は一般的で あるか細胞剅の利用は多くない。当院では、生検 時に捺印迅速細胞䟚を行なうことで、生検組織が 組織険查として適当な材料か否かの情報を、臨床 側に提供している。

（方法）賞腔・番咽頭の腫堭性病変を、組織採取 用鉗子で直視下に採取。スライドガラスに捺印、 95\%エタノール固定後、直ちにP a p 染色し検鏡 した。

（結果）過去 3 年間の睤腔・當咽頭生検者の細胞 診は、33症例で、陽性13例、疑陽性 1 例、陰性 19 例であった。組織部断との比較で、陽性例て腺癌 を扁平上皮癌とした例を除いては、結果はほぼ一 致した。陽性者 13 例の内訳は、扁平上皮癌 5 例、 未分化癌 3 例、腺癌・腺栐毫胞癌・悪性リン八ハ腫 - 髄外形質細胞腫・悪性黑色腫、各々 1 例。疑陽 性者は扁平上皮乳頭畽。陰性者の殆どが リンパ 球の增生を伴う炎症性ポリープであった。

（まとめ）上気道は他の葴器に比へて、発生学的 に複雜であり、発生する腫場も多彩である。今回 の報告も症例数は少ないが、その種類は多く、比 較的稀な症例も経倹した。生検時に迅速細胞を行 なう利点は、組織の性状を報告し臨床とのコミニ ケーションを図ることで、より適切な組織をその 場で再度生検することが可能となり、患者の治療 方針を決める上で有用であった。

今回陰珄例を含め、各症例につき細胞像と組織 像を対比しながら、各種染色を加えて述べる。

\section{4. 耳下腺原発乳頭状腺癌の一例}

舞鶴共済病院䧗床検查科病理 O岩崎由恵 $(M T)$, 山口直則 $(M T)$ 金沢大学医学部第一病理学教室 上田善道 (MD)

耳下腺原発乳頭状腺捳は楆めて稀であり、そ の細胞所見に関しては、ほとんど知られていな い。最近我々は左耳下腺原発の乳頭状腺泊で、 摘出から 3 年 6 力月後に局所再発を来した症例 を経験し、その細胞所見を検討しえたので報告 する。

症例：81才 女性。昭和 61 年 2 月、左耳 下腺腫瘤 (6.5 X4.5X3.5)cmの切除がなされ、平 成元年になり局所の腫第と顠部リンパ節の腫大 を来し、リンパ節生検、ならびに、再発腫溜か らの吸引細胞診で、耳下腺原発乳頭状腺癌の再 発および䫓部リンパ節転移と診断された。

（細胞所見）

細胞は重積性を示し、大小集団で出現し、や や異型の乏しい集団もあるが、明らかに悪性を 疑わせる $\%$ c 比增大、核形不整、大小不同の乳 頭状増殖の集塊を認める。細胞の胞体はライト グリーンでレース状、核はクロマチン微細〜細 顆粒状、核形不整、大小不同、核間距離の不揃 いを認める。PA S染色陽性であつた。

（組織所見）

大型の立方から円柱状細胞が乳頭状構造をと り密に増殖する乳頭状腺癌で、核分裂像も散見 された。その後、化学療法ならびに温熱療法に よる治療が現在も継綍中である。 
295. 聴器癌の一例

\section{社会保険都南総合病院 検查科 ${ }^{1}$ 耳鼻科 $^{2}$ \\ O田中久美子 $(\mathrm{CT})^{1}$ 杉内智子 $(\mathrm{MD})^{2}$ \\ 東京船員保険病院 耳鼻科 ${ }^{3}$ \\ 渡辺悟郎 $(\mathrm{MD})^{3}$ \\ 東邦大学大森病院 病理 ${ }^{4}$ 産婦人科 $^{5}$ \\ 石井真由美 $(C T)^{4}$ 亀田典章 $(M D)^{4}$ \\ 津布久雅彦 $(\mathrm{MD})^{5}$ 大村 剛 $(\mathrm{MD})^{5}$}

聴器癌は他の頭顠部覀性腫呁に比べると稀であ り、またその臨床像は、耳茸、外耳道炎、慢性中 耳资の急性増悪像と類似しており鑑別は困難であ る。今回、真珠腫性中耳炎の急性増悪として治療 中、耳漏の細胞診を行い、術前に扁平上皮癌を示 唆できた聴器癌の一例を経験したので報告する。

【症例】61才、男性。小児期より両側性慢性中 耳炎の罹患あり。平成元年 6 月頃から左耳漏を来 し聴力低下を自覚、同年 8 月当院受診。初診時、 左拍動性耳漏を認め、外耳道壁が膨隆し鼓膜は直 視不能であった。単純X線で乳突洞に骨欠損を認 め、C Tでも中頭蓋窩底、頻関節包に及ぶ軟部組 織陰影を認め、左中耳真珠腫の内耳波及を䈄った。 入院加療後、鼓室形成術の予定となったが、9月 に入っても外耳道の腫脹が残存するため、9月 5 日、耳漏のスメア検査を行ったところ、class V 扁平上皮癌と判定された。9 月 8 日、中耳根治術に 準じて腫場摘出術を施行。手術直後から化学療法、 放射線療法を行い、現在、経過良好である。

【細胞所見】背景には、资症性細胞とghost cel1が みら扎、小型でN/C比大の悪性細胞が、孤立散在性 に出現した。細胞質は厚く濃染し、クロマチンは粗 顆粒状〜濃縮状で核型不整を認めた。

【組織所見】腫場細胞は、リボン状の胞巣を形成し て深く浸潤性発育する squamous cell carcinoma で角化は目立たず、中等度分化型に相当した。

以上の症例を供覧し、耳漏の細胞診の有用性に ついて文献的考察を加えたい。
296. ブドゥ膜悪性黒色腫の一例

大阪船員保険病院病理部、同眼科 ${ }^{1)}$

$O$ 森本好美(CT)、岡田正直 (MD)、山城久和 $(M T)$

渡辺晶子(MD) ${ }^{1)}$ 、浜野孝 $(M D)^{1)}$

国立大阪病院眼科田野保雄(MD)

大阪回生病院病理部坂本泰子(CT)

硝子体の穿刺吸引細胞診により、術前に診断し 得た悪性黒色腫の一例を経験したので、色素性母 斑の細胞像と併せて報告する。

[症例] 49歳、男性。1989年 1 月交通事故。そ の後、右眼視力低下。7 月当科受診。眼底所見： 硝子体耳側上方から中央部にかけて、腫瘤が竹の 子様に突出。9月交通事故による血腫を疑い、硝 子体穿刺吸引細胞診を施行。2 $5 \mathrm{G}$ 針では採取不可 能なため、18G 針を用いた。細胞所見より悪性黒 色腫と診断。右眼球摘出。術後、放射線治療施行。 現在再発、転移は認めない。

[肉眼所見] 摘出された眼球は正常の形を保つ が、固度は低下し、メスで半切する時に、歪んで 切り難かった。半切された眼球内には黒灰色の腫 瘍と、色素で浸淫された硝子体があり、全体とし て墨のように見え、腫瘍と硝子体を判別し難かっ た。腫瘍割面の捺印標本は、メラニン量が多く、 全面に墨を塗ったように見える。

[細胞所見］背景は血性。腫瘍細胞は多く、結 合性がなく孤立性に出現。細胞は多形性を示す( 紡錘形と類上皮形の出現比は 2:1）。細胞質には 黒褐色ドット状顆粒と茶褐色桿状顆粒が充満する。 核形は類円、不整形で、切れ込み、溝、核内空胞 を形成する。核クロマチンは増量、微細顆粒状、 不均等分布。核小体は不整形で 1-2個認める。核 分裂像は認められない。

[組織所見]腫瘍は右眼球脈絡膜の耳側後方4/ 5 を占拠し、最大径割面では、断面積の約 $80 \%$ を 占める。腫瘍の組織型は混合型（紡鍾細胞型優勢 ：B型紡錘細胞〉 $\mathrm{A}$ 型紡釷細胞）である。核分裂 像は少ない（強拡大 10 視野中に 1 個）。 
297. 甲状腺穿刺吸引細胞診の検討

京都大学医学部附属病院病理部 ${ }^{1)}$ 、検査部 ${ }^{2)}$ 、滋 賀県総合医療センター ${ }^{31}$

O桶口佳代子 $(M D)^{11}$ 、伏木悦代 $(C \mathrm{~T})^{1)}$ 、藤原 孝子 $(\mathrm{C} \mathrm{T})^{2)}$ 、漆畑順子、吉村誠之 $(\mathrm{M} \mathrm{D})^{1) 、 3)}$ 山辺博彦 (M D ) ${ }^{1)}$

[緒言] 我々は甲状腺穿刺吸引細胞診の感度、 特異性等の精度について検討したので報告する。 [材料及び方法］当院における1988年 1月から翌 年 3月までの89例、延べ 119 検体を対象とした。 患者の平均年令は 45.9 才、男女比は約 1:7、良性 疾患 73 件（滤胞腺腫 31 件、腺腫様甲状腺腫24件、 橋本病 9件、Graves病 9件) 、悪性疾患46件 (乳 頭癌 41 件、滤胞癌 2 件、低分化癌 1 件、未分化癌 2件）であった。不良検体率は 25\%で良性疾患で は37\%、悪性疾患では8.6\%であり、これらは統計処 理から除いた。[結果］当院では滤胞状腫場を疑

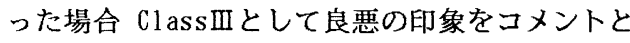
して付加えているが良性の印象を持った濾胞腺腫 の症例を良性群に含めると特異性は $91.3 \%$ あ゙り 悪性検出の感度は $97.6 \%$ あった。確定診断の感 度は乳頭癌 $97.4 \%$ 、滤胞癌(1例）未分化癌(2例) は いずれも $100 \%$ 、低分化癌は陽性所見は得たが組織 型の判定は困難であった。良性疾患では、滤胞腺 腫 $55 \%$ 、腺腫様甲状腺腫 71 . $4 \%$ 、橋本病 $100 \%$ 、Graves 病 $60 \%$ であり、二次変性を伴った滤胞腺腫が腺腫 様甲状腺腫に(35\%)、腺腫様甲状腺腫における過形 成結節が滤胞腺腫に(28.6\%)、経過の長いGraves病 が橋本病 $(20 \%) や$ や腺腫様甲状腺腫 $(20 \%)$ に判定さ れていた。[結語］(1)甲状腺穿刺吸引細胞診は悪 性疾患の検出に有用であり、高感度の術前診断が 可能であった。(2) Class而は手術適用となるケー スが多いが、この中に腺腫様甲状腺腫が含まれる 可能性があり、臨床所見を含めた慎重な検討が必 要と思われた。
298. 結節性甲状腺腫の形態を示した慢性 甲状腺炎の 2 症例

順天堂大学 内科, 同第二外科 ${ }^{11}$, 同病理研究室 ${ }^{2}$, 都立大塚病院検查科 ${ }^{3)}$

○石原明夫 (MD), 稗田正志 (MD), 佐生 隆 (MD) 広瀬俊一 $(\mathrm{MD})$, 田中岳史 $(\mathrm{MD})^{1}$, 古旗 淳 $(\mathrm{CT})^{2}$, 中村眞二 $(\mathrm{CT})^{2)}$, 有輪六朗 $(\mathrm{MD})^{3)}$

慢性甲状腺炎は一般には，び漫性甲状腺腫を示す ことが多い。今回結節性甲状腺腫の形態を示した慢 性甲状腺炎の 2 症例について趣味ある所見を認めた ので報告する。症例 1. M. H. 53才 主婦 主訴は 右前頸部腫瘤, 現病歴：昭和54年12月頃に右前頸部 腫瘤に気づいたが，発熱，圧痛は自覚していない。 近医受診し昭和 55 年 1 月当内科紹介受診, 触診上, $5.0 \times 7.0 \mathrm{~cm}$ 大, 弾性硬のび漫性甲状腺腫を認め, 甲 状腺右葉上極に $5.0 \times 4.0 \mathrm{~cm}$ 大の弾性硬の結節を認 めるが圧痛はない。穿刺吸引細胞診では, 慢性甲状 腺炎の所見を認め, 一部にリンパ球の芽球様細胞の 出現を認める。初診以来年一回の割で約 10 年に亘っ て経時的に細胞診で follow up している。上皮細胞 は好酸性変化の強弱の消長がみられ, 核の变性が目 立ってともあったが悪性を示唆する所見は認められ ない。一方リンパ球は経過中出現細胞が増加するこ となく, 芽球様細胞の継続的出現む認められない。 症例 2. M. K. 63才 主婦 主訴は右前頸部腫瘤, 現病歷：53才甲状腺腫を指摘されている。今年 7 月, 近医で右前頸部腫瘤を指摘され紹介受診, 触診上, $8.5 \times 6.0 \mathrm{~cm}$ 大の弾性硬のび満性甲状腺腫を認め, 甲 状腺右葉上極に $4.5 \times 5.0 \mathrm{~cm}$ 大の弾性硬の結節を認め る。右上極結節の細胞診は sheet 状, 重積性の沪胞 上の cluster が中等大として認められる。細胞胞体は 広く一部は好酸性を示して抢り, 細胞境界が明瞭な あのが多い。核は大小不同が目立ち，大型の核には 明瞭な核小体か認められる。核縁は平滑でクロマチン は微細顆粒状であるがmitosis は認め難い。核小体を 伴う大型核の目立つ細胞が比較的多く出現している。

結節性甲状腺腫の形態を示した慢性甲状腺炎を診 断する際には, 墨性リンパ腫, 小細胞型未分化癌, 小沪胞癌および Hürthle cell carcinoma 等との 鑑別を考慮するととが重要である。 
299. 乳頭状增殖を示す甲状腺良性結節 病変の細胞学的検討 - 乳頭癌と鑑別が困難で あった2例についてー

\section{藤田学園保健衛生大学医学部病理} 社会保険埼玉中央病院病理 "', 外科 ${ }^{2 !}$ 岛田医院 ${ }^{3 !}$

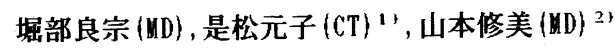
城野健児 (MD) , 田代和弘 (MD)，笠原正男 (MD) 小林一彦 $(\mathrm{CT})^{\prime \prime}$, 平野風 $(\mathrm{CT})^{11}$, 田口滋郎 (MD) ${ }^{3 \prime}$

くはじめに〉乳頭状增殖を示す甲状腺腫瘍の大部 分は乳頭癌であるが, 腺腫樣甲状腺腫（結節）, 所謂乳頭腫などでも乳頭状增殖を示し, 細胞異型 を伴うことがある。今回我々は甲状腺穿刺吸引細 胞診で乳頭状の細胞集団を認め,それらに細胞異 型を伴った 2 例の良性結節病変を経験したので乳 頭癌との鑑別を中心に報告する。

<症例>症例 $1: 39$ 歳。症例 $2: 12$ 歳。いずれも 女性で主訴は前頸部腫瘤。

<細胞学的所見 $>2$ 例とも穿刺吸引細胞診のPAP 染色で細胞採取量は少〜中等度以上で, 背景には 泡沫細胞みられ多核巨細胞の出現は認めなかった。 細胞集団は乳頭状ないしシート状配列を示し, 核 は円形で核形不整がみられた。クロマチンは細網 状で均等分布を示したが, 症例 1 には密に分布す るクロマチンがみられ，すりガラス状を呈してい た。核内細胞質封入体は認めなかった。症例 1 , 2ともに乳頭癌が否定できないためにclass III と 報告した。

<組織学的所見>症例 1 は被包化された腫瘍で, 所謂乳頭腫の像を呈していた。腫場細胞は乳頭状 增殖を示し, 核は円形, 小型で基底側に 1 列に配 列し, 核形不整は軽度であった。症例 2 は乳頭状 増生を示した腺腫样結節であった。

本例でみられた乳頭状集団を, 腺腫椂甲状腺結 節およびバセドウ病などに出現する良性の乳頭状 集団と,さらに被包化された分化型の乳頭㢄につ いても比較検討を加えて報告する。
300. Hyalinizing trabecular adenomaの 1 例

横浜市立大中央検查部

O竹津 恵実子 (CT)、大津 久美子 (CT)、北 村和久 (CT)、津村 みずえ (CT) 、吳 吉 煥 (MD)、下山 潔 (MD) 、桔梗 辰三 (MD)

〔はじめに〕

甲状腺のHyalinizing trabecular adenomaは、 最近注目されてきた希な腫瘍で、その報告むき わめて少ない。今回我々は本症例を経験したの で穿刺吸引細胞像を含め報告する。

[症例]

48 才性。検診にて前頸部腫瘤を指摘さ 礼精查のため当科へ来院。腫瘤は甲状腺右葉 上極に位置し、弾性硬、可動性をむつ。その部 位の吸引細胞診で class Vと判定され、その 後手術を施行される。

[ 肉眼所見]

腫瘤は3.1 $1 \times 3.5 \mathrm{~cm}$ 大で、境界明膫。割面は充実 性・灰黄色で、薄い被膜で被われている。

[組織所見]

腫瘍細胞は細長い紡錐形ないし多稜形である。 これらは類円形 增量した呶ンおよび大小不同

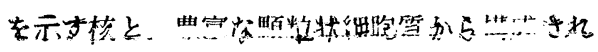
る。細胞群はは薄い血管線維性間質により分葉 され胞巣状構造を呈する。また細胞間にはしば しば硝子様物質の沈着がみとめられる。この 硝子様物質は、P.A.S 染色は陽性、Congo red 染色は陰性を示す。

〔細胞所見〕

細胞は塊状に採取され 個々の腫瘍細胞は楕 円形ないし紡鍾形でライグリー好性の細胞質を有 する。核は細顆粒状の呐代を有し、軽い大小不 同を示す。また核内細胞質封入体あるいは核の しわむ時に認められる。これら細胞はオいジ Gな いしライドリーン好性の硝子様物質を中心に索状配 列を示す。 
301. 甲状腺内胸腺腫の一例

金沢大病理部 ${ }^{11}$ ，第 3 内科 ${ }^{21}$, 金沢大医療短大 ${ }^{31}$ ○得能美香 (MT $)^{11}$, 川岸徳子 (CT $)^{11}$, 水上勇治 $(M D)^{1)}$, 野々村昭孝 $(M D)^{11}$ ，松原藤継 $(M D)^{11}$, 中村 忍 $(M D)^{2)}$, 谷本一夫 $(M D)^{3)}$

甲状腺に発生する胸腺腫はきわめてまれで，現 在までにわが国では数例の報告がなされているの みである。私達は, 穿刺吸引細胞診にて腺癌と診 断された本症の 1 例を経験したので報告する。

〔症例〕16才，女性。父親より甲状腺の腫大を指 摘され, 精查のため入院。臨床的には甲状腺腺腫 が疑われるむ, 穿刺吸引細胞診にて腺癌と診断さ れ，甲状腺严全摘術を施行。

〔細胞像〕重積性に富む細胞集団がみられ，少数 のリンパ球む混在する。腫瘍細胞は, やや大型で N/C比大, 核は類円形。クロマチンはやや增量し 細顆粒状。小型の核小体するられる。大型で重積 性に富むことから腺癌と診断した。

〔病理所見〕腫瘍は大部分, 腺様構造を示し一部 に紡鍾形細胞が充実性に配列。所々にハッサル小 体様の構造物とリンパ球の浸潤をみる。免疫染色 にて, TG(-), CT(-), SC(+),ケラチン (+), Leu-7 $(+), \operatorname{EMA}(+), \operatorname{LCA}(+)$ (リンパ球)であった。

〔まとめ〕甲状腺内胸腺腫はまれであるが, 本症 は細胞診上しばしば腺癌, 扁平上皮癌との鑑別が 困難であり，免疫染色などを行う必要がある。

\section{2. 甲状腺の形筫細胞俥の 1 手術例}

社会保険 小倉記念病院 病理

O鬼木 登与志 (CT), 若林 太 (CT) 安田 三在子 (CT), 田中 小夜 (MT) 山口大学医療短期大学 衛生技臌学科

岩田 隆子 (MD)

山口大学医学部 病理学第一講座

石原 得博 (MD) 横田 忠明 (MD)

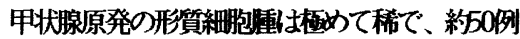
が報告されているにすざない。甲状腺の形質細胞 腫堙性リンハ腫と同样に橋本氏病加曲来する ことが多い。我々は橋本氏病に伴ったIgA 型の

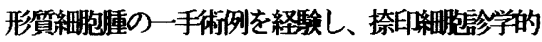
組綪学的及ひ免度学的に検索したので報告する。 症例 $女 69$ 歳女性、1989年5月頃より頝部の胜長 に気付き某医を受部し、諸検查の結果甲状腺澏の 診断。右葉及び狭部の $1 \frac{1}{2}$ の摘出術を受けた。

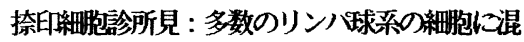
在し比㜞的分化しな形筫練胞の集蝣がみられる。 この形質細胞の核はややや大き濃染していた。リ

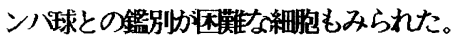

組蟣学的及び免度学的所見 : 正常の構造士大部 分て破塤され、リン八演胞を伴ったリンハ球の浸

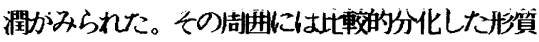

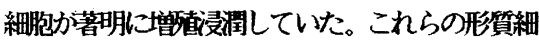
胞には軽度の異型がみられた。これらの形質練胞 はIgA及び $\kappa$ 鎖と強く反応した。血清免疫グロブ リンは姑葉切除後 IgG $1120 \mathrm{mg} / \mathrm{dl} \mathrm{IgA} 487 \mathrm{mg} / \mathrm{dl}$ IgM281mg/dlで全葉切梌後 IgG $1240 \mathrm{mg} / \mathrm{dl} \mathrm{IgA}$

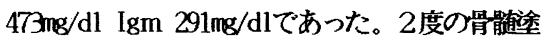
抹所見では形質練胞が2.6\%と3.4\%で，異型相胞さ 認められなかった。

X線所見でも多発性骨骾㣫の所見はなく、全身リ ンハ節の腫大も認められなかった。

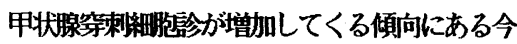
日この症例のように合併した腫瘍も常に考虑し、 スクリーニングをしなければい忛ないと思った。 
303. Papillary carcinoma の特徵を呈した 甲状腺 0xyphilic cell carcinomaの一例

済生会川口総合病院・中検病理

O川嶋活彦(CT), 栗田佳子(CT), 田丸順子(CT)

近内明子(CT), 田丸盛夫(CT), 石川 宏(ND)

埼玉医大・第二病理

高浜素秀(ND)

現在甲状腺0xyphilic cell carcinomaはFollicular carcinoma の亜型として分類されているが、 我々はPapillary carcinoma の特徴を呈する一例 を経験したので報告する。

[症例］58才女性。昭和61年来、Simple goiter として内科にて加療されていたが、平成元年 3 月 USにて右葉に腫瘤を認め、悪性を疑い穿刺吸引細 胞診施行。 class V. Oxyphilic cell carcinoma を推定。同年 5 月 22 日、右葉切除術施行。

[細胞像］背景に少量の壊死様物質・組織球 (多 核十）が見られ、多量の細胞集塊を認めた。大小 の集塊は、不規則重積性〜シート状を呈し、一部 に乳頭状及び滤胞状構造を認めた。 $\mathrm{N} / \mathrm{C}$ 比は一般 に低く、細胞質はライトグリーン好染、重厚で $\mathrm{O}$ $\mathrm{G}$ 好染顆粒を含有し、時に細胞質内空胞が見られ た。核は単核〜数核で明瞭な核小体を認めた。核 縁は不整でシワ状を呈し、核内封入体が少数散見 された。核クロマチンは一般に細顆粒状〜網状、 ヘマトキシリン淡染性で、時に不均一顆粒状核ク ロマチンが認められた。

[組織像] 腫瘤は、右葉中央部に位置し被膜を有 した2. $4 \times 1.5 \mathrm{~cm}$ 大の暗赤褐色結節で、組織学的 には、広笧壊死とそれに対する異物性肉芽性反応 を呈しており、部分的に好酸性顆粒を有する好酸 性細胞の増生を見た。これらは乳頭状及び滤胞状 構造を示し、一部に明暸な被膜内浸潤を認めた。 核は核小体を有し、しわ状の核縁不正が見られ、 少数核内封入体を認めた。以上の所見から $0 x y p h-$ ilic cell carcinoma と診断した。 尚、術後 7 ヶ月の現在、再発を認めていない。
304. 甲状腺の癌と悪性リンパ腫合垪例 一治療による腫場細胞の経時的変化一 1) 2) 桐生厚生総合病院中央検查室病理, 同内科, 恵愛 堂病院, 群馬大学医学部附属病院中央検查部病理 ${ }^{4)}$ O岡田君男(MT ${ }^{\text {? }}$, 石川悦子(CT), , 竹内满喜子(CT) 小暮仁('(MT), 吉田力ツ江'(MD), 小内享(MD), 丸田栄(MD), 䋥野治(MD), 城下尚(MD)

甲状腺原発の癌と悪性リンパ腫合併例を経験し たので，その細胞像と治療による腫瘍細胞の経時 的変化を中心に，組織所見もあわせて報告する。 症例:94歳 女性。前頝部腫瘤を主訴とし精査の ため当院内科を受診。前頝部腫瘤は一年前より漸 次增大傾向にあった。初診時, 全体的には弾性軟 て右葉上極の一部に弾性硬の結節を有する度の 甲状腺腫瘤を触知した。腫瘤の穿刺吸引細胞診に より，弾性軟の部分では覀性リンパ腫，弾性硬の 部分では乳頭癌と診断され，年齢を考慮し，ステ ロイドの投与, 及びコバルト照射にて加療した。 甲状腺腫瘤は縮小したが，その後約二ケ月後気道 狭窄が出現したため，甲状腺全摘が行われた。 細胞所見: 治療前の弾性硬部からの穿刺吸引細胞 診では核内細胞質封入体を有する腺型異型細胞が 乳頭状細胞集塊を形成して多数出現し, また弾性 軟部からの穿刺吸引細胞診では，切れこみ核を伴 う中型ないし大型のリンパ系異型細胞か潵在性に 多数みとめられた。その他, リンハ球を組みこむ Hürthle cellの小集塊も一部にみられた。以上の 所見より，乳頭癌と慢性甲状腺炎を基盤とする悪 性リンハ腫が考えられた。治療後の穿刺吸引細胞 診では, 悪性リンパ腫由来の細胞は全く消失して おり，核内細胞質封入体を有する乳頭癌由来細胞 のみ残存している。治療前と比較すると乳頭癌由 来腫瘍細胞の扁平上化生が徐々に増加し, 角化を 示す腫瘍細胞も徐々に増加し，手術前には大部分 の細胞が壊死と角化を伴う扁平上皮癌で占められ ており,悪性リンパ腫由来細胞はみられなかった。 
305. 胸・腹水細胞診におけるAlcian green 染色（山本法）之酵素抗体法 (CEA・EMA ・ cytokeratin)の二重染色法

\section{兵庫医大病院病理部}

O岡村義弘 (C T) , 三村雅子 (C T)

鳥居良貴 ( C T ) , 平良信弘 (CT)

山本格士（C T)，植松邦夫（MD）

【目的】胸・腹水細胞診において, 悪性細胞と中 皮細胞との鑑別には, PAS 反応, Alcian blue 染 色や酵素抗体法によるCEA - EMAの抗原の検出が 有用であることが知られている. 今回我々は, 胸 ・腹水細胞診材料を用いAlcian green染色（山本 法, 以下A1-G）と酵素抗体法（CEA - EMA - cytokeratin) との重染色を試み, 悪性細胞と中皮細 胞との鑑別診断の有用性について検討した。

【対象】肺癌, 胃癌, 卵巣癌, 膵癌, 大腸癌, 胆 囊癌, 肝内胆管癌, 内膜癌, 乳癌, 舌癌, 肝癌, 中皮腫の 55 症例を用い, Al-G染色とDAK0 Quick 染色キットとの重染色を行なった。

【成績】Al-G染色のみは 55 症例中 28 例が陽性 であった. CEA との重染ではAl-G染色陽性 28 症 例中CEA は 24 例陽性を示したが, Al-C染色陰性 でCEA 陽性も 12 例あった。染色性については， A1-G陽性細胞よりCEA 陽性細胞を多数認めるが, 粘液産生部位之抗原の局在部位に相違があった。 また内膜癌 6 例, 卵巣癌 4 例中 3 例については両 者とも陰性であった. EMA との重染では陽性細胞 数はCEA より少ないが, 45 症例と高率に陽性を 示し, CEA と同様A1-G染色陰性でEMA 陽性も 20 例あった. cytokeratin との重染では 45 症例之 高い陽性を示したが，同時に多数の中皮細胞の陽 性も認められた。

【結語】Alcian green染色 (山本法) 之酵素抗体 法CEA・EMA との重染色により悪性細胞と中皮細 胞との鏗別が容易となり，悪性細胞の診断率が向 上した. なお重染色は 1 時間で出来, 迅速確実な 方法と考える.
306. 体腔液細胞診免疫染色への Microwave 照射効果について

山形市立病院済生館病理

居鶴一彦 ( C T ), 湯田文朗 ( M D ), 有川卓 $(M D)$, 仲島まゆみ $(M T)$, 長岡幸一 $(M T)$, 山形県立河北病院病理

○石川雅一 ( M D )

目的：近年、細胞診断業務化免疫染色が導入さ れ、(1)悪性細胞の確定診断、(2)転移性腫瘍の原発 推定、(3)病原体検索などに活用されている。また、 Mi crowave は迅速な固定、染色など病理技術への 応用が試みられている。今回、我々はMicrowave を体腔液細胞診の免疫染色に応用すべく、諸条件 について検討した。

方法 : 体腔液スメアを $95 \%$ エ タノール固定後、 CEA、LCA、Cytokerat in (DAKO)について免疫染色 （間接法）を行った。(1)内因性ペルオキシターゼ 阻止 $\left(0.3 \% \mathrm{H}_{2} \mathrm{O}_{2}\right.$ 加メ夕ノール)、(2)一次抗体 ( DA KO)ペルオキシターゼ標識抗体 (DAKO、JIR) の各反応 には、Microwave Processer H 2500(BIO-RAD)を 用い、出力 $50 \%(240 \mathrm{~W})$ で 2 秒周期照射した。(1) 内因性ペルオキシターゼ阻止照射時間は、5、10、 15、30秒、1、2、3 分ずっとし、(2)各抗体照射 反応時間は各々、15、30秒、1、2、3、4、5 分ず つとした。反応はCold Plate(MILES)上で行い、 発色は $\mathrm{DAB}(20 \mathrm{mg} / d \ell \mathrm{PBS})$ にょった。比較対照と

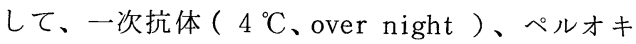
シターゼ標識抗体 $\left(37^{\circ} \mathrm{C}, 15\right.$ 分) 反応の方法を施 した。PAP 法 ( Kit:MILAB )、SAB 法 ( Kit:BioGenex, DIA-IATRON) についても検討した。

結果と考察：内因性ペルオキシターゼは、照射 30秒で完全に阻止された。免疫染色は、CEA， LCA, Cytokeratin ともに15秒から陽性像が確認 された。 
307. 剖検で判明した胸膜悪性中皮腫の一例

兵庫県立成人病センター細胞診室

O森田真代 (C T) , 高橋 満智子 ( C T ) ,

高山 みずほ ( C T ) , 田中八千代 ( C T ) ,

平山裕子 ( C T ) , 前田妙子 ( C T ) ,

高垣 和代 (CT), 指方 輝正 (MD),

兵庫県立淡路病院 松浦 覚 (MD)

近年悪性中皮腫の報告は增加しているが、今回 我々は、生前甲状腺癌と診断され、剖検の結果胸 膜悪性中皮腫と診断された一例について報告する 症例：62才男性。昭和 62 年 7 月頃より咳嗽 呼吸困難あり、某医にてT B と診断され抗結核療 法が施行された。6 3 年 10 月左前頝部腫瘤が出 現し当センターに紹介され入院となる。入院時既 に胸水の貯留を認め、細胞診positive、左前頝部 腫瘤穿刺吸引細胞診suspected 肺穿刺細胞診posi tiveであつた。6 3 年 12 月左䅡部リンパ節生検 が施行され、悪性腫崵の転移を認めHürthle cell carcinoma の可能性が最も考えられた。平成元年 5 月に死亡、副検が施行された。

細胞所見 : 重厚な細胞質を有する大型細胞が集 塊状あるいは孤立性に多数認められた。核は類円 形でほぼ細胞の中心に位置し、核異型の強い細胞 も認められた。核内封入体様の空胞が多く認めら れた。細胞診では組織型の推定は困難であった。

病理解剖学的所見 : 胸膜は両側共全体に肥厚し 強固に癒着し、膠様灰白黄色調の腫場性外観を呈 し、連続性に縦隔、左䅡部に発育していた。甲状 腺は腫瑒の中に埋没する様に存在していたが、外 形は保たれていた。組織学的には立方状〜円柱状 多角形ないし類円形好酸性の細胞質を有する細胞 が管状ないし乳頭状の胞巣あるいは敷石状の配列 を示し、keratin 陽性、コロイド鉄陽性、ヒアル ロニダーゼで消化され上皮型悪性中皮腫であった。
308. 細胞診で悪性胸膜中皮腫が疑われた 1 症例

昭和大学藤が丘病院 組織化学 ${ }^{12}$ 同病院病理科 ${ }^{22}$

O岸本浩次 $(\mathrm{CT})^{1)}$ 、家泉桂一(MT) ${ }^{1)}$

鈴木孝夫 $(\mathrm{CT})^{12}$ 、太田善樹 $(\mathrm{CT})^{2>}$

近藤峰子 $(\mathrm{CT})^{2)}$ 、斉藤多紀子 $(\mathrm{CT})^{2)}$

光谷俊幸 $(\mathrm{MD})^{2)}$ 、佐川文明 $(\mathrm{MD})^{2)}$

悪性中皮腫は中皮細胞より発生する比較的稀な 腫瘍で、転移性腺癌や反応性中皮との鑑別を必要 とする。今回我々は、胸水細胞診にて悪性胸膜中 皮腫を疑つた症例を経験したので報告する。 【症例】44才、男性。既往歴、家族歴には特記すべ き事なし。現病歴：約1年半前頃より夜間咳嗽出 現、近医受診し胸部 X-Pにて右胸水指摘され入院。 結核性胸膜炎の診断のもとに治療するが改善され す 1 年後当院内科入院。胸水細胞診にてClass $V$ 、 悪性中皮腫が強く疑われた。胸膜生検でも悪性中 皮腫として矛盾しない像であった。入院後半年で 死亡。剖検施行、悪性胸膜中皮腫と確診した。

【細胞所見】腫瘍細胞は散在性、及び集塊状で出 現し、多核細胞も見られた。核吅对ノは細顆粒状 で軽度増量、核小体は1〜3個認めた。胞体はラ作 緑に濃染し重厚で、光影的に細胞表面の微䋐毛様 構造が見られた。AL-B染色ではこの細胞表面が染 まり、ヒア吅多ーゼ消化で減弱した。PAS染色では 胞体辺縁に陽性顆粒を認めジア久ターゼで消化された。 免疫染色はKeratin(䄮师口-十抗体、KL-1、CAM5.2)、 Vimentin、EMA、TPAが陽性、CEAは陰性であった。 【剖検所見】肉眼的所見 : 贜側及び壁側胸膜を主 体として、びまん性に灰白色、充実性腫瘍が見ら れ、葉間及び一部肺実質内に浸潤が認められた。 組織学的所見 : 線維性の間質を伴って乳頭状、管 状に配列する異型腫瘍細胞の增殖が見られた。腺 癌との鑑別を要するが、AL-B染色及び免疫染色で は上記と同様で、悪性胸膜中皮腫(上皮型)と診断 した。 
309.腹水の細胞診で診断困難であった小 巟巨大腫瘍の一例

日本医科大学附属病院病理部 ${ }^{1}$ 、第二病理学教室 ${ }^{2}$ 第一外科 ${ }^{3}$ 、小児科 ${ }^{4}$ 、日本医科大学多摩永山病院 病理部 5

○浅川一枝 $(\mathrm{CT})^{1}$ 渡会泰彦 $(\mathrm{CT})^{1}$ 松原美幸 $(\mathrm{CT})^{1}$

梅崎博歌 $(C T)^{1}$ 鈴木桓道(MD) ${ }^{1}$ 横山宗伯 $(M D)^{2}$

江上格 (MD) ${ }^{3}$ 浅野健 (MD) ${ }^{4}$ 前田昭太郎(MD) ${ }^{5}$

小児の腹水細胞診において、診断困難であった 腹腅内腫瘍の一例を経験したので報告する。

$<$ 症例 $>15$ 歳 男子

現病歴 : 平成元年10月上旬より腹部膨満があり、

精査にて腹水貯留、腹部腫瘤が認められ、腹水の 細胞診を施行した。

<細胞所見>腫瘍細胞と思われる小型の異型細胞 を多数認めた。ほとんどの細胞が裸核状で核不整 が目立ち、核内クロマチンは細顆粒状で増量し、 核小体の增大等が認められ、悪性細胞と考えた。 又、広い胞体を持つ類円形細胞も所々に認められ、 これらは比較的厚いライトグリーンの胞体を持ち 同定が困難であった。大部分を占める裸核状の細 胞は、肺の小細胞性未分化癌の細胞形態に類似し ており、神経系腫瘍、その他肉腫等が考えられた。 少々年令が高く、尿中にV M Aが検出されないと いう問題があったが、腹水中の腫瘍細胞はN S E

陽性を示し、神経芽細胞腫を最も矤った。

<病理所見 >腫瘤は巨大で、腹㒄内全域に広がり、 腸管は全て背側へ圧排されていた。重さは4980 g あり、割面は黄白色充実性で脳回状を呈し、一部 に粘液と壊死が認められた。組織学的には、帯状 に走る膠原線維組織を背景に多角形で弱好酸性の 胞体を有し、核の偏在傾向のある腫瘍細胞が多数 の胞巣を形成して増殖している。未分化な間葉系 腫瘍が疑われるが、特殊染色ではKerat in 陰性、 viment in陽性の他は診断に結び付く所見は得られ なかった。現在、電顕所見を含めて検討中である。
310. $P$ a r a h $0 \mathrm{rd} \circ \mathrm{ma} 1$ 例

\section{下関市立中央病院 検査部病理 \\ O杉原誠 (CT) 川元 博之 ( C T ) \\ 谷村 晃 (MD)}

Pa rachordomaはLaskowski (1951)により最初に 報告された腫瘍で末梢の骨や腱に近接して発生し 脊索腫に極めて類似した組織像をとり、切除後、 時に局所再発を示す。

現在までに10例ほどの報告をみるがその組織由来 として滑膜、軟骨由来が考えられるが、現在のと ころ不明である。

我々は左脛骨に発生したParachordomaの症例を 経験したので捺印細胞像、組織像ならびに免疫組 織学的な検討を加えたので報告する。

症例 : 30才女性、約 1 力月前より左脛骨前部疼痛 及び腫脹を主訴にて近医受診、Bone tumorを指摘 され当院整形外科へ紹介、入院となる。

外来時、左脛骨上部外前側に骨透亮像があり、同 部の骨膜反応と軟部組織への浸潤を認めた。又、 全身検索においては原発病巣は認められなかった 肉眼所見: 骨の一部が白色状、粘液腫状で骨破壊 は明らかでなかった。

細胞所見 : 粘液样物質を背景に散在性又は中るい 結合を示す細胞がみられた。細胞は比較的小型で 類円形のものが多くライトグリーンに淡染してい た。核は円〜類円形で核クロマチンは細顆粒状で 均一。核小体は小型ながら目立っていた。

又、胞体に空胞を有する細胞も混在してみられた 組織所見: 腫湯細胞は好酸性細胞質、類円形の核 を有し、それらが網状又は索状に類腺腔形成を伴 い増殖し、軟部組織への浸潤を示している。間質 は粘液様の部や軟骨基質を示す。腫瘍細胞は多形 成に乏しく少数の分裂をみるにすぎない。Al一染 色，PAS染色で胞体が陽性を示した。ジアスター ゼ消化法によりPAS陽性物は消失した。

免疫組織学的所見 : S-100蛋白, EMA, Keratinは 腫瘍細胞に一致して陽性を示していた。

本症例を頭蓋底に発生したChordomaの症例と細 胞像、免疫組織学的に比較検討したので供覧する 


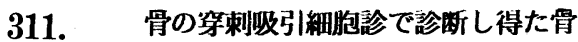
䭒腫の 2 症例

日本医科大学付属多摩永山病院病理部、同内科、 同整形外科 ${ }^{3)}$

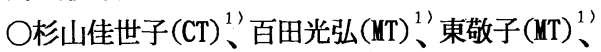
前田昭太郎( MD ) 、浅井邦也(ND)、塚本浩(MD) 、 石坂公人 $(M D) 、$ 、石原正博 $(\text { MD })^{3 !}$

現在当院では、骨腫瘍に対しても積極的に穿刺 吸引細胞診を施行している。その中、臨床所見か らは転移性骨腫瑒が疑われ、骨穿刺吸引細胞診を 施行し、骨髄腫と診断し得た 2 症例について、そ の細胞診所見を中心に報告する。

[症例 1] 63 歳、女性。昭和61年12月、第 4 胸檤より末梢の㾏性麻痺が生じ、C Tにて第 3 ・ 4 腰椎突起の骨融解像を認めた。透視下にて穿刺 吸引細胞診を施行した。

細胞診所見：孤立散在性に核偏在性の中等度異型 細胞が多数認められた。細胞質は好塩基性で核周 明庭が認められ、核には小型の核小体が 1 ～個 見られ、成熟型の骨随腫と診断した。 その後の臨床所見、生検より I g G、 $\kappa$ 型の骨骮 腫と最終診断された。平成元年11月に死亡した。

[症例 2] 57 歳、男性。平成元年 6 月に複視 が出現し、脳腫瘍が疑われた。その後、左肩関節 痛が出現し、上腕骨頝部腫瘍と診断された。透視 下にて穿刺吸引細胞診を施行した。 細胞猃所見: 大型核小体を 1 個有し、大小不同、 クロマチン増量が著しい核より成る高度異型細胞 が孤立散在性に多数認められた。2核性の異型細 胞も多く、又、偏在性の核、核周明庭を示す好塩 基性の細胞質を有するものも認められ、未熟型の 骨髄腫と診断した。

その後の頭蓋骨のX線でpunched-out lesionも認 められた。平成元年12月現在、臨床的に検索・治 療中である。
312. 脂肪肉腫の1症例

\section{三井記念病院中検病理 同外科 ${ }^{12}$}

会田記念病院 ${ }^{2)}$ 同愛記念病院病理 ${ }^{3)}$

O山口みはる(CT) 小海陽子(CT) 山村はるみ(CT)

前川原貴美子(CT) 山崎家春(MT) 早川和志(MD) ${ }^{12}$ 高梨利一郎(MD) 広瀬敏樹(MD) ${ }^{23}$ 福島範子(MD) ${ }^{3)}$

〈症例〉:62才男性。1989年4月下旬より、右側腹 部の膨満感のため当院を受診。5月23日入院とな る。入院時腹部所見では、右上下腹部を占拠する 弾性硬、表面平滑な巨大腫瘤を触知した。軽い圧 痛を認める。術前生検組織診(sure cut)、穿刺吸 引細胞診にて脂肪肉腫を疑った。手術所見では、 腫瘍は後腹膜に位置し上行結腸壁及び十二指腸内 空に浸潤していた。重量は1160gで割面は白色、 多小葉性で水分に富んでいた。 〈細胞像〉:腫汮細胞は大型で多くは散在性で、 一部集塊をなしていた。核は大小不同著明でク叹手 ノは増量し核型不整で核縁は薄かった。核小体は 明瞭で細胞質は淡く所々に小空胞をもっていた。 又、紡鍾型細胞もみられた。背景はきれいだった。 〈組織像〉: 摘出腫場組織は大部分が紡鍾型細胞 で構成され好酸性、線維状の細胞質で光顕的には 脂肪滴が見られなかったため平滑筋肉腫、線維肉 腫などが考えられた。又、細胞質の広い巨核、多 核肉腫細胞もみられsudan III弱陽性の小空胞をもっ ていたがこれは変性脂肪空胞と考えられた。しか LDesmin染色陰性、電顕で紡鍾型細胞にも微小な 脂肪滴が確認されたため脂肪肉腫と診断された。 〈まとめ〉:本症例は術前の生検組織診(sure cut)、 穿刺吸引細胞診で脂肪肉腫を疑ったが摘出腫場の 確診がむずかしく、数種の肉腫の可能性が考えら れた。線維肉腫、平滑筋肉腫、横紋笳肉腫、悪性 線維組織球腫などの腫瘍と鑑別しなければならな いと思われるがその鑑別点と光顕、電顕の所見を 合わせ報告する。 
313. 術前, 附属器腫瘍と鑑別困難であった 後腹膜脂肪肉腫の一症例

社会保険小倉記念病院産婦人科 ${ }^{1)}$, 同検查診断科 ${ }^{2)}$ 山口大学一病理 ${ }^{3)}$

○伊東忠一郎 (MD) ${ }^{1}$, 丹谷一雄 $(M D)^{1)}$, 鬼木 登与志 $(\mathrm{CT})^{2)}$, 安田三佐子 $(\mathrm{CT})^{2)}$, 中西政晴 $(\mathrm{CT})^{2)}$, 若林 太 $(\mathrm{CT})^{2)}$, 横田忠明 (MD $)^{3)}$, 岩田隆子 $(\mathrm{MD})^{3)}$, 石原得博 $(\mathrm{MD})^{3)}$

脂肪肉腫の多くは中年ないし高年の人に生じる が, 我々は最近術前には左附属器腫瘍との鑑別が 困難であった症例を経験したので報告する。

症例：69 歳, 女性。平成元年 7 月末頃から供怠 感と共に, 左下腹部に腫瘤があるのに気付き, 当 院内科を受診した。内科にての注腸透視では異常 なく当科へ紹介されて来た。

Echo.及びCTにて左附属器の solid mass を指摘され，内診にても同部位近傍に超新生児頭 大, 移動性に乏しい軟骨樣硬の腫瘤を認めた。子 宮頸部細胞診ではClass II であった。

開腹したところ, 問題の腫瘤は後腹膜腔に発生 した, 黄色な結節状腫瘤であり, 摘出し, 更に子 宮, 附属器も切除した。

細胞診所見：比較的大型の細胞で, pleomorphicで, N/C大で, クロマチンは微細顆粒状, 胞体は cyanophilic でくずれたレース状で, 胞体 の中心が白っぽく空胞状の, 非上皮性を示唆する 異形細胞が認められる。裸核も多い。

組織診所見：空胞状の胞体を有する異型性のあ る tumor cell がシート状に, 部によってはfi一 brous 飞增殖している。Sudan black B 染色で 陽性顆粒がみられ，その他ビメンチン $(+), \mathrm{Gi}$ $\operatorname{tter}(+), \mathrm{S}-100($ ( ) であった。

治療と予後：テレコバルト (40.5 Gy), Chemotherapyを行った。現在のところ再発の所見は ない。
314. 細胞培養にて診断しえた脂肪肉腫の 一例

山口大学医学部病理学第一講座, 学講座, ${ }^{* *}$ 附属病院中央検査部, *臨床検查医 ***医療技術 短期大学部衛生技術学科

O山下吉美 (MD), 権藤俊一 (MD), 横田忠明 (MD)， 山下 勝 (CT), 村上喜信 (CT), 高橋晆夫 (MD) ${ }^{*}$, 平岡芙美子 $(C T)^{* *}$, 福富順子 $(\mathrm{CT})^{* * *}$ 岩田隆子 (MD) ${ }^{* * *}$

[目的]未分化肉腫においては, 形態学的特徽 に乏しく確診が困難となることがしばしばであ る。今回, 我々は細胞培養にて脂肪肉腫への分 化がみられた未分化肉腫の一例を報告する。

[症例] 症例：55歳, 男性。15年前頃より右大 腿および右前腕部の軟らかい腫瘤にきずく。2 年前頃より腫大し硬度增加したため腫㿔摘出。 右頸部腫瘤も認められ腫瘍摘出, 更にC5椎体亜 全摘を行なった。腫痬は黄色〜灰白色, 弾性軟 であった。（一部の標本は鳥取大学医学部病理 学第一講座より供与された）

[結果] 細胞診所見：腫瘍細胞は孤立散在性。 紡鍾〜類冈形の核, 微細顆粒状のクロマチン, 1 〜 ケの小型の核小体を有し, 少数であるが 多核や大型の核の腫瘍細胞もみられた。胞体は, ライトグリーンに淡染し紡鍾状や多角形のもの も見られた。培養12日目では細胞増生, 核の大 小不同が目立ち比較的豊富な胞体内に多数の脂 肪滴が出現した。組織所見: 多くの腫瘍細胞 はビメンチンに反応したがアクチンやS-10.0 と は反応しなかった。間質には骨形成が目立ち, 粘液腫状であった。

電顕所見：細胞質には多数のintermediate filamentを認めるのみであった。しかし, 培養 12日以後では多数の脂肪滴, mi tochondria, ribosome, phagosome, lysosomal dense body が見られた。所々でbasal laminaも伴っていた。

[結語］肉腫細胞の培養12日目以後に, 胞体 内に多数の脂肪滴が出現したことょり脂肪肉腫 と考えた。しかし，この脂肪滴の出現は腫瘍細 胞が持っていた本来の形質か, 培養中の変性な ぞの他の原因によるものかは検討が必要である。 
315. 穿刺吸引細胞診で診断し得た elastof ibroma $の 1$ 例

聖マリア病院病理部

○中村康寬 (MD), 大田喜孝 (CT), 伊藤園江 (CT), 原武晃子 $(\mathrm{CT})$, 森塚祐子 $(\mathrm{CT})$, 大田桂子 $(\mathrm{CT})$

elastof ibromaは背部肩甲下部に好発する皮下 軟部腫瘤で, 中年以降の女性に多い。その発生機 序としては肩甲骨と後胸壁の摩摖による結合織, 特に elastin と collagenの反応性增殖が考えら れている。わが国では沖縄に多発することが報告 されているが，まれな疾患で，その細胞診所見に 関しては，ほとんど報告をみない。我々は発生部 位より本疾患を疑い, 穿刺吸引細胞診で診断し得 た典型的な elastof ibromaの 1 例を経験したので 報告する。

症例は 53 才, 女性で, 右背部肩甲骨下部に小児 手挙大の弾性硬, 境界不鮮明な腫瘤を認めた。自 発痛はなかった。鑑別診断の 1 つとして elastofibromaを念頭に置いて, 腫瘤の穿刺吸引細胞診 を行なった。細胞像は紡錘形の核を有する小型の 線維芽細胞と, ライトグリーンに染色された繊維 状あるいは真綿状構造物を主体として認めた。ま た特徵的所見と考えられる縄状の elastin 瀻維束 が認められ, これは顕微鏡コンデンサーを下げて 観察するとシダの葉様の構造を示した。以上の細 胞所見より elastof ibroma と診断し腫瘁摘出が行 なわれた。摘出標本の組織学的検索では細胞診像 に対応するような特徵を有する elastase に消化 されにくい変性 elastinの沈着と線維芽細胞, collagnの増加がみられた。これらの細胞診的お よび組織学的特徵とともに, 免疫組織化学, 透過 電顕, 走查電顕所見, Freeze fracture 法による 所見についても言及する。
316. エックリン汗腺癌の一例

市立岡谷病院研究検查科 ${ }^{12}$ 、同病理科 ${ }^{23}$ 、 同皮膚科 ${ }^{32}$ 、同産婦人科 43

O飯塚好伯 $(\mathrm{CT})^{13}$ 山田佐和子(CT $)^{1>}$

小松昭博(CT $)^{13}$ 藤原正之(MD) ${ }^{2>}$

小林早由美(MD) ${ }^{3)}$ 紊滕强平(MD) ${ }^{32}$

徳田安基(MD) ${ }^{33}$ 石井 淳(MD) ${ }^{43}$ 林 誠一(MD) ${ }^{4>}$

比較的希なエックリン汗腺由来の悪性腫瑒を経 験したので報告する。

症例は76歳女性。約25年前より左足外側緣に皮 疹出現。慢性呼吸不全にて入退院を絽り返すも同 部皮疹は放置。3 年前には空豆大となり増大傾向 を示すため、本年 7 月当院皮膚科受診。左足外側 縁に $41 \times 67 \times 55 \mathrm{~mm}$ 大の白色調、一部壊死を伴う弾 性硬の腫瘤あり。左大腿部には手拳大の囊胞性腫 瘤を、鼠径部には超鵎卵大の皮下腫瘤を触知。2 ケ月後には下腿部から陰部及び左側胸部にかけて 米粒大から拇指頭大までの丘疹・結節が多発し11 月20日呼吸不全にて死亡。

病理組織像：原発巣は灰白色粘稠性で表皮直下 から真皮深層へかけて不規則、溯漫性に睡場細佨 が增殖している。この細胞は大小不同性で好塩基 性胞体と類円形核を有し、充実胞巣性、腺隆形成 性に增殖している。また囊胞状に拡張した腺腔、 淡明な細咆の敷石状配列、扁平上皮癌巣の僅かな 混在など組織像は多彩である。睡㷎の辺粶部には 腫大した細胞から成る導管粎構造あり。間筫には $\mathrm{PAS}(-) \mathrm{AB}(\mathrm{PH} 2.5)(+)$ の粘液質留が著しい。解剖 時、画肺及び肝韍に小豆大までの小転移巣あり。

手術標本の捺印細胞診所見 : 粘液性背景の中に 腫場細狍が大小の細饱集塊として出現し概ね平面 的な配列を示し、わずかに腺房栏構造を示す。細 胞は比較的小型のものが多く、細胞質は乏しく菲 薄である。核は類円形ないし棈円形で軽度の大小 不同があり、クロマチンは増量し、核小体は大型 で数個見られる。尚、大腿部の囊咆性腫癌の穿刺 液中にも同様の湩場細胞の出現をみた。 
317. メルケル細胞癌の 1 例

水戸協同病院検查科, ${ }^{1)}$ 同耳鼻咽喉科, 同内科 ${ }^{3)}$

○安蔵充 ( C T ) , 宮国 亨 ( C T ),

川島 真 $(M D)^{2)}$ 小野多知夫 $(M D), 2$,

中島陽一郎 (MD ), 色 石岡 国春 (MD ),

新潟大学医学部第二病理学教室

福田 剛明 (MD)

石渡産婦人科病院

石渡勇 (MD)

希な皮膚腫瘍であるメルケル細胞癌の 1 例を経 験したので報告する。

症例は89歳, 男性, 昭和 63 年 7 月, 右下眼䀫化小 さな赤い結節ができ急速に増大した為, 近医を受 診後, 同年 8 月当院を受診。腫瘤は右㚘部に隆起 性に発育し, 大きさは $5.5 \times 3 \mathrm{~cm}$ で表面は平滑で一 部発赤を伴っていた。生検にて悪性リンパ腫が疑 われ, 治療の為入院となり, 放射線療法が施行さ れ腫瘤は消失。平成元年 2 月, 右煩部、再発し, 捺印細胞診, 組織診, 免疫組織化学的, 電子顕微 鏡学的検索が行われメルケル細胞癌之診断された。 捺印細胞所見: 腫瘍細胞は, 小円形, 裸核状で孤 立散在性または小型細胞集塊で出現し, 核は軽度 大小不同を示し,クロマチンは微細顆粒状で, 核 小体は小型のあのが 1 〜数個見られた。核分裂像 あ散見され, 細胞質や背景に緑色に染まるボタン 状物質も少数認められた。

病理組織学的所見：腫瘍は皮下組織にびまん性に 増生し, その細胞は円形の核を有し, N/C 比が 高く, クロマチンも微細で, 未熟な細胞の形態を 示し, 核分裂像屯多数見られた。また腫瘍細胞は, グリメウス染色(+), フォンタナーマッソン染色(一) で, 免疫組織化学的には, ケラチン(+), EMA(+) N S E(+)であった。

電顕所見：核周囲には中間フィラメントボタンが 見られ，また胞体の末梢部分には限界膜を有する 小型の神経内分泌顆粒が多数観察された。
318. 後腹膜Epithelioid Leiomyosarcoma ๑1 例

日本医科大学付属多摩永山病院産婦人科

○中山裕樹 (MD), 米山剛- (MD), 河村 堯 (MD) 同 病理部 杉山佳世子 ( C T ), 前田昭太郎 (MD )

Epithelioid Leiomyosarcoma は, 従来 Malignant Leiomyoblastoma と呼ばれていたるので, WHO 分類では Leiomyosarcoma 汇区分されている が, 希なるのである。41才の女性の後腹膜に発生 した, この腫場の, 組織像・細胞像を供覧する。

腫湯は直腸と右内腸骨動脈の間の骨盤底後腹膜 より発生し, 小児頭大, 重量 $710 \mathrm{~g}$ で, 带黄赤色 を呈した。表面は多数の出血巣が見られ，3 分の 1 ほぼは脆いカプセル飞覆われるが, 他は柔軟な 䋐毛様の腫場内容がむをだしになっており，上方 で大網・小腸と強く瘾着していた。少量の血性腹 水老認姉。

タッチスメアーの所見は, 結合性の弱い紡錘形 細胞が主である。細胞間は紡錘状の胞体により粗 飞細網状飞結合するすのと, 孤立散在性のるのと が見られる。細胞質は比較的豊富で, 裸核のもの 江極めて少ない。核は楕円形を呈し，巨大核や多 核のるのはなく, 核縁はやや厚いが整で,クロマ チンは粗だが薄い。1 3 個の小型核小体を持つ。 紡鍾形細胞の中に, 細胞質の広細胞がシート状 のクラスターとして散見する。その細胞は稜形を 呈し, 細胞質は明るく広い。核はやや小型で, 楕 円形,クロマチンは粗。核小体は 1 ～ 3 個。

組織像は中型の紡錘形細胞が流れる上ら几配列 するが，核の周囲が明るく広い epitelioid 各所 飞見られる。多数の核分裂像を認也る。Desmin $(+), \operatorname{actin}(+)$, Vimentin $(+)$ 。

タッチスミアーでは典型的な Leiomyosarcoma の像ではなく, 䛦断て苦慮したが, 組織診断で Epithelioid Leiomyosarcoma と診断された。 
319. clear cell sarcoma肺転移 2 症例の細胞 学的検討一特に胸水の細胞像を中心として

\author{
国立札幌病院臨床検查科 \\ ○山城勝重 (MD), 岩本和彦 ( CT ), \\ 平紀代美 (MT), 井出ありさ (MT), \\ 藤田昌宏 (MD)
}

clear cell sarcoma of tendons and aponeuroses は稀な悪性軟部腫瘍とされるが，肺転移症例 2 例 を細胞学的に検討する機会を得たので報告する。

【症例】1）26才女性。2年前に右踵部内側の軟部 腫瘍の手術をらけた(病理診断：clear cell sarcoma)。 その後, 局所再発, リンパ節転移をくりかえした が, 昭和 57 年 1 月, 肺転移のため胸水を生じ死亡 した。2）38才女性。6年前に左手背側の軟部腫瘍 の手術をらけた(病理診断 : clear cell sarcoma)。 昭和 63 年 10 月, 肺転移が発見され, 右肺の wedge resectionを施行されたが，1年後，肺・縱隔リン ハ節転移再発をきたし, 胸水も貯留して死亡した。 【細胞所見】2症例とも検索対象は主に胸水であ り，細胞所見はほぼ同一であった。背景は出血性 だが壊死物質はみられない。腫瘍細胞は多数出現 して扮り，一部平面的潗合するところもあるが， 大部分は散在性であった。核・胞体比はやや大き く, 胞体は淡明で細胞辺縁はほつれる傾向にあっ た。核は円形で扁在化し, 細顆粒状のクロマチン の増量があり, 円形の大きな核小体が 1 個存在し ていた。免疫染色でS-100蛋白陽性, FontanaMasson染色が陽性を示した。

【考案】低分化腺癌との鑑別が問題となるが，臨 床経過, 細胞所見, 特殊染色の結果がポイントに なると思われた。

\section{0. 血管肉腫 3 例の捺印細胞像}

山口大学医学部第一病理 ${ }^{1)}$ 。臨床検查医学講座 ${ }^{2)}$, 付属病院検查部 ${ }^{31}$ ，医療技術短期大学部 4 ) O権藤俊一 (MD) ${ }^{12}$, 山下吉美 (MD) ${ }^{12}$, 横田忠明 (MD) ${ }^{11}$, 石原得博 (MD $)^{11}$, 山下 勝 (CT ${ }^{1}{ }^{1}$, 村上喜信 (CT $)^{1)}$, 高橋睦夫 (MD) ${ }^{2)}$ ，伊世悦子 (CT) ${ }^{3)}$, 岩田隆子 (MD) ${ }^{4)}$

血管肉腫は血管内皮細胞由来の腫汮で皮虚, 四 肢の軟部組織などに発生する。今回皮膚に発生し た 3 例を経験したので報告する。

[症例] 症例 $1 ： 34$ 才女性。28才時, 以前よりリ ンパ浮腫のあった右手背に腫瘤が生じ, 組織検查 でcutaneous angiosarcoma with lymph edema 診断された。局所再発を繰返した後, 肺に転移し, 肺葉切除が行われた。症例 $2: 56$ 才女性。47才時 に乳癌のため右乳房切除術を受け, その後リンパ 浮腫が持続し, 右上腕部伸側に, 易出血性腫瘤が 出現した。生検にてpostmastectomy angiosarcoma と診断された。症例 3：60才男性。右前頭部の皮 成に易出血性腫瘦が出現し, 生検にてcutane ous angiosarcoma之診断され，6力月後, 全身に転移 をきたし死亡した。症例 $1 ， 2$ はそれぞれ肺転移 单, 皮庯腫瘤の切除標本, 症例 3 は剖検時の腫瘍 組織から捺印標本を作製した。

[結果] 細胞像：症例 1,3 では腫瘍細胞がシー 卜状に配列に，軽度の重皘性を伴う細胸集塊を名数 認めた。腫瘍細胞は多角形で, 比較的淡明な細胞 質と円形〜楕円形の大きな核を有し，クロマチン は細〜粗顆粒状で增量し，明瞭な核小体を認めた。 症例 3 ではやや小さな多角形の腫瘍細胞が数個シ 一ト状に配列した集塊之孤立散在性の紡鍾形細胞 を認め, 核は楕円形〜長楕円形, クロマチンは細 顆粒状で小さな核小体を有していた。血管腔様の 裂隙を形成した小集塊も認めた。3例とも背景に は多数の赤血球を認めた。

組織像: 腫瘍細胞がスリット状の血管腔を形成し 血管由来を示唆する部と充実性に増生し上皮性に みえる部を認めた。

[結語]内皮細胞に類似した腫瘍細胞と異形性の 強い未分化な細胞を認め, 捺印細胞診では採取し た部位により細胞像に差があり，後者が目立つ場 合は上皮性腫場との鑑別が必要であった。 
321. 胃生検塗沫細胞診での過小評価例の検 討 （1）粘液細胞性腺掂

\section{横須賀共済病院病理部, 内科*}

O石港仁深(CT), 都丸克浩(MT), 川口幹夫(CT), 栗原正美 (CT)，浅見正敏 (CT)，赫久昌 (MD)， 木村雄二(MD)，坂本 龍(MD)*

【目的】生検塗沫細胞診で陽性と判定できず，組 織診で粘液細胞性腺癌と診断された症例を再検討 し，その細胞像の特徵を明らかにする。

【対象と方法】1988年1月から1989年8月までの胃 生検組織診で粘液細胞性腺遥と診断された際の塗 沫細胞診標本 9 例のうち, 陽性と判定できなかつ た4例を対象とし，陽性例 5 例を対照とした。各 症例につき，下表の各項目を陽性対照の所見と比 較検討した。なお，核の大きさ，染色性について は標本中の好中球と比較して評価した。

【結果】下表に示す通りで, 細胞集塊の重積性, 細胞質の性状で明㬗な差異が認められた。

【結論】散在性に出現する異型細胞は組織球，線 維芽細胞と, 平面的集塊は再生上皮細胞と鑑別を 要する。明瞭な丸い核小体を有する大小不同のあ る核を重視して，過小評価を避ける必要がある。

\begin{tabular}{|c|c|c|}
\hline 榆討項目 & 対象 (4例) & 陽性対照(5例) \\
\hline 異型細胞数 & $120 \pm 132$ 個 & $340 \pm 269$ 個 \\
\hline \multirow[t]{3}{*}{ 出現様式 } & 散在性 & 散在性 \\
\hline & 平面的集塊 & 平面的 \\
\hline & & 重積中 \\
\hline 核 大きさ & 1 2倍, 不同 & 1 2倍, 不同 \\
\hline 核縁 & 均等肥厚 & 均等肥厚 \\
\hline 形状 & 円,贽円 & 円, 梢円, 三日月 \\
\hline 核小体数 - 形状 & 1〜3固·丸い & 1～3個·丸い \\
\hline クロマチン & 增量乏しい & 增量に乏しい \\
\hline 細胞筫 染色性 & 青綠～戻色 & 青緑色 \\
\hline 性状 & 印蒜細胞なし & 印㻴細胞あり \\
\hline $\mathrm{N} / \mathrm{C}$ 比 & 棣々（低～高） & 様々（低～高） \\
\hline 細胞の形状 & 円形～多辺形 & 円形～類円形 \\
\hline
\end{tabular}

322. 胃生検組織診と細胞診不一致例の検討

所沢市市民医療センター臨床検查科, 埼玉医科 大学第三内科, 国立療養所東京病院外科, 同病理 ${ }^{4}$

○田中健次 ${ }^{1}$ (C T), 元村栄喜 ${ }^{1}(\mathrm{C} T)$

勝健一 ${ }^{2}(\mathrm{MD})$, 小松彦太郎 ${ }^{3}(\mathrm{MD})$

田島紹吉 ${ }^{4}(\mathrm{C}$ T)

近年胃内視鏡による直視下生検の普及により， 細胞診のはたす役割は相対的に低下していたが， 現在その役割は見值されつつある。我々の施設で は, 胃内視鏡を開設以来病理組織診と細胞診の併 用を行ない良好な成績を得ている。乙てにその成 績を報告し，併わせて組織診，細胞診の不一致例 について検討を行ったので報告する。

症例は昭和57年 1 月 一平成元年10月30日迄の胃 生検 2785 例で, 乙のうち陰性 2613 , 癌例 172 で, 進行癌58, 早期癌 114 であった。最近の傾向とし て早期癌の占める割合が多く，てれは胃集団検診 の成果の現われである。

癌 172 例の成績は, 組織診: 陰性 7 , 疑陽性 18, 陽性 147 。細胞診：陰性 2 , 疑陽性 4, 陽性 166 であった。このうち両者の不一致は33例あり, 見 落しが組織診 7 例, 細胞診に 2 例あり, 誤陽性と して組織診 4 例, 細胞診に 1 例あった。その原因 として採取量の問題, 正確な採取, 判定とそれぞ れに問題があり今後さらに改善される必要がある。 組織診, 細胞診いずれも陰性という症例はなく, 両者を併用することは大いに意義がある。また組 織診に疑陽性が多いのは, その性格上, 十分な組 織量, 正確な採取が必要であり, 臨床医に左右さ れるあの屯考えられた。細胞診の場合疑陽性は少 なく極めて有効な検查法である。

（まとめ）胃生検診断のためには, 組織診, 細 胞診を併用することは大いに意義があり，臨床医 との情報交換を密にすれば胃生検診断はさらに向 上するあのと考えられた。 
323. S chnitzler 転移を穿刺吸引細胞診で 診断し得た胃内分必細胞癌の一例

日本医科大学第 2 外科 ${ }^{1)}$, 日本医科大学付属第 1 病 院病理部 2 )

○矢野正雄 $(\mathrm{MD})^{1)}$, 渡辺一彦 (MD $)^{1)}$, 秋丸琥甫 $(\mathrm{MD})^{1)}$, 左司 佑 $(\mathrm{MD})^{1)}$, 中川敬夫 $(\mathrm{CT})^{2)}$, 佐藤 春明 $(\mathrm{CT})^{2}$, 大塚俊司 $(\mathrm{MT})^{2)}$, 中川 化 $(\mathrm{MD})^{2}$, 山田宣孝 $(\mathrm{MD})^{2)}$

胃内分泌細胞癌は比較的稀な腫場であり，転移 臓器としてはリンパ節・肝への転移が多いとの報 告があるが, 腹膜への転移は極めて稀である。

今回我々は, 胃原発カルチノィドの診断にて胃 亜全摘施行後 19 ケ月で直腸狭窄を示し, Schnitzler 転移を吸引細胞診で証明し得た症例を経験し たので報告する。

【症例】 50 歳男性。昭和 63 年 1 月 亿胃体部後壁 の胃内分泌細胞癌 $(2 \times 2.5 \times 1.5 \mathrm{~cm})$ 飞て胃亜全摘 術施行。平成元年 9 月飞直腸狭窄, 腹水眝留をを たし, 直腸膀胱窩飞腫場を認め吸引細胞診を行っ た結果, 胃内分泌細胞癌の腹膜播種と診断された。 【細胞像】細胞像は結合の緩いシート状をたは軽 度重積を示す細胞集団が認的らた。胞体は比較 的広く, 核は円〜類円型小型で中心性, 一部やや 偏在を示した。クロマチンは細顆粒状, 核小体は 小型で $1 \sim 2$ 個目立った。PAS, $\mathrm{Al}$ 一青染色は 陰性であった。

【組織像】細胞成分飞富み, 小胞巣状, 索状, をは口ゼット形成や腺腔形成を認めた。細胞は比 較的小型, 類円形で偏在し, クロマチンは微細顆 粒状で核小体は明瞭であった。グリメリウス染色 陽性, 免疫染色ではN S E一部陽性であった。

以上の所見上り広義のカルチノイド, いわゆる 内分泌細胞癌, 髄様型と夕なされる。

なお，電顕的検討を加え報告する。

\section{4. 胃平滑筋肉腫の 2 例}

社会保険三島病院検查科病理, 论尿器科, 僙須賀共 済病院病理部, 東京医科歯科大学医学部第一病理 ${ }^{4}$ O斎藤友恵 $(M T)^{1}$, 安田椇弓 $(M T)^{1}$, 竹内弘幸 $(M D)^{2}$, 赤羽久昌 $(M D)^{3}$,木村雄二(MD) $)^{3}$, 青木 望(MD) ${ }^{4}$

【はじめに】胃原発の悪性腫瘃のうち平滑筋肉腫 の占める割合は約 $1 \%$ である。最近，我々は胃の 平滑筋肉腫 2 例を経驗したので, 切除噤本の捺印 細胞診所見を中心に報告する。

【症例 1】55歳男性。主訴は下血。消化管精查 にて胃体部大驾側に粘膜下腫場を指摘され，噴門 部胃部分切除が施行された。腫瘍の最大径は $8 \mathrm{~cm}$ で，胃壁外発育を示ていた。細胞診では，腫㾥細 胞は, 大小不同の類冈形〜紡鍾形で核緑の肥厚の ない核を有し，クロマチンは軽度増量していた。 細胞缕度が高く, 細長形の胞体を有する細胞と裸 核状の細胞とが見られ，細胞間結合が強い部分で は細胞筫辺緑が不明暸であつた。組織学的には， 腫崵の辺縁部で浸潤性発育と姫結節形成が, 中心 部では壊死巣がみられる平滑筋肉腫であつた。

【症例2】59歳女性。主訴は心窖部痛。精査に て胃体部前壁側に粘膜下腫瘍を指摘され，腫癔摘 出十胃壁部分切除術が施行された。腫湟は胃頪外 に有茎性に発育しており，最大经は $4 \mathrm{~cm}$ ある。 細胞診では, 腫瘍細胞は, 大小不同のある主とし て紡錘形で核緑の肥厚のない核を有し，一部の細 胞に明暸な核小体が認められた。細長形の胞体を 有する細胞も見られるが, 大多数は裸核状で, 症 例 1 に比し核密度は低かつた。組織学的には，よ く限局し，被包化された平滑筋肉腫であつた。

【まとめ】胃の平滑筋肉腫は粘膜下に発育するた めに術前の胃生検にて診断されないことがあり， そのために術中の迅速細胞㟝・組織診による良性 悪性診断が要請される。最近 2 例の胃の平滑筋肉 腫の術中迅速細胞診を経験したので，その捺印細 胞診所見を中心に報告した。 


\section{5. 胃平滑笳肉腫 5 例の検討}

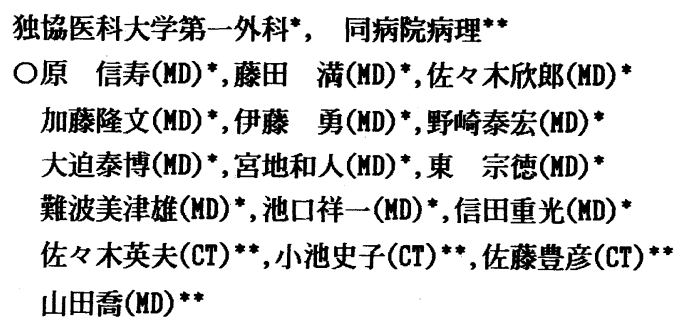

胃平滑筋肉腫は胃悪性腫場のうちでは約0.1〜 $1 \%$ と稀な腫湯である。そして、その術前診断は 困難な場合が少なくない。今回我々は当科で経駼 した胃平滑筋肉腫 5 例について報告する。 （症例 1)は44才の男性で集検で胃の異常を指摘さ れ、内視鏡検查で嗔門部小弯後壁に漬場形成を伴 う粘膜下腫瑒を認めた。細胞診で平滑筋腫の診断 を得て噴門側胃切除術を行ったが、術後の検索で 平滑笳肉腫と診断された。 （症例2）は72才の男性で集検で胃の異常を指摘さ れ、内視鏡検查で前庭部前壁に粘膜下睡瘍を認め た。内視鏡的ポリペクトミーによる採取組織診よ り平滑筋肉腫の診断を得たため、幽門側胃切除術 を施行した。 （症例 3)は73才の女性で負血を主訴に内視鏡検查 を施行し、穹隆部大弯後壁側に潰瘍を認め、組織 診および細胞診ともに平滑筋肉腫の診断で胃切除 術を行った。 （症例4）は63才の男性で心䆟部痛を主訴に内視鏡 検查を行い、嗔門部小弯前壁側に漬場形成を伴う 粘膜下腫瘍を認めた。組織診及び細胞診で平滑筋 肉腫を疑い、胃全摘術を施行した。 （症例 5)は77才の女性で上腹部不快感を主訴に内 視鏡検查を施行し、穹隆部後壁大弯僛に漬瘍形成 を伴う粘膜下腫場を認めた。組織診で平滑筋腫、 細胞診で平滑筋肉腫の診断を得たため、胃全摘術 を施行した。

細胞像としては細胞質は類円形不整形、または 細長く大きく、核は類円形が多く大小不同が強い。
326. 震胞腔を形成した脺腺扁平上皮癌の 1 例

京都市立病院臨床検查科 $\mathrm{O}$ 金岡明博 (CT), 黒木登美子（CT），衣笠松男（CT），三宅秀一 （CT），川辺民昭（CT），古市佳也（CT）， 金 栄治 (MD)，廂巣晃昌 (MD)

膵癌の多くは膵管系より発生する腺癌であり, 腺扁平上皮癌は比較的稀な腫瑒で膵癌の $4-11 \%$ と 報告されている.

我々は術中に採取された腫瘍震胞内容液細胞診 で角化型扁平上皮癌細胞を認め, 術後摘出材料の 組織診にて腺扁平上皮癌と診断した症例を経験し たので報告する。

症例は57歳, 男性. 1988年5月頃より慢性膵炎 で外来にて経過観察中，同年11月症状悪化のため 入院. 精查の結果CEA $11.4 \mathrm{ng} / \mathrm{ml}$,CA19-9 144U/m1 と上罚し，腹部Cヤおよび超音波検査にて膵体部に 震胞性病変を認め, 悪性が強く疑われ, 翌年 4 月 6日膵摘出術が施行された。

腫場は大きさが80×30×25mmでほほ膵全体をしめ， その中央汇長径約 25 mmの不整な囊胞空を認めた。 腫瘍の大部分は角化, 重層傾向の強い分化型扁平 上皮癌て，一部に管状，索状增殖を示す腺癌の胞 宩を混在して認めた。なお震胞壁は大部分扁平上 皮癌䉓より構成されていた。免疫組織化学的検索 では, CA19-9(t),CEA(t),EMA(t), Keratin(t)で, 扁平上皮癌部と腺癌部とに若干の染色性の相違を 認めたがほぼ同様の結果を示した。

露胞内容液の細胞診では, 多数の壊死性物質を みる污い背景に, 細胞質の形, 染色性に多样性を 認め, 濃染性の核を有する角化型扁平上皮癌細胞 を散在性に認めた。また, retrospectiveに観察 すると核偏在し，空胞状の細胞質で細顆粒状の明 るい核網を呈する類円形細胞の小集団を認め腺癌 細胞の混在が示唆された。 
327. 悪性 ラ氏島腫晹の一例

千葉労災病院病理 ${ }^{1)}$ 同内科 ${ }^{2)}$

千葉大学医学部第二病理学教室 ${ }^{3)}$

帝京大学市原病院病理 ${ }^{4)}$

○市東 功 (CT) , 今野暁男 (MD $)^{1)}$, 柴崎正已 (MT $)^{1)}$

野瀬晴彦 $(\mathrm{MD})^{2)}$, 䆶沢 七 $(\mathrm{MD})^{3)}$, 小山芳徳 $(\mathrm{CT})^{4)}$

松岦 理 $(\mathrm{MD})^{4)}$, 菅野 勇 $(\mathrm{MD})^{4)}$, 長尾孝一 $(\mathrm{MD})^{4)}$

今回われわれは, アルコール性肝障害で経過観察中 に, 悪性ラ氏島腫瘍を合併した症例を経験した。 症例：41歳 男性 昭和 63 年8月中旬より持続的な 心窩部痛と背部痛が出現し当院内科外来を受診し, アミラーゼが高值を示したため急性膵炎を疑い入 院した。入院時の検査では, アミラーゼ, CA 19-9 が軽度の上昇とエステラーゼ 1 の著明な上昇を認 めた。腹部超音波検查所見およびアルコール多飲 歴より腫瘤形成性慢性膵炎と診断したが, 腫瘤の 增大を認めたため膵生検を施行した。その後, 腹 部超音波, $\mathrm{C}$ T 検查で肝転移も認められた。外科 的に内瘦術を行なった際には肝腫瘍の一部も摘出 した。

細胞学的所見：超音波ガイド下穿刺吸引細胞診に よって得られた多数の腫瘍細胞は, 出血性背景の 中に充実胞巣状あるいは樹枝状に集塊を形成して いた。また一部には口ゼット様配列や毛細血管中 心の集塊も出現していた。核は円形〜類円形で大 小不同性がありクロマチンは細顆粒〜粗顆粒状の ものまで認められた。N/C比は比較的大きく小型 の核小体が 1 数個程度認められた。細胞質は薄 くライトグリーンに淡染していた。肝腫瘍も同様 の所見であった。

病理組織所見：腫瘍細胞はランゲルハンス島細胞 類似の円形〜惰円形を示し核は異型性が少なく充 実珄に増殖し一部でロゼット様配列や腺房様構造 を認めるところもあった。免疫組織化学的にはイ ンシュリンや他の内分泌ホルモン, $\alpha_{1}$-アンチトリプ シン, NSEは陰性であった。

以上の所見に電顕的所見をあわせて報告する。
328. 血中 A F P 高値を示した朝葴原発癌 の腹水細胞診

横須賀市民病院病理科 ${ }^{1}$, 同婦人科 ${ }^{2}$, 相互生物医 学研究所病理 ・細胞診センター 3

$\mathrm{O}$ 小沢尚男子 $(\mathrm{M} \mathrm{D})^{1}$, 高橋伸二 $(\mathrm{C} T)^{1}$, 木村実 千明 $(M T)^{1}$, 日野 㑆 $(M D)^{2}$, 大塚重則 $(C T)$ ${ }^{3}$, 田中昇 $(M D, D D S)^{3}$

血中A F P 著しい増加を示す疾患は肝芽腫 ，肝細胞癌などであるが転移性肝虞はまれであ る。血中 A F P の著しい高値を示す症例で, 腹 水細胞診, 十二指腸生検, 頝部リンパ節所見, 免疫染色等で, 膵原発癌を推定し, 剖検によっ て確認し得た一例を報告する。腹水癌細胞の顕 微分光測光のデーターを併せて報告する。臨床 的事項：59才男性。1989年 5 月中旬下腹部痛。 A F P 高值 $(24600 \mathrm{ng})$, L D H 高值 $(1064 \mathrm{nt} / \mathrm{l})$ に て肝癌を疑い,腹部Echo, C T 施行, 腫痬は陰性 。腹水貯溜, 内視鏡にて十二指腸Vater乳頭部 に小腫㢇及び頝部リンパ節腫脹が認められ，腹 水細胞診と同時に生検が施行。腹水細胞診所見 :異型細胞は,孤立散在ないし疎な結合性を示す 小集塊として出現。大型で単核, N/C比大,核形 不正な細胞と重積性多核細胞。一部小型核より

なる腺腔椂構造を示す集塊を認めた。PAS反 応でビマン性陽性。免疫染色で A F P 陽性であ つた。土指腸及び頝部リンパ節生検所見：䯣 样癌で転移性低分化型腺癌と診断。A F P 染色 陽性及び E M A 染色陽性。解剖学的所見: 膵頭 部を中心に $20 \times 17 \times 15 \mathrm{~cm}$ の腫瘍塊は十二指腸， 総胆管,胆囊,胃,肝及び後腹膜に浸潤。組織学 的には低分化型腺癌であり，胆臺浸襲部は高分 化乳頭腺管型を示し，何れも A F P 染色陽性。 結語 : 臨床的にAF P が高値を示したが, 肝癌 と診断し得る根拠がなく原発不明の転移癌と考 えられていたが，十二指腸及び䅡部リンパ節生 検所見, 更に腹水細胞診から膵原発癌を推定し ，剖検によって確認し得た。 
329. 膵の類破骨細胞型巨細胞癌の 1 例 一特に捺印細胞像についてー

高知医科大学第二病理 ${ }^{1}$ 、松山市民病院臨床検査 ${ }^{2}$ $O$ 大朏祐治 $(M D)^{1}$ 、真辺俊一 $(C T)^{1}$ 、園部 宏 $(M D)^{1}$ 、 岡田雄平 $(\mathrm{CT})^{2}$ 、河合凱彦 $(\mathrm{MT})^{2}$

膵の類破骨細胞型巨細胞癌は、通常の巨細胞癌 に比し予後は良いとされている稀な疾患である。

我々は胆囊やリンパ節転移を来した症例を経駼 し、その捺印細胞、免疫細胞学的並びに走查電顕 所見について検索したので報告する。

症例は71才女性で、昭和63年10月末に閉塞性黄 㾝のため入院し、Echo、ERCP、十二指晹造影等で 検索した結果、胆霊・膵頭部に腫瘍が見出された。 手術枋料では、径 $5 \times 5.5 \mathrm{~cm}$ 大の十二指腸内腔に突 出した膵頭部腫暍、径 $3 \mathrm{~cm}$ 大の胆露腫㡫並びに総 胆管周囲リンパ節腫大を認めた。いずれの腫瘤も 灰白ないし赤褐色で壊死を伴っていたが、境界は 比較的明暸であつた。

捺印細胞所見：脺と胆囊腫湯は同様の所見で、 胞体豊富な多核細胞と単核細胞が認められ、いず れの細胞の核も明暸な核小体を有し、核質は明る いが、核縁の肥厚は認めなかつた。多核巨細胞は、 核が集簇傾向を示し、胞体辺緣はやや肥厚してお り破骨細胞に類似した形態を示していた。

免疫細胞化学的所見: S-100 蛋白 $\alpha$ 要分画抗体 とMB-1抗体が多核巨細胞胞体に陽性であつた。 走查電䫓所見：PAP 染色標本から作製した試料 においては、大型から小型のものが区別され、核 に対応する部での不整やPitsを認めるものの、表 面はほぼ平滑であり、不規則な突起をのばして互 いに相接している像がしばしば観察された。

これらの所見は、病理組織学的検索結果に支持 された類破骨細胞型巨細胞癌の捺印細胞像であり、 本腫湯は稀な腫演ではあるが、細胞学的に特徴的 な所見を有しているので、膵十二指腸部腫瑒の診 断に際して十分に留意すべき疾患と考える。
330. 広沉な肝転移を伴った直腸カルチノイ ドの一例 : UV- 顥微分光測光による検索

中野棇合病院*相互生物医学研究所病理 - 細胞診 七ン夕 ${ }^{* *}$ 、東京医科歯科大学第 2 病理 ${ }^{* * *}$

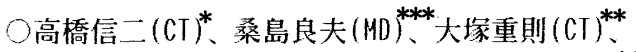
鐮田孝一 $(\mathrm{CT})^{*}$ 、波多野吉治 $(\mathrm{CT})^{*}$ 、上野喜三郎 $\left(\mathrm{CT}^{* *}\right.$ 、 春日 猛(MD)、田中 昇 $(M D, D D S)^{* * * *}$

消化管カルチノイドは悪性度が低く転移は比較 的希であるといふれている。肝重量5000g を越之 る広沉な転移を伴った微小直腸カルチノイド( 径 $6 \mathrm{~mm}$ )の症例について細胞学的所見と共に腫瘍細胞 のDNA ploidy patternを娭索し得たので報告する。 [症例] 82歳女、腹部腫瘤を主訴に来院、内視鏡 肝穿刺吸引細胞診、病理組織診にて直腸力ルチ， イド及び、その肝転移と診断され、6ケ月後に死 亡 [肝穿刺細胞診所見］異型性に乏しい腫場細 胞は集塊ないし散在性に出現。小型で $\mathrm{N} / \mathrm{C}$ 比大、 核は円形ないし類円形でクロマチンは細顆粒状で 均等に分布。HP/DAPI重染色による UV-顕微分光 測光の检討では，DNA 2Cの細胞を主体とする diploid patternであった。[生娭所見］直腸粘膜

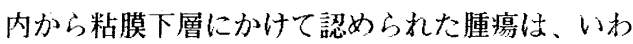
叻る古典的力ルチノイドに相当する像を示した。 腫瘍細胞は、好銀・銀親和性反応陰性であったが 電影的に胞体内に神経内分泌顆粒を確認した。 [剖検所見]直腸生検部位に一致して残存した 6 $\times 3 \mathrm{~mm}$ のカルチノイドを認めた。肝は重量約5000 gで、強い出血・壊死を伴うカルチノイドの広沉 な転移の他、少数のリンパ節転移が認められた。

[考察] カルチノイドが本例の如く広沉な肝転移 を示すことは極めて希である。 DNA ploidy patternの検索によりカルチノイドの悪性度を判定で きるとする報告もあるが本例は転移巣が diploid で、ploidy patternから，その悪性度を解析する ことはできなかった。カルチノイドの悪性度を予 知, 判定することの困難さが本例によって示され た。原発巣、残存原発病変は微細のためcyt ometry は不可能であった。 
331. 肝臓原発悪性血管周皮腫の一例

東京都教職員互助会三楽病院検査科病理

O岩淵祐子（ C T ）, 石川恵子（ C T ）

東京医科歯科大学第一病理学教室

寺田充彦 $(M D)$, 鼻山 茂 $(M D)$

肝臟原発悪性血管周皮腫の一例を経験したので その捺印細胞像について報告する。

症例：30才、女性。1989年 2 月、肝腫大指摘に より、当院入院精查。中程度の貧血と軽度の肝機 能障害あり。エコーにて肝右葉全体を占める巨大 なCystic lesionあり、肝腫瘍が疑われ、肝右葉 切除が施行された。

挣印細胞所見：腫瘍細胞は結合性に乏しく、散在 性あるいはシート状に出現。細胞形態は、多くは 紡錘形であるが、胞体が少なく裸核状にみえる不 整形または線維状の細長い細胞も見られ、突起状 に伸びた胞体が特徵的であった。核は比較的大型 で偏在傾向はあまり見られず、円〜卵円形を示し、 切れ込みが見られた。クロマチンは顆粒状凝集を 示し、量は少なく、核小体が著明に認められた。 又、腫瘍細胞が数ヶで管腔様構造を形成している のが散見された。

組織所見：切除標本は灭白色充実性腫湯。巨細胞 を混じ、鍍銀染色では、腫瘍細胞 1 〜数ヶをとり 囲む血管周皮腫のパターンを示すSarcomaであり、 上皮膜抗原 $(-)$ 、A F P $(-)$ 、第 UII因子関連 抗原 $(+)$ で、悪性血管周皮腫に符合した所見で あった。
332. 肝カルチノイド腫瘍の 2 例

国立がんセンター病院臨床検査部

○當銘良也 (CT) 、岸紀代三 (MD) 、上井良夫 (MD)

国立がんセンター研究所病理部

坂元亨宇 (MD) 、広橋説雄 (MD) 、下里幸雄 (MD)

カルチノイド腫瘍は気管支および消化管に好発す る腫瘍であるが今回、われわれは稀な肝カルチノ イド腫瘍を経験したので報告する。

症例 1、7 4才、女性、腫瘍は $\mathrm{S}^{8}$ を中心に認め られ、大きさは $5.9 \times 5.5 \times 4.0 \mathrm{~cm}$ 、被膜を有 さない黄色調境界明瞭な充実性の腫瘍で、中心部 に出血巣を認めた。

症例 $2 、 30$ 才、女性、腫瘍は右葉にあり、10.5

X $10 \times 6.5 \mathrm{~cm}$ 、境界明瞭黄白色調を呈し、出血 壊死を伴い、一部被膜を形成する。

[挎印細胞像] 症例 1、比較的小さい N / C 比 の高い腫瘍細胞が散在性で平面的に認められる。 細胞筫は微細顆粒状で、核はほぼ円形、やや偏在 性で大小不同はほとんど認められない。クロマチ ンは顆粒状で小さい核小体が 1 ～2 認められる 。症例 $2 、$ 比較的大き $\mathrm{N} / \mathrm{C}$ 比の低い腫瘍細 胞が散在性で平面的に認められる。細胞質は豊富 で微細顆粒状、ライトグリーンに染まる封入体様 構造を多数の細胞質に認める。核は円〜棈円形で 偏在傾向が強く大小不同性は中等度、クロマチン は顆粒状で核小体は目立たない。

[組織像] 2 例ともに腫瘍細胞は索状、胞巣状に 配列し、グリメリウス染色、クロモグラニンA、 LU-243 などが陽性であり、カルチノイド腫瘍と 診断された。症例 2 に見られた封入体様構造に 一致してケラチンが陽性、クロモグラニンAはそ れを避けるように陽性であった。

[電顕像] 2 例ともに100 200 nmの神経内分泌 顆粒を認め、症例 2 の封入体様構造に一致して中 間径フィラメントの集族を認めた。

2 例ともに臨床的検査では他臟器に腫瘍を認め ないことから肝原発の可能性が高い。 
333. 肝末分化肉腫の一例

\author{
ME S P 細胞研究所細泡診断部1 \\ 京都大学医学部病理学教室第一講座 ${ }^{2}$ \\ 同 外科学教室第二講座 ${ }^{3}$ \\ 奥山隆三 $(C T)^{1}$, 䅱國伸哉 $(M D)^{2}$, 岡田 茂(MD) ${ }^{2}$ \\ 韓 秀炫 $(M D)^{3}$, 森敬一郎 $(M D)^{3}$, 小沢和惠 $(M D)^{3}$
}

肝末分化肉腫は、1978年Stocker らにより 提唱された比較的稀な肝原発悪性腫瘍である。今 回我々は本症の一例を経験し、部検時の捺印細胞 診で興味ある所見を得たので報告する。

<症 例 $>$

28 歳男性、渡米中、発熱を伴う右季助部痛を 生じ、肝膿瘍の診断でデブリドメントを受け、こ の際に上記腫瘍と診断される。㷌国後、肝より後 腹膜にかけ浸潤する腫瘍を切除しえたが、2 月月 後に腹妧内に広範な浸洞性再発をきたして、全経 過6力月後にて死亡、剖唡を行った。

$<$ 肝腫瘍部捺印細胞診所見 $>$

集塊を形成しない単核及び多核の $\mathrm{N} / \mathrm{C}$ 比の高 い細胞であり、多核巨細胞が目立つ。単核細胞は 紡錘形細胞と円形紏胞をほぼ半数ずつの割合で認 め、直径は約30 $\mu \mathrm{m}$ から $100 \mu \mathrm{m}$ である。細 胞筫は少量、ほぼ均質でグリーンに染まり、所に よってPAS陽性の硝子様均質物を認める。核は 粗大顆柆状に濃染し、核小体は目立たない。核分 裂像や変性壊死像を多数認める。

<考 察>

本症例は本邦2 3例目の肝末分化肉腫である。 本症は比較的稀な若年者肝腫瘍であるが、その予 後は極めて不良であり、早期診断、摘出、化学療 法が必須と考えられる。しかしその細胞診に関す る文献は世界的に見ても僅かである。本細胞診所 見からは鑑別疾患として、血管肉腫、横紋筋肉腫、 平滑筋肉腫、線維肉腫、悪性線維性組織球腫等が あげられる。中には、本例のように初診時には臨 床的に肝膿瘍と貲別の困難な症例むあり、本細胞 診の所見は診断の一助となりうるものと思われる。
334. 粘液産生微小肝内胆管癌の 1 例

福島労災病院中央検查科

管野英明 ( C T )，白土秀宗 (CT)，鎌田文子(CT)

臨床病理科 箱崎半道(MD)

内 科 猪狩咲子(MD), 石橋潤一(MD)

外 科 黒河内一郎(MD)

我々は, 総胆管の拡張より肝内胆管腫瘍を疑い, 術中胆道鏡で, 左肝管上下行枝分岐部にポリープ様 腫瘤を認め, 肝外側域合併切除を行なうあ, 腫瘍を 確認出来ず, 術后胆道鏡下胆汁細胞診で陽性となり, 1 週后の胆道鏡で, 術中と同じ部位に腫瘤を認め, 生検の結果, 胆道癌之診断され再手術を行い $\phi 2 \mathrm{~mm}$ の微小癌であった症例を経験したので報告する。

症例：65才男性, 主訴は腹部膨満感で 平成元年 2 月 10 日当院受診, エコー, CTにて, 総胆管及び 左肝内胆管の限局性拡張を認め, 精查の為入院した。

ERCPでは, 胆囊及び左肝管は造影されず, 総胆 管内に不整形, 又左肝管の送 $\mathrm{V}$ 字形の陰影欠損を認 めた。しかしェコー下PTCの胆汁細胞診は陰性で あったが, 術前検索の結果, 左肝内胆管腫瘍の疑で 外科転科し手術を施行した。術中胆道鏡で左肝管上 下行枝分岐部にポリープを認めたが生検出来ず, 肝

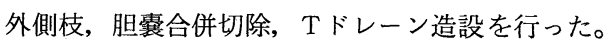
この時, 胆管内にはゼリ一状粘液の充満がみられた。 その后 5 回行なわれた Tドレーン胆汁細胞診は陰性 であったが, 背景に粘液が, 又異型細胞がみられた 標本が各 1 回あった。

胆道ファイバーにより直接採取胆汁で腺癌細胞陽 性, 1 週后胆道鏡下生検で胆道癌(中分化腺管腺癌) と診断され，6月 12 日, 肝内側区域切除が追加され， 腫瘍は $\phi 2 \mathrm{~mm}$ の粘液産生腺癌で粘膜下組織 まで浸 潤がみられた。

尚, 臨床的一般検査に特記すべき所見なく, 胆汁 内CA-19-9 のみが，488,000.211,000 と高值で あった。

以上, 肝内胆管の微小癌で胆汁細胞診が有用であ った症例について述べた。 


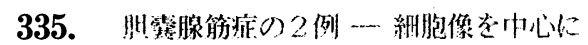

默取大学第一外科

O村惕子(MD)、采原志津子(MI)、西江 浩(MD) 塩田摃成 (MD)、松井孝犬(

木村等㦄 $(M D)$ 、貝原信明(MD)

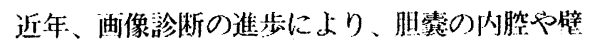
の微細な罢常所見が描出叮能となり、胡囊腺筋症 は術前診断が可能矢疾患の一つと尔つてきた。組 織学的には、Rokitansky-Aschoff sinuso增殖を 伴う胆震粘膜及び筋層の過形成性病変と考えられ ているが、成因についてはまだ諸説がみられ、そ の細胞像に関してははな゙あまり報告圭みない。

今叫、我《は、胆霊腺筋症の穿刺吸引及び割面 の捺印による細胞像を観察しえた症例を2 例経験 したので報告する。

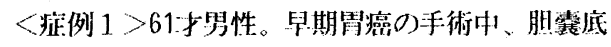
部に小指䫒大の硬い腄嵧を発見し、㢡膜側より第

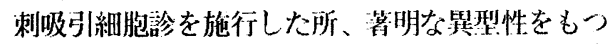
腺上皮集団が多数認められた。 $N / C$ 比の大きい重 皘性のある集団で、核の大小不间・極性の乱れが あり、クロマチンはやや粗で核緣は不整であった

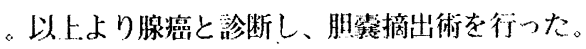
滴出標本の割面捺印から娄同様の細胞像を得たな 、永久組織診では腺筋症と部断された。

<症例 $2>37$ 才男性。人開ドックで胆擘譬の著明 大肥厚を指摘され、CT · US - ERCP - ang iography にて腺筋症と診断された。エコーガイド下穿刺吸 引細胞彰では、正常円柱上皮とともに、赤くめだ つ核小体をもつ円柱上皮も存存し、筋瀻維様の紡

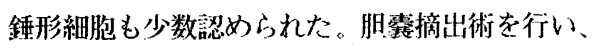
永久組織彰で腺筋症と衫断された。

主とめ 胆囊隆起性病変に対して棈極的に第刺吸 引細胞䇏が行われるようになったが、胆囊の良性 腄瘍の細胞像はあまり報告がない。今可、腺筋症 の2例を経験したが、1例は者明筫型性のため 腺癌との鑑別が困難であり、今後更に検討を要す ると思われた。
336. 心囊液細胞診により疑われた心囊原発 性悪性中皮腫の一例

愛媛大学医学部病理学第二, 附属病院中央検查部 ${ }^{2}$ ○近藤万里 $(\mathrm{C} \mathrm{T})$, 日野典文 $(\mathrm{C} \mathrm{T})^{2}$

池内五十鉿 $(M T)^{2}$, 宮本一雄 $(M D)^{2}$

田部井 亮 $(M D)^{1}$

心囊原発の悪性中皮腫は極めて稀であり, 向井 （1988）らは悪性腫瘍により死亡した2649例 の剖検中, 工例であったと報告している。

演者らは心囊液細胞診によって悪性中皮腫が疑 われた心囊原発の悪性中皮腫を経験したので報告 する。

(症例) 77才, 男性。死亡の 8 ケ月前より学作 時の息切れや動悸を自覚し, 次第に増悪したため 入院した。臨床検查上, 胸部 XP にて胸水, 心工 コーにて心囊水を認め, 胸部 C T で心囊肤の腫瘍 性肥厚を認めた。入院 1 ケ月後に収縮性心外膜炎 症状を呈して死亡された。

(細胞所見) 腫瘍細胞は不規則な集塊状ないし孤 立散在性に見られ，個々の細胞は主に類円形を呈 したが，なかに奇形細胞も混在していた。胞体は 全体的に青緑色に淡染し, 時に不染空胞も見られ 辺縁にはブリスター様突起が見られた。核は，類 円形で偏在ないし中心性に位置し時に核分裂像が あった。クロマチンは細網状ないし細顆粒状で軽 度増量があり，Iから４個の核小体を有した。

(病理組織所見) 腫瘍はヒアルロン酸を分泌し, 免疫組織化学的にはサイトケラチン陽性を示す2 相性悪性中皮腫の所見を呈した。また，電顕像に おいてもマイクロビライやデスモゾームなどの中 皮腫の特性が見られた。 
337. 心外膜血管肉腫の一剖検例

兵庫県立姬路循環器病センター 研究検查部病理 ○田中百合子 (CT), 西田光楎 (CT) , 橋本 幸子 ( $\mathrm{C} T \mathrm{~T})$ ，古本 勝 (MD)

神戸大学医学部病理学第一講座 上野 洋 (MD)

A F I Pに依九ば、心外膜を含めた原発性心臟要 性腫湯の中では、血管肉腫の頻度が高いとされて いるが、その報告例は未だ文献上稀少である。今 回我々は剖検により、心外膜原発の血管肉腫を経

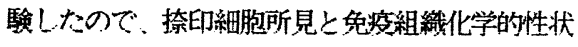
について報告する。

症例：23才、女性。平成元年 5 月心 部痛老 自覚。7月心タンポナーデの精查のため本院へ転 入院した。心空刺の際に心外膜腫痹の一部老生

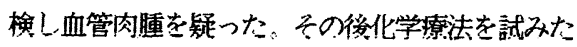
が反応せず、顔面と上下肢の浮腫が准行し、8月 末突然の徐脈に上り死亡した。

細胞所見：多数の赤血球至背景に、紡鍾形細胞 が散在性に、一部集団でみられた。核は棈円形。 不整形で軽度の大小不同至認め、クロマチンパ夕 ーンは絊顆粒状であった。核小体は1個から数個 認ぬた。兔然組織化学的検索ではV i ment, i nの局在を認めた。

組䋘所見 : 多彩な像からなる血管性腫場で主と して以下の成分加らる。

(1)腫大した内皮細胞索有する不整形の血管㓐(2) inusのid椂の不規則な血管腔(3)昖張した血 管腔に突出する e ndovasucul ar p a p i 11 a.t $i \circ n の$ 部分(4)充実性増殖を示す 部分(5)海綿状血管腫の如き拉張した血管腔。免疼

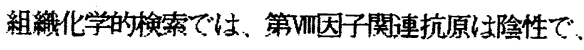
(3)の乳頭状增殖部分にUF, A - 1 の局存を認丸た。
338. 心臟原発血管肉腫の 1 剖検例

藤田学園保健衛生大学病院 病理科 ${ }^{1}$
同 臨床検查研究部病理 ${ }^{2}$, 医学部病理学教室 ${ }^{3}$
$O$ 黒田 誠 $(M D)^{1}$, 满口良順 $(M D)^{1}$, 舟橋正範 $(C T)^{2}$,
平沢 浩 $(C T)^{2}$, 田代和弘 $(M D)^{3}$, 城野健児 $(M D)^{3}$,
笠原正男 $(M D)^{3}$

心蔵原発血管肉腫は極めて希な疾患である。画像 診断により発見され、生検により血管肉腫と診断 され突然死により剖検された症例を経験し、心襄 穿刺細胞診の所見を再検討し、その有用性につき 考察したので報告する。

症例：38 歳男性。平成元年 8 月胸部圧迫感を主 訴として受診し胸腹水貯留を指摘され、さらに心 不全症状が出現したため、本院 C C U 入入院。心 エコー、MR I にて右心房腫瘍と診断され、心夕 ンポナーデ改善の目的で行った手術の際に生検を 行い病理組織学的に血管肉腫と診断された。術後 38 日目に突然死し、剖検が施行された。

心囊穿刺細胞診所見: 背景に好中球、赤血球を認 め、その間に内皮細胞様および組織球様の異型細 胞が出現していた。内皮様異型細胞は類円形でう イトグリーンに好染する胞体を有し、核は類円形 で、位置は中心性、核緑は中滑で均等にやや盵厚 し、クロマチンは顆粒状、核小体は明瞭で $1 \sim 2$ 個認めた。一部には内腔を形成し毛細血管類似の 構造む見られた。組織球様異型細胞は広い胞体で やや泡沫状、核は類円形で遍在性、クロマチンは 顆粒状、核小体は一個認めた。上皮様結合を示す 両者の胞体内には赤血球の貣食を認めた。

剖検所見：心重量は $1200 \mathrm{~g}$ と著しく重く、腫 瘍は出血性で心豊内を全周性に発育していた。組 織学的には紡鍾形の腫瘍細胞が不規則な血管胿を 形成し、類洞様構造す観察された。免疫組織学的 には第怔因子は陰性であったがこれは脱分化のた めと考えられた。肺に多発性小結節性の、また副 腎に顕微鏡的な転移巣が認められた。これらの組 織像之心襄穿刺細胞診像を比較検討した。 
339. 加サイ外リーにおける固定法の模討 一腫堭細胞のD N A ヒスド゙ラムの固定法による差異一

栃木県立がんセンター 娭查技術部1. 研究娭查 部2)、外科 ${ }^{3}$

O市川 明 (MT) ${ }^{1}$ 、島村香也子 (MD) ${ }^{2)}$ 、小山 靖夫 (MD) ${ }^{31}$

フローサイト灼リーを用いた腫瘍細胞の生長解析は、細 胞の形態学的観察とあいまって、患者の診断およ び治療に欠くべからざる情報を与えるものである。 今日、フローサ仆怩にによるDNA分析は広く普及し、ア 《忓固定液を用いた検体処理法が確立されたかの 感があるが、われわれは、病理畑で従来使用され てきた各種の固定液の特徵を生かし、それを吅サ

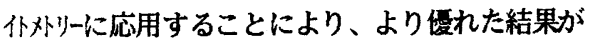
得られるのではないかと考元、実験を行っている。

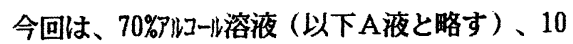
\%緩衝机归)液 (以下F液) および加変法液 (以

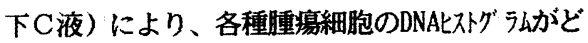
のような差異を示すかを模討したので報告する。

[材料と方法] 10症例、7種類の摘出腫湯組織 (大腸癌3、甲状腺癌2、乳癌、䀒細胞癌、膀胱癌、

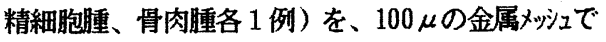
滤過後Hanks液で3回洗浄し、3等分してA、F、C 液のいずれかに、4 Cで1日以上浸漬した。測定に 先立ち、 $0.5 \% \bigwedge^{\circ} フ^{\circ}$ 沙処理 $\left(37^{\circ} \mathrm{C} 、 30\right.$ 分) と $0.1 \%$ RNase処理 (室温、30分) を行い、型のごとく Propidium iodide染色を施して、サイト年吅グラ II s (488nm、250mW、Pはゴンレー゙ー）で測定、解析には 彷外 30 (BD社)を用いた。

[成績] 睡場の種類に拘わらず、DNAL訃グラムの CV值はC 液が最も低く、ついで F液、A液の順で あった。どの固定夜でも、大腸癌の2例と精細胞腫、 骨肉腫の症例にAneuploidか認められたが、C液で は更に、乳癌、盰細胞癌および膀胱癌の症例でも Aneuploidが観察でき、検出率が最も高かった。

[結論］今回検索の範囲では、C液が最も良好 な成績を示した。今後更に検討を続けたい。
340. D A P I染色による

D N A 蛍光顕微測光法の技術的検討

昭和大学藤が丘病院組織化学 ${ }^{12}$ 、病院病理科2) O鉿木孝夫 $(\mathrm{CT})^{1)}$ 、岸本浩次 $(\mathrm{CT})^{1)}$ 、家泉桂一 $(M T)^{1)}$ 、光谷俊幸 $(M D)^{2)}$ 、佐川文明 $(M D)^{2)}$

【目的】近年、腫場細胞のD N A 定量の研究が盛 んになってきたが、今だに技術的な問題点が多い。 そこで我々は、その一方法であるD A P I 染色に よるD N A蛍光顕微測光法について検討した。 【方法】消化器系・泌尿器系腫瘍などの種々の疾 患材料を用い、藤田らの方法により標本を作成し、 Z E I S S 社製蛍光顕微測光装置UMS Pにより 技術的検討を行った。更にZ E I S S 社製画像解 析装置I B AS - 2000 と連動させ、fluoroimage analysisを試みた。

【結果・考察】(1)D A P I の最大蛍光波長は470 n⿴囗十、その蛍光強度は強く、長時間励起しても蛍 光滅衰は認めず、定量に適した色素であると考え た。(2)同一症例で新鲜標本とパラフィンおこしの 測定結果を比較したところ、若千の差はあるが、 本質的にはほぼ同様の結果となった。このことに より検体の状態によって、測定し易い方法を選択 出来ると考えた。(3)細畇の密集している所では値 が低く出る傾向があった。これはD A P I の浸達 性によるものと考えた。(4)papanicolaou標本で目 的細胞を座標登録し、脱色後D A P I 染色を行い、 markした細胞を自動ステージ機構により順次呼び 出し、D N A 定量を行った結果、良好な定量性を 得た。papanicolaou標本で先に目的細胞をmarkす るということは、蛍光像から細胞を同定するより も確実性が高く有効な方法だと考えた。更に、蛍 光像の画像解析を行うことにより、D N A-AR E A, D A-形状係数, DNA核内分布, cell cycle と細胞像の関係等の多面的解析が出来、細 胞診への応用も可能であろうと考えた。 
341. 多数のリンパ節転移を認めた子宮頸部 Adenoma malignum の一例

北海道社保中央病院産婦人科

守谷修而 (MD) 佐藤春美 (MD) 田畑雅章 (MD) 植松正 (C T) 佐藤ひろみ (C T)

北海道対がん協会 沓沢武 (MD) 清野邦義 (CT) 手稲溪仁会病院産婦人科一戸喜兵衛 (MD)

大久保仁 (MD)

子宮頸部の高度分化型粘液産生腺癌（いわゆる Adenoma mal ignum) は細胞診断上異型性がそ しく、古くから進行癌で発見されるてとが多く、 予後不良とされていた。今回われわれは多数のリ ンパ節転移を認めた粘液腺癌を経験したのでその 細胞像について報告する。患者は 59 才主婦（妊 1 産 0$) 89$ 年 2 月集験をはじめて受䛦、主訴は 多量の粘液性帯下、出血、腰痛で、肥厚した子宮 頸が硬く触知された。マーカーはC A 1225 が 116 とやや高值 C E A 正常。細胞診では粘液背 景の中に扁平上皮細胞は殆んど認められず、シー 卜状、棚状、ロゼット状の腺細胞集団が多数認め られた。特に大小不同の粘液空胞が特徵的で不規 則な網目様配列を呈しまた核小体も目立ち、大小 不同もあるがクロマチンは細顆粒.状であった。広 汎性子宮全摘術を施行、摘出子宮頸部は殆んどが 腫場細胞で置換され、ムチン産生の腺組織が back to back の形態をとり、また浸潤の尖端では明 らかに腺癌とみなされる形態を示した。リンパ節 は 7 力所に転移を認め、いずれも粘液像で充満し ていた。
342. 子宮䅡部 Adenoma malignumの 1 症例

\section{昭和大学藤が丘病院 病院病理科 ${ }^{11}$ \\ 同組織化学研究室 ${ }^{2)}$ \\ O北村隆司(CT $)^{12}$ 、中川信廣(CT $)^{13}$

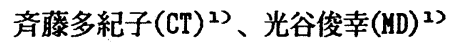 \\ 佐川文明(MD) ${ }^{1) 、}$ 鈴木孝夫(CT $)^{2)}$}

Adenoma malignumは頝管由来の最も高分化な腺 癌である。今回我々は、術前子宮䅡部擦過細胞診 で腺癌が疑われ、手術材料により腺管の著明な浸 潤性增殖が見られ、Adenoma malignumと確診し得 た症例を経験したので報告する。

【症例】47才、主婦。家族歴、既往歴に特記すべ きことなし。現病歴：約1年前より灰白色の帯下 を認め、平成元年9月、当院婦人科を初診。内診 及び臸鏡診において子宮䅡部の著明な肥大を認め 子宮頝部擦過細胞診にて ClassIV（腺癌の疑い）、 同時に施行された子宮䅡部組織診においてAtypical glandular hyperplasia と診断。同年10年16 日腹式拡大子宮全摘術及び両側付属器摘出術施行。 摘出標本において、Adenoma malignumと診断。

【細胞所見】睡煌細胞は主にシート状、柵状、合 胞状配列を示す集団として出現。軽度の核大小不 同を認め、核クロマチンは細顆粒状〜細網状密で 増量を示しほぼ均等に分布。また軽度の核形不整、 核分裂像もみられた。核小体は小型で 1 〜数個。 細胞質はライトグリーン好性、レース状〜泡沫状 であった。

【組織学的所見】手術材料 : 頝管腺の著明な異常 増殖がみられた。浆膜側に達する浸濉性增殖が認 められた。腺管の極性はほぼ保たれ間質への浸潤 もみられなかった。

以上の如く、生検においては悪性と断定出来な かったが、細胞診において上記の如く悪性が疑わ れた。この様な症例においては、Adenoma malignumの可能性を念頭におく必要があると考えられ る。また本症例において腫瘍細胞のDNA測定およ び画像解析を施行したので加えて報告する。 
343. 子宮頸部に発生した腺様囊胞癌の 1 例

北九州市立小倉病院産婦人科

○末永俊郎 (MD), 橋本和法 (MD), 神尊敏彦 $(M D)$, 兼崎陽子 ( $M D)$, 尾上敏一 $(\mathrm{MD})$ ，森敏尚 $(\mathrm{MD})$

子宮頸部の腺様㐮胞癌はまれな腫瘍であるが， 我々は最近その一例を経験したので, その細胞学 的所見, 病理学的所見を報告する。

症例は88才で, 46才で閉経し, 71才で直腸癌の ためMyles 手術の既往がある女性が, 不正性器出 血を認めたため, 当科を紹介受診した。

子宮頸部には，やや腫大した後唇より発生した 易出血性のポリープ状の腫瘍を認めた。細胞診は

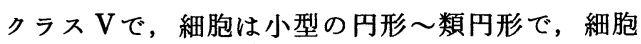
質は比較的明るく, 核は偏在傾向を示さず, 核の 大小不同が見られる。核小体は目だたず，細胞配 列は部分的に小腺腔状を示した。細胞集塊は比較 的平面的で重積性に乏しかった。

高龄者のためまず放射線治療を行ったが，腫 瘍の反応性がそしかったため, 準広沉子宮全摘出 術を施行した。

組織学的には, 細胞質が狭小で, 濃染核からな る小型の基底様細胞が瘾合性の細胞索または充実 巣を形成していた。所々飞好酸性の硝子体をいれ た円柱空隌が見られ, 腺様囊胞癌の特徵を示して いた。

腺様霊胞癌は, 気管・気管支に好発する癌腫で あるが, 婦人科領域では稀な腫瘍で, 報告では高 齢者に多く，40才以下の症例は汪とんど見られな い。子宮頸部扁平上皮癌に比べ，早期にリンパ節 転移をきたし， 5 年生存率も覀いとされている。

臨床経過に文献的考察を加えて報告したい。
344. 子宮頸部Mucoepidermoid carcinoma つ 2 例

琉球大学医学部産婦人科 $*$, 中央検查部 $* *$

那覇市立病院中央検查室 $* * *$

山城竹信 $(\mathrm{MD}) *$, 東 政弘 $(\mathrm{MD}) *$, 中山道男 $(\mathrm{MD})$ *) 豊田善成 $(\mathrm{CT}) * *$, 平良嘉邦 $(\mathrm{CT}) * * *$

Mucoepidermoid carcinoma は粘表皮癌の変異型 で, 子宮頸癌の $4 \sim 5 \%$ を占める非常に予後の悪い疾 患である。我々はMucoepidermoid carcinomaを 2 例経験したので, その細胞像と組織像を中心に報告す る。

[症例 1 ] 43 歳の主婦, 平成元年 2 月頃より不正出血 があり, 子宮頸部の低分化型扁平上皮癌 IIIb期の診断 で紹介された。腫瘍は放射線療法にて消失し経過観察 中である。

[症例 2] 55歳の主婦, 平成元年 9 月頃から大量不正 出血があり, 子宮頸癌 IIIb 期, Mucoepidermoid cancer の診断で紹介された。放射線療法中である。

[細胞診] 症例 1. クラス $\mathrm{V}:$ 血性背景の中に大型の異 型細胞と比較的小型の異型細胞が混在している。大型 の異型細胞は紡鍾形または多稜形の広い胞体を有し辺 縁はやや不明瞭である。中に多染性を示す集団むみら れる。一方, 小型の異型細胞はやや核偏在傾向を示し 腺系を思わせる。核は円または棈円形でクロマチンの 増量, 核小体の明瞭化, 核縁の不整等はあまり見られ

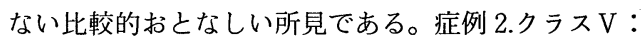
血性背景の中に比較的小型の異型細胞集団が平面的な 配列で認められた。胞体は紡鍕形, 多稜形を呈しライ トグリーン淡染, 辺縁は不鮮明である。核は偏在傾向 を示すむのと中心性に見られるむのとが混在している。 核形は円または棈円形で核縁の不整等はあまり見られ ない。クロマチンは増量し, 顆粒状に凝集しているが 核小体は著明ではない。

[組織診] 症例 1.2 : 明るい大型の核と広い細胞質を有 する癌細胞が島状あるいは索状に増殖している。分化 傾向の乏しい扁平上皮癌細胞を主体とする腫瘍である が, 一部に淡明な胞体を有し粘液産生のみられる腺細 胞が混在している。腫瘍細胞の一部に A P S 染色, Alcian blue 染色にて粘液を認め epidermoid carcinoma と診断した。 
345. 子宮頸部明細胞癌の 1 例

九州大学医学部婦人科学産科学教室

○藤原孝恵 (MD)，井町正士（MD），

塚本直樹 $(\mathrm{MD})$, 渡辺寿美子 ( CT ), 中野化雄 (MD)

子宮頸部明細胞癌は頸部腺癌の約 $2 \sim 3 \%$ と稀 な疾患である。今回われわれは子宮頸部明細胞癌 の 1 例を経験したので、その細胞所見および組織 所見について報告する。

症例は66歳、経妊 6 回経産 4 回、閉経43歳で、 平成元年10月、不正性器出血を主訴として近医を 受診した。カリフラワー状に発育した腫瘤を子宮 腔部に認め、子宮頸癌と診断され当科を紹介され た。子宮頸部は易出血性の脆弱な腫瘤で置換され ており、胵壁に浸潤を認め、腫瘤は䐋入口部から $2 \mathrm{~cm}$ の部位まで達していた。子宮傍結合織は軽度 に肥厚していたが、膀腅鏡および直晹鏡では異常 なく、遠隔転移屯認めず、子宮頸癌而a 期と診断 し、12月 1 日から放射線治療を施行した。

細胞所見：比較的きれいな背景のもとに、豊富 で淡明な細胞質を有する腫瘍細胞がシート状ない し腺房样に出現している。核は類円形で、核縁の 肥厚は認めないが、クロマチンは細顆粒状に増量、 核小体は著明である。巨大な核や多核の細胞む散 見された。一部には細胞境界明瞭で蜂巣状構造を とる部分や、細胞質にそしく裸核状となり hobnail 型と思われる部分が存在した。また砂粒体を 少数ながら認めた。

組織所見：淡明な胞体をむつ腫焬細胞および hobnail 型の腫演細胞の両者が増殖し、主に乳頭 状の構造をとるが、管状あるいは充実性の構造の 部位む混在した。
346. C I S 、A I S を伴った子宮頚部 カルチノイドの 1 例

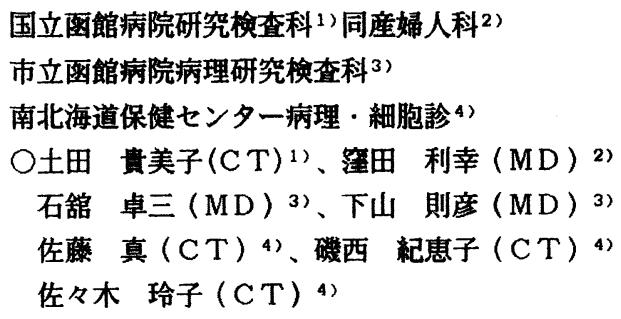

最近演者らは、頝部癌の診断で手術した子宫を 組織学的に精查した結果、C I S、AＩＳ を伴 つた子宫頝部カルチノイドと判明した 1 症例を経 験したので、術前細胞診所見を中心に組織所見並 びに電顕所見を併せ報告する。

【症例】38才。女性。4妊3産。不正性器出血を 主訴とし某医を受診、㸚部扁平上皮祝が疑われ、 当院に紹介された。子宮䅡部生検で浸潤性の非角 化型小細胞性扁平上皮癌と診断し、広範性子宮全 摘術を施行した。

【病理組織所見】肉眼的に、子宮腟部に直径 $3 \mathrm{~cm}$ 大の隆起性腄瘾を認めた。組織学的には大型胞巣 を形成する翼型細胞の浸潤性增殖があり、その細 胞配列パターンからカルチノイドが疑われ、グリ メリウス染色、電顕的検索を施行し、同腫埸と診 断した。なお本腫湯と連続し A I S と見做しう る異型細胞群があり、また SC J 部にカルチノ イド病巣と非連続性に C I S 病変をも認めた。 【細胞診所見】極めて $\mathrm{N} / \mathrm{C}$ 比大の小型異型細 胞を集塊状一孤立散在性に多数認める。これら異 型練胞の核は類円形で大小不同性に之しく小型核 小体を 1 数個認め、クロマチンは細顆粒状であ る。以上の所見より術前細胞診では非角化型小細 胞性扁平上皮癌と判断したが、診断確定後仔細に 観察すると、極めて疎な上皮性結合を示す細胞集 団、リボン状細胞配列を想定しうる連珠状配列を 示す上皮細胞、また腺細胞と考えられる細胞集団 の出現等もあり、多彩な細胞像が称められた。 
347. A I S と扁平上皮癌の合併した 2 例

東京医科大学産婦人科学教室 ${ }^{1}$, 同 病院病理部 ${ }^{2}$ $\mathrm{O}$ 猪脇順子 $(\mathrm{MD})^{1}$, 岩㴊浩之 $(\mathrm{MD})^{1}$, 作永穂高 $(\mathrm{MD})^{1}$, 岡部一裕 $(\mathrm{MD})^{1}$, 横山明子 $(\mathrm{CT})^{2}$, 若梘よしえ $(\mathrm{CT})^{2}$, 越川真理子 $(\mathrm{CT})^{2}$, 海老原善郎 $(\mathrm{MD})^{2}$, 根岸能之 $(\mathrm{MD})^{1}$

子宮頸部扁平上皮癌の上皮内癌および微小浸潤 癌に関しては, 細胞診断学的に容易になりつつあ るが，AＩＳに関しては，いまだ困難な要素が多 い。我々は最近, A I S と扁平上皮癌の合併した 2 例を経験したので, 細胞学的, 組織学的に検討 を加え, 報告する。【症例 1 】52才女性。性器出 血を主訴に当科を受診した。胵部タッチスメアで は, 炎症性背景の中に, 上皮内癌を考えさせる, hyperchromatic で核の大きい傍基底細胞が散在 し, 他に異常角化細胞もみられ, 細胞の多形性に 富んでいるため, 微小浸潤癌を想定した。また, 頸管腺細胞の中で, hyperchromatic で配列不整 のある細胞集団がみられた。ねらい組織診では, dysplasiaの像しか得られなかったが, 拡大子宮 全摘により，A I S 抢よび上皮内癌をみとめた。 腺癌部分は A I S の像が殆んどであったが,一部 に浸潤癌の所見をみとめ, 腺癌之扁平上皮癌には 移行像がみられた。【症例 $2 】 30$ 才女性。集団検 診にてクラスVを指摘され, 他院にてねらい組織 診の結果, 微小浸潤癌と診断され当院を受診した。 当院の組織診では, 微小浸潤扁平上皮癌の他に, A I S の像があり, 広汎子宮全摘を行った。摘出 子宮には，広範囲に非定型的上皮内癌の像があり， 一部に微小浸潤癌があり, 他にA I Sの像をみと めた。両者には移行像をみとめた。

A I S は, reserve cell由来との考え方ああり, これらの症例のように, 腺癌と扁平上皮癌の $2 つ$ の形態が共存し, それぞれの移行像がみられると いうことは, reserve cel1の両面性という点で興 味深い。乙の点については, ケラチンモノクロー ナル抗体を用いて免疫組織化学的にも検討を加え た。
348. 子宮頸部上皮内腺癌の 2 例

松戸市立病院病理科細胞診

O根本 充弘 ( CT ), 富塚 幹男 ( CT ), 浅沼 勝美 (MD)

相互生物医学研究所・細胞診センター 田中 昇 (MD, DDS)

子宮頸部腺癌は頸部癌の約 $5 \%$ と少なく形態学 的にも多彩であり，さらに頸部上皮内腺癌（A I S）を細胞診によって把握することは困難である。 われわれは子宮頸部擦過細胞診で異型細胞を認め 腺澏を強く疑い生検を行ったところ頚部腺癌でか つAISが疑われ，手術摘出材料についての精查 によって A I S と確認された2 例を報告する。

【症例 1】45才，主婦，5娃 4 産，1987年 7 月に 集検細胞彰で異常が認められ，精査によって頸部 癌と診断され当院婦人科に紹介された。受診時の 莖部擦過細胞診でも悪性を疑う腺型の異型細胞が 認められ生検を行わずに子宮拡大全摘術施行。

【症例 2】36才，主婦，4妊 3 産，1987年11月に 癌検㟝細胞診で異常を指摘され精検の目的で来院。 受診時の頸部擦過細胞診で異型細胞を認め, さら に生検て腺㜔と晾断され子宮搪大全摘術施行。

【細胞所見】2例とも非腫瘍性背景に，シート状 および軽度重積性を示す細胞集塊が出現し，核は 軽度〜中等度の大小不同があり，核間距離は不均 等であった。核縤はやや不整であるが肥厚はなく， クロマチンは微細顆粒状を示した。核小体は小型 で数個認められた。

【組織所見】症例 1 は来院前の生検で，症例 2 は 来院時の生検で 2 例ともAＩＳの疑いであった。 さらに摘出されたそれぞれの子宮頸部を12分割し て検索した結果, 症例 1 は $9^{\circ} \sim 2^{\circ}$ の方向, 症 例 2 は $3^{\circ} \sim 7^{\circ}$ の方向にS C J 上り内子宮口側 に頸管腺上皮を置換しつつ進入する上皮内腺癌が 認められた。

【まとめ】細胞診で上皮内腺澏を診断するのは困 難であるが, 細胞所見より腺系癌細胞であるうと の診断は可能であると思われた。 
349. 細胞診にて診断が困難であった子宮頸 部小細胞非角化癌の 1 例

\author{
沼津医師会病院 \\ ○福本ひろみ(CT)、会田幸司 $(\mathrm{CT})$ 、若生裕行( CT) \\ 小林美和子(CT)、鈴木言子(CT)、 \\ カ・龒ギ・医院 \\ 印牧義孝(MD) \\ 国立東静病院 \\ 鈴木昭夫(MD)、山岸豊(MT)
}

子宮頸部における、小細胞非角化癌は稀なるの であるが、今回、我々は細胞診にて診断困難であ つた1例を経験したので報告する。

症例: 60 才主婦 月経歴; 53 才閉経

妊娠璴：4妊 2 産（流産 2 回）

1987年、1988年の癌検診では異常なしであった。 1989年7月、不正性器出血を主訴として来院、 コルポにて頸部上層に脆弱なtumor を想めた。接 触出血あり、細胞診と共にpunch biopsyを施行し た。

細胞所見：核の大小不同はなく、核型は円〜楕 円型、核縁の肥厚はみられない。クロマチンは細 〜粗顆粒状で増量し、核小体はさほど目立たない 。細胞質は青染性できわめて狭小、 $\mathrm{N} / \mathrm{C}$ 比が大き く裸核状のあのが多く認められた。細胞辽縁は不 明暸で、結合性は踈、散在性のあのが目立ってい た。

組織所見: 円形〜類円形の核からなり、クロマ チン分布は粗顆粒状で、 N/C比は増大している。 細胞境界は不明瞭であり、血管浸襲む認められな い。核分裂像は強拡で 1 視野に $2 \sim 3$ ケ所認めら れた。

以上の上うな所見から細胞診では悪性は疑われ たすのの判定は困難であったが、組織診にて小細 胞非角化癌と診断された。
350. 子宮頸部境界病変ならびに子宮頸癌に おけるras癌遺伝子産物の発現とHPV感染について

札幌医科大学産婦人科学講座

二瓶岳人 (MD), 寒河江悟( $M D$ ), 武田智幸( $M D)$, 麦倉 裕 $(M D)$, 工藤隆一 $(M D)$, 橋本正淑 $(M D)$

我々は ras 癌遺伝子産物である $\mathrm{p} 21$ の発現の有 無について免疫組織化学的判定を行い, 子宮頸部 扁平上皮の癌化過程の比較的初期である, 軽度異形 成の段階から認められる事を報告してきた。一方 HPVは, 子宮頸部前癌病変, そして子宮頸癌の発 生と何らかの関係があることが示唆されている。 Vira Pap はFilter DNA hybridization法を用い てHPVゲノムを検索し, 細胞診に出現するHPV感 染細胞の有無をみている。

今回, 我々は子宮頸部病変における ras 癌遺伝 子産物 $\mathrm{p} 21$ の発現の有無と HPV感染の有無の関連 性について検討してみた。Vira Pap, 細胞診を施 行し, かつ生検, 円錐切除, 子宮全摘出術を行っ た12例について, その摘出組織を $\mathrm{ABC}$ 法によって ras 癌遺伝子産物 $\mathrm{p} 21$ の免疫組織化学的染色を行 った。

その結果, 異形成群では $\mathrm{p} 21$ 陰性例が多く, 浸 潤癌では逆にp21陽性例が多かった。Vira Papは 浸潤癌では少なく, 異形式・上皮内癌で陽性例が 多かった。以上よりHPV感染と ras 癌遺伝子産物 の発現には病巣の高度化により違いが認められた。 さらに症例を増やして, HPV感染が ras 癌遺伝子 の活性化に関与するか否か検討中である。 
351. 子亳頭部腙異形成のスクリーニング (第2 報)

\section{千葉県対がん協会}

O小石川裕子(CT), 長田広子(CT), 角 敏子(CT) 吉田美紀子(CT), 鳰池克寛 (CT), 石川 明 (CT) 山口圭子 (CT)

\section{千葉大学産婦人科}

深沢一雄 (MD), 岩崎秀昭 (MD), 久保田浩一 (MD) 河西十九三(MD), 望月 博 (MD), 武田敏(MD) 高見沢裕吉 (MD)

千葉県対がん協会で過去 2 年間に扱つた子宮須 癌検診で異型細胞が検出され精検を施行した 55 16 例中, Biopsyc゙Glandular dysplasia (腺異 形成）と診断された症例は 27 例であつた。但し この間, 2 回のBiopsyともGlandular dysplasia を認めたものが，2例含まれている。これ等につ いて, 精検時及びスクリーニング時の細胞標本を 再検討し，その中に含まれる異型細胞の形態を解 析した。

組織学的には扁平上皮系の異型が共存する例が 半数に達しており, 細胞所見上, 扁平上皮系異型 被胞の出現は更に高率であつた。

Gianuuiar ayspiası に特異的な細胞像を明示 することは困難であるが, 腺細胞異型所見の中で 核小体増大にこだわらず細胞集団を含む総合的細 胞所見 (軽度核大小不同, 軽度クロマチン増量, 一部の核延長型）を重視する必要があると思われ る。

著しい核配列の乱れ，極性の乱れ，クロマチン の粗大化は, Glandular dysplasia ではなく, A I S以上の所見に属する。
352. 子宮頸部軽度異形成と鑑別を要する扁 平上皮癌症例の細胞診について

総合会津中央病院病院病理部

O古川恵子 (C T), 九島已樹 (MD), 昭和大学医学部第二病理学教室

滰本雅文 $(\mathrm{MD})$,

昭和大学病院臨床検查部病理検查室 津田祥子 (C T)

子宮頸部細胞診で軽度異形成（クラス III a ）と 判定された症例のなかに、組織診で上皮内癌を含 む扁平上皮癌がとき汇認められることがある。 今回はそのような症例28例について、細胞標本の 再検討を行い、細胞診上の特徴を明らかにすると 上むに、画像解析装置 (IBAS-2000)を用いて、細 胞標本上の異型細胞の形態計測を行った。 組織学的には大部分が大細胞非角化癌の上皮内癌 之微小浸潤癌であった。異型細胞数では、一枚の プレパラート上にみられる表・中層型核異常細胞 数は、細胞診で軽度異形成を想定し、組織診屯軽 度異形成であった症例（MD群と略す）と、細胞 診で軽度異形成を想定し、組織診が上皮内癌であ った症例（C I S 群と略す）および微小浸潤癌で あった症例（M I C 群と略す）とでは前者より後 2 者のほうが多数の核異常細胞が見られた。旁基 底型核異常細胞および裸核状細胞はM D群に少な く、M I C 群、C I S 群の順に多く見られた。ま た少数ながら C I S 群の症例で表・中層型癌細胞 と考えられる細胞が見られた。画像解析装置によ る形態計測では、核、細胞質それぞれの面積、最 大径、最小径、形状係数を測定し、検鏡による質 的診断との関係を検討した。

表層型扁平上皮癌細胞を含む表層型核異常細胞が 主体で、細胞診に扔いて単に、「軽度異形成」と されている症例が少数ながらうられたので、今後 そのことを念頭において、より一層注意深く検鏡 することが必要であると考えた。 
353. 妊娠時頸部細胞診における異型細胞 出現例の追跡について

川崎協同病院産婦人科 1), 中検病理 2), 昭和大学 医学部第二病理 3 ), 神奈川県予防医学協会 4 )
藤原理恵 $(M D)$ 1), 佐藤育男 (MD) 1)
野末悦子 (MD) 1), 古嶋英代 (CT) 2)
新保京子 (CT) 2), 鳴子富男 (MT) 2)
塩川章 (MD) 2) 3), 松岡規男 (MD) 4)

本院では妊婦全例に初診時に子宮頸部擦過細胞診 を行なっているが, 昭和59年から 5 年間に約 1,630 例中 class III a 以上の異型を呈したものを19例経験 した。年齢は17〜41才 (平均 28.0 才) で, 妊娠 $5 \sim 30$ $\mathrm{W}$ の時期に異常がみられた。細胞像は妊娠性変化 に加えて核異型がみられ class III a としたものが大 半であるが, class III b 1 例, class IV 1 例, class $\mathrm{V} 1$ 例を経験した。症例 $1 ： 30$ 才, 妊娠 $8 \mathrm{~W}$ 時 class IV, 組織診むCISであり, 子宮摘除を行なった。 症例 $2: 34$ 才, 5 W時 class III a であったが, 3 年後 の非妊時に class III b となり, 手術では CISであった。 症例 $3: 34$ 才, $6 \mathrm{~W}$ 時 class III a であったが, 流産後 陰性化。1 回の出産を経て, 4 年後に 8 W で人工流産 施行時に class II a, 1 力月後に class III b, 4 力月後 には class Vとなり，手術では微小浸潤癌であっ た。症例 $4 \sim 14$ の11例 (20〜38才)では 5 10Wの間に class III a 以上の異型が出現したが，妊娠中期〜出 産後に陰性化している。乙の中で症例 4（37才）は class V と診断したが，組織学的には細胞異型は 高度なあのの極性が保たれており Dysplasia と診 断された。経過観察し $37 \mathrm{~W}$ で帝王切開施行後, 陰性 化している。その他は人工流産後受診中断など, 経過不明である。

〔まとめ〕妊産婦に対する子宮頸部細胞診は比較 的若年者の CIN の発見に効果があり, 早期発見・ 治療に有効である。しかし, 妊娠に伴う細胞異型 が出現する場合ああるので組織診の併用により適 正な診断に注意せねばならず,一方で細胞診が陰 性化してあ䈌重な経過観察が必要である。
354. 子宮頸癌と妊娠を合併した患者にお ける細胞診、コルポ診、組織彭からみた若年婦人 の癌スクリーニングの必要性について

$\begin{array}{ll}\text { 兵庫県立成人病センター産婦人科 } \\ \text { 木村あずさ ( M D ) } & \text { 岡村 昌幸 ( M D ) } \\ \text { 衣笠 万里 ( M D ) } & \text { 西村隆一郎 ( M D ) } \\ \text { 大津 文子 ( M D ) } & \text { 長谷川和男 ( M D ) } \\ \text { 武内久仁生 ( M D ) } & \\ \text { 兵庫県立成人病センタ一検查部細胞診室 } \\ \text { 指方 輝正 ( M D ) } & \text { 木崎 智彦 ( M D ) } \\ \text { 藤原 武 ( M D ) } & \text { 高橋満智子 ( C T ) } \\ \text { 高山みずほ ( C T ) } & \text { 田中八千代 ( C T ) } \\ \text { 平山 裕子 ( C T ) } & \text { 前田 妙子 ( C T ) } \\ \text { 森田 真代 ( C T ) } & \text { 高垣 和代 ( C T ) }\end{array}$

近年、比較的若年層婦人の子宮癌検診に対する 認識が高まり、受診珎も㘿加傾向にある。乙れに 伴って、若年婦人の初期子宮頸癌患者の検出も増 加しつつある。しかし、とれら若年婦人は強く挙 児を希望する場合には妊孕力の保持という問題が あり、また比較的稀ではあるが頸癌に妊娠が合併 していた場合の臨床的な取り扱いはきわめて慎重 に対処するてとが要求される。乙の意味から、て れら若年婦人に対する子宮頸癌検診はその診断治 療という観点から今後重要となってくる。我々は S. $50 \sim$ H. 1 までの 15 年間に子宮頸癌に妊娠、を合 併した患者13例を経験している。乙れら患者の発 見に至った経緯をみると、妊婦検診中、細胞診が なされ頸癌が検出されたすのは 6 例、患者自身が 積極的に癌検診を受け、頸癌とと屯に妊娠が判明 したものは 6 例であった。他の 1 例は妊娠中には 癌検診が施行されず、産裖検診中に頸癌が発見さ れた症例であった。また13例の患者の平均年令は 33.5 才で、その臨床進行期は 0 期 5 例、Ia期 2 例、 Ib期 6 例であった。そこでてれら症例の細胞診、 コルポ診、組織診などから、妊婦や若年婦人にお ける癌スクリーニングの必要性について検討した ので報告する。 
355. 子宮䫫部に多数のCharcot-Leyden 結晶が認められた 1 例

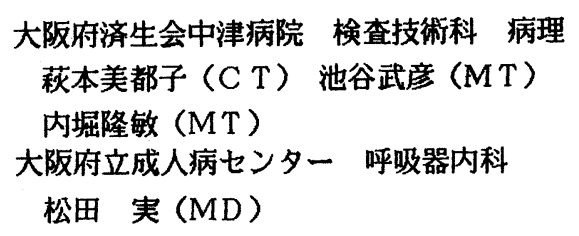

今回我々は子宮顠部擦過標本中に多数の Charcot-Leyden結晶を認め、検査の結果、癌に より形成された子宮一直腸瘦により直腸から混 入したものと考えられる症例を経験したので報 告する。

患者 81 才性 5 妊3産

盶往歴：昭和48年、子宮頸癌にて子宮および附 属器全摘除術施行。組織型は扁平上皮癌であっ た。昭和62年、S 状結腸癌発症し、人工肛門造 設術を施行した。組織型は腺癌であった。 現病歴：平成 1 年10月子宮癌再発によりRadiation治療中。

子宮頚部擦過標本：多数のCharcot-Leyden結晶 が認められた。しかし、好酸球はほとんど認め られなかった。

直腸分泌物標本：多数のCharcot-Leyden結晶 および好酸球が高率に認められた。 なお、血中の好酸球は10\%であった。

以上よりこれらCharcot-Leyden結晶は直腸で 形成され、子宮一直腸瘦より子宮内に混入した と考えられた。

Charcot-Leyden結晶の認められた報告例は、 喀痰、胸水、腹水ではあるが、子宮䫫部擦過 標本、および直腸分泌物標本上に認められた報 告例はなく、稀れな症例と思われるので報告す る。
356. 大腸癌と子宮頸部癌の重複癌の一例

赤心堂病院 娭查科 ${ }^{11}$ 婦人科 ${ }^{21}$ 外科 ${ }^{31}$

O采数りツ子(CT $)^{11}$ 、勝間田孝明(MT $)^{11}$

市川尚 $(M D)^{21}$, 中島秀晶 $(M D)^{21}$, 昆晃 $(M D)^{3)}$

真宮裕 $(M D)^{3)}$, 尾上明 $(M D)^{3)}$, 佐々木喜一 $(M D)^{3)}$

防衛医科大 麻醉科青木正 (MD)

重複癌の発生頻度は2 10\%といわれ、年代の 推移とともに增加しつつある。大腸重複癌の他葴 器癌としては胃癌が最も多く以下乳癌、子宮癌の 順である。今回我々は回盲部大腸癌と子宮頸部癌 の同時重複虏を経験したので報告する。

[症例] 66歳 女性 4 妊 4 産

平成元年 6 月右下腹部圧通、便秘にて来院。同 年 8 月 10 日大腸内視鏡検査で回盲部直下に隆起性 病变を認娼 D p sy施行。腺癌と診断され8月23日 右結腸半切除術、組織診においては腺癌であった。 腹膜、右結腸動脈領域と付属りンバ節に転移を認 めた。子宮および付属器への浸潤精查の為婦人科 受診。肉眼的に特に所見は認められなかったが子 宮頸部スメアで扁平上皮癌を考えた。11月28日両 側付属器を含む単純摘出術施行。1 扁平上皮癌であった。

〔細胞像〕子宮頸部のスメアでは全体として旁 基底型を中心とした閉経像であった。核はクロマ チン細顆粒状及び核濃縮像を示し細胞質は比較的 広く境界不明膫な合胞状の細胞集団が見られた。 又一部には細胞質はレース状でライトグリーンに 淡染、核の大小不同、重積性が見られクロマチン は細顆粒状であった。以上の細胞像より扁平上皮 癌を考えたが一部に腺癌を思わせる細胞集団を認 め、重複癌が大腸癌の再発かを迷ったが術後摘出 標本は非角化型扁平上皮癌であった。

〔組織像〕回盲部はBorrman型の進行癌で組織 学的には中分化型の乳頭状腺癌であった。子宮の 組織標本は充実性で扁平上皮癌の増殖がみられ腺 の退縮が著明であった。組織診断は大細胞性非角 化型扁平上皮癌であった。 


\section{7. 性器外臟器癌の子宮頸部転移の細胞像}

\section{九州大学医学部婦人科学産科学教室}

O重松敏之 (MD), 井町正士 (MD), 塚本直樹 (MD), 渡辺寿美子 (CT), 中野仁雄 $(\mathrm{MD})$

子宮頸部細胞診に、子宮以外の藏器の腫煬細胞 が出現する頻度は稀で、子宮頸部細胞診の約 0.01 \%といわれている。そのなかで性器外臟器由来の 腫湯細胞が出現することは、約半数と報告されて いる。なかでむ、子宮頸部に病理組織学的に転移 を確認された症例は少ない。今回われわれは、子 宮頸部細胞診で性器外臟器由来の腫演細胞が出現 した症例のなかで、病理組織学的に子宮頸部に転 移を確認された 6 例について細胞病理学的に検討 した。

6 例の内訳は、胃癌 3 例、結腸癌 1 例、回盲部 癌 1 例、胆管癌 1 例であった。いずれの細胞診む 綿棒擦過により採取した。胃癌の 3 例では比較的 きれいな背景に、異型腺細胞が主に集団を形成し て出現していた。核は類円形〜紡錘形、大小不同 を軽度に認め、クロマチンは正常ないし細顆粒状 に増量、核小体はやや腫大したものを $1 \sim 2$ 個認 めた。細胞質はレース状で比較的豊富であり、細 胞境界は明瞭であった。3 列すべてに印鑑細胞を 認めた。結腸癌の1例では核の大小不同を認め、 細胞質の豊富な異型細胞が集団として出現してい たが、背景はきれいであった。回盲部癌の 1 例で は大小不同をほとんど認めない類円形の核を有す る細胞が、シート状ないしは柵状に出現していた。 クロマチンはやや増量し、核小体は軽度腫大して いるが、正常腺細胞とほとんど区別できなかった。 胆管癌の 1 例では、大小不同を軽度に認める類円 形〜紡錘形の核と豊富な細胞質を有する細胞か、、 多数シート状あるいは柵状に出現していた。

6 例飞共通している所見は、比較的きれいな背 景に正常な子宮内膜細胞とは異なる細胞を認めた ことであり、細胞の異型の程度は重要な所見では なかった。
358. 子宮原発悪性リンパ腫の一例

\author{
札幌医科大学産婦人科学講座 \\ ○堀本江美 ( M D ), 寒河江语 (MD), \\ 工藤隆一 ( M D ), 橋本正淑 ( M D )
}

子宮原発の悪性リンパ腫は極めて稀な疾患で我 が国では10数例報告されているに過ぎない。今回 子宮原発の悪性リンパ腫の一例を経験したので細 胞ならびに組織所見を中心に報告する。

症例: 70 才, 主訴, 血尿打よび性器出血, 入院 後 1 側の水腎症が認められ, ガリウムシンチ, およ び C T で子宮, 内腸骨リンパ節, 後腹膜リンパ節 の腫大が認められた。その他の検査所見ではLDH 値が著明上昇していた。Ann Arbor分類では Stage II Eとされるもので, 化学療法後, 症状の改善を みた。

しかし更に放射線治療を追加したが約 1 年后死 亡。

子宮頸部細胞診 : 出血を背景に $N / C$ 比がきわめ て大で, 裸核状に見える円形の細胞が散在性に出 現していた。これらの細胞の核は $4 \mu$ 程度で小型 の屯のが目立った。細胞形態は種々で核形が不正 で切れ込み屯認める細胞, 過染性の核を有する核 形不正な細胞, 小型円形核で濃染した細胞, 核ク ロチンが核縁に凝集した細胞，比較的大型でや〉 細胞質が目立ち核小体の肥大した細胞等に大別さ れた。これらの細胞は小型であるがそれぞれ大小不 同と形態の不正, 核クロマチンの増量から非上反 性の悪性腫瘍の存在が考えられ, 胞性頸管炎で の均一な形態のリンパ球とは異った細胞所見を呈 した。

子宮頸部生検組織, 中型 小型で $\mathrm{N} / \mathrm{C}$ のきわめ て大きく大小不同が著明なりンパ球と思われる 細胞がびまん性に分布しており, 免疫組織化学的 検討より B 細胞由来のびまん性悪性リンパ腫中細 胞型と診断された。 
359. 卵管原発の明細胞癌の体腔液中細胞像

\author{
西宮市立中央病院 臨床病理科 \\ O桧山弘道 ( C T )、野村京子 ( C T )、 \\ 玉井正光 ( M D )
}

卵管原発の明細胞癌は極めて稀で、我々の症例 が本邦で 2 例目の報告例である。今回、我々は術 後再発として胸腹水及び心襄液中に多数の $\mathrm{mi} \mathrm{r} \mathrm{r}$ or b a 11 pat tern と砂粒体が同時飞出現 した症例を経験したので報告する。

〔症例〕患者は 50 歳、女性。下腹部膨満感を主 訴として来院した。子宮癌検診にて子宮筋腫の指 摘をらけていたため精査したところ、子宮筋腫及 び右卵巣腫瘍と診断され、子宮全摘及び両側附属 器摘出術が施行された。手術時、約 $200 \mathrm{ml}$ の血 性腹水があり、細胞診で腺癌細胞を認めた。腫瘤 は成人頭大で、病理診断は右卵管原発の明細胞癌 であった。術後 2 年して頸部リンパ節に転移し、 胸腹水及び心囊液が貯溜して癌死した。〔細胞像】 赤血球、リンパ球を背景にシート状や重積性の細 胞集塊が多数出現していた。集塊の中には球形中 空なmirror ball pat ternが多数存 在した。その細胞は、細胞質が広く、レース状で 明るく、核は類円形で大小不同がややあり、ク口 マチンは顆粒状で 1～3 ケの小さな核小体を持っ ていた。砂粒体は心囊液中に多数出現し、不規則 重積性の細胞集塊内に存在していた。P A S 染色 では、主に不規則重積性集塊を成す細胞が陽性を 呈した。〔組織像〕腫瘍細胞は淡明な細胞質に富 み、乳頭状、充実性あるいは管腔や囊胞を形成す るといら多様な発育形式を示した。腺腔部では h ob n a i 1 型細胞がみられた。〔まとめ〕体腔 液中 r m i r r o r ball pat t e r n 砂粒体 が同時に出現した場合、卵巣原発の明細胞癌であ る可能性が高いといわれている。しかし、極めて 稀ではあるが本例のよ5に卵管原発のこともあり 留意すべきであると思われた。
360. 卵巣浆液性境界腫場の腹水細胞像

琉球大学医学部第 1 病理学教室*

同 産婦人科学教室 $* *$

$\bigcirc$ 新垣京子 $(M D) *$, 仲間 健 (MD)*, 山城竹信 $(M D) * *$, 東 政弘 $(M D)^{* *}$

腹膜播種を伴った浆液性境界腫晹の 1 例を経験 した。症例は 22 歳未婚女性。昭和 63 年 12 月頃より 腹部膨満感を覚え, 平成元年 1 月某医を受診し開 腹術を施行された。開腹時, 表面に乳頭腫様の発 育を伴う, 小児頭大の両側性卵巣囊腫が認められ た。表層病変部を部分切除し内容液を吸引して手 術を終了したが, 再度腹部膨満が出現したため本 年 4 月琉大産婦人科へ紹介された。

当科で再開腹を行なったところ、膜腔内には浆 液性腹水が $200 \mathrm{ml}$ 貯留し, 左側卵巣に小児頭大の, 右側卵巣に超手拳大の囊腫がみられ, 左卵巣囊腫 の表層部には, 低乳頭状の小腫瘤が増殖していた。 又, 大網や腹膜に播種を思わせる米粒大の小腫瘤 が散布していた。

腹水細胞所見では, 背景に出血壊死像は無く, 多数の中皮細胞の他に炎症性細胞抢よび組織球が 出現して抢り, それらに混在して, 低乳頭状発育 を思わせる上皮細胞の集塊が散見され, 同様な細 胞が孤立散在性にあ出現していた。それらの細胞 は, 小型類円形, 全般に均等で, 胞体にややそし く, 偏在する円形核をむち, クロマチンは粗顆粒 状，核小体は目立たない。又, psammoma body を推定させる小石灰化巣も散見された。病理組織 学的には, 左卵巣囊腫は乳嘴状発育を呈する浆液 性境界腫瘍であり, 腹膜播種を伴っていた。

卵巣の浆液性境界腫湯の腹水細胞像は, 組織像 をよく反映して㧍り, 異型性はみられるが腺癌細 胞に比べると悪性所見に乏しく, 反応性中皮細胞 や中皮腫との鑑別が重要であると考えた。 
361. 腹水細胞診および腹腔内擦過細胞診 による卵巣癌の腹腔内蔓延状況の検討

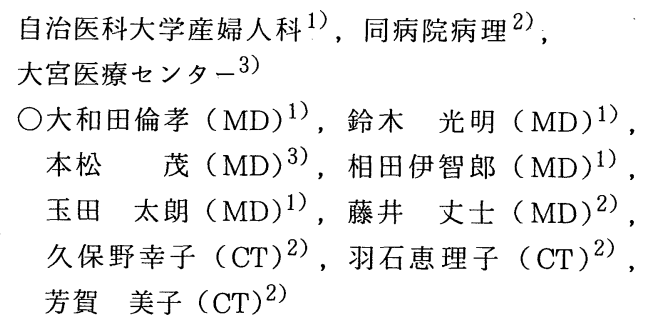

卵巣癌における腹腔内蔓延状況を把握する目的 で，1988年より従来行っていた腹水細胞診に加え て, 新たに腹腔内擦過細胞診を実施している. 現 在までにのべ30例に施行したので，その成績を報 告する. 対象は1988年以降に自治医科大学産婦人 科で治療を行った卵巣癌30例である。臨床進行期 別分類は I 期 4 例， II 期 3 例，III 期 17 例，IV 期 3 例および再発 3 例である。組織型別では浆液性癌 17 例, 粘液性癌 5 例, 類内膜癌 4 例, 明細胞癌 2 例, その他 2 例である. 30 例のうち, 初回手術時の細 胞診施行例は 13 例, SLO時の施行例は 14 例, 再 発手術時の施行例は 3 例である。細胞採取部位は 腹水, ダグラス窝, 腸骨窝, 直腸, 大腸, 小腸, 胃，肝および横隔膜表面である。その結果，初回 手術例では，I 抢よびII期の症例では腹腔内細胞 診は全て陰性であったが, III , IV 期では全例で悪 性細胞が確認された。採取部位別の陽性率は, 腹 水 $82 \%$, 大腸 $80 \%$, 膀胱窩 $73 \%$, 腸骨窝64\%など, 近接臓器・組織での陽性率が高かった。な招, 肉 眼的に陰性と判断された部位のうち，約 $10 \%$ が細 胞診陽性であった。 SLO例では, 癌性腹膜炎を 呈したIV期の 1 例が全ての部位で陽性を示したが， 他の13例は全て陰性であった。な抢, 擦過細胞診 による組織型の推定は, ある程度可能だが, 困難 な症例むかなりみられた。細胞形態についても報 告する予定である。
362. 卵巣腫大の著明でない進行卵巣癌の臨 床細胞学的検討

\section{勤医協中央病院病理科}

○吉川郁子 (CT)、中邦子 (CT)、尾崎睦美 $(C T)$ 小松一弘 (MD)、中川祐子 (MD)、小玉孝郎 (MD) 勤医協札幌病院産婦人科

坂本和利 $(M D)$ 、古堂俊哉 (MD)、片桐博 (MD)

臨床症状から進行した卵巣癌が疑われるにもか かわらず卵巣の腫大を認めない症例を経験した。 乙れらの卵巣癌は原発不明の悪性腫瘍として扱わ れ開腹手術によりはじめて診断されるてとが多く 臨床細胞学的にあ興味のある問題である。

【症例 1 】40才、腹部膨満感により精查し、腹水 中に腺癌細胞を認める。CA $1259550 \mathrm{U} / m \ell$ 之高值 であるが画像診断上は特に明確な異常を認めなか った。腹水は多量に採取され、黄色やや透明であ り、パパニコロー染色にて重積された集塊にNC 比大、核の濃染、大小不同を認める腺癌細胞を認め

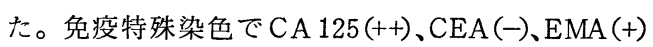
であった。開腹術の腹腔内の検索により卵巣原発 の墏液性卵巣癌之診断された。

【症例 2 】2 才、腹部膨満感により精查し、腹水 中に腺癌細胞を認める。CA $1258600 \mathrm{U} / m \ell$ 之高值で あるが画像診断上は腹水多量以外飞特に明確な異 常を認めない。腹水細胞は症例 1 と同様の腺癌細 胞を認め、免疫特殊染色でCA $125(++) 、 C E A(-)$ EMA (+)であった。開腹術の腹腔内の検索により卵 宩原発の墏液性卵巣癌之診断される。

【考察】卵巣腫大のない進行卵巣癌は通常両側卵 巣に癌が存在し、腹腔内の播種を認め、組織学的 には漿液性腺癌であるという共通した特色を認め serous surface papillary carcinama of the ovary (WHO) の名称が用いられている。これら の症例の腹水腺癌細胞を中心にその臨床細胞学的 特徴について報告したい。 
363. 中間型トロホブラストにおける細胞 学的検討 ( P S T T を中心に)

宝塚市立病院中央検查室病理 ${ }^{1)}$ 同産婦人科 ${ }^{2)}$

太子やえ (C T ) ${ }^{1)}$ 小松敏也 (C T ) ${ }^{11}$

伊熊健一郎 (MD) ${ }^{2)}$

兵庫県立西宮病院病理 與梠 隆 (MD)

兵庫医科大学産婦人科 竹村 正 (MD)

Intermediate trophoblast (以下It) は正常 妊娠に扣いて子宮内膜や子宮筋層にも存在し、䋐 毛構造の構築に関与するととなく、妊娠の着床部 にて母体細胞と混在し母体血管へと侵入してゆき 新たな絨毛間腔の形成に関与するものと考えられ ている。即ち、母体之胎児間での血液循環に重要 不可欠な役割を果たしている。しかしItに関する 細胞診断学的所見および組織診断学的所見には未 だ不明な点が多い。

1984年 Kurmanらが定義付けしているように免 疫組織化学的にhuman placental lactogen (以下 hPL）を多く含む単核、紡錘型のItから成るPlacental site trophoblastic tumor (以下PSTT) $に$ ついて先頃細胞診学的に検索する機会を得たが、 今回我々はPSTTを含む一連の絨毛性疾患における Itの局在及び形態学的所見について検討した。

材料は 妊娠 12 週 (人工流産)、妊娠26週(子宮内 胎児死亡)、妊娠 40 週 (正常分娩)より得られた胎 盤、及び胞状奇胎、侵入奇胎、絨毛癌、PST と診 断された症例から得られた手術標本を用いた。

上記症例に扑て、Cytotrophoblast Syncytiotrophoblast Intermediate trophoblastを鑑 別すべく $\beta$-HCG hPL PLAP Keratin SP1等の免 疫組織化学的検索を試みた。同時にタッチスメア についてもhPLの局在を指標にItを同定し、組織 診と細胞診との対比を行い若干の知見を得たので 報告する。
364. in vitroおよび in vivoにおける婦 人科悪性腫瘍の細胞学的比較検討

\author{
大阪医科大学産婦人科学教室 \\ O植木 健 (MD), 植田政嗣 (MD), 岡本吉明 (MD) \\ 山田隆司 (MD), 前田隆義 (MD), 杉本 修 (MD)
}

【目的】近年, 婦人科悪性腫瘍の診断や治療の基 礎的検討に種々の培養細胞が用いられているが. in vitroの特殊な環境下で増殖する培養細胞の形 態は生体からの䐣離細胞とは異なることが多い。 培養細胞から得られた知見を細胞診断学に役立て る際, その in vitroとin vivoにおける形態学的 類似・相違点を明確にしておくことが重要と思わ れるので以下の検討を行った。【方法 IOMC-1 (頸 部扁平上皮癌株), $\mathrm{OMC}-2$ (内膜腺癌株) , $\mathrm{OMC}-3$ (卵 巣ムチン性腺癌株), OMC - 4 (頸部腺癌株), OMC-6 (内 膜間質肉腫株）を用いた。各々の原腫瘍組織擦過 - 捺印細胞, 培養細胞および異種移植腫瘍組織掩 印細胞の形態をPapani colau 染色により対比した。 【成績】単層培養細胞では, OMC-1,2,3,4はいず れも多稜形ないし紡鍾形で、上皮性敷石状配列を なし, 核縁は肥厚, 核クロマチンは細〜粗顆粒状 で明瞭な核小体がみられた。細胞質はレース状で ライトグリーンに染色された。OMC-6は線維状な いし紡錘形で, 細胞間結合はゆるく、核クロマチン は細顆粒状で明瞭な核小体がみられ, 細胞質は比 較的豊富で菲薄であった。これらを原腫瘍細胞診 所見と比較すると, 上皮性・非上皮性の特徵は保 持されていたが, 組織構築を反映しないことから, 扁平上皮系・腺系の区別や由来臓器の推定は困難 であった。移植腫瘍择印細胞診では, お抢むね原 腫瘍での所見に類似していたが,核縁の肥厚や不 整, 核クロマチンの増加, あるいは多核細胞や mitosisの出現が目立ち, 核小体もより明瞭に観 察された。【結論】培養実験での形態学的変化の 解釈には, 培養細胞では構造異型が反映されない こと, その移植腫瘍組織細胞診では細胞異型がや や強調されることに留意すべきと考えられた。 
365. 便細胞診で悪性リンパ腫が考え られた一例

市立加西病院 $\bigcirc$ 足立弝 (CT)、松代光代 (CT) 黒鄉文雄 (MD)、坪田徹 (MD)、本岡龍彦 (MD) 神戸大学医学部第二病理学講座

藤盛孝博 (MD)、北沢花平 (MD)、前田盛 (MD) 兵庫県立成人病センター指方輝正 (MD)

恶性りンパ腫は消化管では粘膜深首ないし、粘 膜筋椱直下のリンパ組織から発生し、回腸末端部 に好発する。我々はこのたび便細胞診で異型リン パ球を多数認めた一例を経験したので報告する。

症例：6才、男子、体重 $18 \mathrm{~kg}$

主訴 : 腹痛

約3ヶ月前より、時々腹痛を訴えるも臍疝痛と のことで経過観察中であったが、1 1 月下旬より 症状增覀し、平成元年 11 月 29 日紹介入院す。

上腹部正中に軽度圧痛を伴う、可動性、弹性硬 の旌卵大の腫瘤を触診した。その他頸部、腋窩、 鼠径部にえん豆大以下の軟いリンパ節を多数触診 した。

細胞所見：便細胞診では粘血便で、食物残渣等 の他の成分は殆んど認められず、多数のリンパ球 と組織球で占められていた。リンパ球は小〜中型 でN/C 比大、クロマチンは粗顆粒状で1 数個 の明暸な核小体を認めるもの、また裸核状のもの 等あり、变性強く確定診断には至らなかったが、 悪性リンパ腫が強く疑われた。手術時择印細胞診 にても便細胞診に認められたのと同様の異型りン パ球を認めた。

病理組織学的所見 : 腫瘤は回腸末端部に在り、 大きさは $4.0 \mathrm{~cm}$ の球形をなし、表面暗赤色易 出血性で、横行結腸まで腸重積を形成していた。 腫瘵割面での基部は白色充実性のようにみえた。 組織学的には中等大の比較的つぶのそろった腫 瘍細胞がびまん性に增殖し、核は円形で核膜明瞭 である。核小体が目立つものもある。びまん浸潤 は辺緑ではリンパ汇胞が残存しているところや、 一見starly-sky様のところもあった。
366. 胸水中に腫瘍細胞が出現したマクロ グロブリン血症を伴った悪性リンパ腫の二例

群馬大学医学部附属病院中央検查部病理

群馬大学医学部附属病院第二内科*

国立栃木病院研究検查科 $* *$

O関口桂子(CT), 堀越美枝子(CT), 細村泰夫(MD) 倉林良幸(MD)，小山徹也(MD)，伊藤秀明(MD)， 城下 尚 $(M D)$, 神山由香利 $(M D) *$, 小島 勝(MD)**

縦隔より発生し腫瘍細胞を胸水中に認めたマク ログロブリン血症を合併した悪性リンパ腫を経験 したので細胞学的所見に加えて兔疫学的所見を合 わせて報告する。症例は64才、男性。平成元年 8 月中旬より夜間の喘鳴が出現し 9月12日当病院を 受診し、胸部 $X$ 線にて胸水眝留を認め9月18日人 院となった。人院時の末梢血検査は赤血球数 471

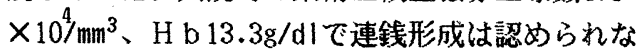
かった。白血球数は $8 \times 10^{3} / \mathrm{mm}^{3}$ であったがリンパ 球の $1 \%$ 異型を認めた。血清免疫グロブリン IgG1116mg/dl 、|gA274mg/dl、|gM1373mg/dl は、胸水では|gG794mg/dl、|gA186mg/dl、|gM $3262 \mathrm{mg} / \mathrm{d}$ 〕 と単クローン性に著しく増量してい た。しかし、尿中のBence-Jones 蛋白は陰性で あった。また骨能への腫瘍細胞の浸潤は認められ なかった。胸水のギムザ染色標本では小リンパ球 に混じて異型を有する中〜大型の腫瘍細胞が散見 された。大型の腫湯細胞のN/C 比は低く、核は偏 在傾向を示し一部に多核細胞を認めた。核型は不 整を示し切行込みや花菜状のものも認めた。核小 体は明膫で1 〜数個認めた。細胞質は好塩基性を 呈し、核周明庭を示し一部の細胞に空胞を認め た。胸水のセルブロックの免疫染色標本では出現 細胞の大部分はりンパ球でこ机らは1gG、IgA、 IgM、火鎖、入鎖のいずれも陰性、MT-1、UCHL-1 は陽性を呈したことから T 細胞性りンパ腫と診断 し反応性にマクログロブリ血症が合併したと考え られる。 
367. 穿孔性腹膜咨ををえした空腸悪性リン パ腫の一例

一 腹水悪性細胞の D N A 解析を中心として—

東邦大大橋病院病理, 第三内科, ${ }^{2)}$ 相互生物医学研 究所病理 ・ 細胞診センタ- ${ }^{3)}$

○藤田正志 $(\mathrm{CT})^{1)}$, 田口勝二 $(\mathrm{CT})^{1)}$, 岩原 実 $(\mathrm{CT})^{1)}$, 甘利保子(CT) $)^{1)}$, 直江史郎 $(M D)^{3}$, 河口 健 $(\mathrm{MD})^{2)}$ 町井 潔(MD), 大塚重則(CT), 田中 昇(MD, DDS $)^{3)}$

腹水細胞診で悪性リンパ腫と判断したが、その 後、剖検にて空腸・その他にリンパ球様細胞浸潤 をみたにすぎず、悪性リンパ腫の存在に疑いがる えれた。そてで、生前の腹水細胞診の材料でDNA 定量分析し、悪性リンパ腫と確認出来た例を経験 したので報告する。

症例：40才、女性、(事務員)

主訴： 腹部膨满感、下痢、黒色便

現症： 昭和 63 年 5 月 9 日 主訴にて入院。腹水細 胞診で大ささ㤝ば均一で径 8 10 10mの、細胞が孤 立散在性にみられた。N/C 比は高く核の切れ込み あり、クロマチンは細顆粒状で細狍分裂像が混在。 細胞質類円形、塩基性でそしい。以上から悪性り ンパ腫と判断した。しかし、X線唀視下で空腸に 辺縁不整の狭窄をみた他に、諸検查で悪性所見は 得られなかった。6月 6 日空湯穿孔で死亡。剖検 にて空腸穿孔部を中心に消化管・子宮・卵单にリ ンパ球様細胞漫潤をみたが、明確に悪泩リンパ腫 といえる所見がなかった。

そこで、生前椱水細胞彰標本にHP/DAPI 重染 色を施し、UV-顕政分光測光にて, 生前細胞診 所見の確認を行った。との結果、出現細胞は 3.65 にピークをるつD N A 量分布を示し、悪性リンパ 腫として矛盾しないと判断された。

本例任、画像診断・生検にて確定猃断が得られ ず、細胞診のみが診断の決め手となった例であり、 日常細胞診の結果をより客観的に評価する上で、 D N A 定量分析が極めて有効であった。
368. 術前診断が困難であった前縦隔悪性リ ンパ腫 (Hodgkin 病、結節硬化型) の 1 手術例

県西部浜松医療センター 胸部外科 ${ }^{1}$, 呼吸器科 ${ }^{2}$ 同 検査科病理 ${ }^{3}$, 同 細胞診 ${ }^{4}$

O佐々木一義 $(M D)^{1}$, 半沢 儶 $(M D)^{1}$, 由佐俊和 (MD) ${ }^{1}$ 馬場雅行 (MD) ${ }^{1}$, 橋爪一光 (MD) ${ }^{2}$. 笠松紀雄 (MD) ${ }^{2}$ 小澤享史 $(\mathrm{MD})^{3}$ ， 村松一己 $(\mathrm{CT})^{4}$, 倉形順子 $(\mathrm{CT})^{4}$

縦隔腫瘍の中で悪性リンパ腫の占める割合は約10 \%とされているが, 本邦においてはNon-Hodgkin リ ンパ腫が多く、縰隔病変を主体としたHodgkin 病は 比較的稀と考えられる。今回我々は, 術前の形態学 的確定䛦断が困難であったため手術を施行した, 前 縦隔Hodgkin 病の 1 手術例を経験したので，その捺 印細胞所見と組織所見との比較を中心に報告する。

【症例】 31 才男性。昭和63年4月に咳嗽，発熱等の 症状で近医を受診, 胸部異常陰影を指摘され当セン ターに入院した。画像所見では, 前維隔を占拠する 巨大な縱隔腫瘍を認めた。前胸壁より 3 回の針生検 を施行するも，線維性組織の他に特記すべき所見が 得られず，また腫瘍は急速な増大傾向を示したため 昭和63年 6 月, 手術を施行した。腫瘍は前上縦隔に あり $12 \times 9 \times 5 \mathrm{~cm}$, 右肺上葉への浸潤を認め, 腫瘍 摘出・右上葉切除術を施行した。

【切除腫瘍捺印細胞所見】細胞成分は少ないものの 大型でやや濃縮した核を持った裸核状細胞，核小体 の比較的目立つ数個の核を持った多核細胞，その他 リンパ球，線維芽細胞等が散在性に認められた。

【病理組織所見】腫瘍組織は膠原線維の増生が著明 で，その線維性組織の中に細胞浸潤が島状に認めら れた。浸潤する細胞は異型性のないリンパ球, 単核 巨細胞そしてReed-Sternberg細胞と考えられる多核 巨細胞等であった。以上よりHodgkin 病, 結節硬化 型と診断された。 
369. 胃病変を初発症状としたA $\mathrm{T} L$ の 一例

社会保険佐賀病院 検查科 $*$ 内科 $* *$ 外科 $* * *$ O吉井 務 $(\mathrm{CT}) *$ 山下文彦 $(\mathrm{MD}) * *$ 桑木利光 (MD) ** 樋口隆一 (MD) *** 石橋興一 $(M D) * * *$

聖マリア病院病理部

大田喜孝 $(\mathrm{CT})$

佐賀医科大学病理学教室

徳永 藏 (MD)

今回、胃病変を初発症状とし、手術後A T L と 診断された症例を経験したので報告する。

患者は 50 才男性で、血便を主訴とし来院、入院 時の検查で胃にBor r man 3 様の腫瘤を認め、生検 では悪性リンパ腫が強く疑われた。入院時表在 リンパ節腫張や、血液学的には異常が認められず 胃原発の悪性リンパ腫と診断。2 週間後胃全摘 出術を施行。手術時の細胞診及び組織診検查に よりNon-Hodgk in's Lymphoma, diffuse and medi um-size cell type と診断された。しかし手術 より 2 ケ月半後、末梢血に異常リンパ球が出現、 核異型も強く数的增加傾向を示すため A T L を疑 心検查 ATLV抗体250倍以上で、モノクロ 一ナル抗体によるリンパ球サブセット検査では Inducer/helperT の性格を示した、腫場切片の免 疫学的検索では Pan T T 4 陽性, Pan B 陰性で あったため、胃に発生した悪性リンパ腫は T cell 由来で、末梢血に出現した異常リンパ球と免疫学 的に類似性を持つものと思われた。手術後 6 ケ 月後には腹水の貯溜を認め、細胞診検查で悪性リ ンパ腫細胞が認められた。その後1ケ月後に重 症感染症で患者は死亡した。この症例は胃病 変を初発症状としたA T Lと思われ、胃原発の悪 性リンパ腫でも A T L の存在を念頭において、注 意深い経過観察が必要と思われた。
370. 経過中, 尿に腫瘍細胞が出現した非 ホジキンリンパ腫の一例

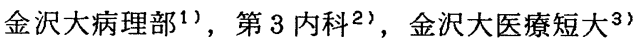
○久富元治 (CT $)^{11}$ ，川岸徳子 (CT $)^{11}$ ，野々村昭孝 $(M D)^{11}$ ，松原藤継 $(M D)^{11}$, 中村 忍 $(M D)^{21}$, 大竹 茂樹 (MD $)^{11}$, 明 茂治 $(M D)^{2)}$, 浅井由美子 $(M D)^{21}$, 谷本一夫 $(M D)^{3)}$

悪性リンパ腫細胞が尿中に出現することはまれ である。私達は, 覀性リンパ腫の膀胱浸潤にとす ない，尿中に腫瘍細胞の出現した B 細胞性リンパ 腫の一例を経験したので報告する。また，化学療 法にとむなう細胞像の変化についてす供覧する。

〔症例] 78才, 男性。昭和63年8月, 右ソケイ部 腫瘤触知。精查にて骨盤腚内に腫瘤が発見され， 生検にて，非ホジキン悪性リンパ腫，び慢性，大 細胞型と診断。64年1月より化学療法放射線療法 開始。7月より，尿中に腫瘍細胞が出現し，これ は死亡時まで持続した。同年11月，全身転移にて 死亡。

〔細胞像〕尿中の腫瘍細胞は, やや大型で, 核小 体が目だち，ときに 2 核の細胞す散見される。免 疫染色にて B 細胞性であった。死亡直前の腹水中 には, 治療にともなう細胞像の変化がみられ，木 ジキンリンパ腫様の核小体の大きな多核巨細胞が 多数, 出現した。

〔まとめ〕悪性リンパ腫細胞が尿中に出現するこ とはまれである。本例では化学療法にとすない， 興味ある細胞像の変化が観察された。リンパ腫で あ細胞診上治療にともなう細胞像の変化に十分に 注意する必要があると考えられた。 
371. 乳腺細胞診より発見されたCML の 1 例

鹿児島市医師会病院

○下津高志 (CT), 内村清孝 (CT), 黒木 力 (CT) 宮原幸実 $(\mathrm{CT})$, 大原正行 $(\mathrm{CT})$, 田中和彦 $(\mathrm{CT})$ 田中貞夫(MD)

鹿児島市立病院

上野洋二 $(\mathrm{CT})$, 藤崎人美 $(\mathrm{CT})$

症例：42歳, 女性。平成元年 9 月28日, 右乳房 の腫瘤を主訴として外科を受診。腫瘤は $2 \times 2$ $\mathrm{cm}$ 大, 可動性であり乳腺症の診断のもとに穿刺 細胞診を施行する。囊胞内容液は血性であり標 本には上皮細胞成分は少なく, 背景に多数の異 常白血球を認めた。細胞診でCMLの浸潤が疑わ れた。10月 6 日, 内科へ紹介。軽度の肝腫大と 高度の脾腫を認め, 末血所見はWBC16.54万， RBC305万, Hb8.9g/d $\ell, H t 27.1 \%$, Plat134.9万 であり血液像, 骨髄所見, さらに $\mathrm{Ph}^{\prime}$ 染色体より CMLと確診された。

細胞所見：出血性を背景に多数の血小板とと あに異常白血球を認める。顆粒球系が多く, 骨 髄芽球は $3.8 \%$, さらに各種成熟段階の顆粒球系 細胞が見られリンパ球は $1.8 \%$ 之少ない。赤芽球 系細胞も散見され, eosinophilia, basophilia が 認められた。これら細胞像は末血・骨䯣像とも に同様であり骨䯣は有核細胞数 82.2 万過形成を 示し, 巨核球の増加, $\mathrm{M} / \mathrm{E}$ 比の著しい高値が認 められた。

CMLは臨床症状に乏しく, 本例は偶然にも乳 房腫瘤を主訴として発見された。細胞同定には Giemsa染色が必要であり, Papanicolaou 染色 のみでは困難と思われた。乳房腫瘤は穿刺後消 失しCMLの浸潤と考えられた。
372. 二種類の $\mathrm{M}$ 成分 $(\mathrm{IgD}-\kappa, \mathrm{BJ}-\kappa)$ を 認めた多発性骨髄種の一例

$$
\begin{aligned}
& \text { 明石市立市民病院 病理 }{ }^{1)} \text { 内科 }{ }^{2)} \\
& \text { 中井真理子 }(\mathrm{CT})^{1)} \text {, 石丸俊子 }(\mathrm{CT})^{1)} \\
& \text { 岩本葉子 }(\mathrm{MT})^{11} \text {, 竹岡 成 }(\mathrm{MD})^{1)} \\
& \text { 林 謙宏 }(\mathrm{MD})^{2)} \text {, 中村 豊 }(\mathrm{MD})^{2)}
\end{aligned}
$$

IgD- $\kappa$ 型多発性骨䯣腫は極めて稀で, 本邦では 本例を含め 17 例にすぎない。一方， BJ 蛋白は L 鎖の dimerであり, 主に尿中に認められ, 血清 中には認めがたいとされている。今回我々は二種 類の M成分 $(\mathrm{IgD}-\kappa, \mathrm{BJ}-\kappa)$ を認めた多発性骨髅 種の一例を経験し, 酵素抗体法にて myeloma cellにIgD及びBJー をを同定しえたので報告する。 【症例】71才男性。全身倦怠感・食欲不振等を主訴 として来院。

【入院時所見】著明な貧血を認めるも黄疸・表在リ ンパ節腫脹なし。肝脾腫も認めず。尿蛋白 (\#), $\mathrm{BJ}$ 蛋白 $(+)$, 総蛋白 $8.3 \mathrm{~g} / \mathrm{d} \boldsymbol{\ell}$, 骨䯣有核細胞数 $10.3 \times 10^{4} / \mu \ell$, myeloma cell $84 \%$, セルロスアセテート膜電気泳動では $\gamma$ 領域に $2 つ$ つ成 分を認めた。一方, 血清免疫電気泳動では抗 $\operatorname{IgD}$ ，抗 $\kappa ，$ 抗 $\mathrm{BJ}-\kappa$ とそれぞれ $\mathrm{M}$ bowを形成 し, 尿免疫電気泳動では抗 $\kappa$, 抗 $\mathrm{BJ}-\kappa$ とそれぞ れM bowを形成した。

【経過】MP療法, 血漿交換療法, 血液透析を行な うも効なく第 54 病日に死亡する。

【細胞像】骨骾中の myeloma cell は大小不同, 核型不整，核網は繊細で強い異型性を認めた。酵 素抗体法 (LAB法) ではmyeloma cellはIgD及 びBJー $に$ に強い陽性を示し, PAP・APAAP法に よる二重染色では IgDで染色される myeloma cell とBJ- で染色される myeloma cell とに分 かれたがこれら myeloma cellの形態上の差異 は明確ではなかった。 
373. 尿細胞診を対象とした 検体取扱について

板橋中央総合病院研究所（IML）：病理

高桑妃佐子 (CT) . 畠山重春 (CT) 後藤恵子 $(\mathrm{CT})$. 熊谷智子 $(\mathrm{CT})$. 中野佼成病院 病理部 三浦妙太 (MD)

板橋中央娭診センター 扣藤敬三（MD）

尿中の細胞は変性が起き易く、㑒抹してもスラ 佧ガラス面放細胞剝離を来し易いため、娭体 迈理に工夫が必要である我々の施設注、グルー

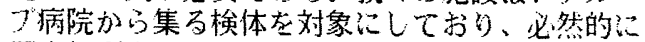
固定処理迄只時間龙経過した検体取扱和ざる。 得ない。そ己て、尿の取报法改善し、䚾活满足 す心き結果得ているのて報告する。現在までに 経験したのは次の3法でする。

1. 生尿を遠沈し、オールフロストスライドガラ 入 ( AF) 经塗抹。

2.サコマノ液に保存した沈渣遠心後、怆湓 抹。

3.サコマノ液に保存した沈渣を遠心後、ボリ工 ルリジン塗布スライト（PL）に塗抹。

いつれも沈渣を血液式に涂抹するかオートスメア 処理苔行い、スプレー固定後パバニコロウ染色。

結果：AFでは、細胞剥離纲防げるが、表面の凹凸 汃背景に目立与、鏡娭の邪魔となる。生尿注固定 まで時間を経ている為、核の脰化など細胞の変 性が著明て古り、悪性細胞ては診断困難症例が多 からた。又、粘液长含七尿では細胞が粘液に覆わ れるなど、細胞観察に困難を感しさせる傾向沉古 った。一方、等コマ/液保存した沈渣てもAF㳊よ 方影響法同様で古るが、固定によって変性が防が れ、良好な形態を保持し、背景もき机いで苟った。 サコマノ液保存沈渣をPLに塗抹した場合は、AFて 見ら机た影讣出現せず、鏡検し易い上、細胞保持 率、形態保存も良好で节った。

細胞成分の少ない娭体ですPLでは細胞量の保持 が良好であった。時間経過汇よる細胞変性は沈渣 茾コマ/液に再浮游させることにより防ぐこと がてきた。ただし、サコマノ液を用いる場合、赤

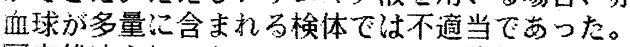
固定後遠心してもバフィーコートが分離できず、 一様に沈渣になってしまう為である。
374. 前立腺高分化型腺癌の細胞像

\author{
三重大学医学部病理 \\ O北本正人 ( C T ), 駒田佐多男 (MD), 矢谷隆 \\ - ( MD )
}

前立腺癌の死亡率は欧米諸国では高く，男性の癌 死亡率中第 2 位から 3 位を占める国が多い。本邦で も近年の増加傾向は著しく, その増加率は世界第 1 位であり，高龄化社会では特に注意を払わねばなら ない癌のひとつになりつつある。

前立腺癌の診断に際しては，欧州を中心として近 年, 前立腺穿刺吸引細胞診の有用性が示され, 我が 国でも施行頻度は増してきている。

前立腺癌には他臟器の癌に比べて極度に異型性の 乏しい高分化型腺癌や，細胞診断上注目すべき異型 像をみせる節状型腺癌 (中分化型腺癌, Gleason 分 類の pattern 3 ) がある。核の退形成の異常性はそ の微細な部分が重要な視点となるため, 多細胞性, 疎結合性, 核密集性や核重畳などの核配列異常, 微 小腺房形成などから総合的な判定が望まれる。

今回われわれは過去 2 年間に施行された前立腺穿 刺吸引細胞診で, 高分化型腺癌と診断した 7 例（陽 性 6 例．疑陽性 1 例を含む) の腺細胞異常を組織診 と比へ観察した。組織診断では高分化型腺癌5 例, 中分化型腺癌 (篩状型腺癌) 1 例, 低分化型腺癌 1 例であった。結果は, 高分化型腺癌細胞の主要所見 は次の様である。主に小さな細胞集団として現われ る。核は小型で, 核輪郭は類円形や多角形, 発芽状 のものや鋭く尖ったものもみられる。小型核に大型 の核小体がみられることもある。細胞質は薄染性ま たは難染性である。微小腺房形成がみられるなどの 所見が示された。 
375. Adenomatoid tumor の一例

戸田中央臨床検查研究所病理

O福田正彦(CT) 大川裕子(MT) 山田範幸(MT) 戸田中央総合病院泌尿器科 田辺一成 (MD)

日本医科大学老人病研究所病理 片山博徳(MT) 防衛医科大学校第一病理 河合俊明(MD) 済生会川口総合病院病理 石川宏(MD)

Adenomatoid tumor は傍精巣器官に好発し、 中皮起原が有力とされている比較的まれな良性 腫湯である。今回我々は、精巣䩪膜に発生した Adenomatoid tumor の一例を経験したので、そ の掩印細胞像を中心に報告する。

庭例 58歳、男性。15年前より左精巣に小さな 腫瘤を認めていたが放置していた。1989年 7月 31日腫瘤の增大が出現し、戸田中央総合病院秘 尿器科受診。触診にて左精栄下端に 1 c 腫瘤を認め、同年 9 月28日左精巣腫㾇の診断の もとに摘出術施行。腫瘦割面は灰白色で渦巻状 模様を呈し、精巣䩗膜との連続性をもち、境界 明暸であった。

捺印細胞所見 腫瘍細胞は小型で大小不同や異 型にそしく、類円形から多稄形まで多彩で、相 互に結合する僋向を示し、細胞集塊の辺緑や細 胞境界は不明暸であつた。核は類円形で核縁の 肥厚はみられず、クロマチンは微細顆粒状で軽 度增量していた。小型の核小体が1個みられる ものが多く、核内空胞もしばしば認められた。 細胞質はレース状でライトグリーンに淡染し大 小の空胞形成がみられた。

組織所見 立方状の上皮様細胞と扁平な内皮様 細胞が不規則な管腔形成するかあるいは索状配 列を示し、PAS染色(-)、ア阳涑青染色(+)の粘液 を産生しており Adenomatoid tumorと診欮した。 酵素抗体法ではEMA、Vimentin、Factor-泟など が陰性でKeratinのみが陽性を示した。

奄㩆所見 細胞質内小器官は乏しく、多数の微 絾毛を有する細胞質内空胞やトノフィラメント をもつ腫瘍細胞がデスモゾームにより接合して いた。
376. 成人に発生した精巣Leydig細胞腫 の 1 例

帝京大学溝口病院 臨床病理科 *、同泌尿器科** O吉元 真 $(C T)^{*}$, 山田 正人 $(M T) *$, 水口國雄 $(M D) *$, 金親 史尚 $(M D) * *$

睪丸間質細胞由来の Leydig 細胞腫は発生母地 の機能、間質細胞の Androgen 産生能を保ちつつ 腫瘍化する比較的稀な腫瘍で全睪丸腫瘍の0.3 $3 \%$ と言われている。今回、我々は左陰囊内腫瘤 を主訴とし来院したLeydig細胞腫を経験したので 細胞学的、組織学的検討を加え報告する。

\section{【症例】}

49才男性。平成元年8月頃より左陰囊が徐々に大 きくなるのに気付き 9 月当院必尿器科を受診。

\section{【検査所見】}

左陰囊内に鶏卵大の無痛性腫瘁を触知。陰毛、陰 茎は正常で女性化乳房も認められず、各種ホルモ ン、腫瘍マーカ一等も異常値を示さなかった。

【手術時捺印細胞診】

腫瘍細胞は結合性強く、細胞境界明瞭で胞体は円 形〜多形で明るく、一部胞体内に滴状の好酸性物 質を認めた。核は軽度の大小不同を伴い、クロマ チンは粗顆粒状で 1 2 個の核小体を認めたが N /C比は小で、細胞分裂像も少なく、細胞学的には 強い悪性を示唆する所見は得られなかった。また 強い異型を示す定型的 Seminoma との鑑別も比較 的容易であった。

【病理所見】

被膜化された $4 \times 4 \mathrm{~cm}$ の出血を伴う黄白色、弾性 硬腫瘍で中型多形の淡明胞体を有する細胞が索状 〜不正形な集族巣として見られ被膜浸潤(-)、血管 、リンパ管侵襲(-) で中間型 Leydig 細胞腫と診 断された。以上の所見に免度染色、電影所見を加 え報告する。 
377. 陰囊水腫夜にみられたバンクロフト 系状虫

社会保険横浜中央病院検査部 ${ }^{1)}$, 同泌尿器科 ${ }^{2)}$

O富木直人 $(\mathrm{C} \mathrm{T})^{1)}$, 渡辺美代子 (MT $)^{11}$ 小池勝利 $(M T)^{1)}$, 斎藤 忠則 $(M D)^{2)}$ 林 志隆 (MD) ${ }^{2)}$,

横浜市立大学医学部病院中央検査部細胞診 桔梗辰三 (MD)

我々は、陰囊穿刺液細胞診で、バンクロフト 釆状虫のミクロフィラリアを認めた症例を経験 したので報告する。

患者は、27歳、男性、昭和63年10月中旬に中 国福建省より修学生として来日、現在日本語学 校に通学中、平成元年 9月中旬より陰囊の腫張 を訴え、他医に 2度受診するも回復せず、10月 下旬当院泌尿器科を受診し、陰囊穿刺が行われ た。

塗抹所見 : Papanicolaou染色では、赤血球に 混じり、赤茶色に染まった数多くの細長い虫体 が認めら扎たため、無染色標本とGiemsa染色を 追加した。

虫体所見：長さ2 $40 \sim 300 \mu$ 、幅3 5 $\mu$ で薄い 被鞘を有し、ほとんど無色透明、頭部は鈍円、 尾部は細くなっている。体内には細胞核が認め られる。マレー禾状虫のミクロフィラリアとの 鑑別点は、尾核の有無で鑑別が可能である。

なお、種の同定に関しては、横浜市立大学医 学部奇生虫学教室の大島教授に判定をいただき バンクロフト采状虫のミクロフィラリアと診断 した。

まとめ: 最近寄生虫疾患は、少なくなり、特 にフィラリア症は、関東地域ではほとんどみら れない。しかし、一度これをみておけば次の機 会には極めて簡単に思い出せるであろう。

\section{8. 督血管笳脂肪腫の 1 例}

斎生会松阪総合病院検查科 ${ }^{11}$, 泌尿器科2)

松阪中央総合病院郜床病理科 ${ }^{3)}$

O前田勝彦(C.T. $)^{1)}$ 伊藤真子(C.T. $)^{1)}$

笠井久豊(C.T. $)^{1)}$ 森 脩(M.D. $)^{2)}$

上森 昭(C.T. $)^{3)}$ 石原明徳(M.D. $)^{3)}$

症例：45才 女性。成人病検診のため当病院受診、 腹部エコーにて右腎下極に2cm大の hyperechoic mass が認められ，1989年3月12日，精査のため 入院した。腎血管筋脂肪腫が疑われたが悪性腫瘍 む否定できなかった。4月5日 堅部分切除術が施 行され，術中捺印細胞診で督血管筋脂肪腫を疑い， 迅速組織診断で堅血管筋脂肪腫と診断された。 細胞所見：重積性を示す細胞集塊は，細胞の配列 不整, 核間距離不定, 細胞境界は不鮮明であった。 細胞形態は紡鍾形細胞が主体を占め細胞筫はは泡抹 状，核は卿円形から長円形で，N/C比は小であっ た。核クロマチンは細網状で，小型の核小体が 1 〜2個認められた。ときに細胞集塊の中に細胞質 が空胞状で不染性の大型細胞がみられ，核は偏在 性でN/C比流小さく，脂肪細胞と判定された。一 方, 散在性の細胞群は，ほとんどが円形核を有す る裸核状の細胞で，孤立性または pair で出現し た。細胞質及じ細胞境界は不明暸だった。核は類 円形で核の大小不同（2〜3倍大）がみられた。 クロマチンは細網状または細顆粒状で，核小体は 1〜2個認められた。また，ごく小数ではあるが， 線状配列を示す細胞群がみられた。

まとめ: 本症例は紡鍾形細胞, 脂肪細胞の出現か ら腎血管筋脂肪腫と判定される。裸核状細胞は, 督細胞癌との鑑別が困難であるが, pairの核配列 は平滑筋練胞の連珠状配列核に類似し，堅血管筋 脂肪腫の判定に有効な手がかりになると考えられ た。電顕像, 免疫組織化学染色についても報告す る。 
379. Congenital Mesoblastic Nephromaの 1 例

久留米大学第二病理 ${ }^{1}$, 同小児外科 ${ }^{2}$

○入江砂代 $(\mathrm{CT})^{1}$, 藤戸好典 $(\mathrm{MD})^{2}$,

矢野博道 $(\mathrm{MD})^{2}$, 入江康司 $(\mathrm{MD})^{1}$, 森松 稔 $(\mathrm{MD})^{1}$

近年，典型的腎芽腫とは臨床経過や組織像の異 なる腎腫瘍の報告があり，新生児期にみられるも のに congenital mesoblastic nephroma(以下 CMNと略)がある。今回CMN : cellular variant と考えられる稀な症例を経験したので報告する。 症例：3 生日, 男児。在胎 40 週, $3400 \mathrm{gr}$ にて分 婏。生後まむなく血尿が出現し, 右腹部腫溜を触 知し当大学小児外科入院。腎芽腫の診断にて手術 施行。腫瘍は右腎中央部に位置し, $10 \times 7 \times 6 \mathrm{~cm}$,

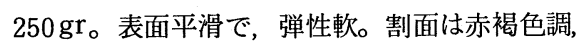
分葉状で小出血壊死巣をみる。細胞所見 : 腫瘍 の一部を捺印標本とし，パパニコロウ染色を行い 観察した。腫瘍細胞は壊死を背景とし集塊状〜孤 在性に出現し，ライトグリーン好性の紡錘形細胞 質に，楕円形核を有し，クロマチン網は細顆粒状 密であった。多数の裸核状細胞もみられるが，大 小不同はみられなかった。以上は線維芽様細胞の 増殖する病変と考えられた。組織像・電顕像 : 紡鍾形細胞の束状で互いに交叉し増生し, 出血壊 死をみる。核の大小不同はみられないが細胞成分 に富み，また，核分裂像を $4 \sim 5$ 個／高視野みと め, CMN : cellular variant と診断した。電顕 像も線維芽様細胞から構成されていた。 なおCMN : cellular variantと鑑別を要するも のとして, 腎芽腫の肉腫型 clear cell sarcoma of kidney があり, 肋骨転移栄針生検細胞診像を 併せ報告する。
380. 副腎褐色細胞腫の一例 一特に E G C及びクロモグラニン A + B の免疫細胞化学一

公立甲賀病院 検查科

○迲岡俊幸 (CT)、山本昌弘 (CT)、川尻敏夫 (MT)

済生会滋賀県病院 検查部

小林忠男 (CT)、植田正己 (CT)

大阪大学医学部附属病院 病理部

桜井 幹已 (MD)

【目的】蝎色細胞腫はカデコールアミン産生を特 徴とする内分泌系腫場でその形態同定にグリメリ ウス (GR) 染色等が一般的に利用されてきた。我々 は内分泌系腫湯スクリーニング用マーカーとされ ているEGC (Endocrine granule constituents、 藤沢薬品）及びCRAB（クロモグラニンA+B、藤 沢薬品)を副腎褐色細胞腫例を用いて調べたので 述べる。

【症例】 30 歳、男性 主訴: 下㢉 臨床経過： 著明な体重減少及び下痢のため内科受診。頭痛、 高血圧症状はなし。消化管造影又は（検查にて 胃・大晹ボリープと左副腎の腫瘍の存在がが示唆 された。左副腎摘出術施行、術前の尿中カテコー ルアミンは高値で術後低下した。

【結果】捺印細胞所見 : 大型で上皮様配列を示す 細胞が平面的に出現し細胞質はライトグリーンで 顆粒状を示し核の大小不同著明。褐色細胞腫の細 胞像と一致した。免疫細胞化学：内分泌顆粒成分 の検索でEGC 及びCRABはいずれも細胞質において 強い陽性反応を示した。又これらは電子顕微鏡的 にも胞体内に神経内分泌顆粒として確認された。 尚、S-100 も陽性であった。GRは陽性を示すも背 景の染色性も強かった。

【まとめ】ク口ム親和性細胞に由来する褐色細胞 腫の細胞化学的手法はGRに代表されて広く使用さ れているがこれらの方法ではアミン以外の物質も とらえるという指摘もある。ここに示したEGC 及 びCRABはこれらの腫湯のスクリーニングに更に有 用な染色法と考える。 
381. 副腎外発生を示した褐色細胞腪の1 例

日本医科大学老人病研究所, ※同付属第 1 病院外 科

$$
\text { 清水一（CT），横田隆 (CT), 枝川旺子 (CT) }
$$

片山博徳 (MT) , 大網弘 (MD) , 秋丸王虎本 $(M D) \%$ 生司 佑(MD) ※

褐色細胞腪は副腎睢質飞好発する。今回我々 壮右後腹膜副督外発生の本腫瘍定経験したので 捺印像を中心竍告する。

症例：51才男。昭和 61 年 12 月より、時々上腹部 痛を訴えていた。昭和62年7月エコー,CT等の検 査で右㓢筒原発褐色細胞腪を疑われ、第一病院 外科へ紹介された。入院時所見：右季伊加部に圧 痛孛訴え、触診により血圧は $110 / 68-208 / 11$ 0Hgmm となり、内分泌検査では褐色細腫を疑わせ る価を示した。手術所見：腫瘍は、右腎上極か ら下大静脈および右觜静脈を取囲むように増殖 し、大ささは $7 \times 5 \times 2.8 \mathrm{~cm}^{3}, 170 \mathrm{~g}$ であった。右副 腎之腫瘍は鮮明に境界され、腪煬と交感神経幹 との関係は不明であった。術後血压は正常化し、 退院となった。肉腿所見: 腫瘍は厚い被膜で被

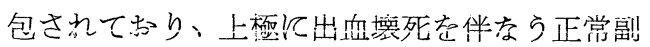
眯が認められた。割面は死黄色、結節状で結合 織性隔壁を有し、一部に出血壊死が見られた。 捺印細胞像: 腄場細胞は不整形、円形、紡鐘形 梨状と多形性を示し、散在性飞出現。核は偏在 傾向を示し、クロマチンは微細〜疎顆粒状で、 中心性に赤染する核小体が1〜2個認められた。 細胞質がレース状の胞体内に好酸性および好塩 基性の微細頪粒状構造物を核に近接して認めた。 組織像 : 大型の多形性を示す細胞の増殖があり、 その中に線維が不規則に増殖してみられた。核 内には細胞質変入によるinclusionが認められ た。胞体は盽富で好塩基性を示し、濃染した微 細軞粒状の構造物が見られた。
382. B C G 膀脱内注入療法の尿細胞診 越谷市立病院臨床検查科

○高橋玲子(CT), 砂川 進(CT), 吉原靖之(CT)

榎本秀雄 (CT), 桜井義一(MT), 飯野捷子(MT),

岡田 基(MD)

同 泌尿器科

諸角誠人 (MD)，高須秀彦(MD)

順天堂大学第一病理

塩津英俊(MD)

表在性膀胱腫瘍に対する B C G 膀胱内注入療法 が行われるよらになって10年余り経過した現在、 本療法を有用とする多くの報告がなされている。 今回我々は深達の程度が粘膜固有層までの原発性 膀脱癌に対寸る本療法の有効性について、尿細胞 診により検討した。

対象: 対象例は 12 例で、男11例女 1 例、年令は 61才〜78才である。症例 $1 \sim 8$ は多発する papillaryな tumorで、9〜12は non papillaryで あった。これらは T U R-B t あるいは random biopsyにより、移行上皮癌 grade $1 \sim 3$ 、 stageは pTis, pTa, pT1であった。

方法：全例において、BC G $80 \mathrm{mg}$ 生食40mgを 膀注。投与間隔は週 1 回で 8 週行い投与終了より 4 週後に組織診による効果判定を行った。細胞診 では投与前、投与中、投与終了後のfollow up時 の細胞像について、背景の炎症性の変化、細胞変 性、腫瘍細胞数、結核性変化の有無などについて 検討した。

結果：B C G 投与により尿細胞診では、好中球 増加、リンパ球、組織球の増加、腫瘍細胞の変性 が見られた。また、ほとんどの症例では腫瘍細胞 は多少のばらつきはあるが順次減少し、8回終了 時には認められなくなった。 
383. Nephrogenic adenoma の一例

大宮赤十字病院検查部病理, 同泌尿器科, 同外科 O伊佐山絹代 (CT) , 清水誠一郎 (MD) ,

三田健司 $\left(C T^{1)}\right)$ ，兼子耕 $(M D)^{1)}$,

大和田文雄 $\left(M D^{2}\right)$, 諏訪敏一 $(M D)$

Nephrogenic adenoma (以下N・A)は下部尿路 に発生する希な良性腫瘍で、尿細管に類似した組 織像を呈するものである。今回我々は膀脱に発生 した本症の一例を経験したので報告する。

<症例 $>72$ 歳, 女性。既往歴及び家族歴に特記す べき事はない。昭和61年1月頃より排尿困難、尿 線中絶を自覚するも放置していた。同年 9 月末内 科受診し、血尿を指摘された。10月精査目的で泌 尿器科受診し膀脱鏡検査で三角部から顠部に多発 広基性の隆起病変が認められた。尿細胞診はクラ 又吕。10月15日TUR-Bt施行。10月29日腫暍全摘術 が施行された。

<細胞像 > 自然尿は出血炎症性背景で10 20個程 度の細胞からなるシート状及び索状クラスターが 少数出現していた。細胞は円形から楕円形、細胞 径30 $\mu m$ ぐらいで、N/C 比はやや高く胞体はライ トグリーン好性で厚く、顆粒状を呈していた。核 はやや偏在し軽度の核形不整・核膜肥厚が認めら れた。クロマチンの増量は弱く均等分布しており 悪性とはいい難かった。

<組織所見>Hobnail patternをを示す腫瘍細胞が 大小の腺腔を形成し、密に増殖しており細い血管 を有する狭い間質が介在していた。腫瘍の浸潤性 增殖は見られなかった。腫瘍細胞は淡明かつ豊富 な細胞質を有しており、核は基底側に偏在し小型 でクロマチン増量はなく異型は弱かった。

くまとめ>N・A は希な腫瘍でありYoung らは30 年間で113 例の報告があったとしており、本邦で は過去7 年間に9 例の報告しかない。日常の尿細 胞診でN・A と診断することは難しいがこのよう な希な腫瘍の存在も念頭に置き検鏡する必要があ ると思われた。
384. 膀腅原発 Mesonephric Adenocarcinomaの一例

\section{春日部市立病院臨床検査科病理}

O舟橋光政 (CT), 神津ゆかり (MT), 萩原久子(CT)

独協医科大学第二病理

上田善彦(MD), 滝本寿郎 (MD), 平林かおる(MD)

溝口康司(MD)

独協医科大学第一病理

山田 喬(MD)

Mesonephric adenocarcinoma (Clear cell adenocarcinoma)は、婦人科領域において稀に認 められるが、泌尿器における報告はさらに少な い。今回、我々は膀胱原発のClear cell adenocarcinomaの一例を経験したので報告する。 症例は、73才女性。平成 1 年 1 月、尿閉にて当院 泌尿器科入院。CT及びEchoにて膀胱から尿道にか けての腫瘍を認め、4月 7 日尿道腫演切除術、5 月 8 日膀胱 -子宮及び卵巣全摘術が施行された。 [細胞所見]尿細胞診では、出血性背景のなかにご く少数の類円形異型細胞が孤立性に認められた。 腫瘍捺印細胞診では、腫瘍細胞は、シート状から不 規則な重積性集団を主体に認められ、ときに腺管 様配列を伴っていた。細胞質は、ライドリーン淡染性 のものが主体を占め、レー状ながら細胞境界は明 瞭であり、PAS染色において、しばしば顆粒状陽 性物質(グリエーゲン)を有していた。核は中心性ない し偏在性で、著明な核形の不整は認められず、吅 マ乎はは微細顆粒状を呈し、1 個から数個の明瞭な 肥大した類円形核小体を有していた。

[病理組織所見] 腫瘍は、膀胱頝部・前壁・後壁 及び尿道にかけて広がり、子宮には頝部漿膜面に 微小な浸潤像を認めるのみであり、膀胼原発と考 えられ、Clear cell adenocarcinomaと診断され た。 
385. 原発性膀羘絨毛癌の 2 症例

大分医科大学付属病院検査部病理 ${ }^{1}$. 泌尿器科 ${ }^{2}$ O林田蓉子 $(\mathrm{CT})^{1}$. 長浜純二 $(\mathrm{CT})^{1}$. 横山繁生 $(\mathrm{MD})^{1}$

田崎義久 $(M D)^{2}$.和田瑞隆 $(M D)^{2}$

非妊娠性䋐毛癌は卵巣、睪丸、後腹膜、縦隔等 に胚細胞腫崵の一型として見られる他、稀に消化 管、肺、膀胱等にも発生することが知られている 。今回、我々は高齢男性に発生した原発性膀脱 絨毛癌 2 例の摘出腫瘍の捺印及び尿細胞診を検討 する機会を得たので報告する。

【症例 1】72才・男性。肉眼的血尿を主訴とし て来院、入院となる。諸検査で膀胱にほぼ全周性 の腫瘍が認められた。尿細胞診と生検が行われ、 䋐毛癌と診断された。膀胼全摘術と化学療法が行 われたが、顆粒球减少症にて術後 42 日で死亡。

【症例2】70才・男性。血尿にて近医を受診、 検查・加療目的のため当院に転院となる。諸検査 で膀胱に巨大な隆起性腫瘍が認められ、両肺には 既に転移巣が見られた。尿細胞診と生検が行われ 、䄉毛癌と診断された。化学療法が行われたが、 全経過約 5 力月で呼吸不全のため死亡。

【細胞所見】尿細胞診では、出血・壊死を伴った 腫瘍性背景の中に異型性・多形性に富む腫瘍細胞 が集団あるいは散在性に出現していた。腫瘍細胞 は小型から大型の単核細胞と多核細胞からなり、 クロマチンの増加と粗凝集、複数の好酸性核小体 が著明で、裸核細胞や核分裂像も目立った。また 捺印標本もほぼ同様の所見を呈していた。

【組織所見】症例 1 では、H C G陽性の合胞体細 胞とラングハンス細胞よりなる䄉毛癌の他に明ら かな移行上皮癌の部が見られたが、移行上皮癌内 にも単核および多核の H C G 陽性細胞が散見され た。一方、症例 2 は純粹な䄉毛癌の像であった。

【まとめ】剖検でも膀羘以外に原発を思わせる部 位は認めら扎なかった。細胞診上は、G3の移行 上皮癌との鑑別が難しく、尿中に高度異型細胞が 出現する場合には䋐毛癌を考慮する必要がある。
386. 6 回の経尿道的膀胱腫瘍切除術後に 肺転移を来たした若年性膀脱腫瘍の 1 症例

信州大学医学部泌尿器科 ${ }^{1}$, 同中央検査部 ${ }^{2)}$, O井門懭介 $(\mathrm{MD})^{1)}$, 山上 修 $(\mathrm{CT})^{2)}$ 林茂子 $(\mathrm{CT})^{2)}$

【はじめに】今回, 我々は, 第 1 回目の経尿道的 膀胱腫湯切除術を 17 才の時に受けた後, 7 回目の 経尿道的膀胱腫場切除術時に肺転移が発見された 症例を 5 年間にわたって尿細胞診と組織診断で追 跡したので検討報告する。

【症例】17才, 男性. 昭和58年16才の時, 無症候 性肉眼的血尿が出現. 翌年, 膀胱腫崵と診断され, 昭和 60 年 2 月に径約 $4 \mathrm{~cm}$ 大と $1 \mathrm{~cm}$ 大の有茎性乳頭 状腫瘍の経尿道的切除術を受ける. 組織学的彭断 は移行上皮癌 $\mathrm{G} 1>\mathrm{G} 2, \mathrm{pT} 1 \mathrm{a}>$ 移行上皮乳頭腫 で尿細胞診は class IIIbであった。

【経過】昭和 60 年 6 月には径約 $1 \mathrm{~cm}$ 以下の多発性 再発を認め, 細胞診は class V, 組織学的診断は 移行上皮癌, $\mathrm{G} 1=\mathrm{G} 2, \mathrm{pT} 1 \mathrm{a}$ で, 術後テスパ そン $60 \mathrm{mg}$ 膀腅内注入を施行. 同年 11 月細胞診が class Vで再発を認め, MMC $20 \mathrm{mg}$ と ADM $40 \mathrm{mg}$ の膀 胱注入を施行後, 3 回目の切除術を行った。 その後 放射線照射を $4000 \mathrm{rad}$ 施行し，62年 9 月までに6回 の経尿道的切除術を抢てなう。1 年後, 7 回目の 手術の際に, 右肺転移が見つかり, 中肺葉切除術 と膀脱全摘出術をおこなった。膀胱の組織学的診 断は移行上皮癌 $\mathrm{G} 2 \gg \mathrm{G} 3, \mathrm{pT} 1 \mathrm{a}-\mathrm{pT}$ is で脈管侵襲 を認めなかった。再び右肺転移が見られたので化学 療法後に, 下肺葉切除を平成元年11月に行った。 【まとめ】本症例の経尿道的切除標本はいずれも 表在性で，粘膜下浸潤はなくかつ経時的な悪性度 の変化も見られなかったが，肺転移をきたした。 その原因は不明ではあるが，1 年間受診しない間 にC I S に変化していたてとや, 経尿道的切除術の 際の腫瘍細胞の脈管内侵入も考えられうる.

若年者における膀胼腫瘍で, 頻回の再発がみら れる際は, 厳重な注意が必要である。 